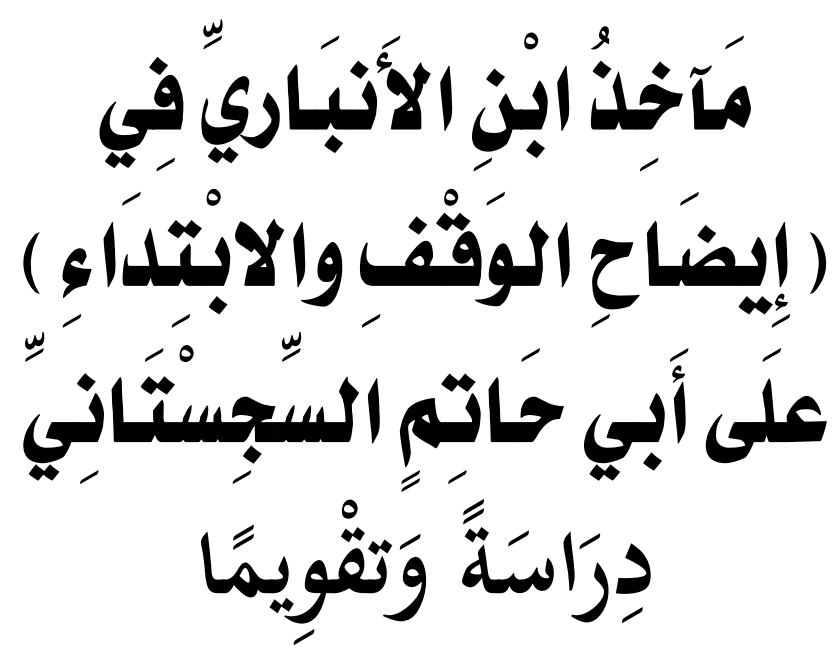

(اعداد

د/ أبمز السبيد أحمد هيومي الجندي

الأستاذ المساعد في كلية اللغة العربية بالمنوفية

جامعة الأزهر 


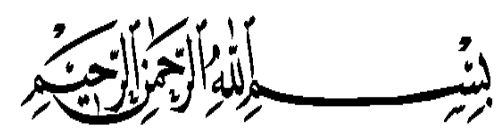

المُقدِّمَةُ

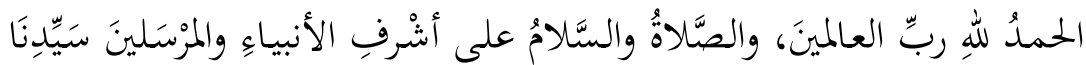

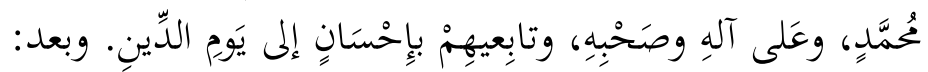

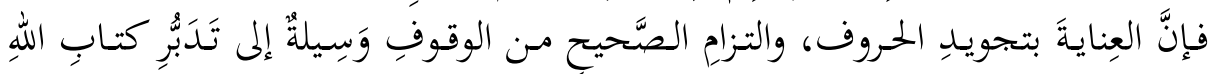

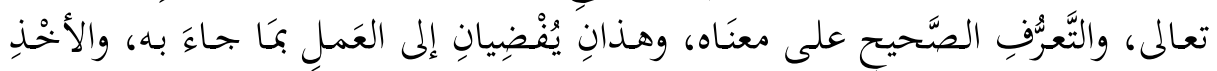

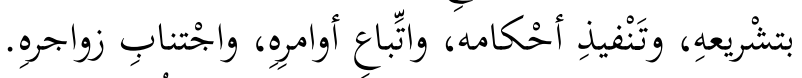

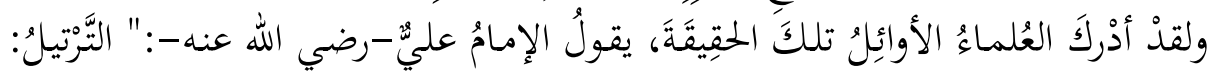

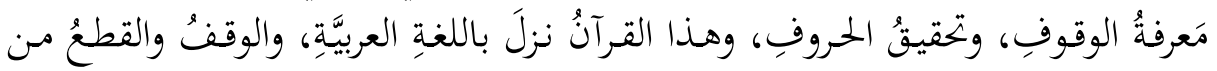

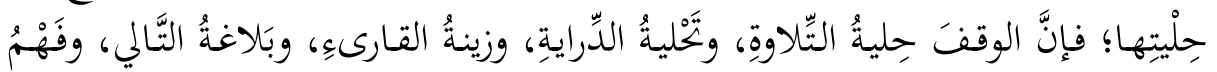

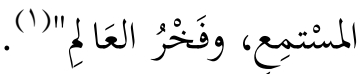

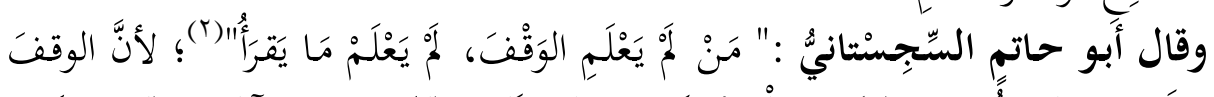

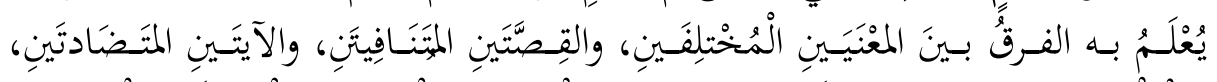

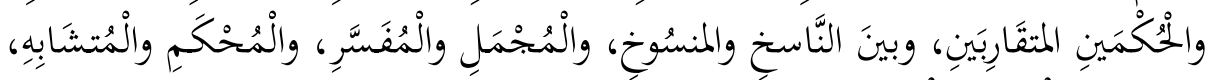

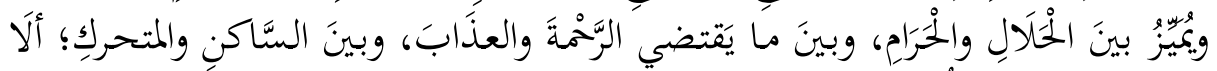

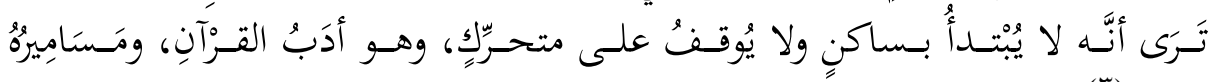

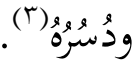

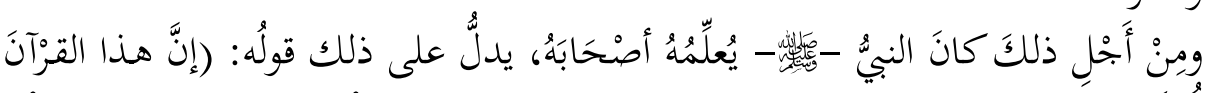

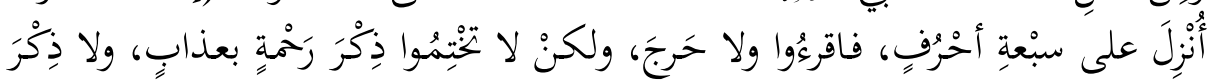

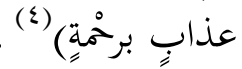

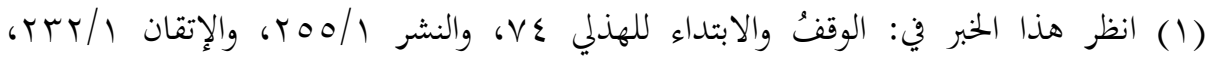

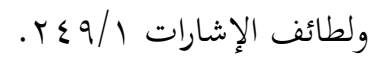

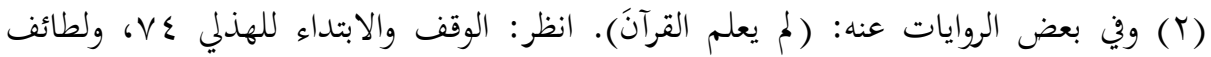

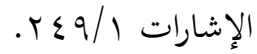

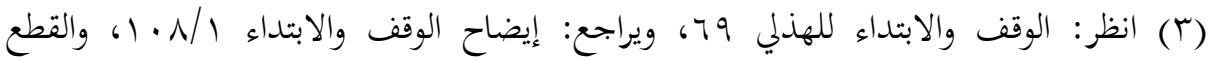

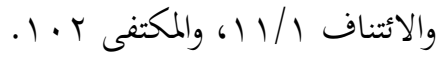

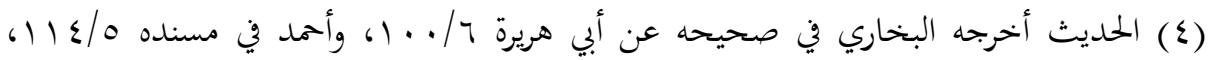

$$
\begin{aligned}
& \text { أ }
\end{aligned}
$$




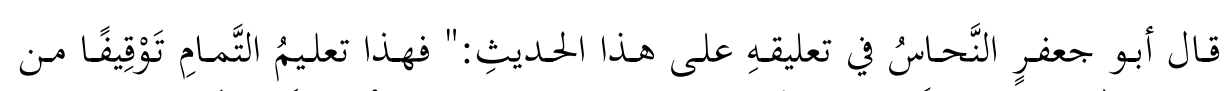

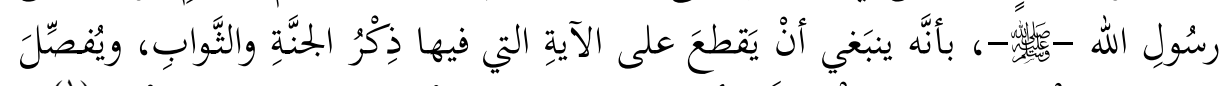

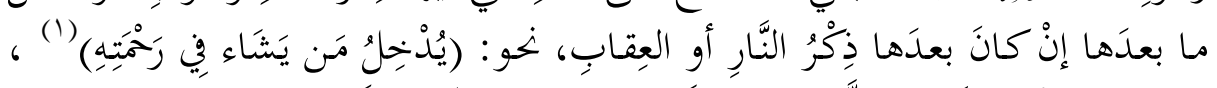

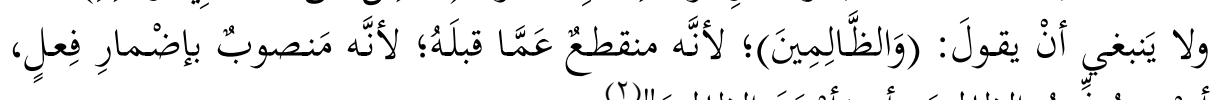

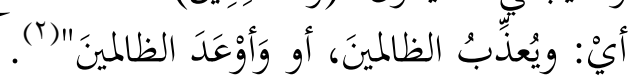

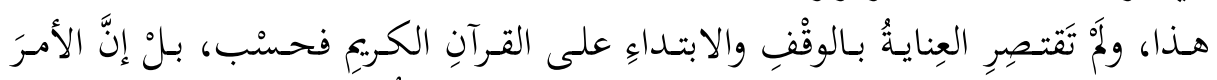

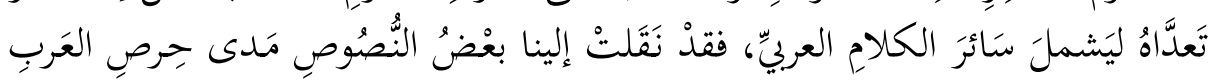

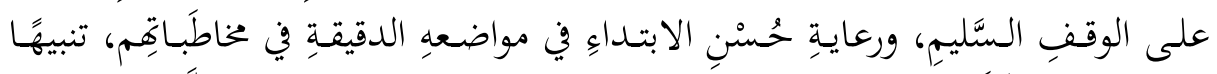

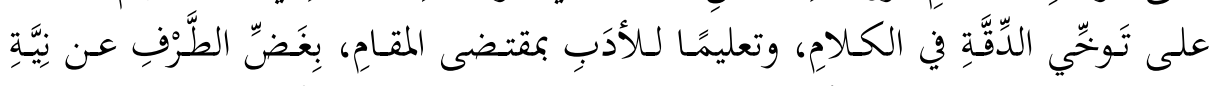

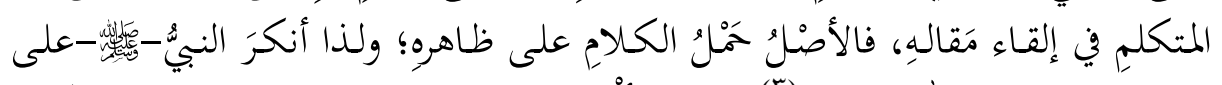

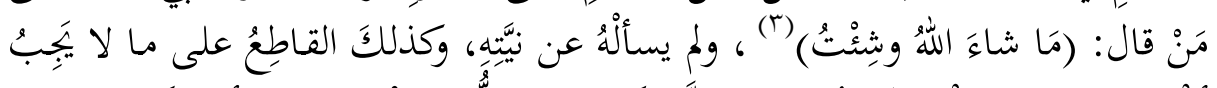

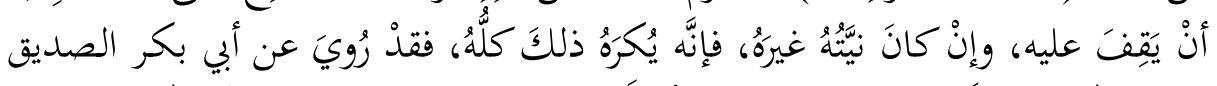

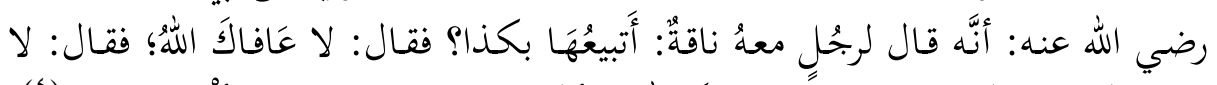

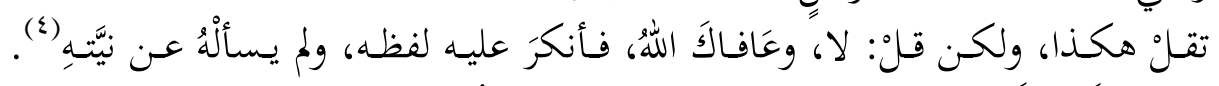

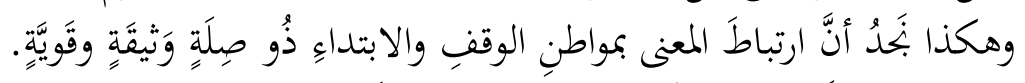

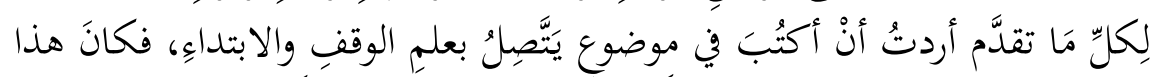

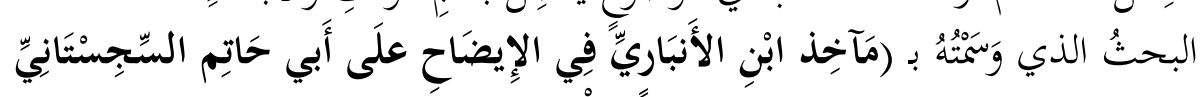

\section{"دِرَاسَةَ وَتَقْوِيمًا").}

كما دفَعني لاختيار هذا البحثِ أمورٌ أخرىى، منَها:

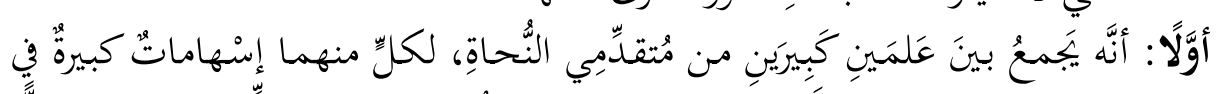

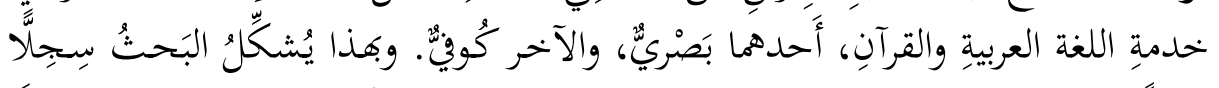

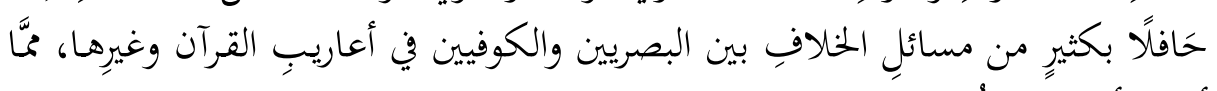

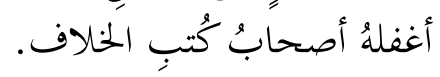

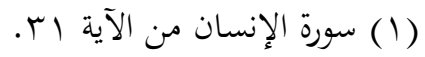

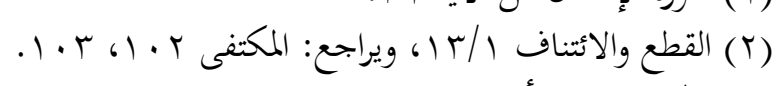

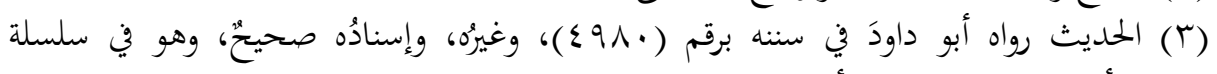

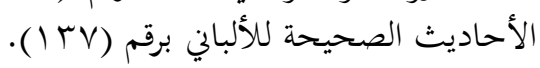

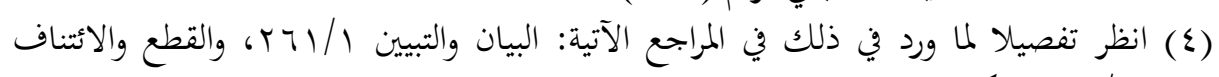

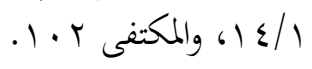




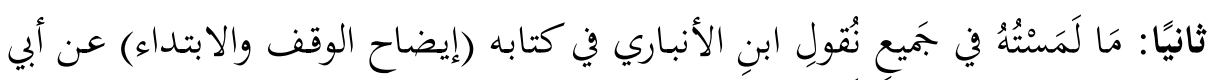

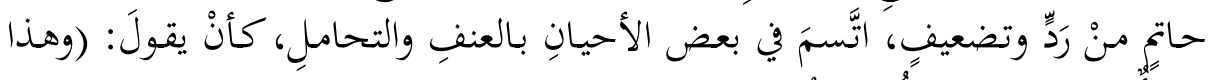

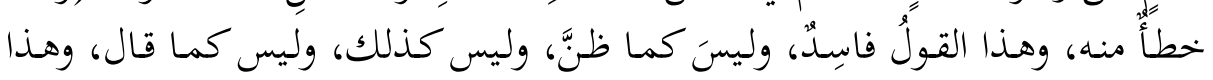

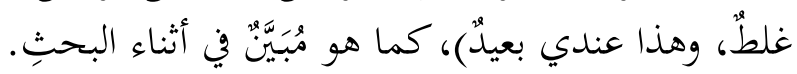

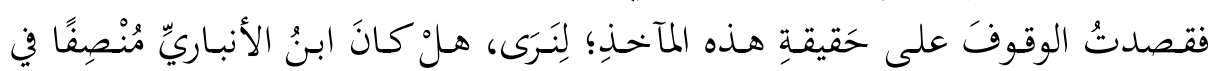

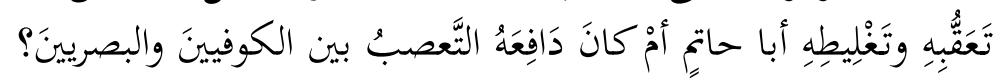

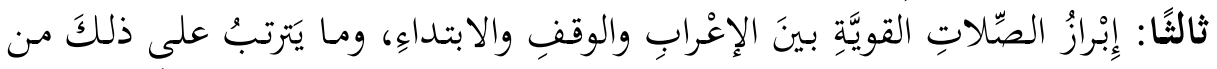

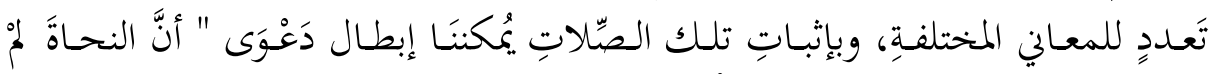

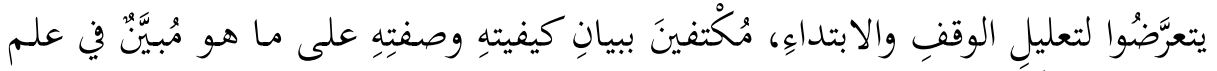

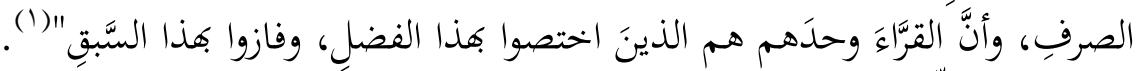

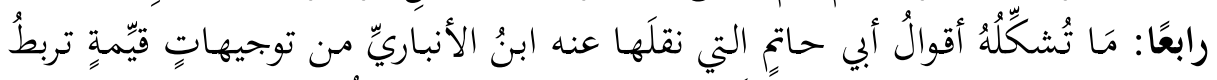

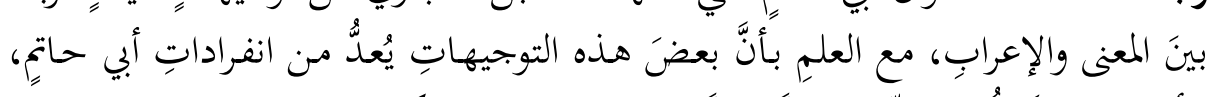

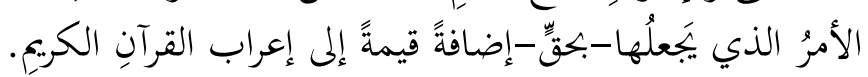

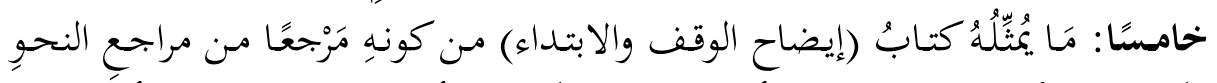

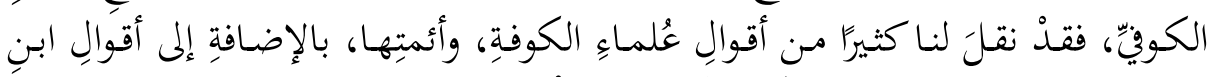

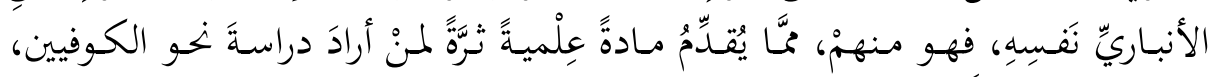

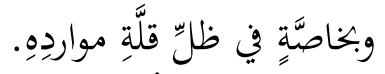

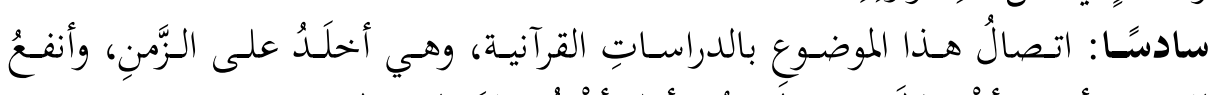

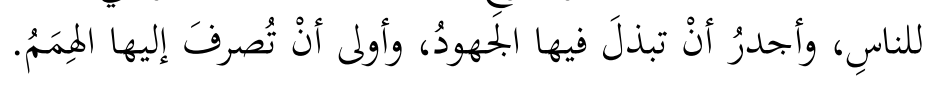

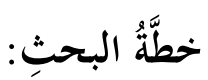

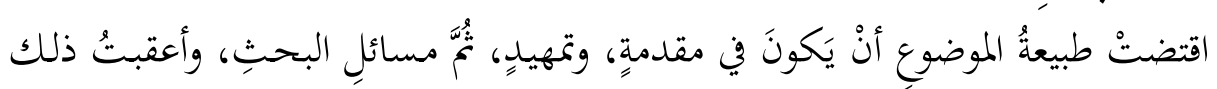

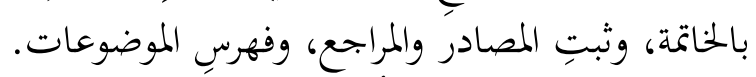

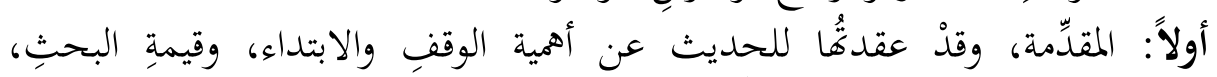

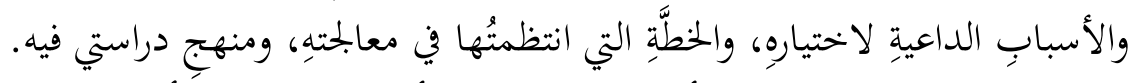

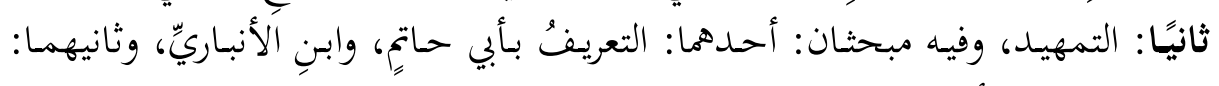

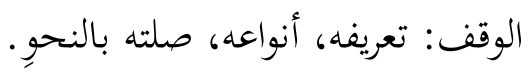

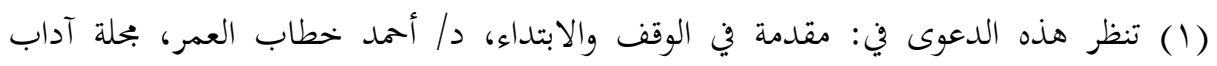

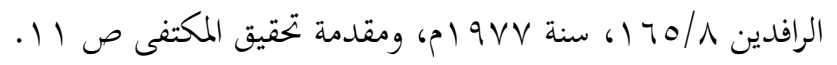


ثالثًا: مسائل البحث، وفيه قصرتُ الحلديثَ على جميع المآخحذِ التي نسبها ابنُ الأنباري

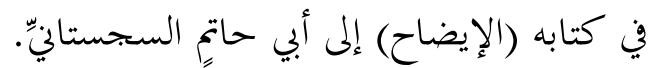

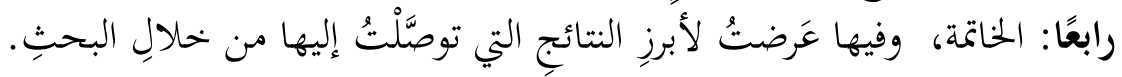

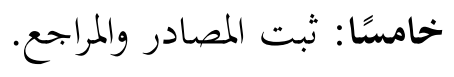

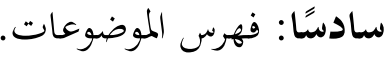

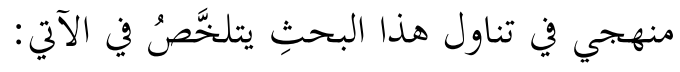

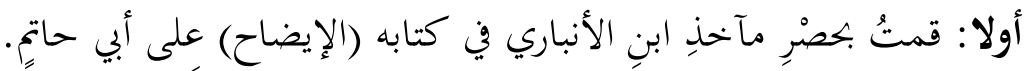

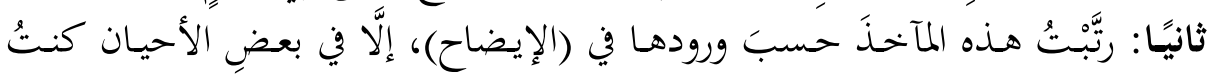

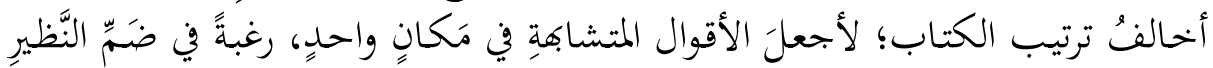

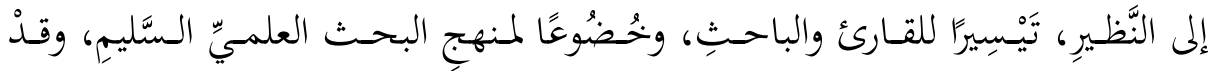

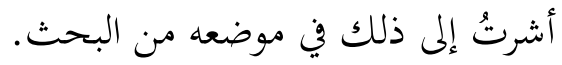

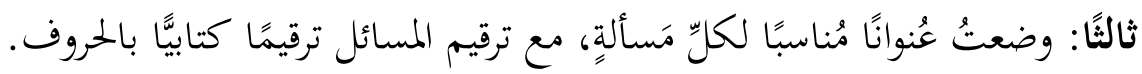

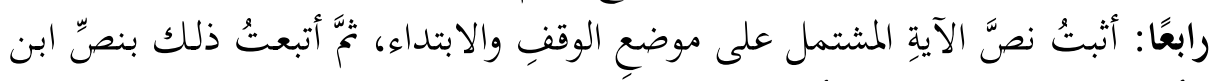

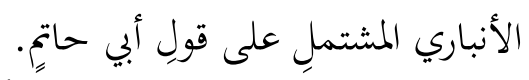

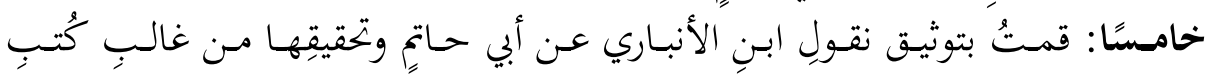

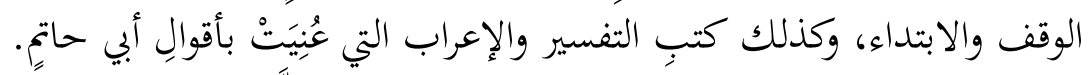

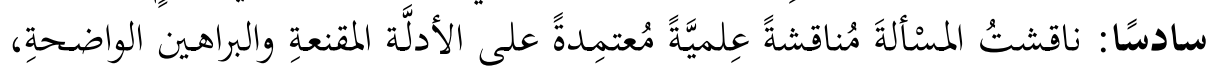

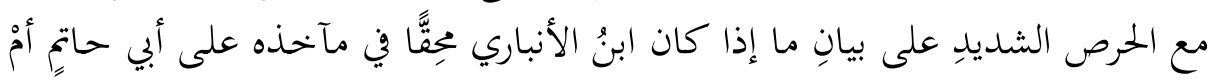

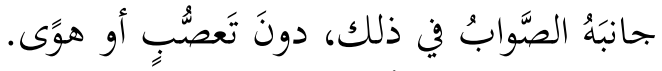

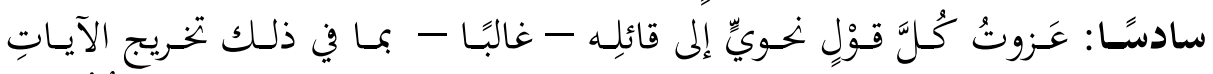

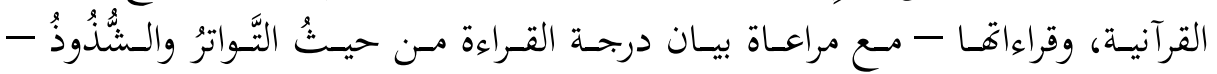

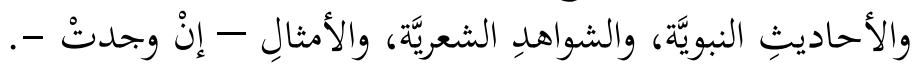

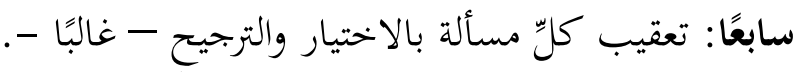

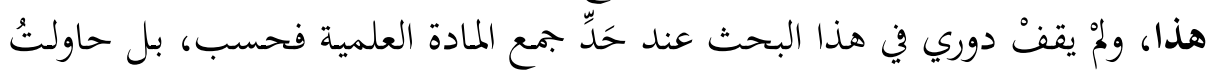

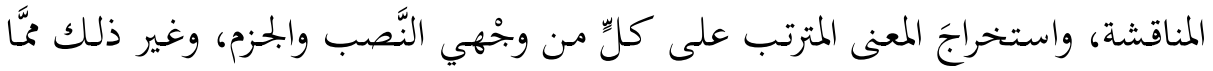
تقتضيه طبيعةُ البحثِ العِلميِّ.

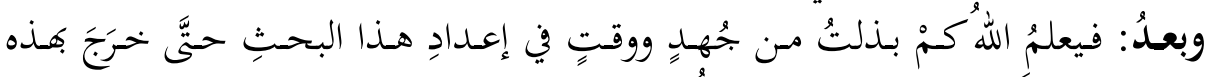

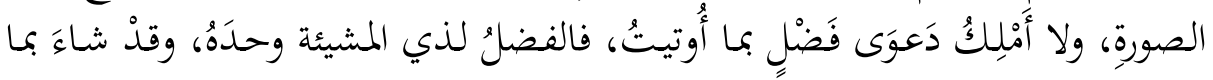


=

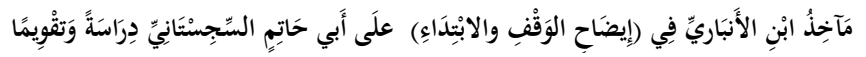

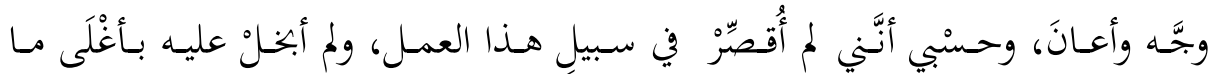

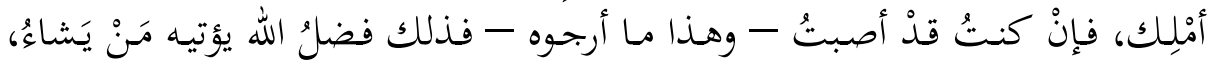

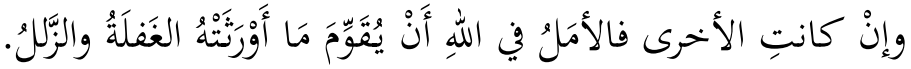

واللهُ من وراءِ القصدِ، وهو يَهدي السَّبيلَ. 


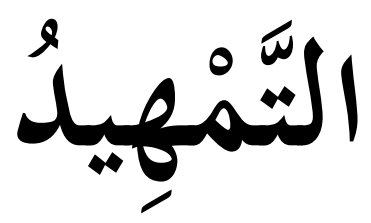

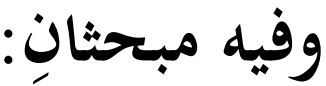

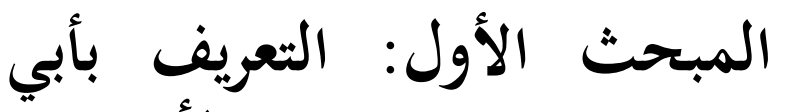

حاتم، وابنِ الأنباري.

المبحث الثاني: الوقف: تعريفه،

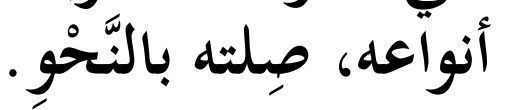




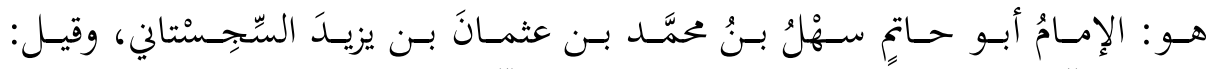

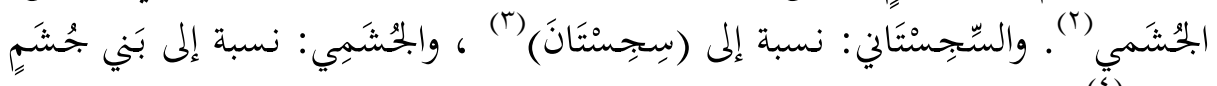
بالولاءٍ)

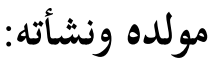

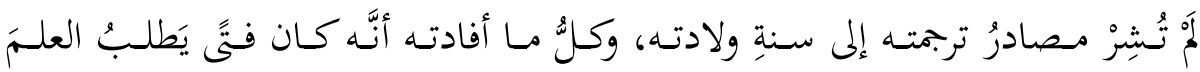

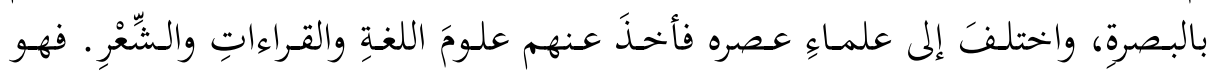

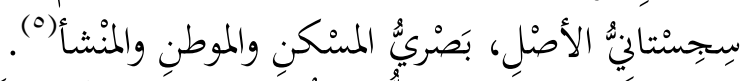

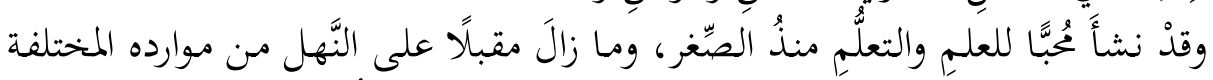

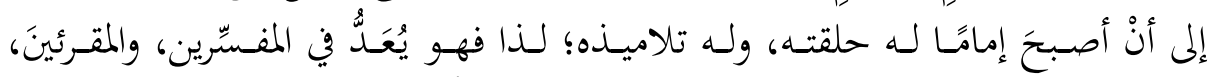

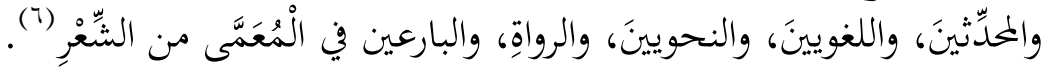

صفاته:

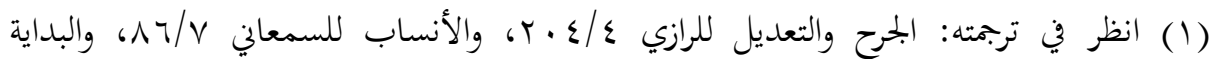

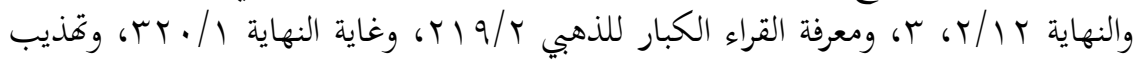

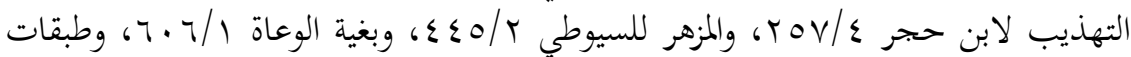

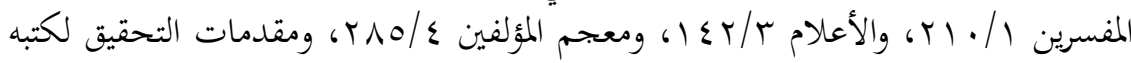

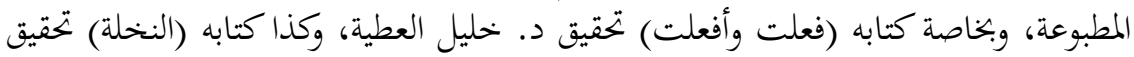

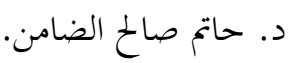

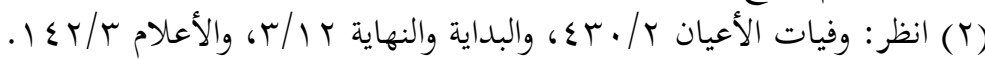

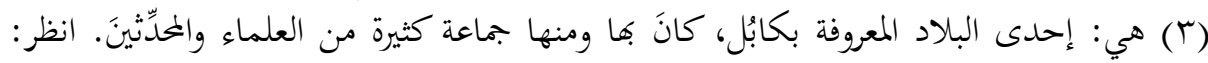

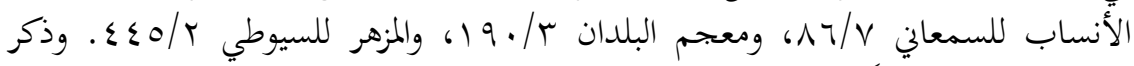

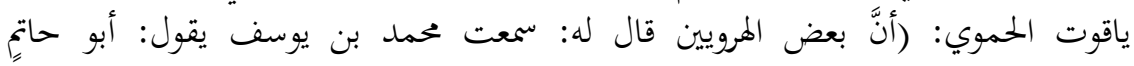

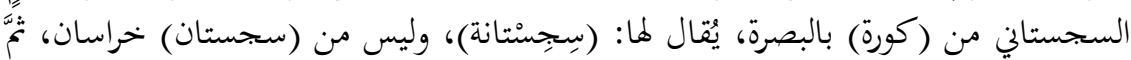

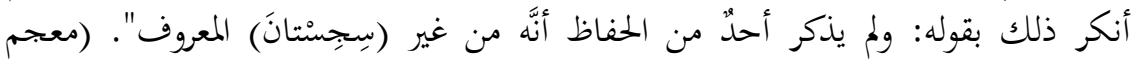

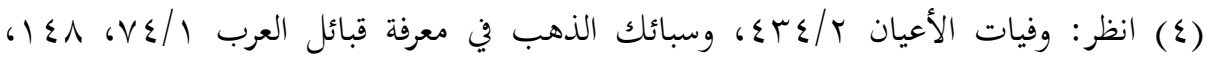

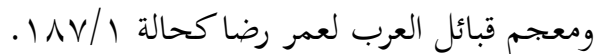

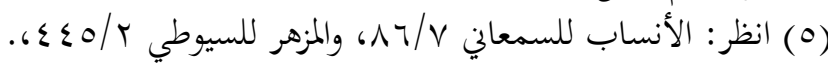

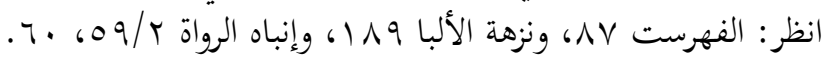




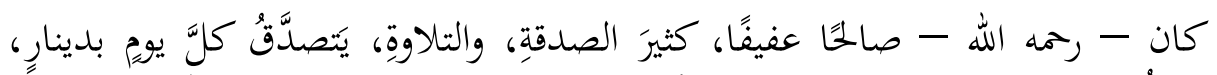

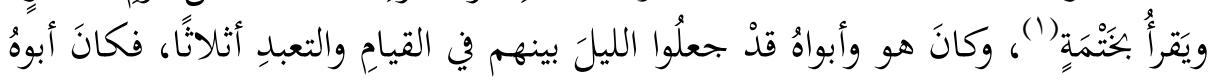

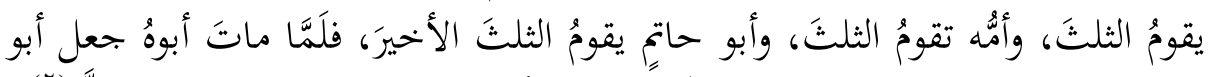

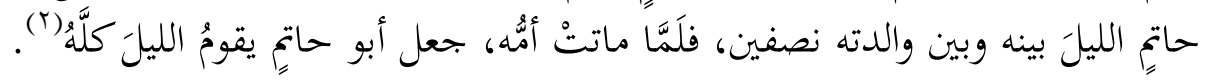

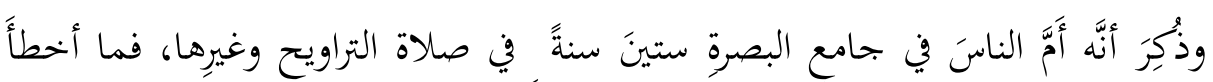

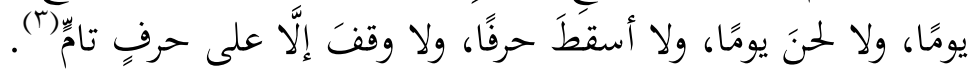

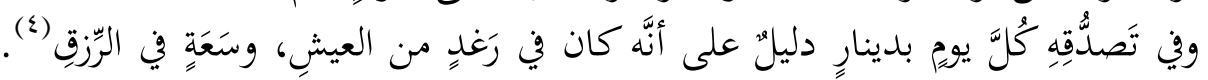

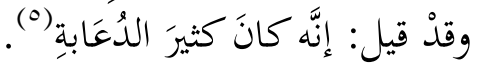

\section{ثناءُ العلمايٍ عليه:}

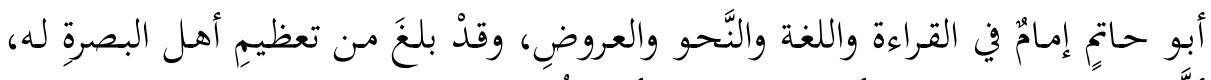

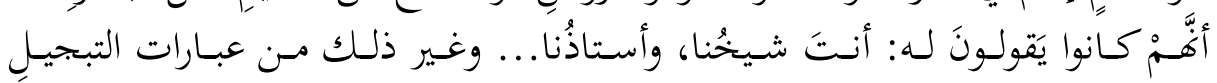

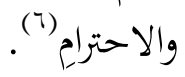

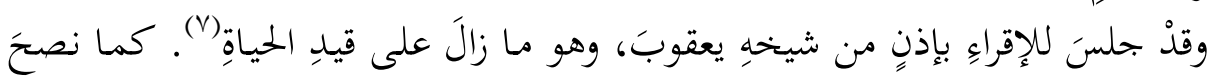

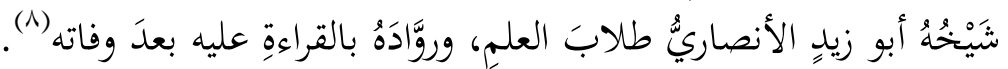

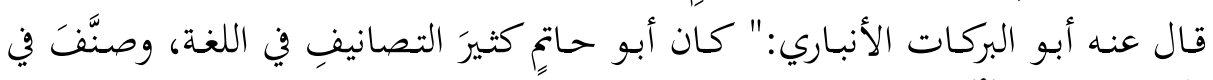

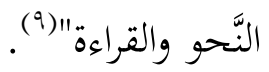

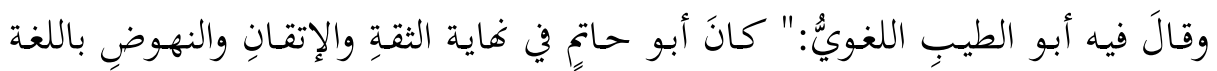



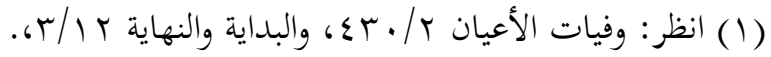

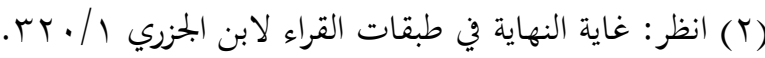

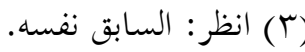

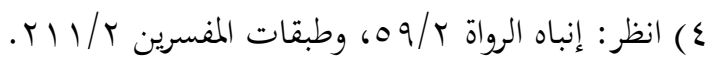

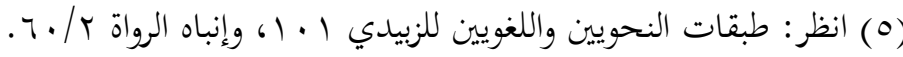

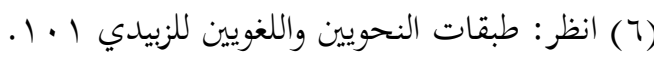

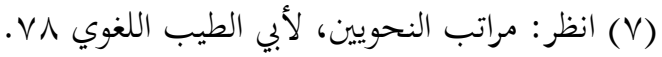

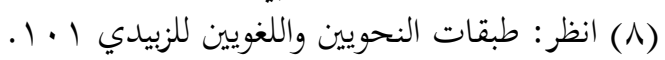

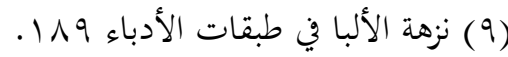

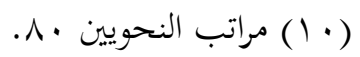




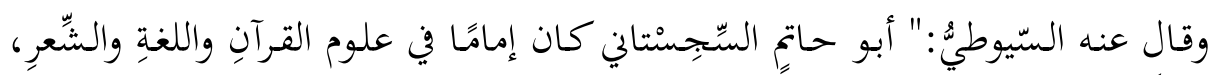

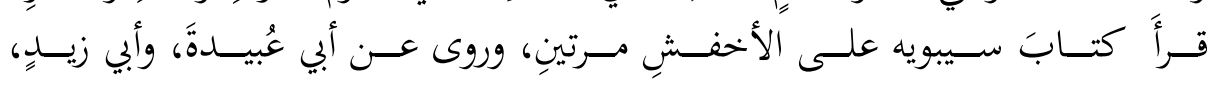

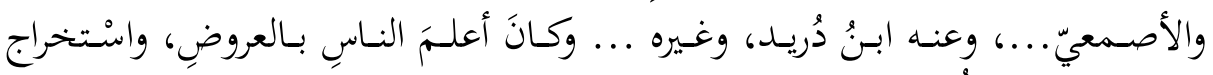

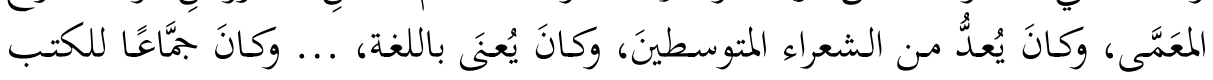

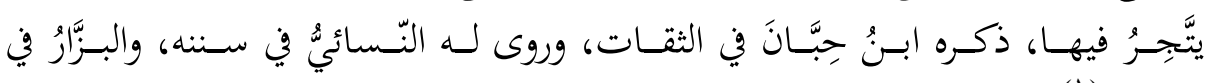
مسنده "(1)

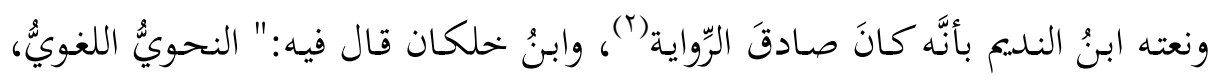

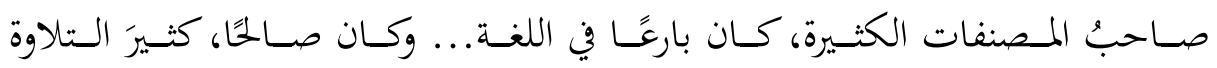
والصدقة" (r) ماحب.

\section{مذهبه النَّحوي والعَقَدِي:}

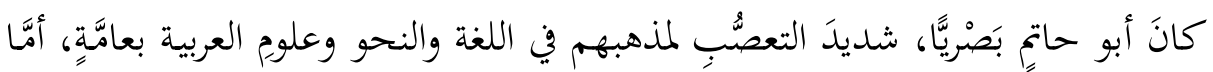

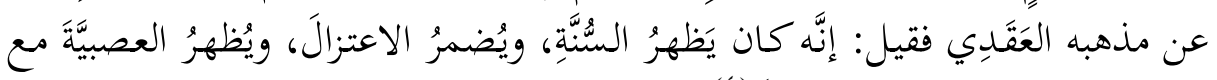

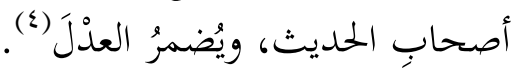

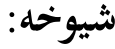

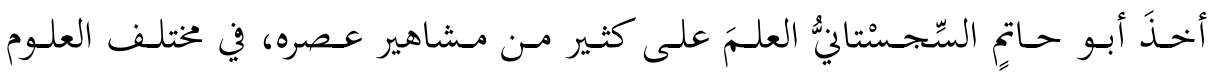

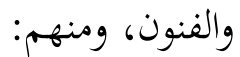

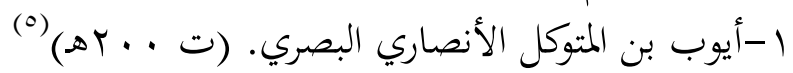

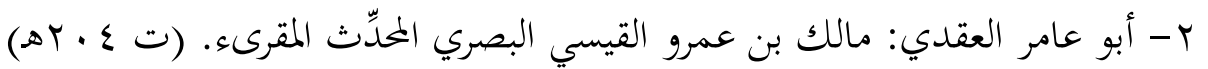

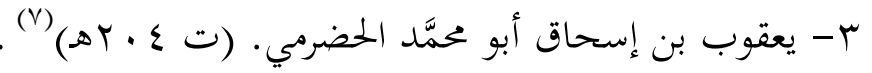

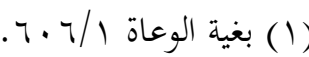

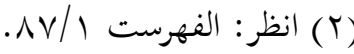

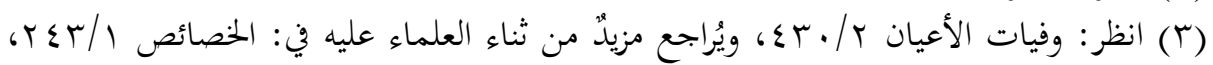

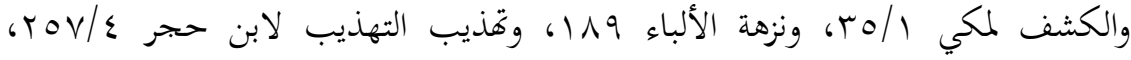

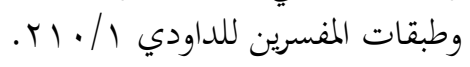

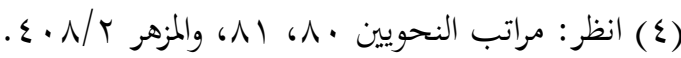

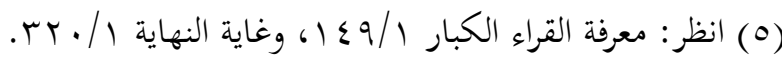

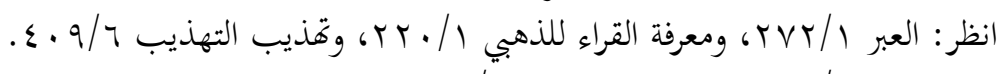

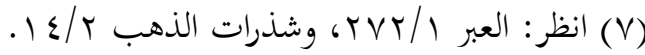




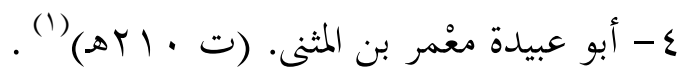

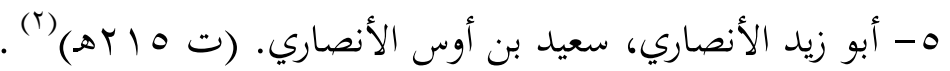

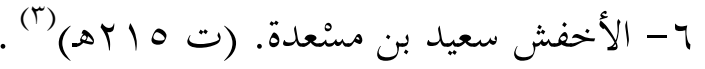

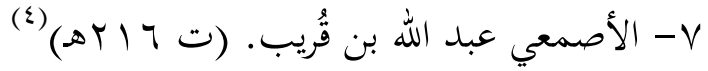

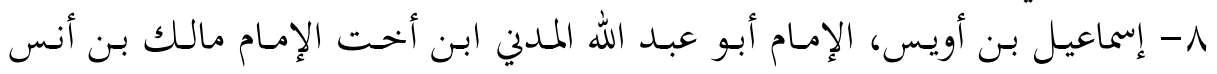

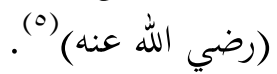

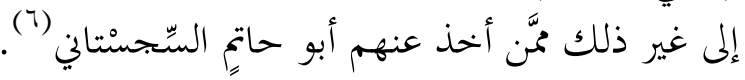

\section{تلاميذه:}

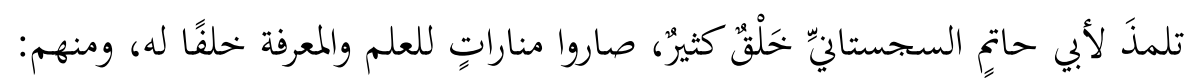

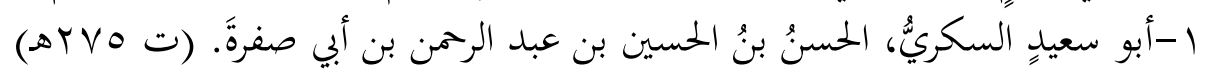

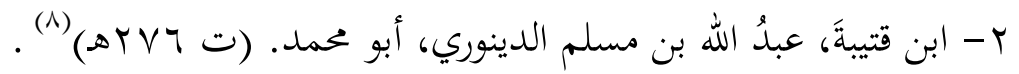

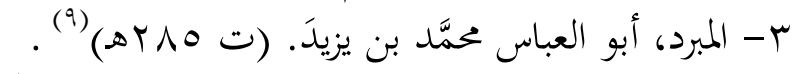

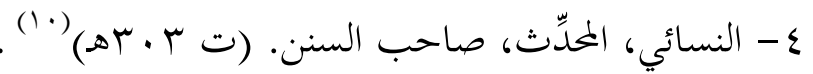

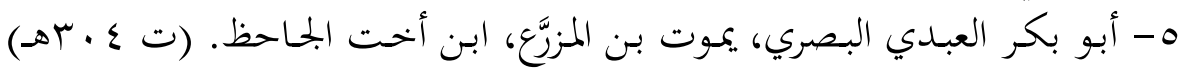

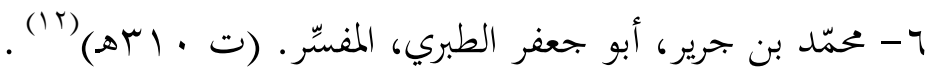

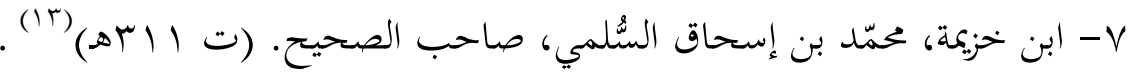

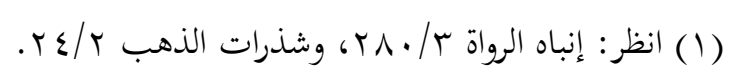

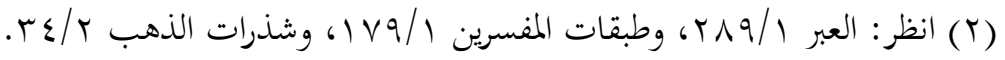

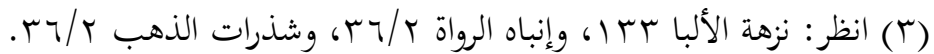

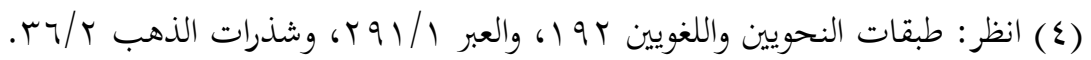

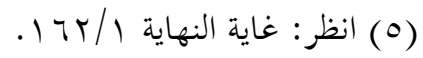

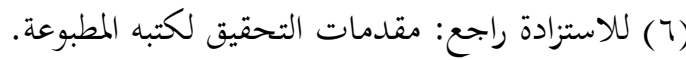

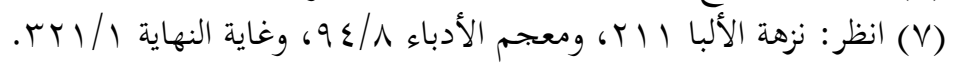

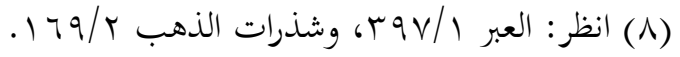

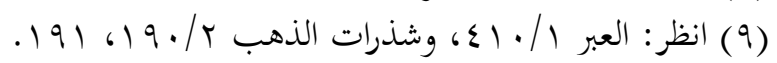

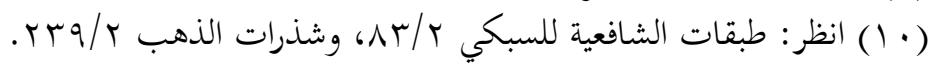

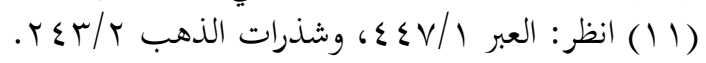

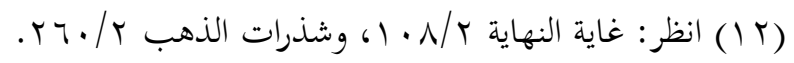

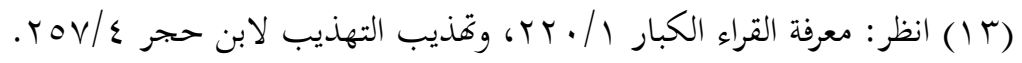




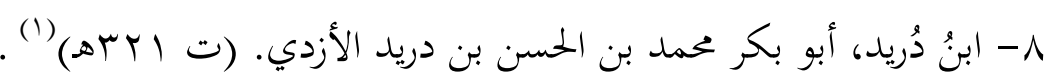

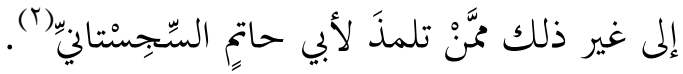

\section{آثاره ومؤلفاته:}

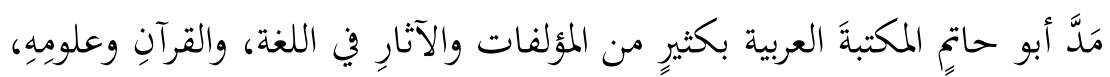

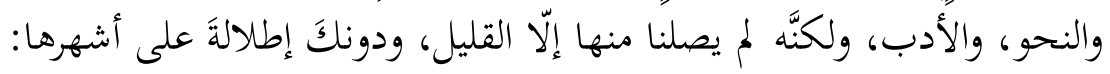

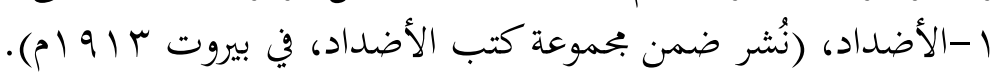

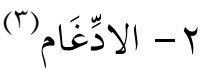

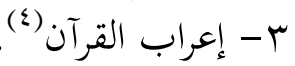

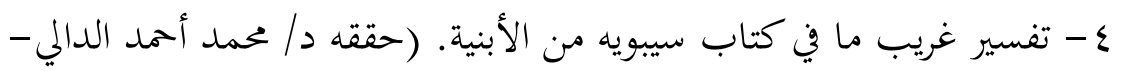

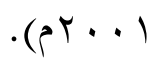
0- فعلتُ وأفعلت. ( حققه د / خليل إبراهيم العطية، 199 ( 99 (م).

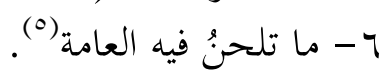

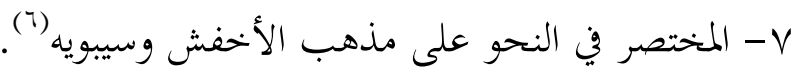
1 - المذكر والمؤنث. (حققه دا د إبراهيم السامرائي).

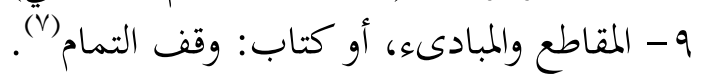
.

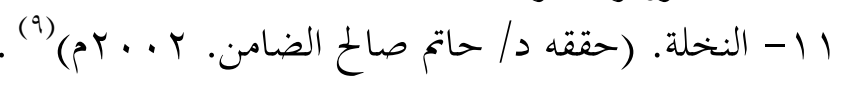
وفاته:

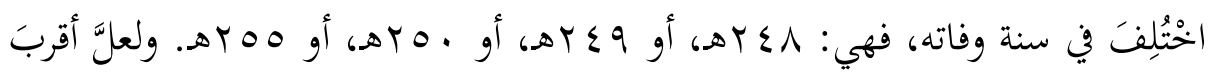

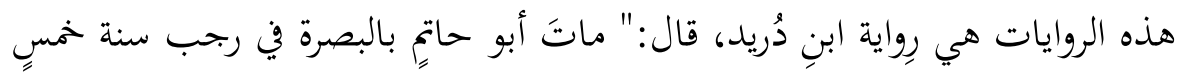

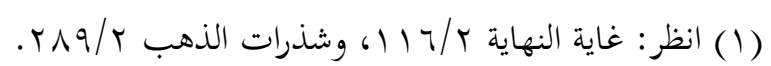

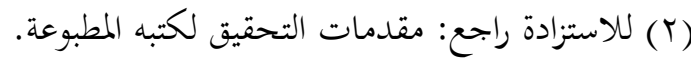

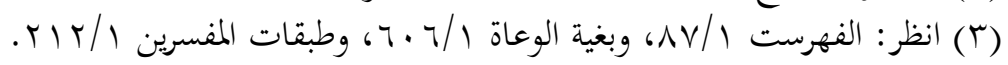

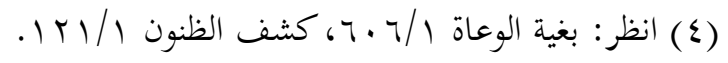

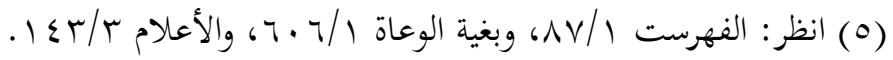

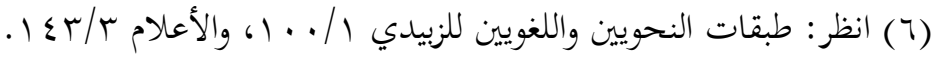

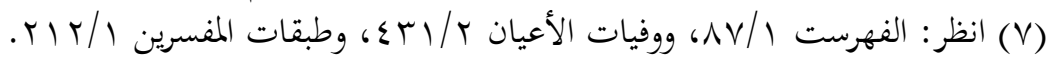

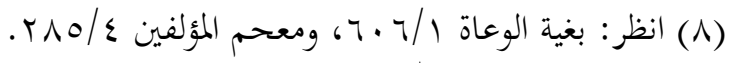

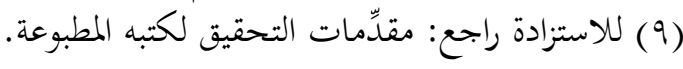




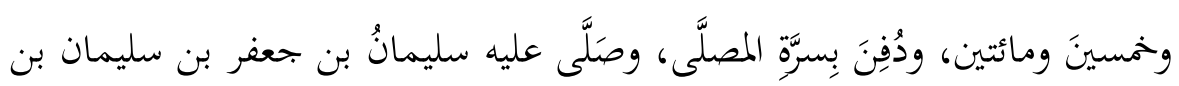

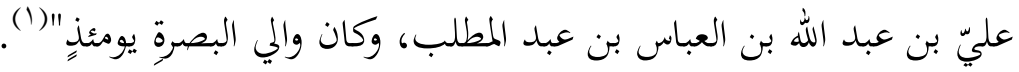

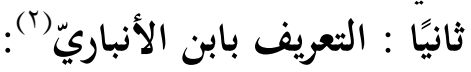
اسمه ونسبه:

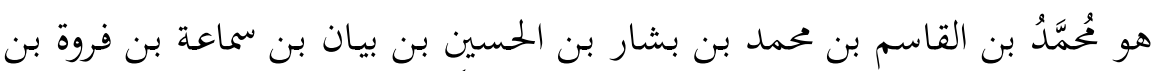

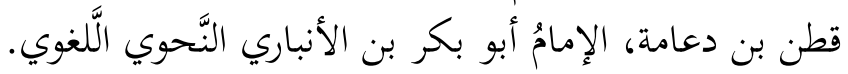

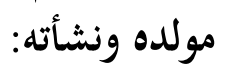

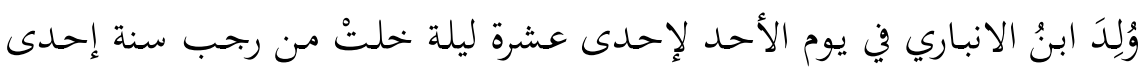
وسبعين ومائتين (r)

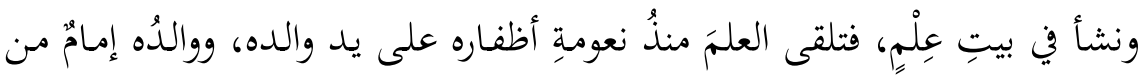

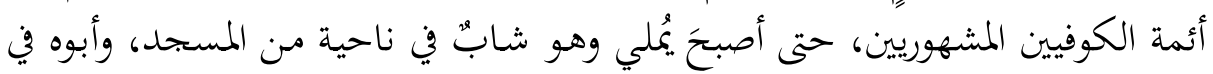

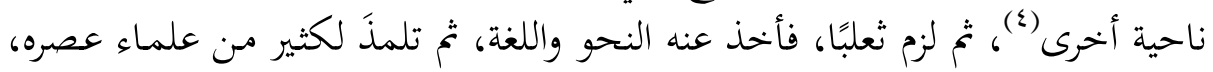

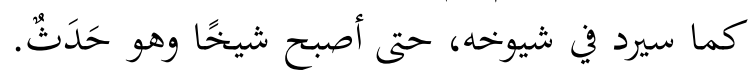
صفاته:

كان ابن الأنباري صدُوقاً زاهداً متواضعاً فاضلاً، أديباً ثقةً خيِّرً من أهل السنة حَسَنَ الطريقة (0)

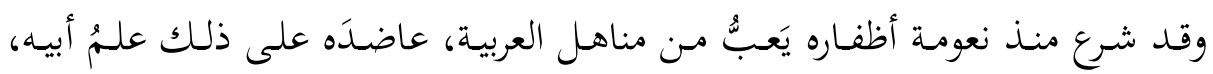

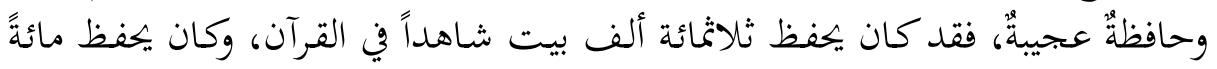

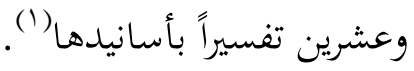

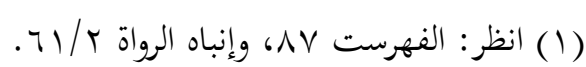

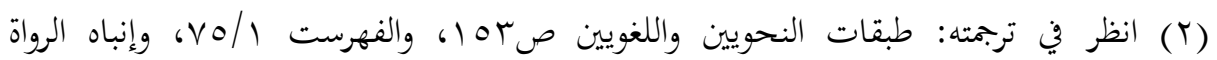

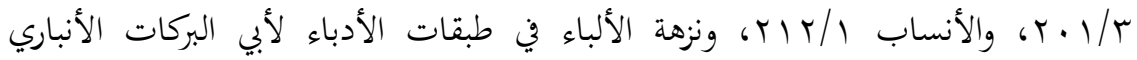

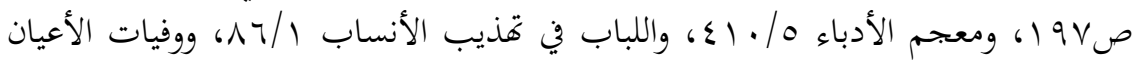

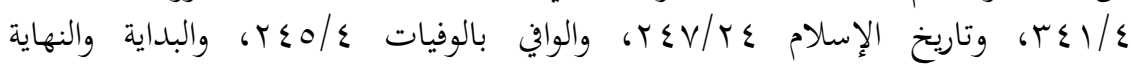

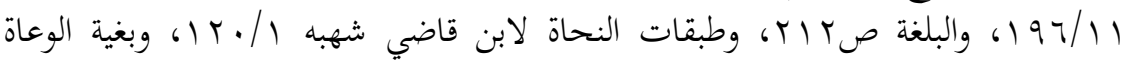

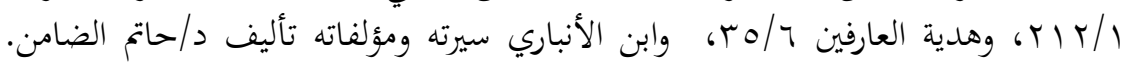

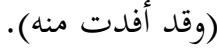

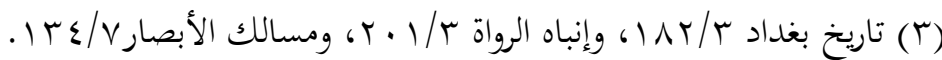

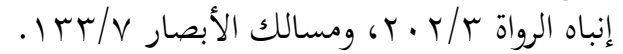

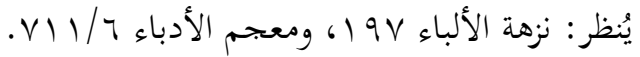


وذُكر أنّه مرض فعاده أصحابه فرأوا من انزعاج والده أمراً عظيماً فطيّبوا نفسه فقدال:

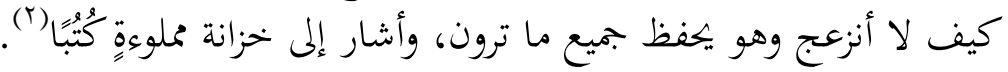

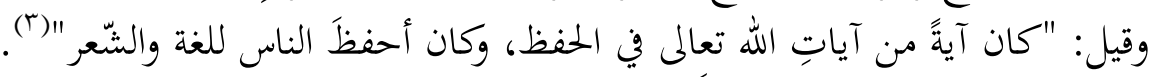

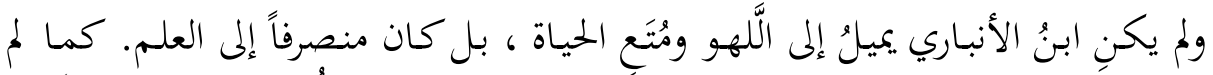

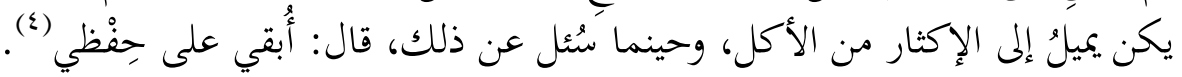

\section{ثناءُ العلماء عليه:}

كَثُرُ ثناءُ العلماء على أبي بكر بن العلماء عليه ألباري، وإليك بعضَ أقوالهم فيه:

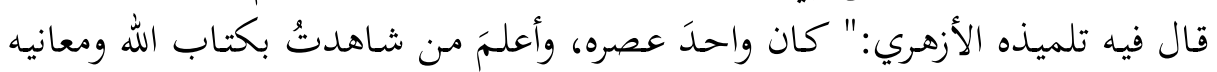

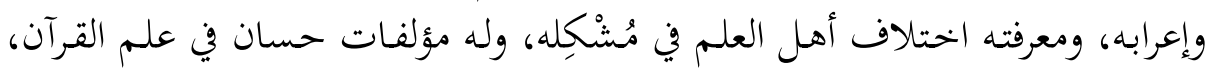

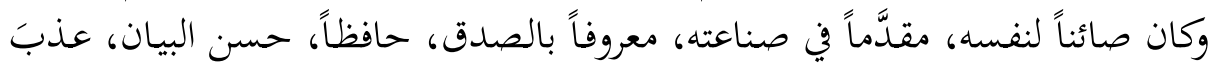

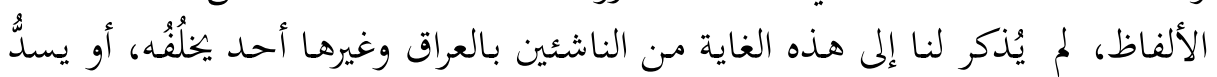

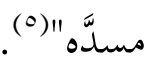
وقال فيه أبو البركات الأنباري:" كان مـن أعلم النـاس، وأفضلهم في نحو الكوفيين،

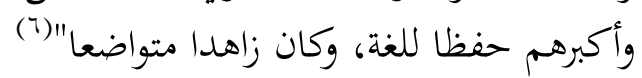

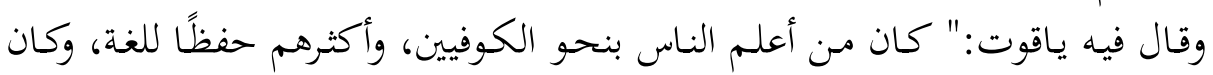

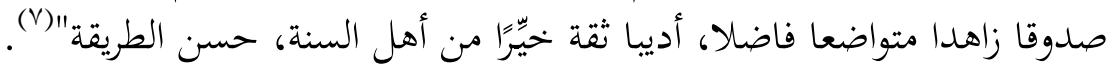

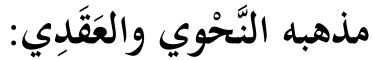

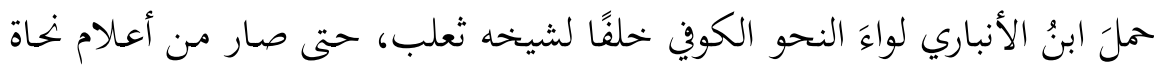

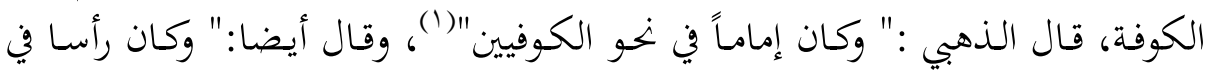

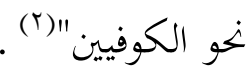

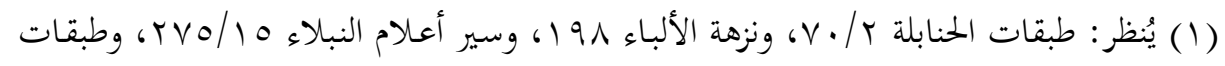
الحفاظ إن بر.

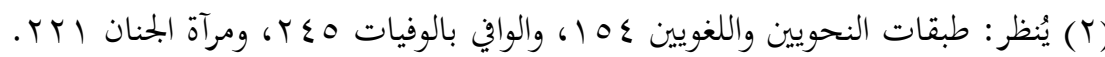

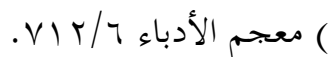

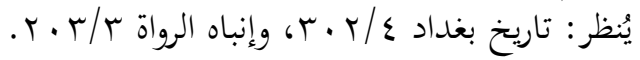

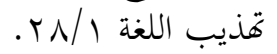

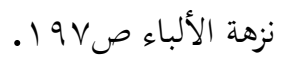

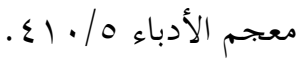


ويقول د/المخزومي:" وأمـا أبو بكر بن الأنباري فهو الذي ترسَّم خطا الكوفيين،

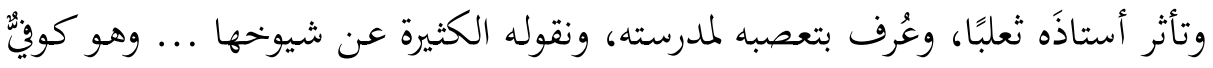

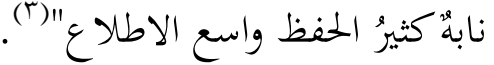

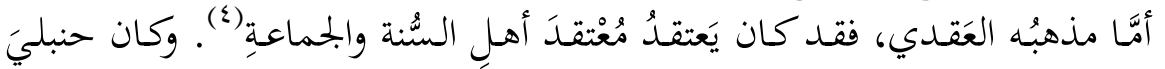

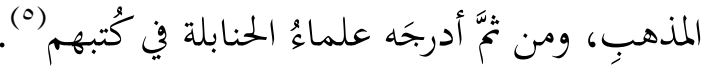

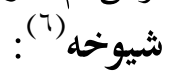

تلقـى أبـو بكـر بـن الأنبـاري العلـمَ على كثير مـن مسشاهير عصره، في مختلف العلوم

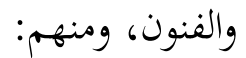

- أحمد بن الحسين أبو جعفر (V)

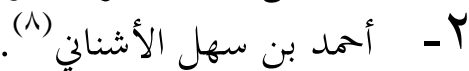

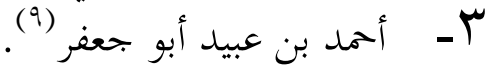

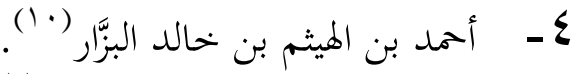

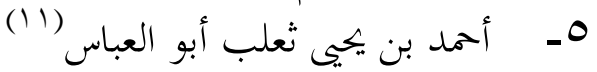

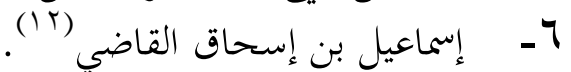

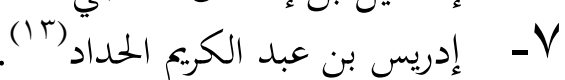
A

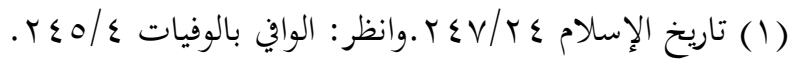

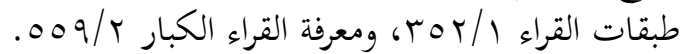

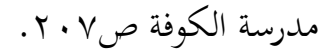

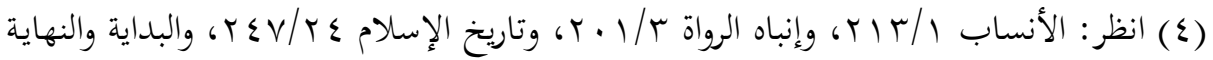

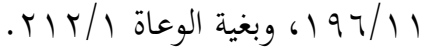

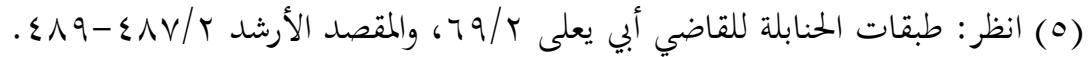

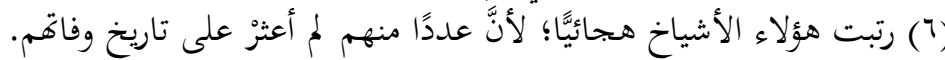

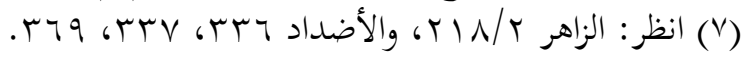

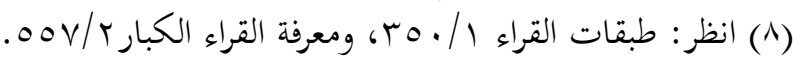

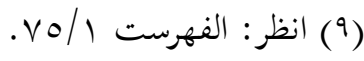

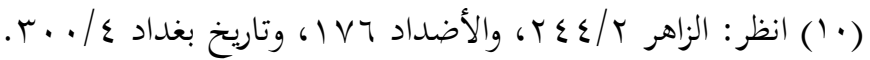

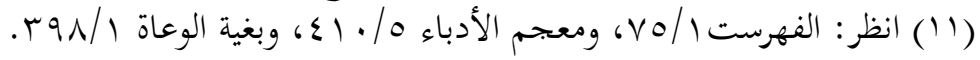

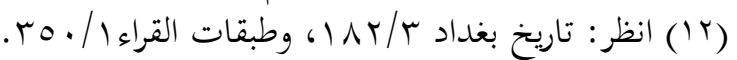

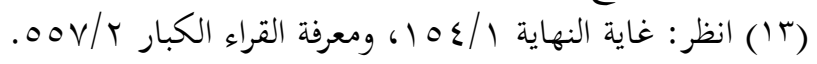

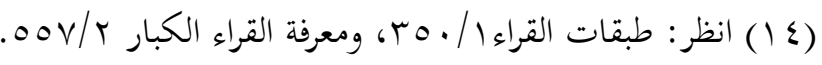




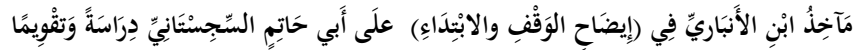

$$
\begin{aligned}
& \text { 9- القاسم بن محمد الأنباري(أبوه) (1). }
\end{aligned}
$$

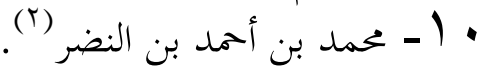

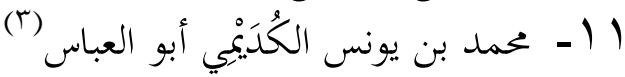

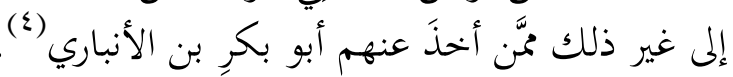

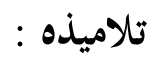

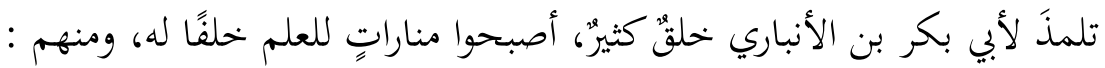

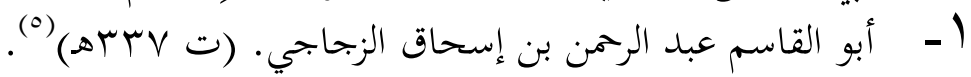

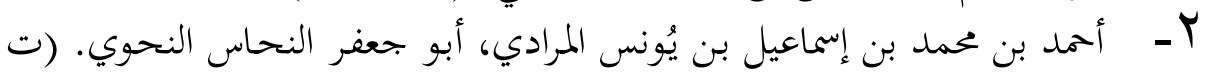

(i) (ATR

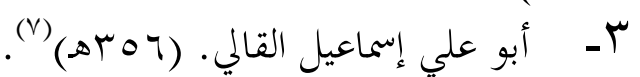

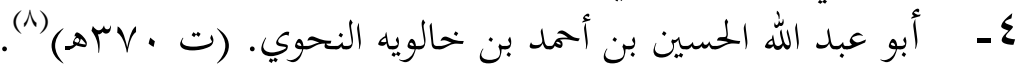

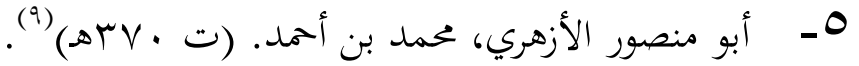

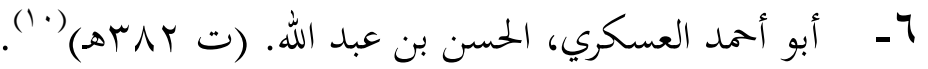

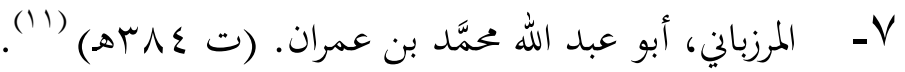

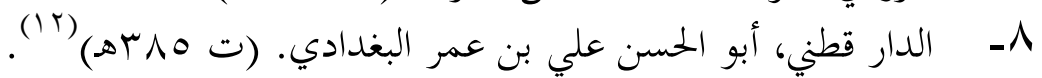

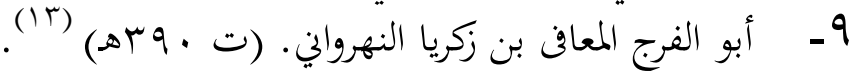

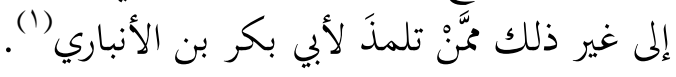

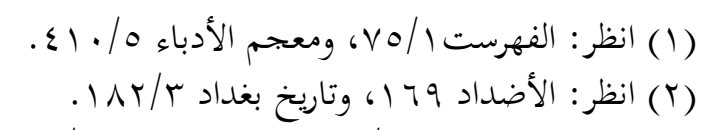

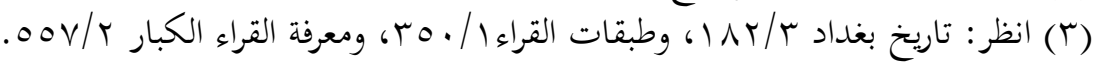

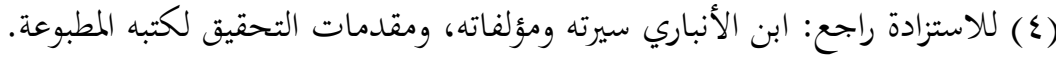

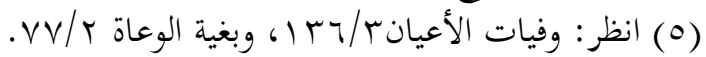

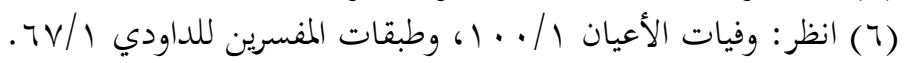

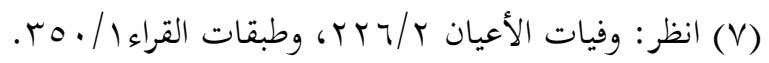

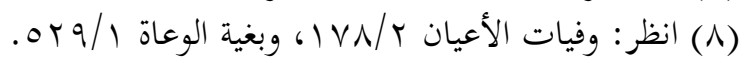

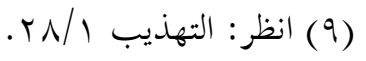

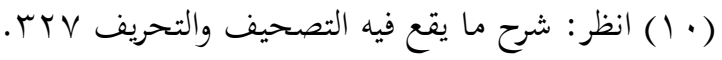

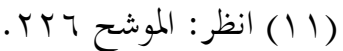

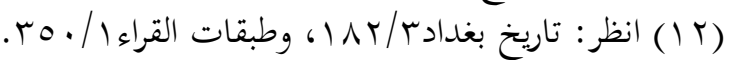

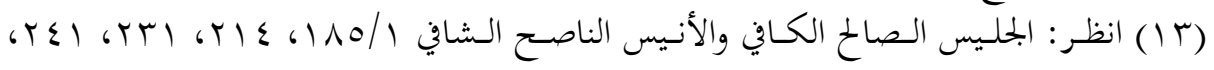




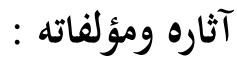

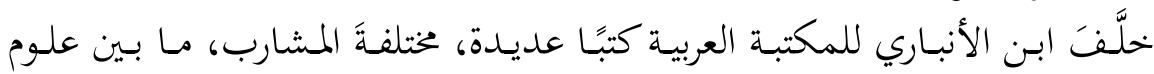

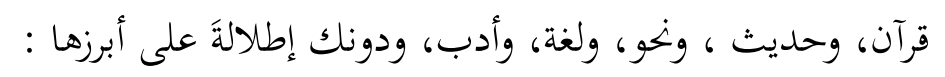

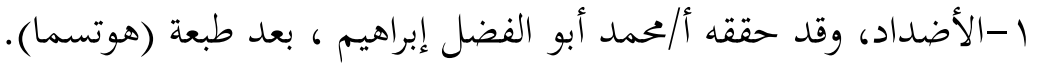

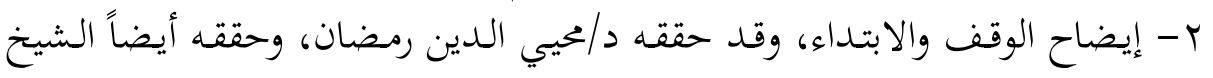

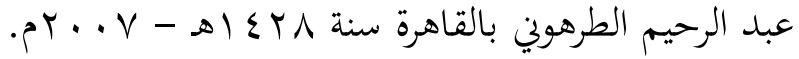

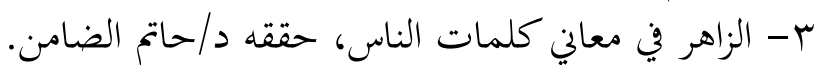

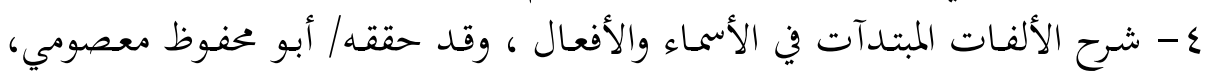

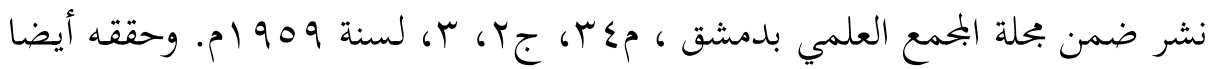

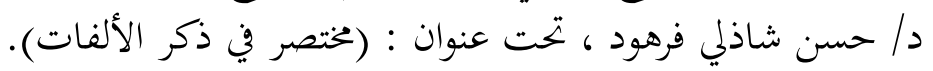

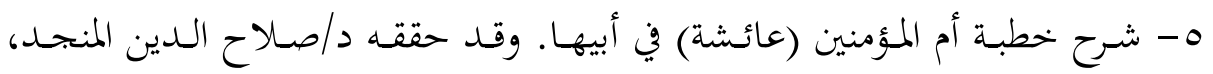

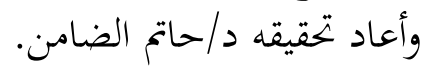

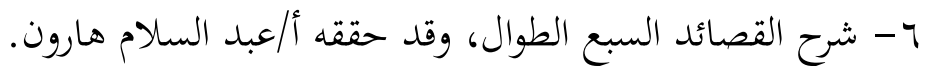

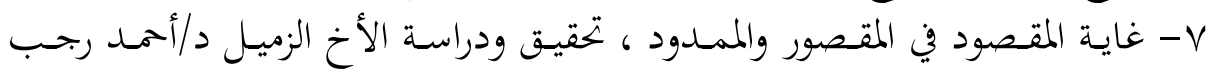

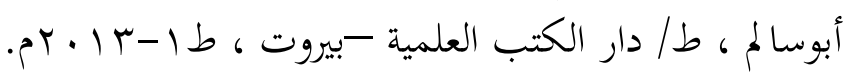

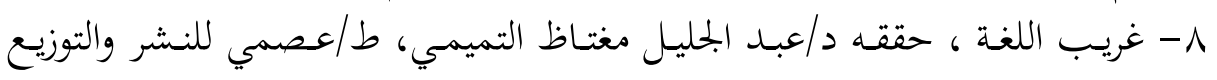

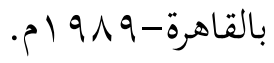
9- المذكر والمؤنث، حققه د / طارق الجنابي ، وحققه أيضا الشيخ/ محمد عبد الخالق عضيمة. • 1 - مرسوم الخط ، وحققه د//متياز على عرشي ، وأعاد تحقيقه د/حاتم الضامن.

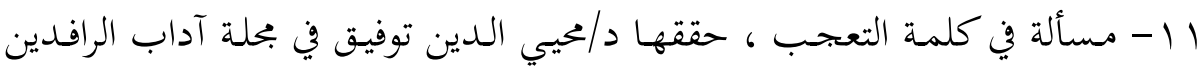

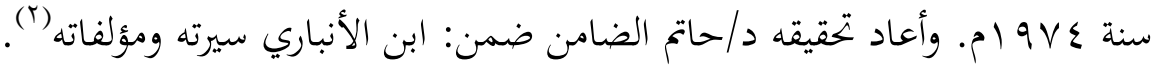
وفاته:

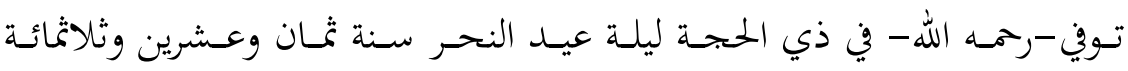

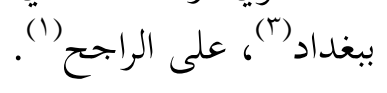

(1) للاستزادة راجع : ابن الأنباري، سيرته ومؤلفاته، ومقدمات الات التحات التحقيق لكتبه المطبوعة.

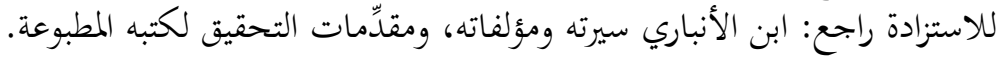

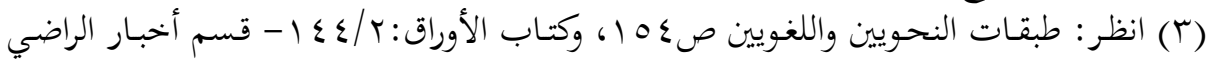

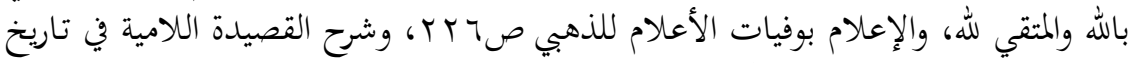

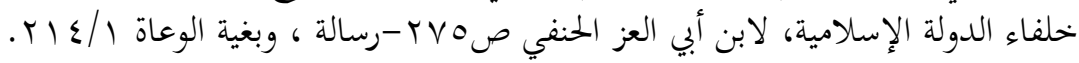




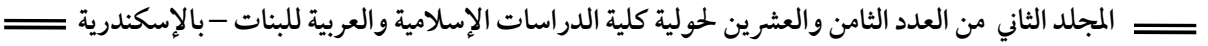

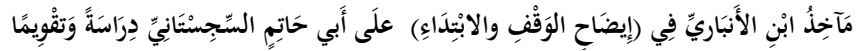

(1) وقيل: إنه توفي سنه سبع وعشرين وثلاثمائة. انظر : تاريخ العلماء النحويين ص. 1 1، ومسالك

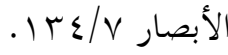

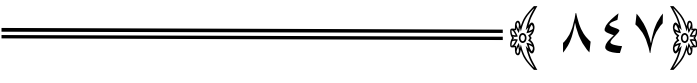




\section{المبحث الثاني: الوقف: تعريفه، أنواعه، صِلته بالنَّحْو}

أولاً: تعريف الوقف:

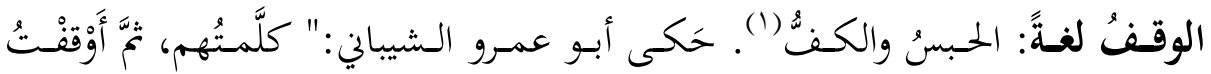

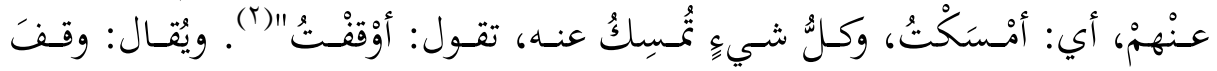

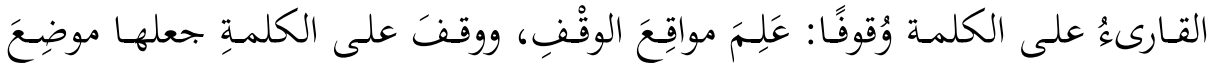

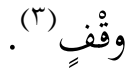

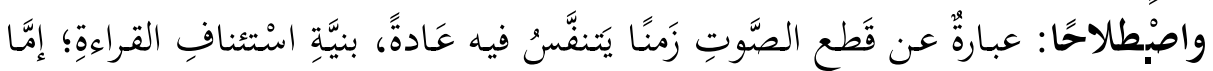

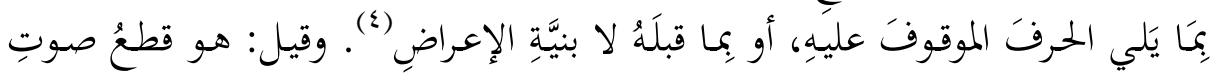

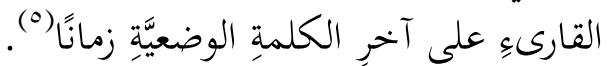

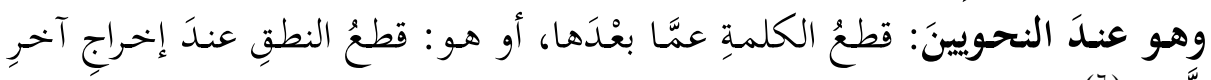
اللَّفة: (7) هذا، وقد يَستخدمُ بعضُ النحويين - كسيبويهٍ - الوقفَ بمعنى البناءٍ على السكون،

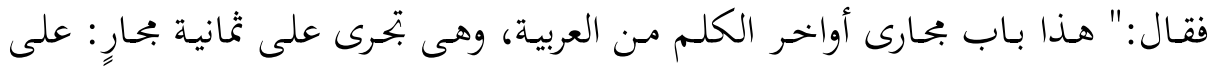

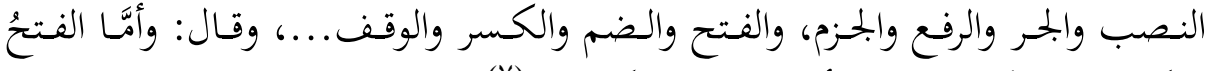

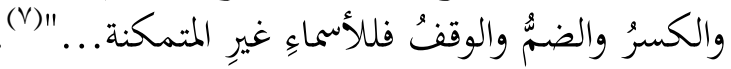

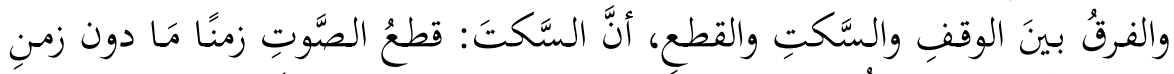

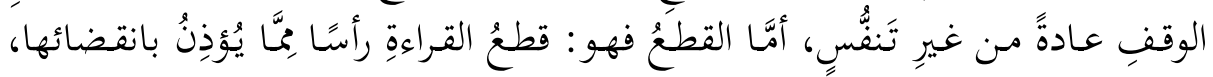

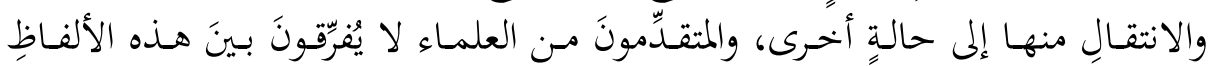

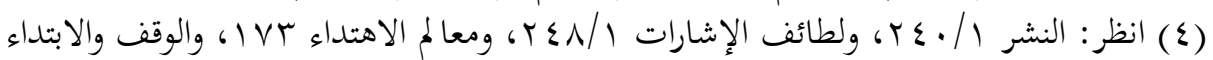




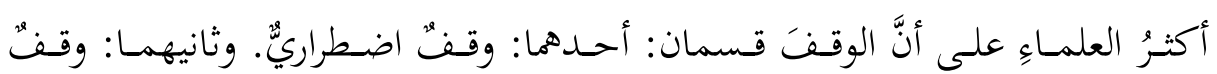

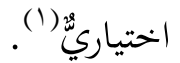

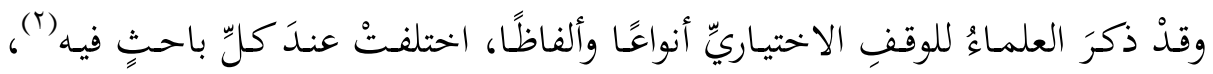

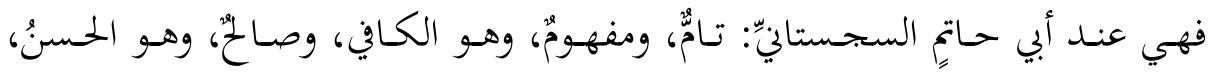
وناقصٌ، وهو القبيح.

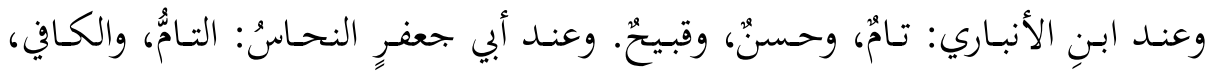

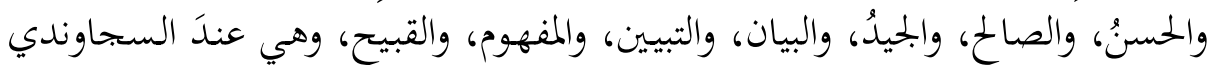

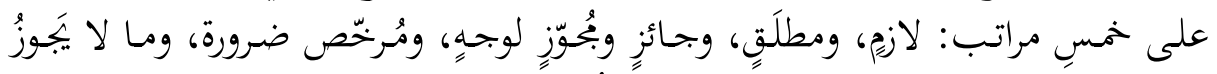

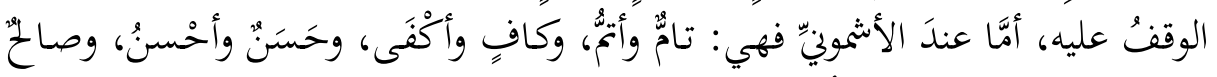

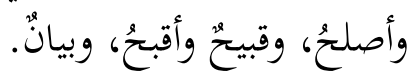

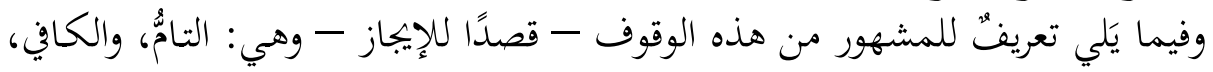

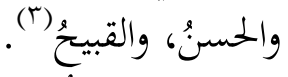

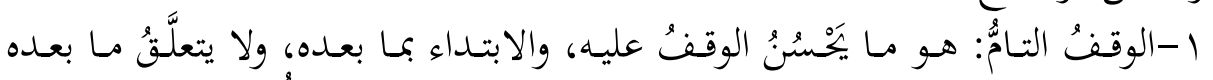

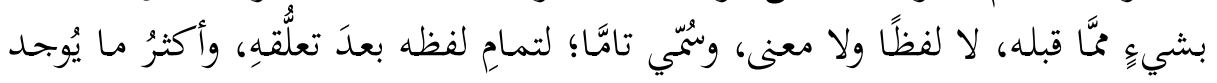

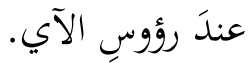

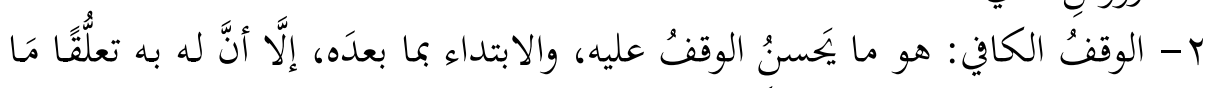

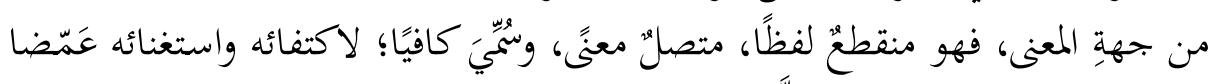

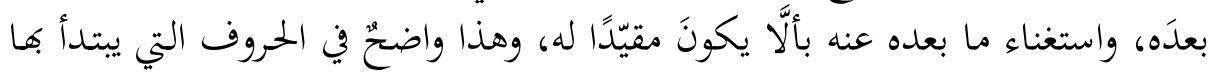

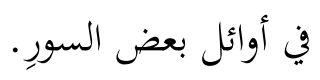

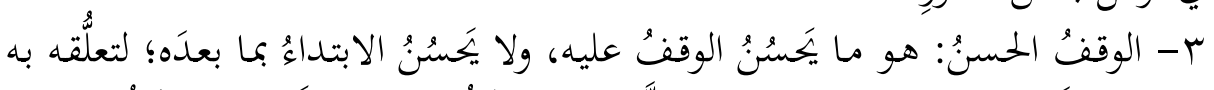

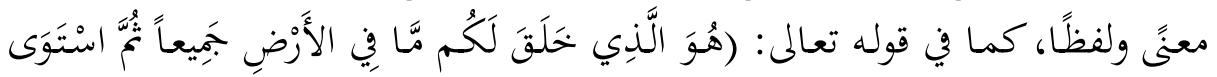

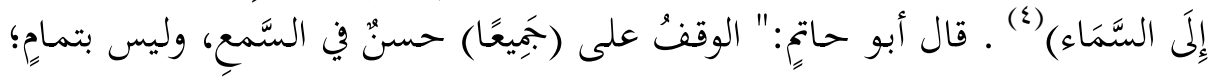

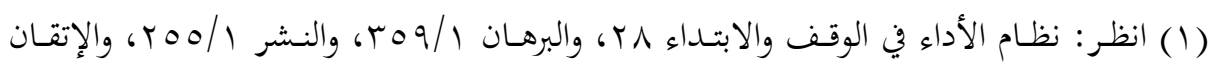

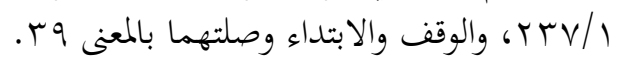

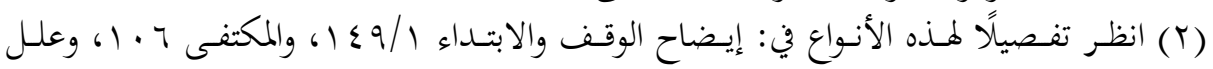

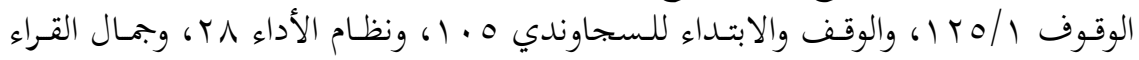

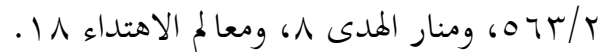

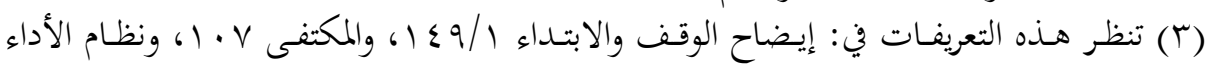

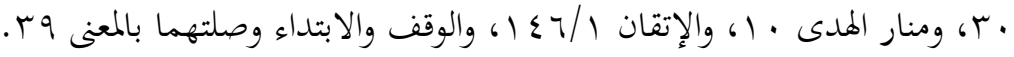

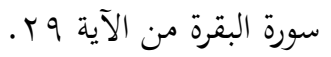




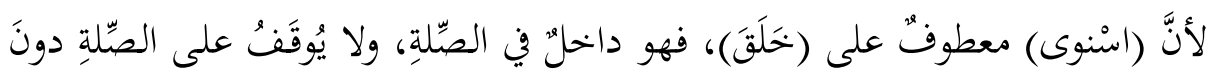
الموصُولِ، ولا على الموصُولِ دونَ الصِّلةِ" (1).

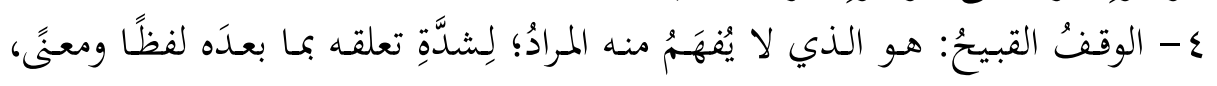

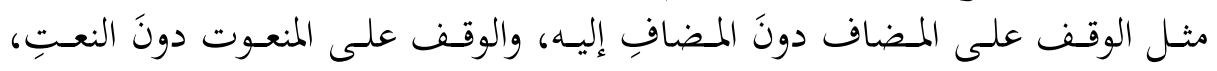

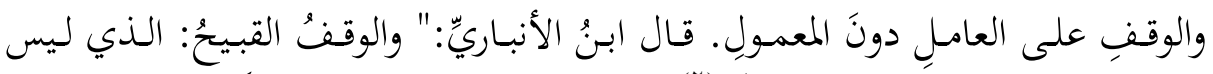

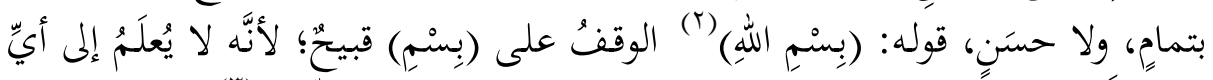

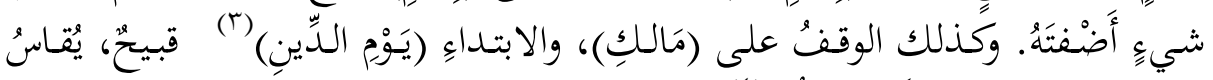

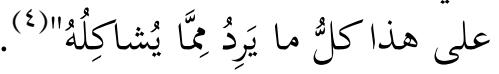

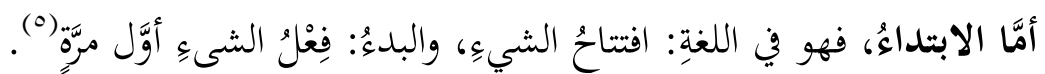

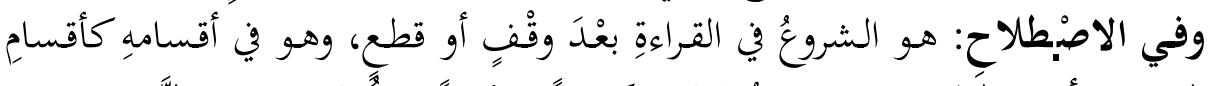

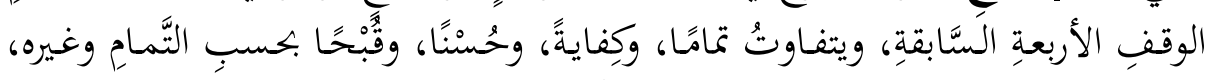

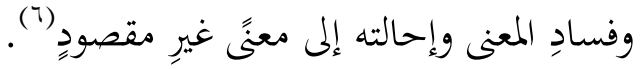

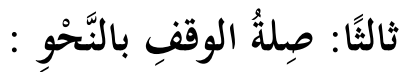

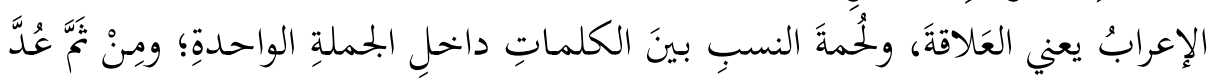

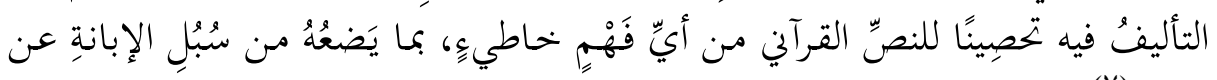
معانيه (v)

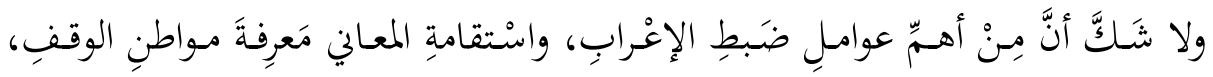
ومواطن الابتداءٍ في الكلام.

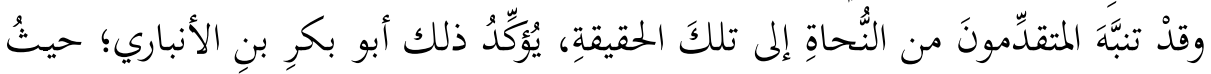

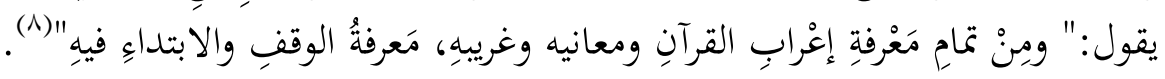

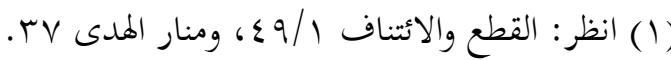

$$
\begin{aligned}
& \text { (Y) جزء من الآية الأولى من سورة الفاتحة. }
\end{aligned}
$$

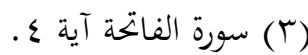

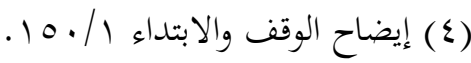

$$
\begin{aligned}
& \text { (1) انظر: اللسان، والقاموس المخيط (بدأ). }
\end{aligned}
$$

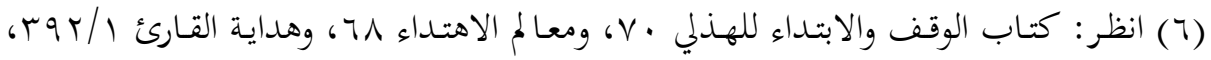

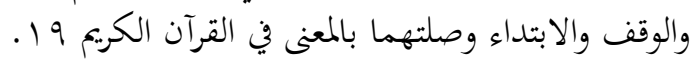

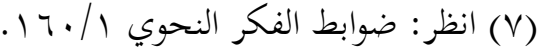

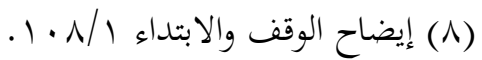




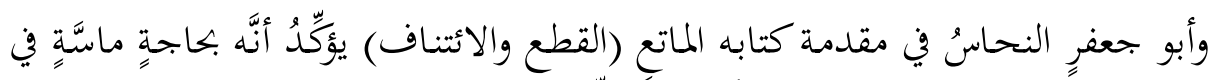

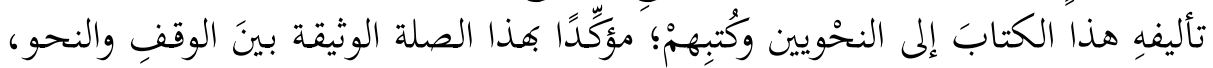

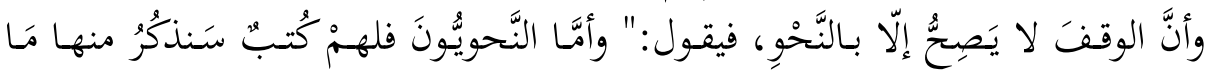

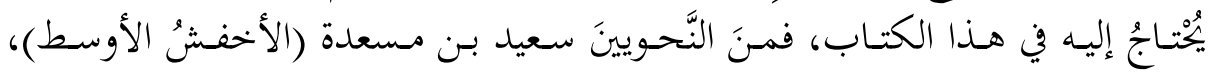

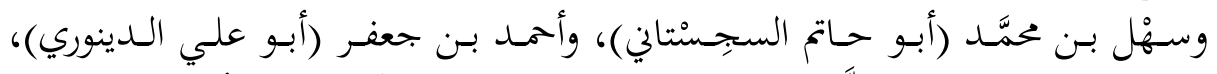

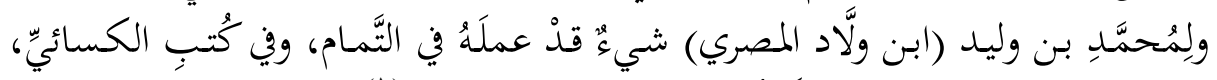

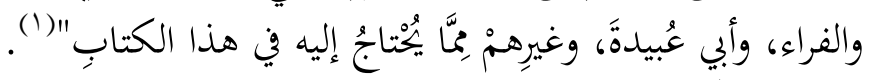

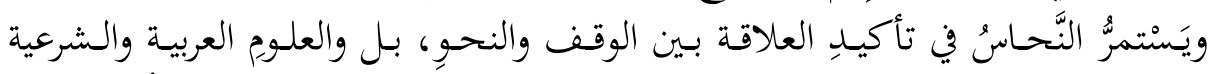

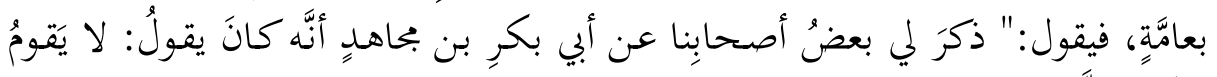

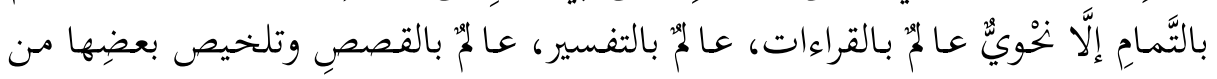

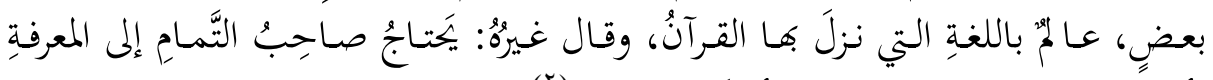

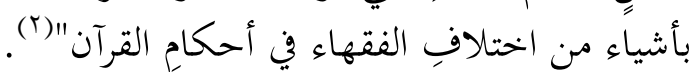

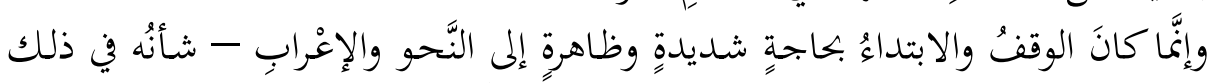

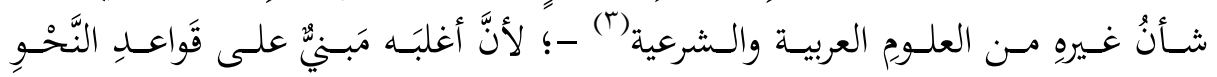

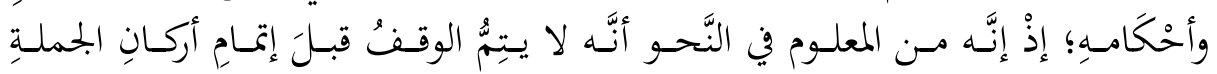

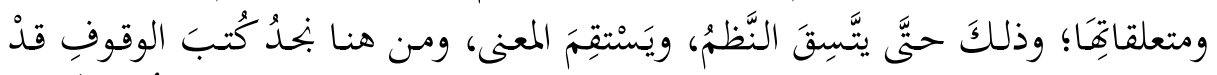

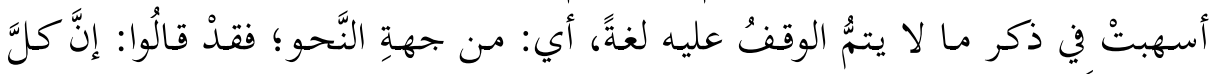

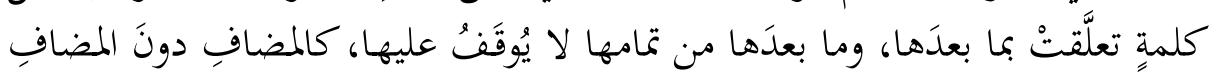

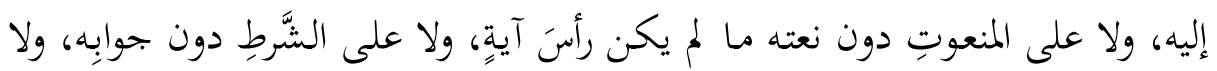

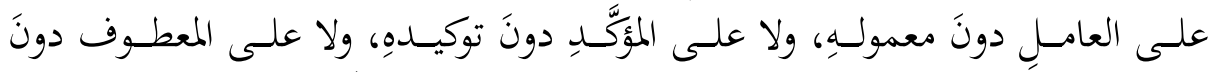

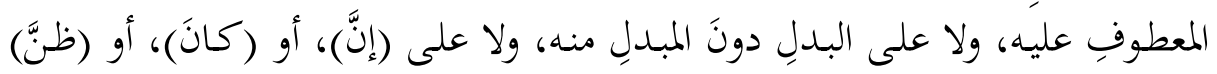

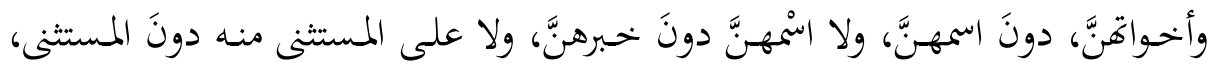

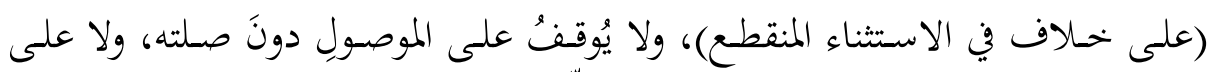

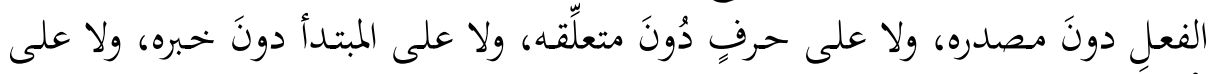

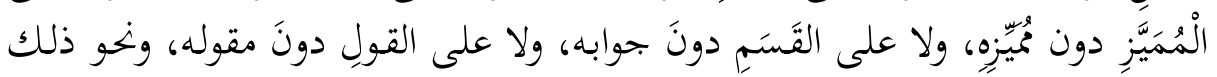

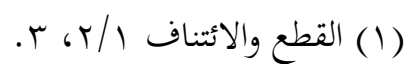

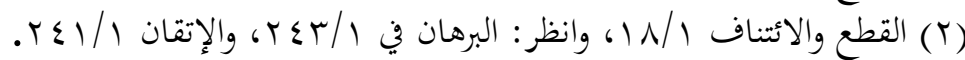




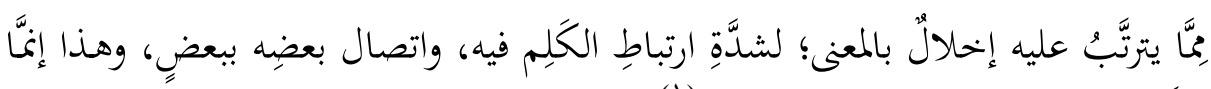

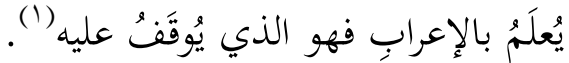

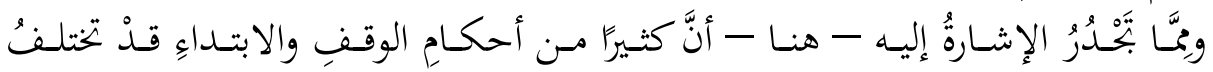

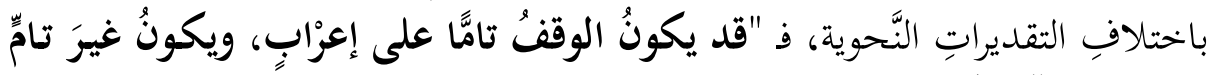

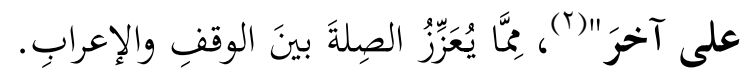

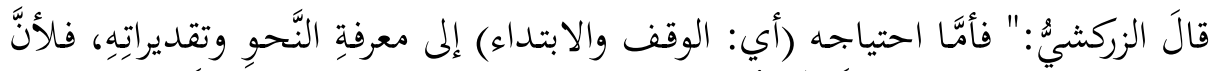

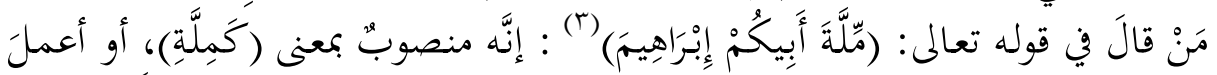

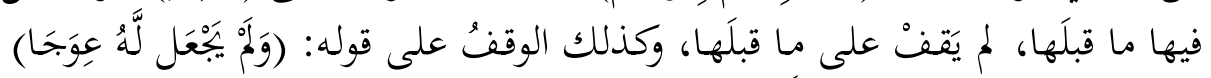

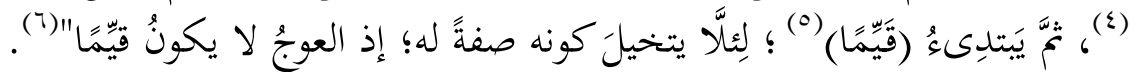

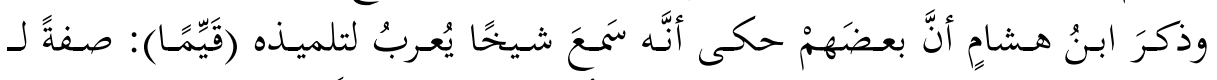

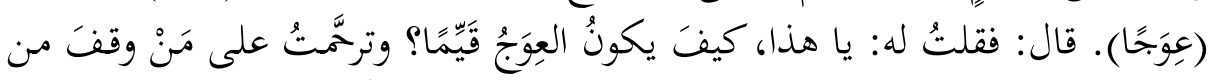

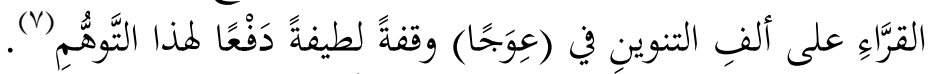

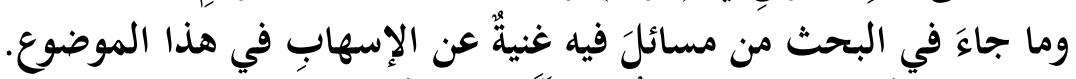

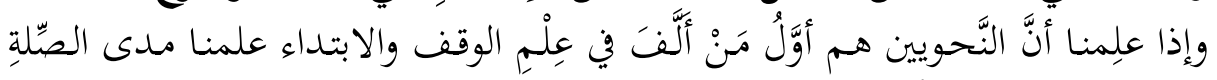

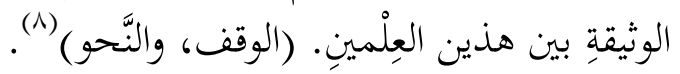

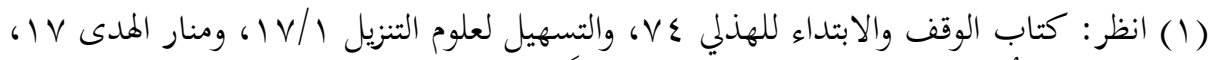

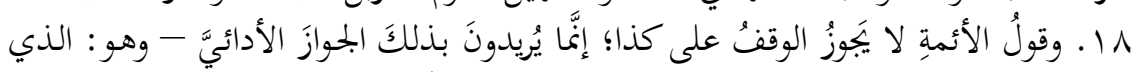

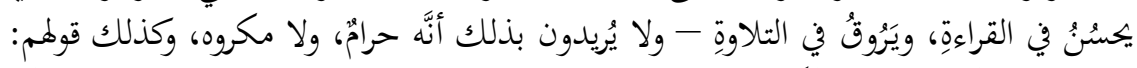

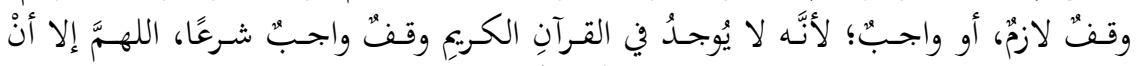

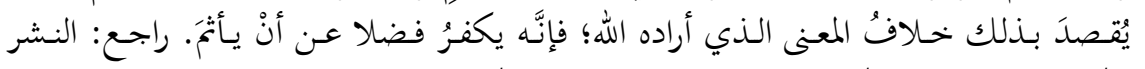

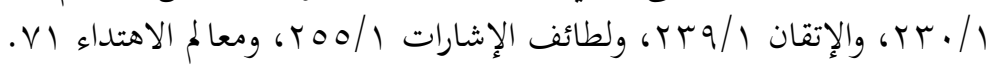

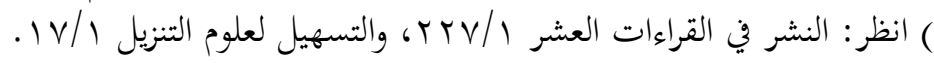

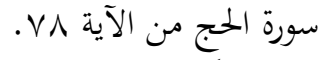

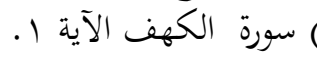

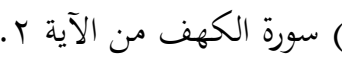

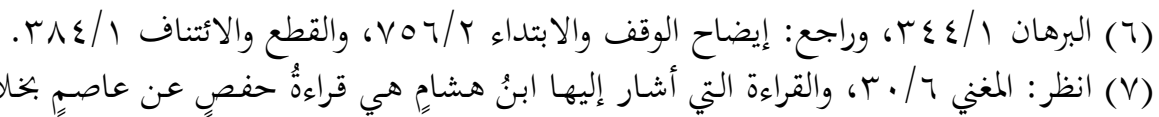

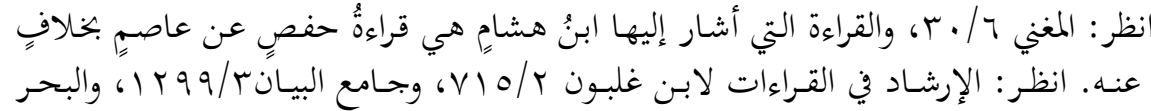

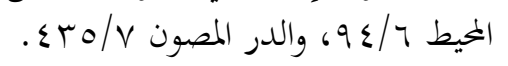

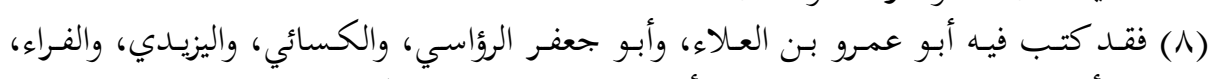

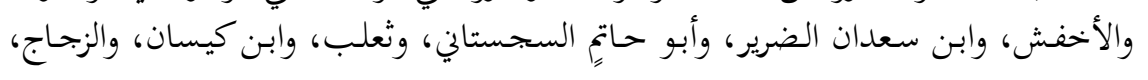




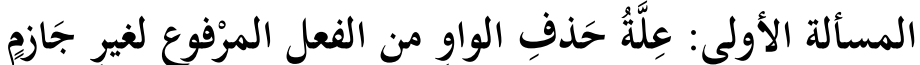

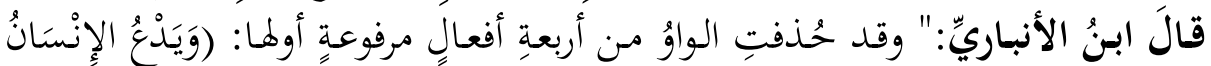

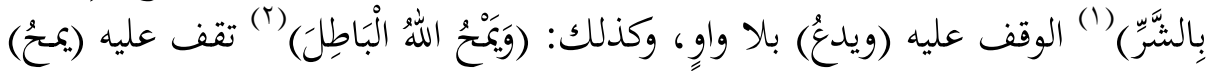

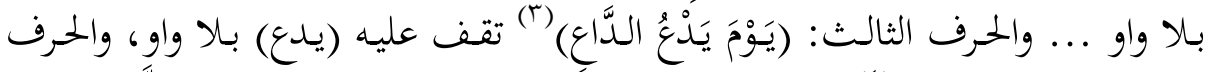

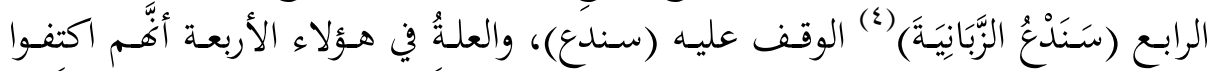

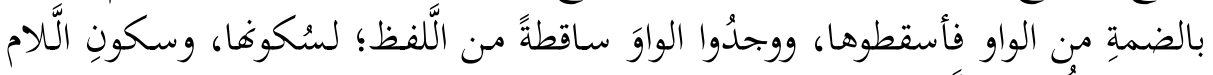

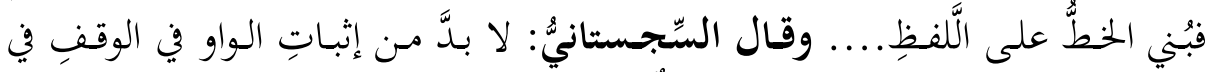

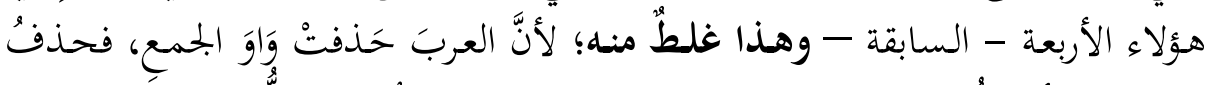

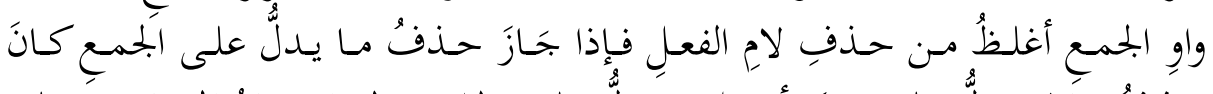

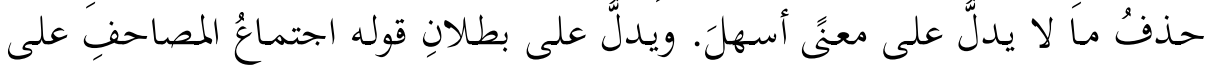

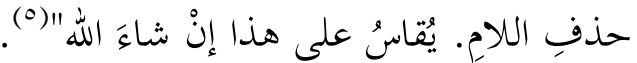

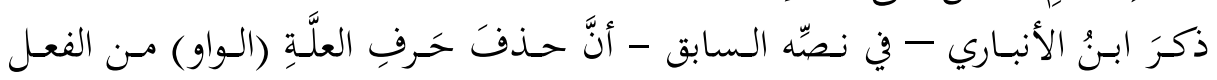

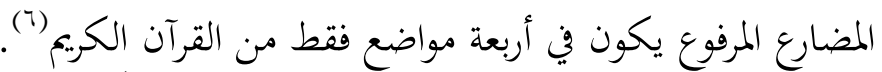

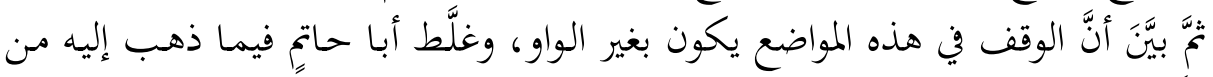

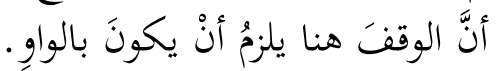

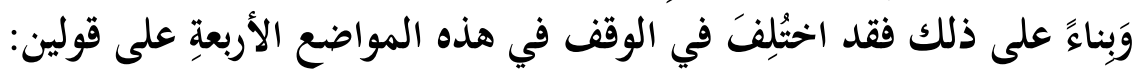

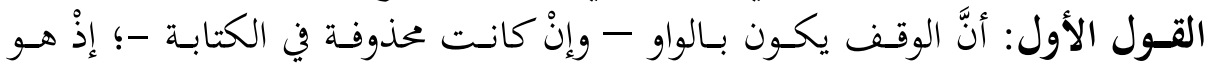

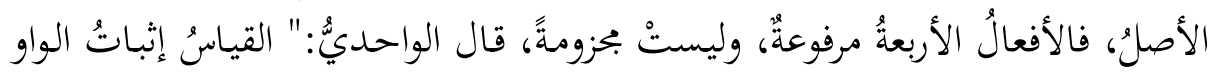

وابن الأنباري، والنحاس، والسيرافي، وهؤلاء كُلُهم من النحاة بل من مُتقدميهم. انظر تفصيلا

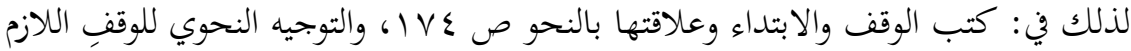

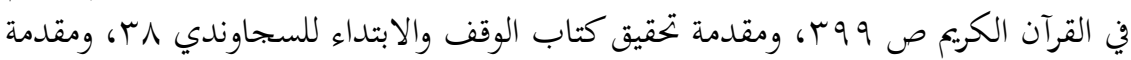

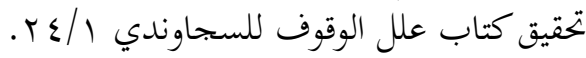

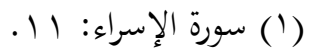

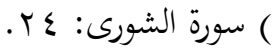

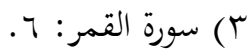

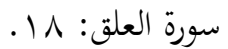

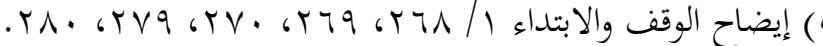

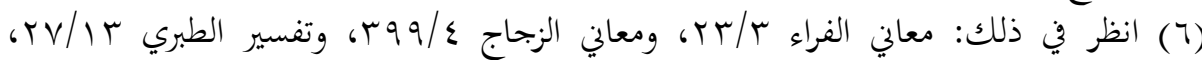

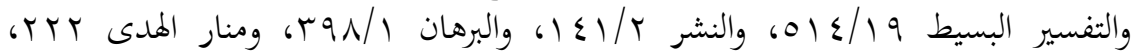

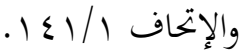




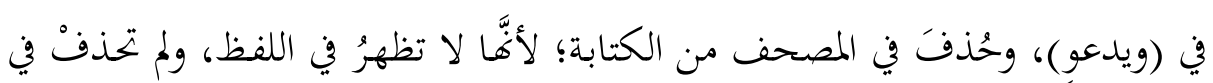

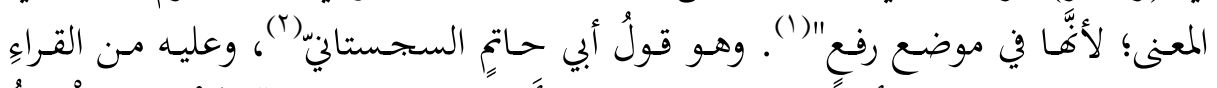

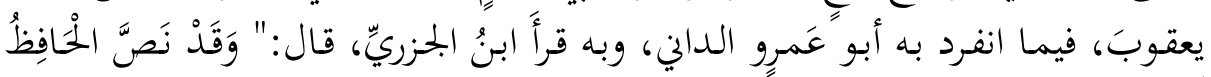

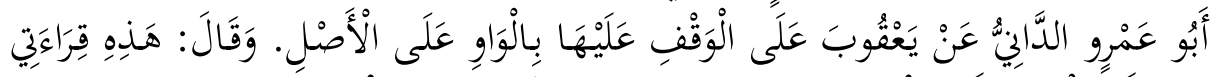

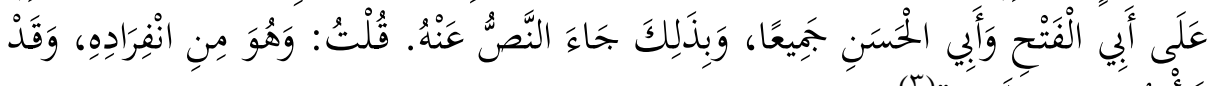

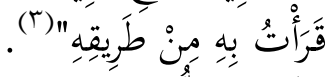

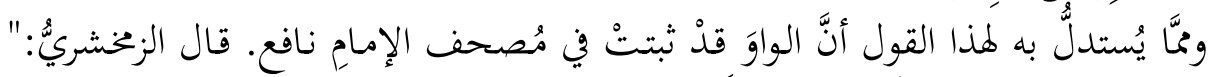

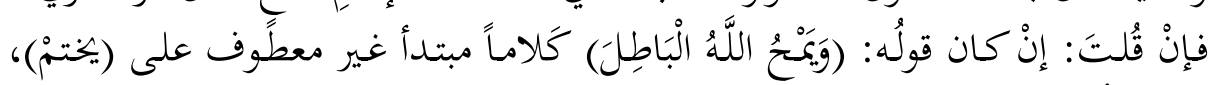

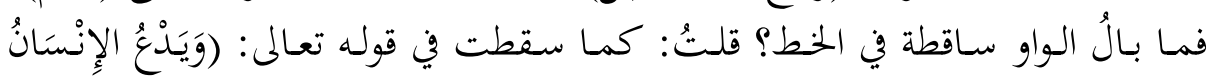

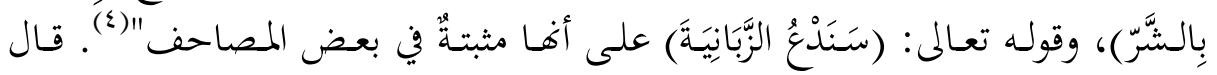

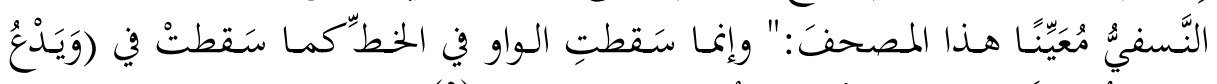

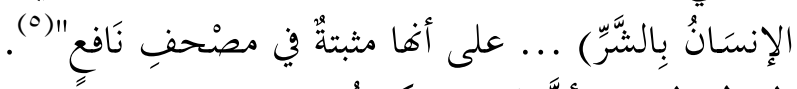

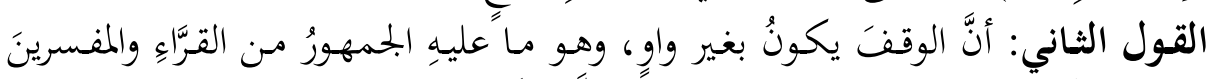

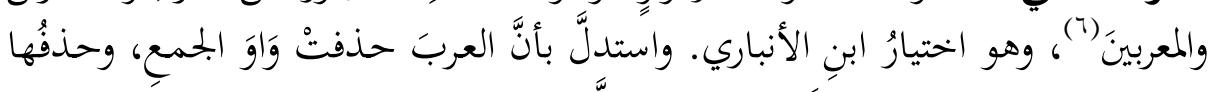

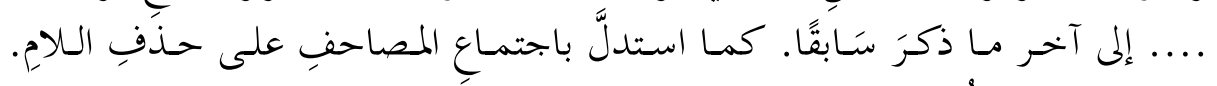

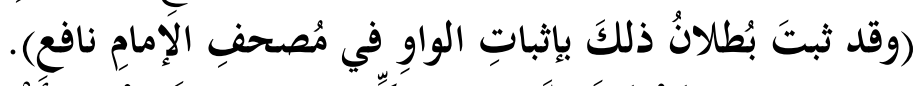

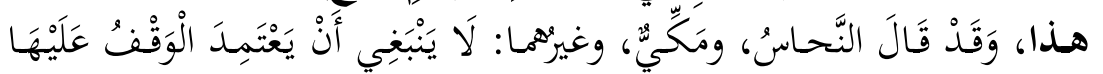

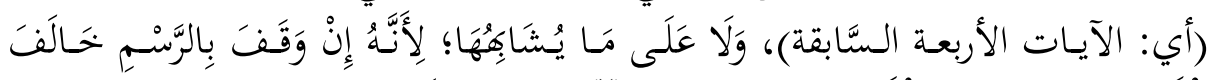

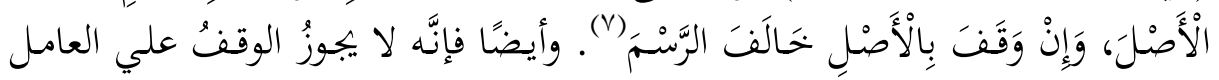

دون معمولِه.

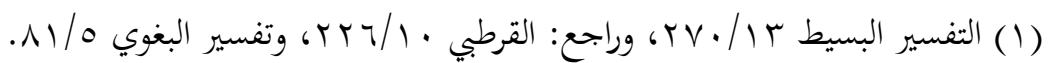

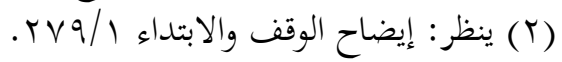

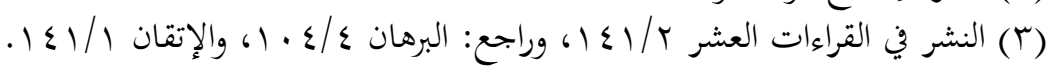

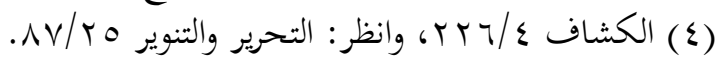

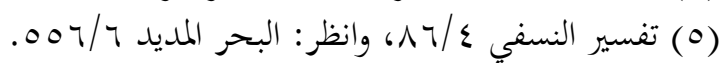

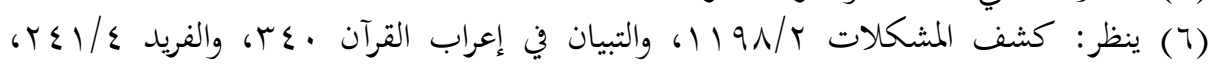

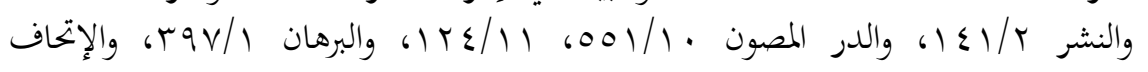

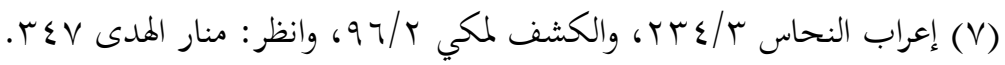




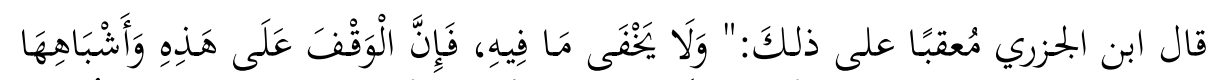

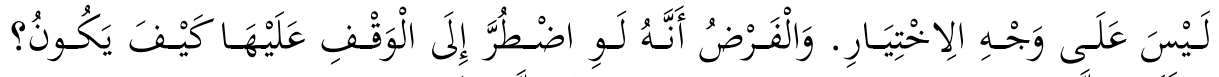

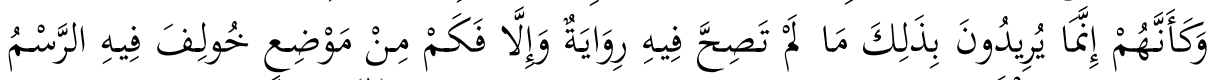

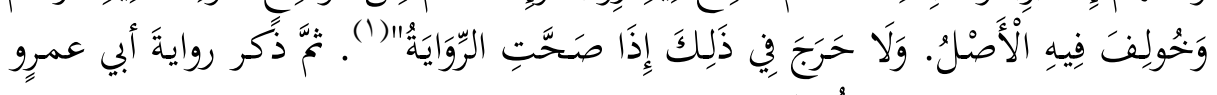

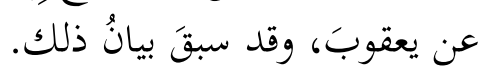

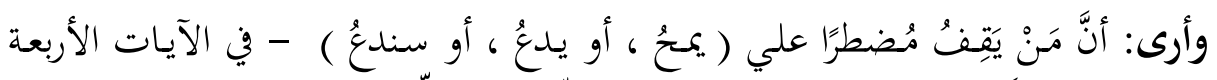

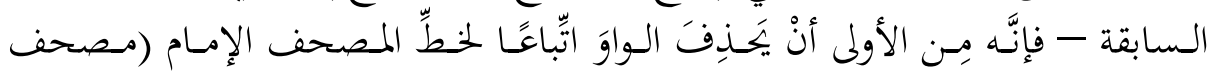

$$
\text { عثمان) ( عثان) }
$$

\section{أمَّا عن عِلَّة سُقوطِ الواو لفظًا في هؤلاء الأربعة فقد اختُلِفَِ فيها على النحو}

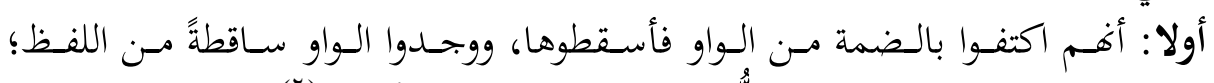

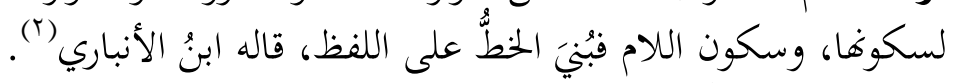

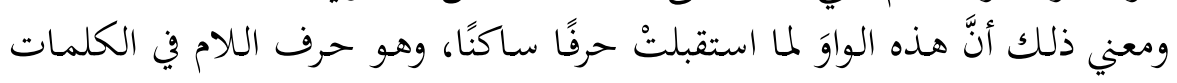

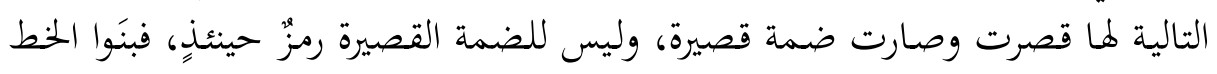

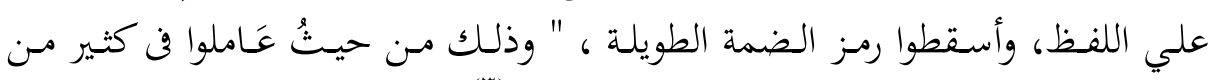

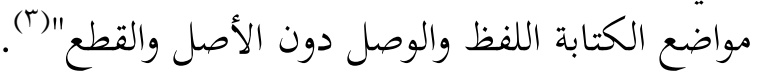

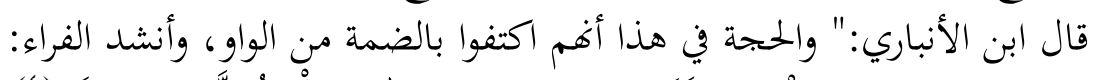

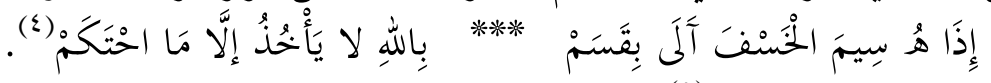

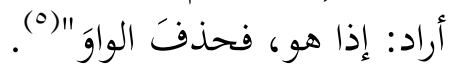

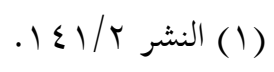

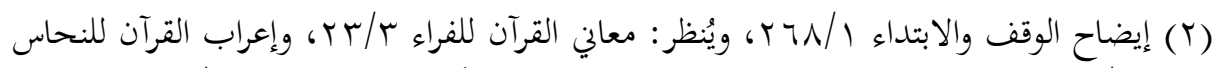

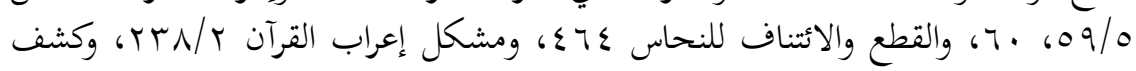

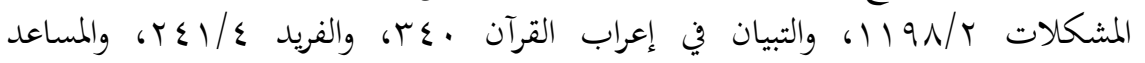

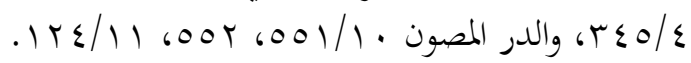

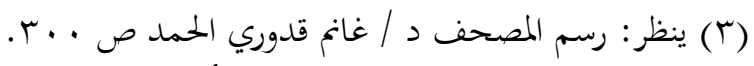

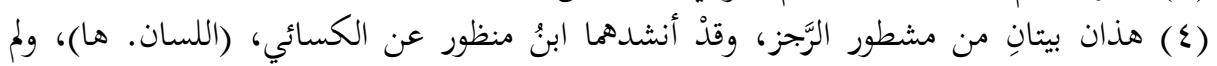

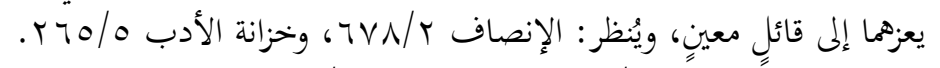

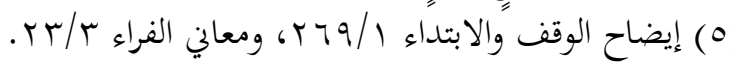




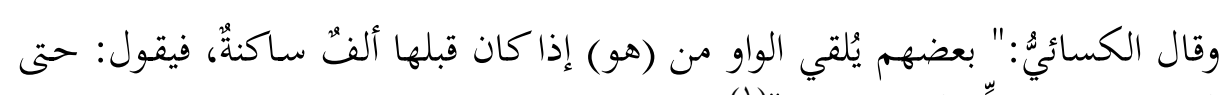

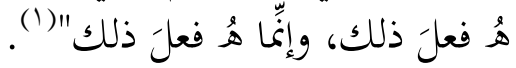

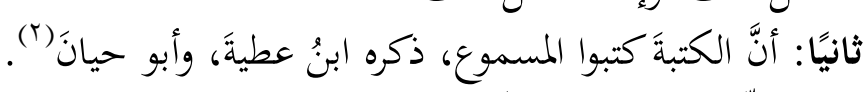

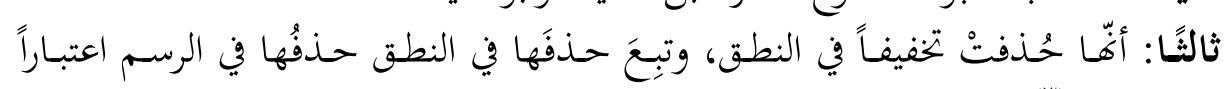

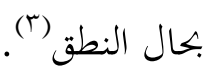

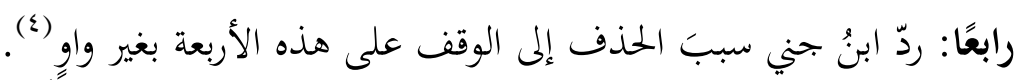

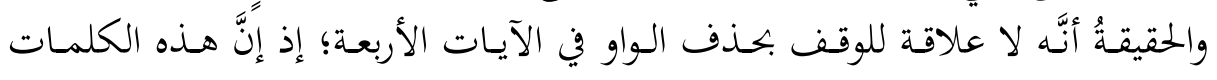

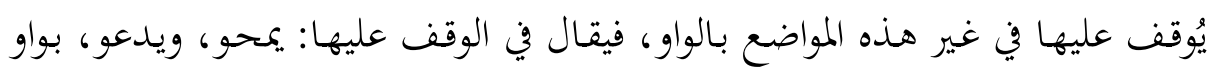

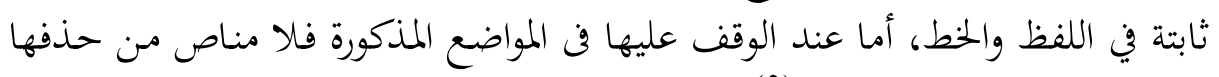

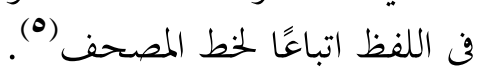

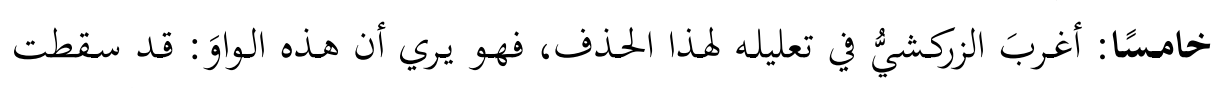

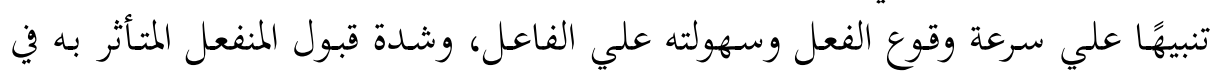

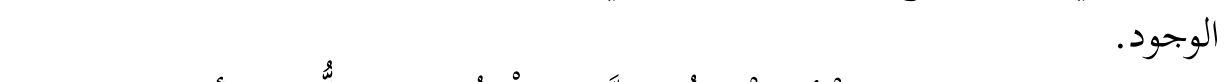

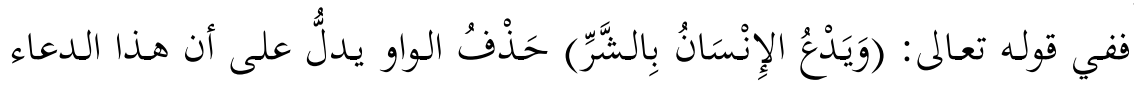

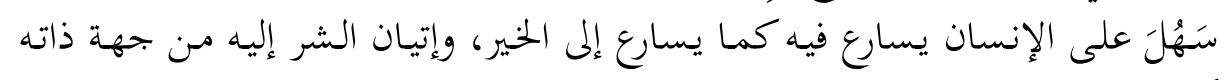
أقرب إليه من الخير.

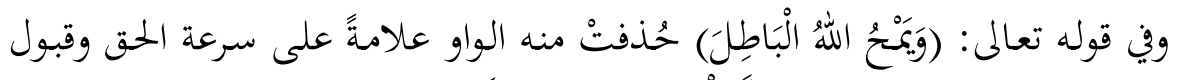

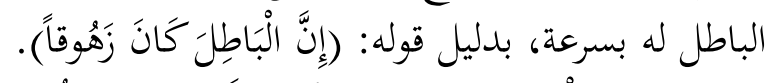

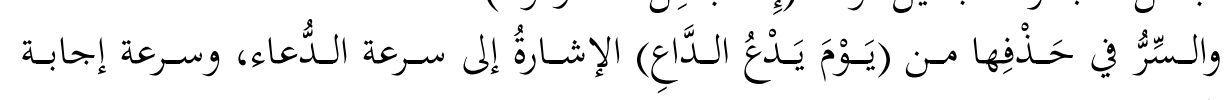

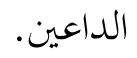

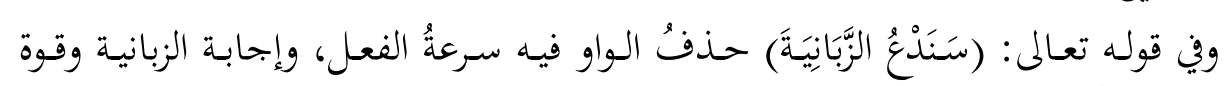
البطش (1)

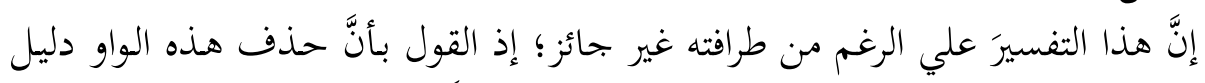

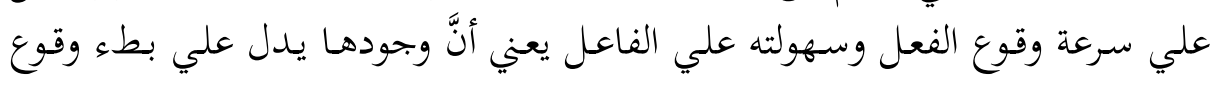

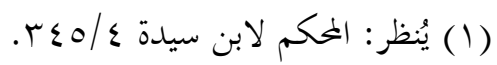

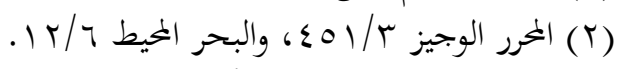

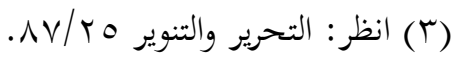

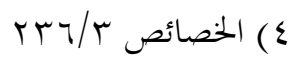

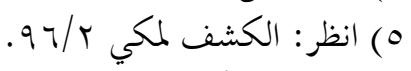

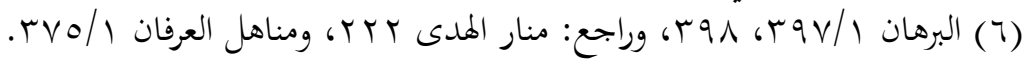


الفعل وصعوبته علي الفاعل. وقد ثبتت الواو في مواضع أخري من القرآن الكريم، نحو

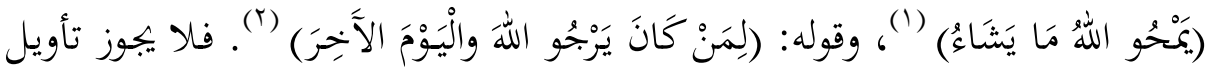

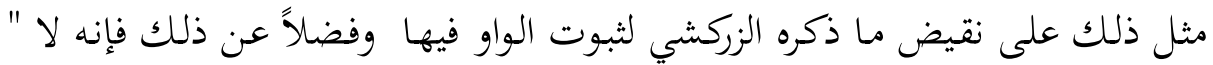

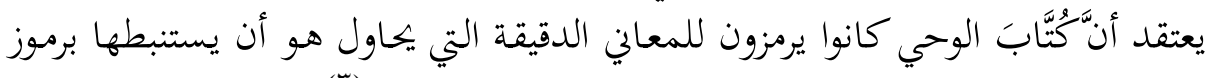

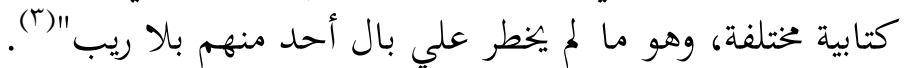

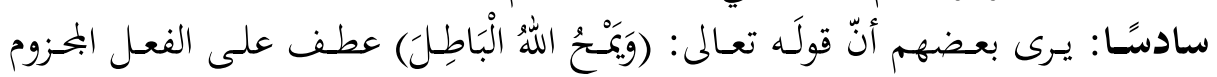

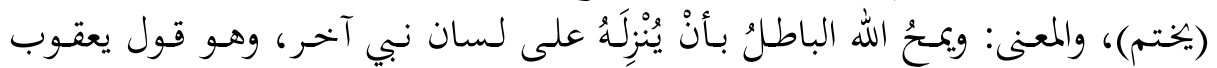

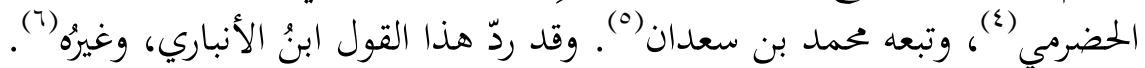

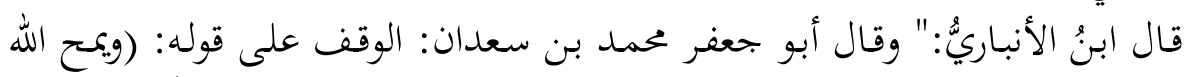

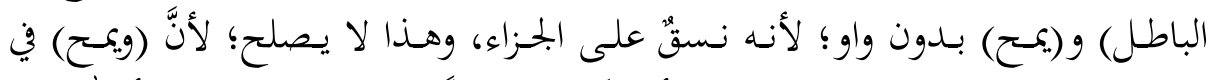

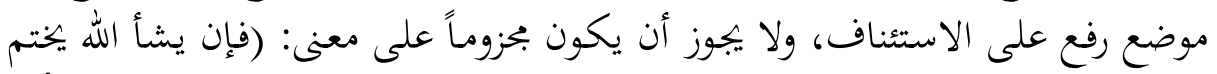

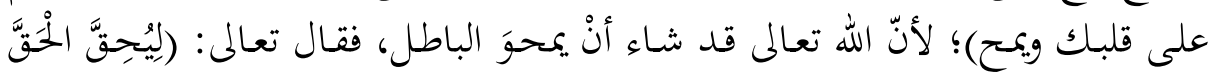

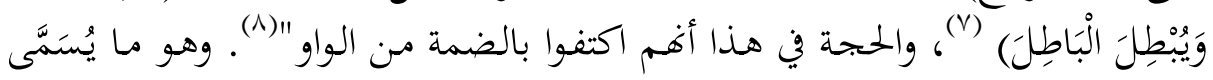

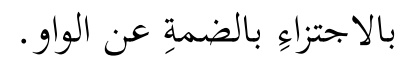
وقال أحمد الأشموني: "وقيل موضع (يمح) جزم عطفاً على (يختم)، وليس كذلك الفيك

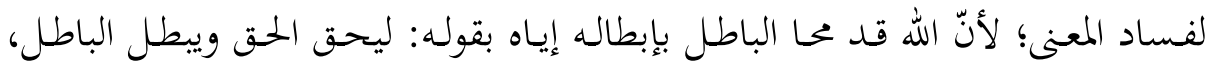

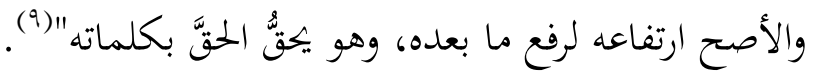

$$
\begin{aligned}
& \text { (1) سورة الرعد آية جهr. }
\end{aligned}
$$

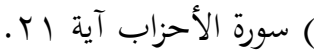

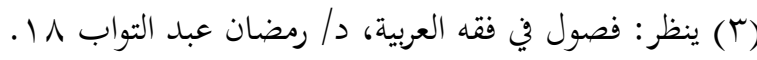

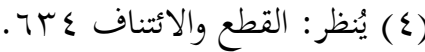

$$
\begin{aligned}
& \text { (0) يُنظر : الإيضاح }
\end{aligned}
$$

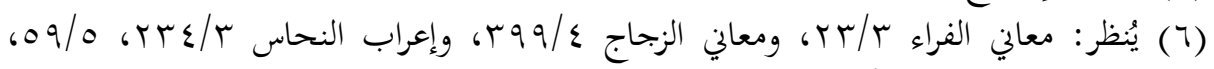

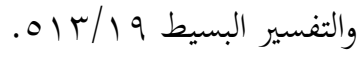

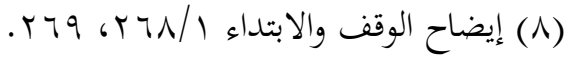

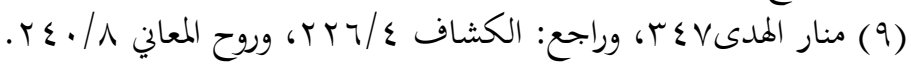




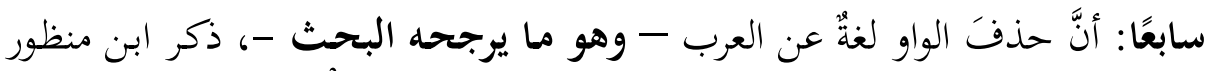

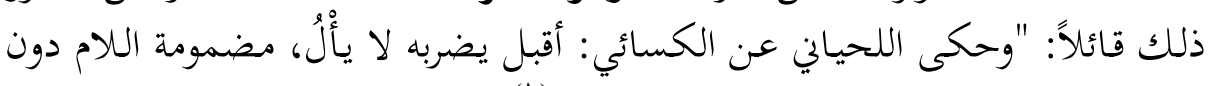

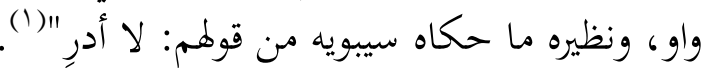

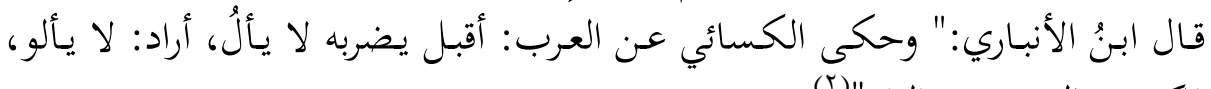

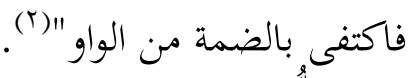

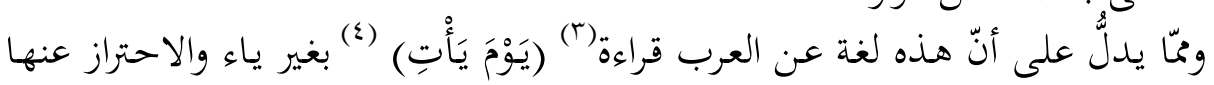

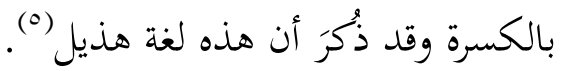

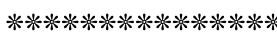

\section{المسألة الثانية: معنى (كَلَّاَ)}

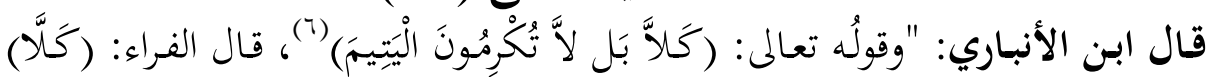

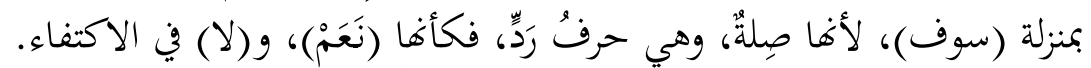

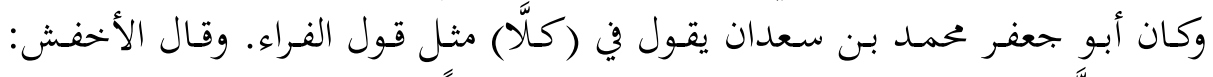

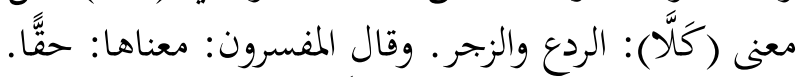

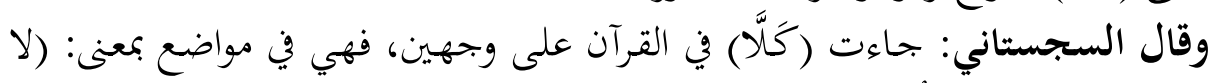

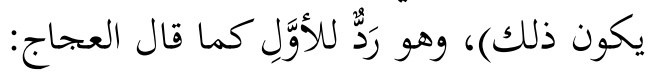

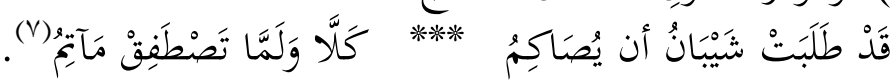

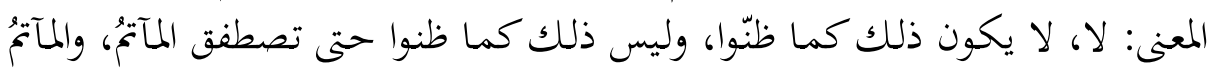

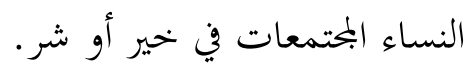

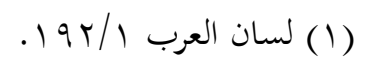

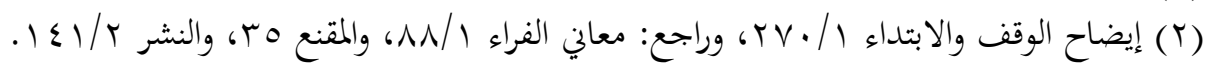

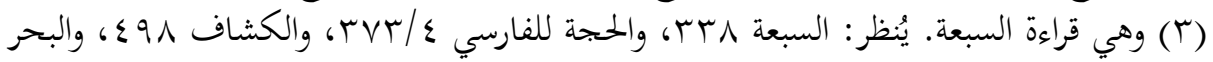

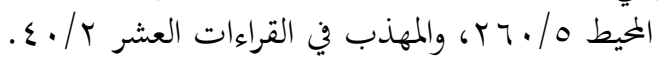

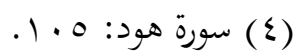

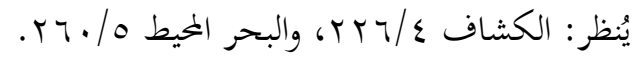

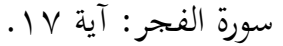

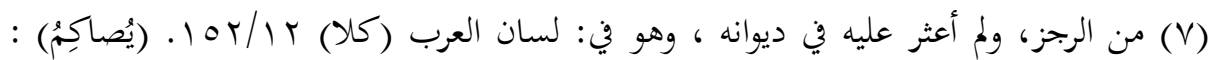

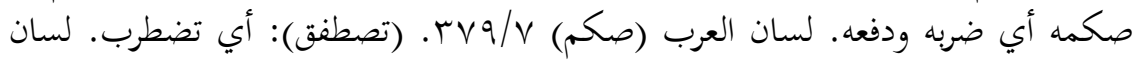

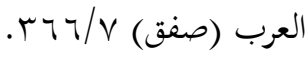


قال وبتجيء في معنى: (ألا) التي هي للتنبيه، يُستفتح بها الكلام كقوله: (أَلا إِنَّهُمْ يَتْنُونَ

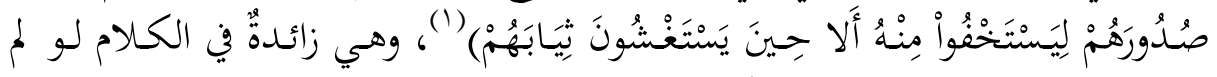

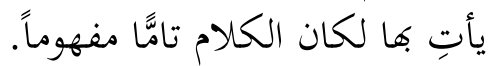

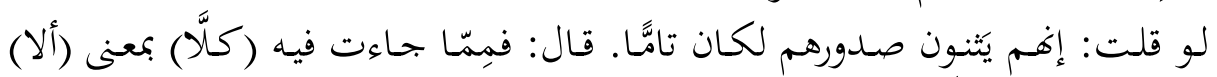

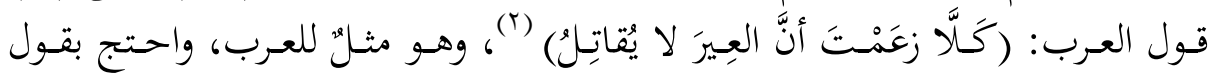

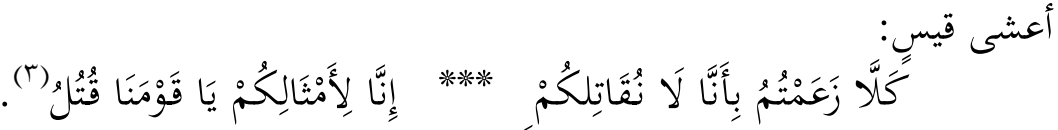

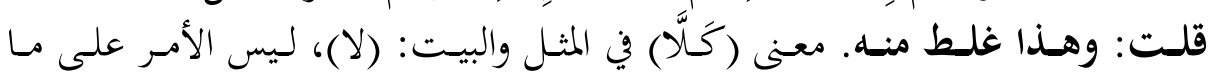
يقولون.

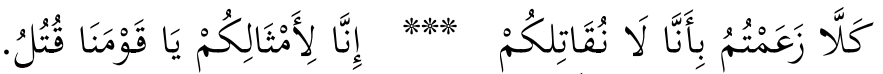

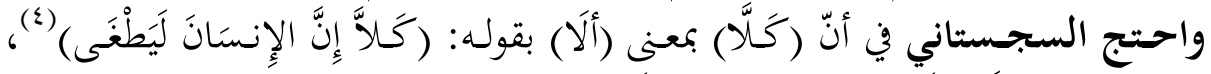

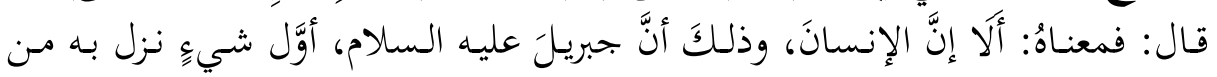

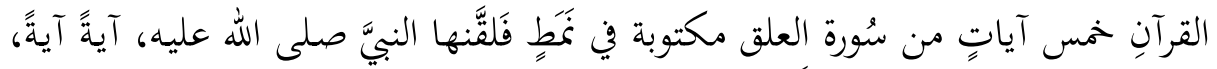

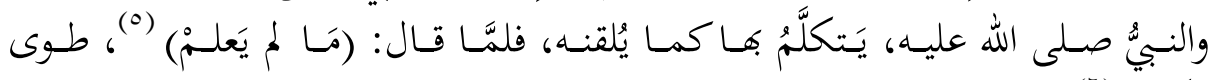

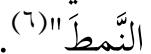

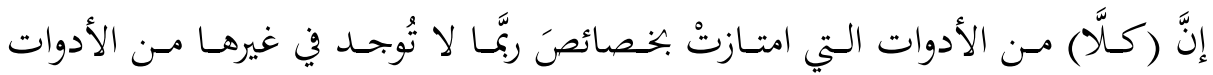

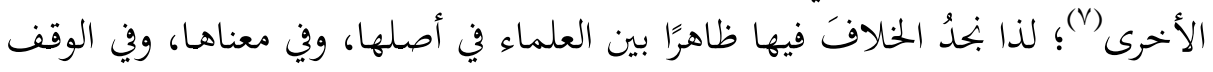

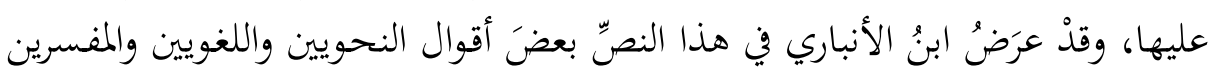

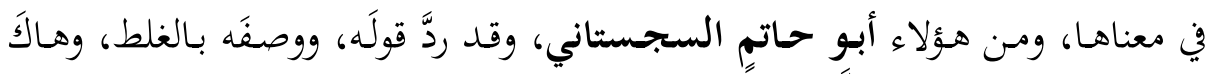

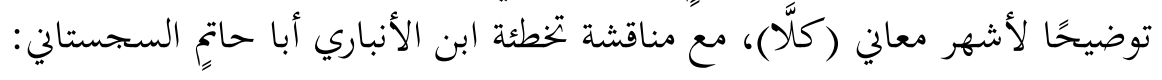

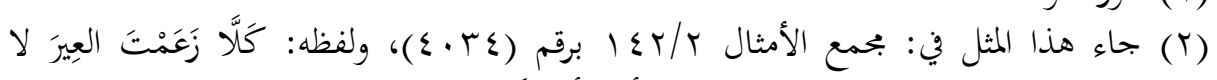

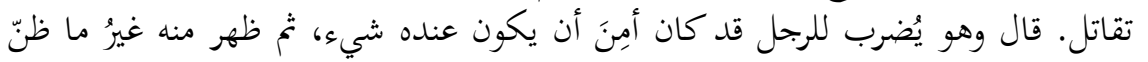

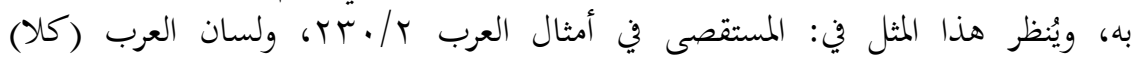
$.10 \mathrm{r} / 1 \mathrm{r}$

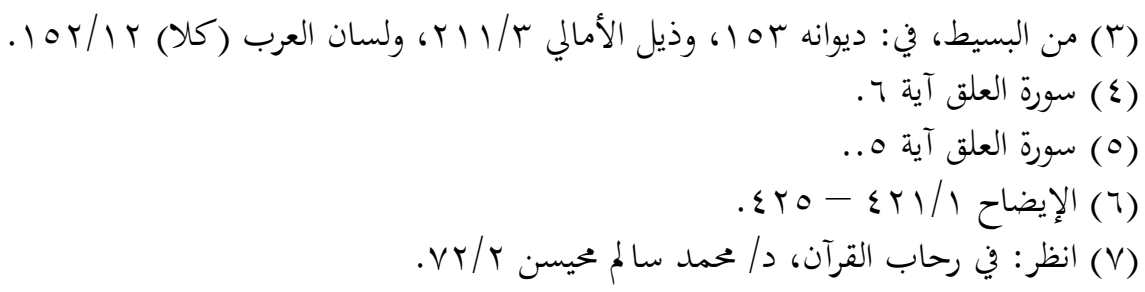




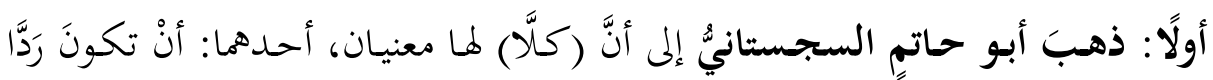

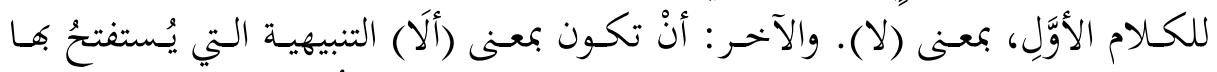

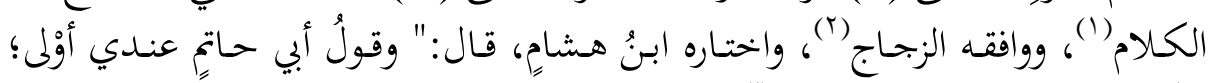

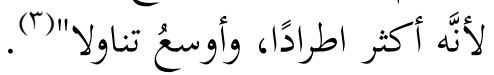

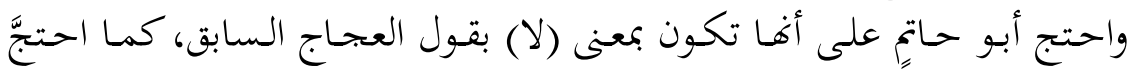

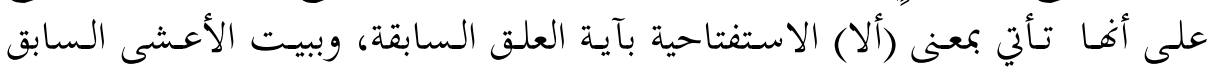

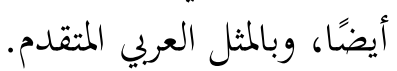

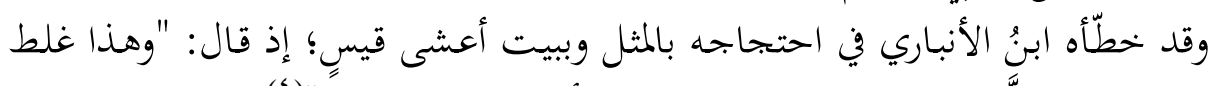

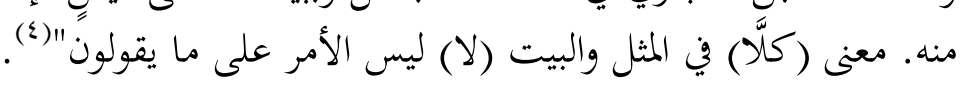

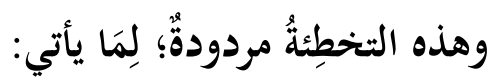

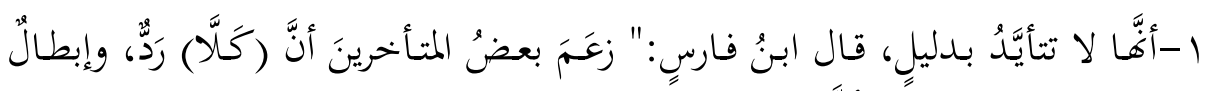

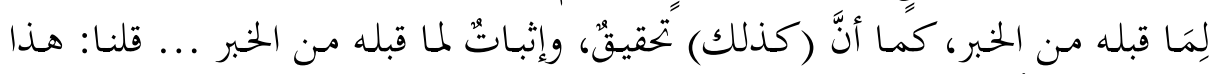

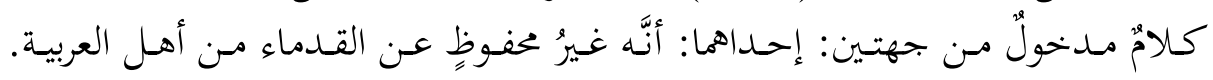

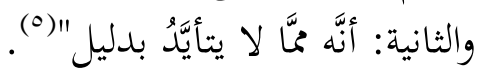

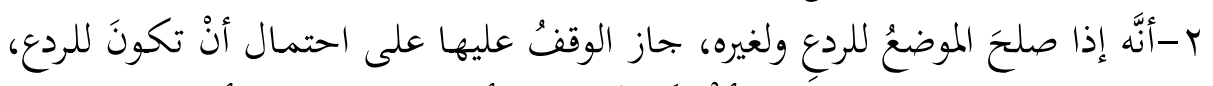

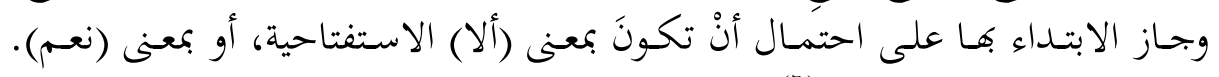

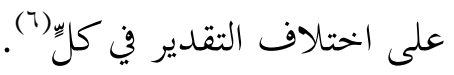

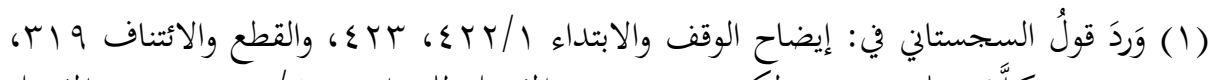

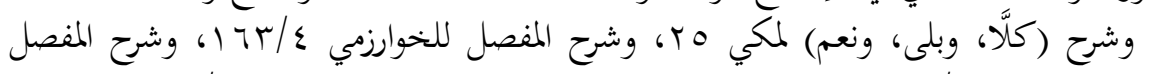

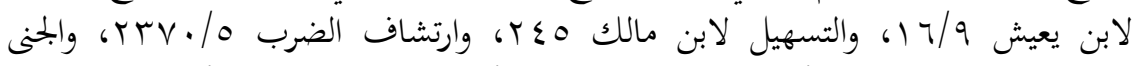

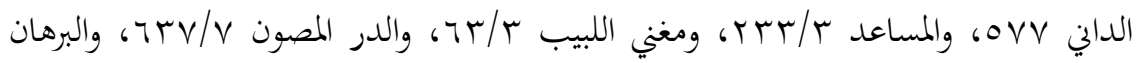

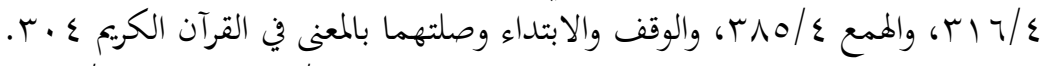

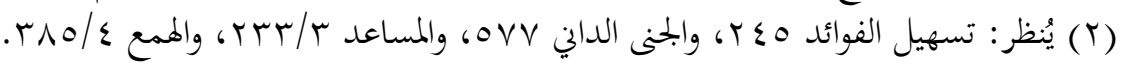

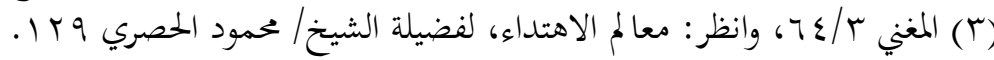

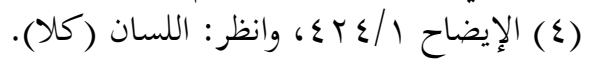

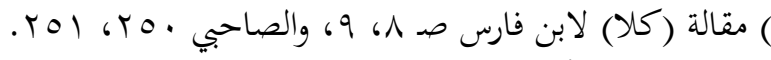

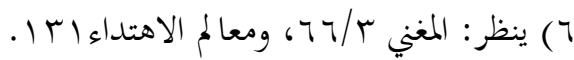




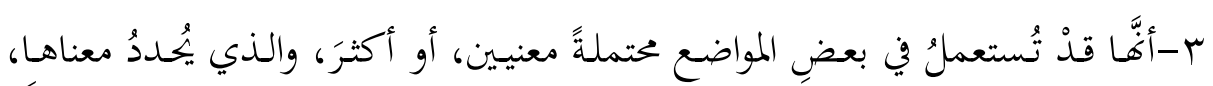

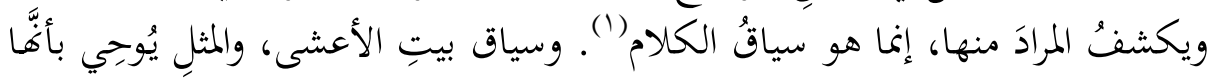

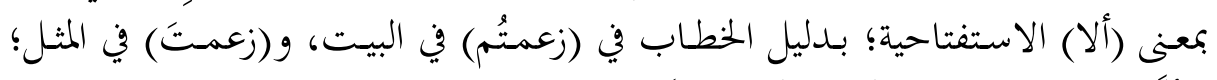

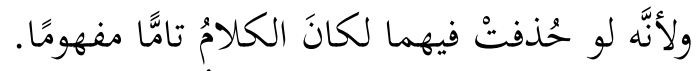

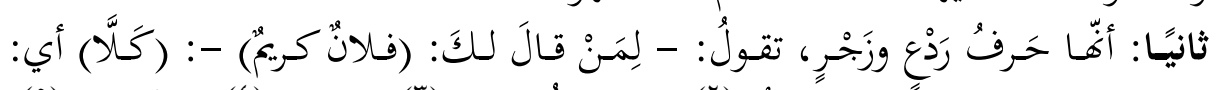

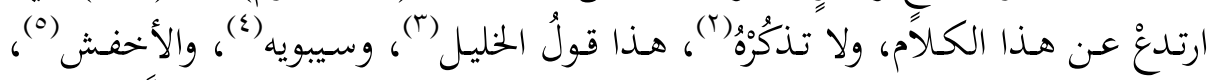

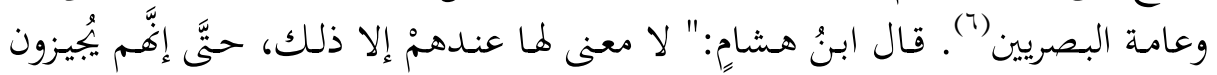

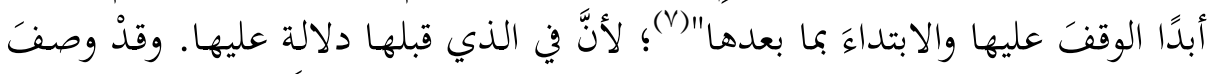

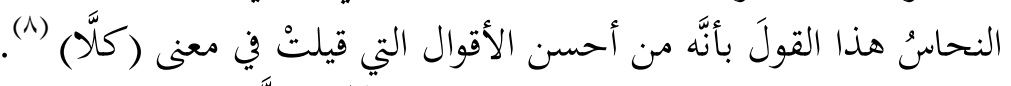

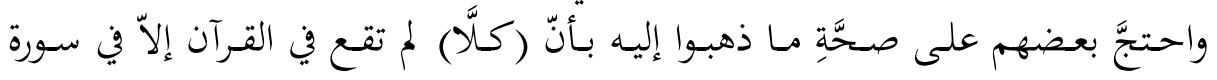

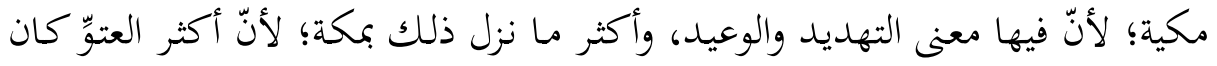
(9)

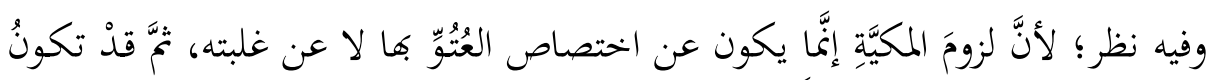

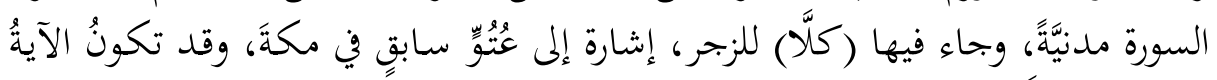

التي فيها (كأَ) مكيَّة لا السورة كلهاء (1).

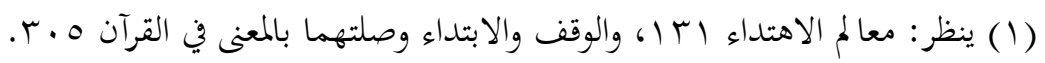

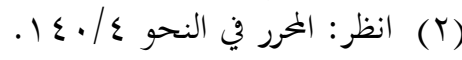

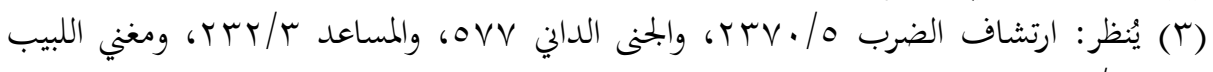

$$
\text { . . Th }
$$

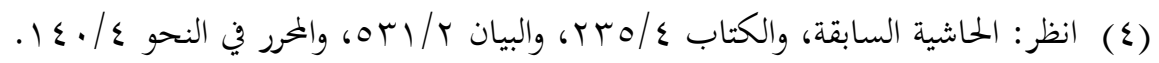

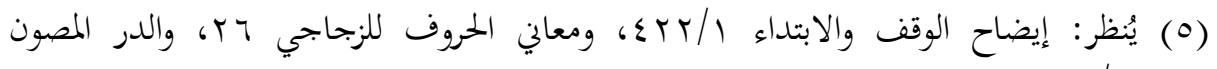

$.7 \mathrm{rV} / \mathrm{V}$

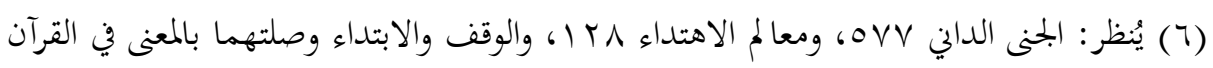

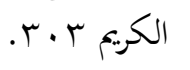

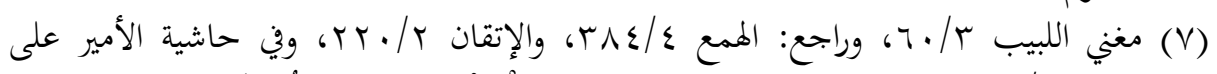

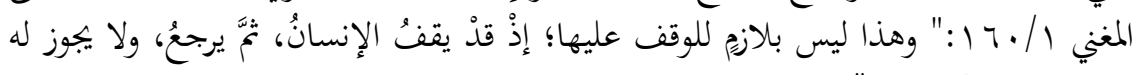

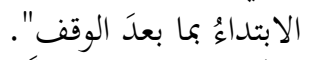

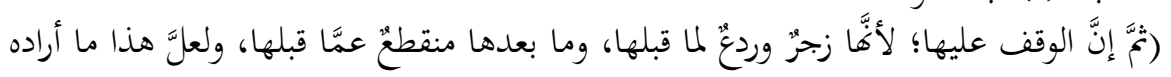

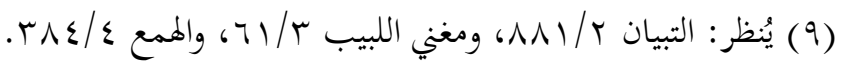




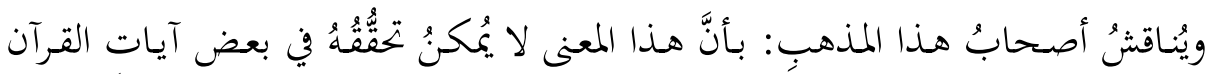

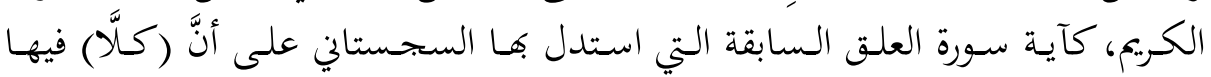

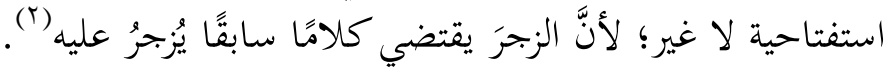

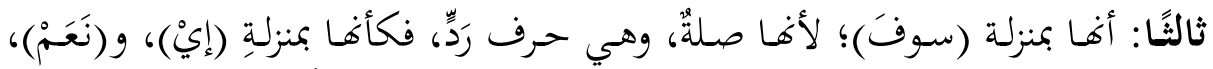

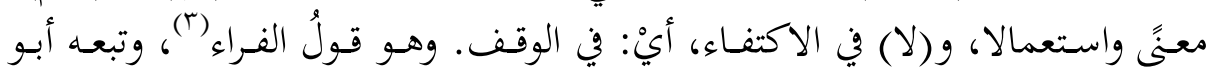

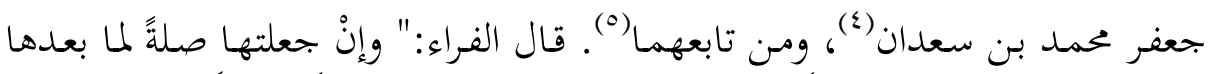

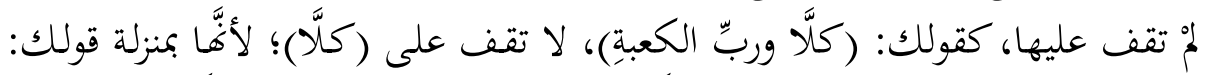

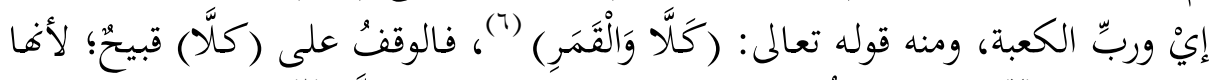

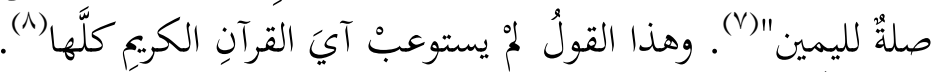

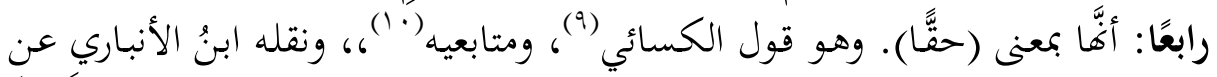

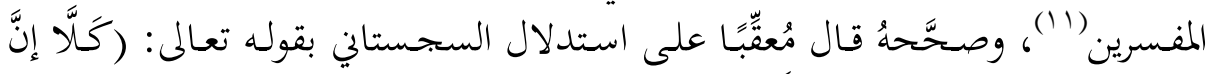

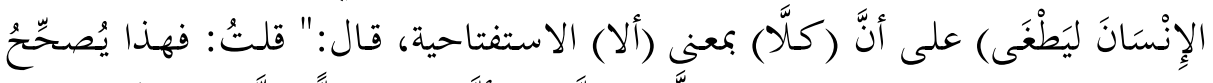

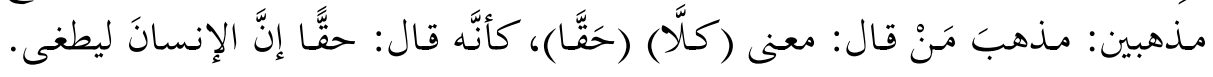

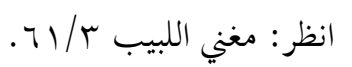

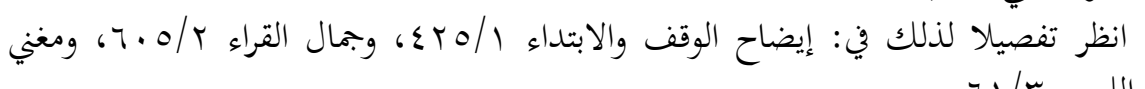

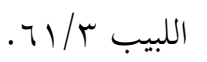

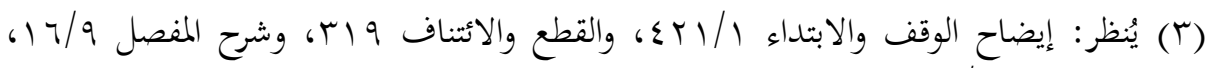

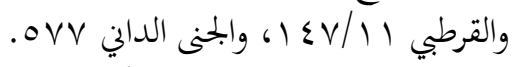

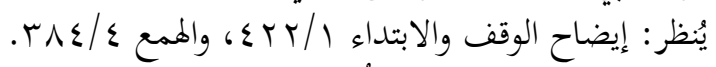

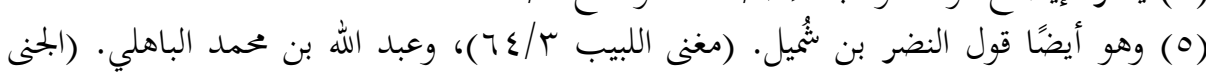

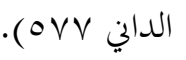

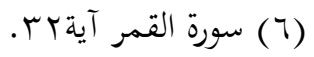

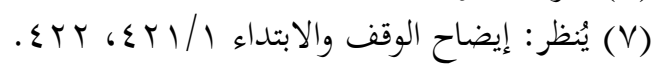

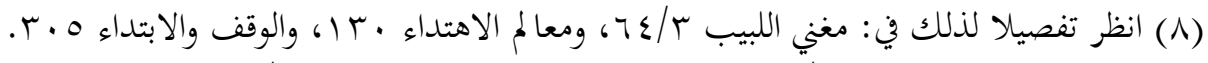

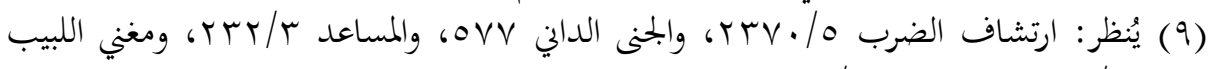

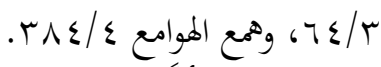

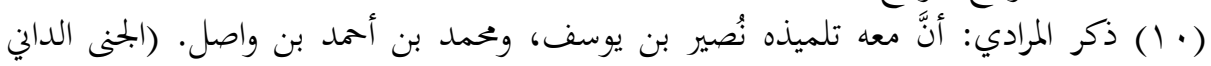

(11) إيضاح الوقف والابتداء / I / I ع، وانظر: المقصد لتلخيص ما في المرشد بr. 


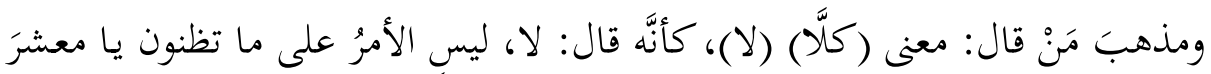

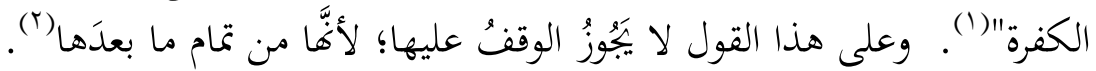

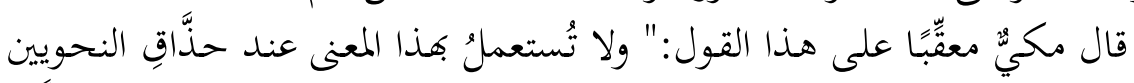

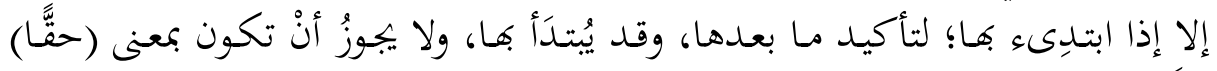

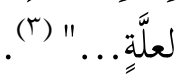

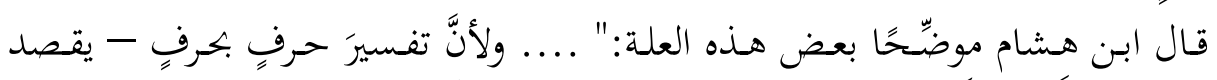

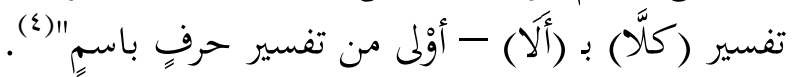

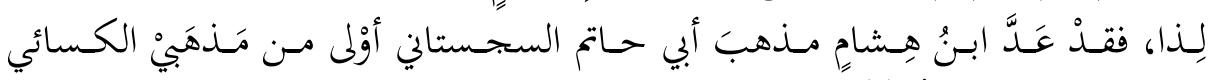

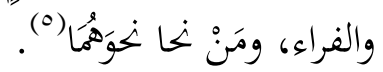

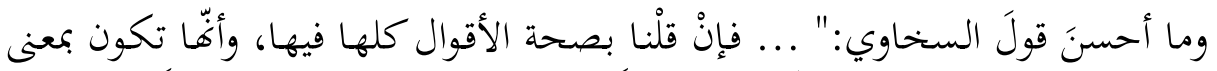

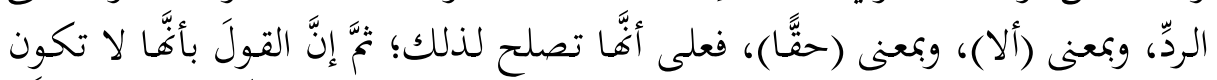

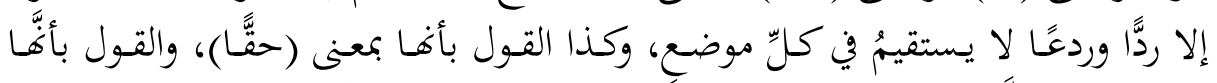

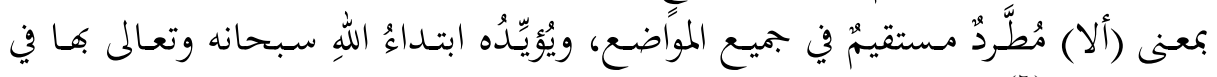

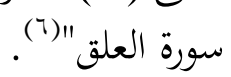

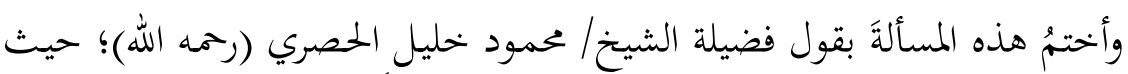

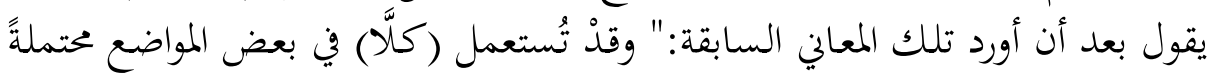

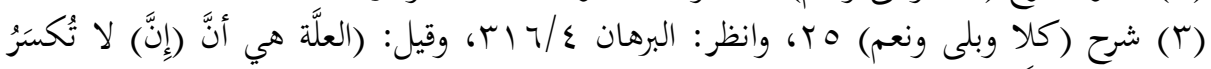

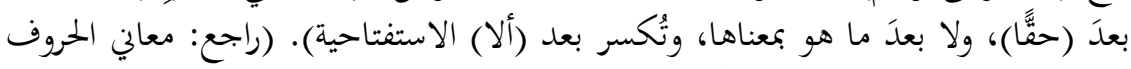

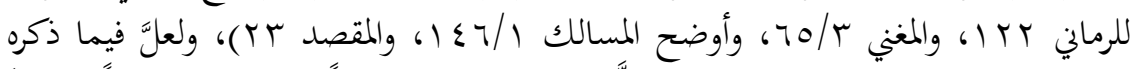

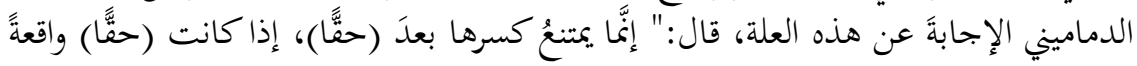

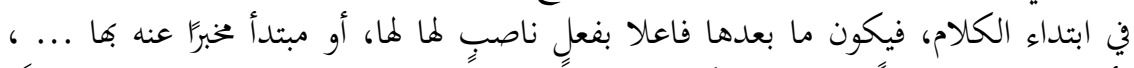

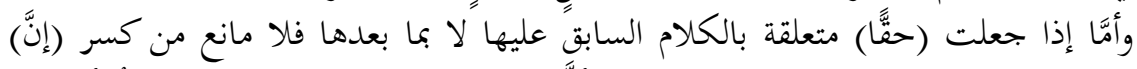

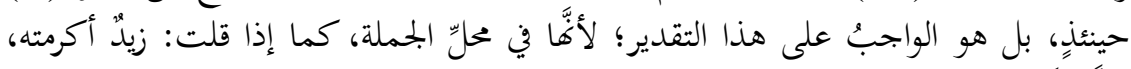

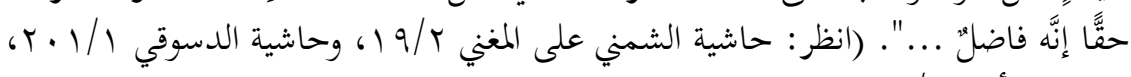

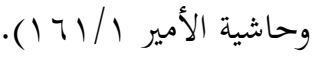

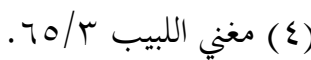

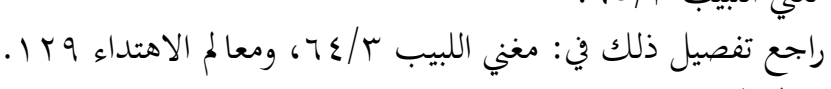




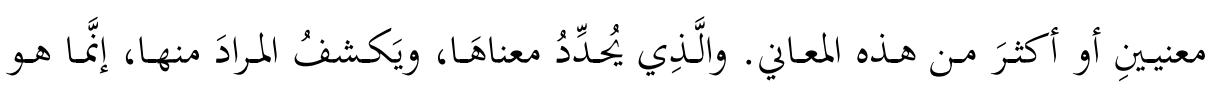

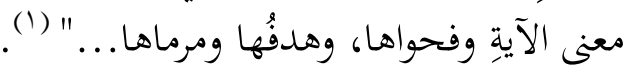
*******************

\section{المسألة الثالثة: أوجه إعراب (ذَلِكَكَ) فِي قوله تعالى: (ذَلِكَ الْكِتَابُ لَا}

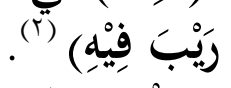

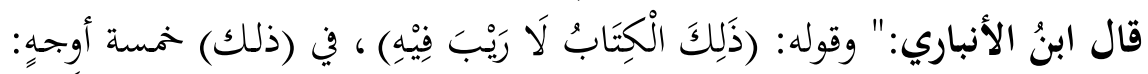

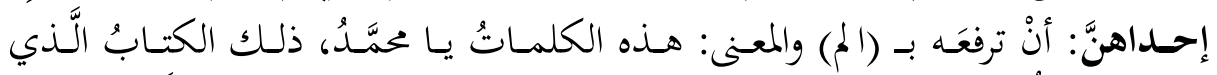

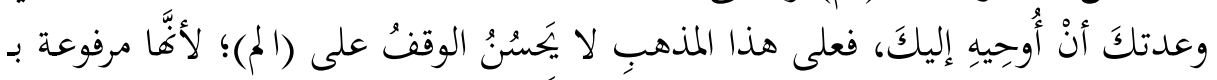

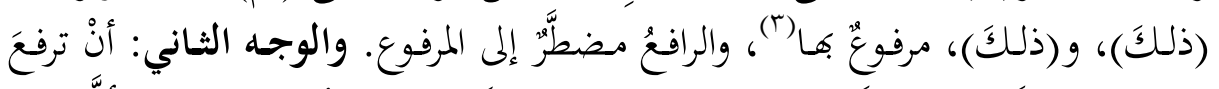

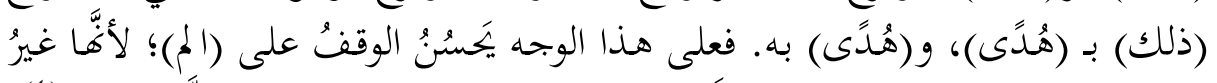

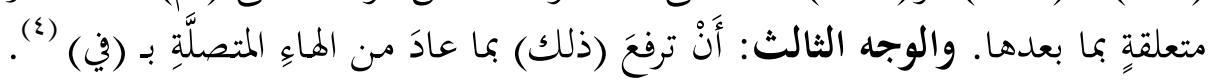

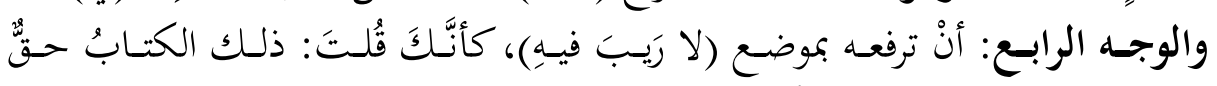

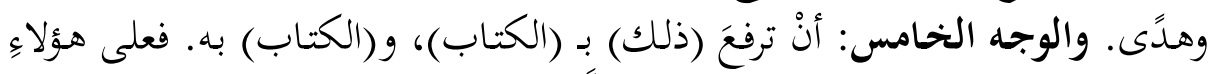

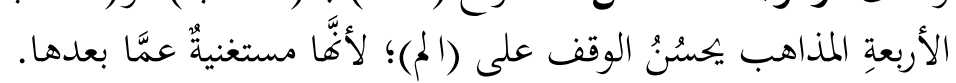

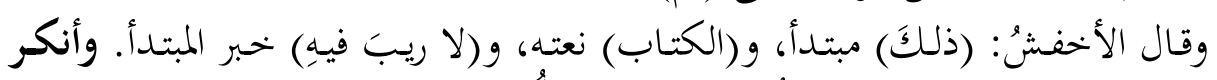

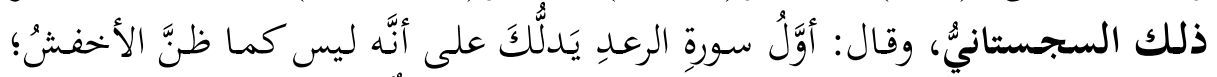

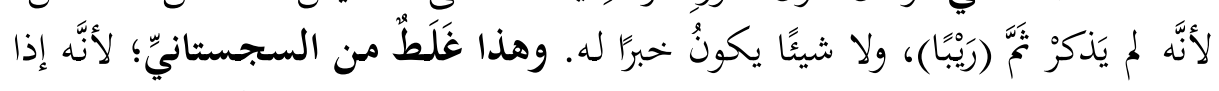

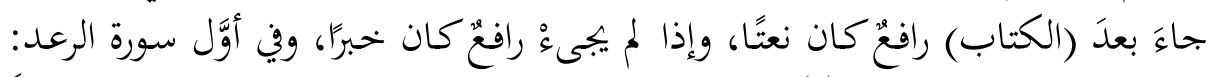

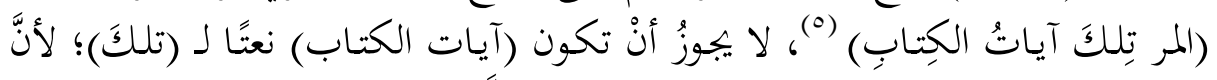

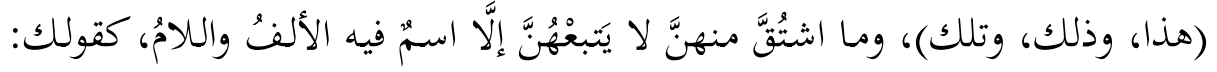

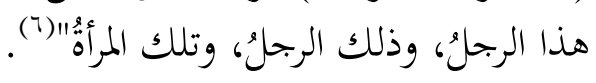

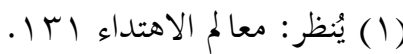

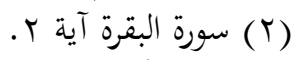

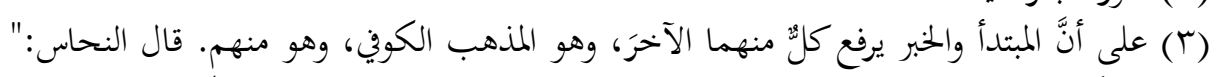

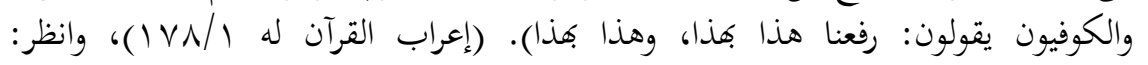

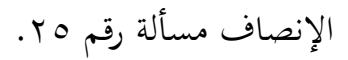

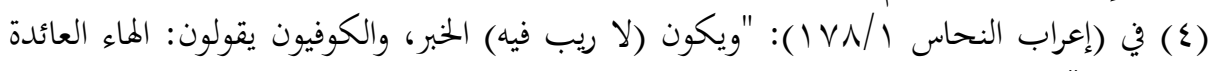
الخبر". (7) الآية الأولى من سورة الرعد.

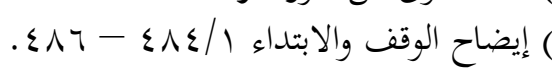




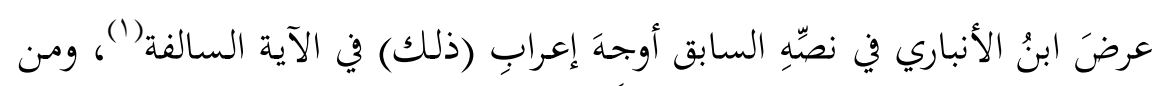

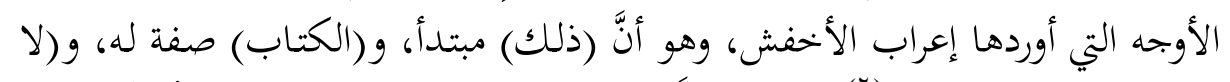

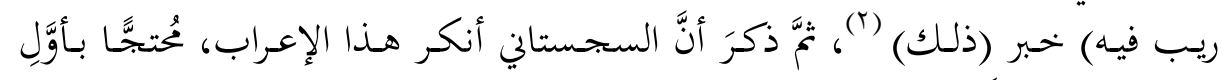

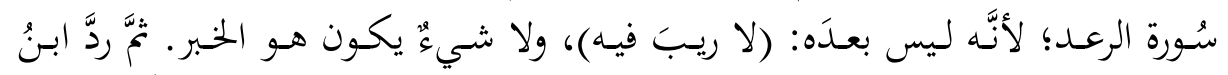

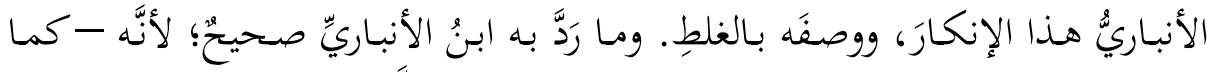

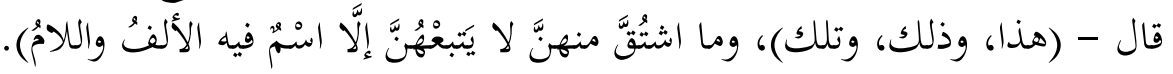

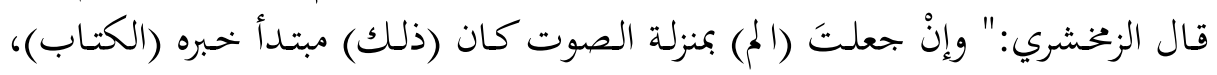

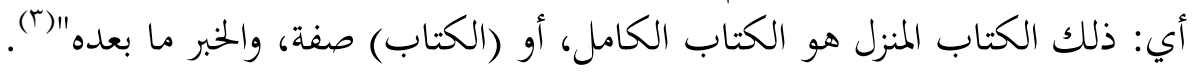

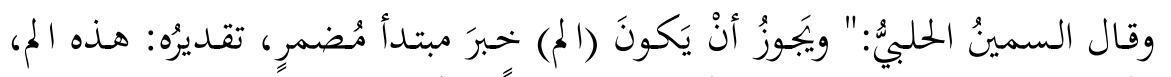

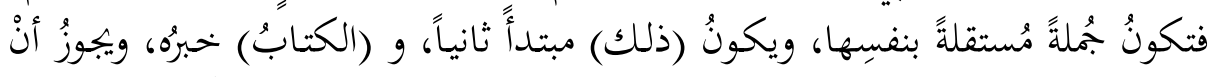

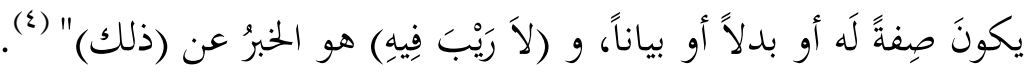

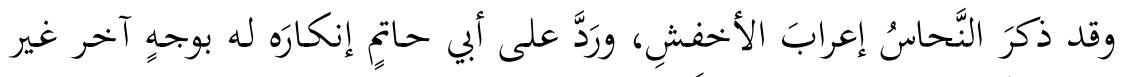

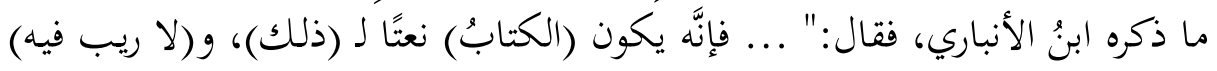

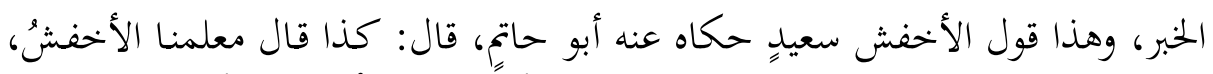

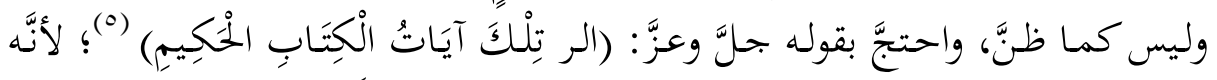

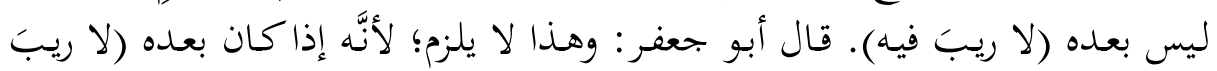

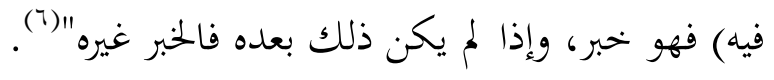
*******************

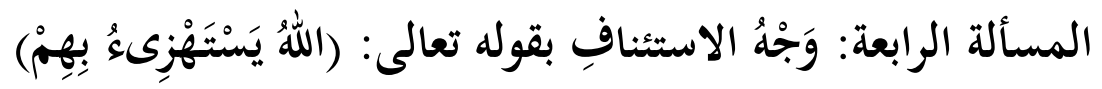

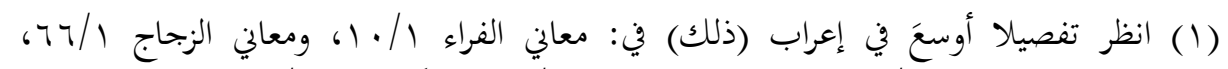

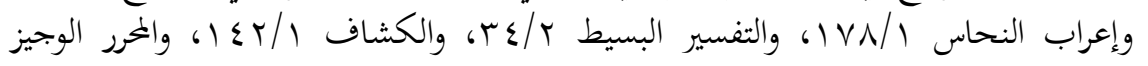

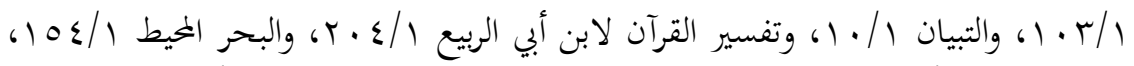

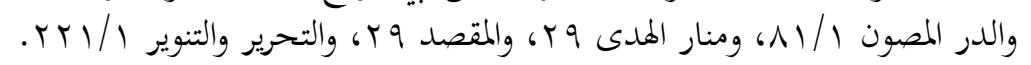

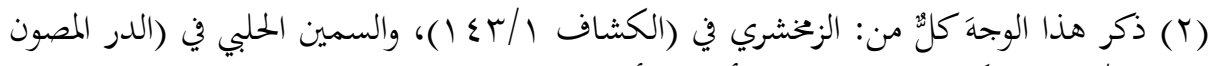

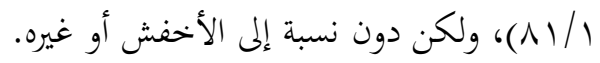

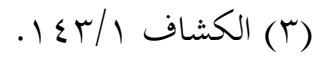

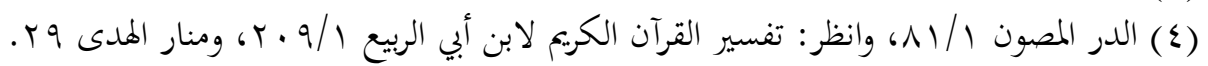

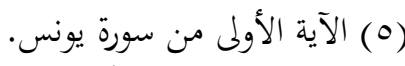

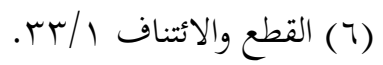




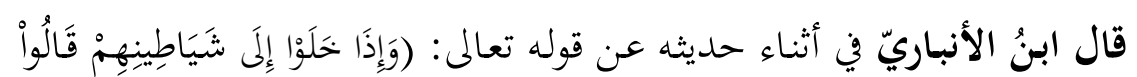

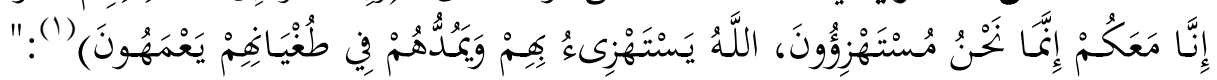

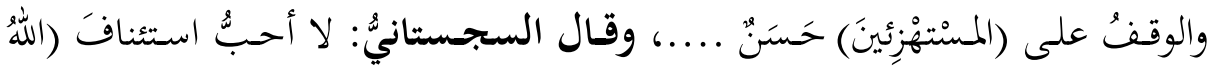

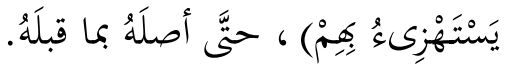

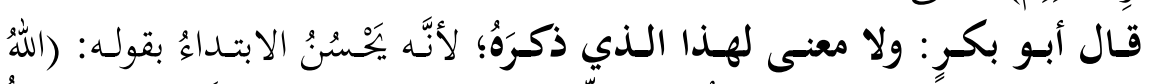

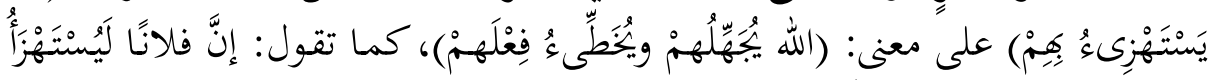

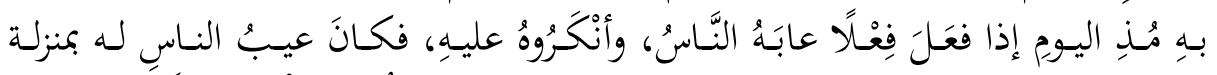

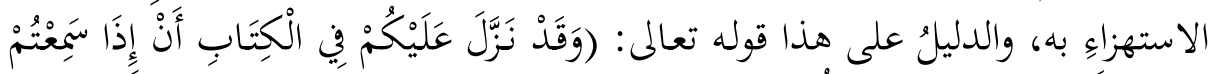

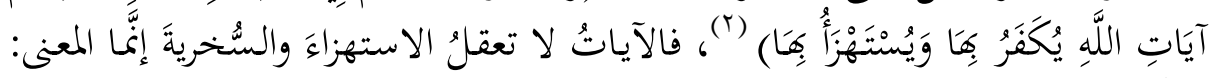

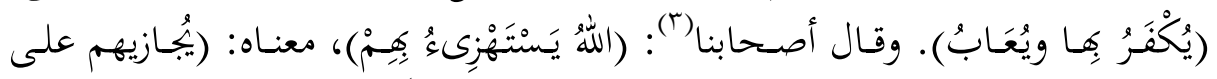

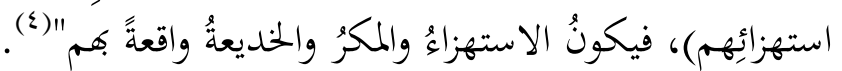

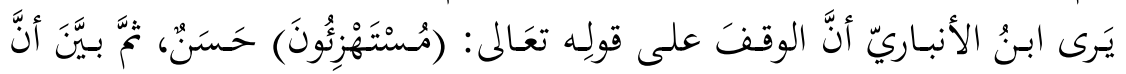

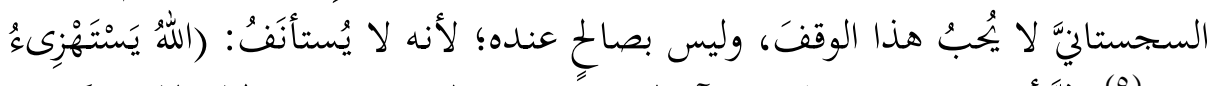

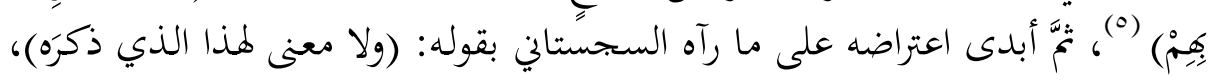

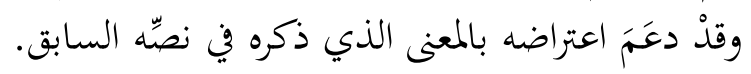

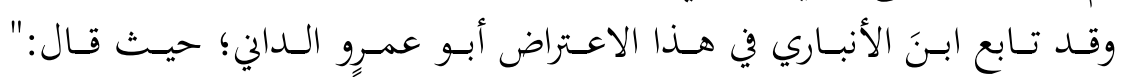

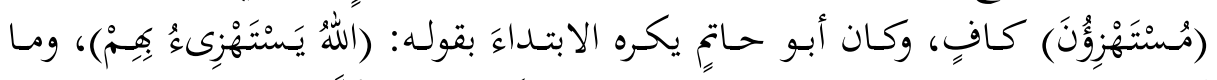

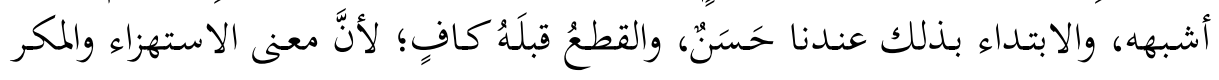

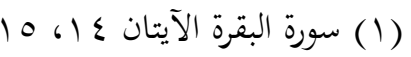

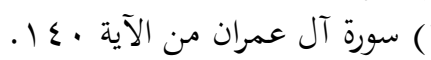

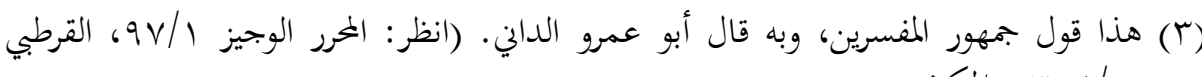
إ)

.( 1 T.

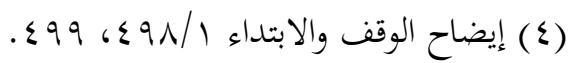

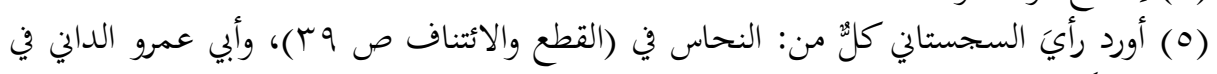
(المكتفى صآي المسجن) (1) (1)، والشيخ زكريا الأنصاري في (المقصد ص ع ؟)، وأحمد الأشموني في (منار الهدى ص 


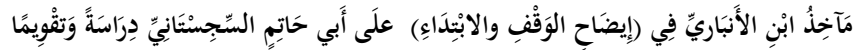

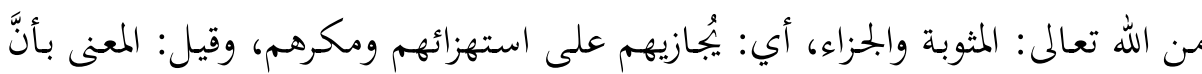

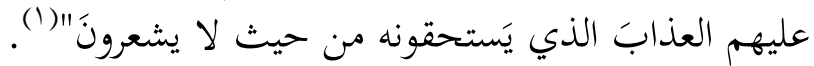

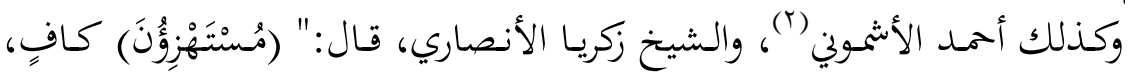

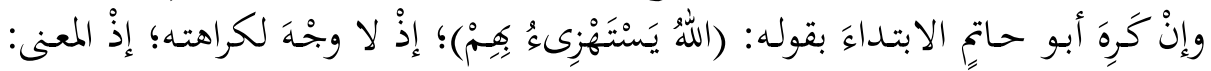
أنَّه تعالى يجازيهم على استهزائه الايتهم" (").

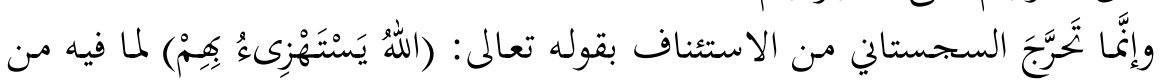

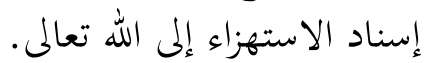

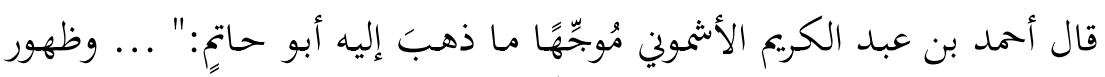

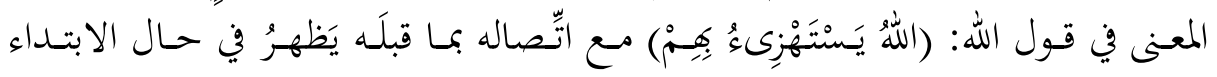

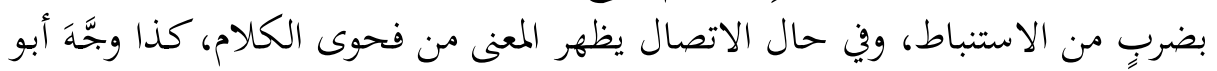

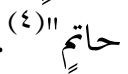

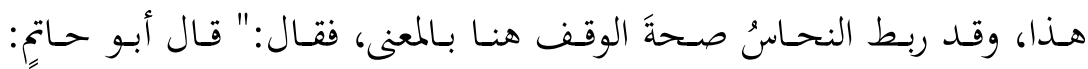

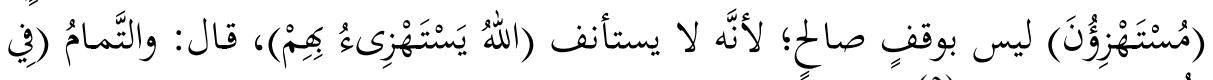

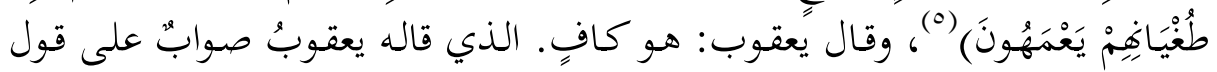

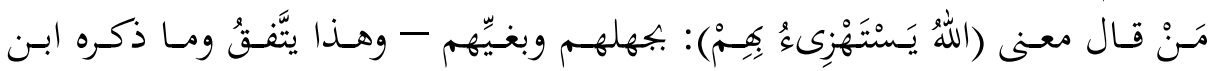

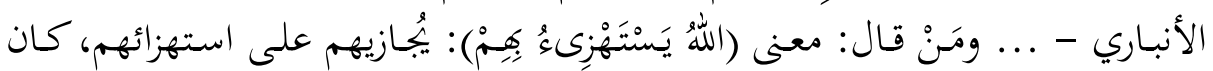

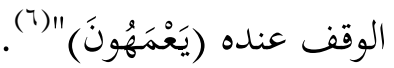

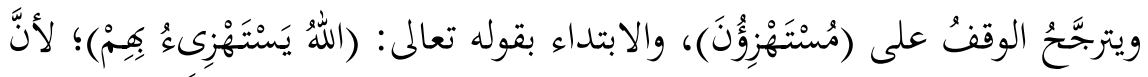

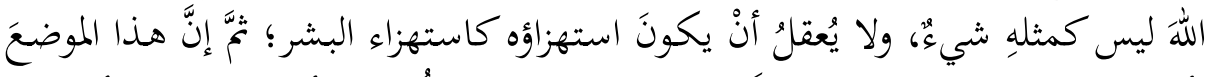

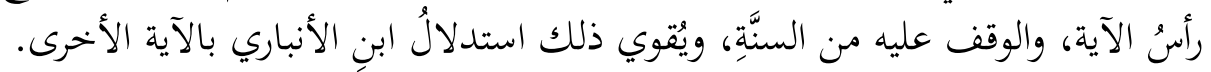

$$
\begin{aligned}
& \text { (1) المكتفى ص } 919 \text { (1)، • 1 1 ا. }
\end{aligned}
$$

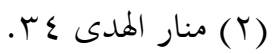

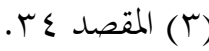

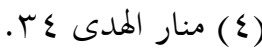

$$
\begin{aligned}
& \text { (1) سورة البقرة من الآية 1. } 1 . \\
& \text { (7) القطع والائتناف وَّ. }
\end{aligned}
$$




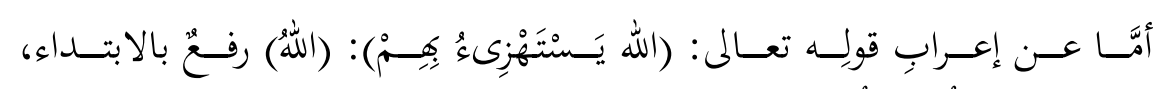

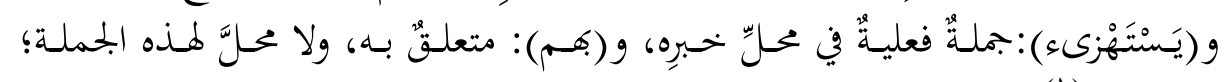

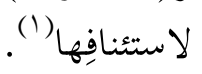

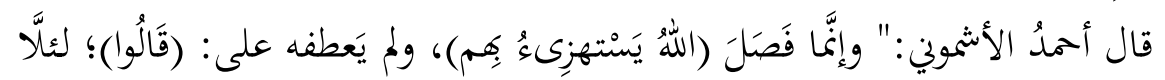

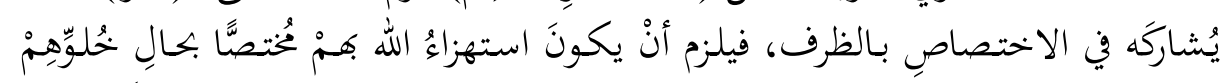

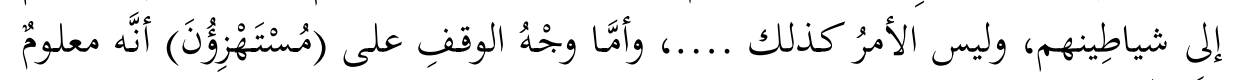

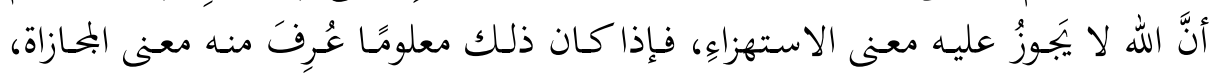

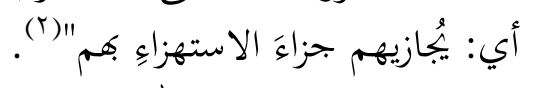

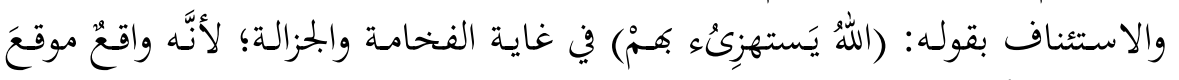

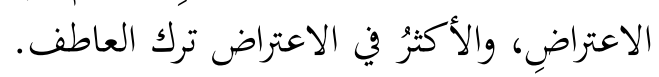

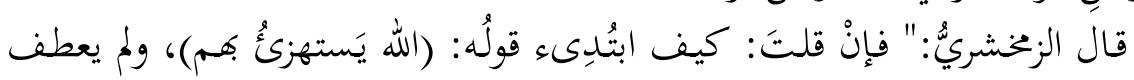
على الكلام قبله؟

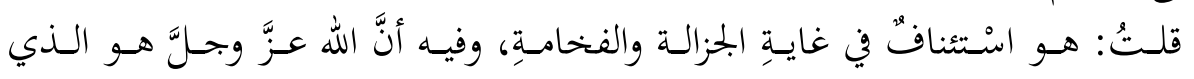

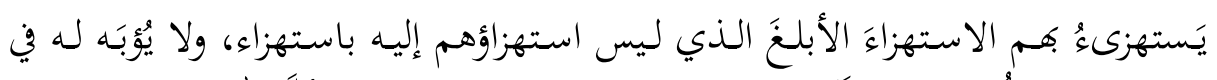

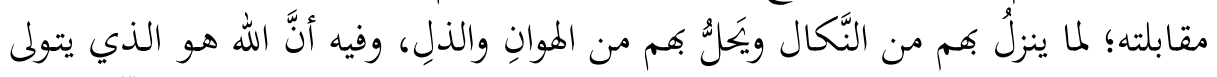

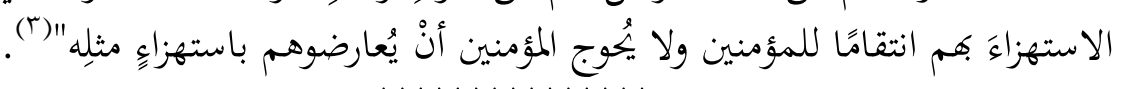
***********************

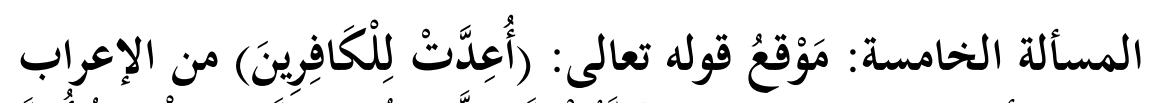

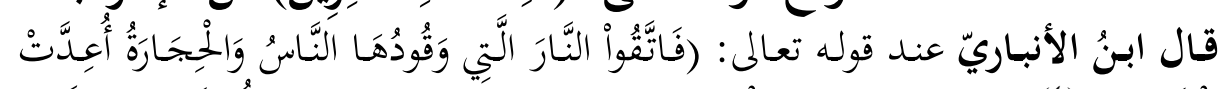

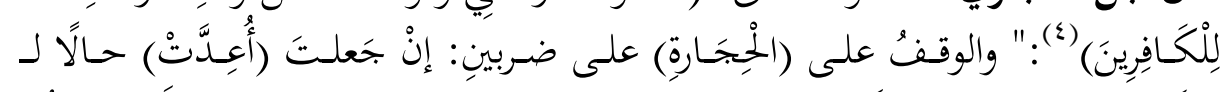

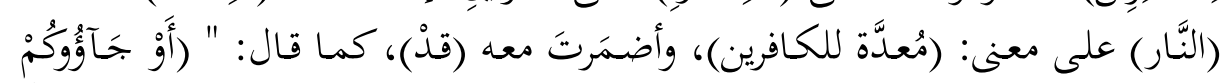

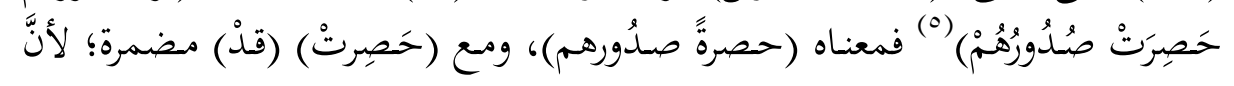

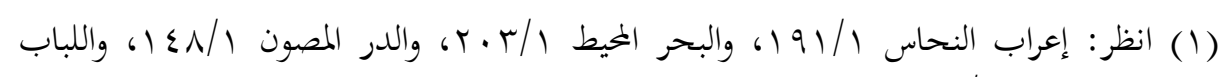

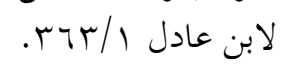

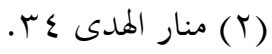

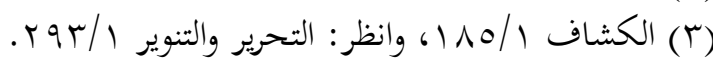

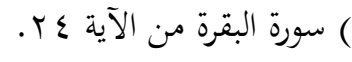

سورة النساء: من الآية .9. 


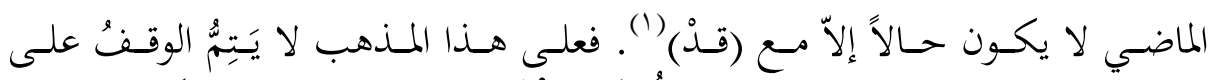

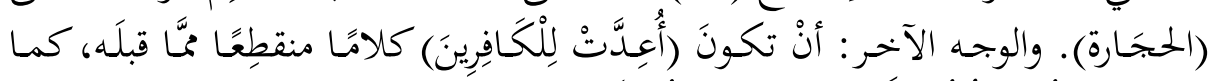

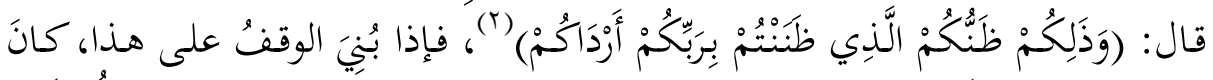

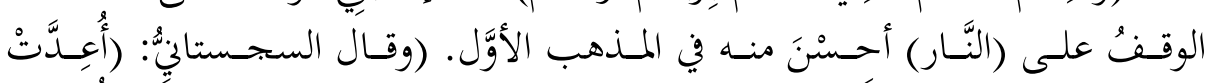

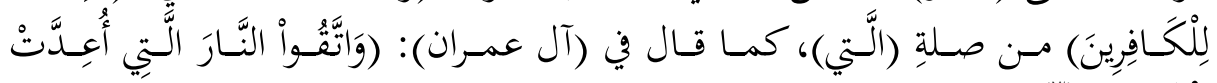

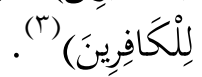

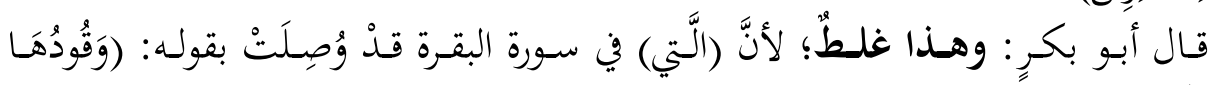

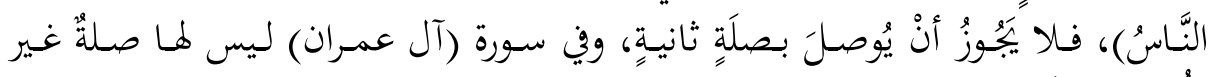

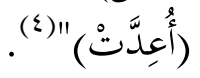

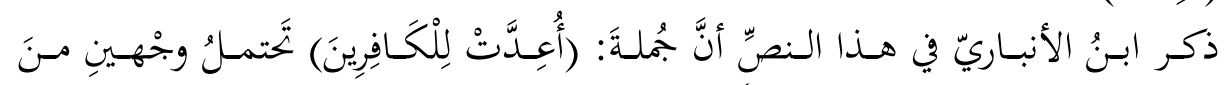

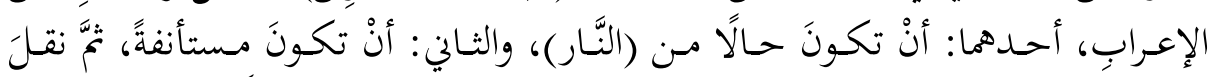

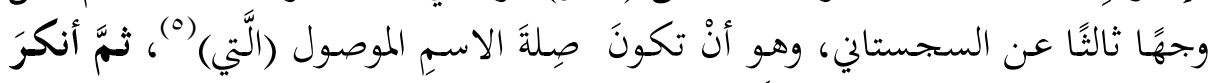

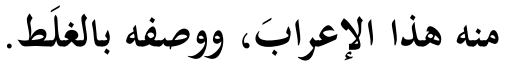

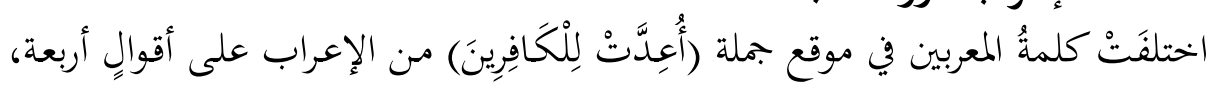

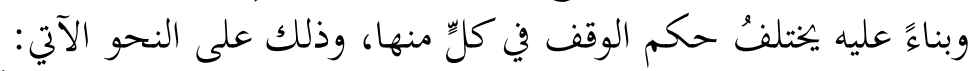

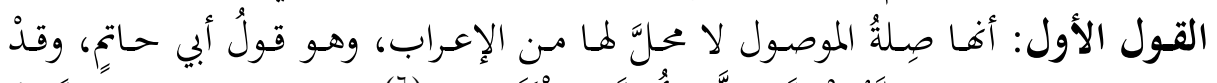

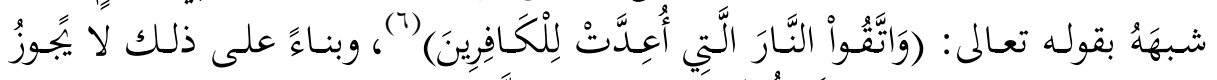

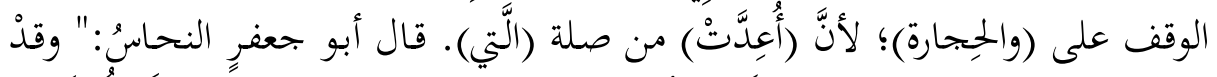

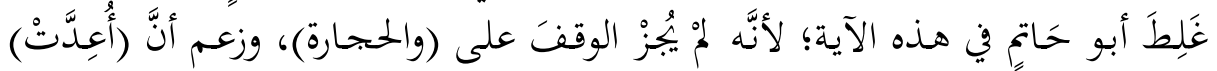

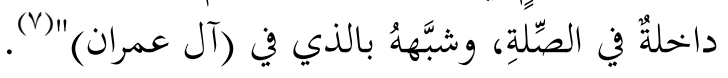

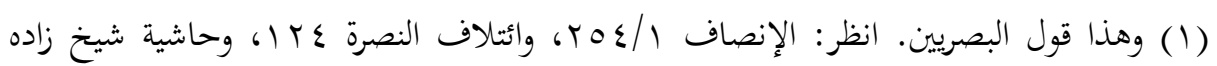

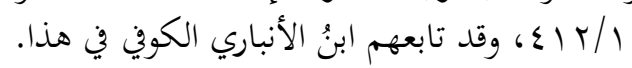

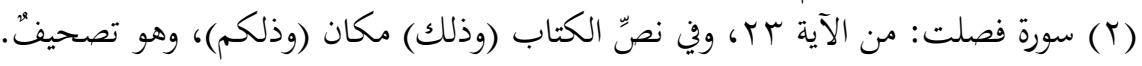

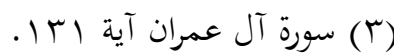

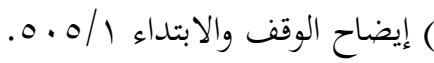

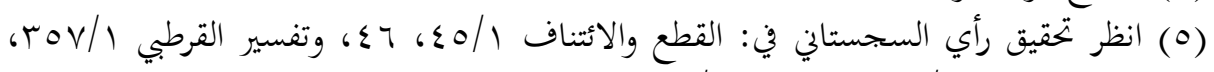

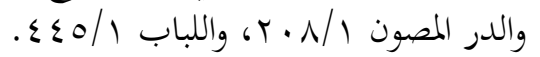

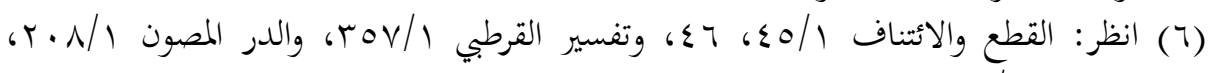

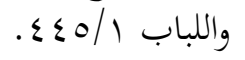
(V) القطع والائتناف / (V) 


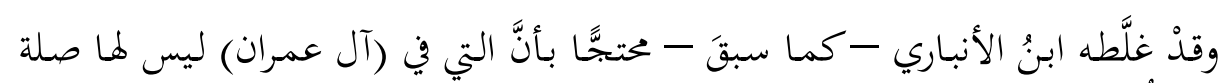

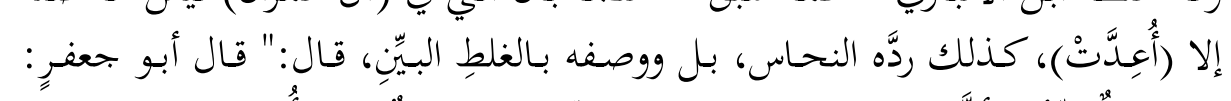

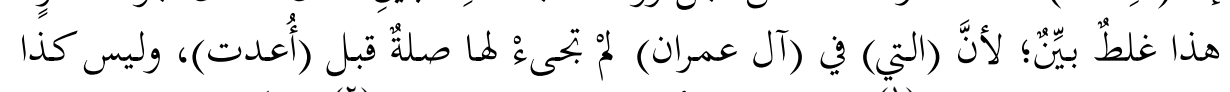

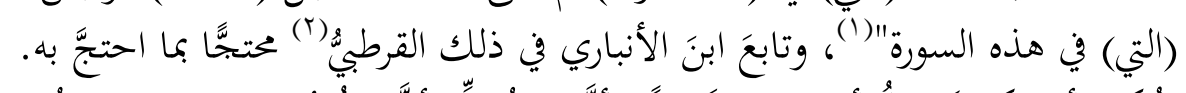

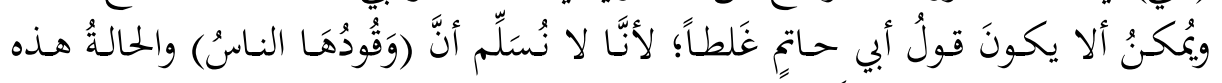

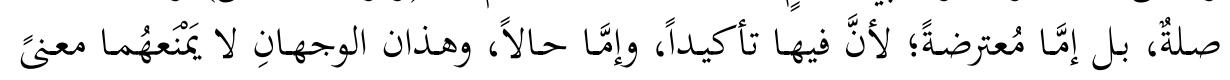
ولا صناعة (").

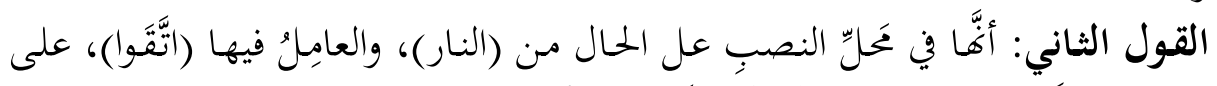

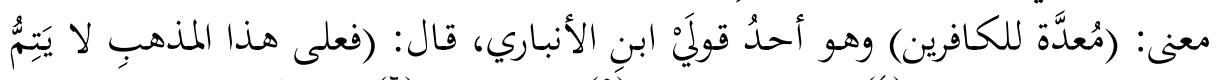

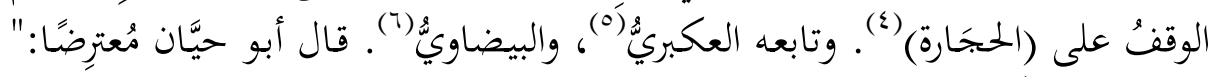

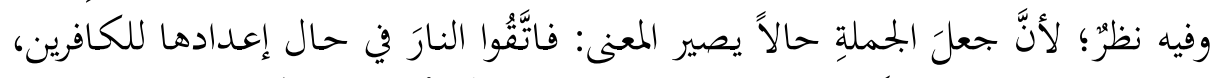

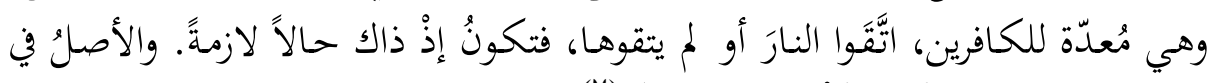

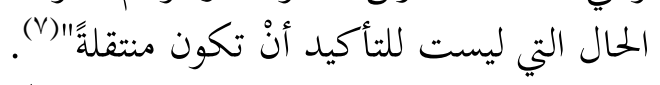

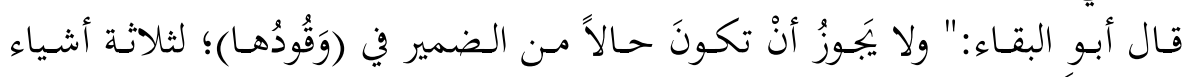

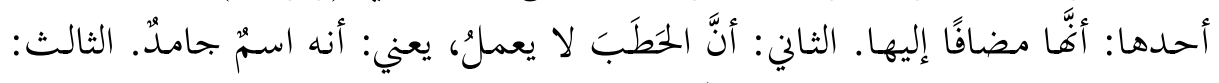

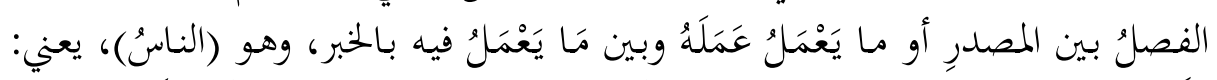

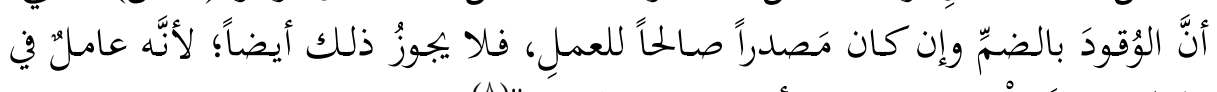

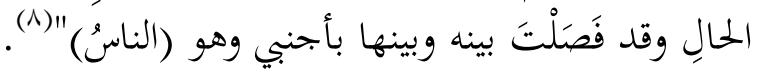

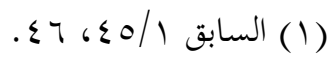

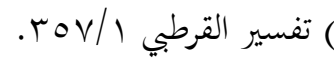

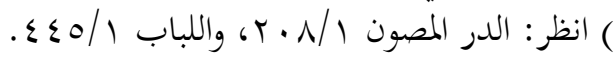

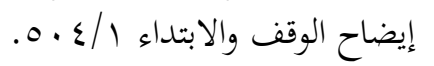

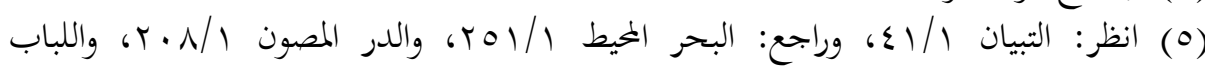

$$
\begin{aligned}
& \text {. } \varepsilon \leqslant 0 / 1
\end{aligned}
$$

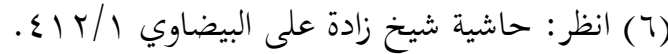

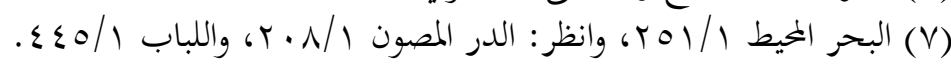

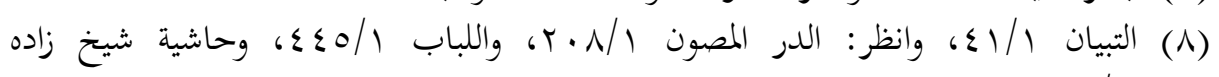

$$
\begin{aligned}
& \text {. } 2 \mid r / 1
\end{aligned}
$$




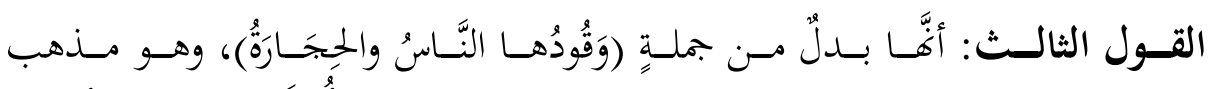

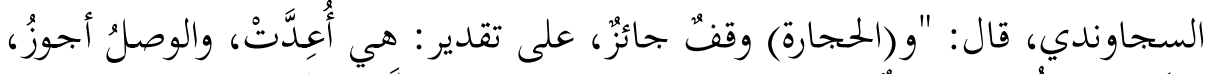

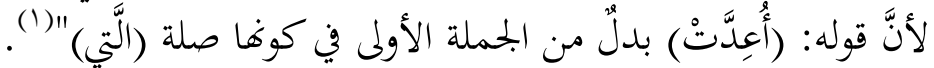

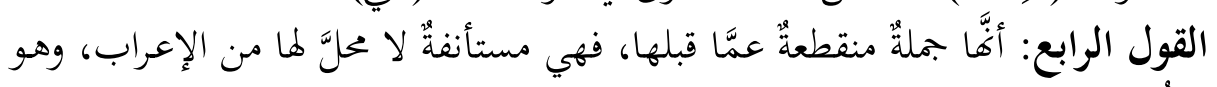

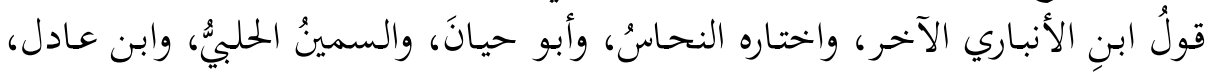

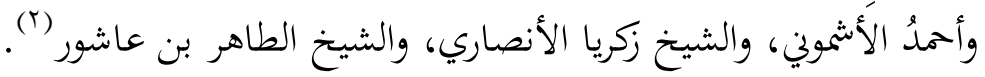

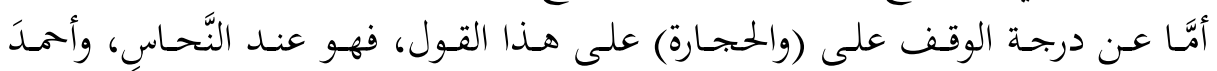

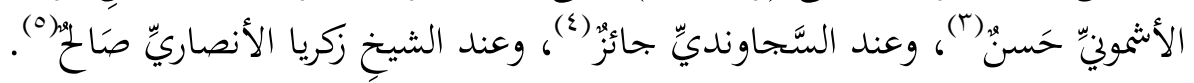

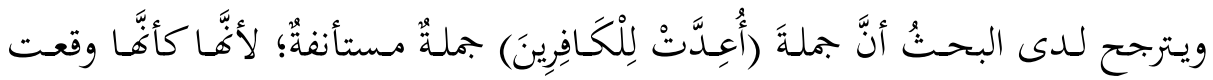

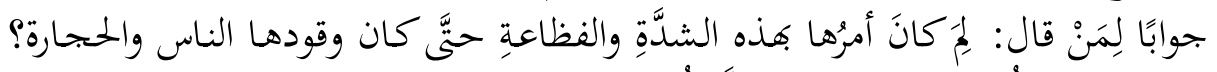

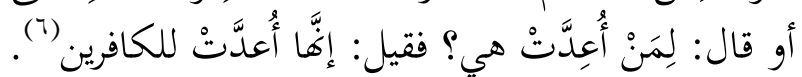

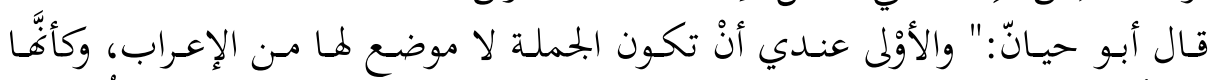

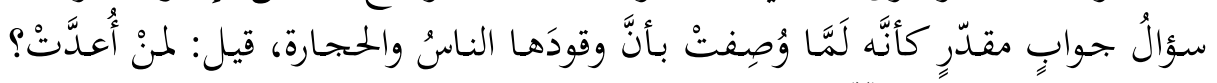

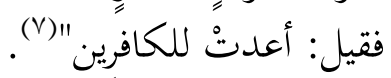

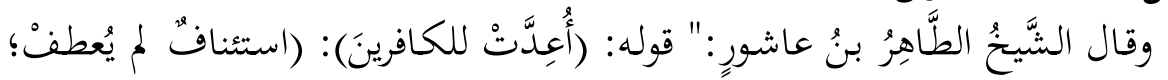

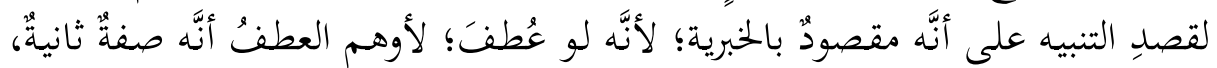

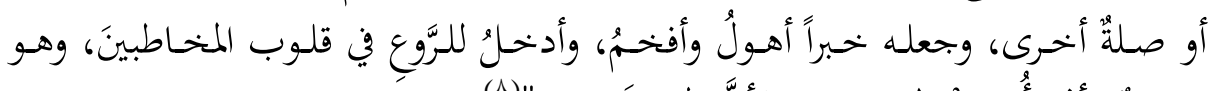

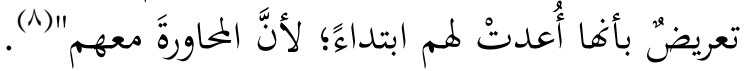
*********************

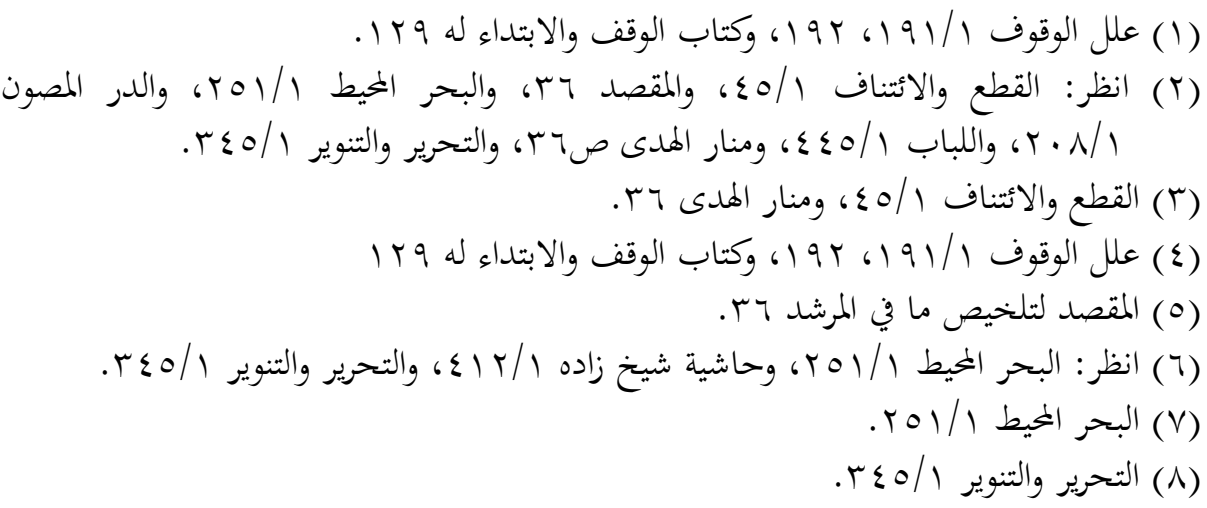




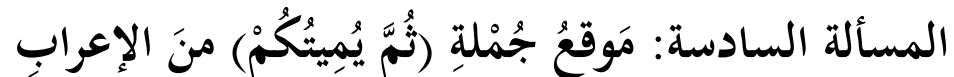

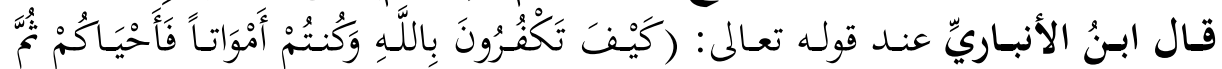

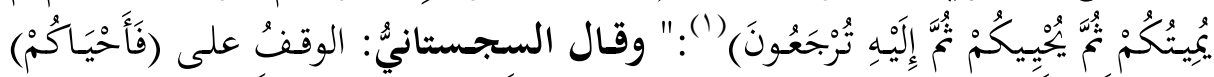

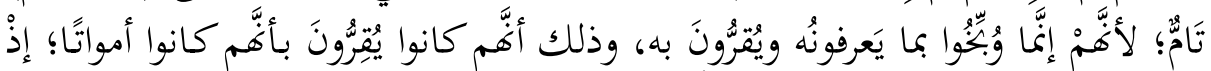

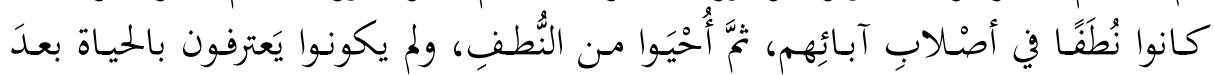

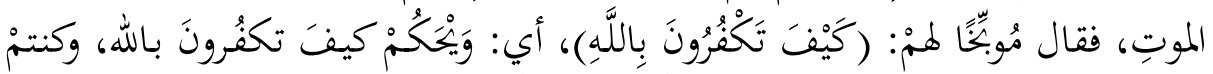

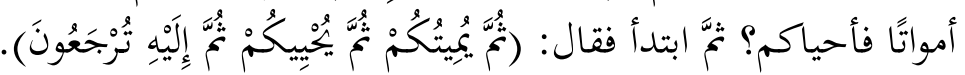

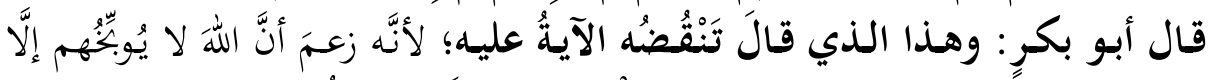

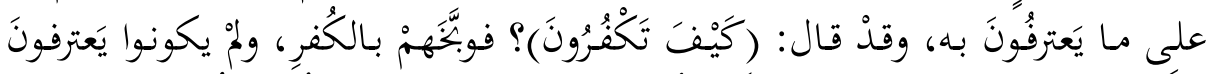

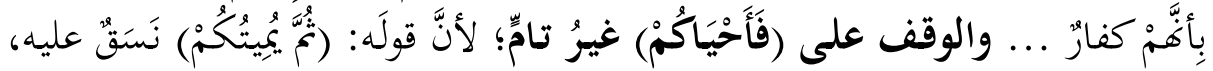

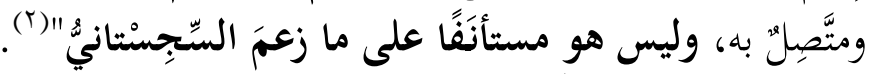

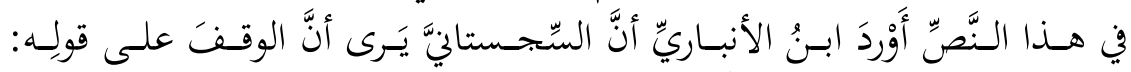

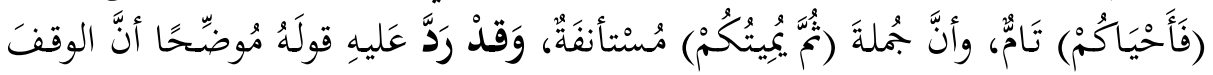

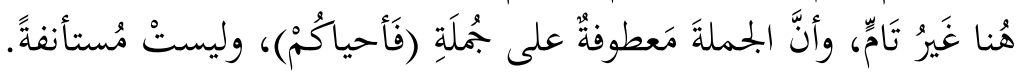

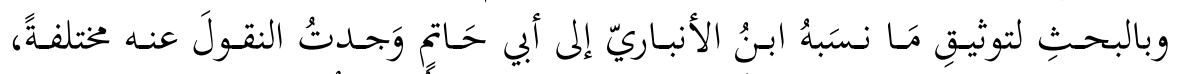

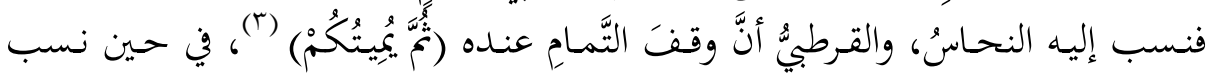

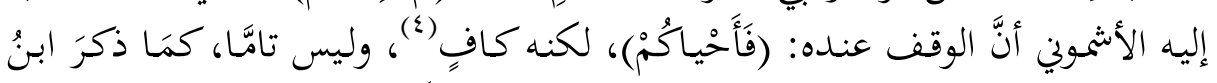

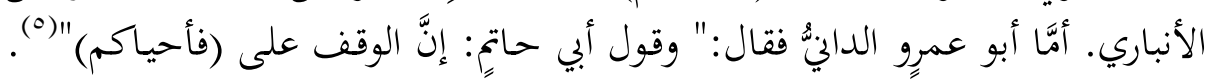
ولمُ يُبيِّن حكمَّهُ.

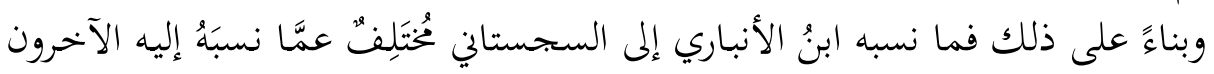
متَّن سبقَ ذكرهمْ.

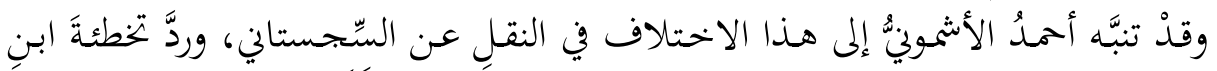

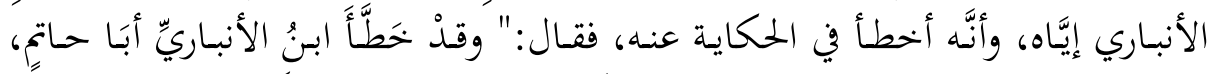

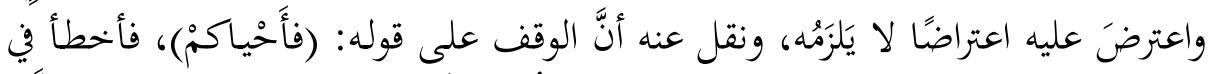

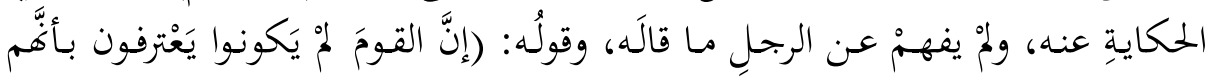

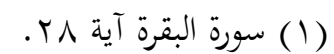

(T) إيضاح الوقف والابتداء / / / (T)

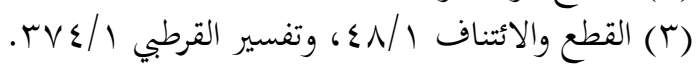

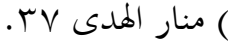

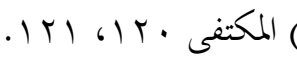




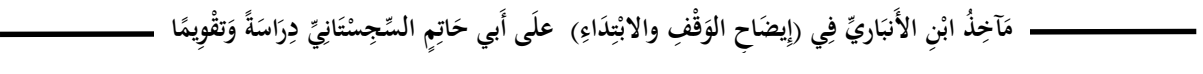

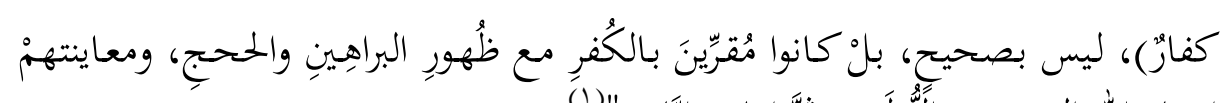

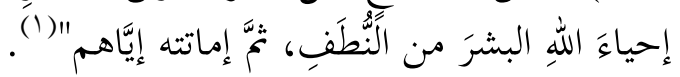

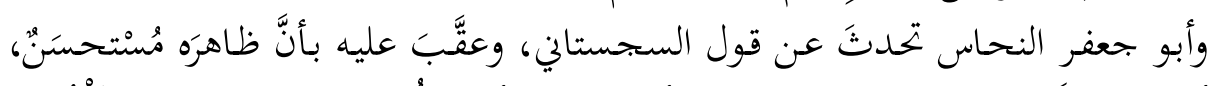

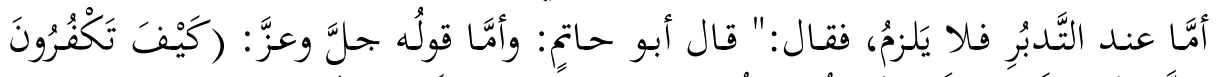

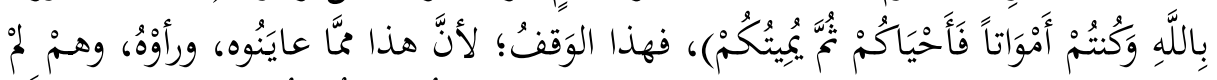

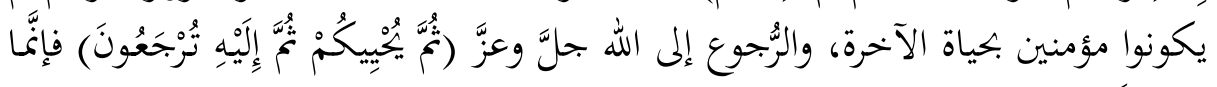

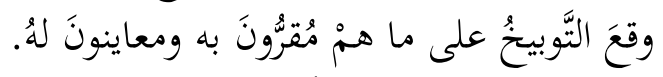

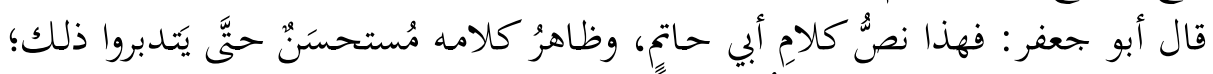

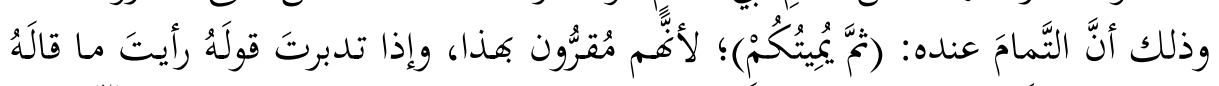

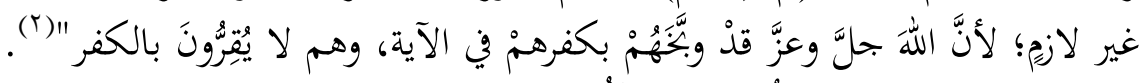

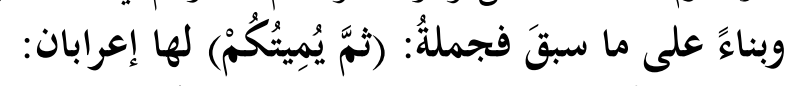

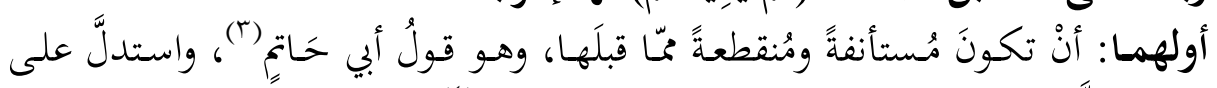

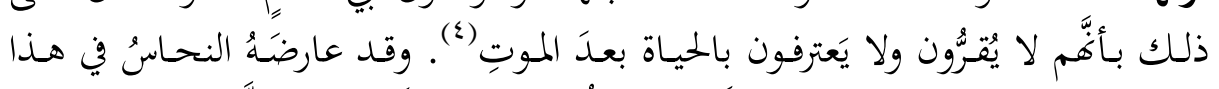

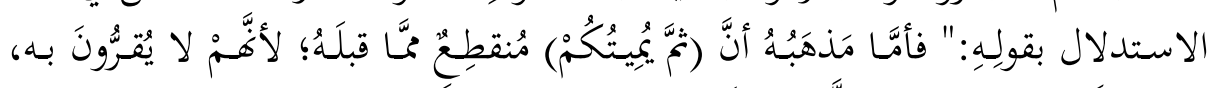

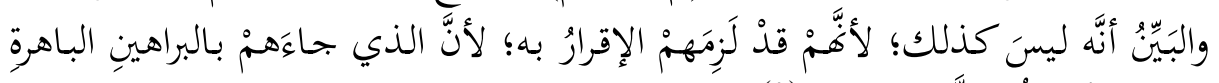

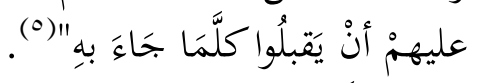

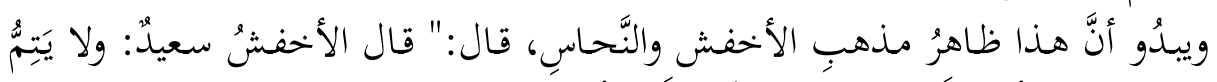

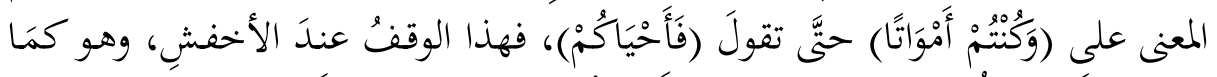

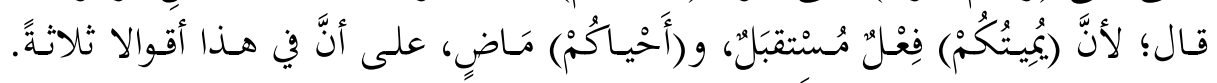

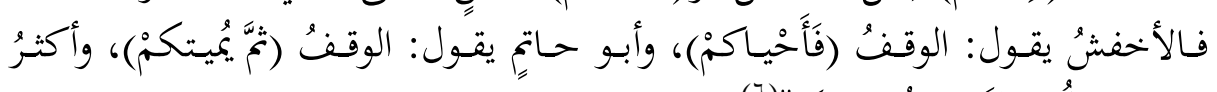

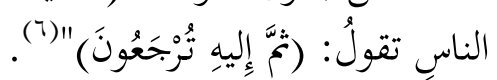

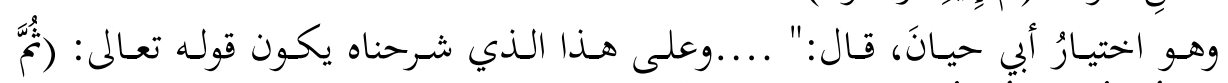

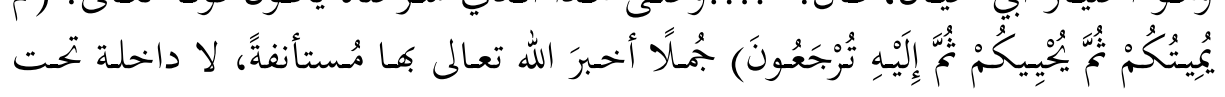

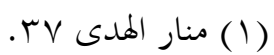

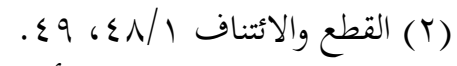

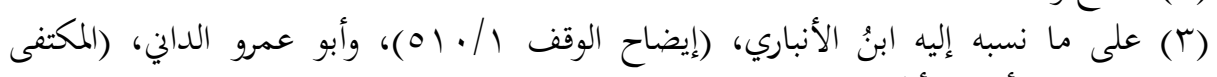

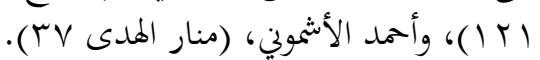

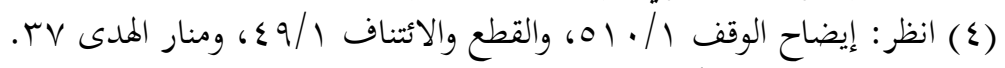

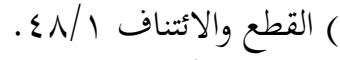

$$
\begin{aligned}
& \text { السابق } 1 \text { ـ }
\end{aligned}
$$




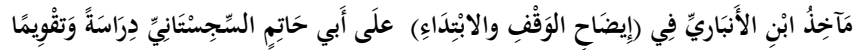

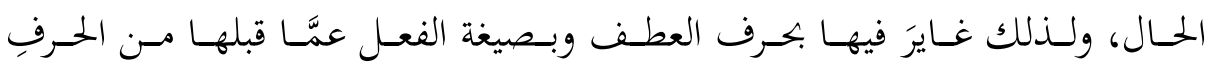

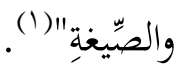

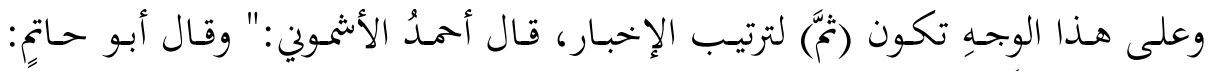

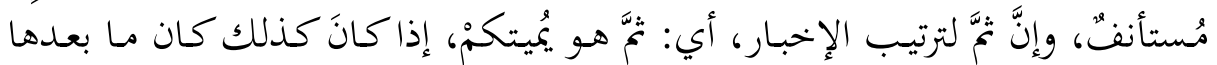

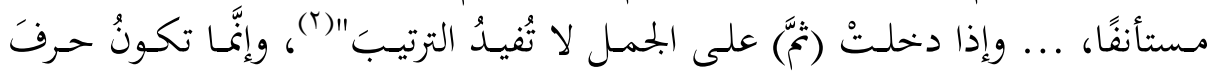

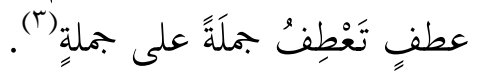

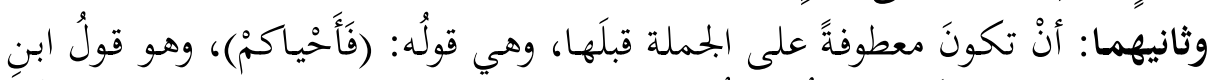

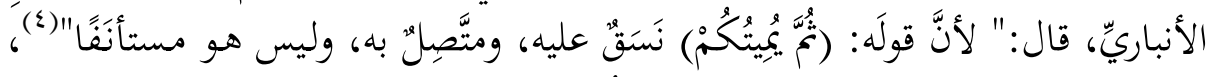

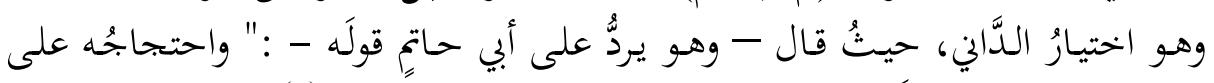

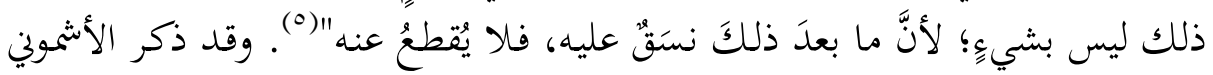

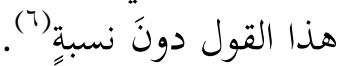

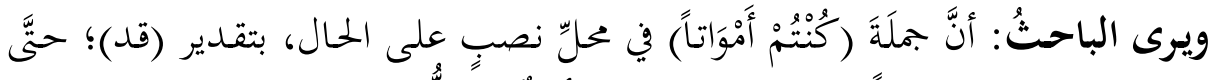

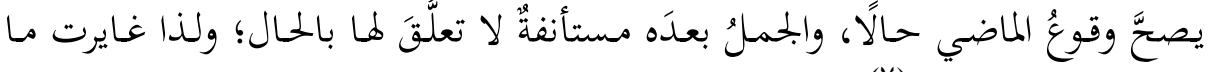

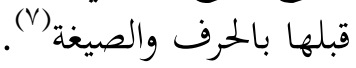

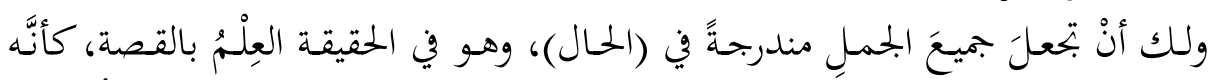

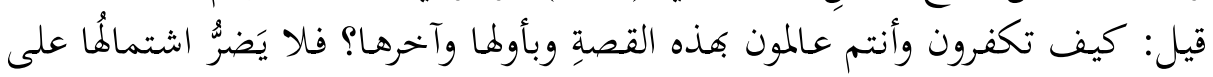

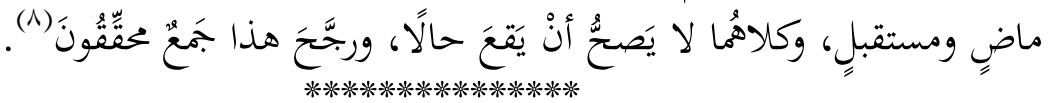

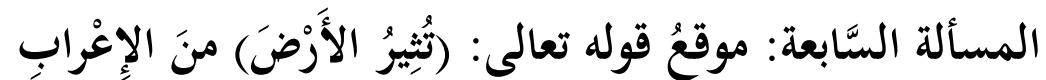

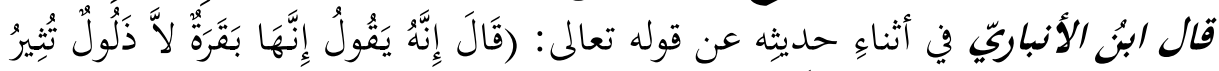

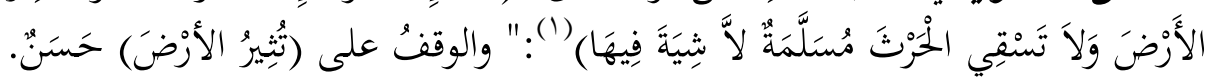

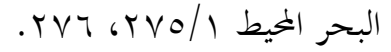

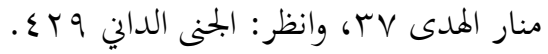

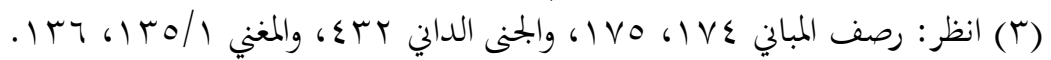

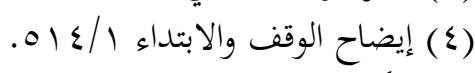

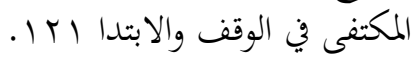
rV الفئ.

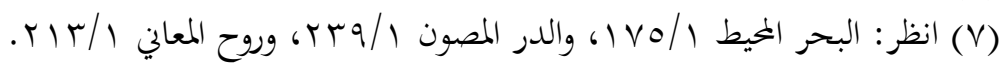

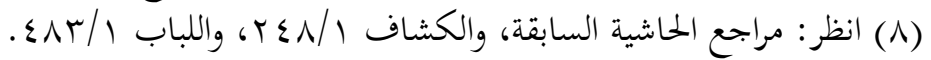




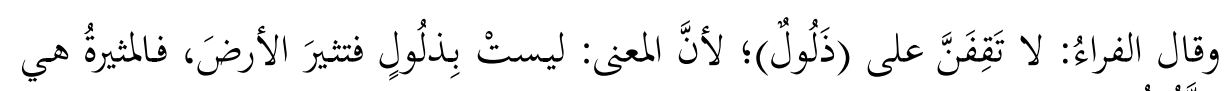
الذَّلَولُ.

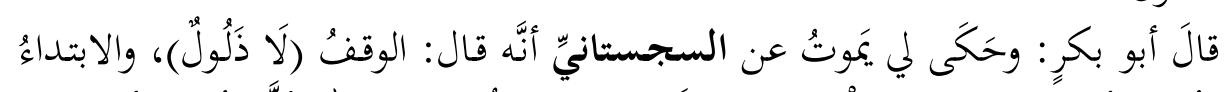

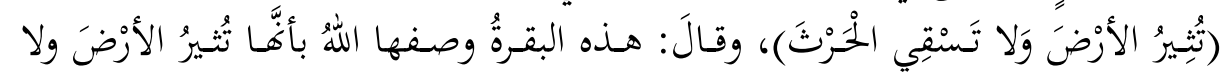

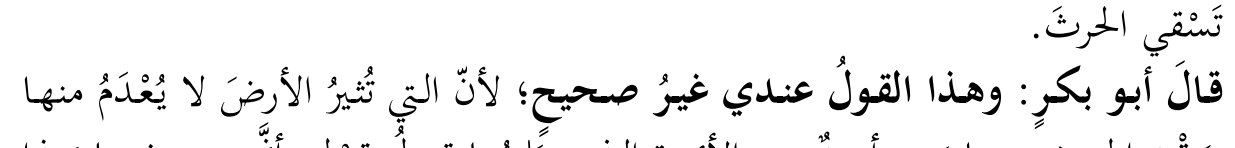

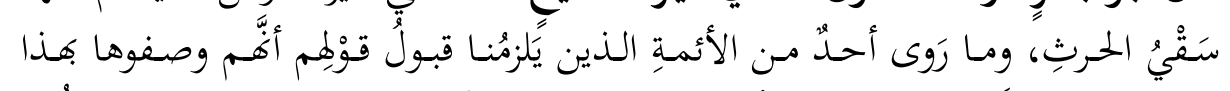

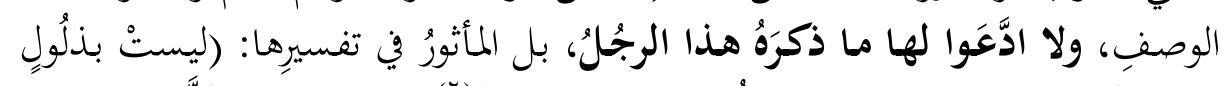

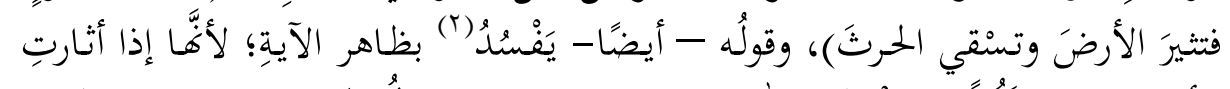

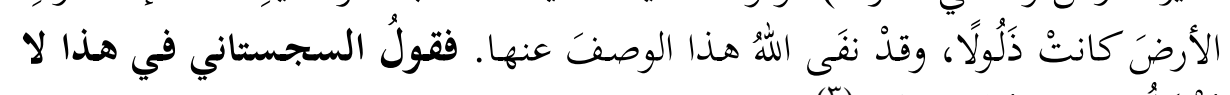

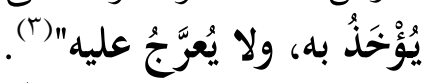

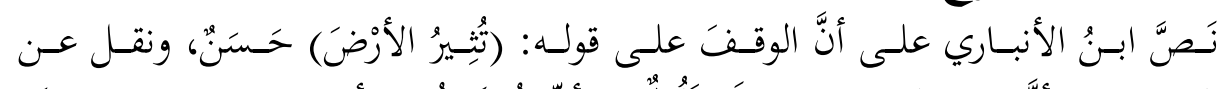

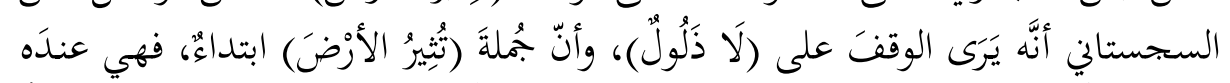

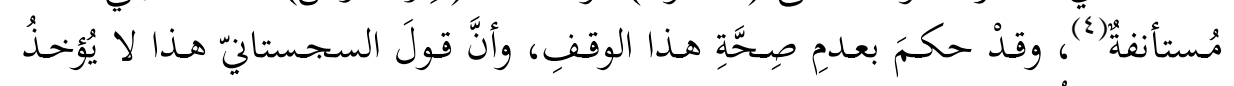
به، ولا يُعوَّلُ عليه.

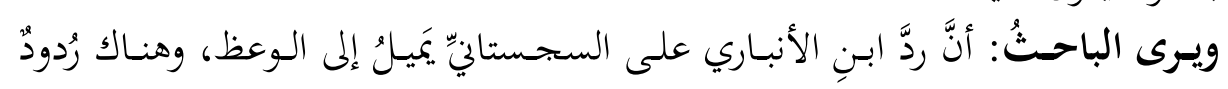

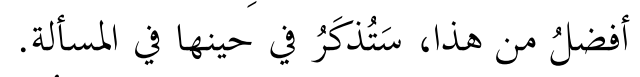

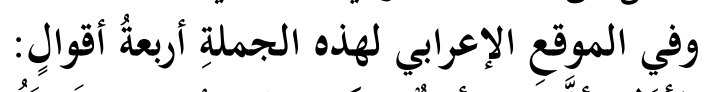

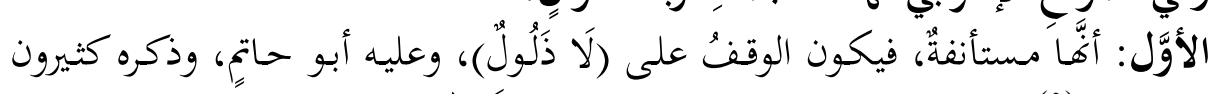

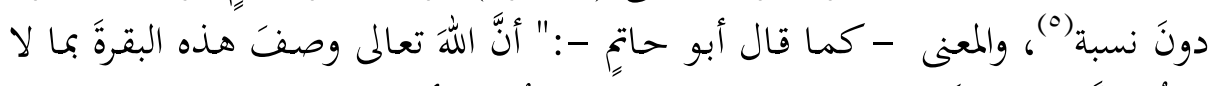

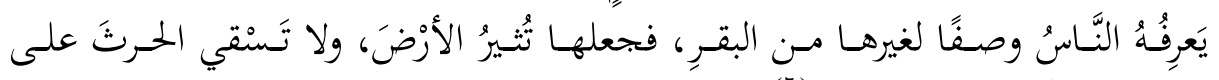

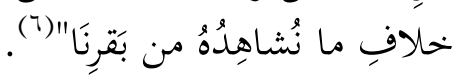

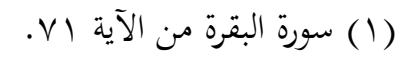

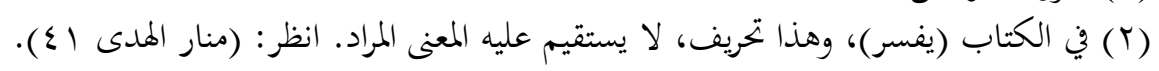

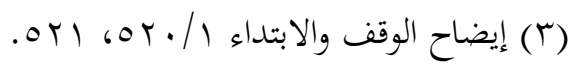

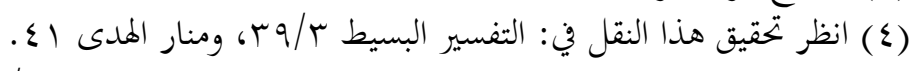

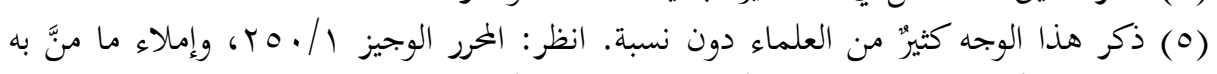

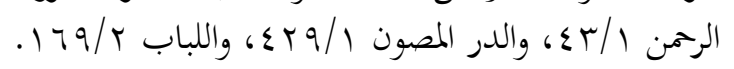

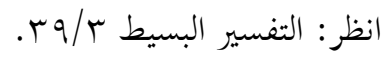




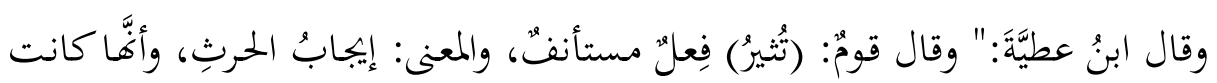

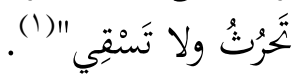

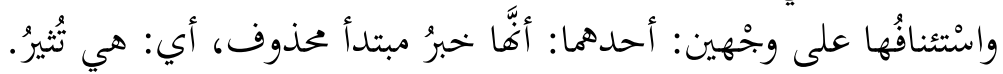

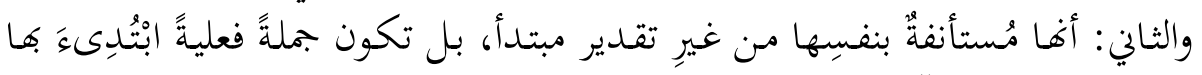

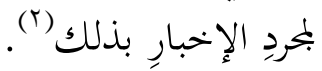

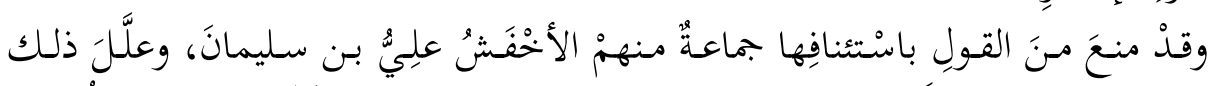

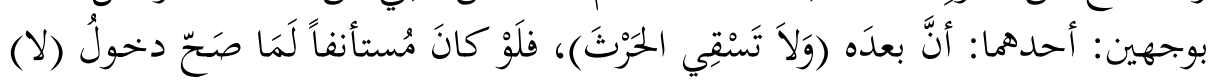
بينَه وبين (الواو).

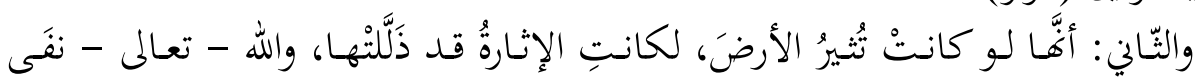

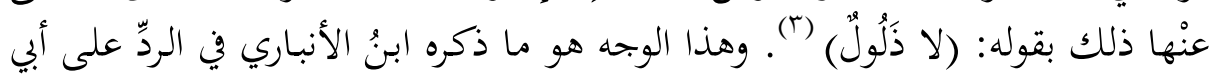

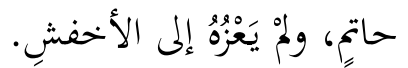

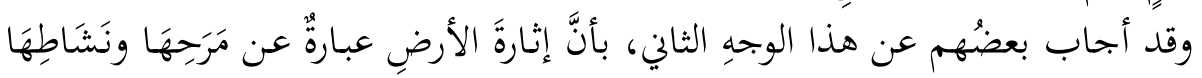

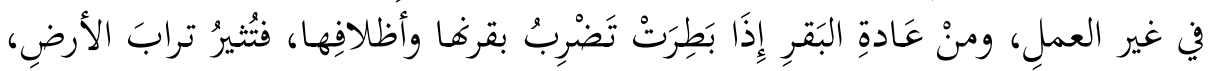

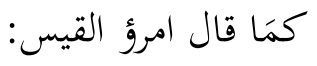

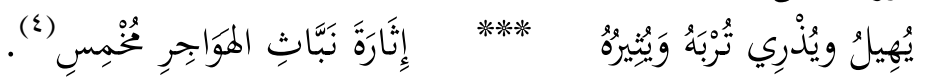

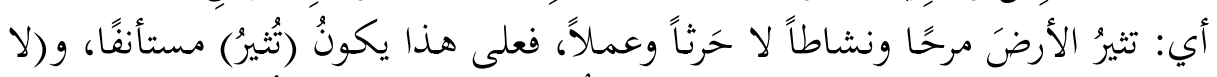

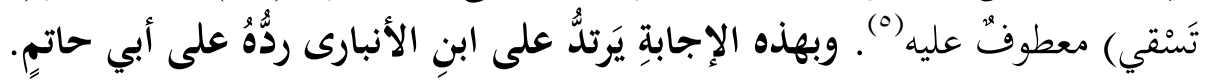

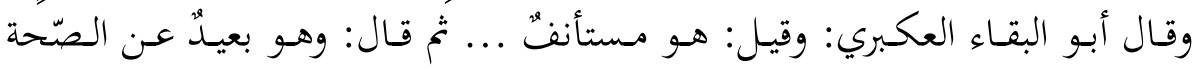

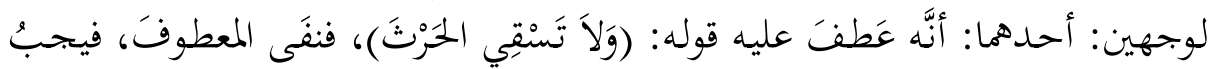

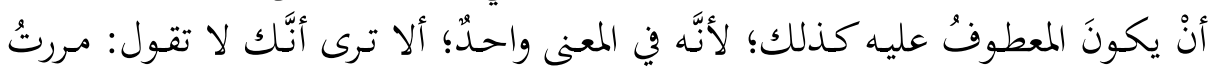

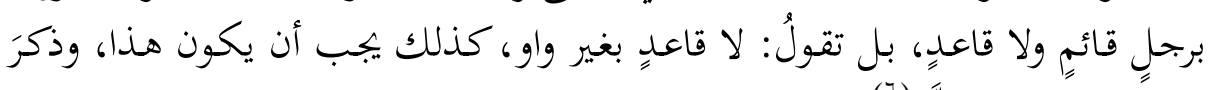

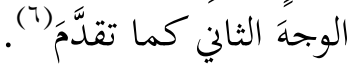

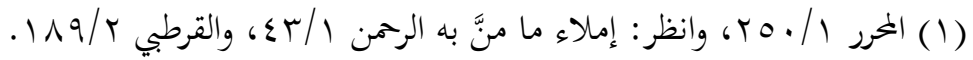

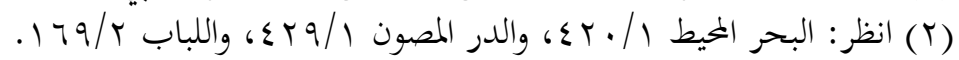

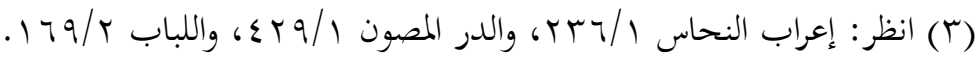

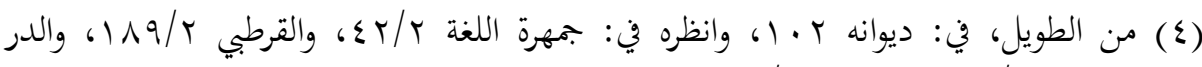

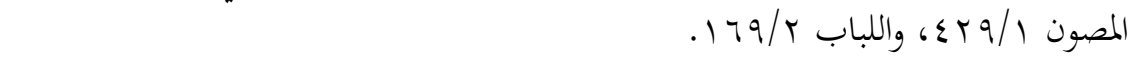

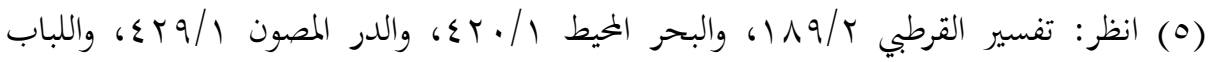

$.179 / \%$

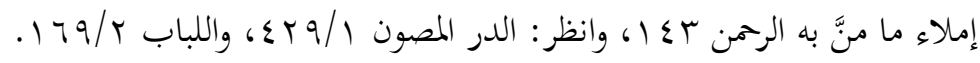




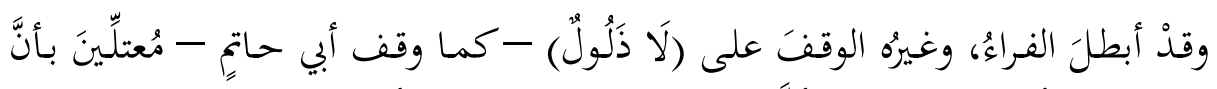

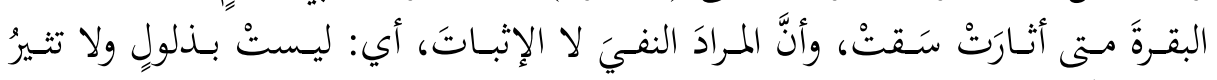

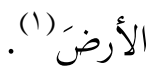

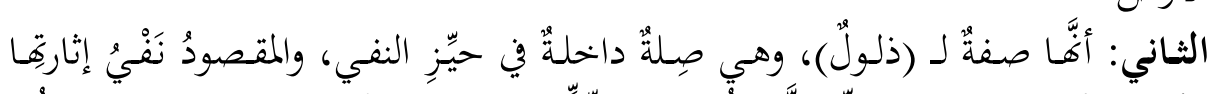

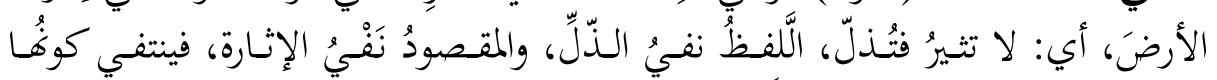

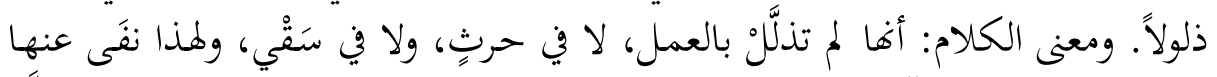

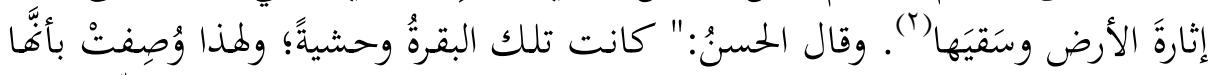

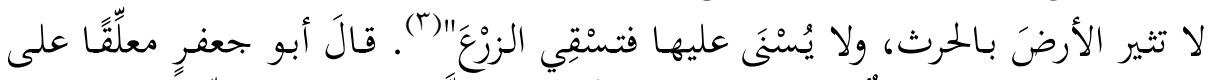

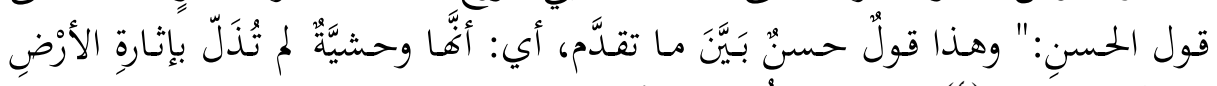

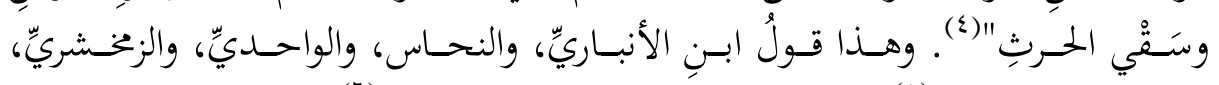

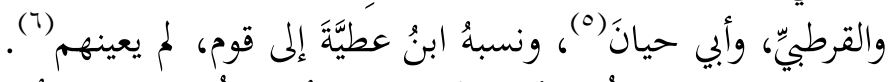

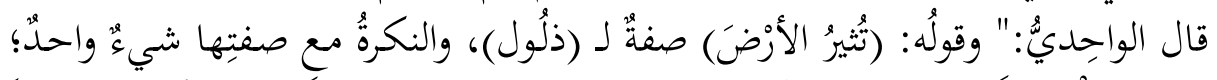

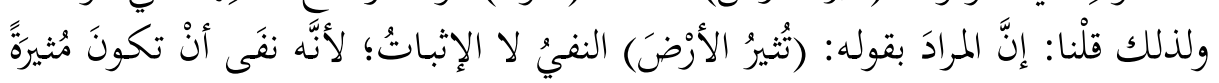

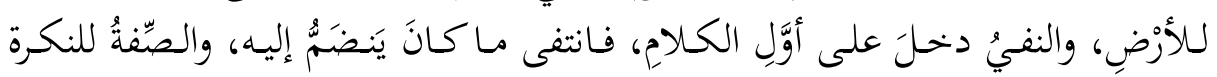

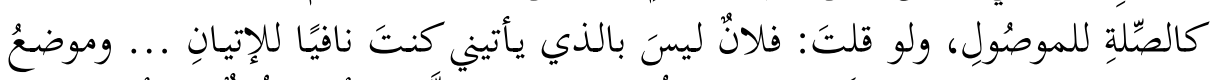

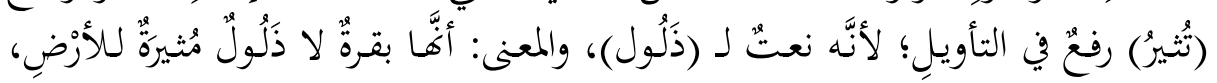

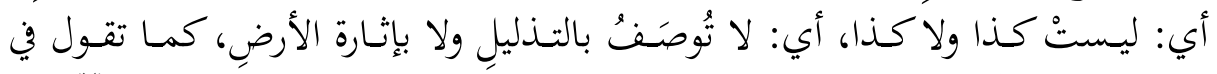

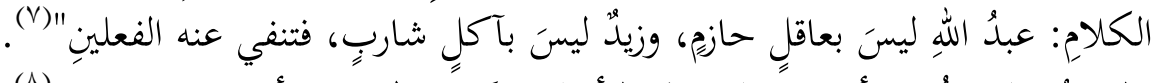

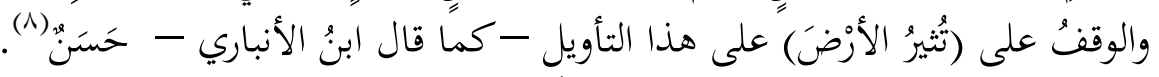

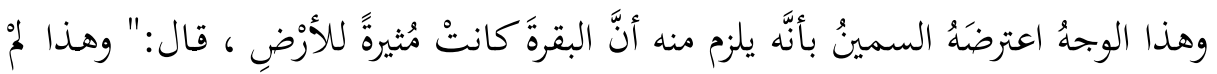

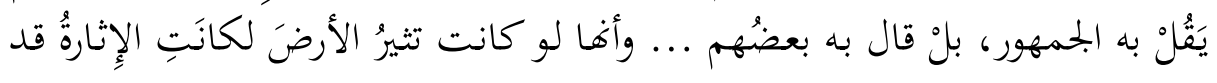

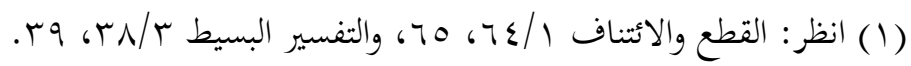

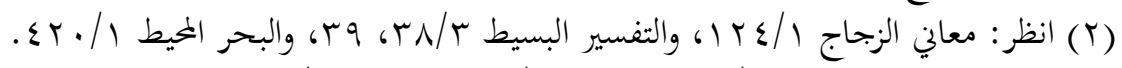

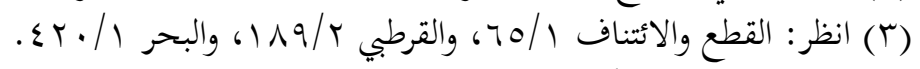

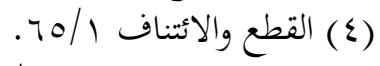

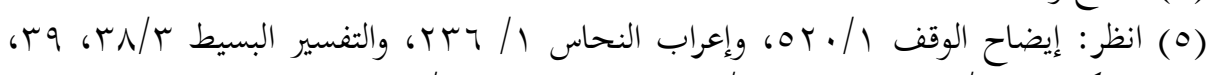

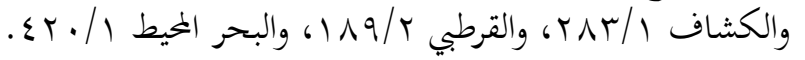

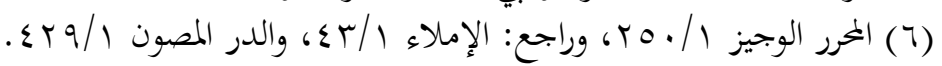

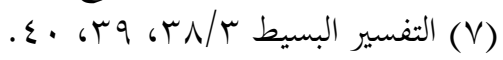

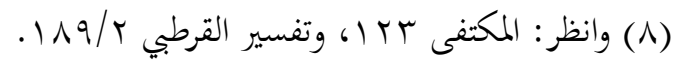




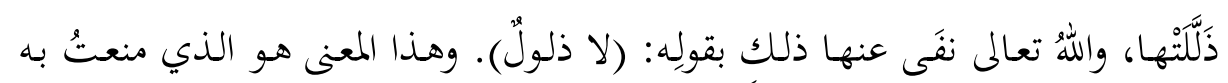

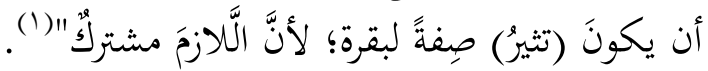

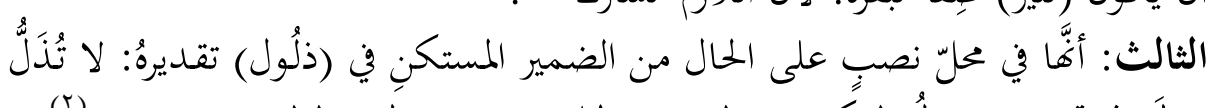

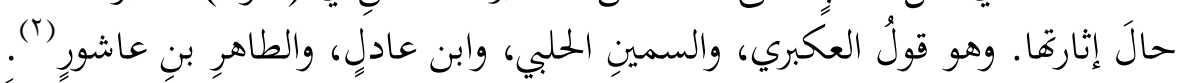

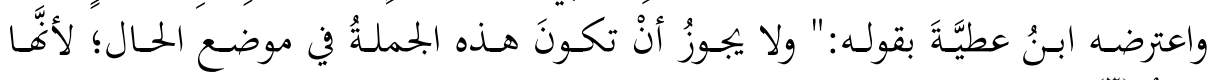

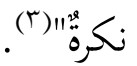
وردَّ عليه السَّمينُ فقـال:" وأمَّا قولُ (ابن عطية): (لا يجّوز أن تكون حالاً يعني: مـن (بقرة)؛ لأفَّا نكرة.

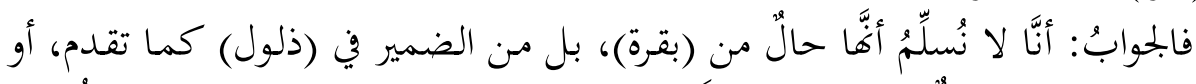

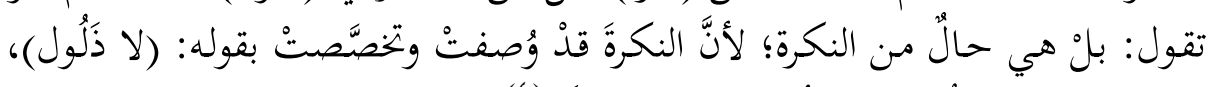

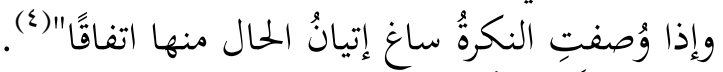

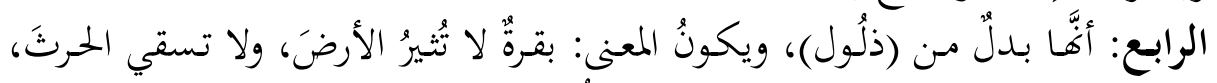

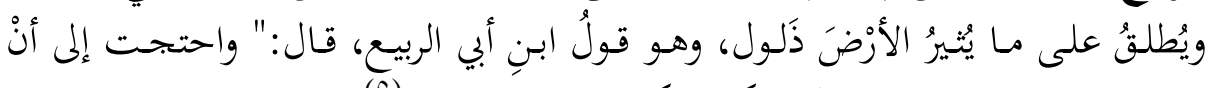

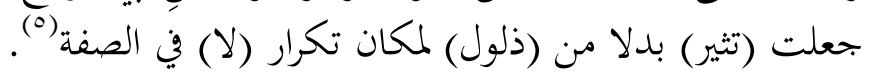

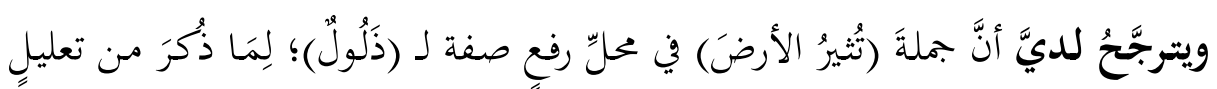

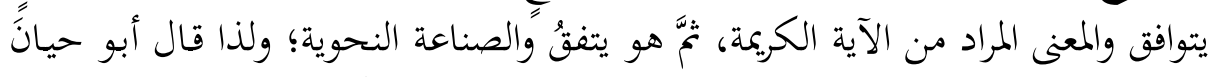

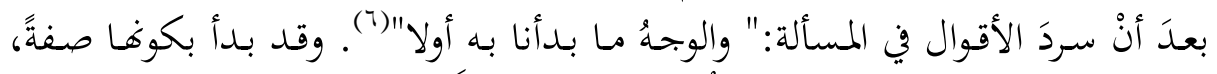

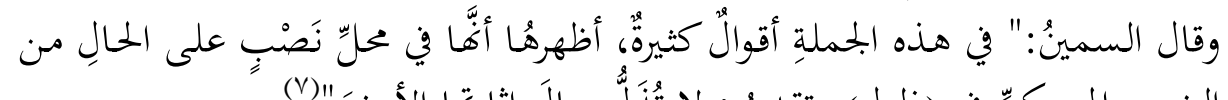

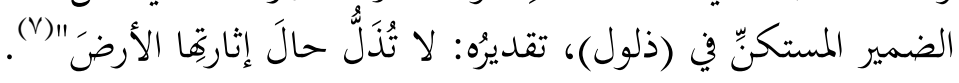

المسألة الثامنة: موقعُ قوله تعالى:

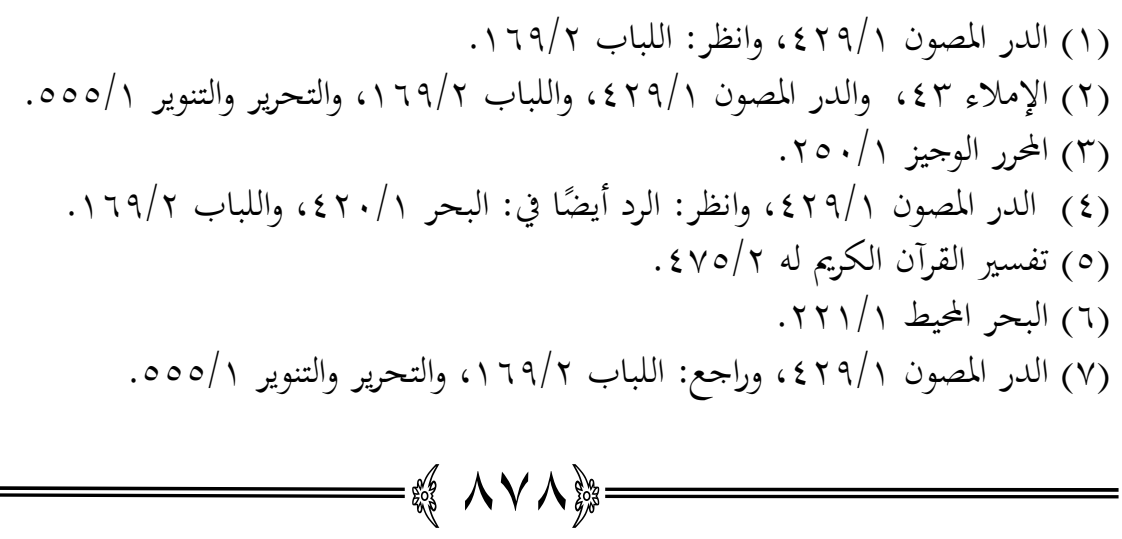




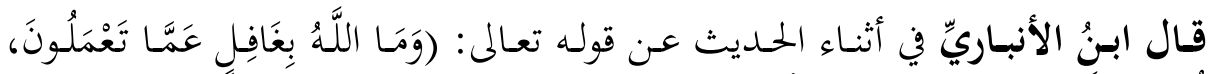

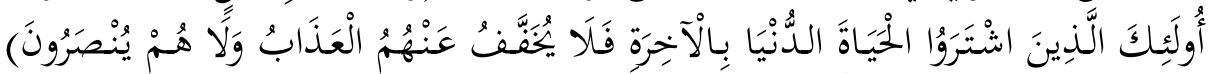

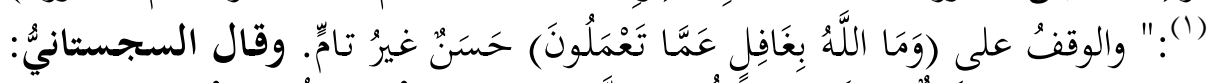

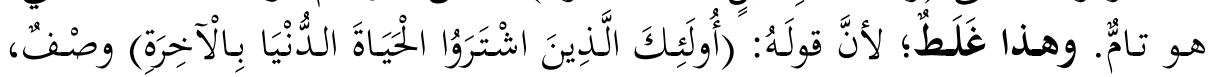

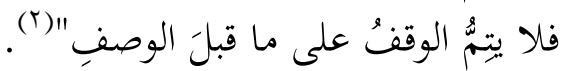

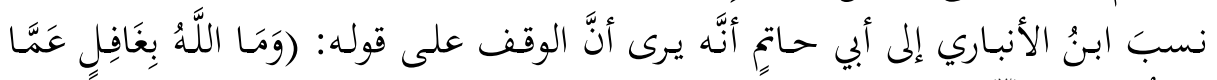

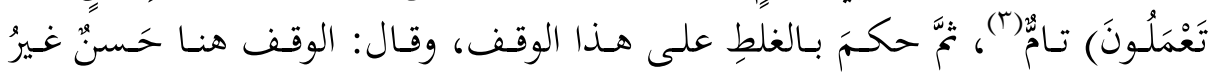
تانيّ)

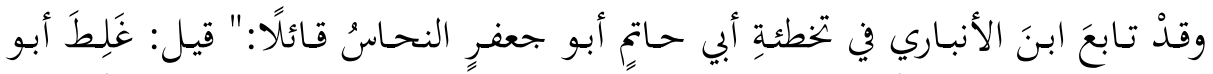

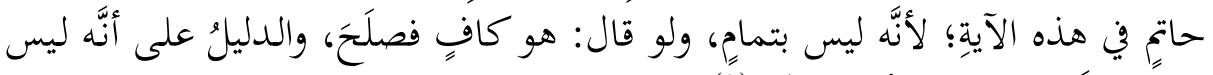

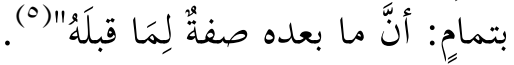

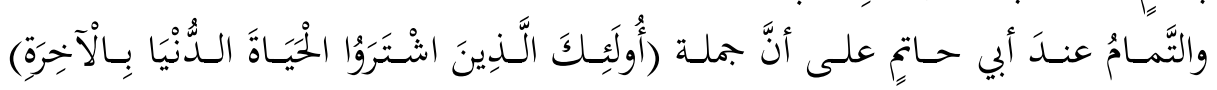

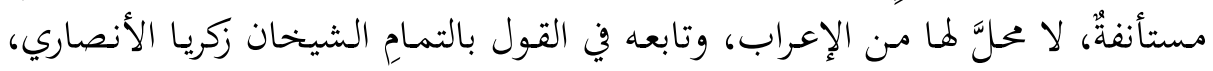

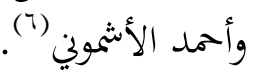

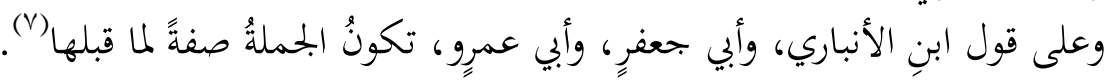

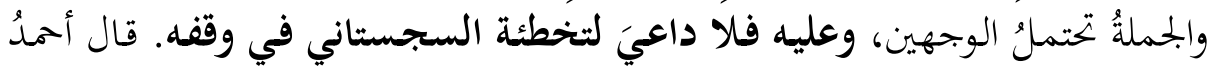

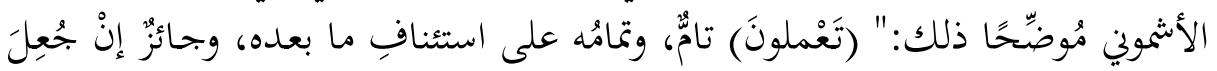

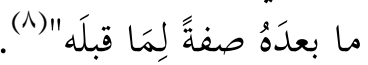

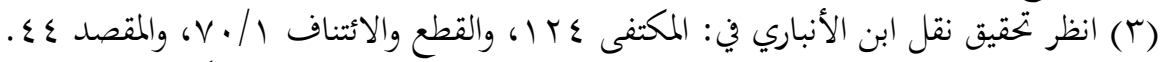

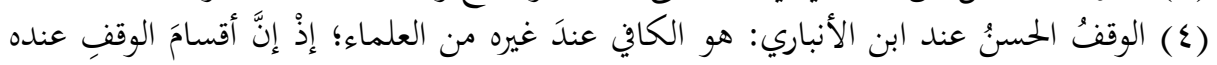

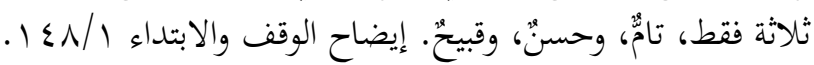

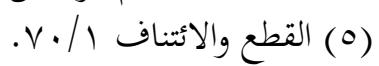

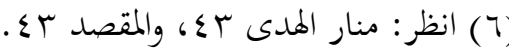

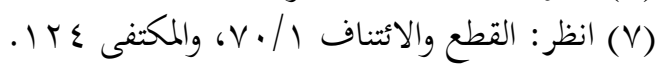

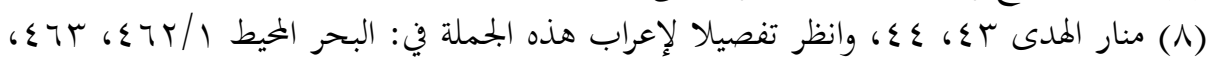

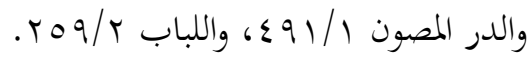




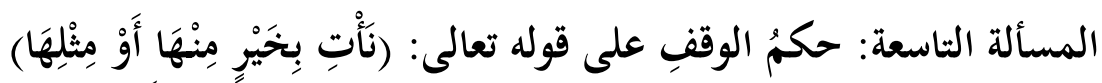

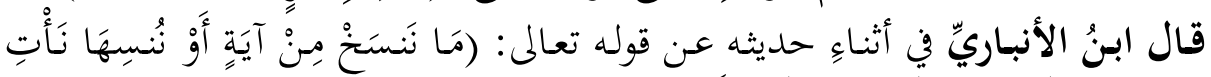

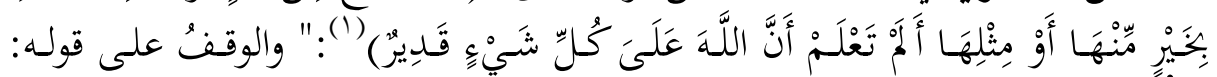

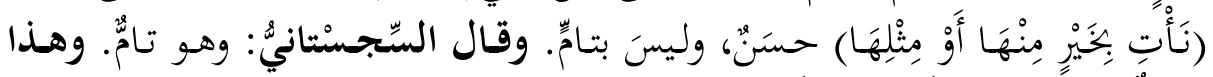

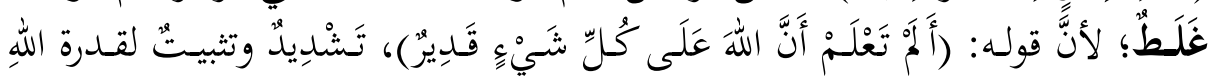

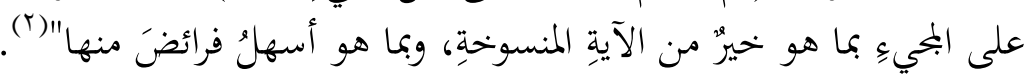

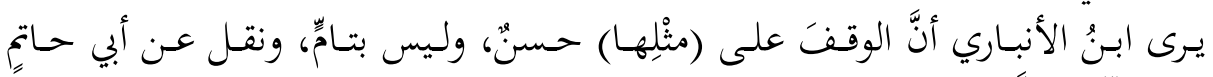

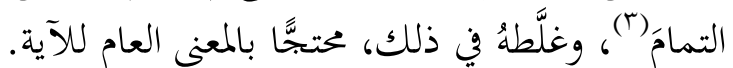

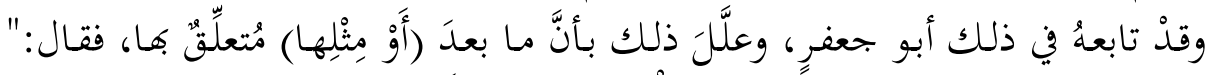

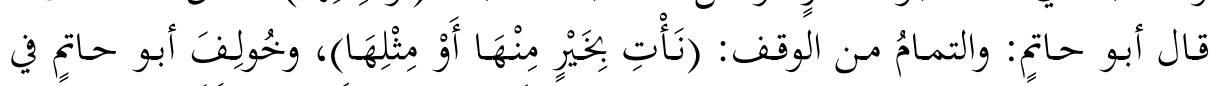

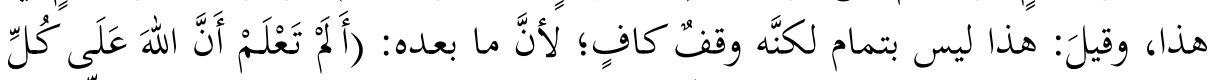

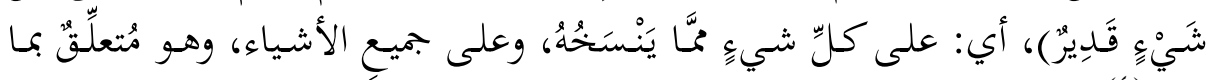
قبله" () (3)

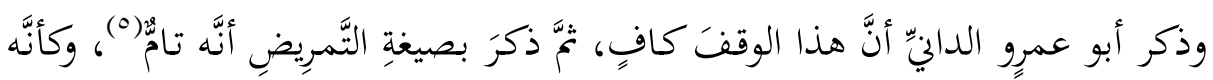

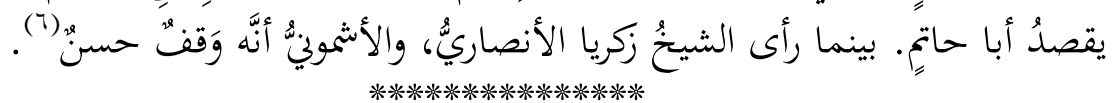

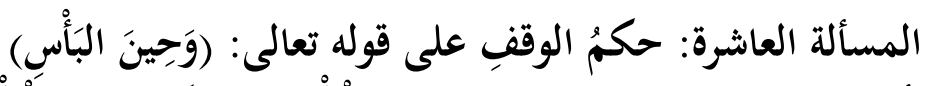

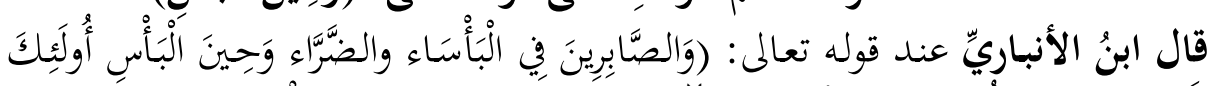

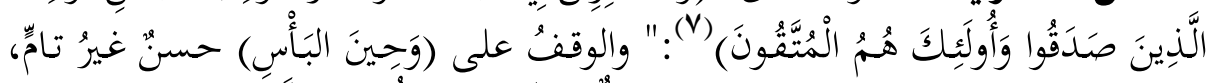

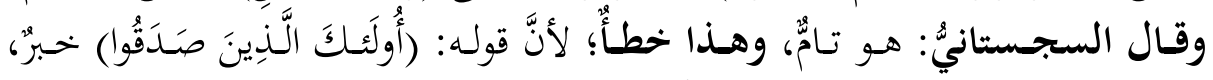

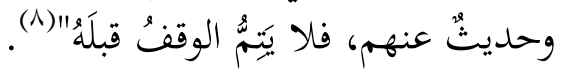

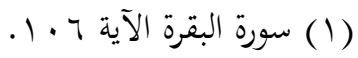

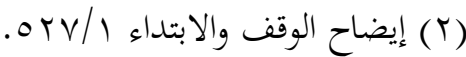

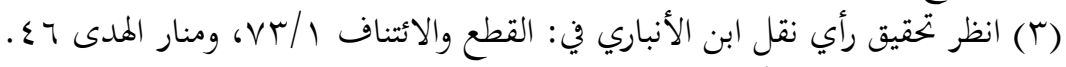

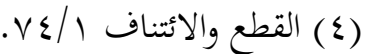

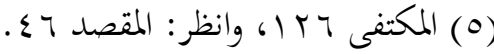

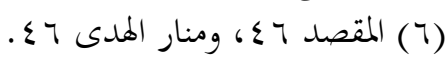

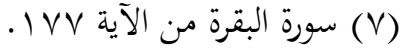

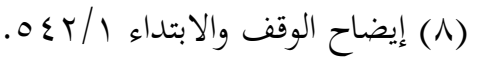




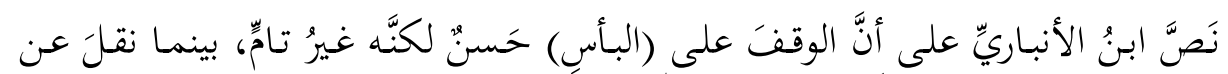

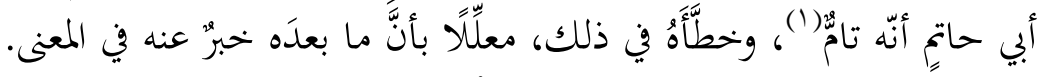

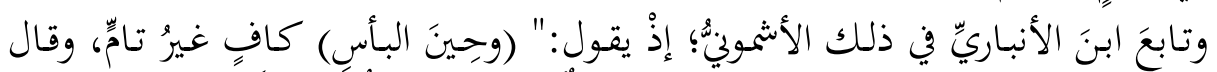

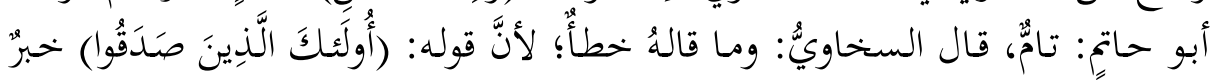

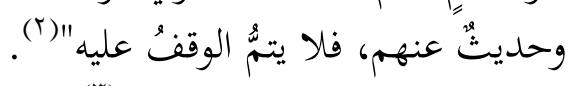

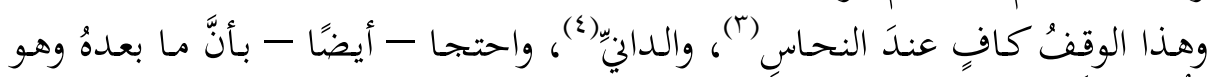

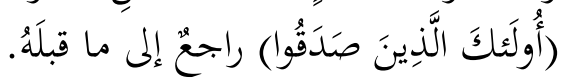

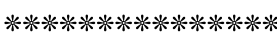

\section{المسألةُ الحاديةَ عشرةً: حكمُ الوقفِ على قوله تعالى: (لِلنَّاس)}

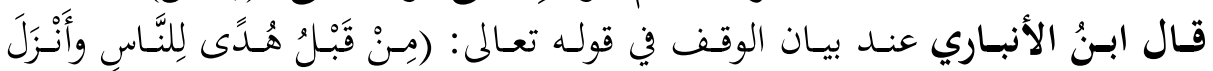

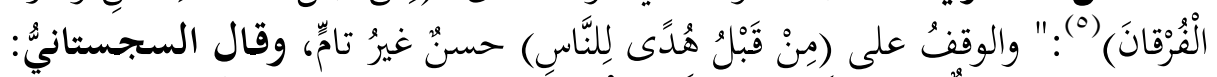

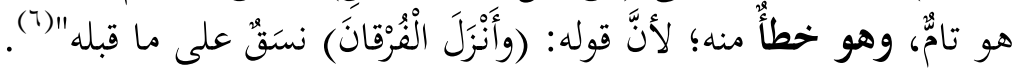

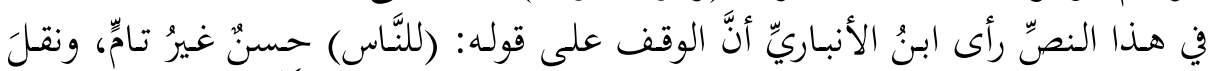

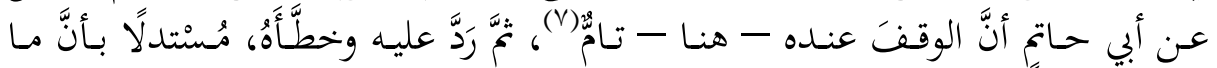

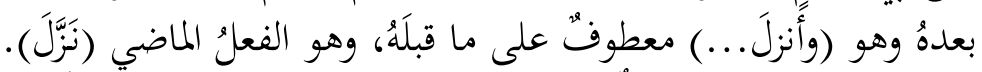

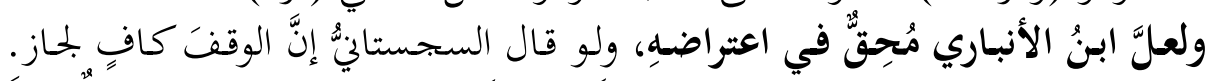

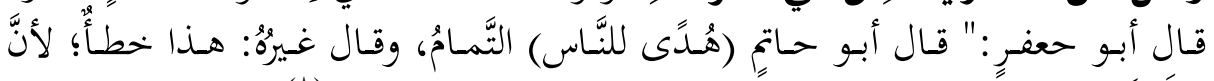

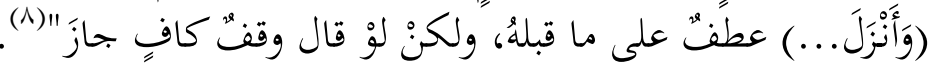

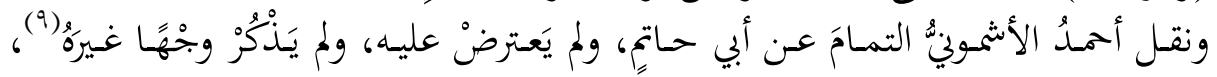
وهذا دليُ موافقتهِ. بينما ذكرَ الشيخُ زكريا الأنصاريُّ أنَّهُ وقفُ كافٍٍ (·').

$$
\begin{aligned}
& \text { (1) ينظر النقل في: منار الهدى بـه، نقاً عن السخاوي. }
\end{aligned}
$$

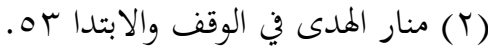

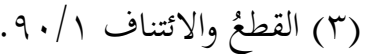

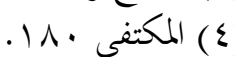

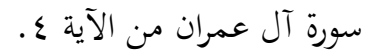

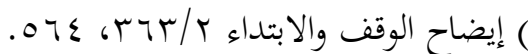

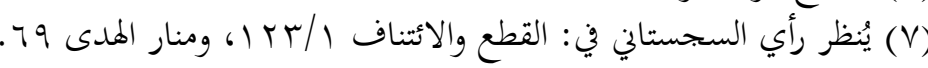




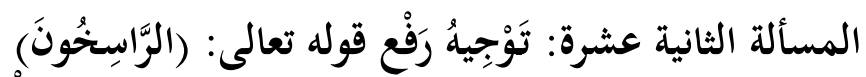

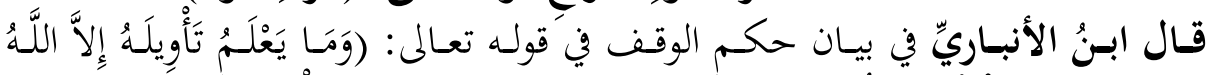

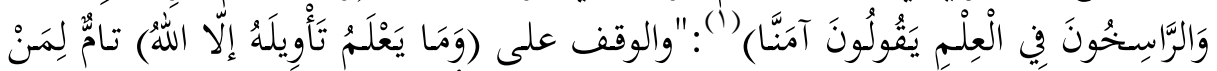

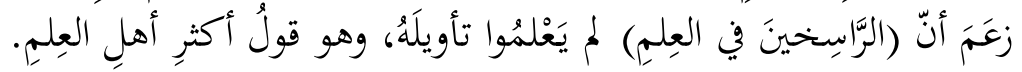

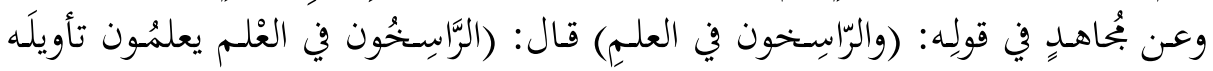

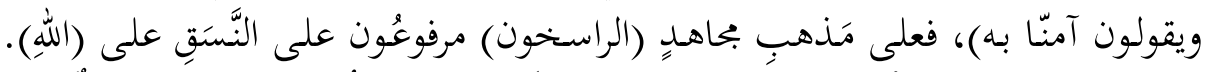

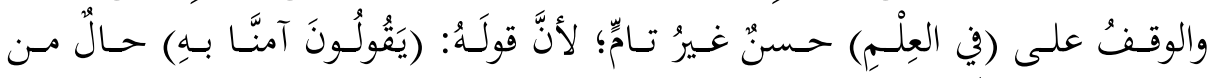

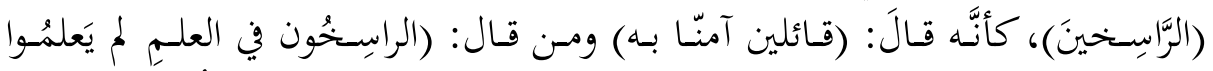

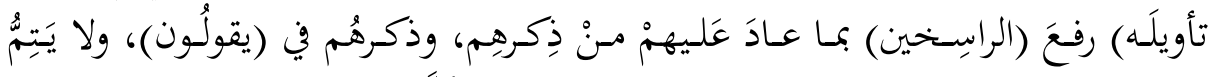

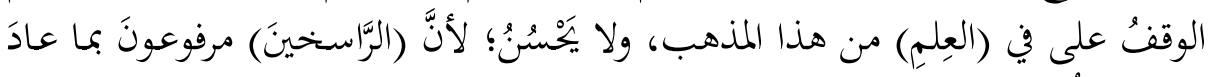

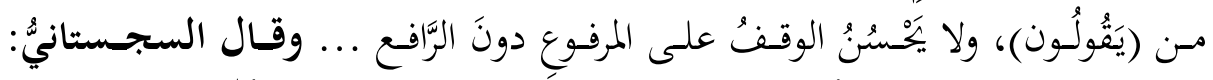

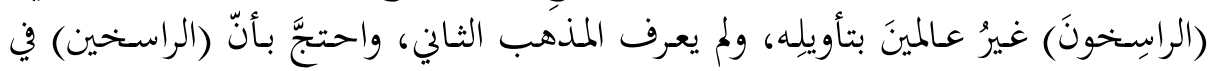

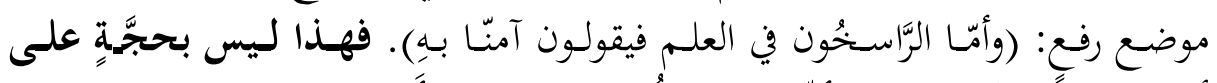

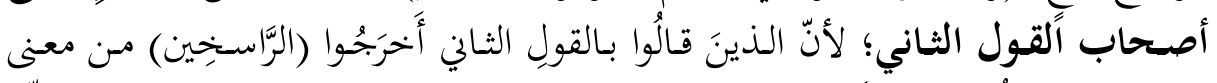

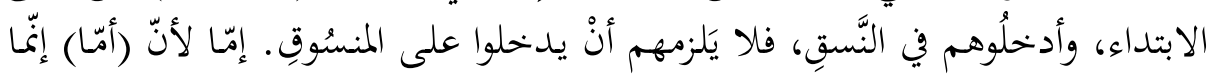

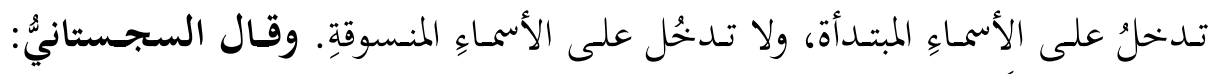

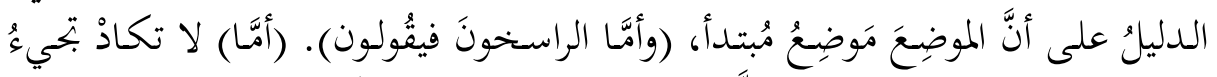

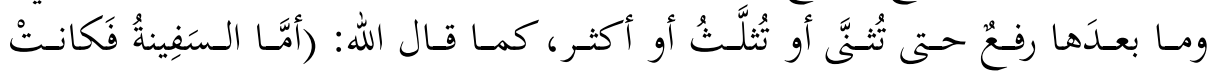

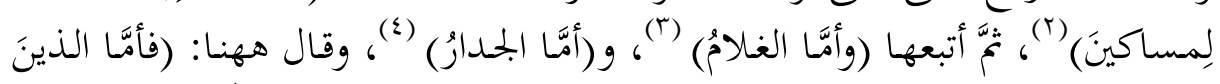

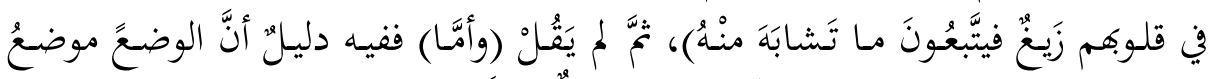

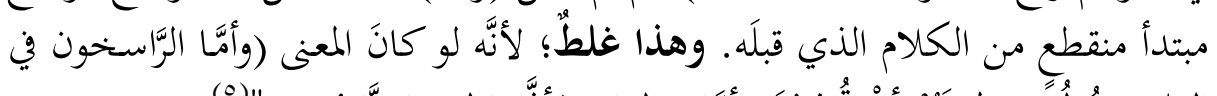

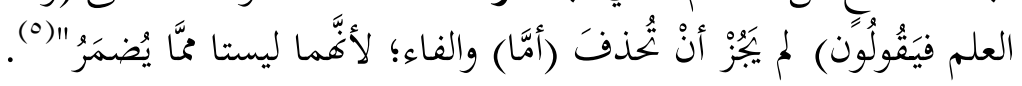




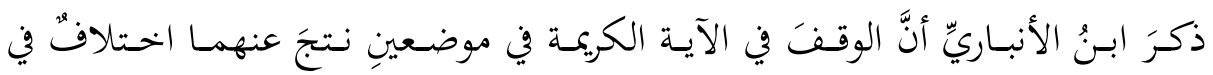

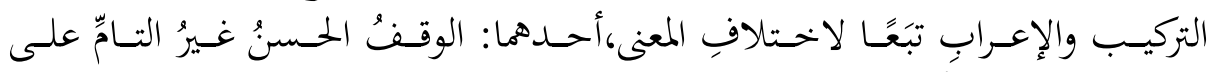

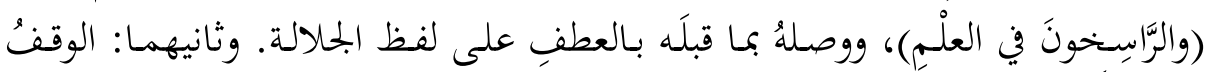

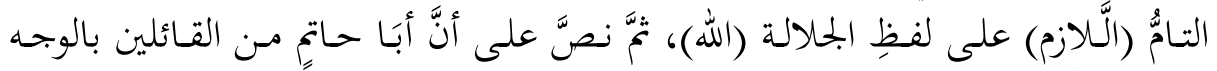

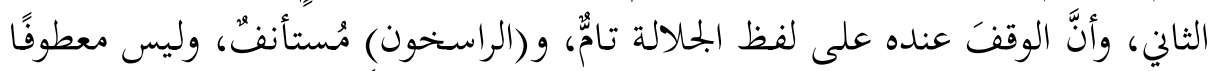

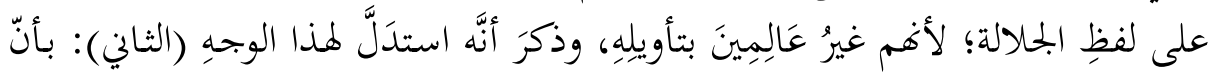

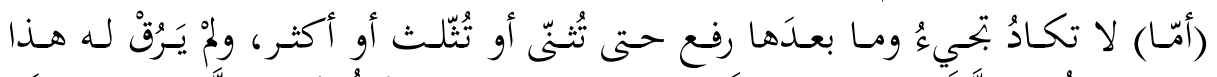

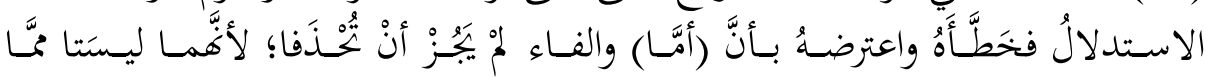

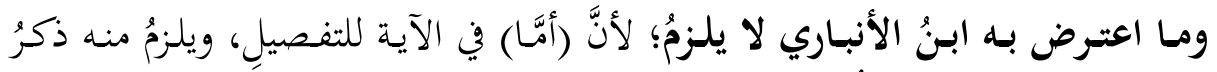

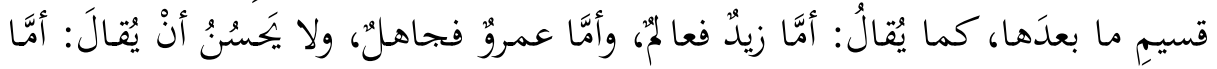

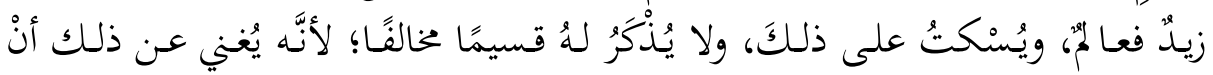

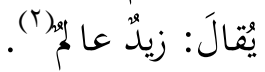

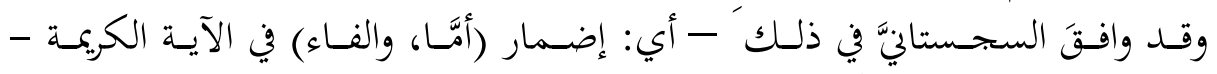

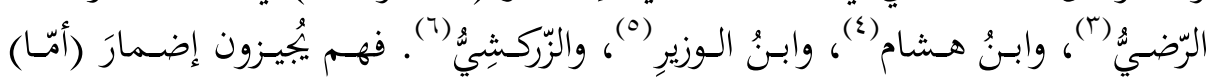

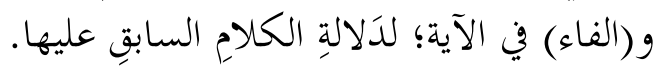

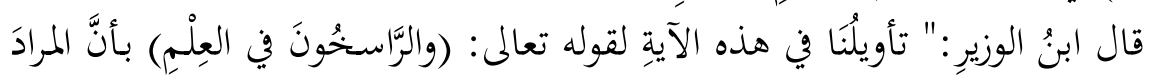

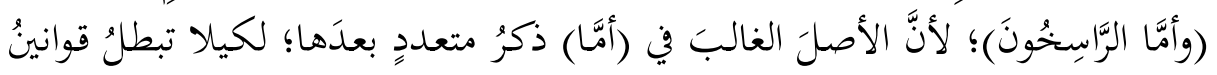

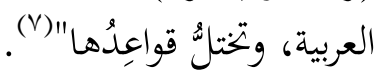

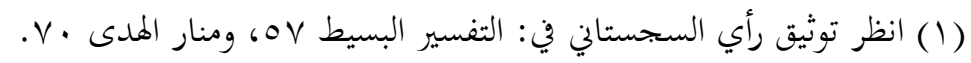

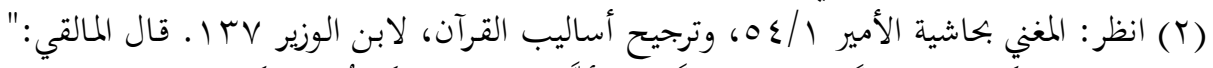

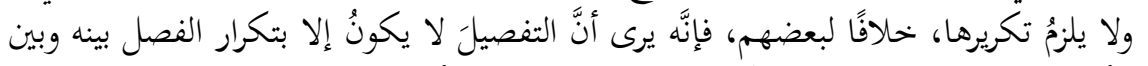

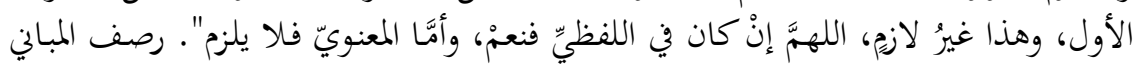

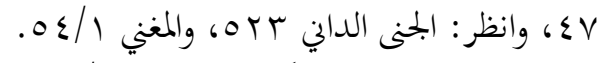

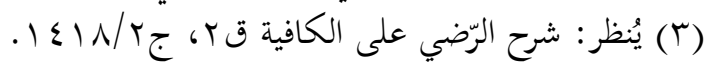

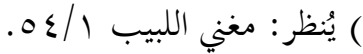

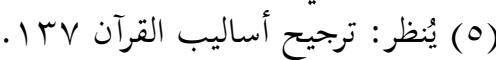

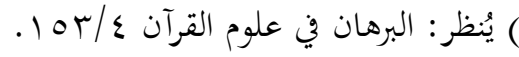

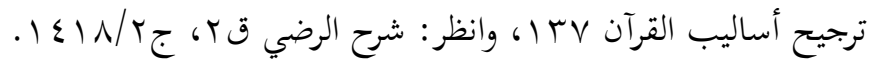




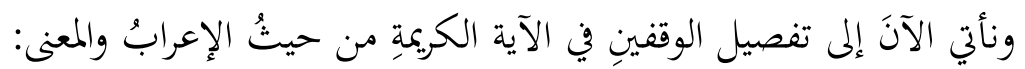

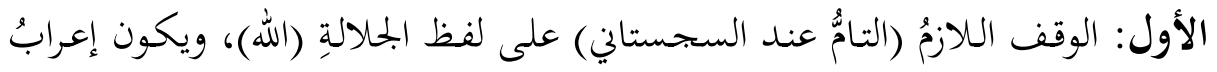

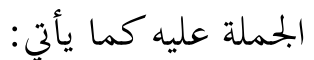

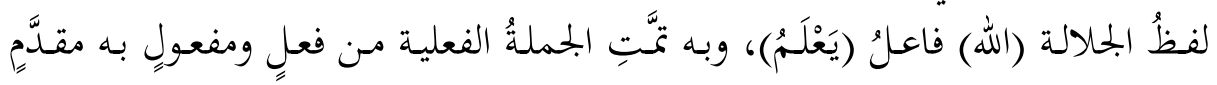
وفاعل.

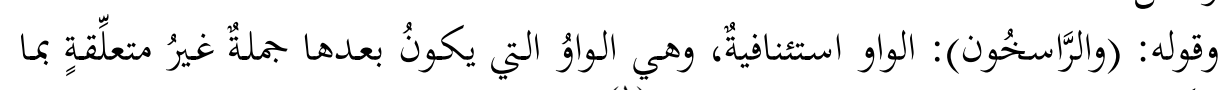

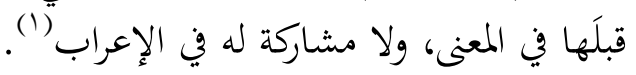

و (الرَّاسخون): مبتدأُ مرفوعُ، وجملة (يَقُولُون آمنَّا به) في محل رفع خبر المبتدأ. والجمملة

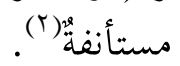

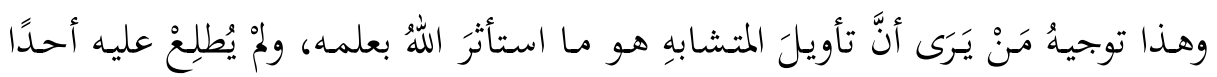

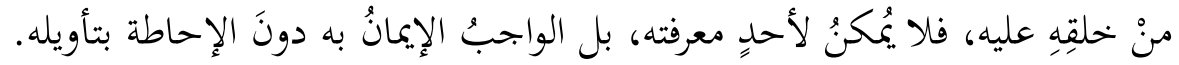

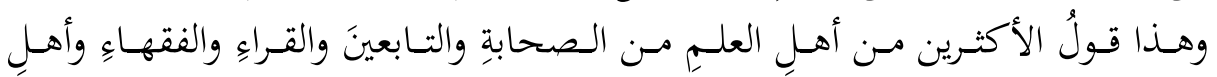

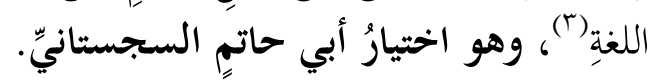

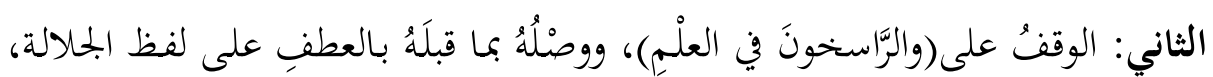

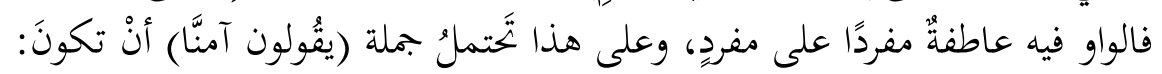

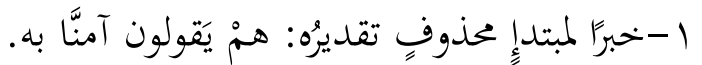

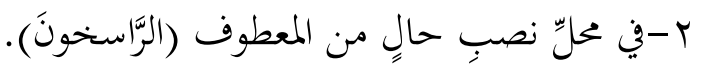

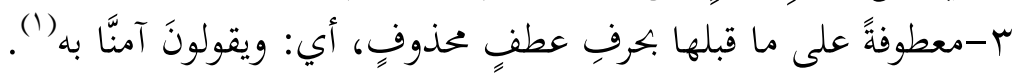

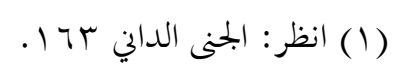

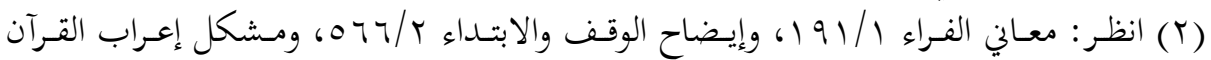

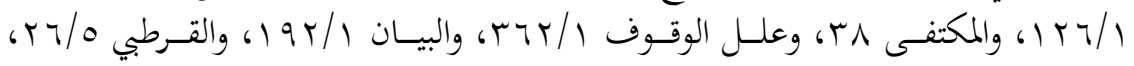

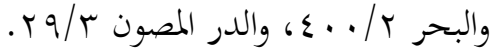

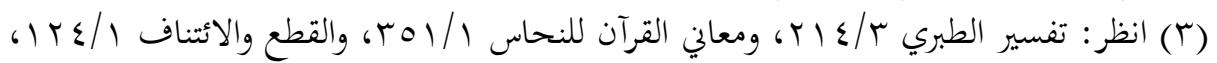

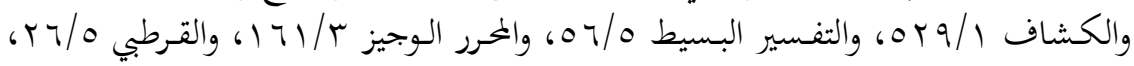

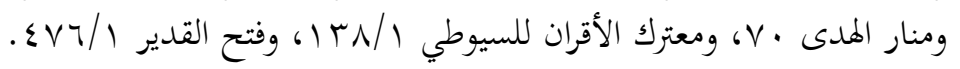




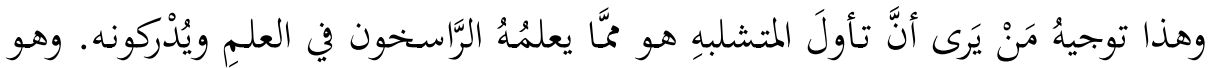

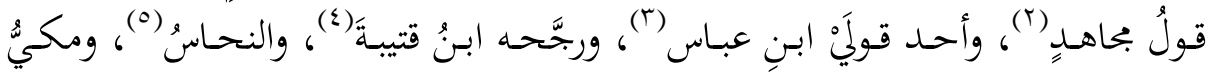

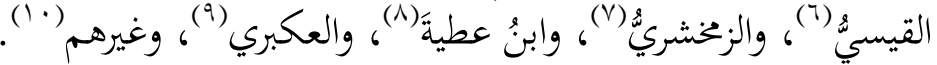

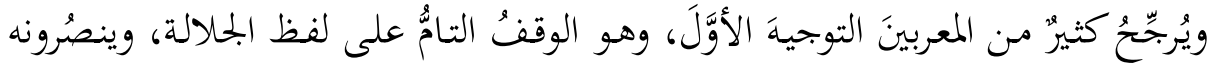

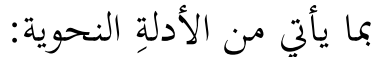

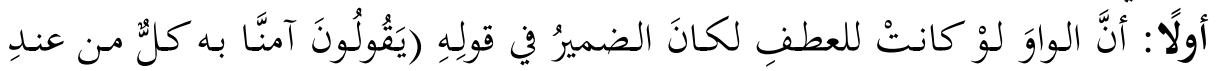

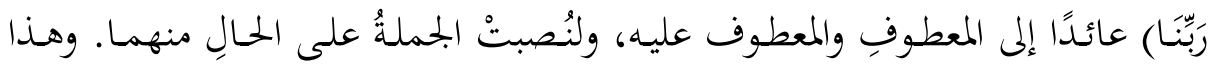

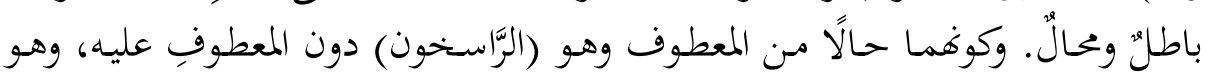

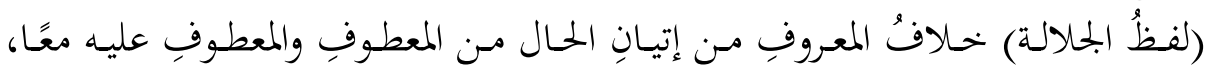
كقولك: جاءَ زيلّ وعمروٌ راكبَيْنِ (11).

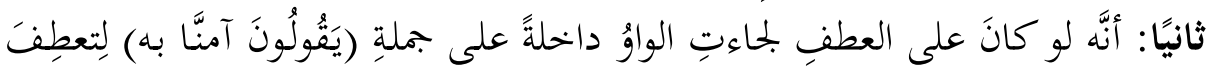

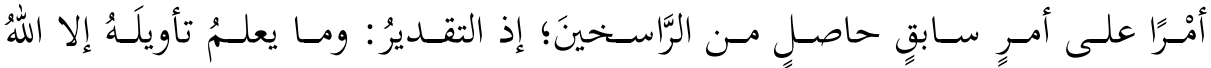

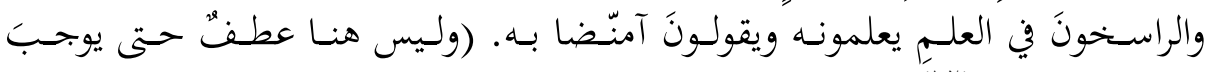

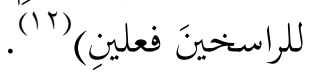

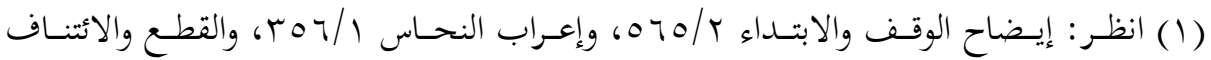

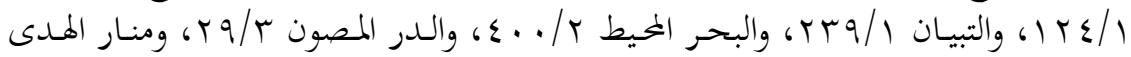

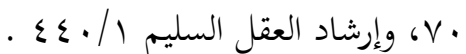

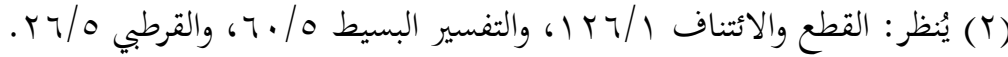

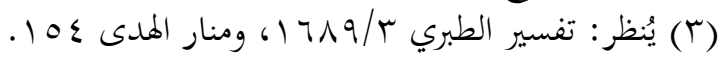

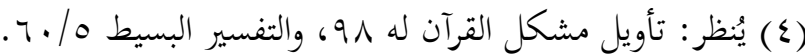

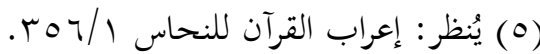

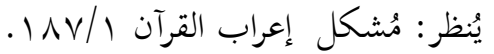

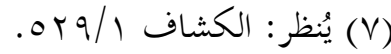

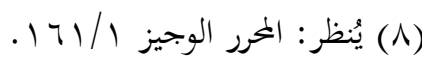

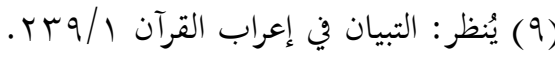

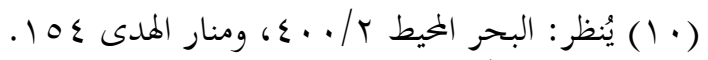

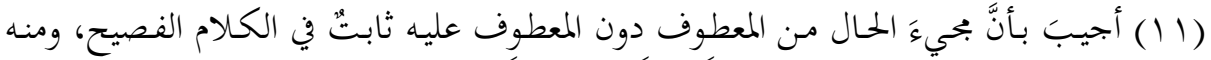

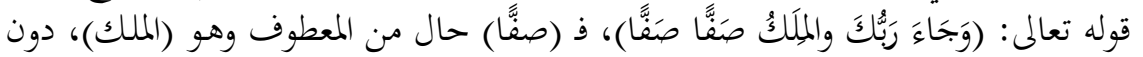

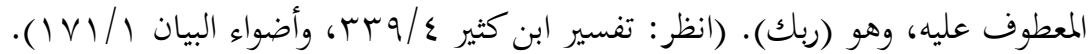

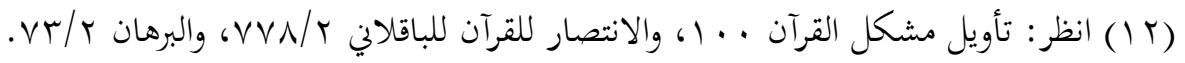




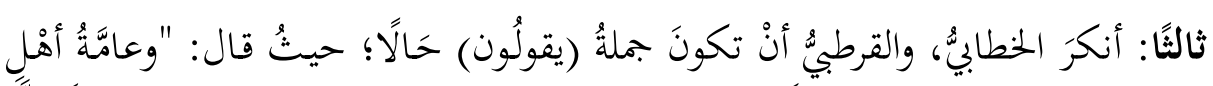

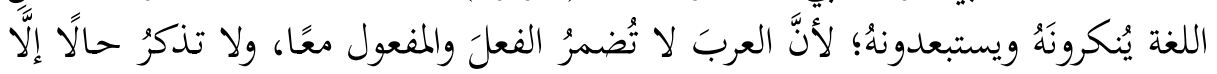

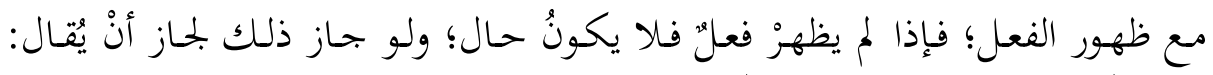

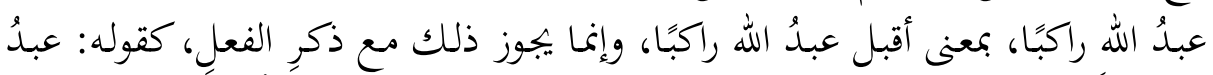

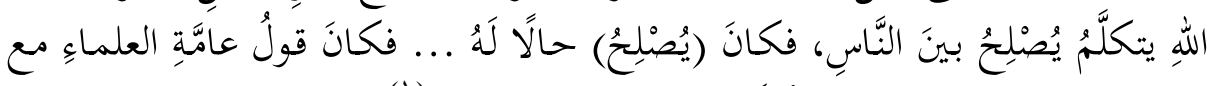

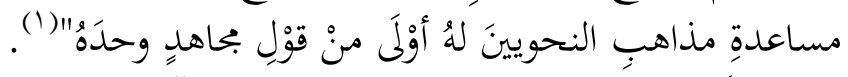

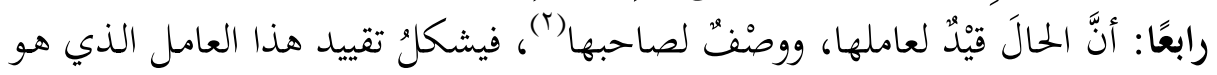

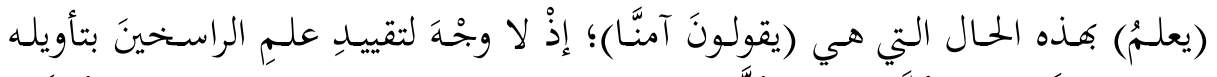

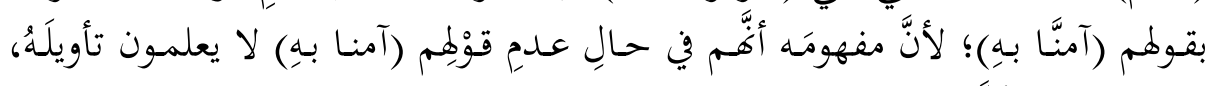

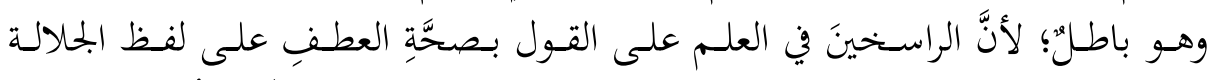

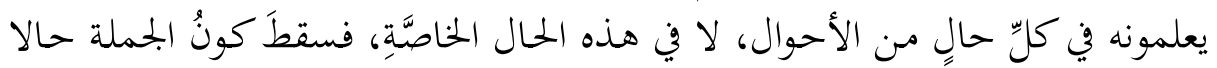

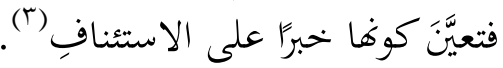

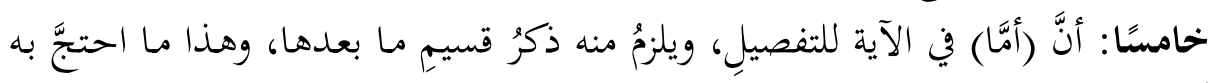
أبو حاتع كما سبق.

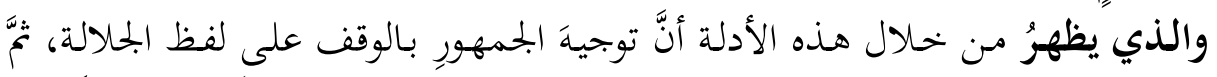

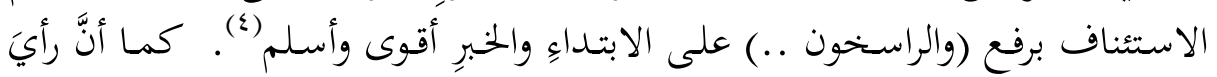

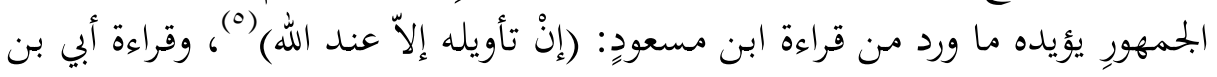

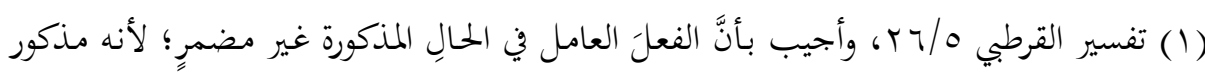

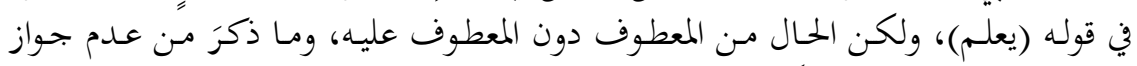

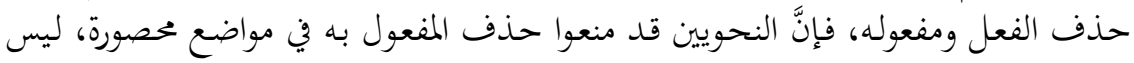

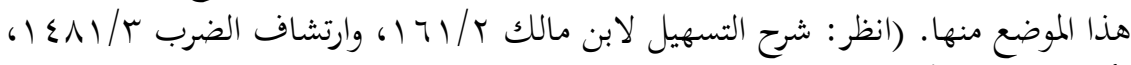

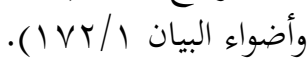

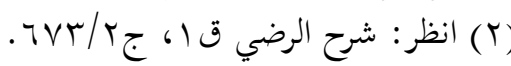

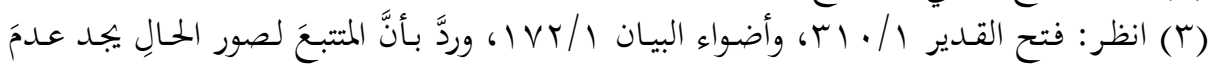

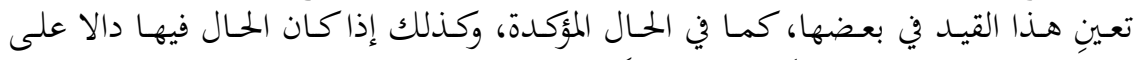

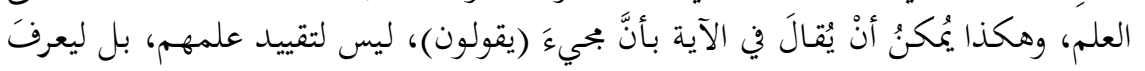

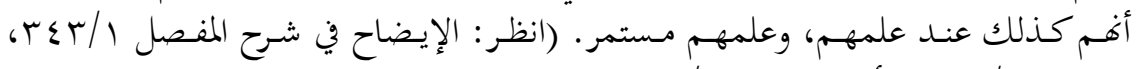

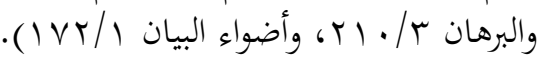

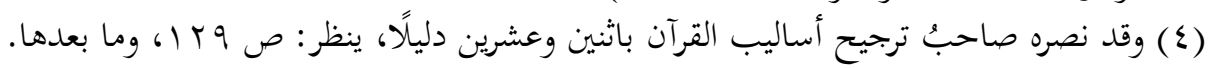

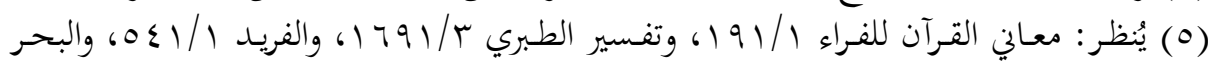

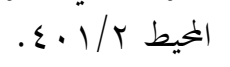




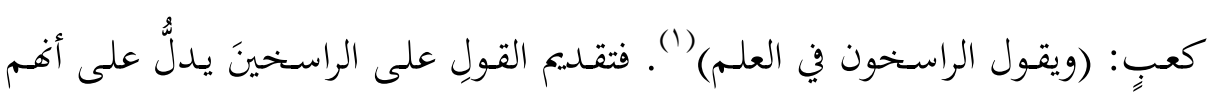

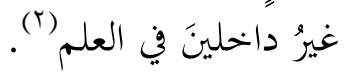

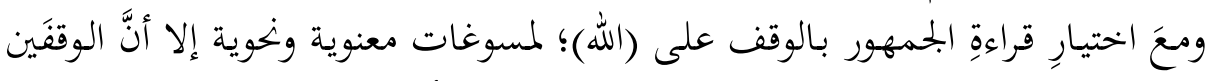

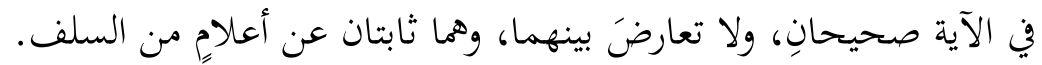

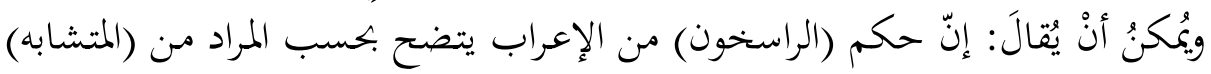

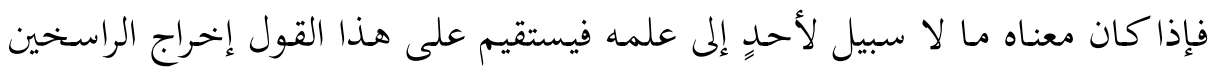
من علم تأويله، ويكون حكم (الراسخون) الرفع على الابتداء.

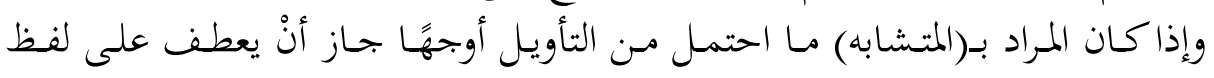
الجلالة.

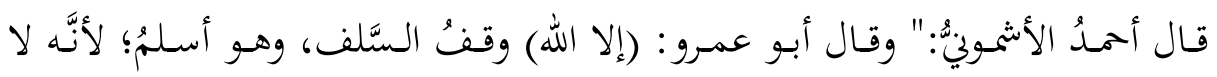

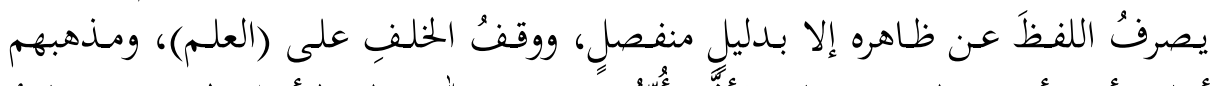

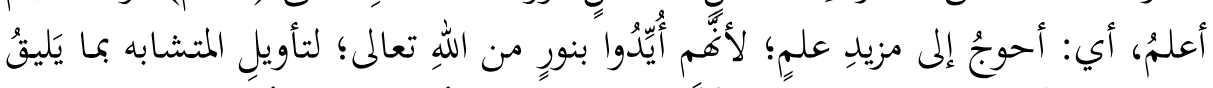

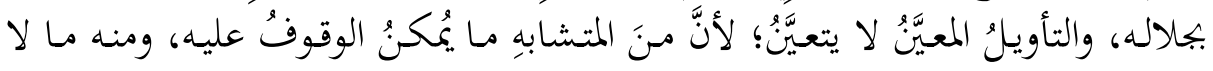

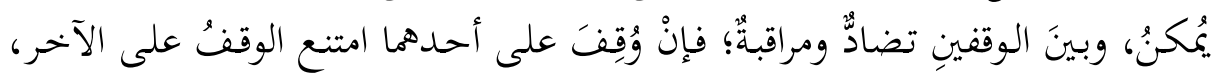

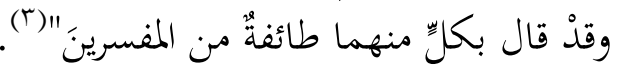

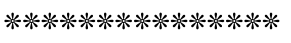

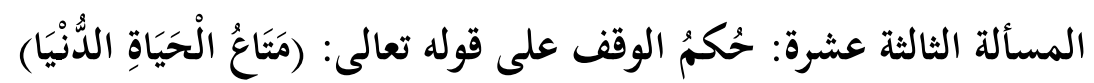

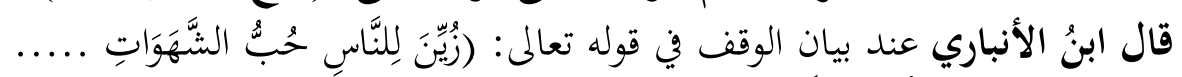

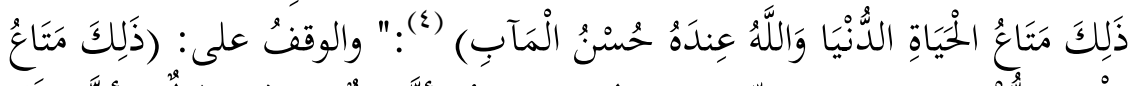

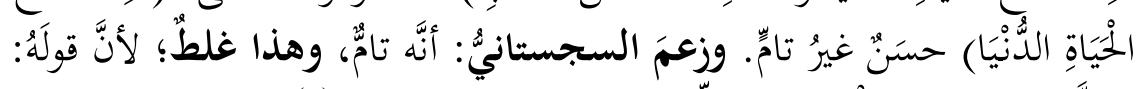

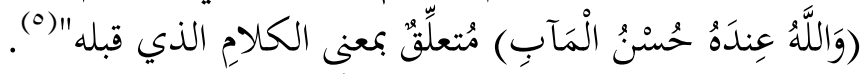

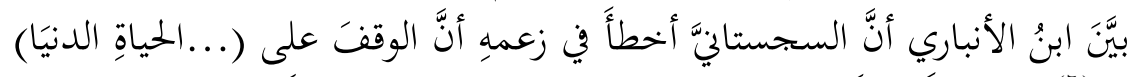

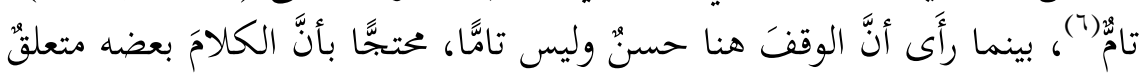

بعضٍ

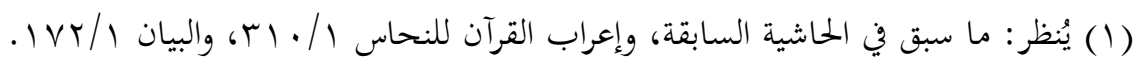

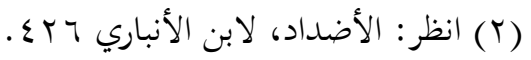

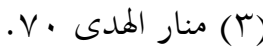

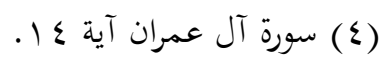

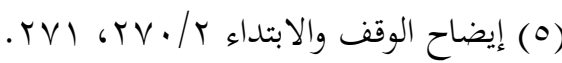

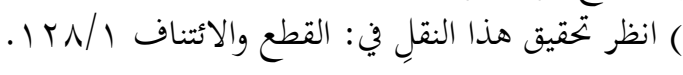




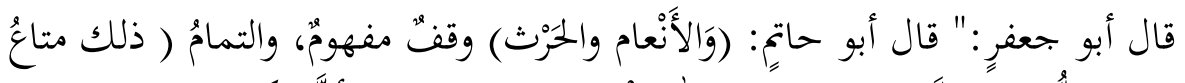

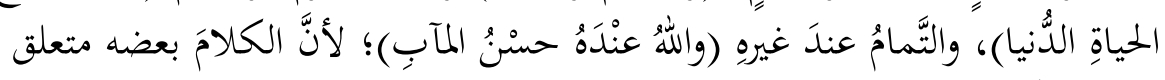

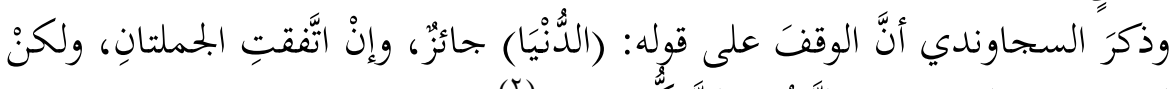

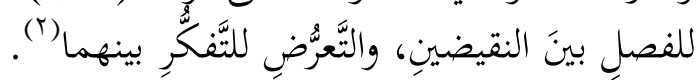

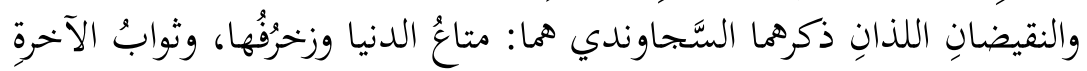

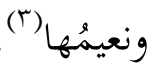

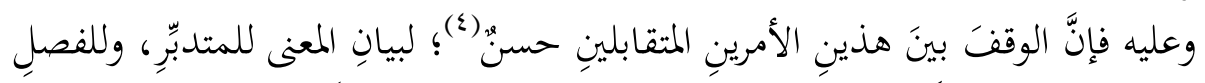

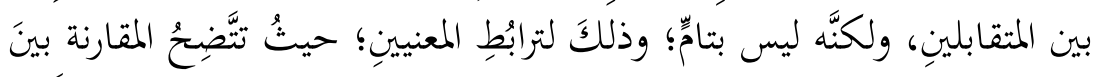

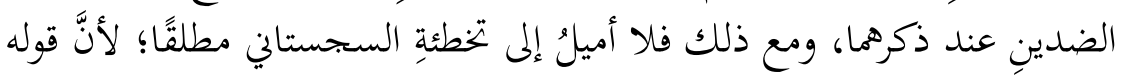

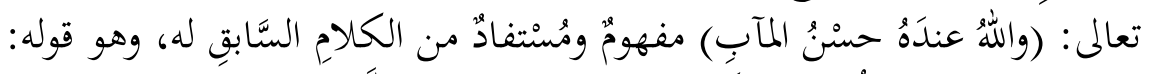

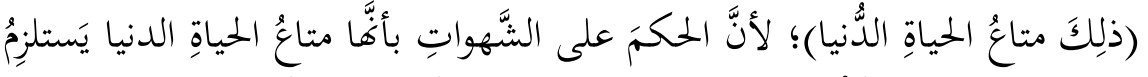

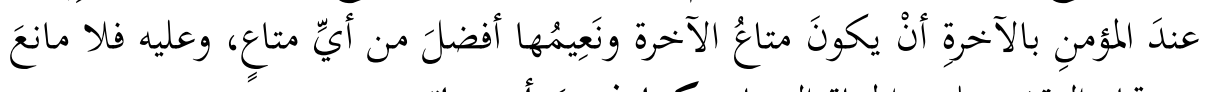

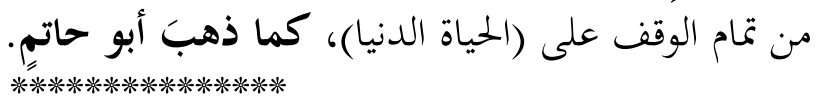

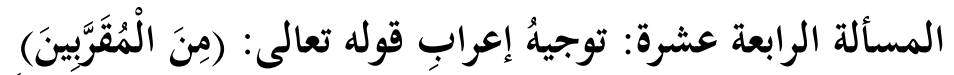

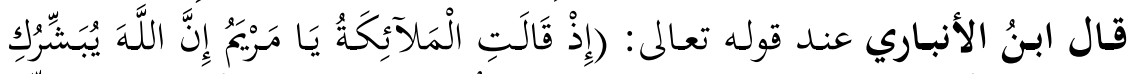

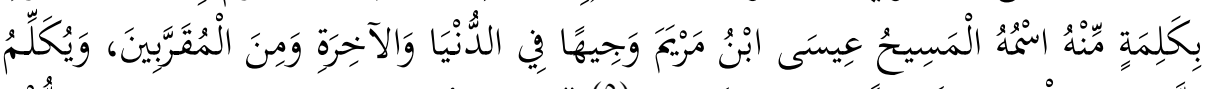

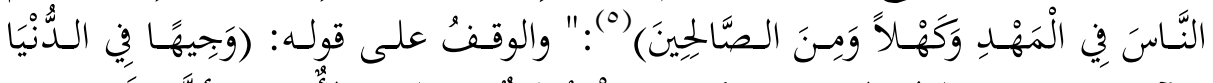

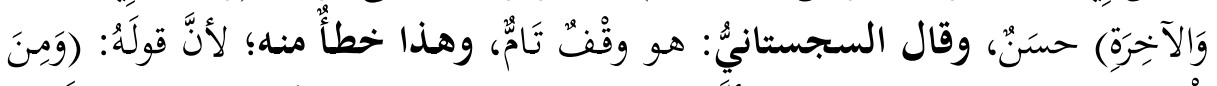

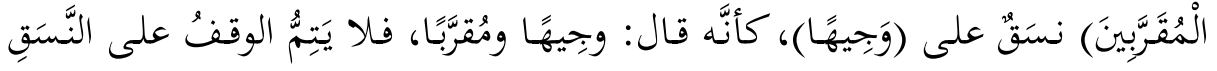

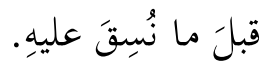

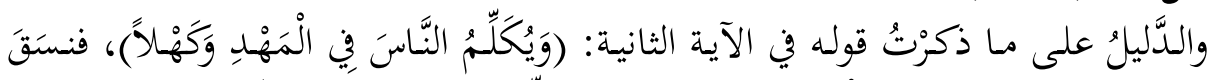

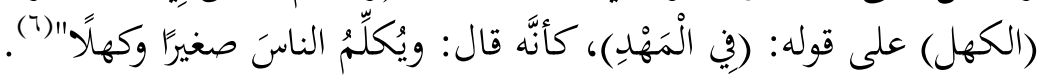

$$
\begin{aligned}
& \text { (1) (1) السابق ذاته. }
\end{aligned}
$$

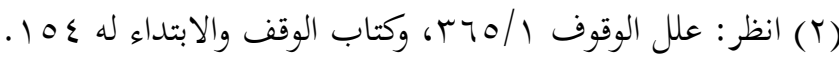

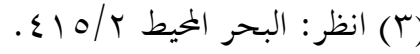

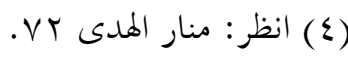

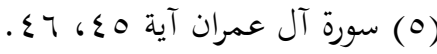

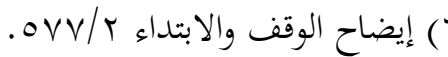




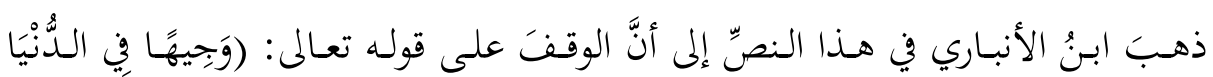

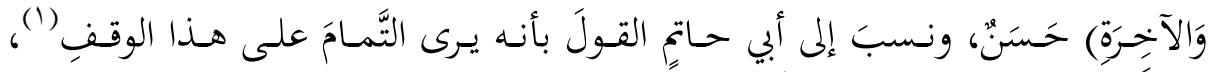

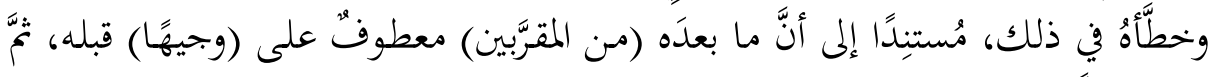

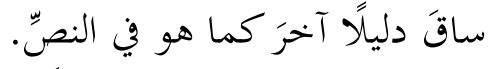

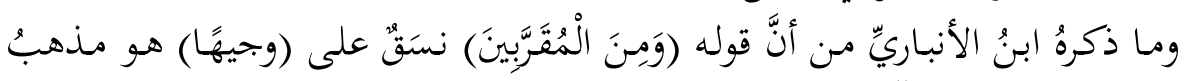

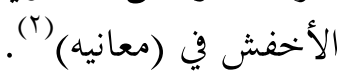

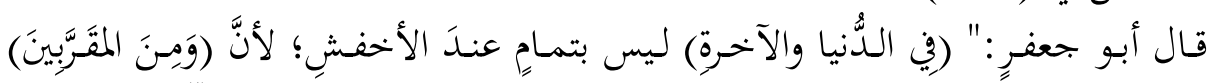

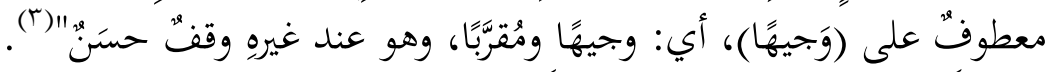

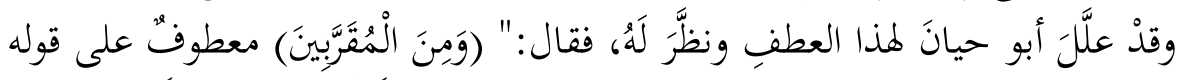

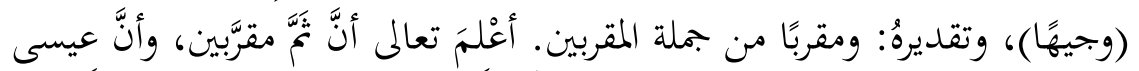

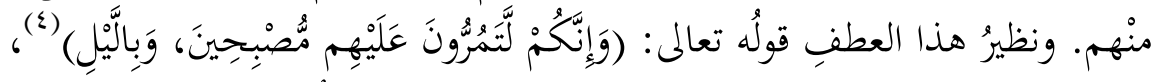

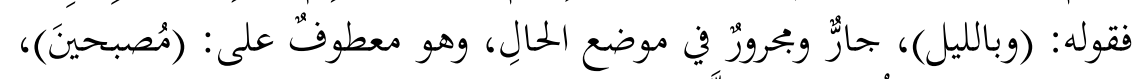

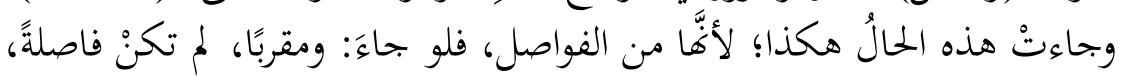

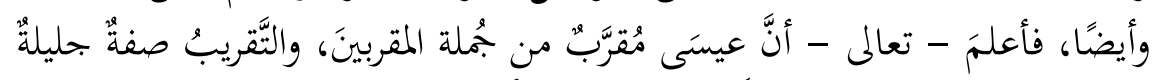

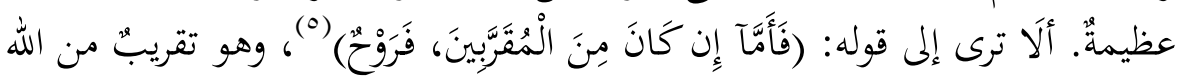

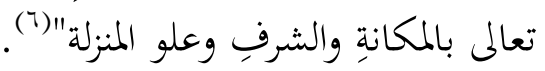

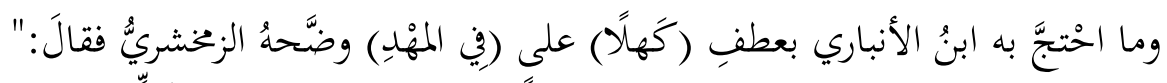

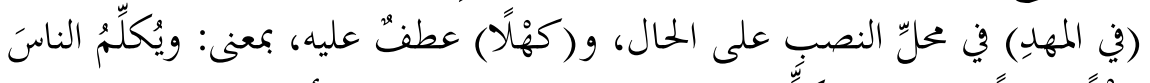

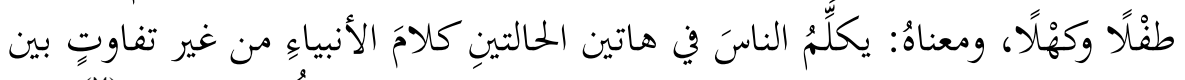

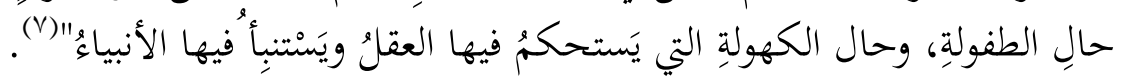

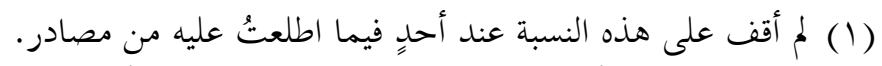

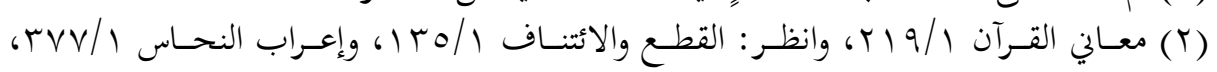

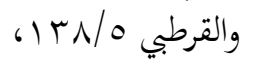

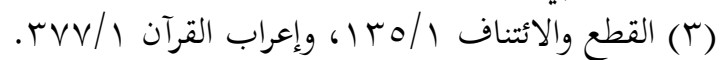

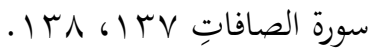

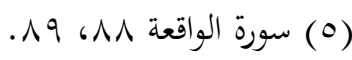

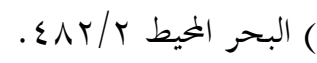

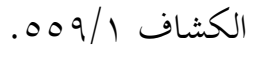




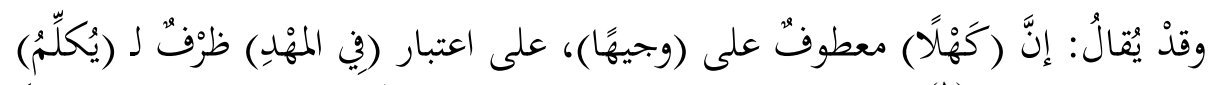

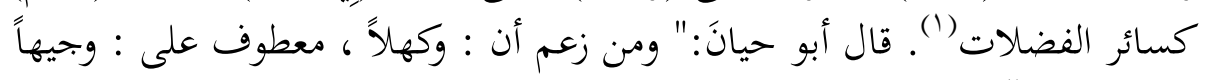

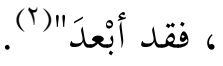

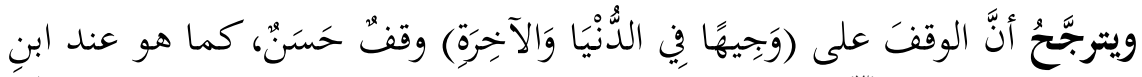

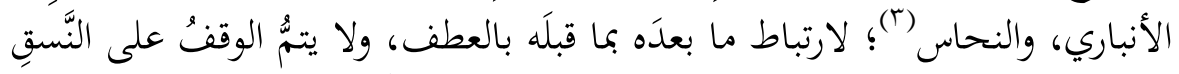

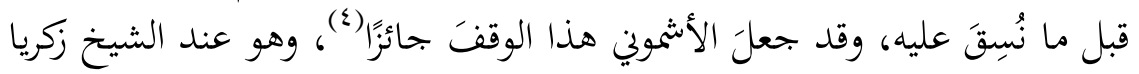

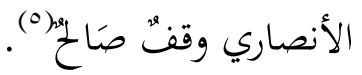

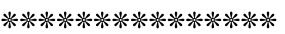

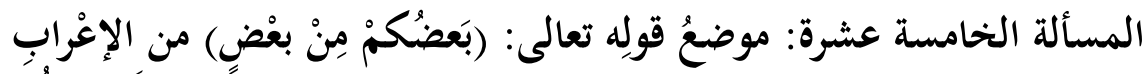

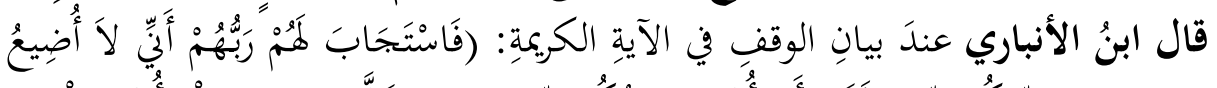

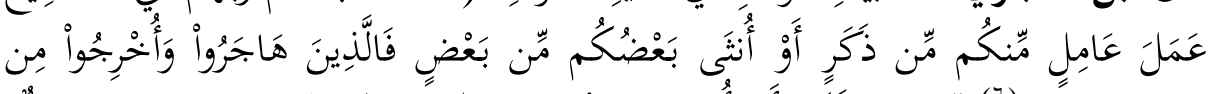

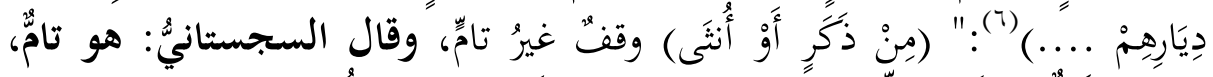

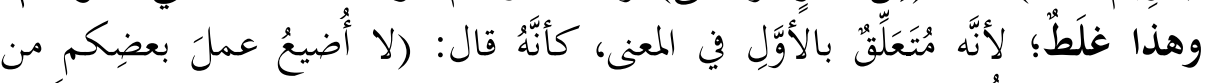

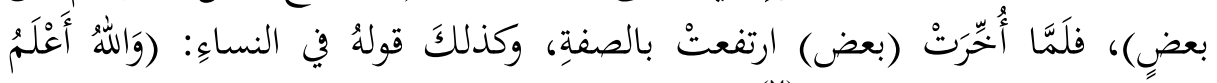

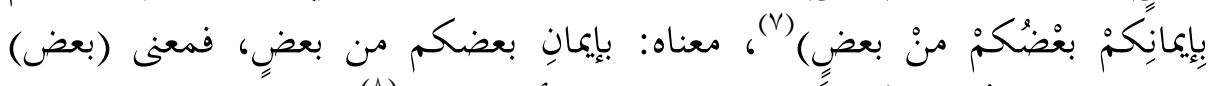

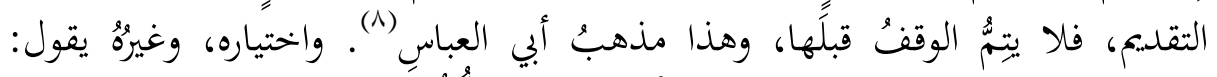

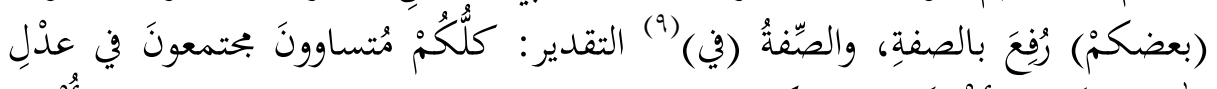

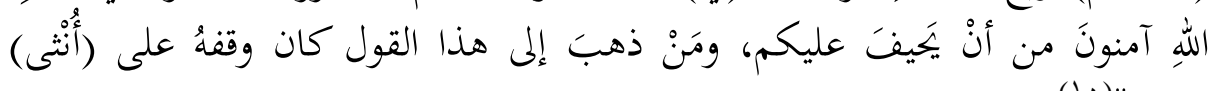

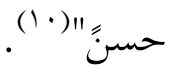

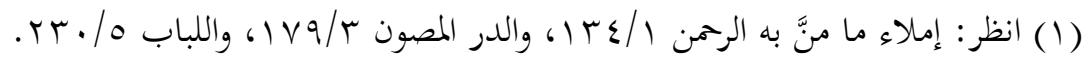

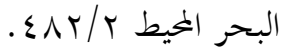

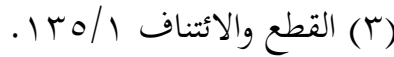

$$
\begin{aligned}
& \text {.VV ألهار }
\end{aligned}
$$

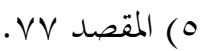

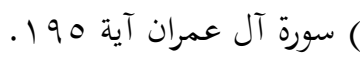

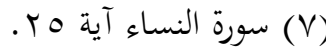

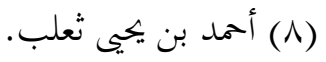

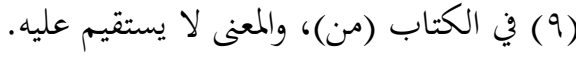

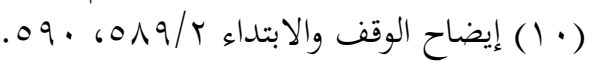

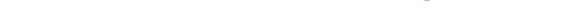




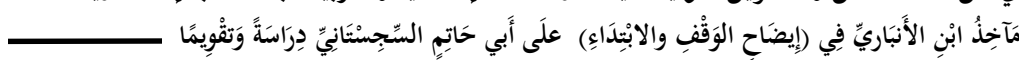

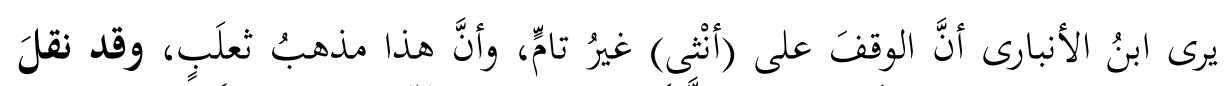

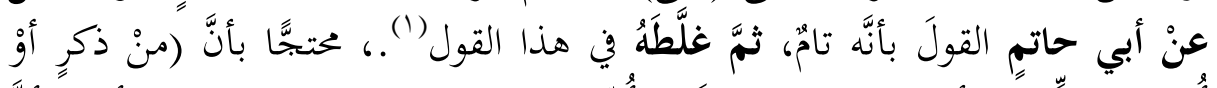

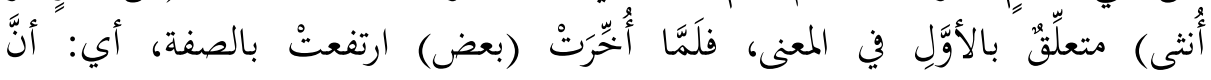

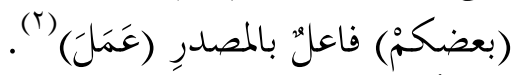

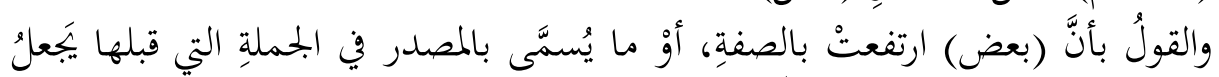

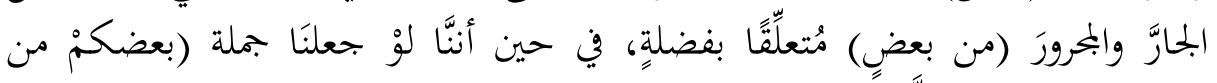

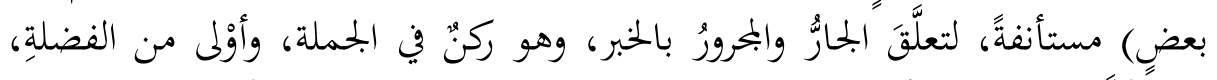

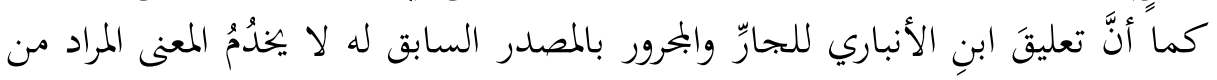

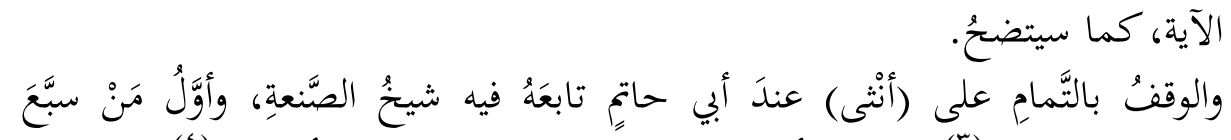

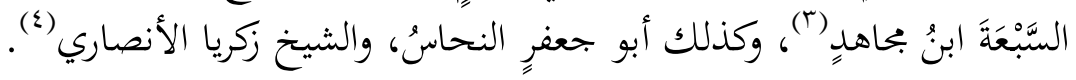

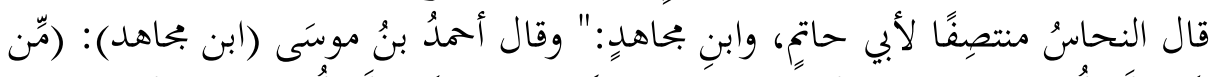

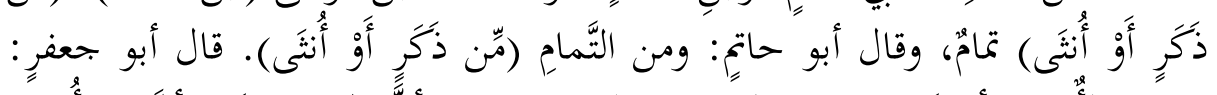

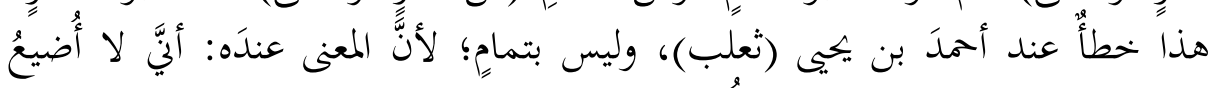

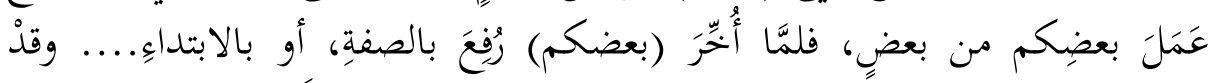

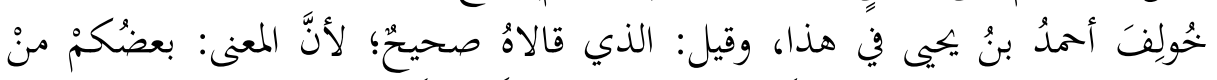

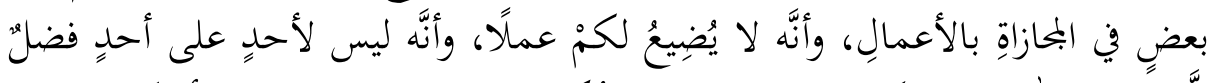

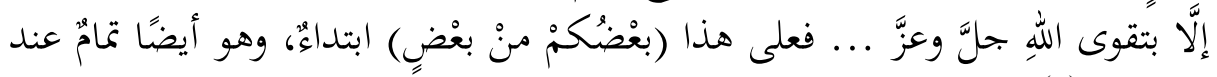
أبي حاتعم" (•)

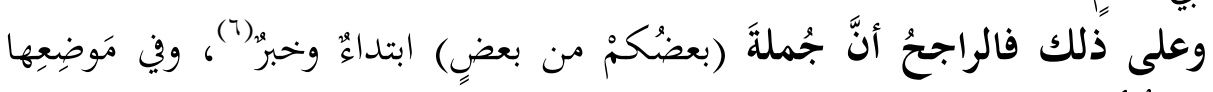

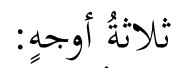

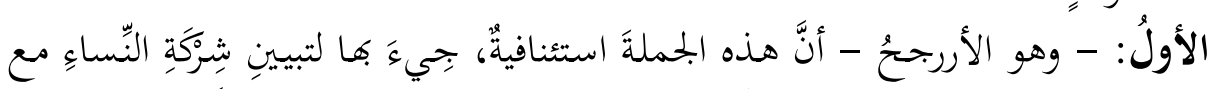

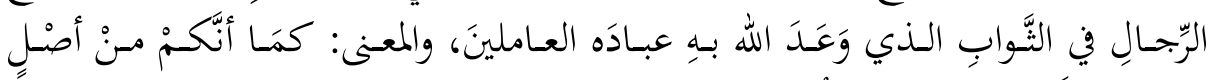

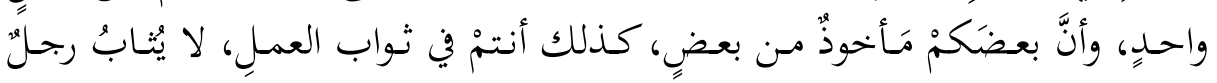

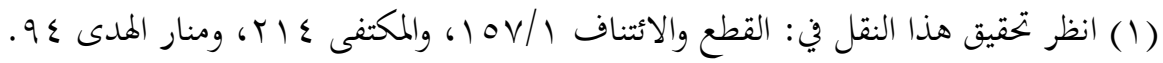

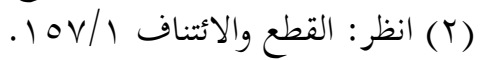

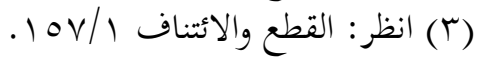

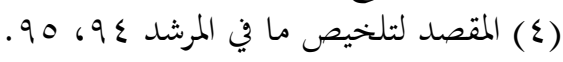

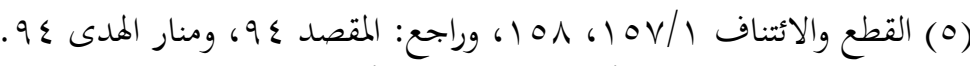

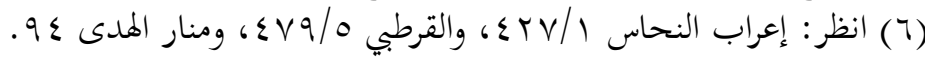




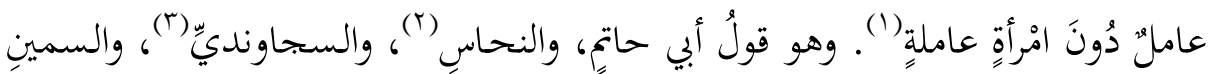

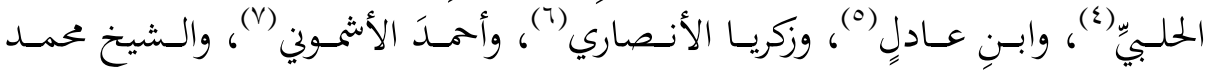

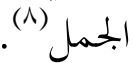

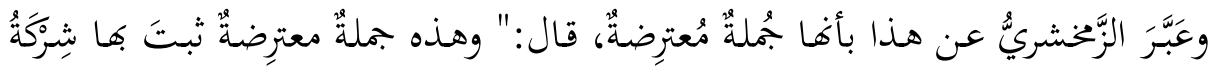

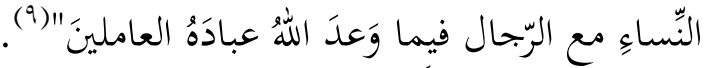

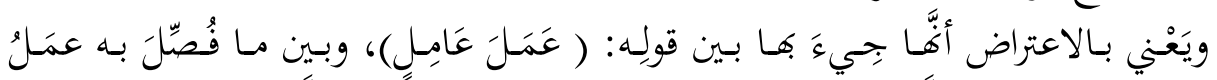

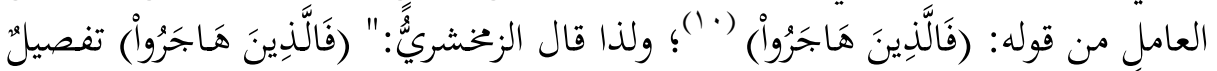

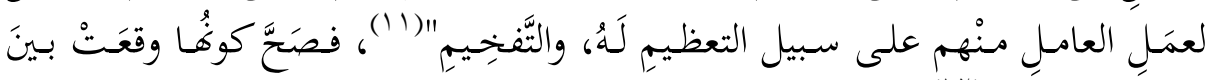

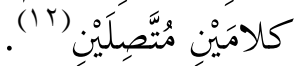

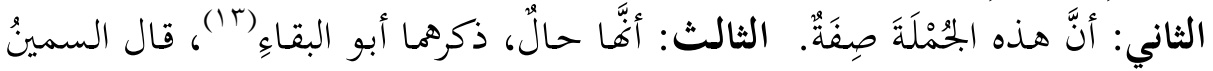

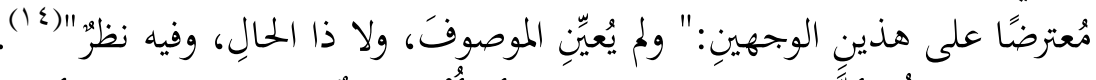

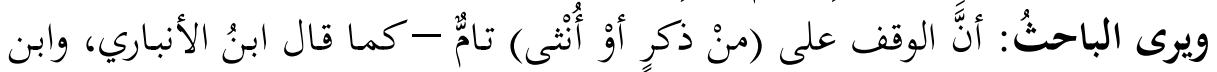

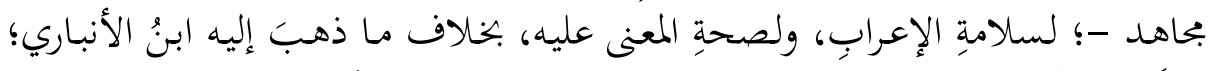

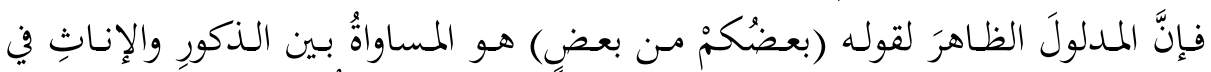

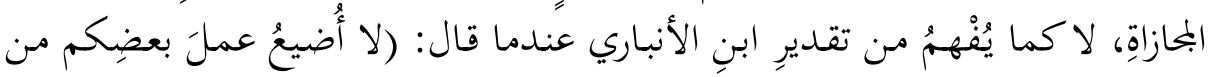

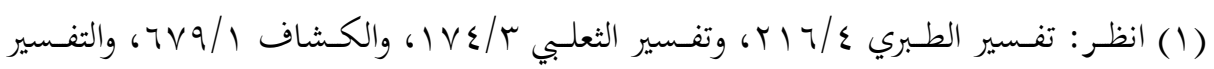

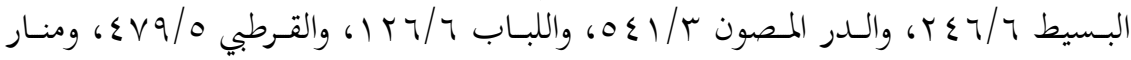

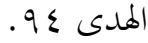

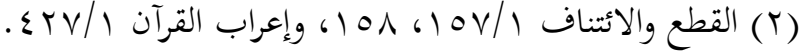

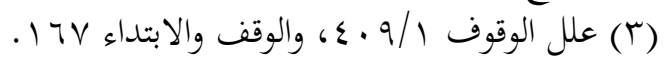

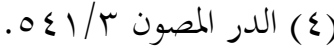

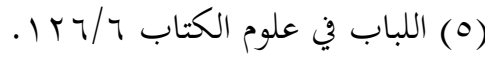

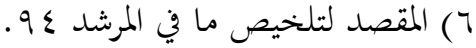

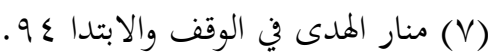

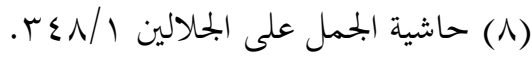

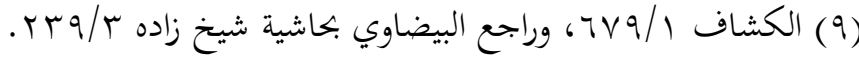

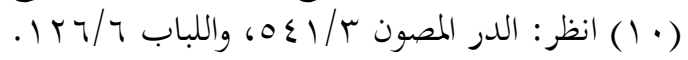

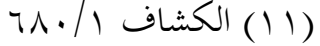

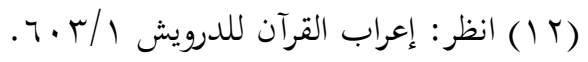

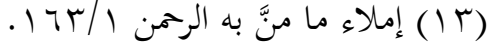

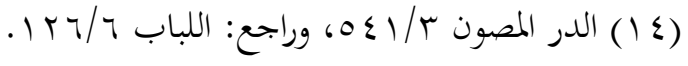




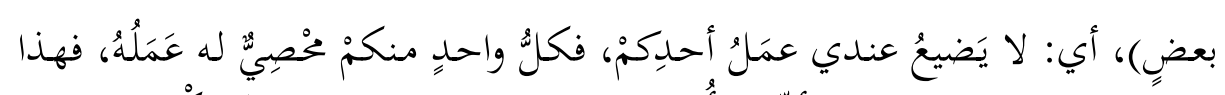

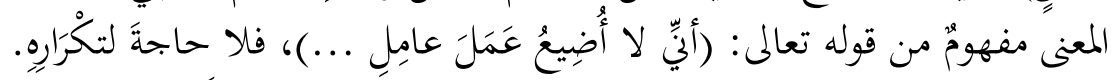

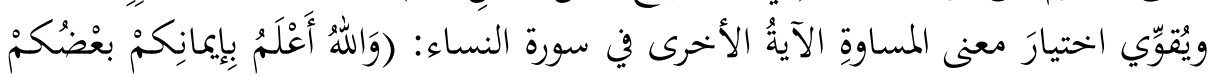

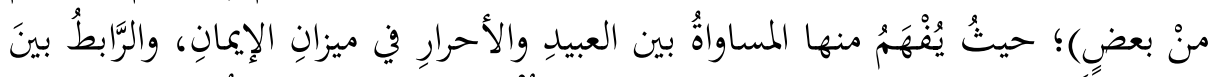

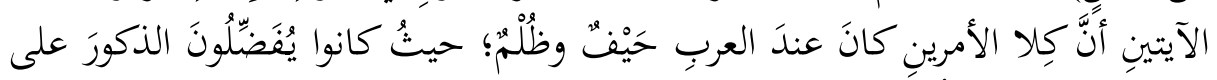

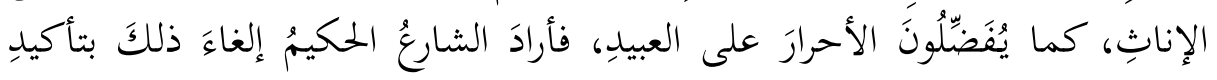

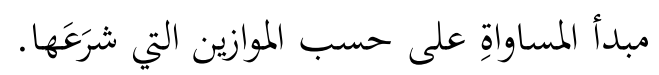
********************

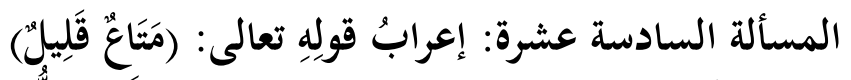

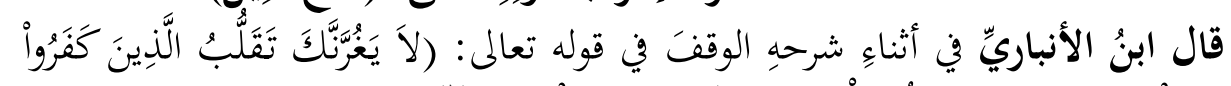

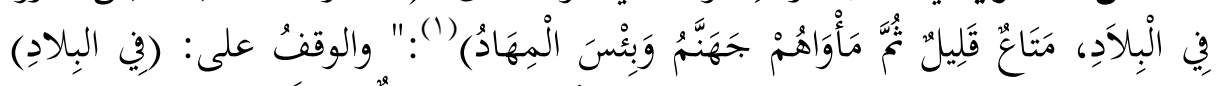

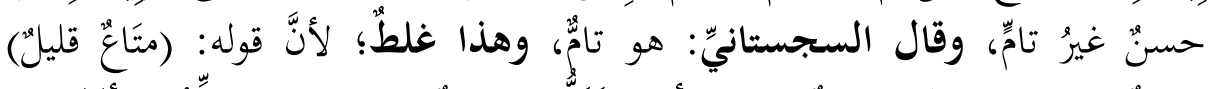

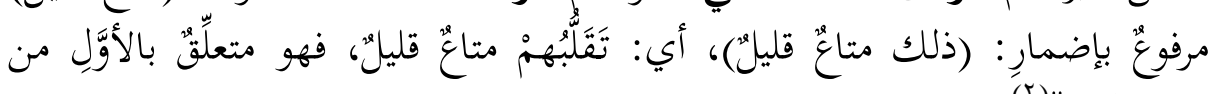

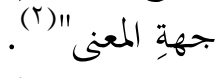

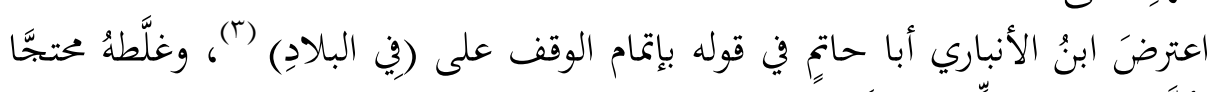

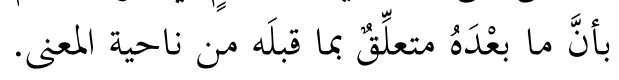

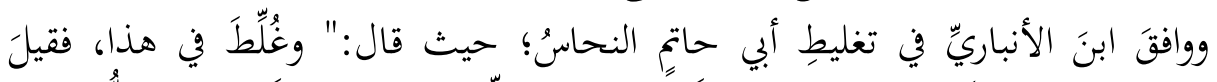

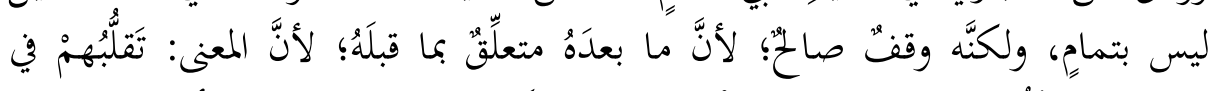

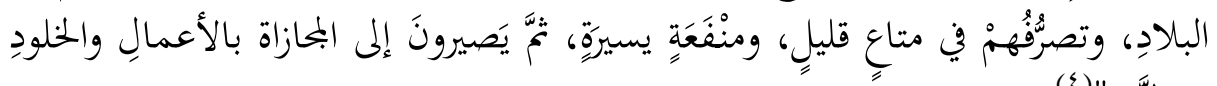

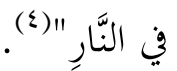

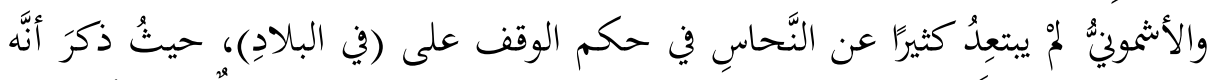

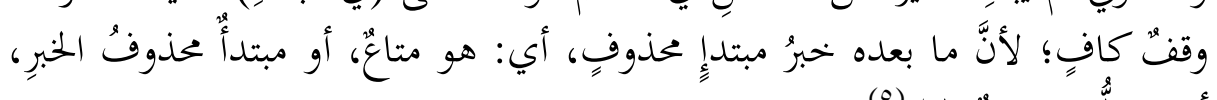

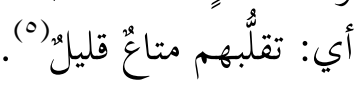




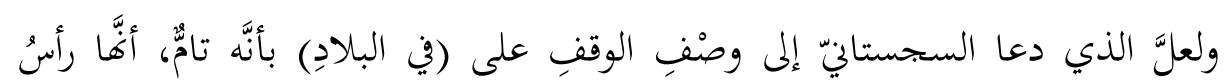

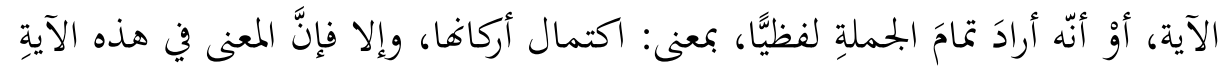

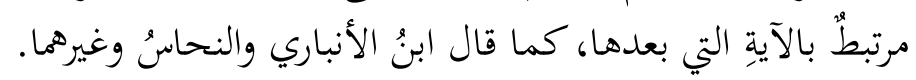

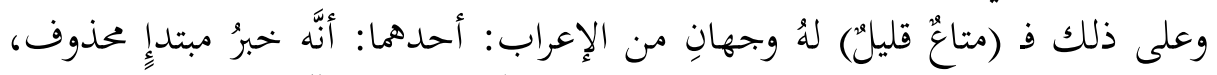

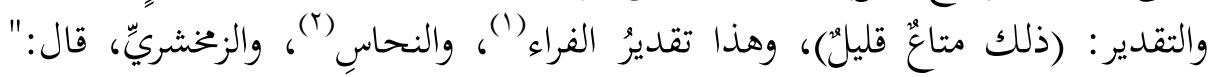

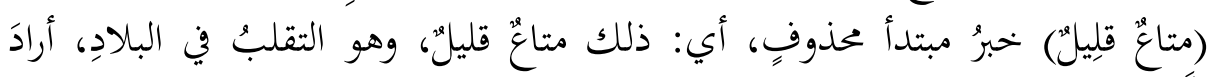

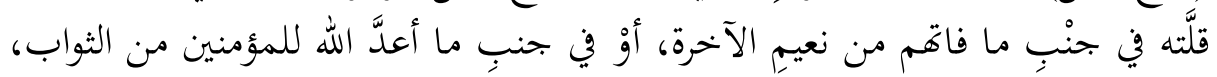

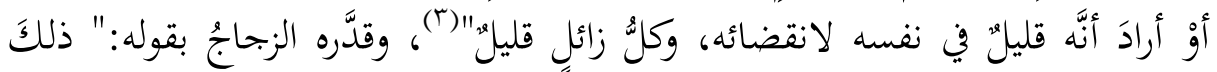

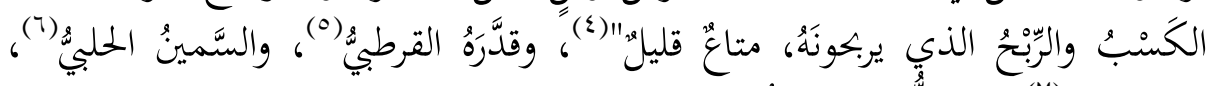

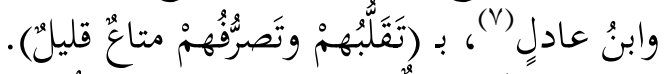

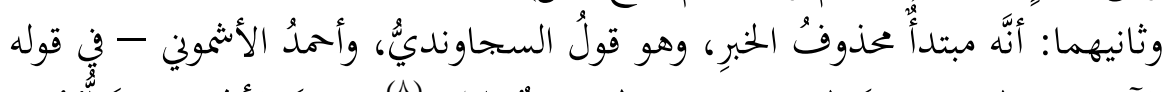

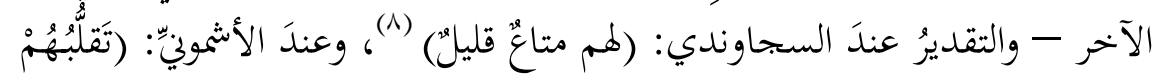

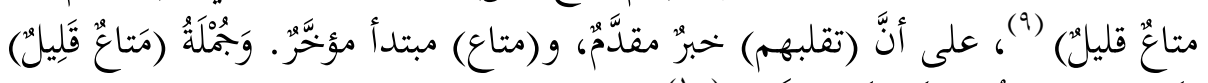

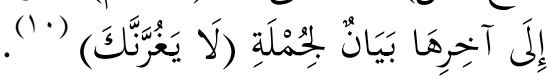

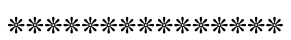

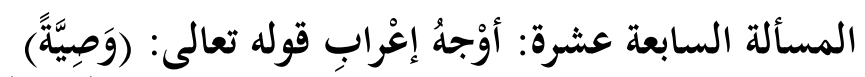

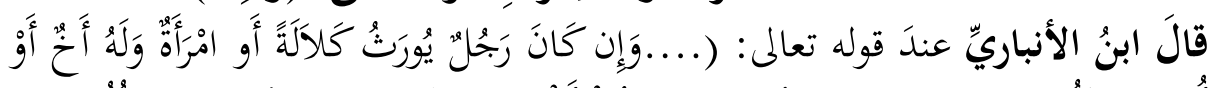

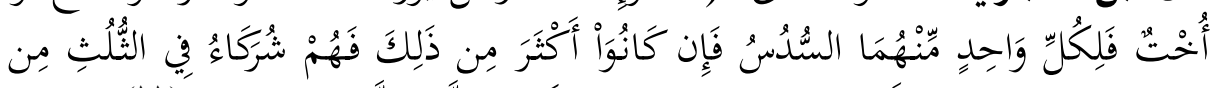

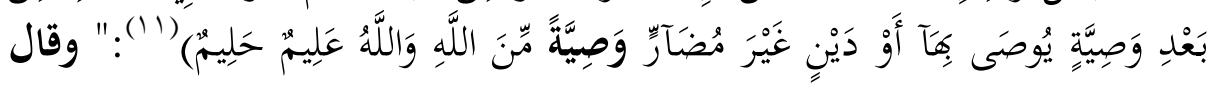

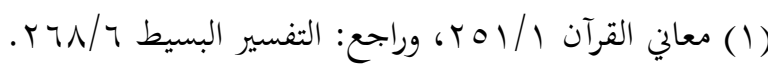

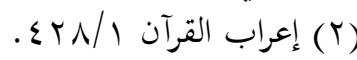

$$
\begin{aligned}
& \text { }
\end{aligned}
$$

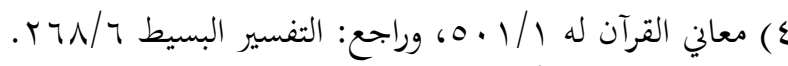

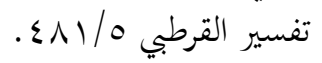

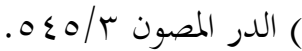

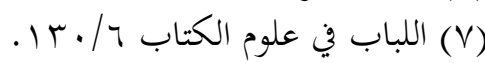

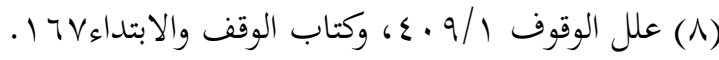

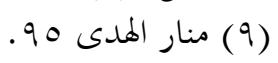

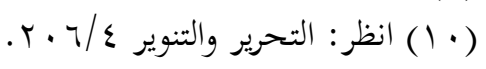

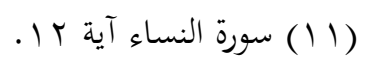




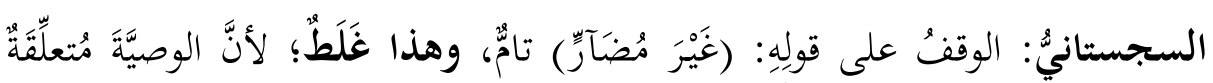

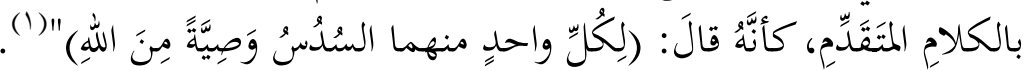

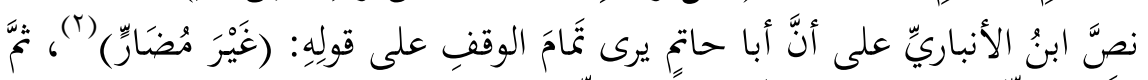

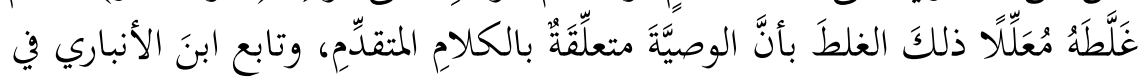

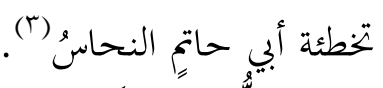

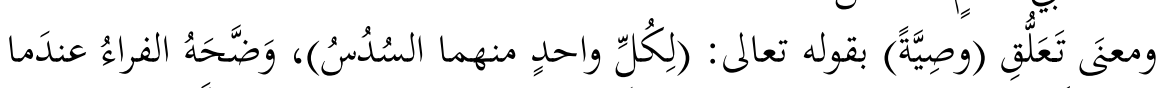

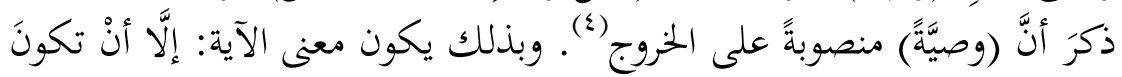

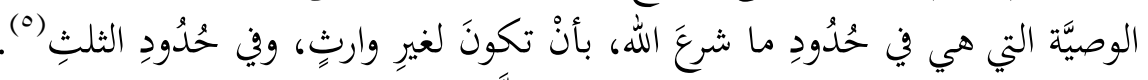

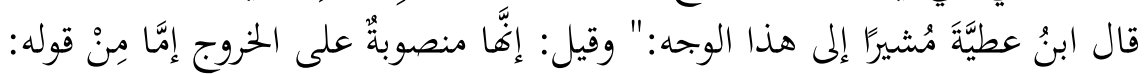

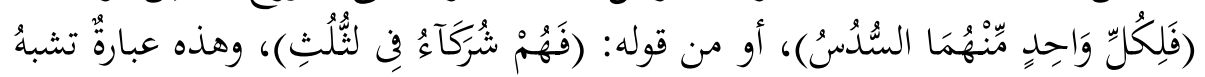

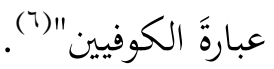

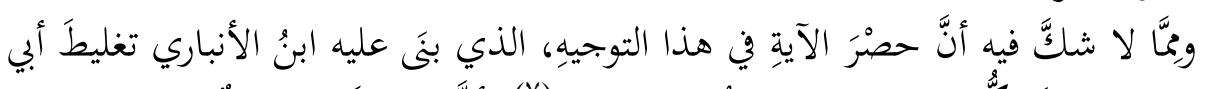

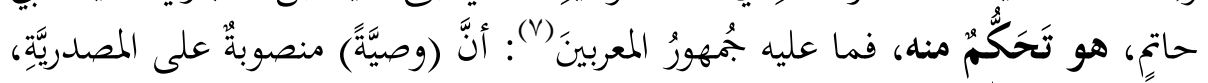

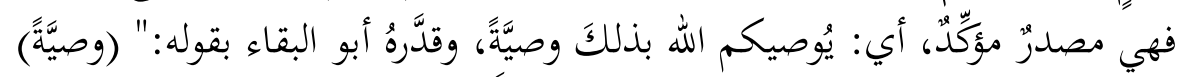

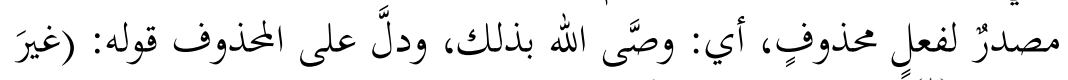

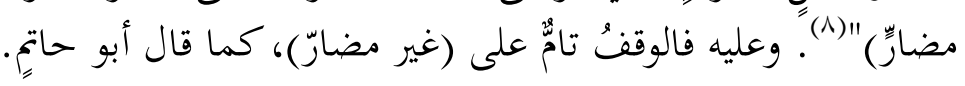

$$
\begin{aligned}
& \text { (1) إيضاح الوقف والابتداء / ع ـ } 09 .
\end{aligned}
$$

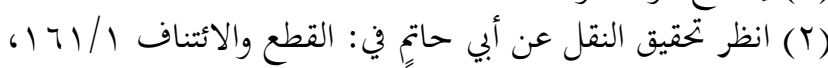

$$
\begin{aligned}
& \text { (ז) السابق ذاته. }
\end{aligned}
$$

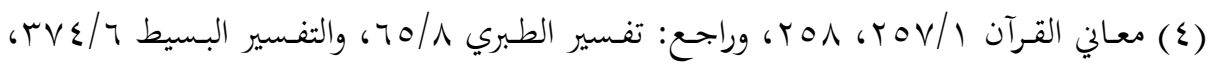

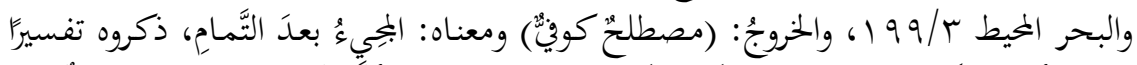

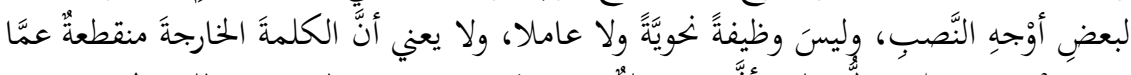

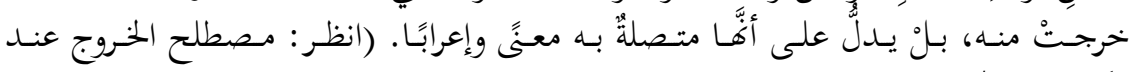

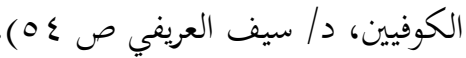

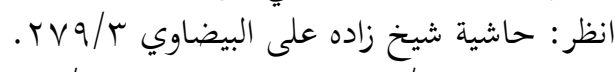

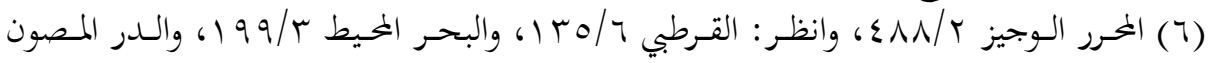
ا

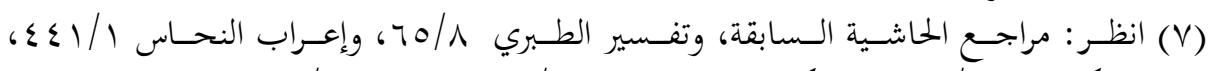

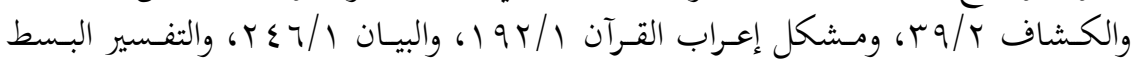

$$
\text { rrv } r / 7
$$

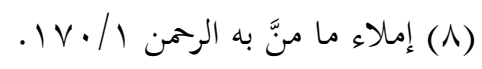




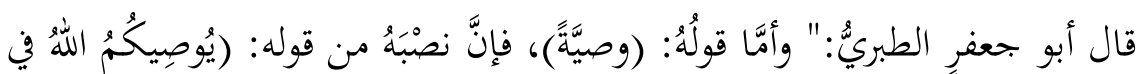

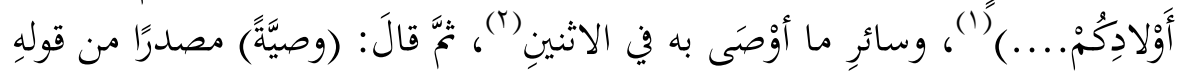

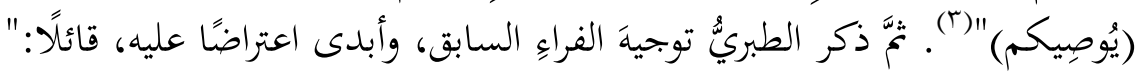

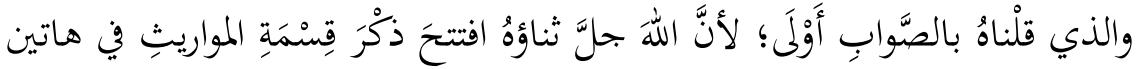

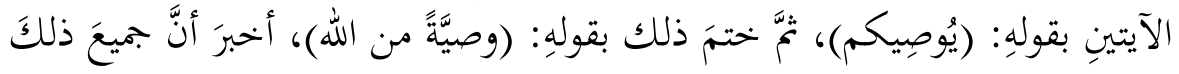

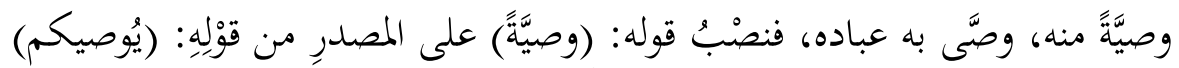

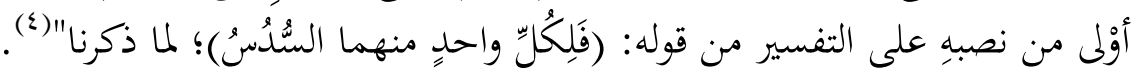

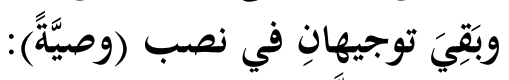

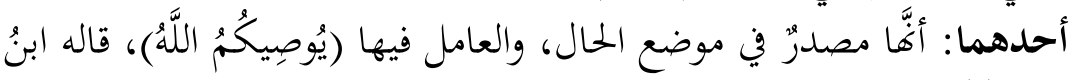

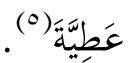

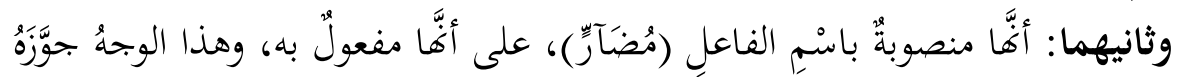

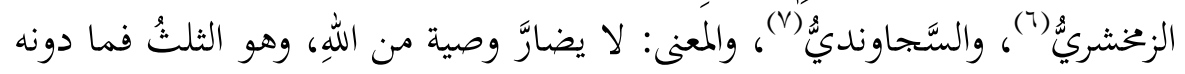

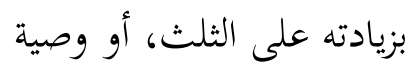

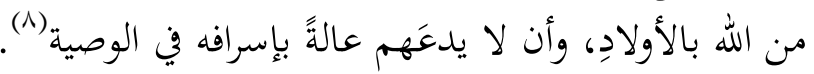

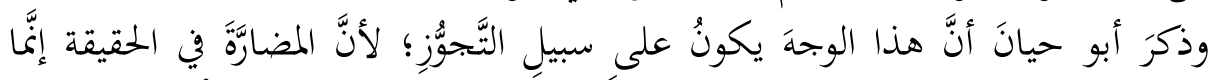

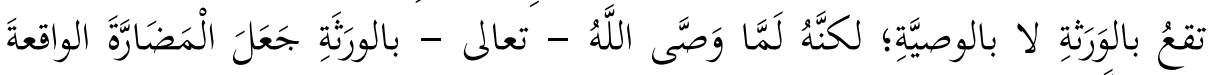

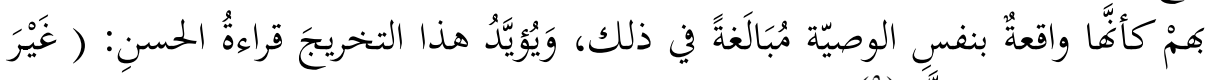

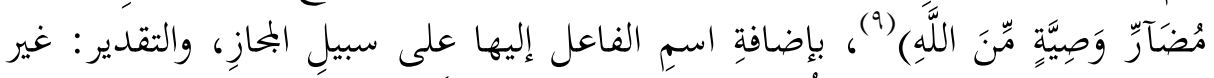

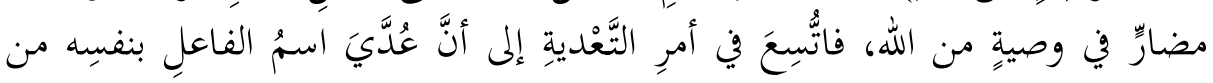

$$
\begin{aligned}
& \text { (1) سورة النساء آية 11. }
\end{aligned}
$$

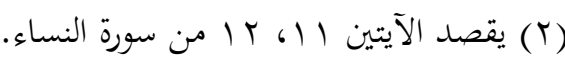

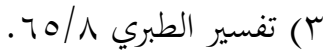

$$
\begin{aligned}
& \text { ( ) ( ) السابق ذاته. }
\end{aligned}
$$

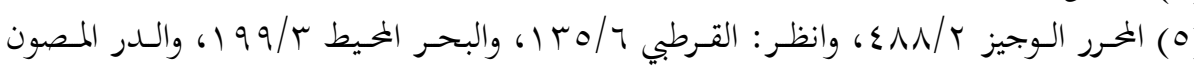

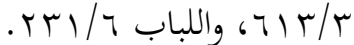

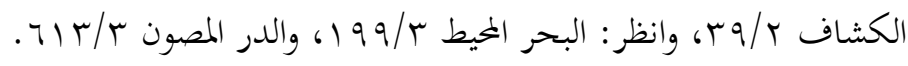

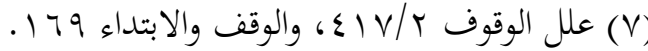

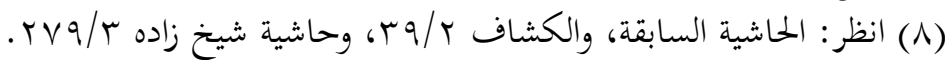

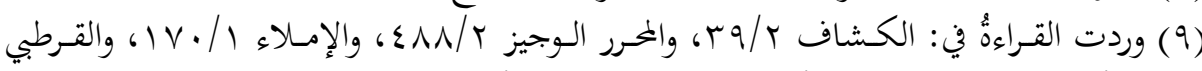

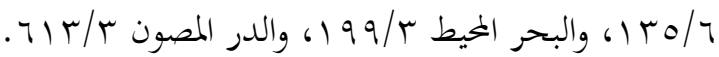




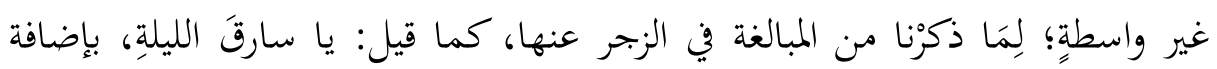

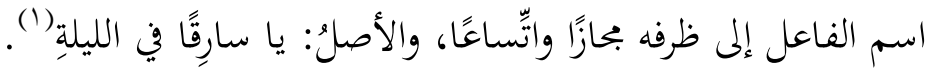

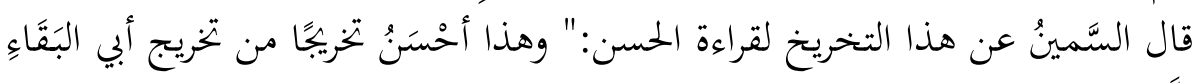

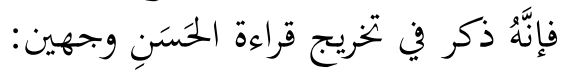

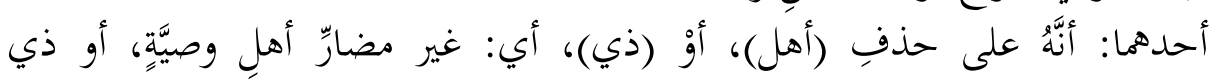

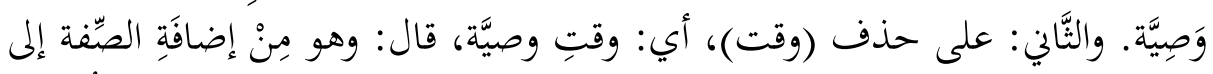

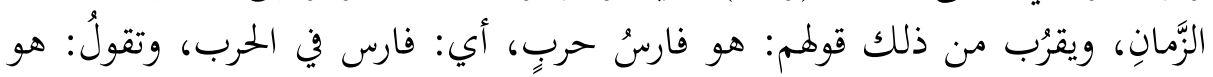

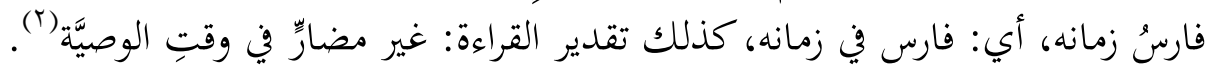

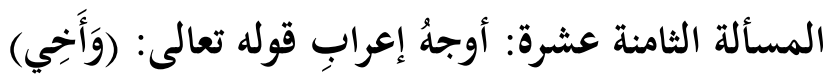

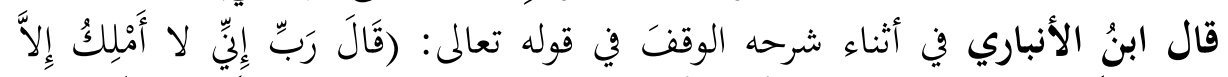

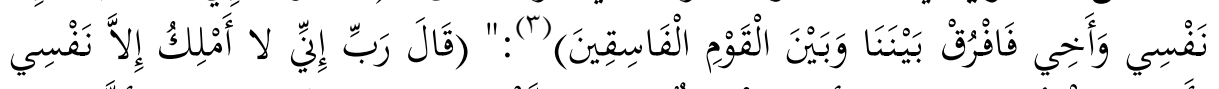

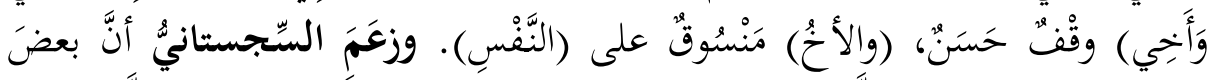

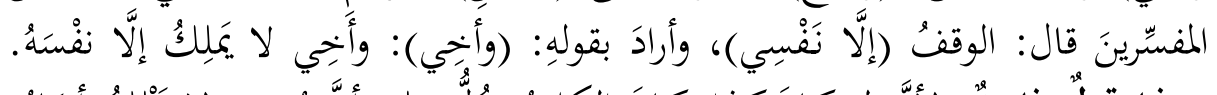

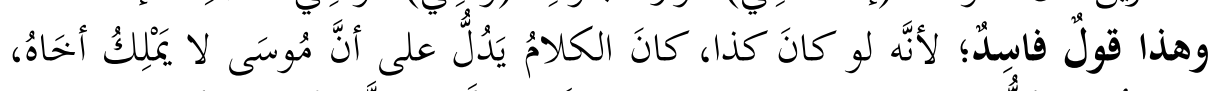

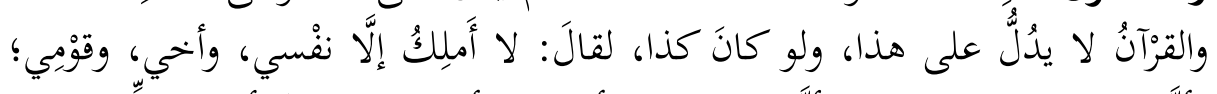

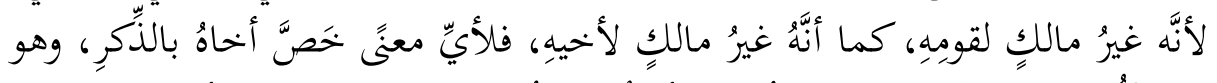

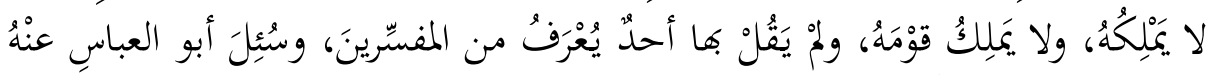

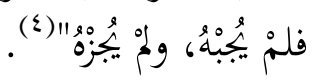

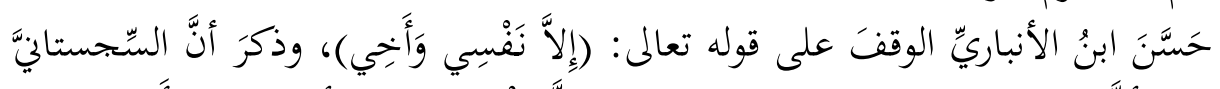

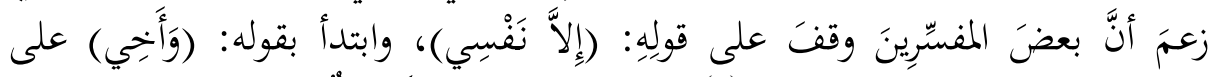

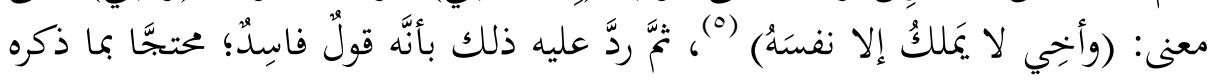

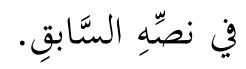

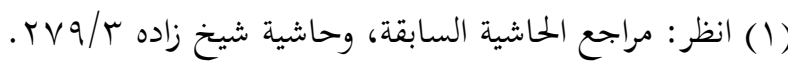

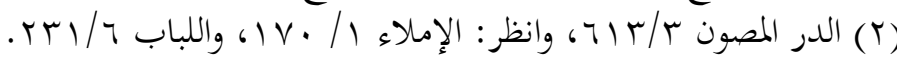

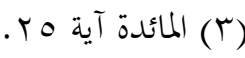

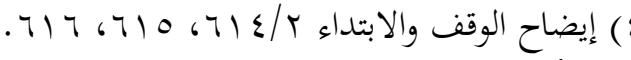

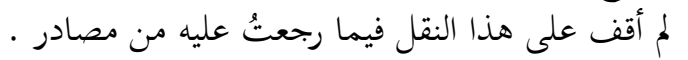




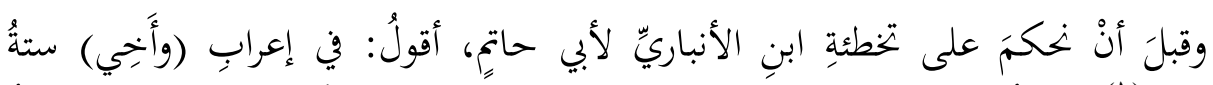

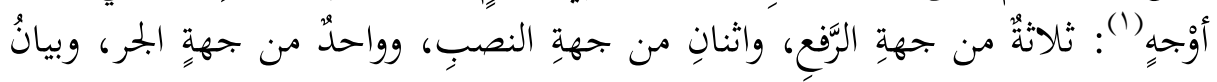

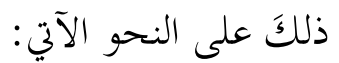

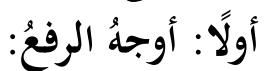

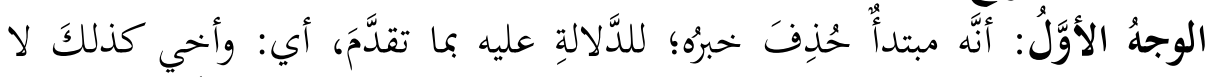

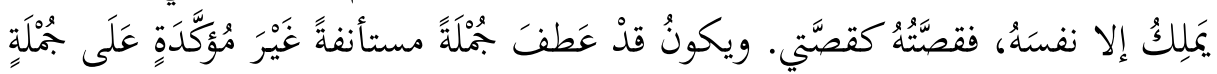

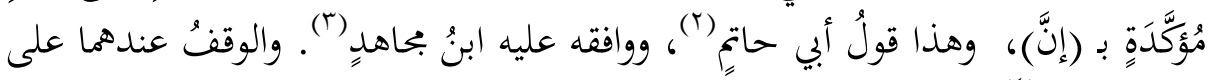

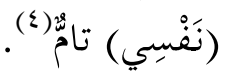

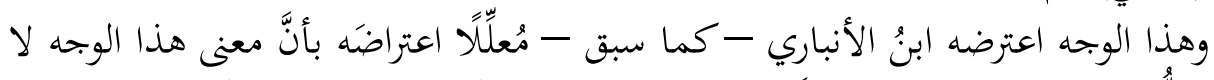

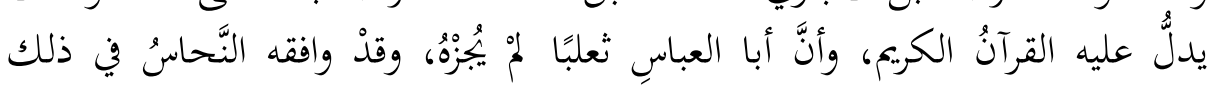

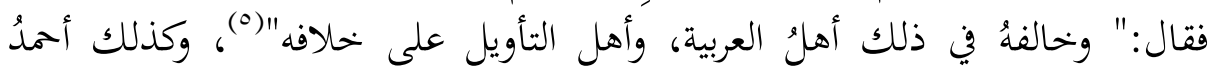

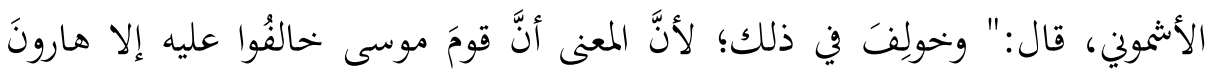

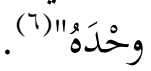

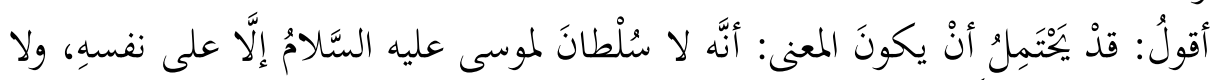

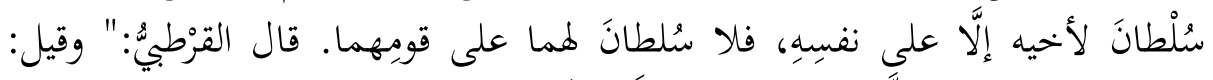

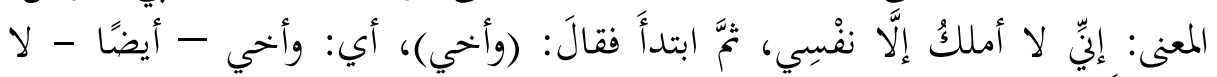

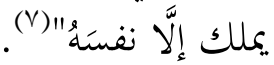

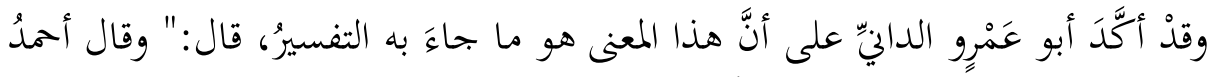

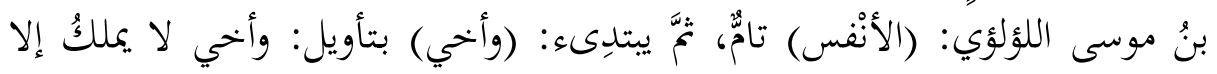

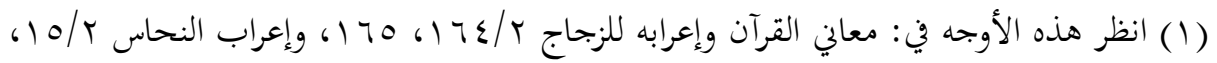

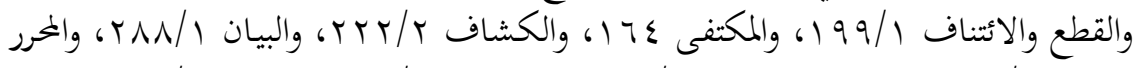

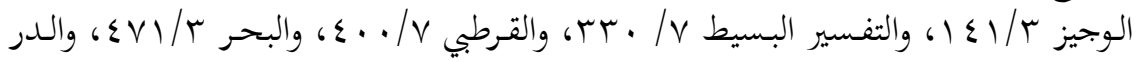

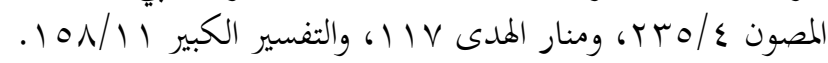

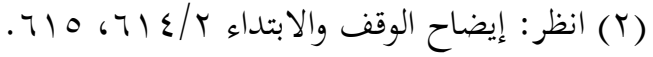

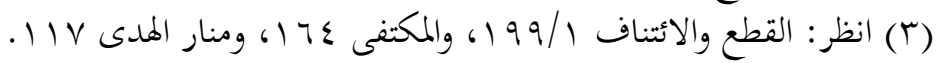
( ) ( ) انظر : مراجع الحاشية السابقة.

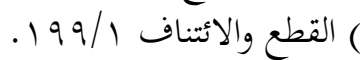

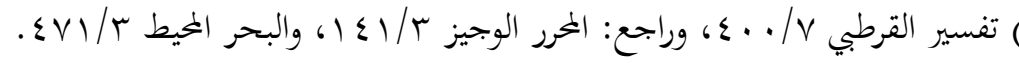




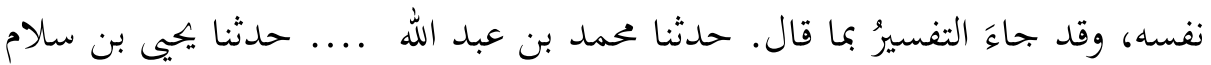

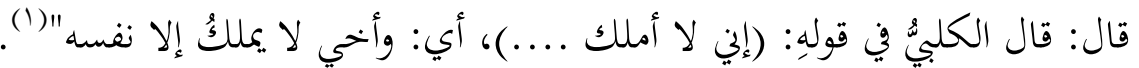

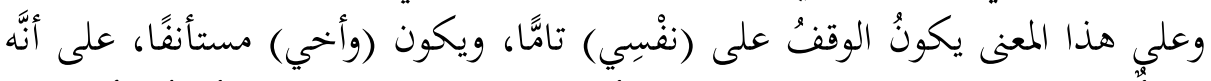

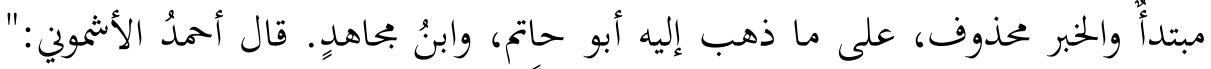

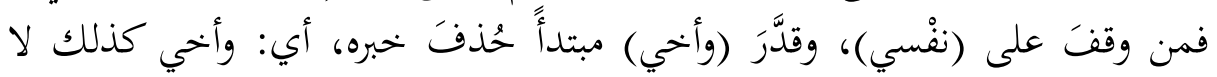

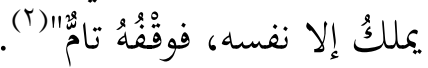

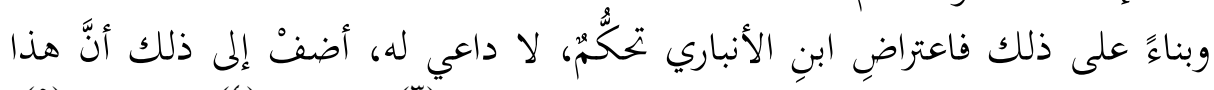

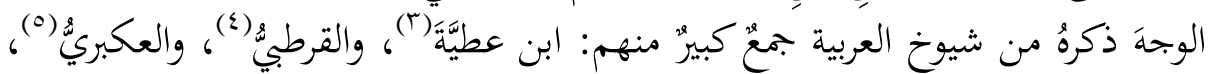

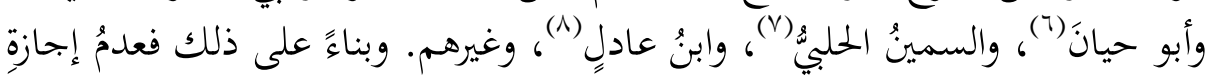

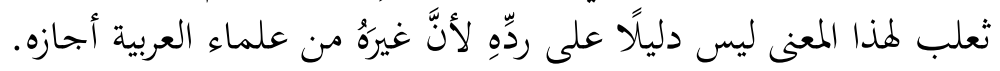

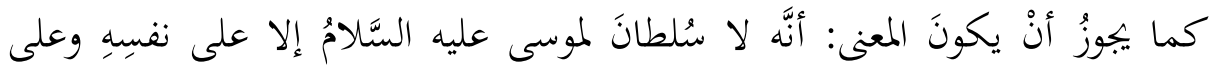

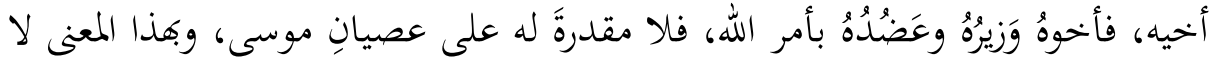

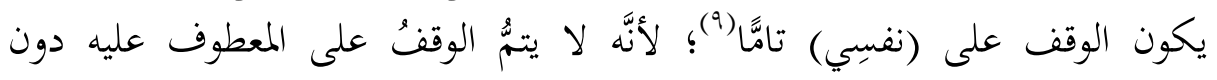

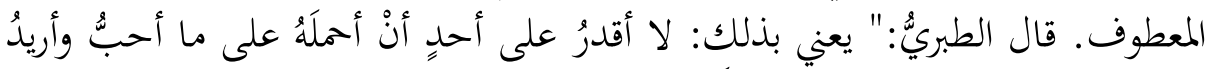

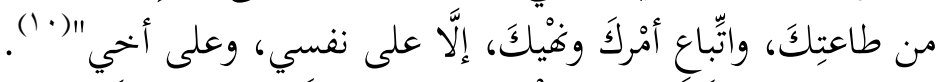

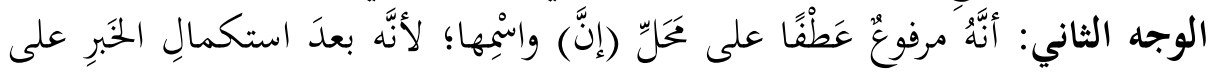

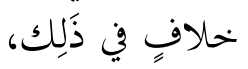

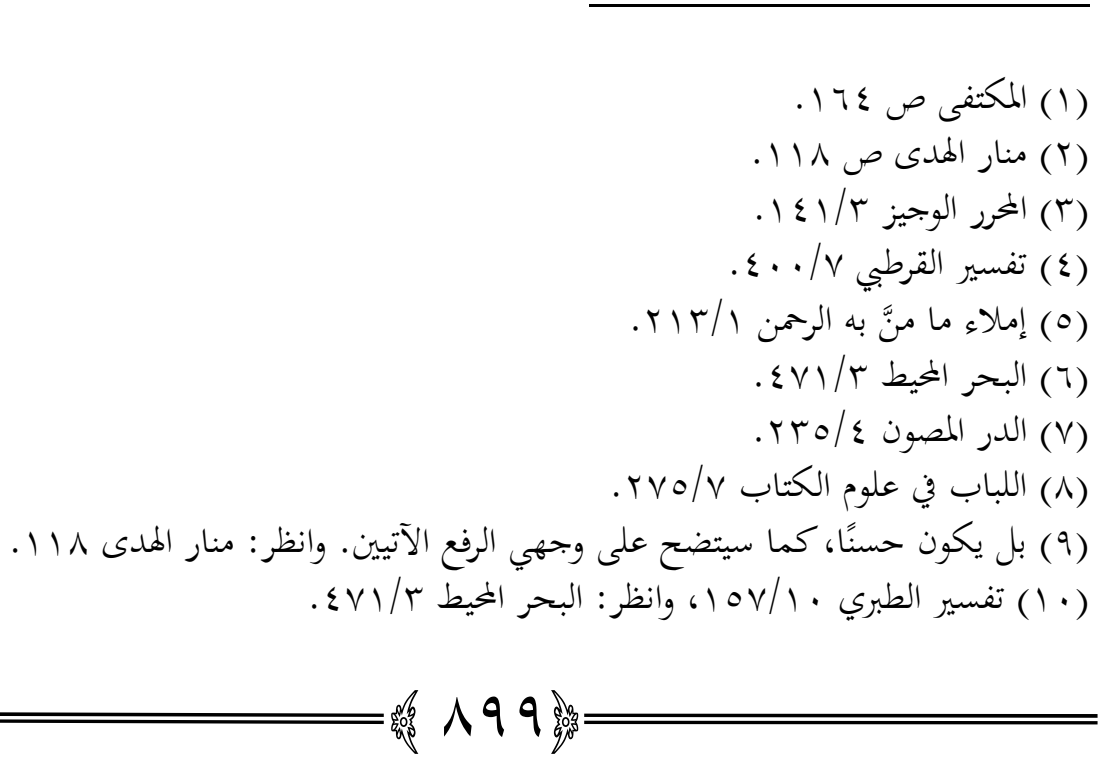




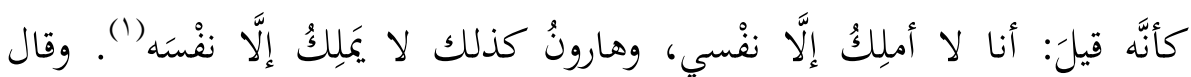

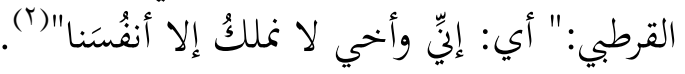

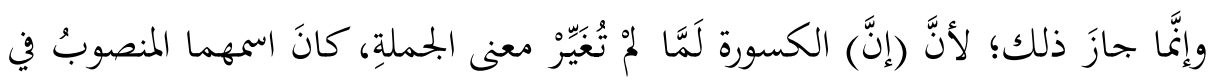

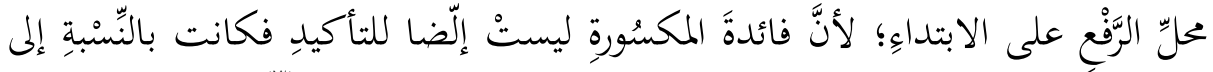

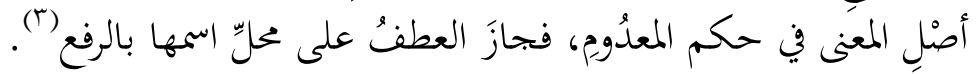

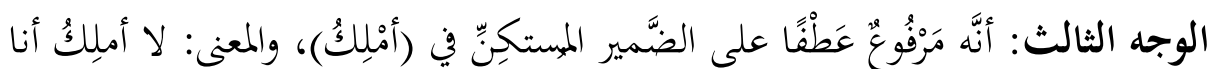

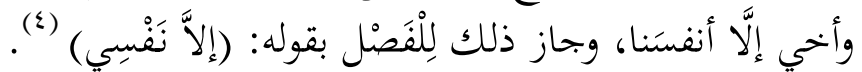

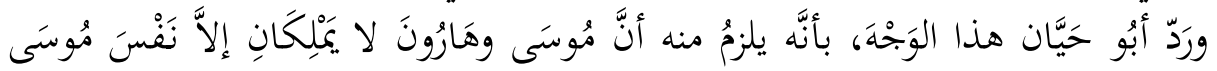

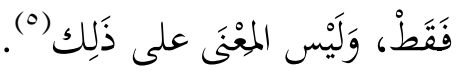

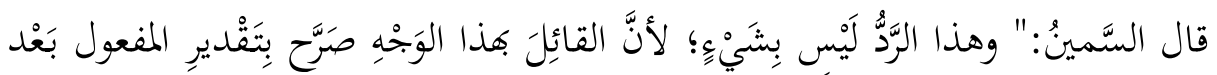

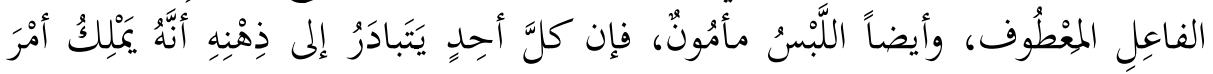

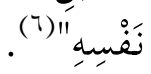
وقيل: لا يََِوزُ هذا الوجهُ؛ لأنَّ المضارعَ المبدوءَ بالهمزة لا يَرْفعُ الاسمَ الظاهرَ، لا تقول:

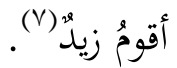

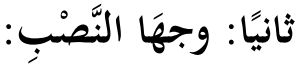

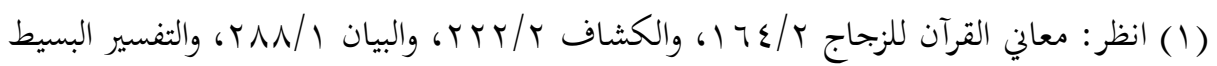
.rr./V

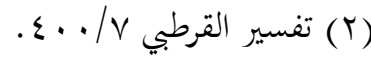

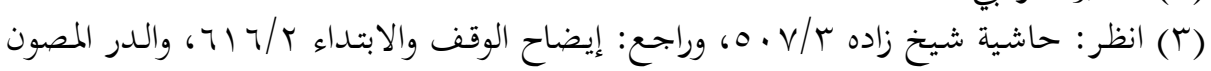
. TrOp

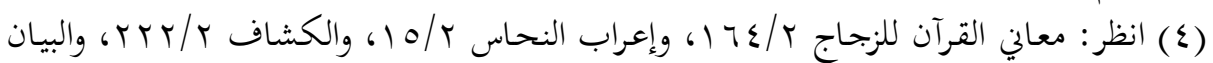

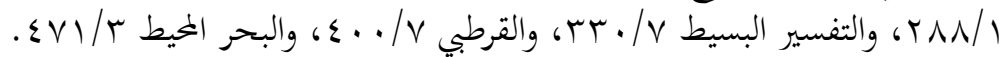

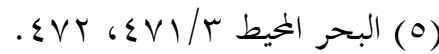

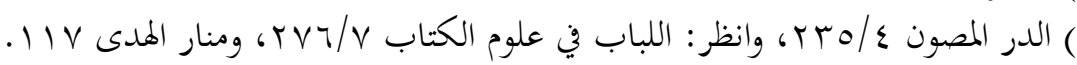

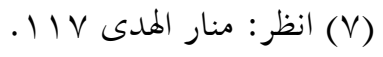




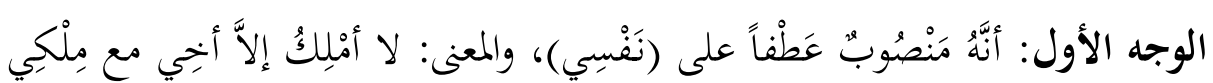

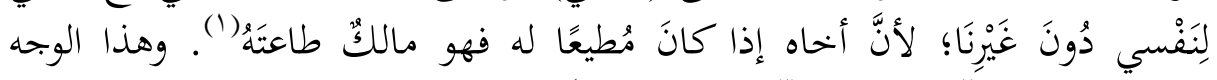

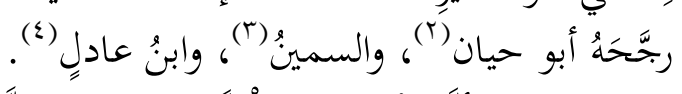

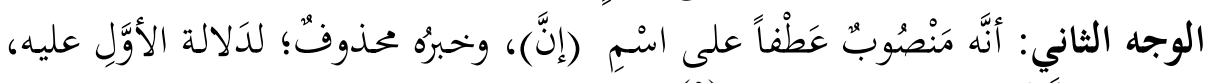

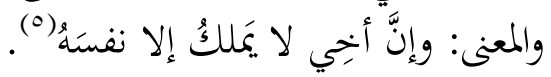

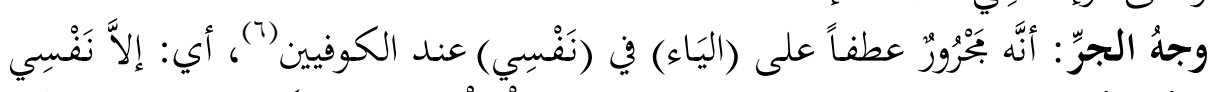

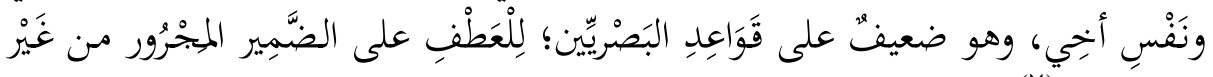

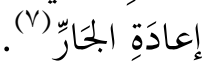

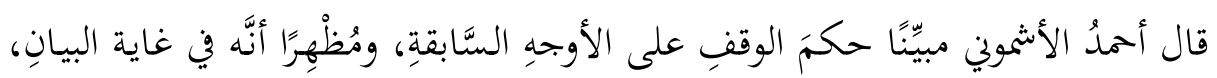

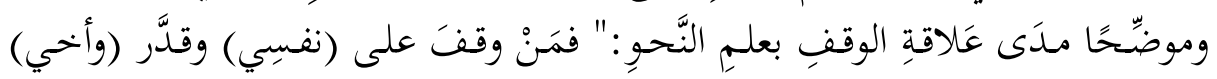

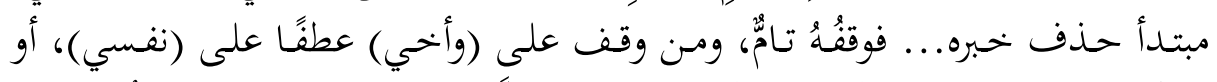

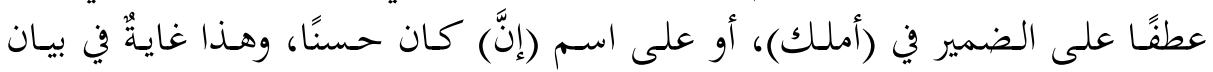

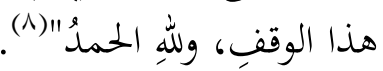

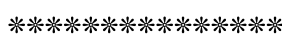

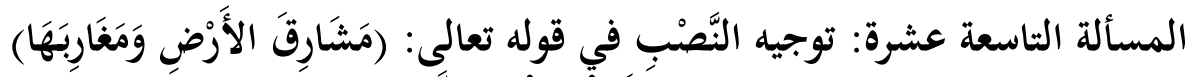

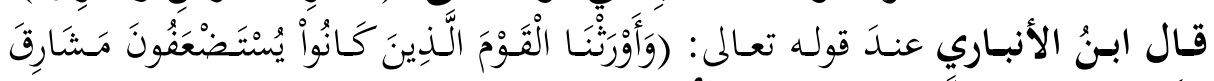

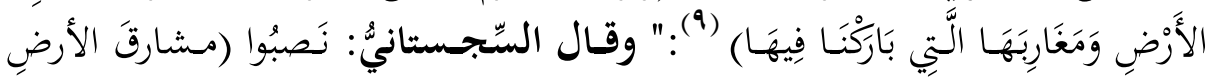

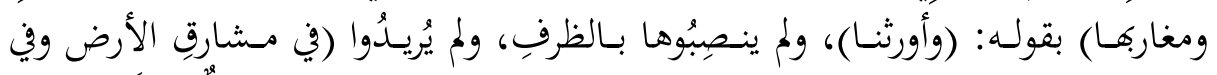

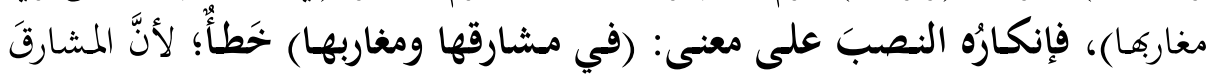

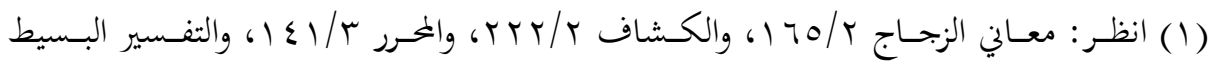

$$
\begin{aligned}
& \text { آוT/V }
\end{aligned}
$$

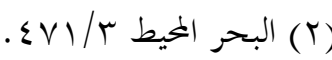

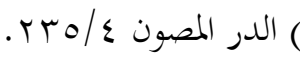

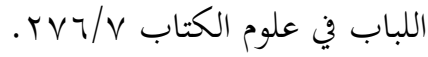

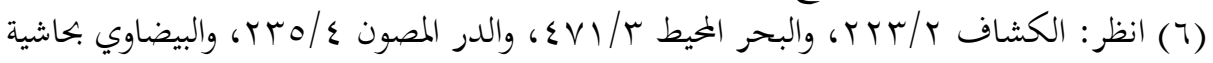

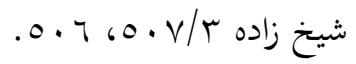

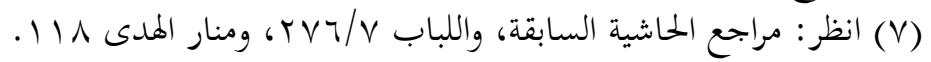

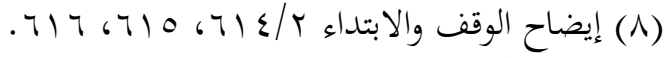

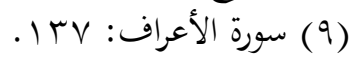




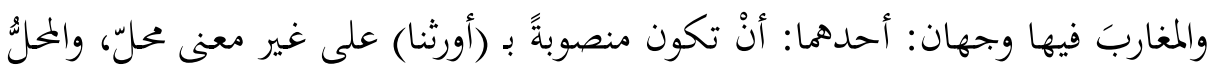

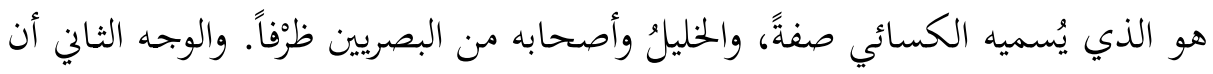

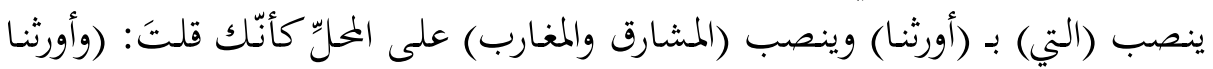

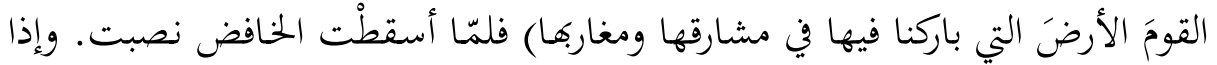

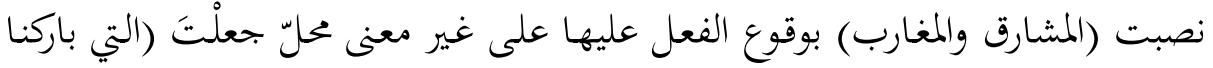

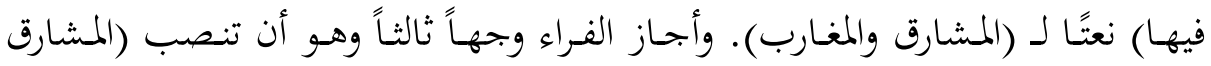

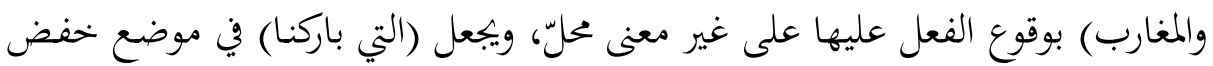

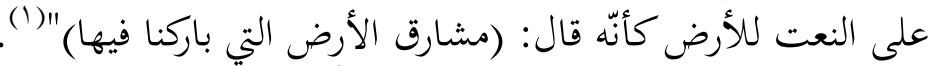

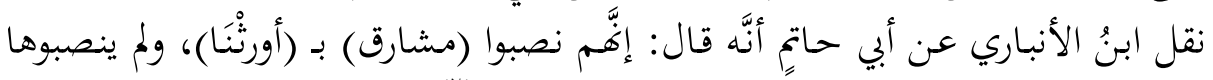

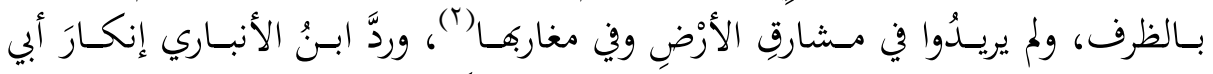

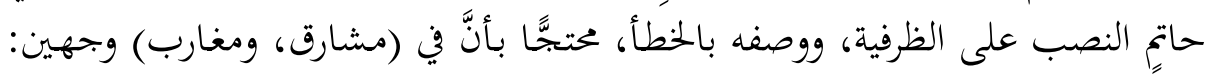
وللوقوفِ على حقيقة هـه المسألةِ، أقول: اختلف المعربون في توجيه النصبِ في قوله

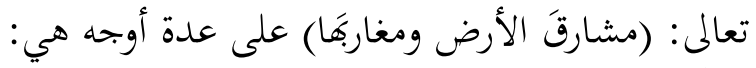

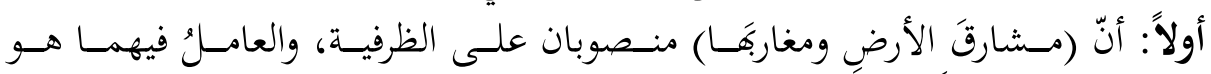

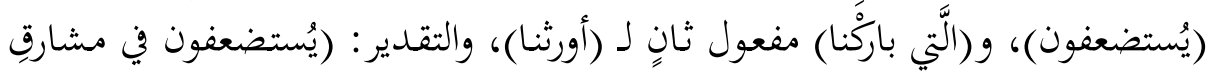

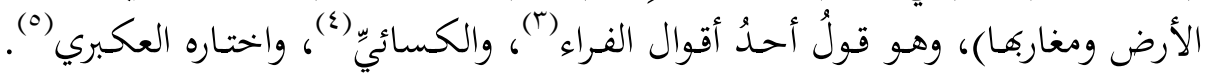

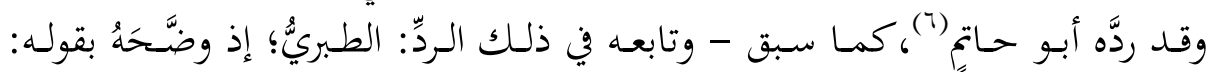

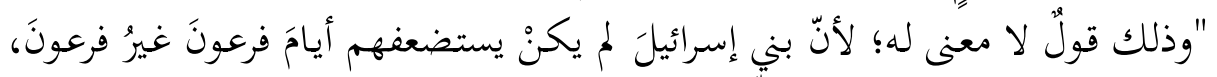

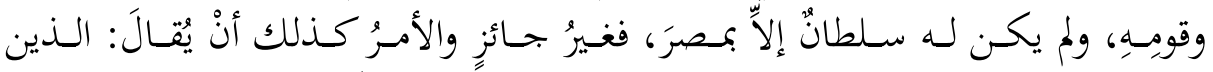

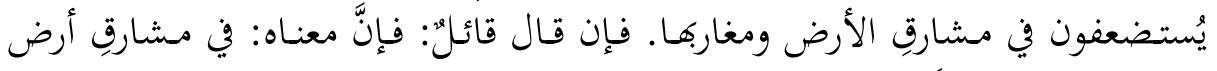

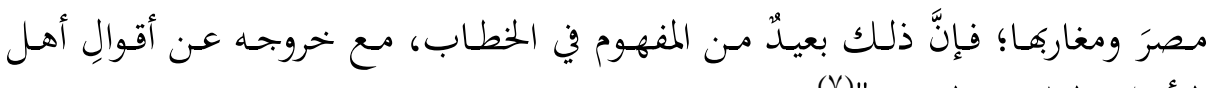

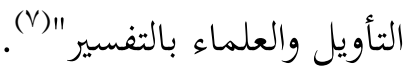

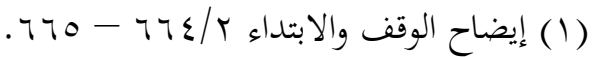

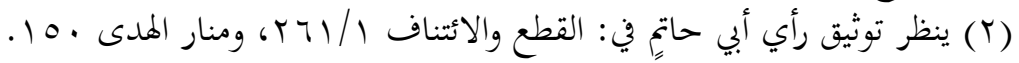

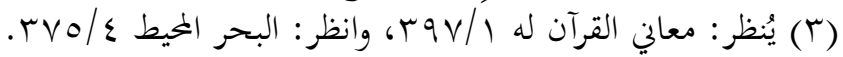

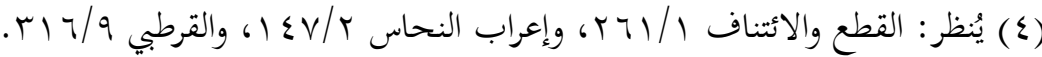

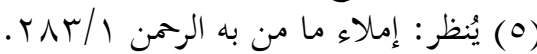

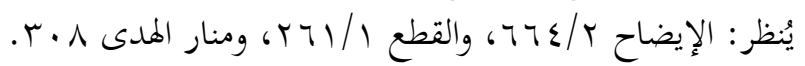

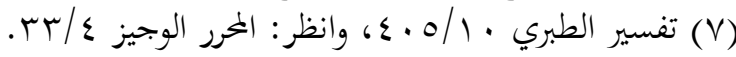




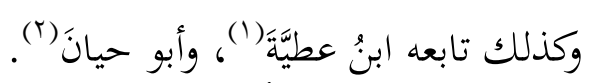

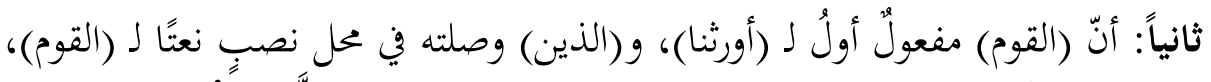

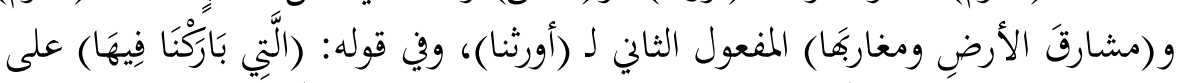

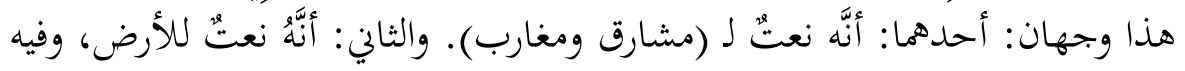

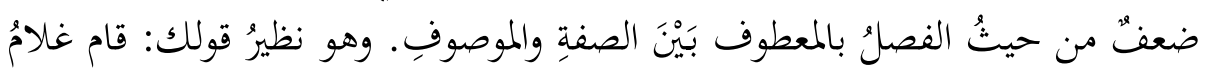

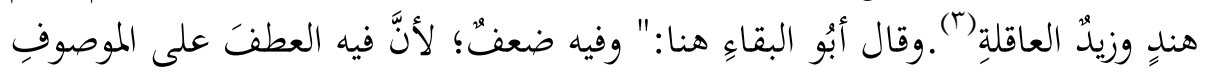

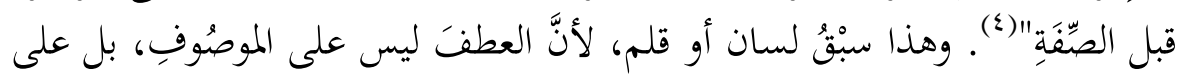

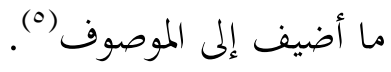

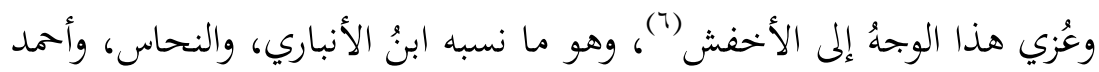

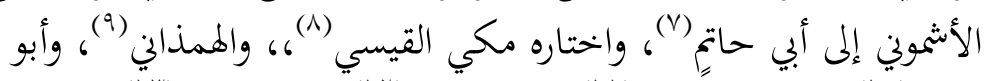

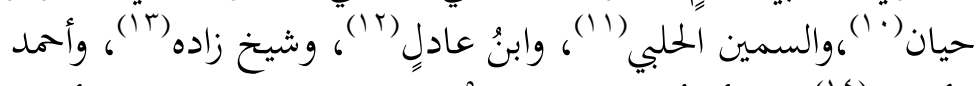

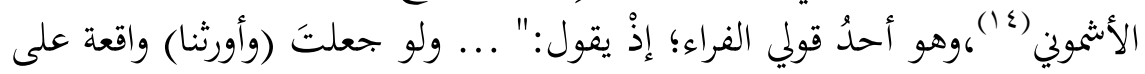

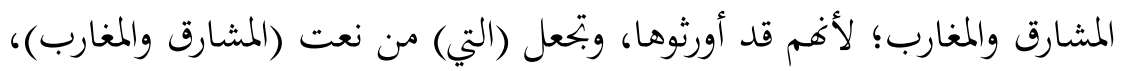

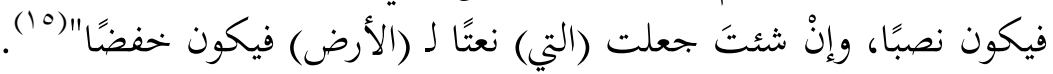

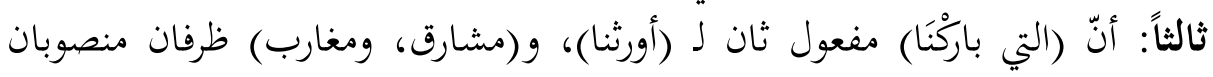

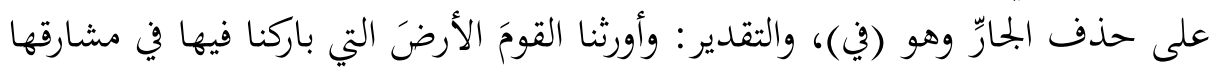

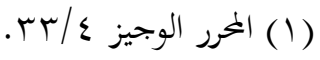

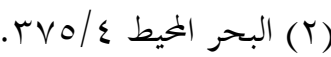

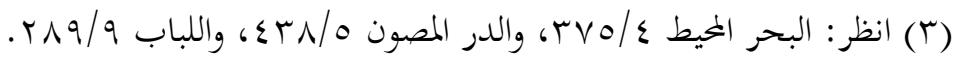

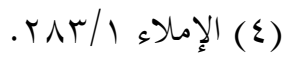

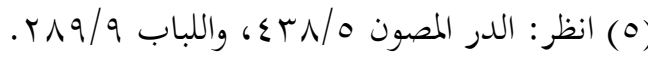

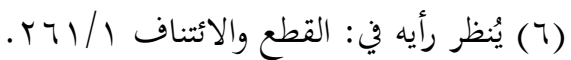

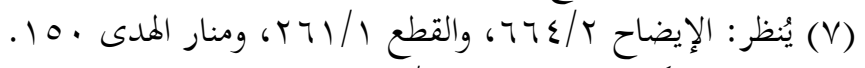

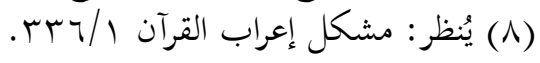

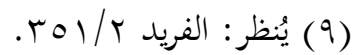

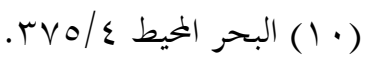

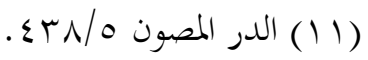

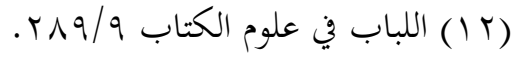

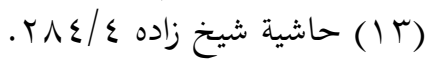

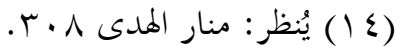

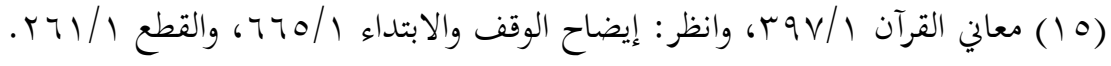




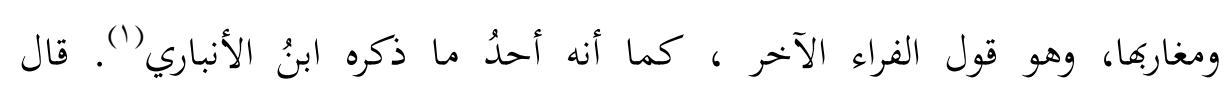

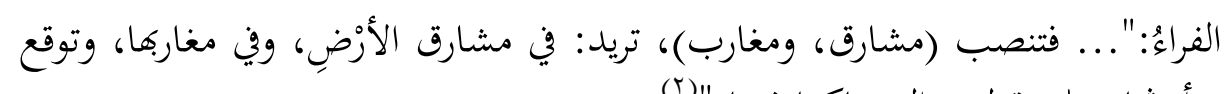

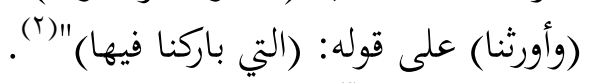

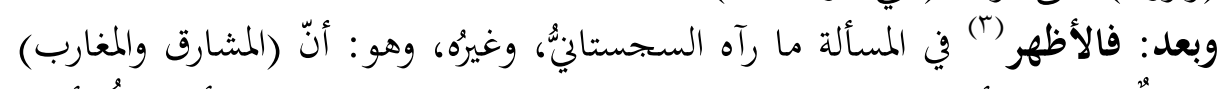

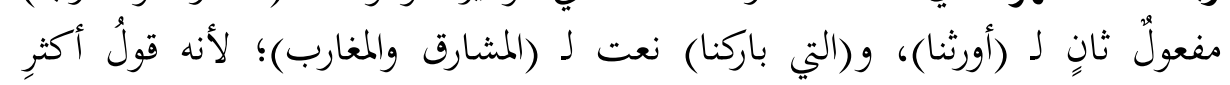

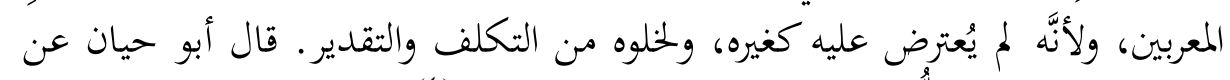

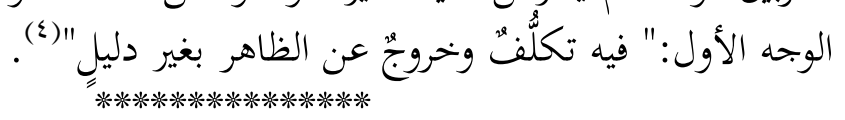

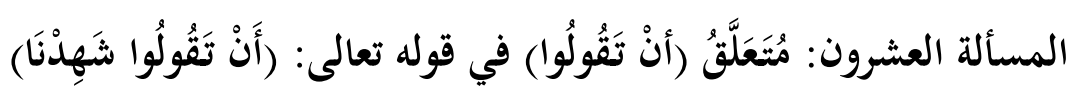

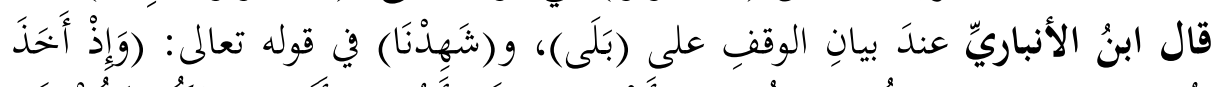

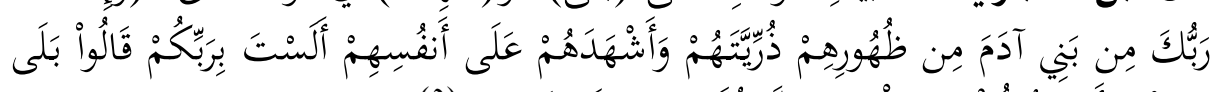

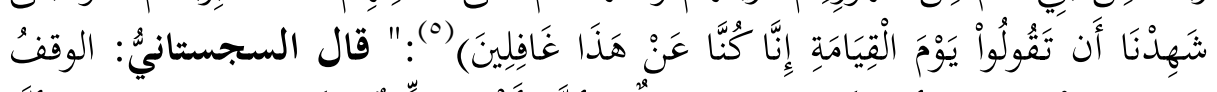

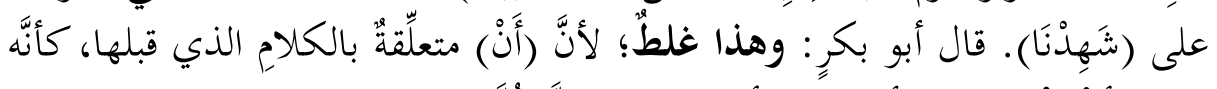

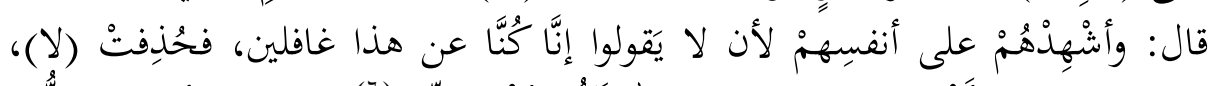

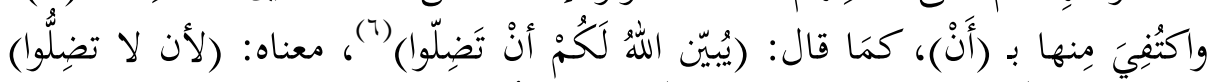

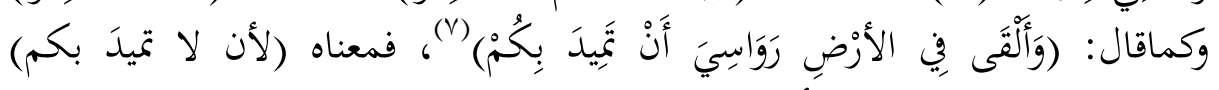

$$
\begin{aligned}
& \text { فحذف (لا) واكتفى منها بـ(أن)، قال الراعي الراعي: }
\end{aligned}
$$

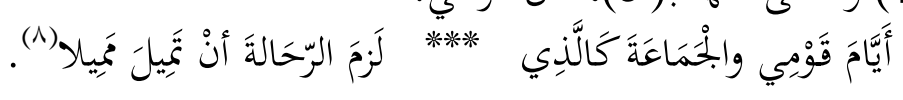

$$
\text { (1) (1) إيضاح الوقف والابتداء (1) }
$$

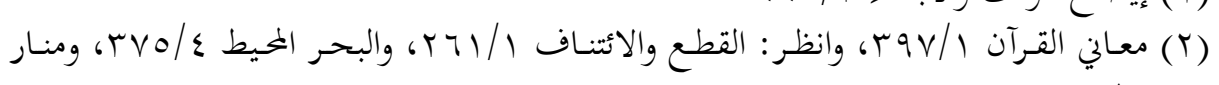
الهدى . 10.

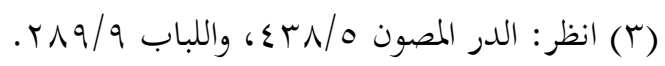

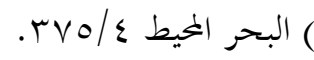

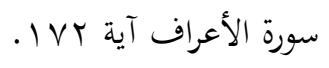

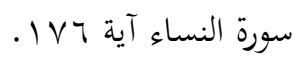

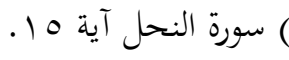

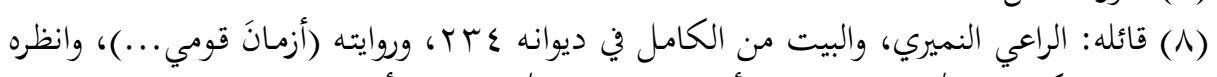

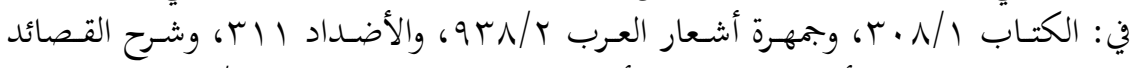

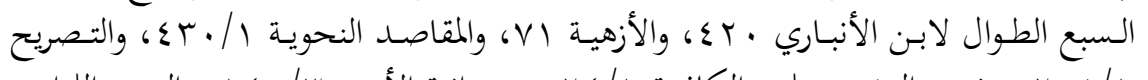

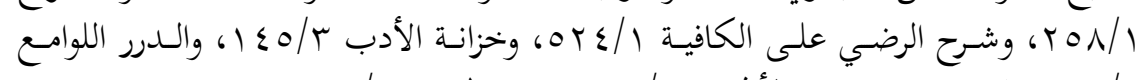

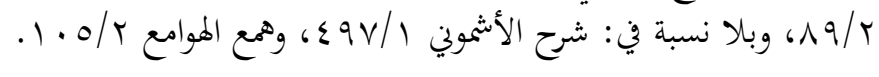




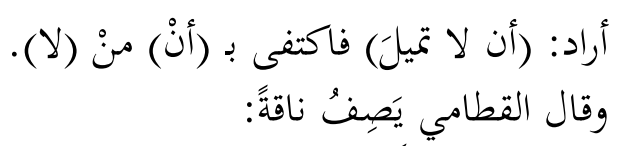

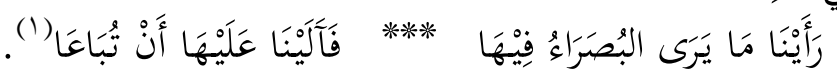

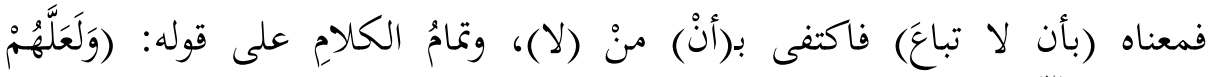

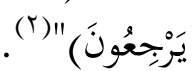

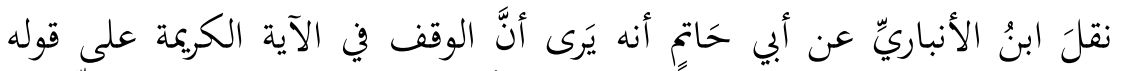

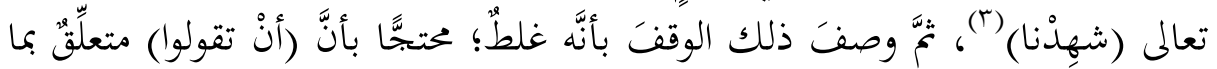

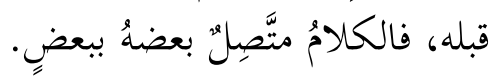

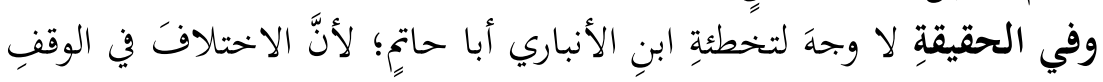

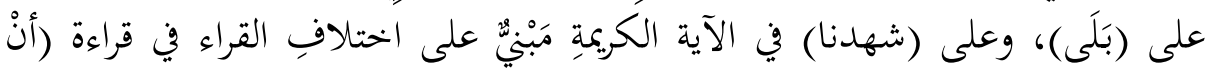

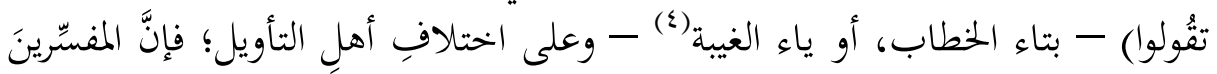

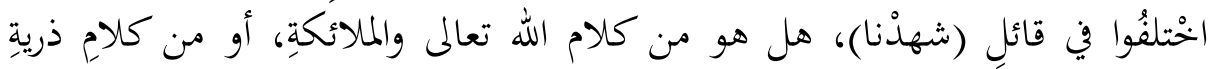
آدم؟ وتفصيلُ ذلك على النح النحو الآني:

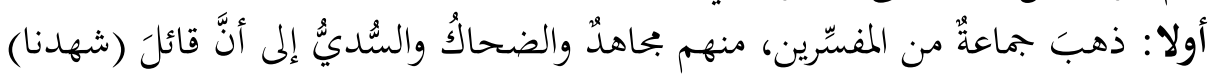

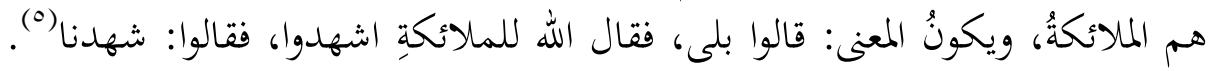

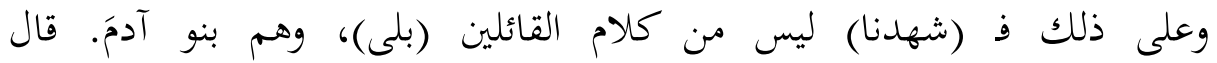

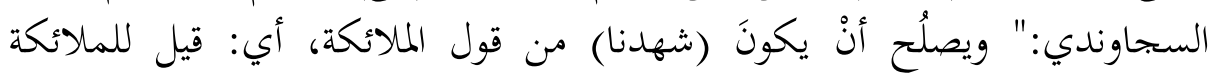

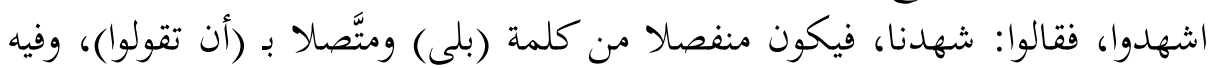

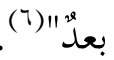

البيت من الوافر، ورؤي البيت في ديوانه بـ، (عرْفنا ما يرى ...)، وانظره في: تفسير الطبري

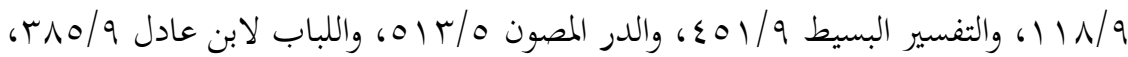

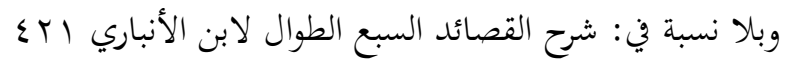

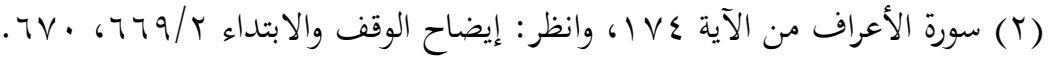

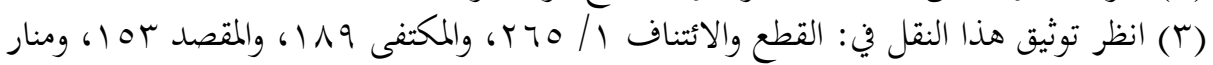

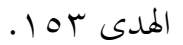

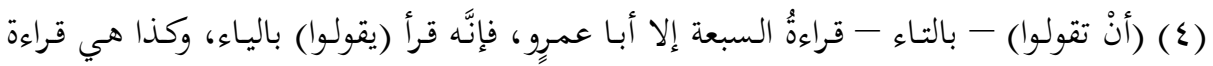

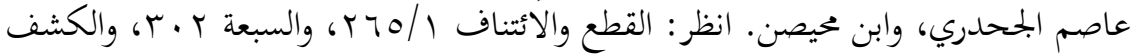

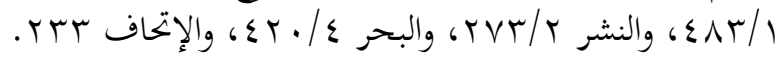

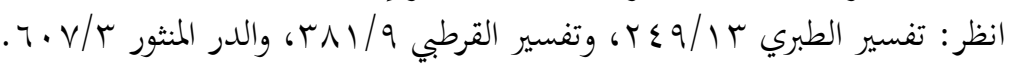

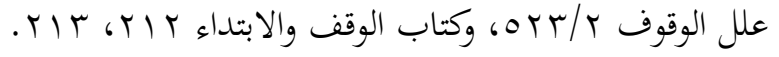


وقيل: قالوا بلى، فقال الله تعالى: (شهدنا)، فـ (شهدنا) من كلام الله تعالى (1)

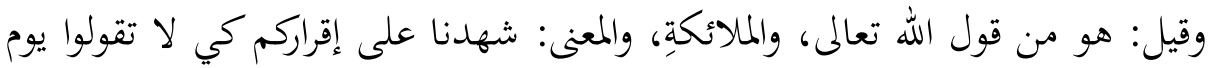

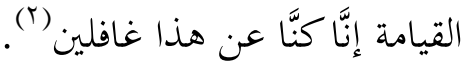

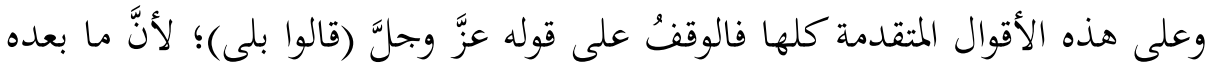

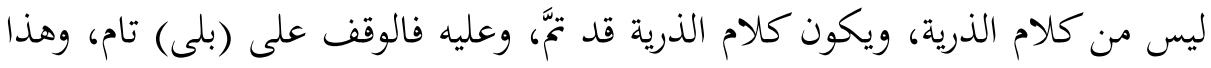

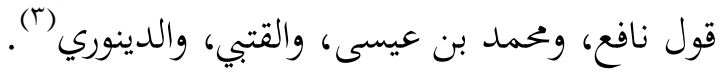

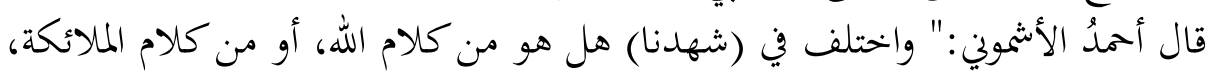

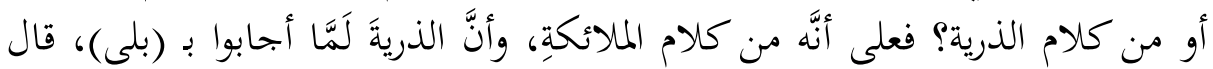

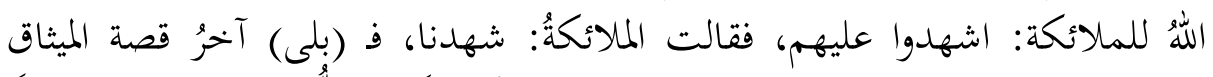

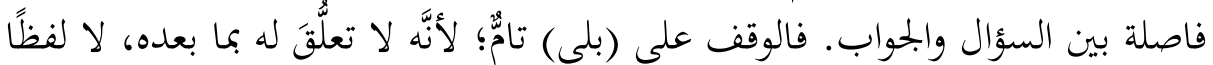

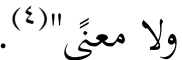
وعلى ذلك فمقول القول محذوف، تقديره: بلى أنت ربُّنا، وجملة (شهدنا) استئنافية لا

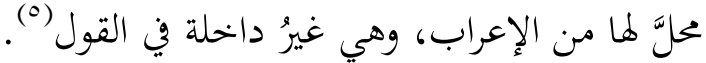

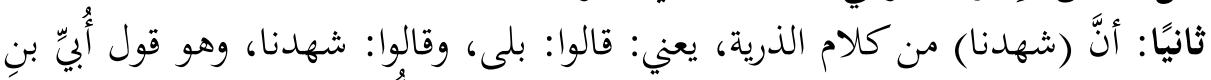

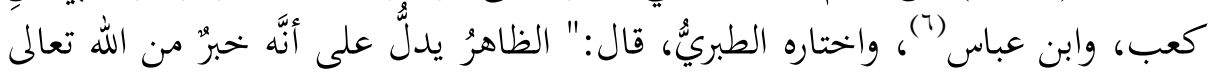

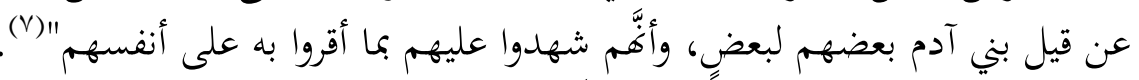

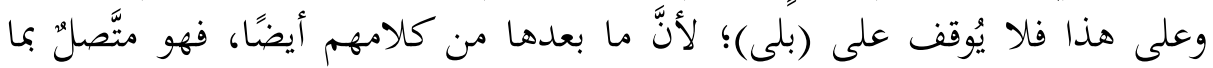
(شهدنا) على التمام (^). وهو قولُ عُ الأخفش، وأبي حاتمٍ السجساني، وأحمد بن

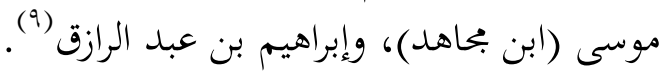

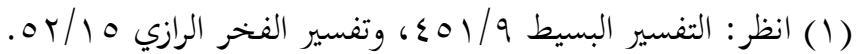

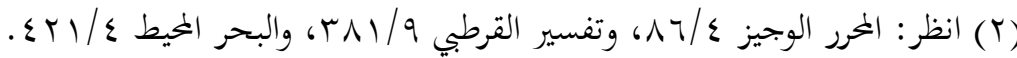

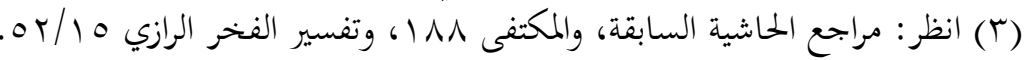

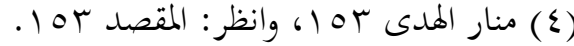

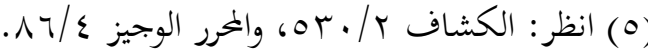

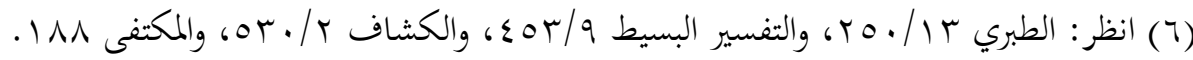

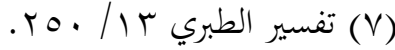

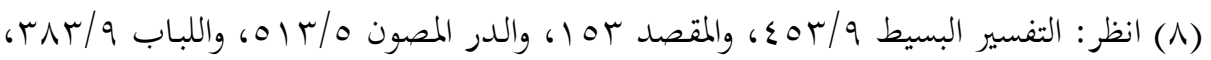




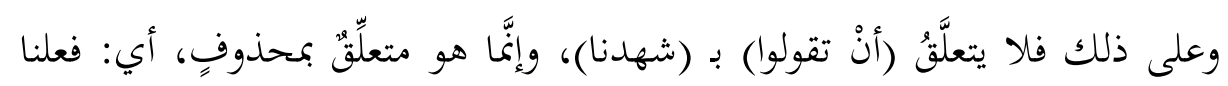

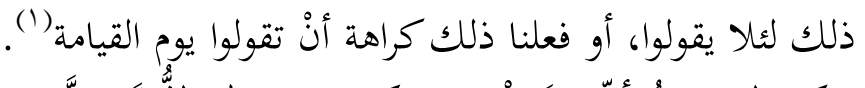

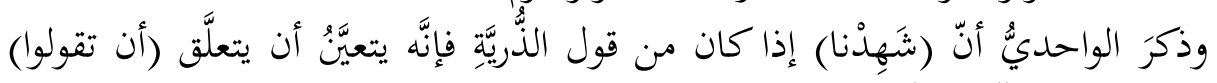

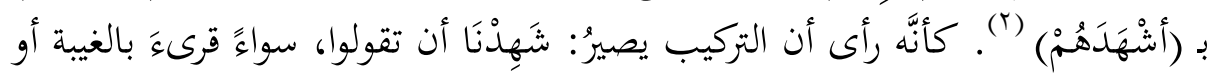

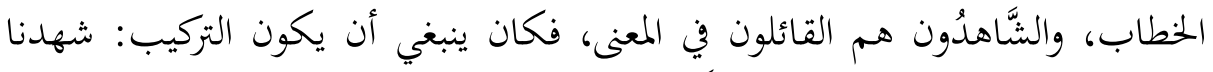

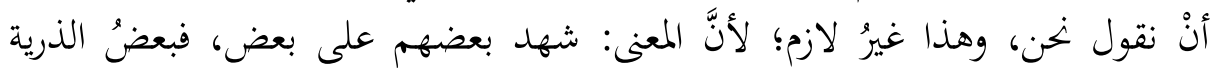

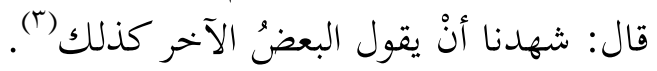

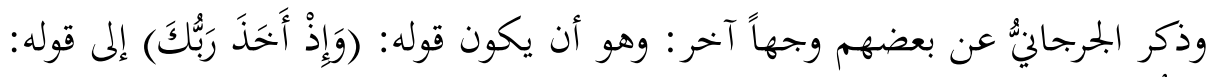

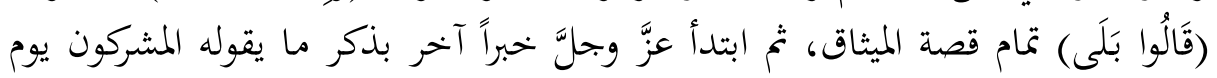

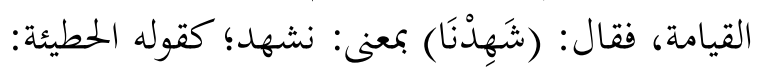

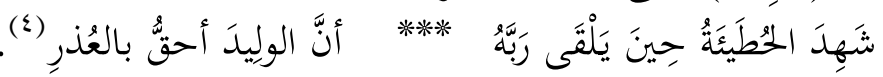

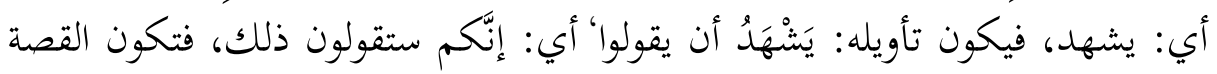

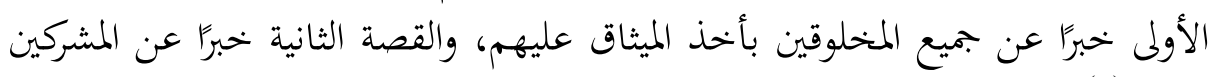
خاصةً) (0).

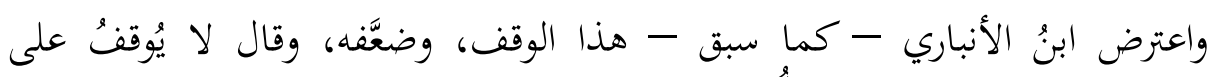

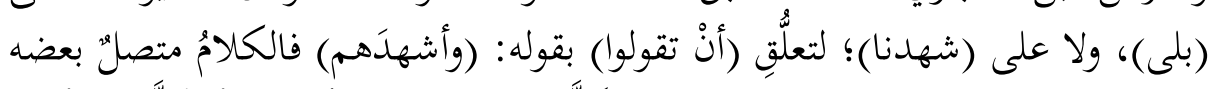

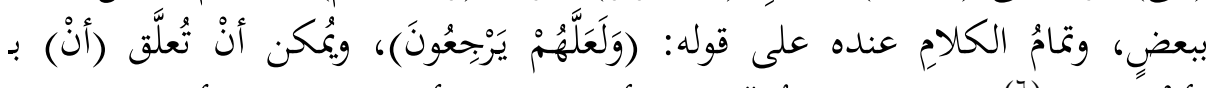

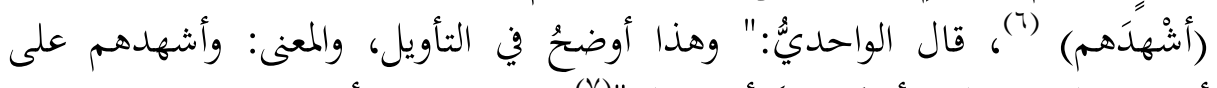

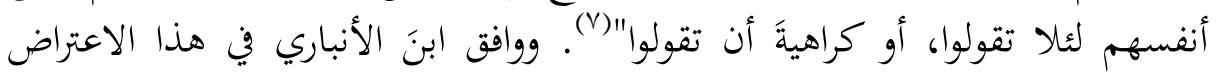

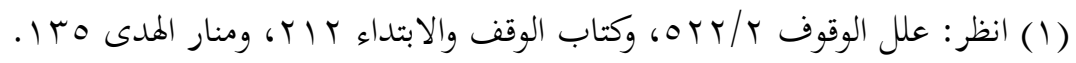

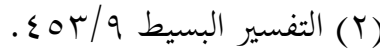

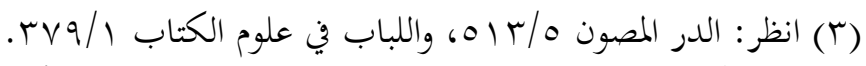

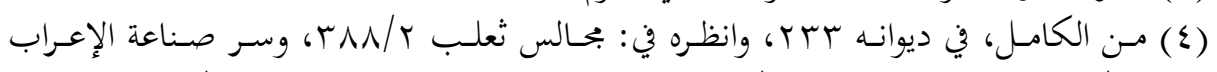

$$
\begin{aligned}
& \text { 1 / } \\
& . r \wedge \varepsilon / 9
\end{aligned}
$$

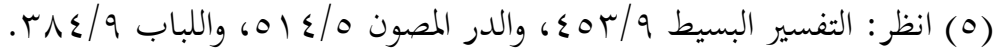

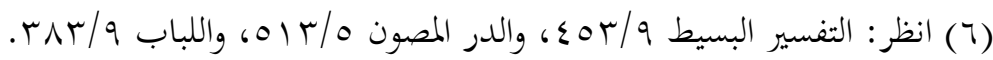

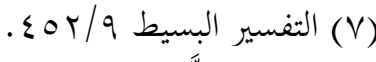

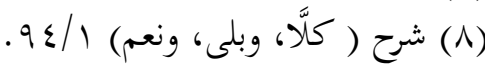




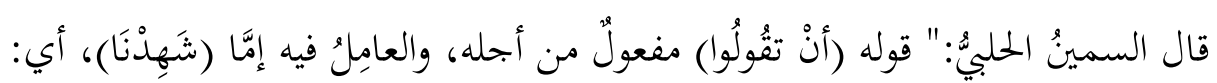

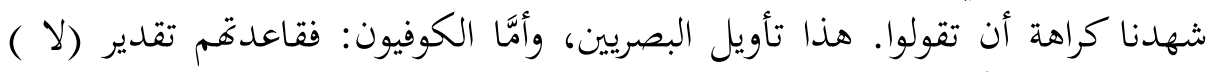

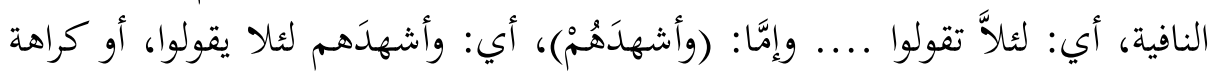

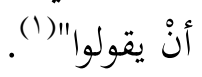

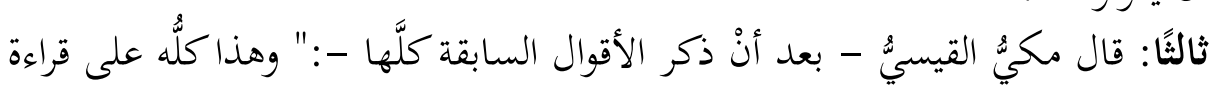

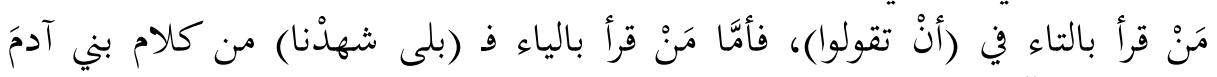

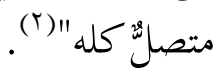

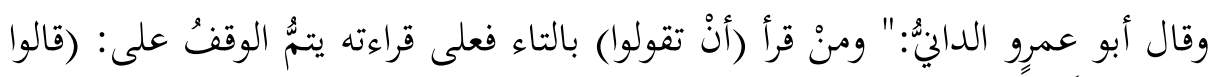

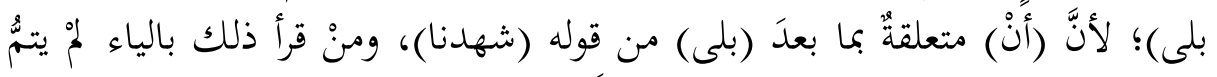

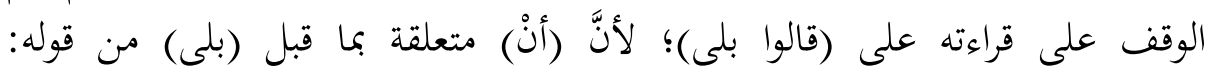

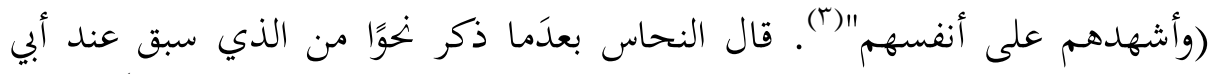

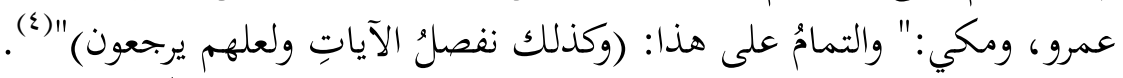

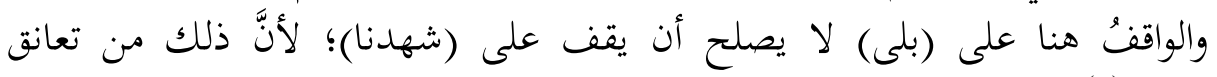
الوقف (o)

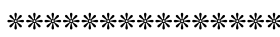

المسألة الحادية والعشرون: توجيةُ إعرابٍ (مَنْ) في قوله تعالى: (ومَنِ اتَّبَعَكَ مِنَ

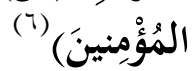

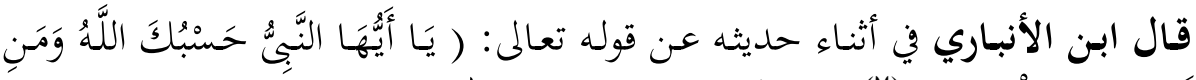

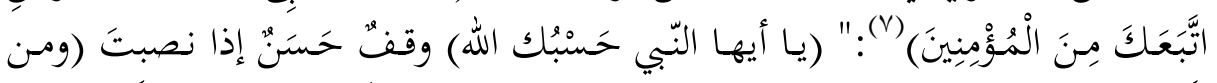

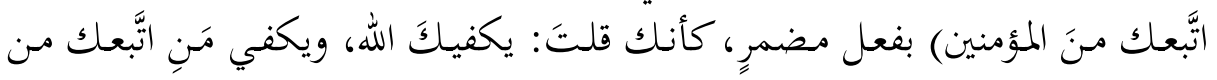

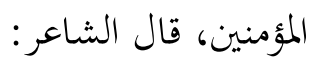

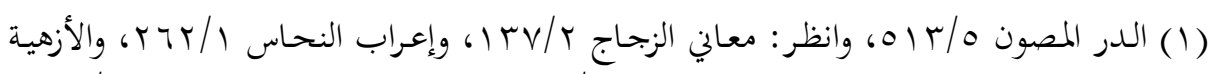

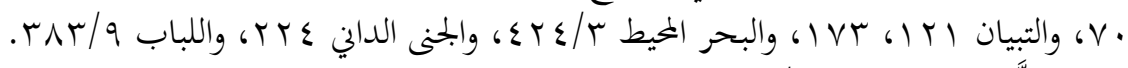

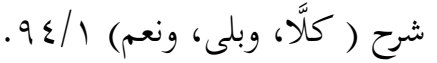

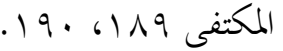

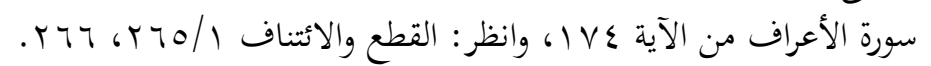

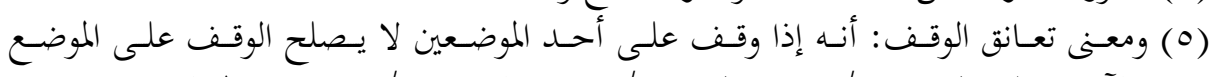

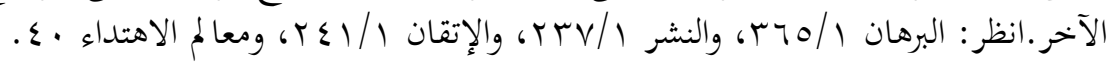

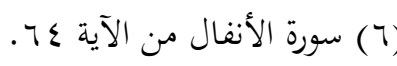

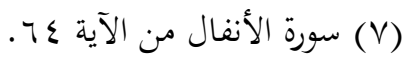




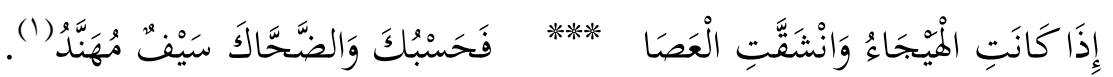

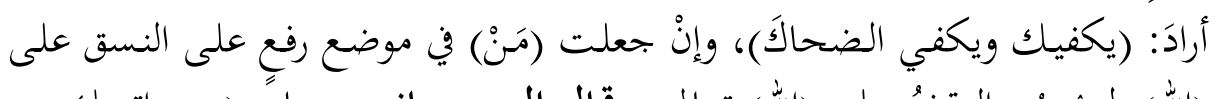

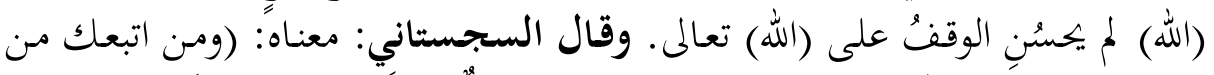

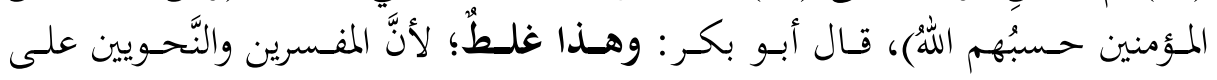

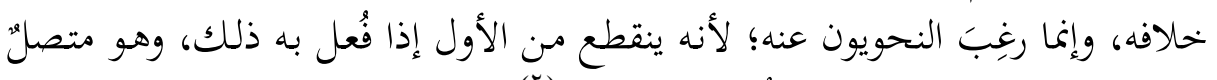

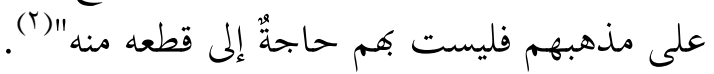

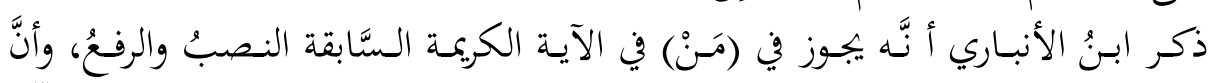

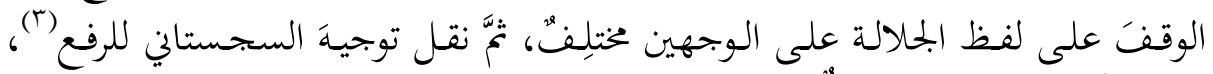

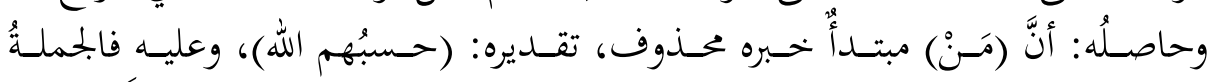

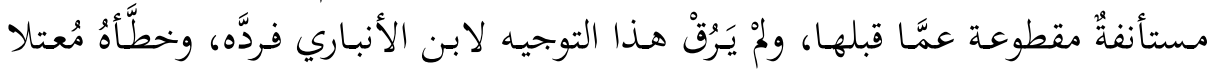

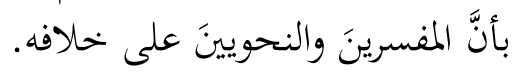

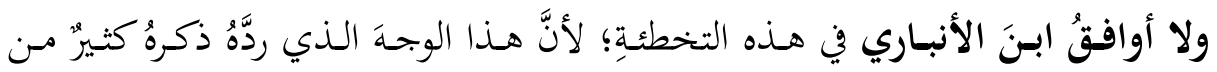

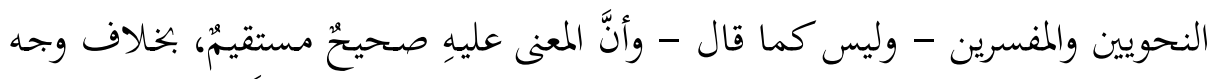

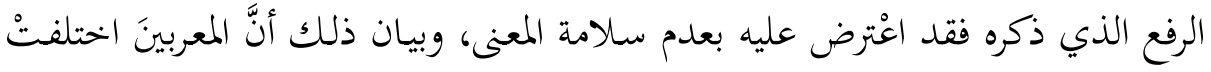

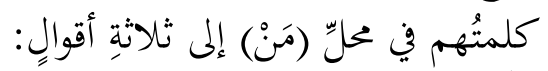

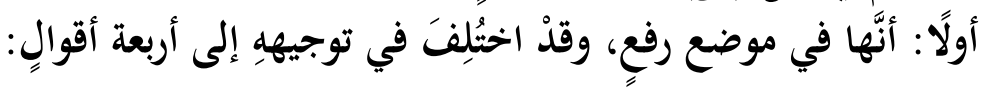

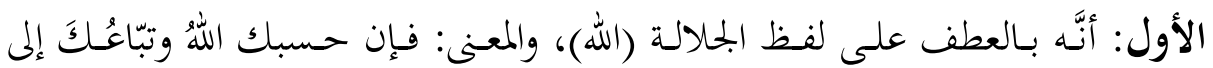

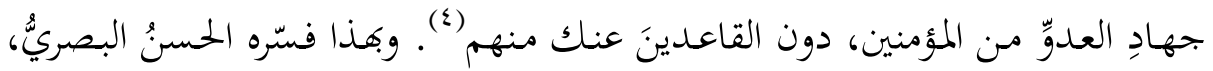

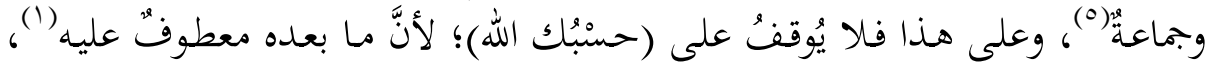

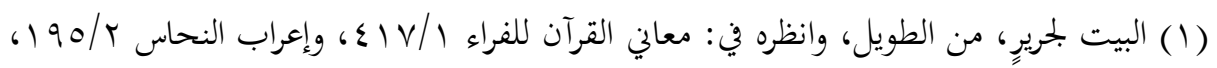

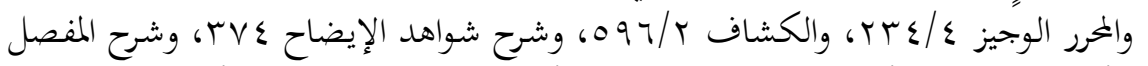

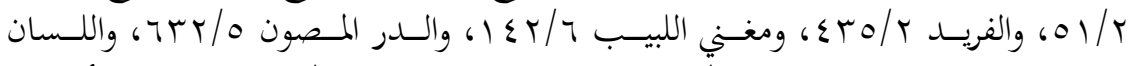

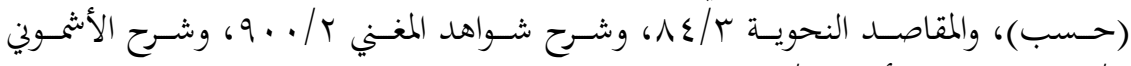

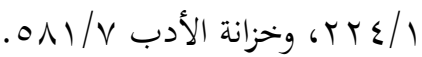

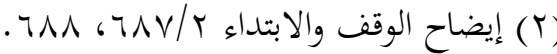
.

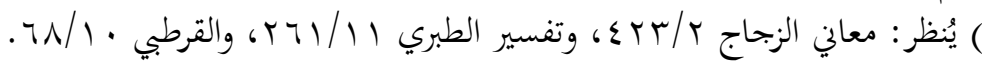

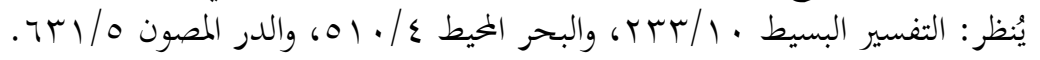




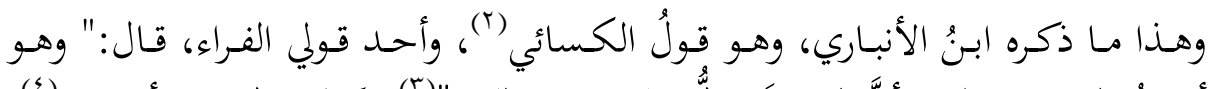

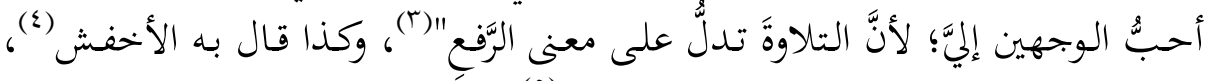

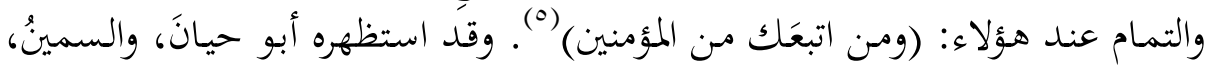

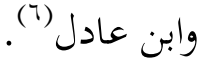

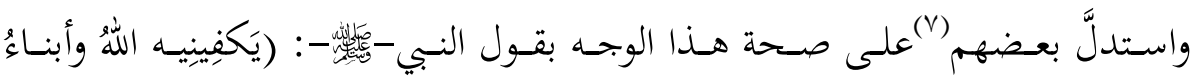
قَمَيْلةَ)

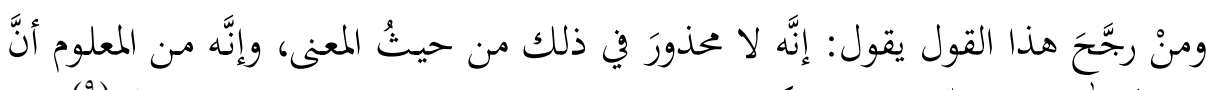

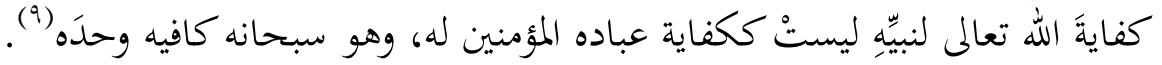

وفي هذا القول نظرُ من عدَّة أوجهِ:

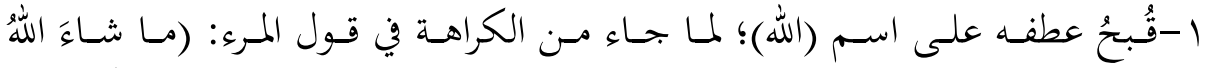

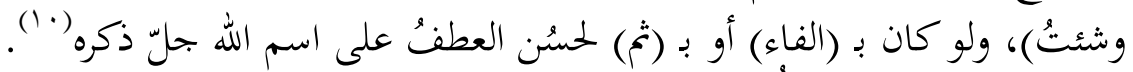

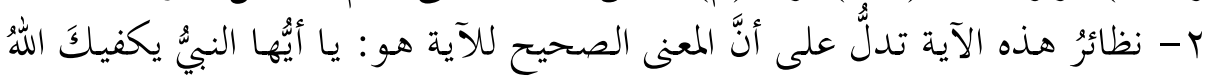

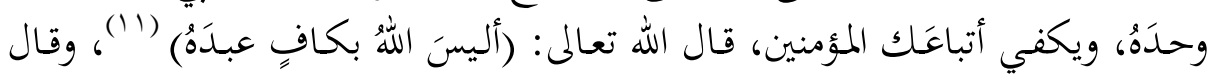

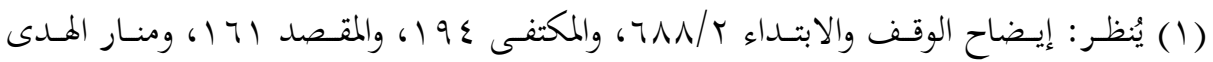
.171

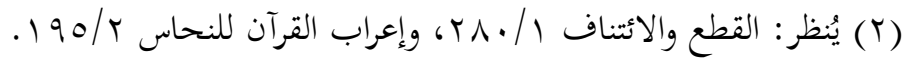

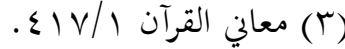

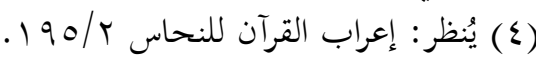

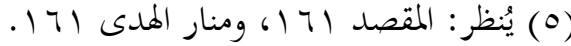

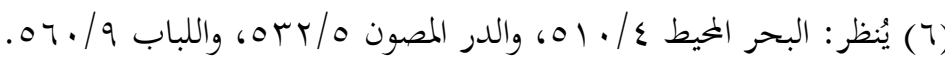

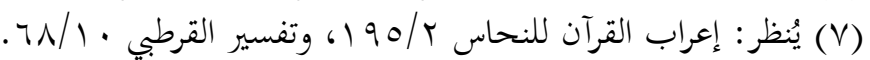

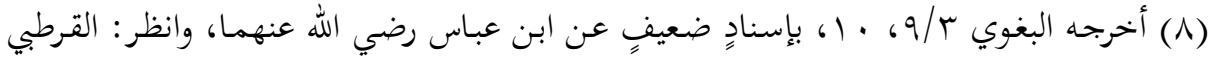

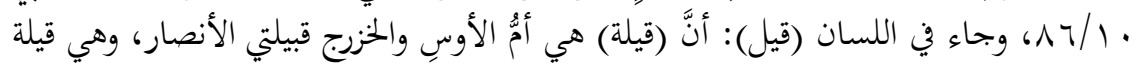

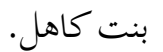

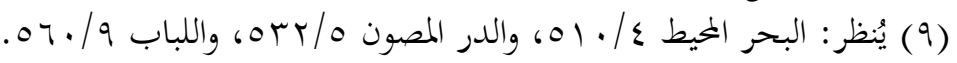

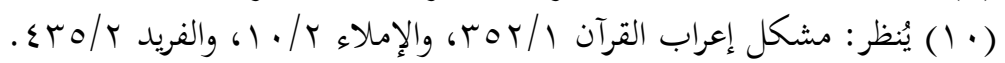

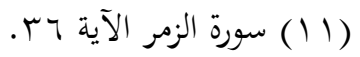




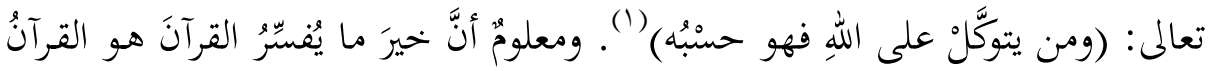

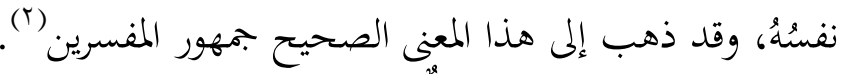

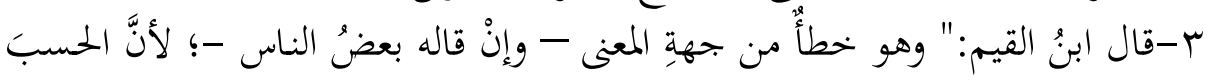

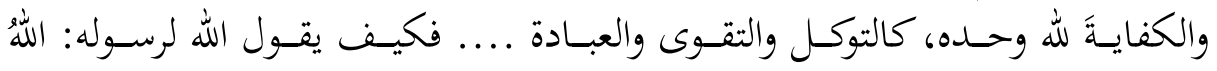

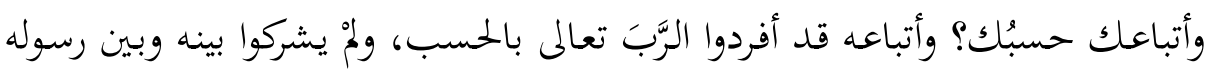

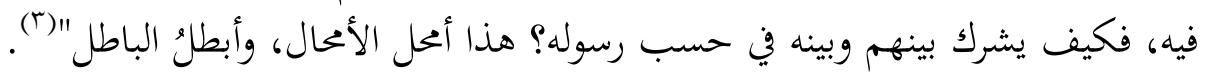

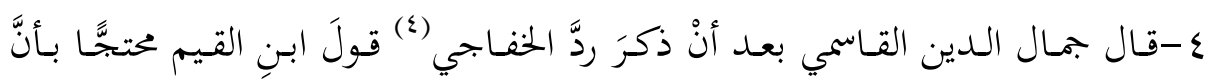

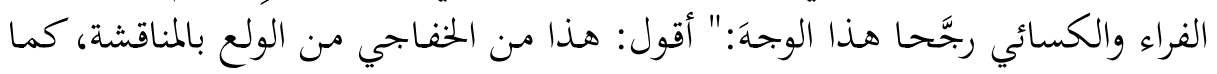

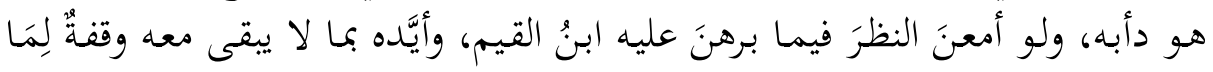

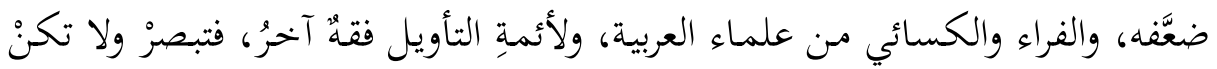

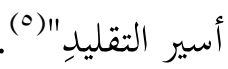

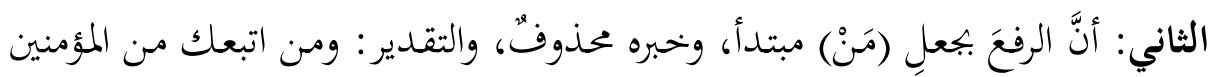

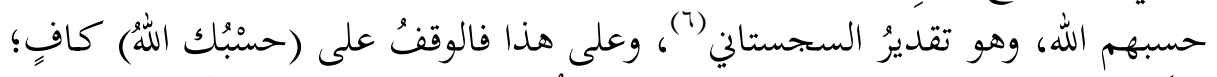

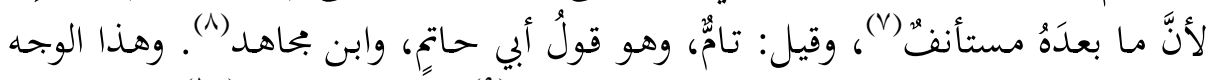

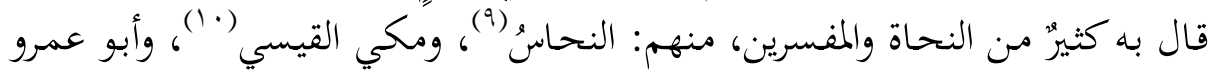

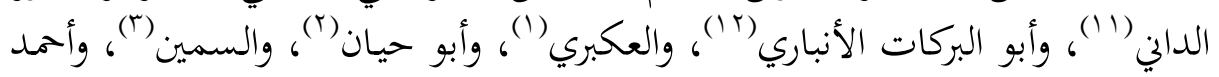

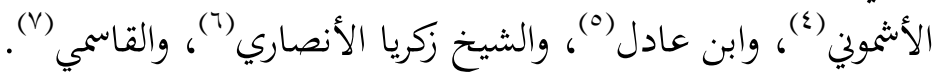

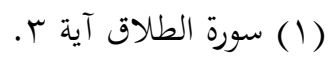

(T)

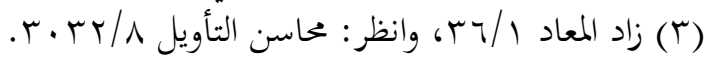

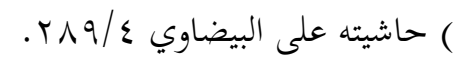

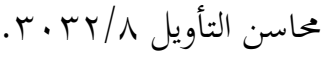

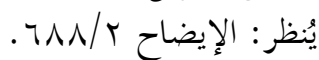

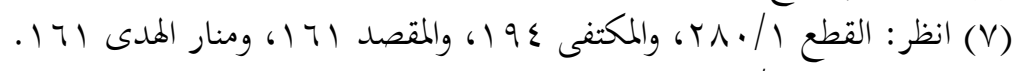

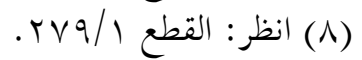

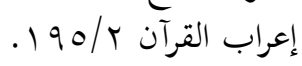

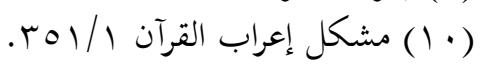

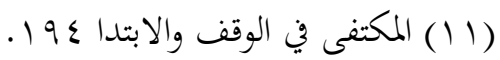

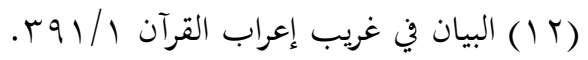




$$
\text { واستشهد النحاسُ على هذا الوجهِ بقول الفرزدق: }
$$

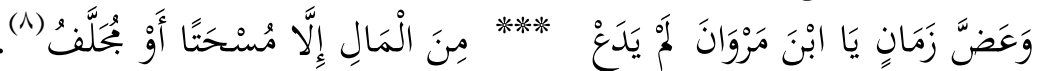

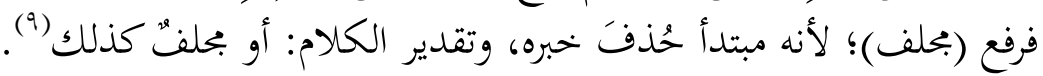

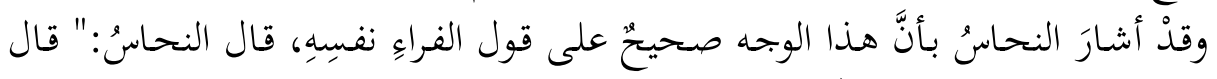

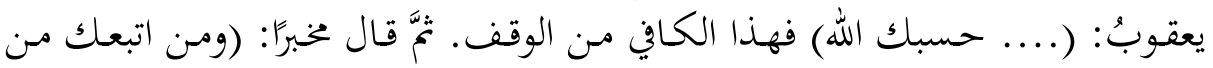

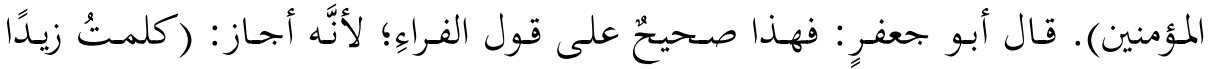

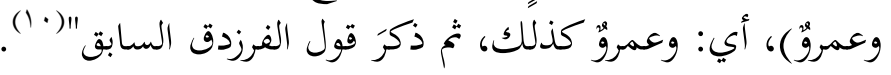

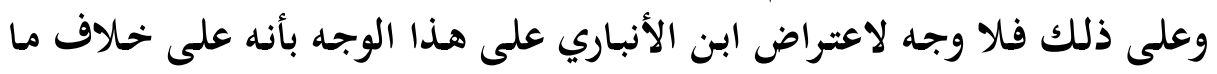
عليه النحويون والمفسرون.

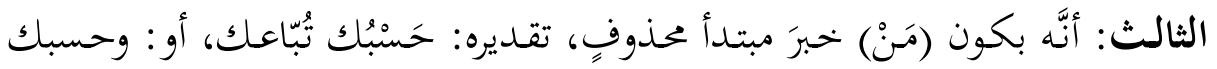

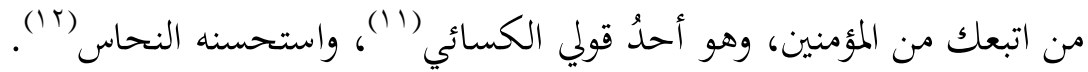

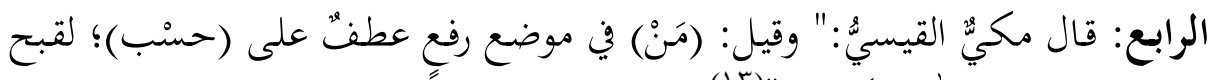

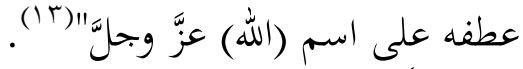

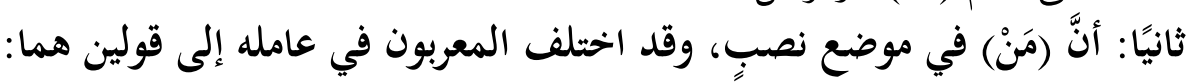

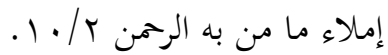

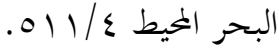

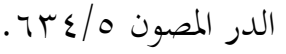

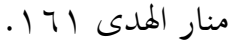

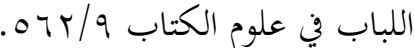

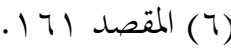

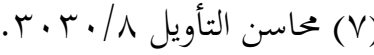

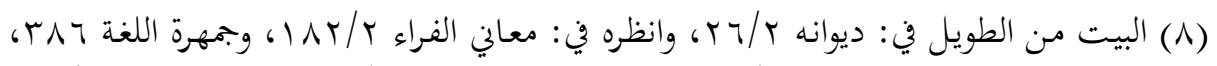

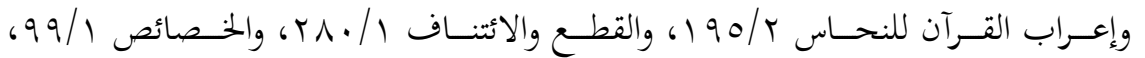

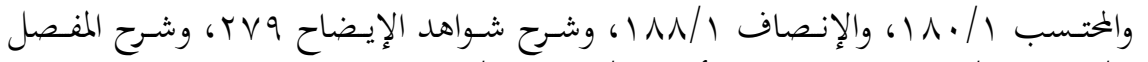
الما

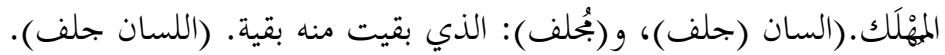

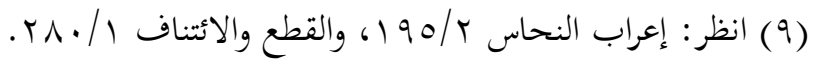

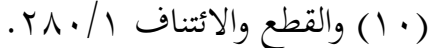

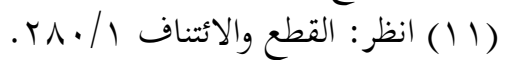

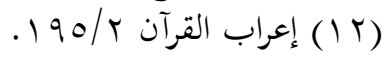

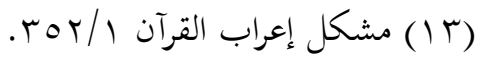




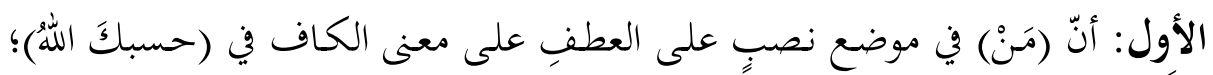

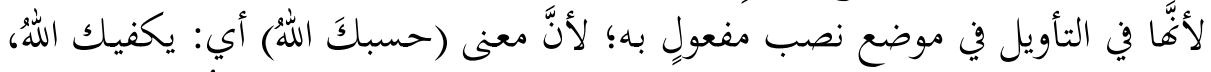

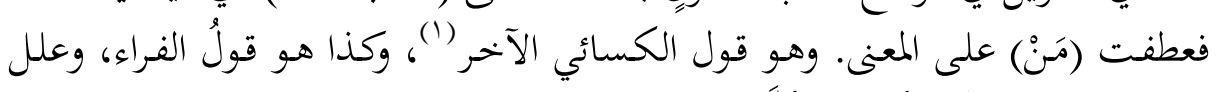

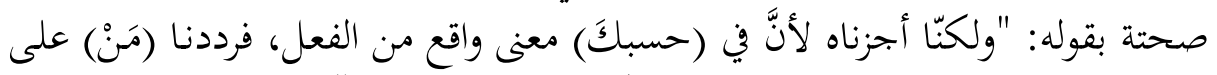

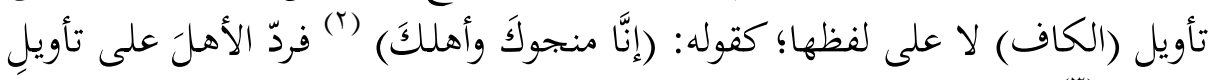

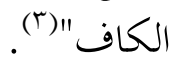

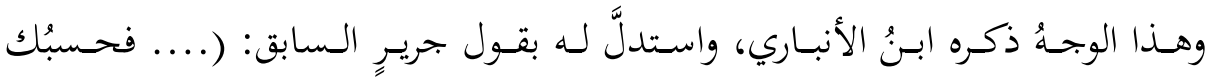

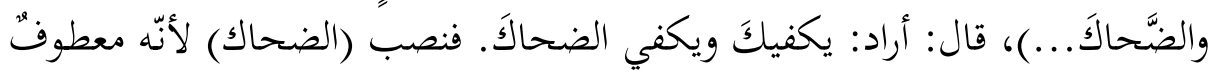

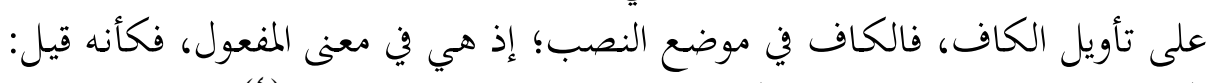

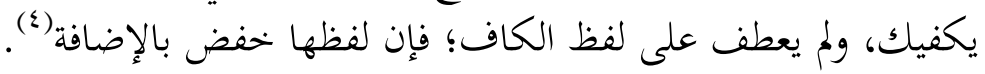

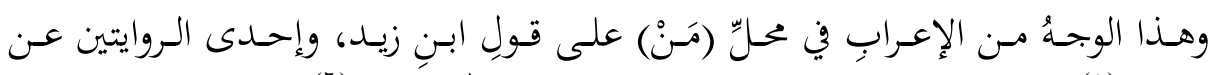

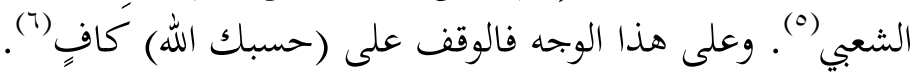

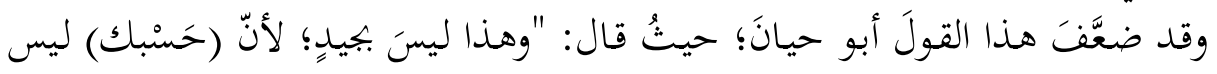

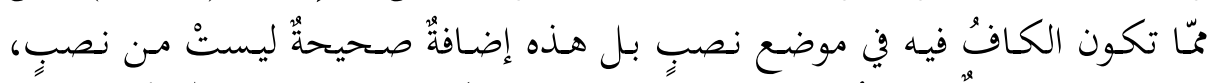

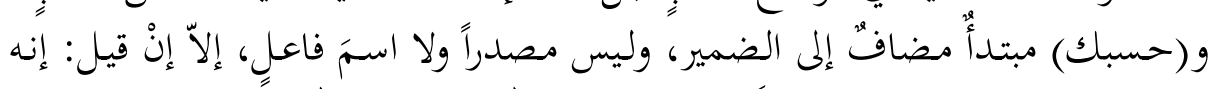

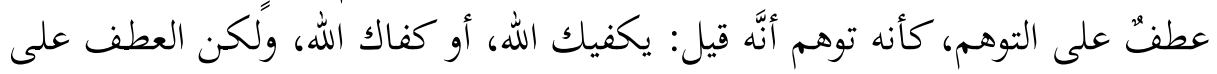

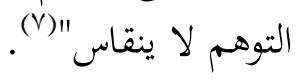

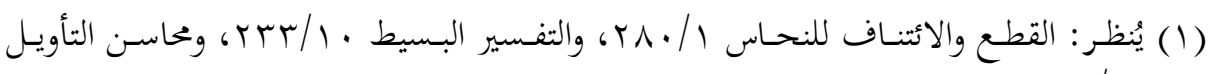
.r.r. $r / \Lambda$

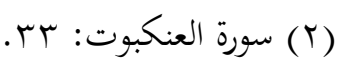

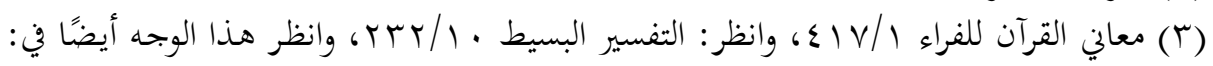

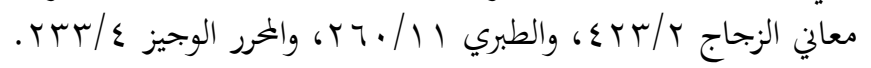

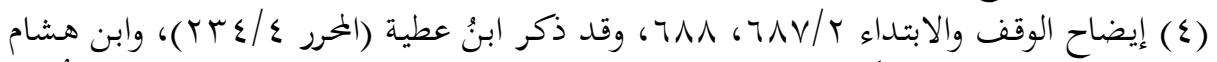

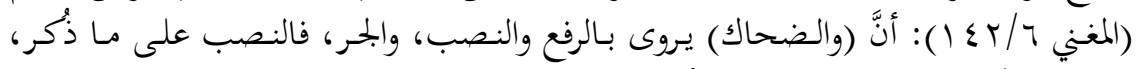

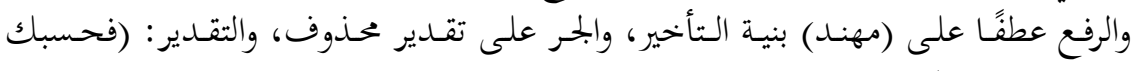

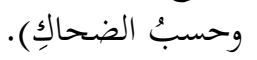

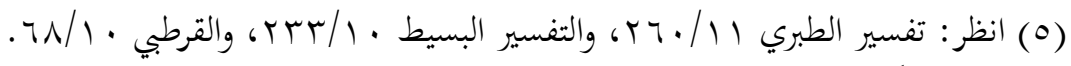

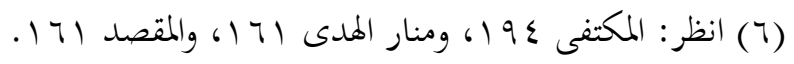

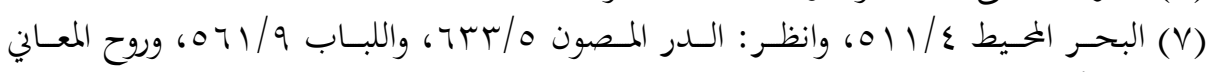
$. \mu / r / 1$. 


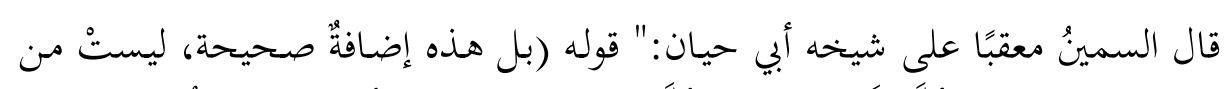

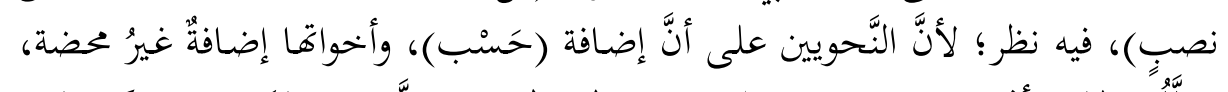

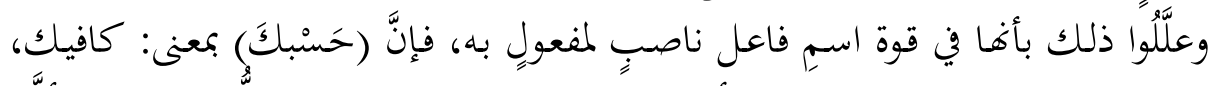

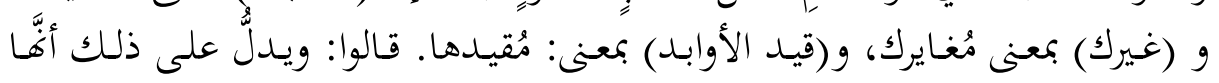

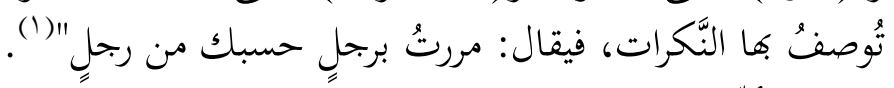

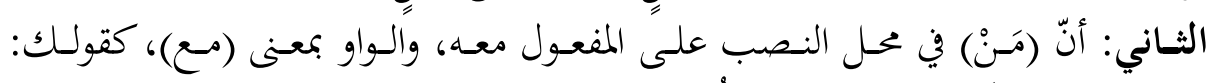

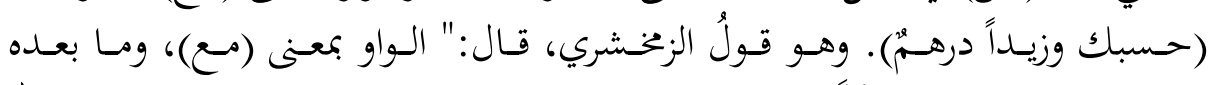

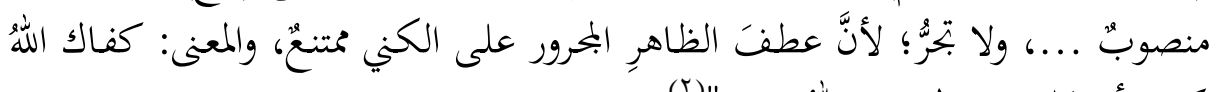

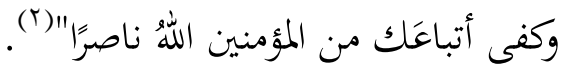

وتعقب أبو حيان هذا القول بأنه مخالف لكالام سيبويه (r)، فإنه جعل زيداً في قولهم:

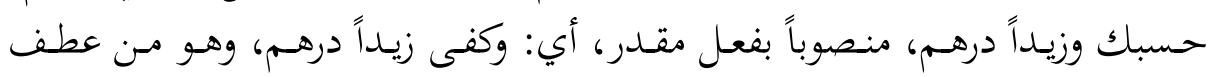
الجمل عنده (๕)

ثالثًا: أنَّ (مَنْ) في موضع جرٍّ، وقد اختلِف في توجيهه على قولين:

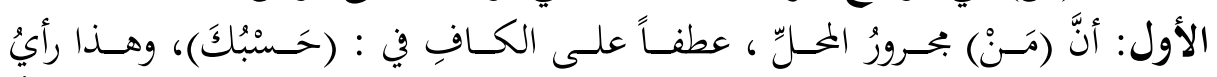

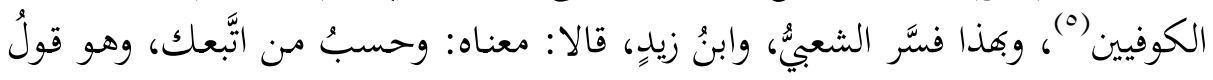

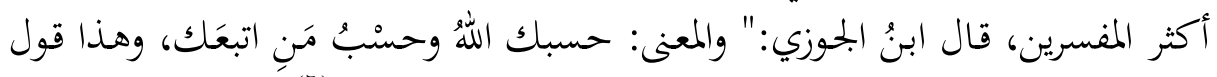

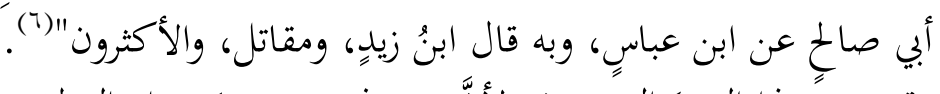

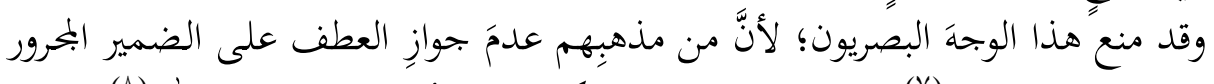

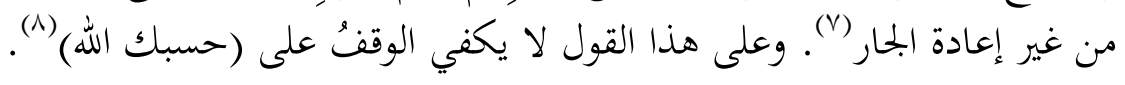

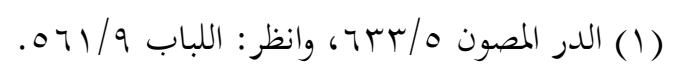

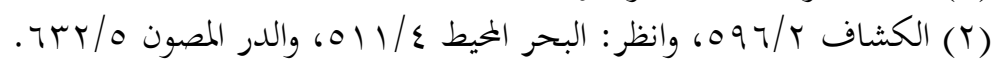

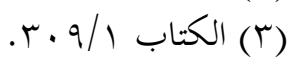

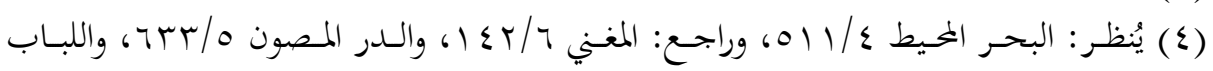

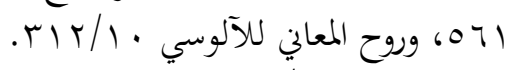

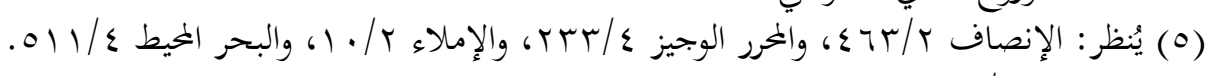

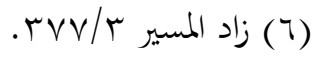

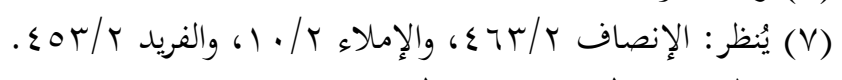

(^) 


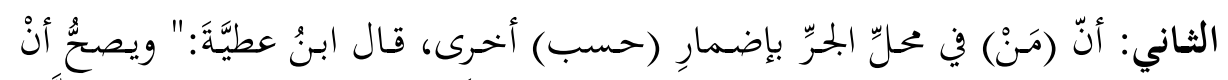

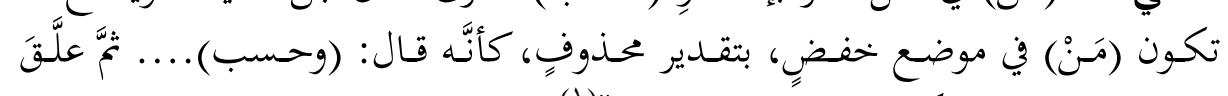

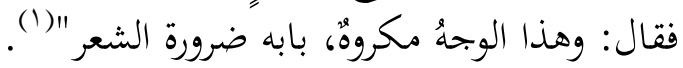

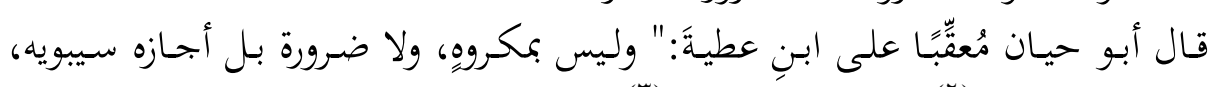

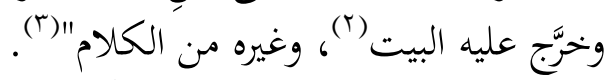

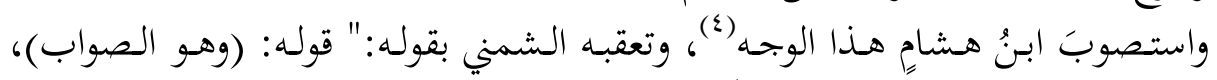

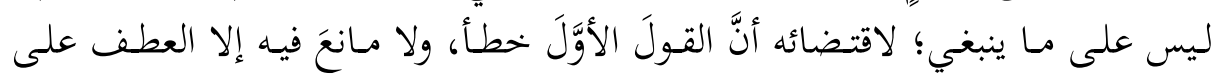

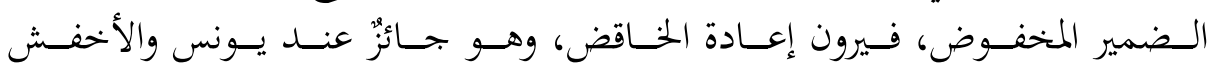

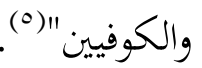

والذي يترجح لي في وجه النصب أنّ الواو في قوله (ومن اتبعك) بمعنى (مع)، و ومَنْ)

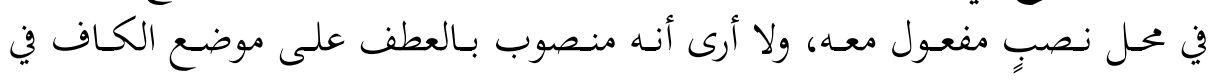

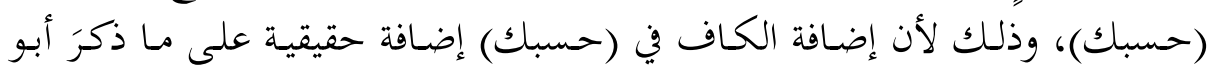

حيانَ.

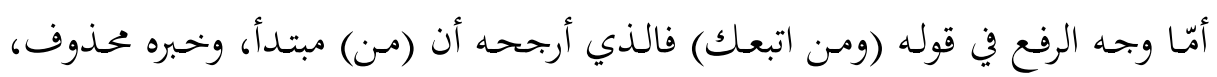

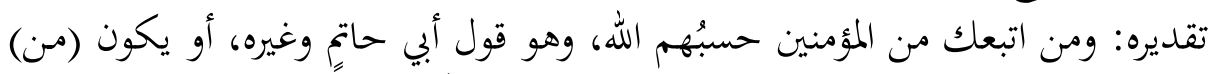

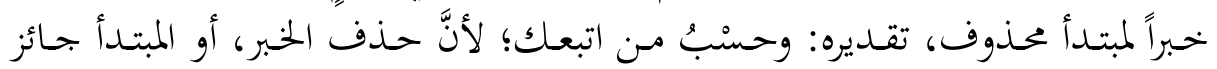

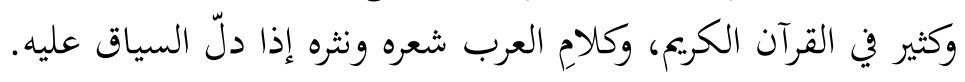

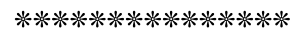

المسألة الثانية والعشرون: أوجه إعراب قوله تعالى: (فَاللَّهُ أَحَقُق أَنْ تَخْشَوَوْهُ)

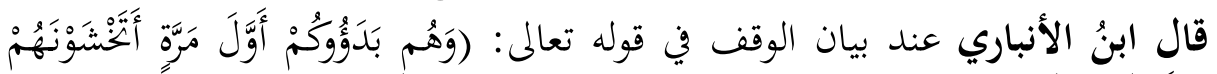

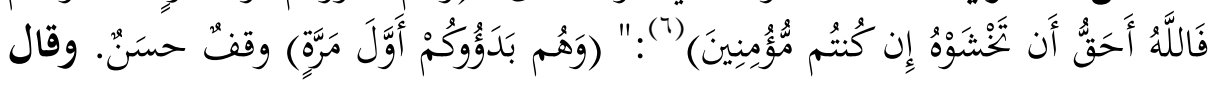

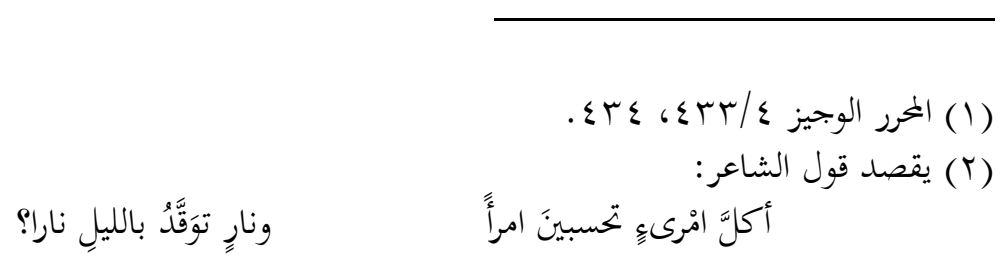

$$
\begin{aligned}
& \text { والتقدير : وكلّ نارِ. }
\end{aligned}
$$

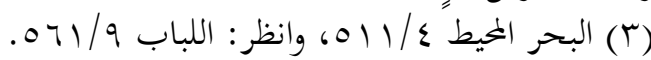

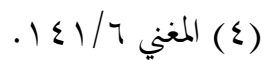

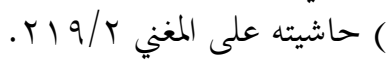

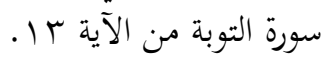




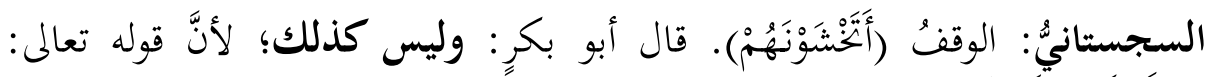

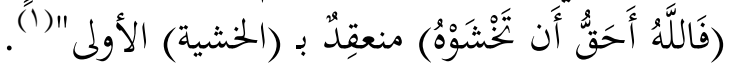

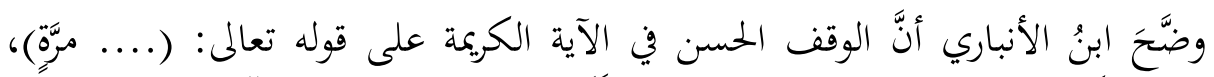

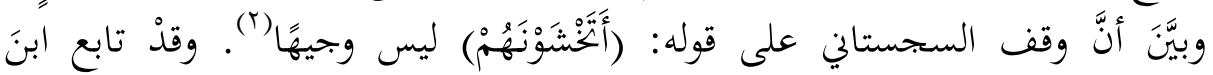

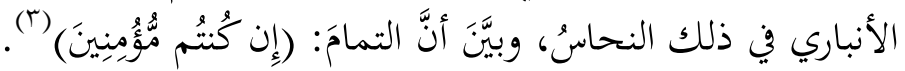

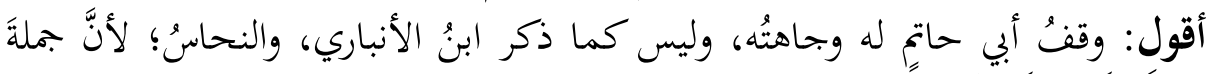

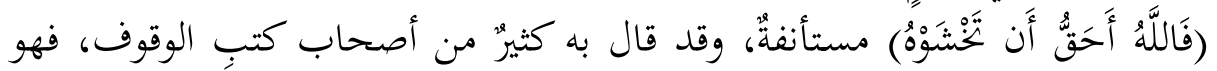

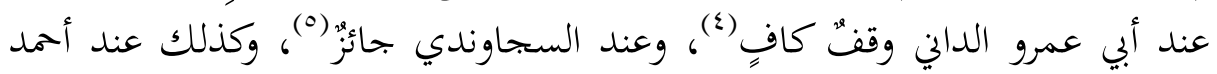
الأثموني (7)

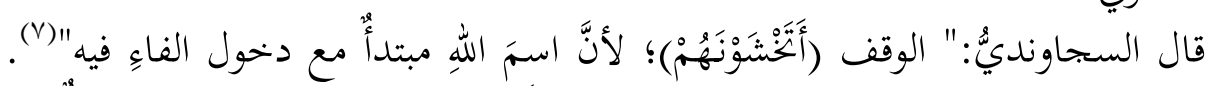

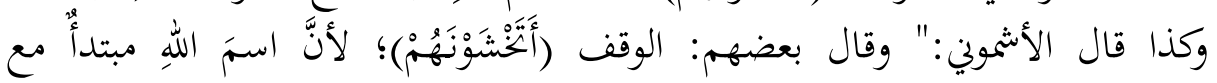
(^) الفاء.... (^) وقد قال بابتدائية لفظ الجلالة - هنا - كثيرٌ من معربي القرآن(9)، ولكنَّهم اختلفوا في

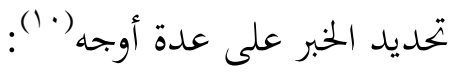

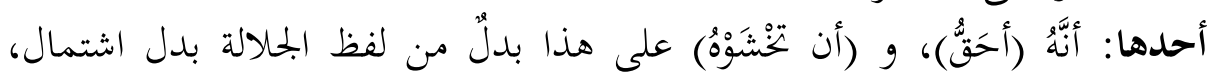

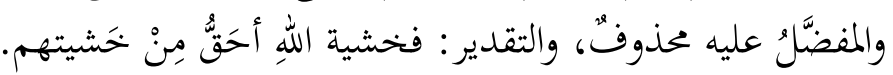

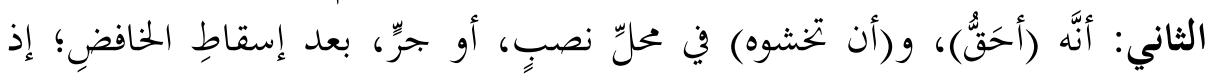

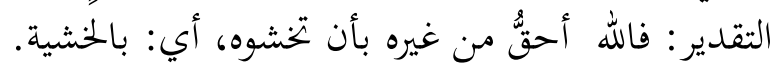

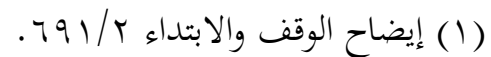

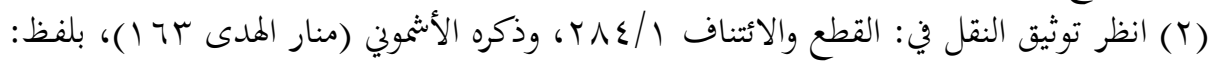

$$
\begin{aligned}
& \text { (وقال بعضهم). }
\end{aligned}
$$

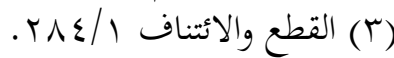

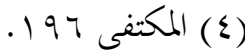

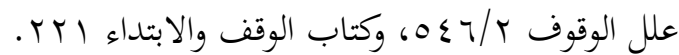

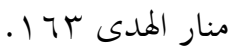

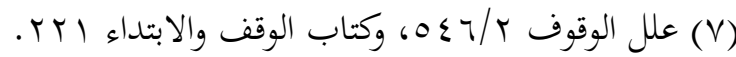

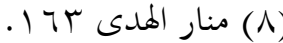

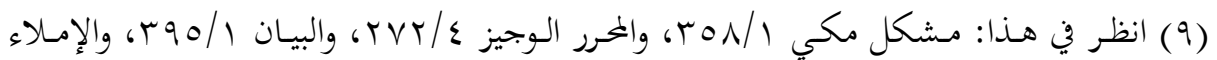

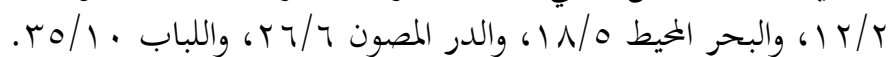

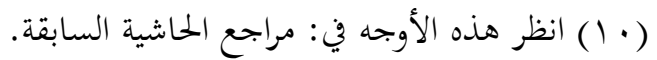




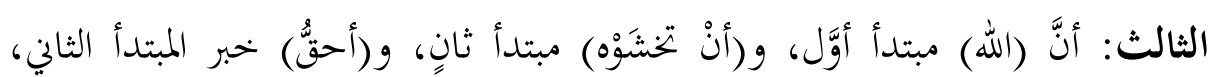

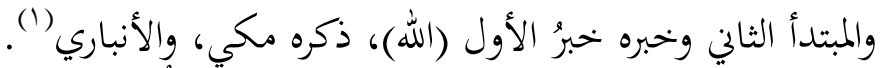

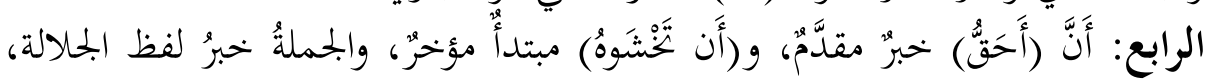

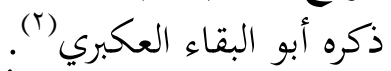

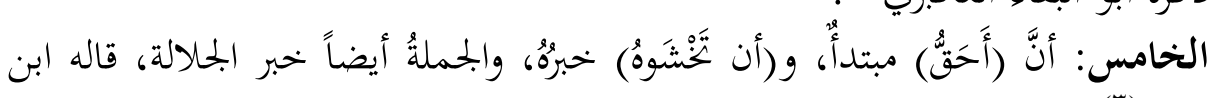

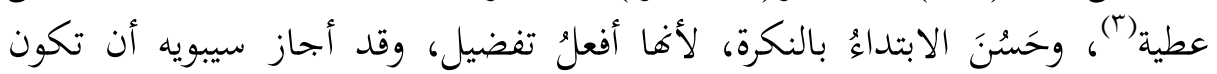

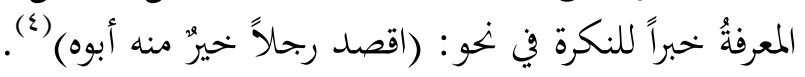
*********************

\section{المسألة الثالثة والعشرون: حقيقة اللامِ في قوله تعالى: (لِيَجْزَيَهُهُم)}

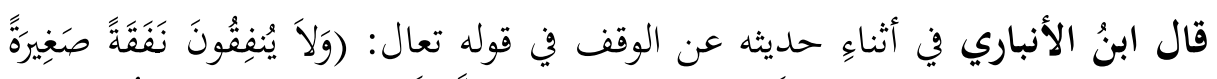

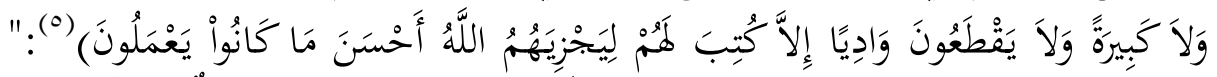

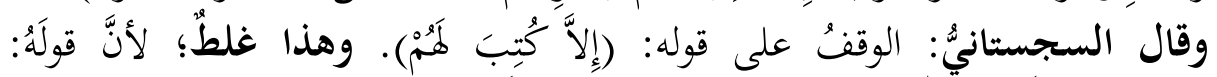

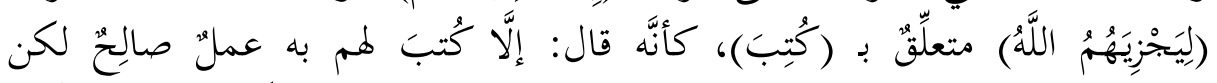

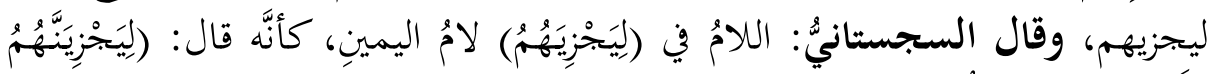

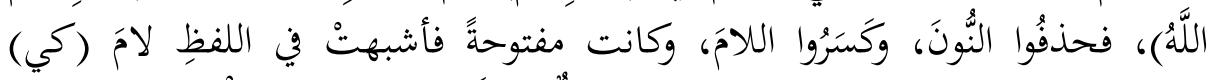

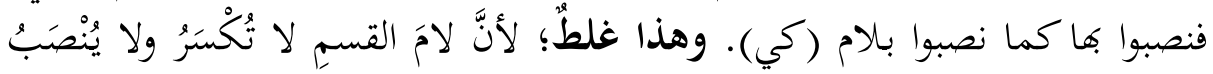

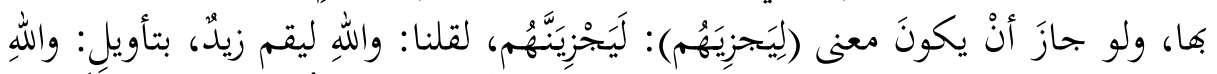

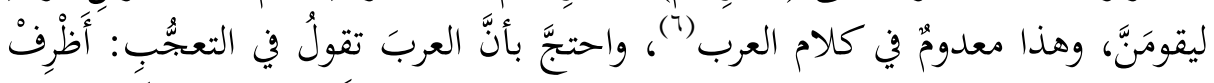

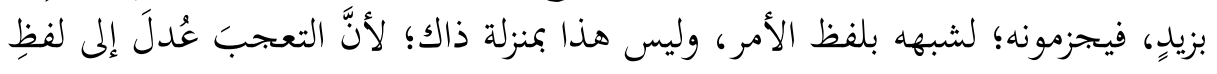

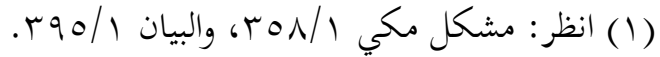

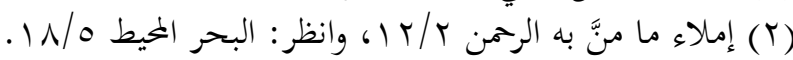

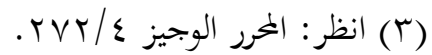

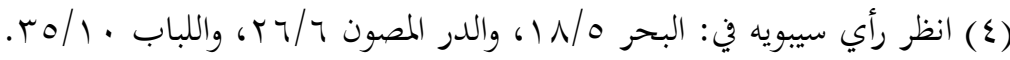

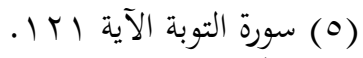

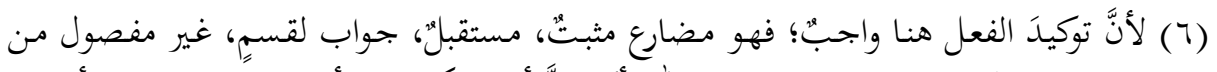

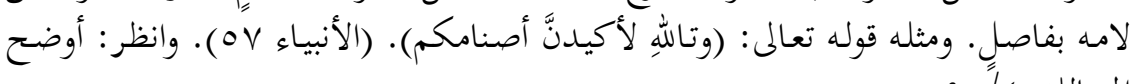

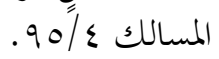




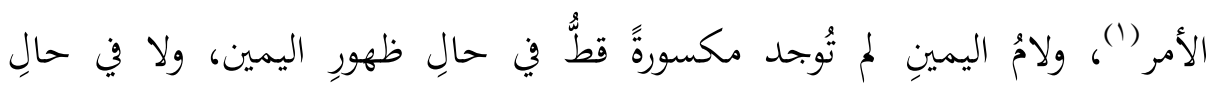
(ז)" (إضمارها

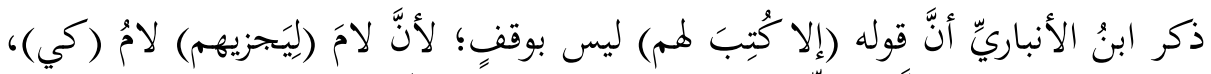

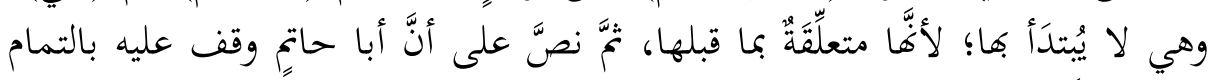

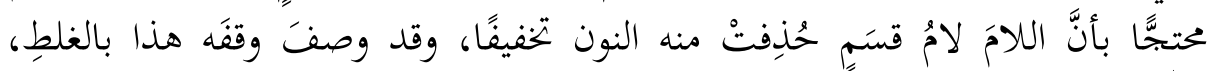

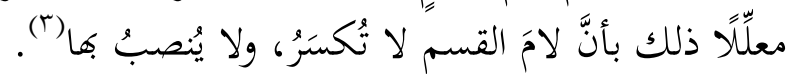

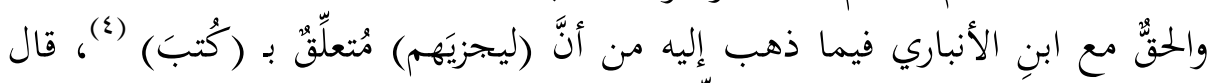

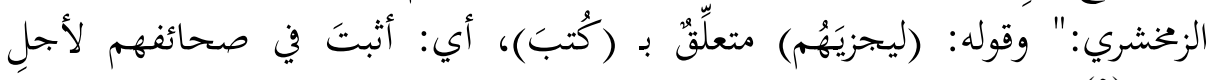

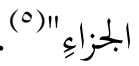

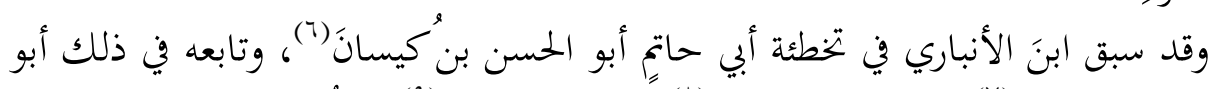

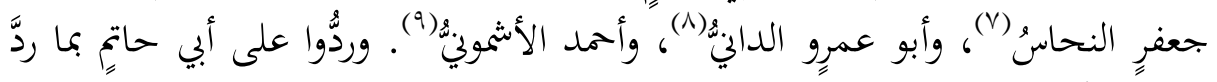
به ابنُ الأنباري في نصِّهِ السَّابق.

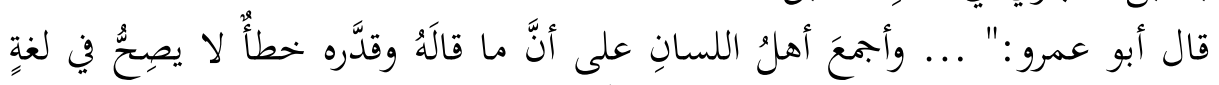

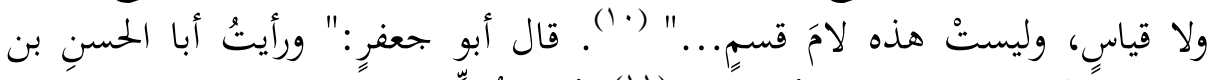

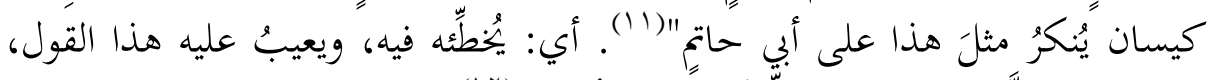

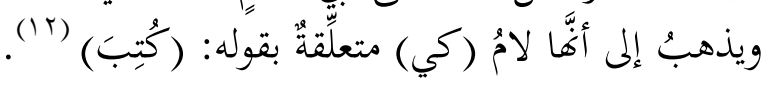

(1) وقـال النحـاس:" والفـرق بينهمـا: أنَّ هـذا موجـود في كـلام العرب، وكسرُ لام القـسم غـير

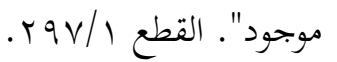

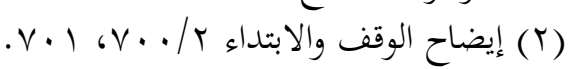

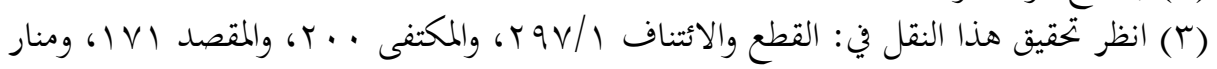

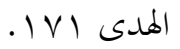

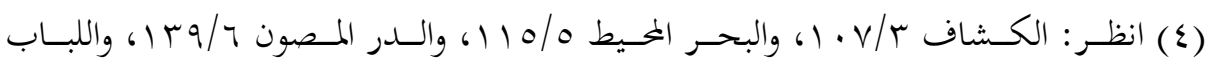
. r TN/1.

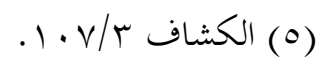

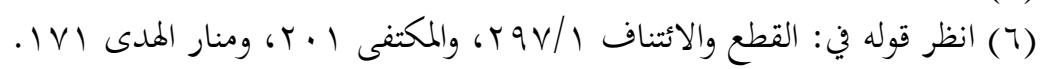

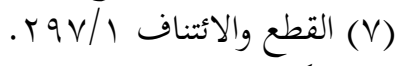

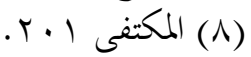
. IV| (9) منار الهدى (9)

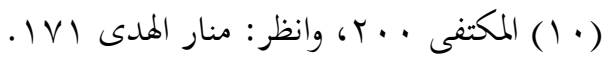

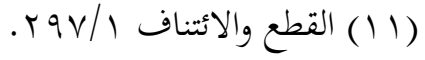

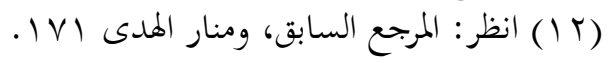




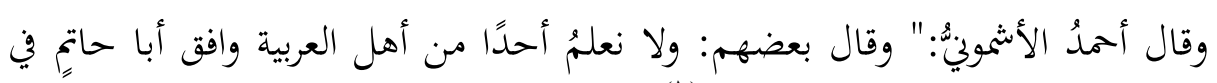

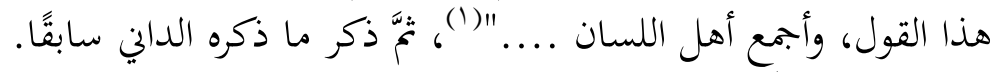

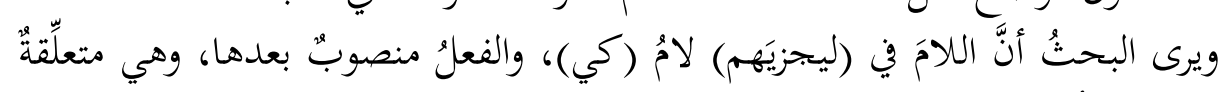

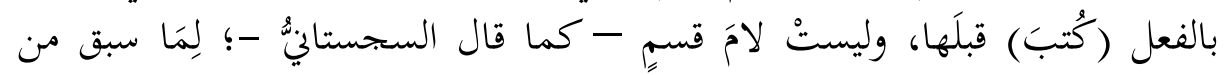
تعليلٍ رائع في كلام ابنِ الأنباري.

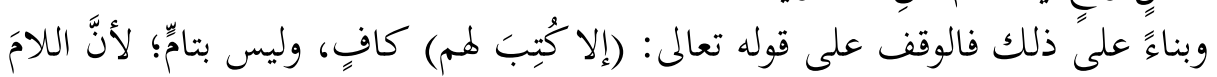

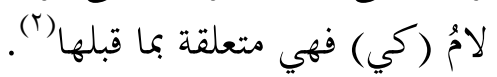

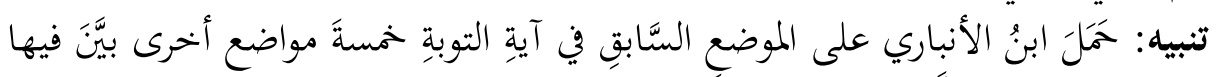

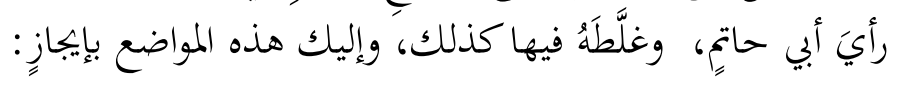

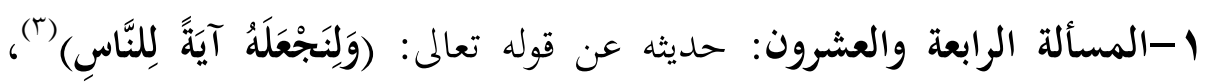

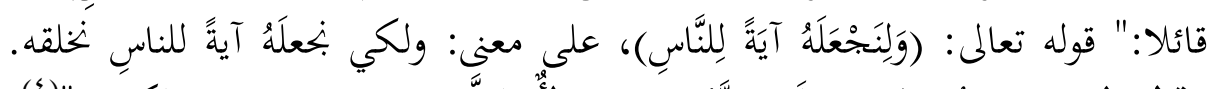

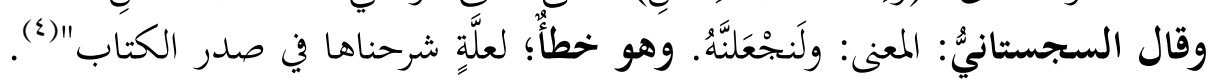

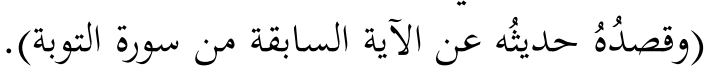

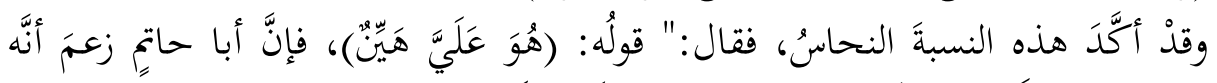

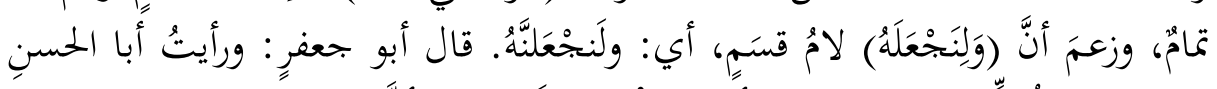

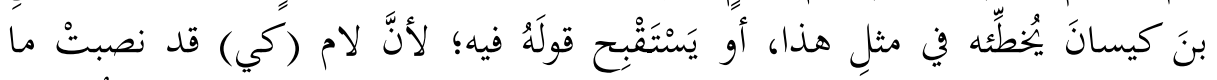

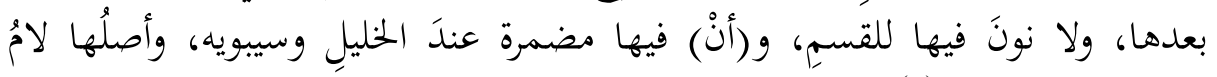

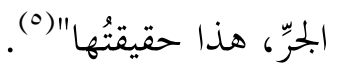

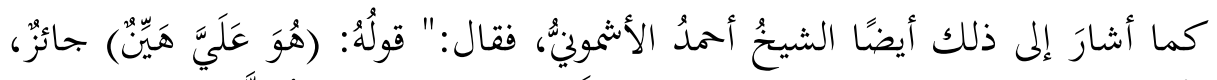

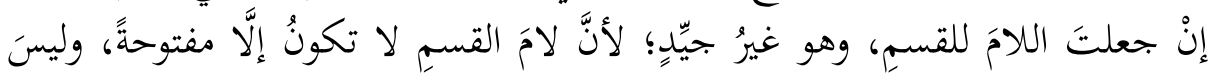

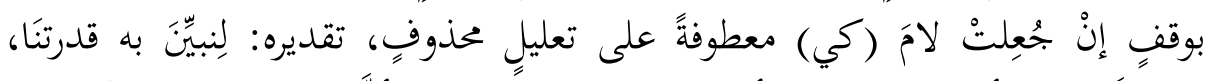

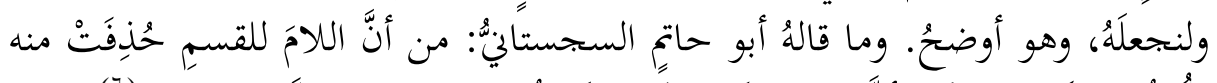

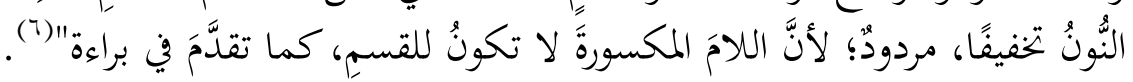

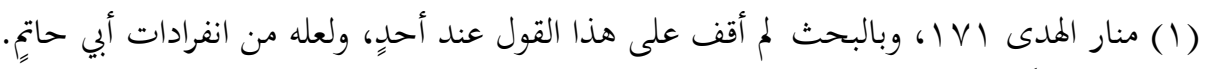

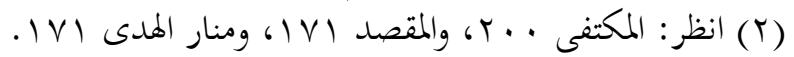

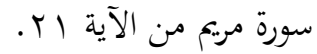

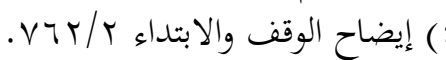

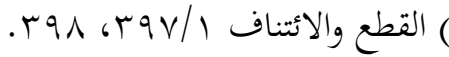

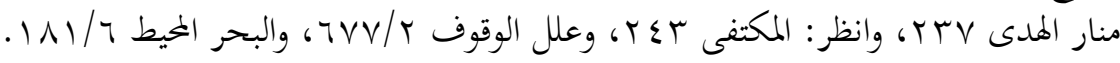




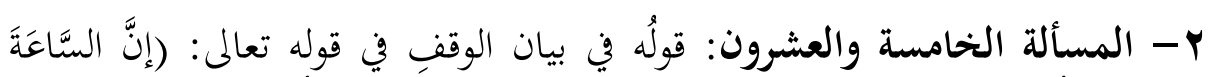

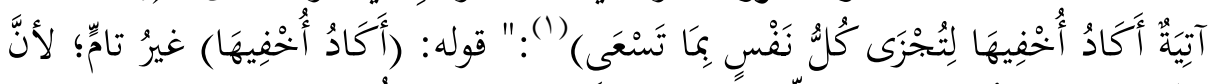

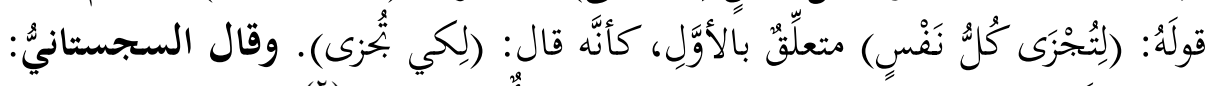

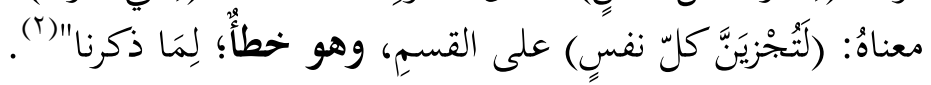

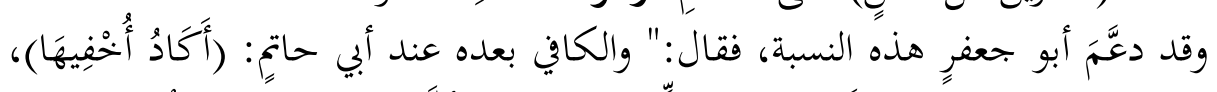

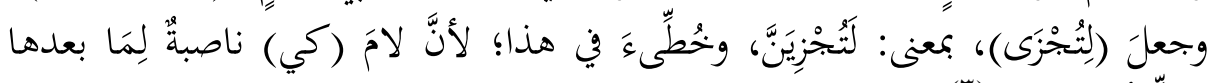

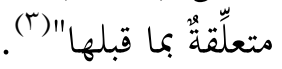

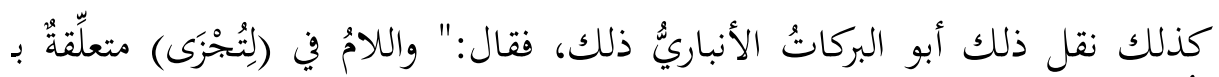

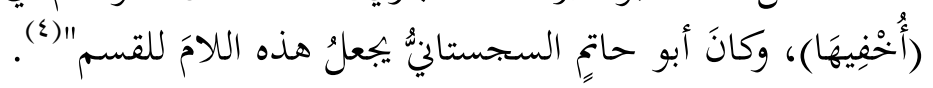

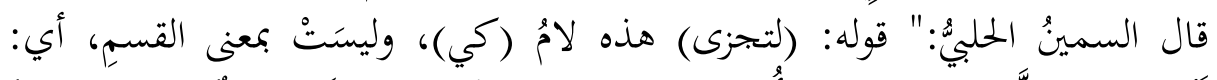

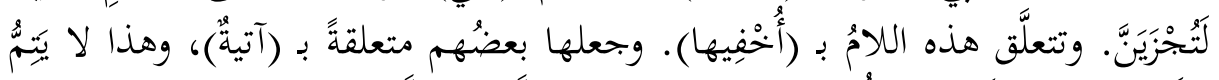

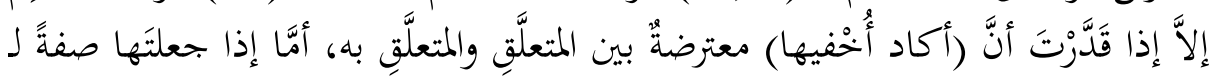

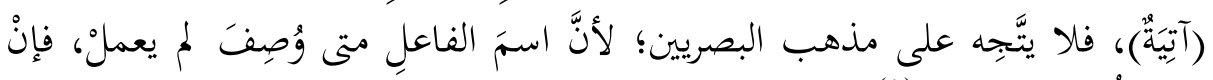

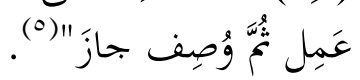

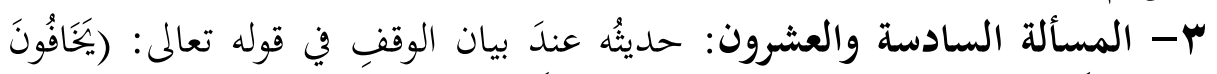

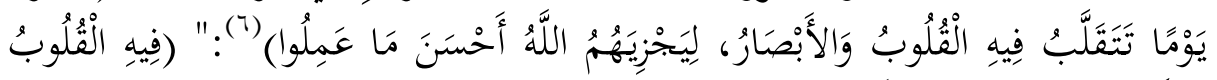

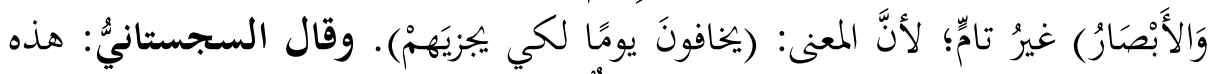

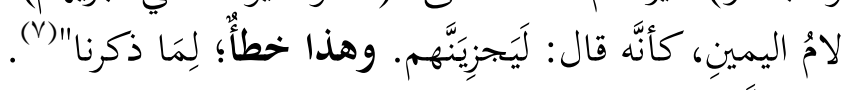

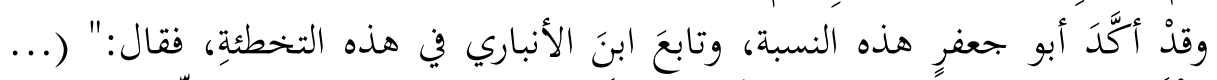

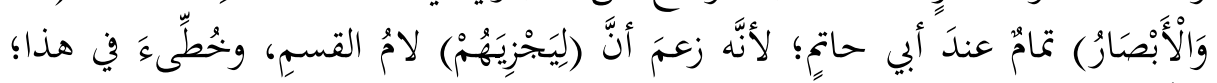

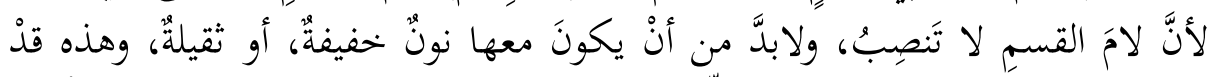

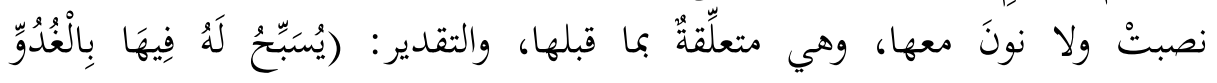

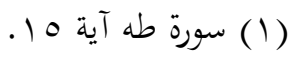

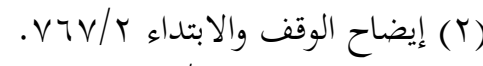

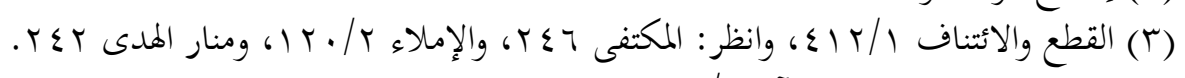

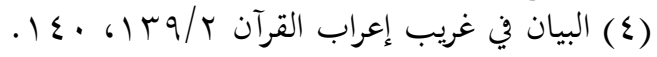

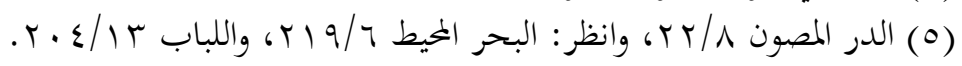

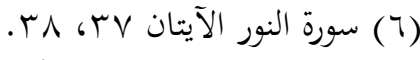

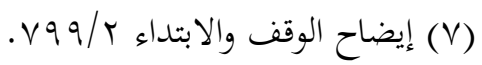




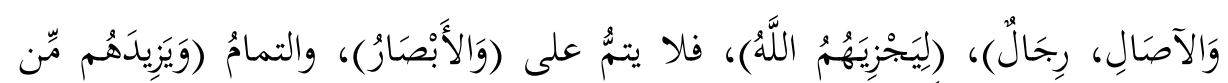

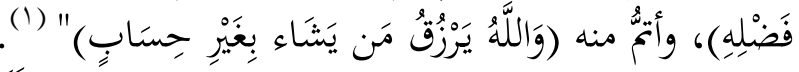

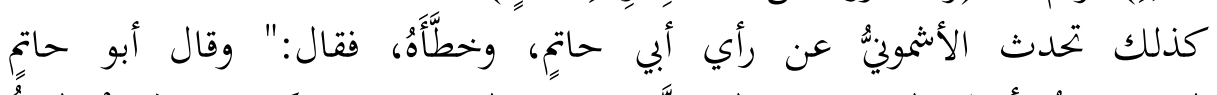

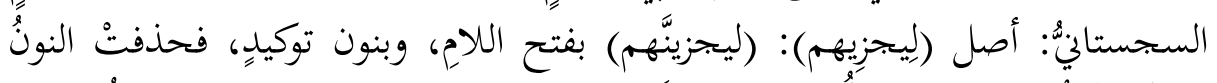

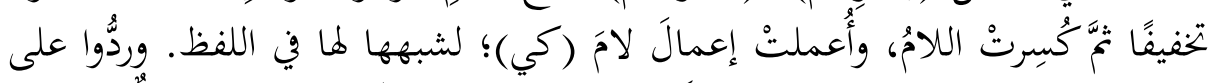

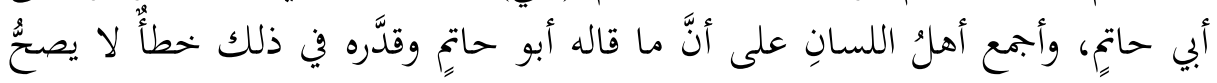

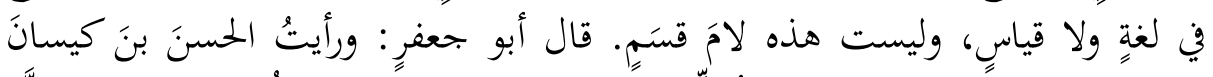

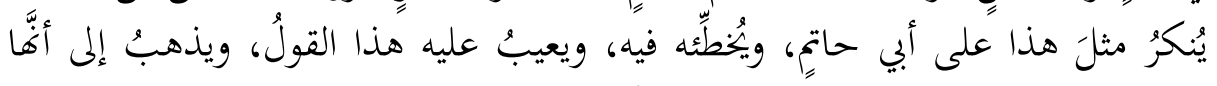

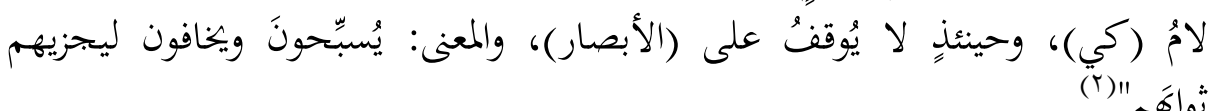

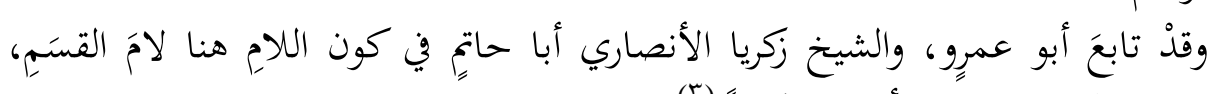

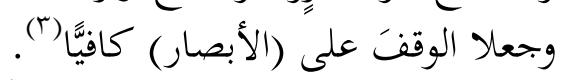

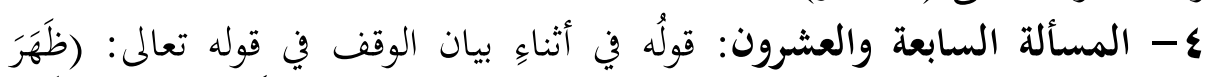

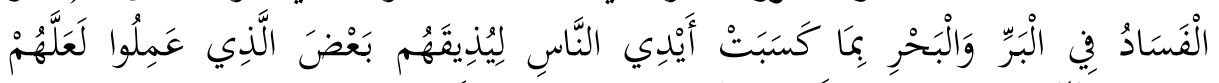

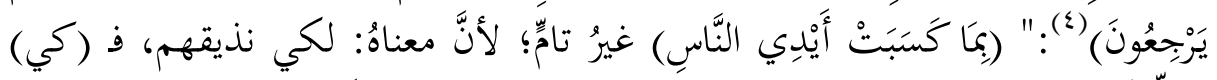

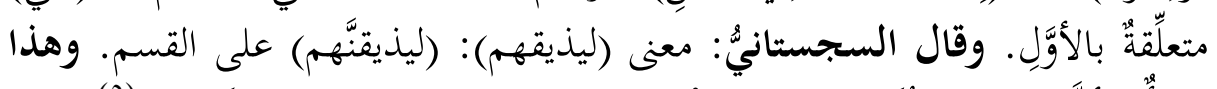

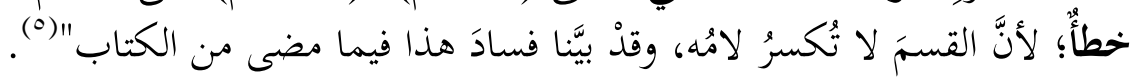

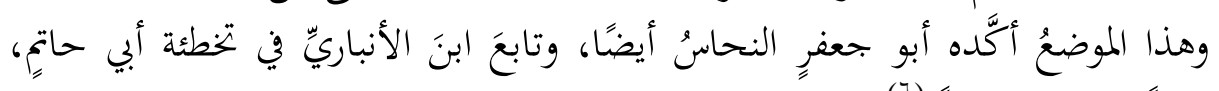

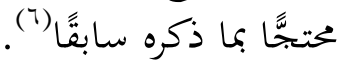

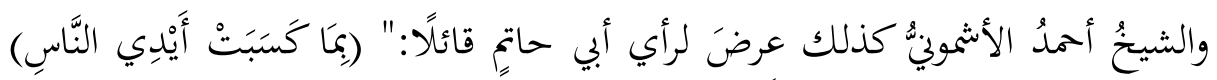

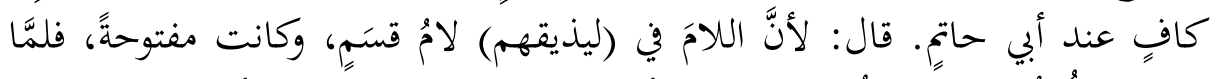

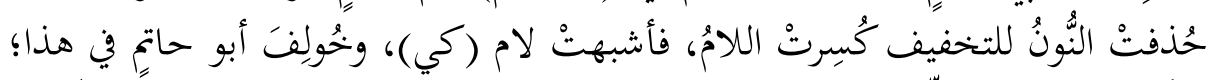

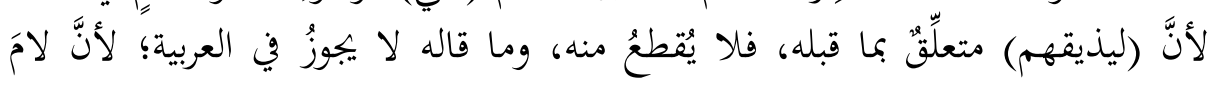

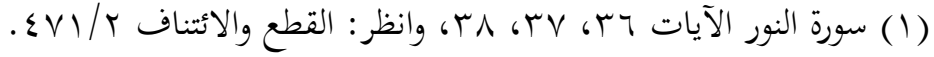

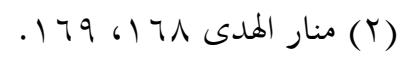

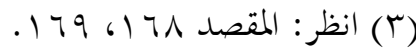

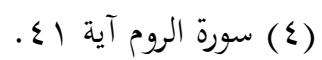

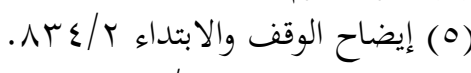

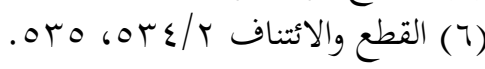




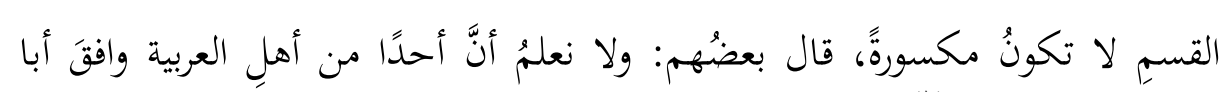

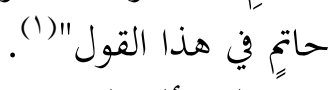

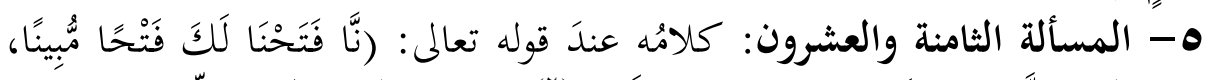

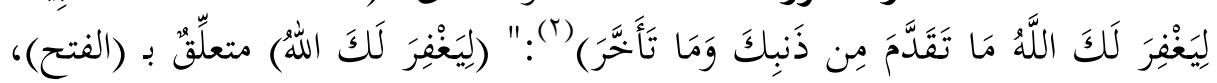

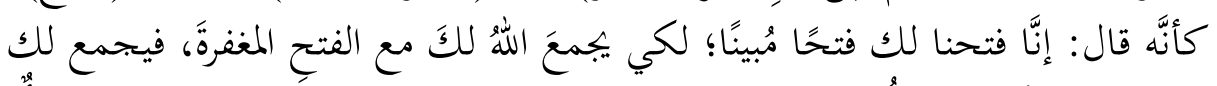

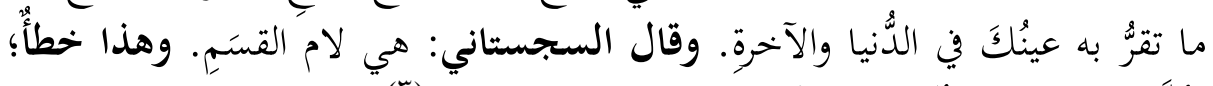

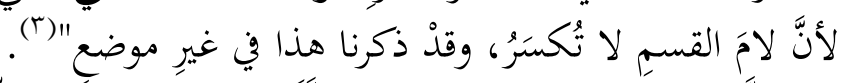

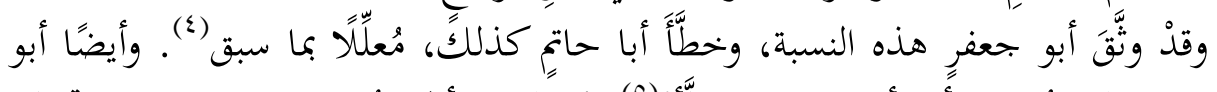

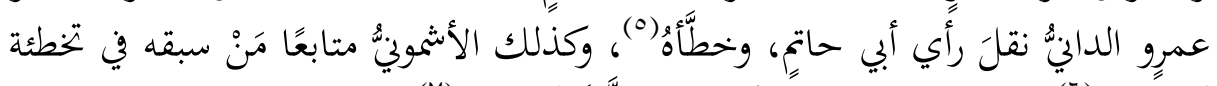

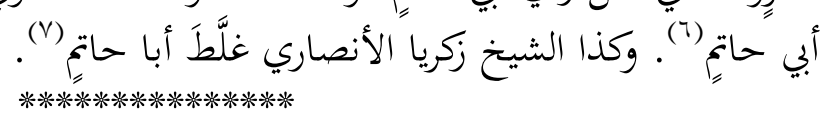
المسألة التاسعة والعشرون: موقع جملة (قَالَ الْكَافِرُونَ إِنَّ مَذَا لَسَاحِرٌ مُّبِينْ) من

\section{الإعراب.}

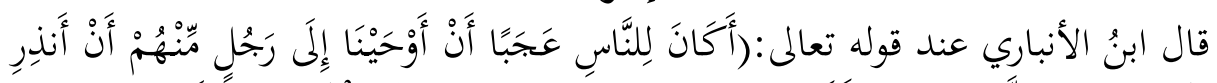

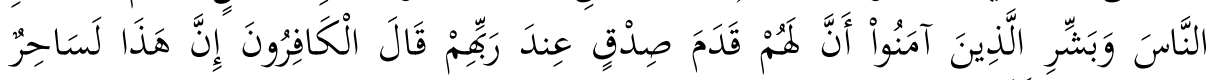

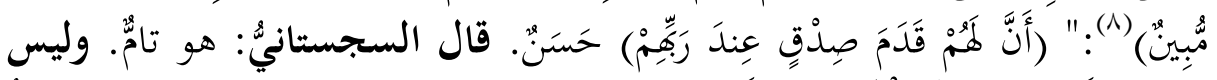

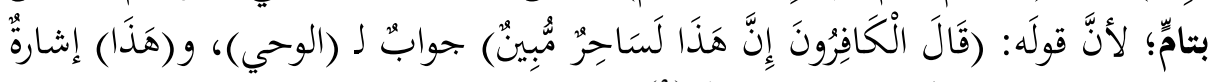

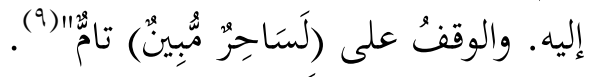

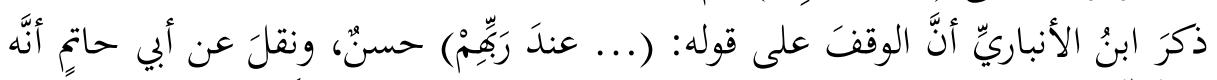

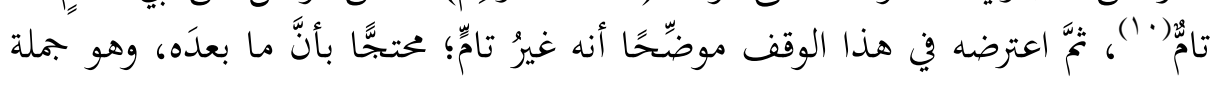

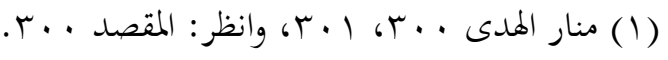

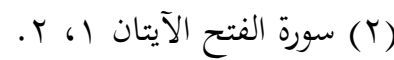

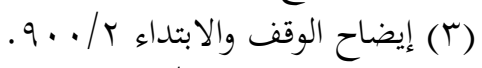

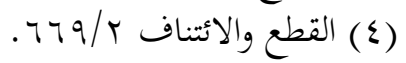

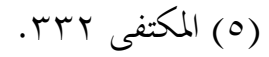

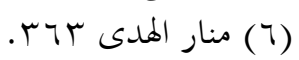

$$
\begin{aligned}
& \text { (V) المقصد rاדr. (V) }
\end{aligned}
$$

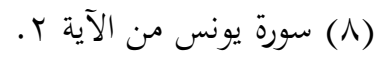

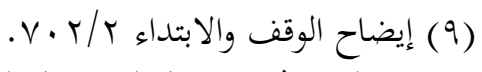

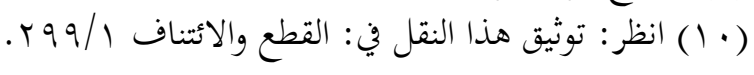




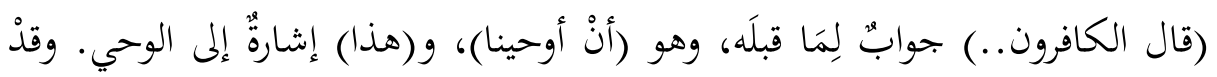

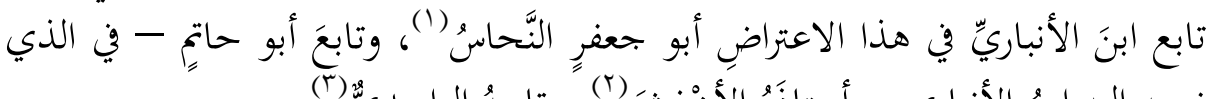

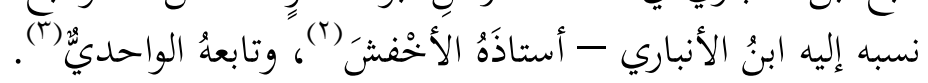

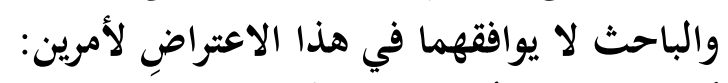

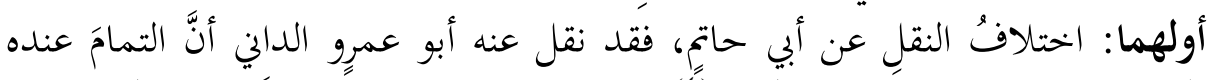

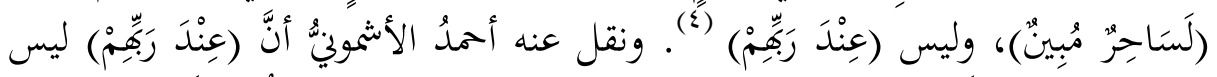

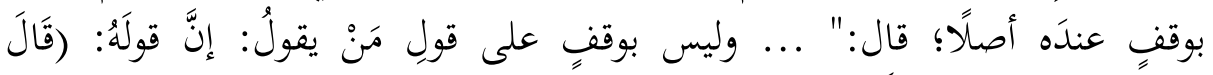

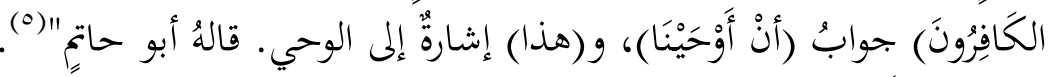

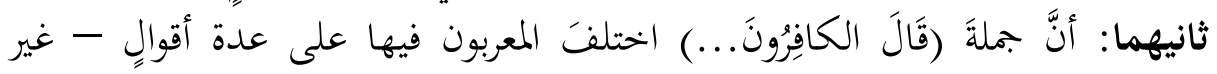

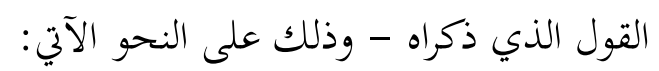

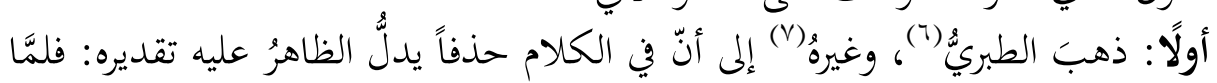

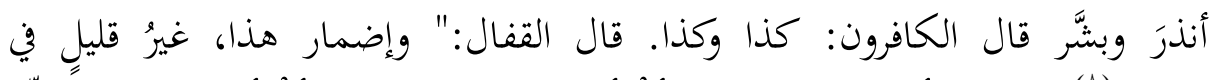

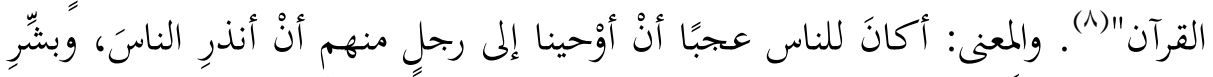

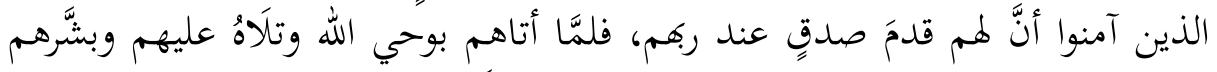

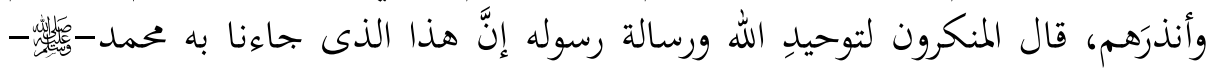

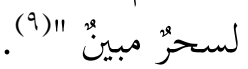

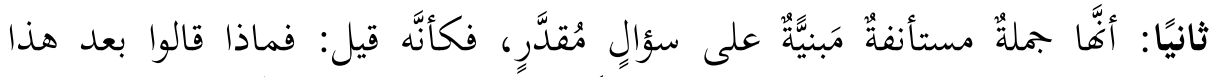

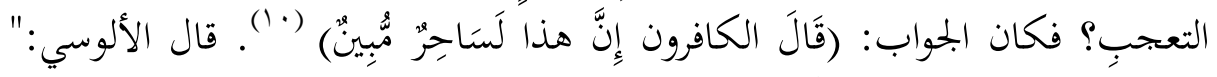

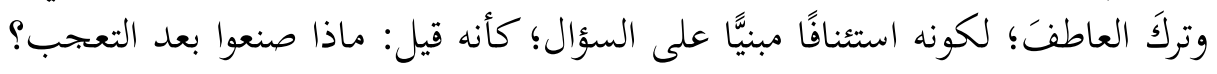

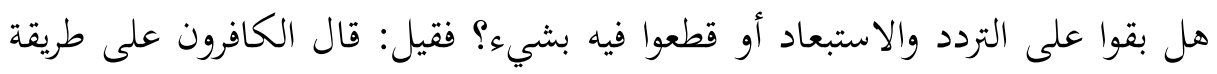

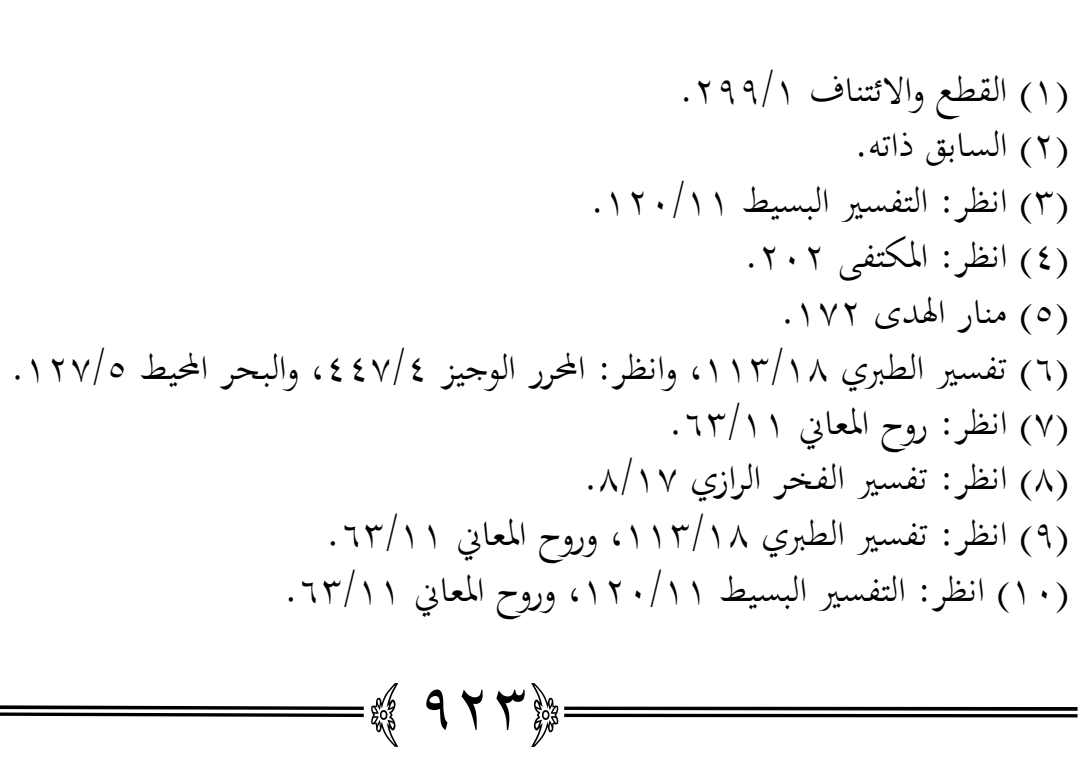




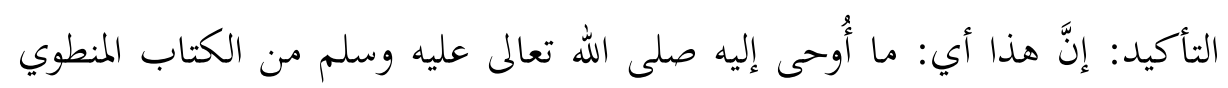

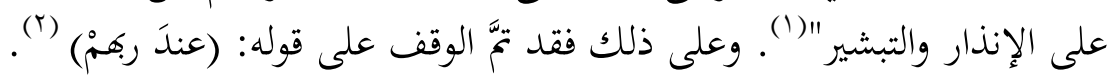

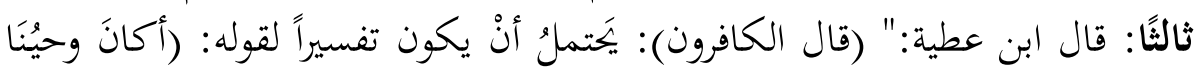

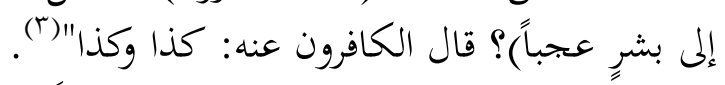

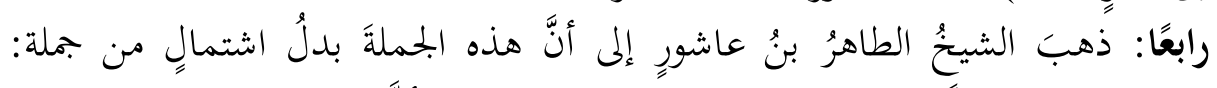

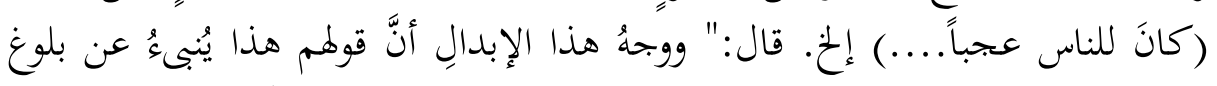

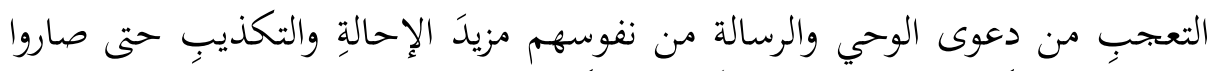

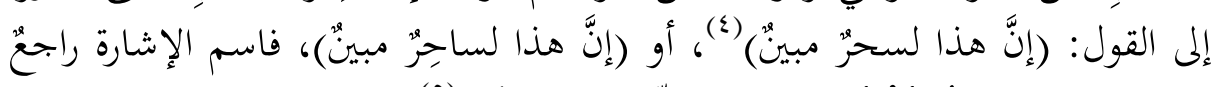

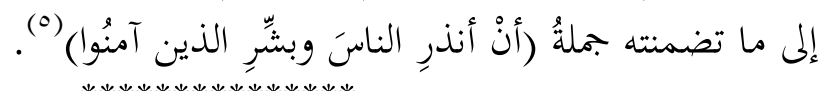

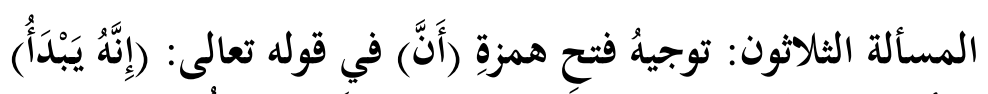

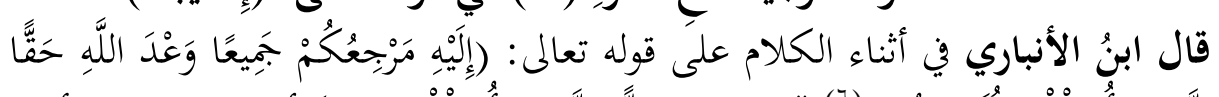

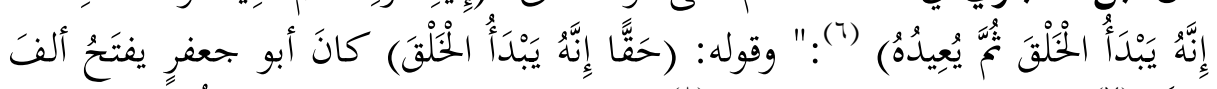

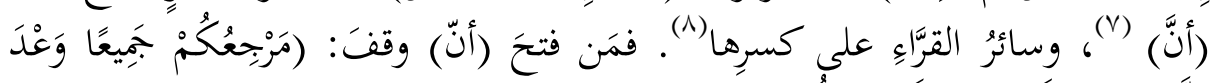

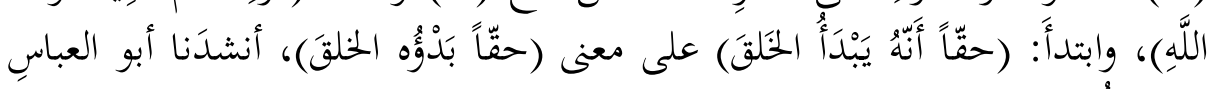
لابنِ الدُّمَيََْة: أَحَقًا عِبَادَ اللهِ أَنْ لَسْتُ حَائِيًا

$$
\begin{aligned}
& \text { (1) (1) (1) وروح المعاني (1/1) }
\end{aligned}
$$

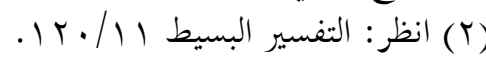

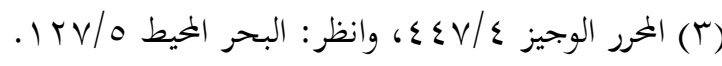

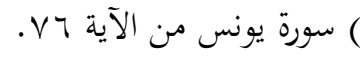

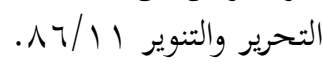

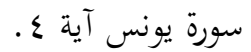

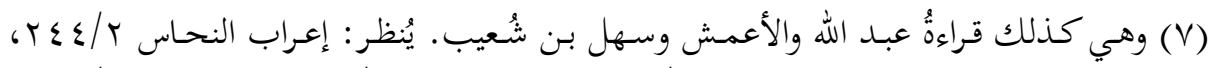

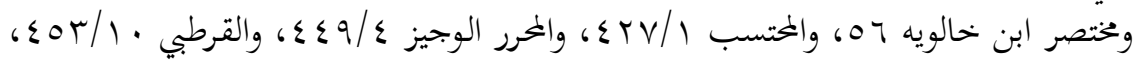

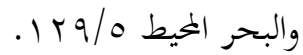

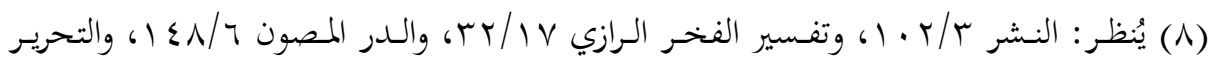

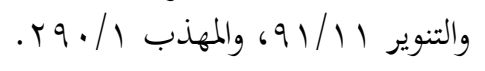

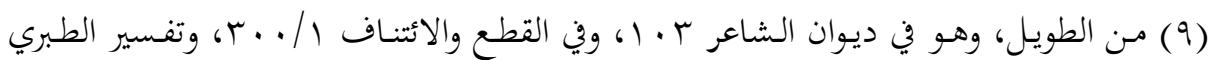

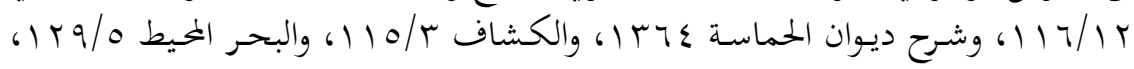

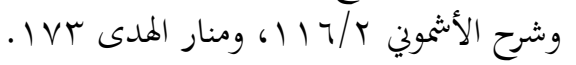




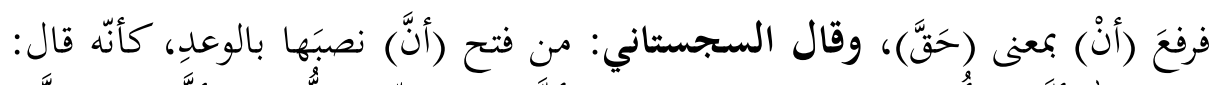

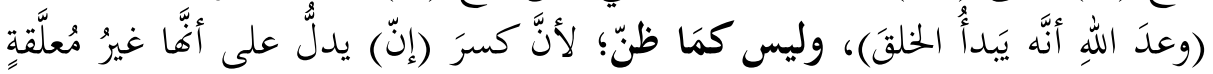

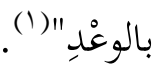

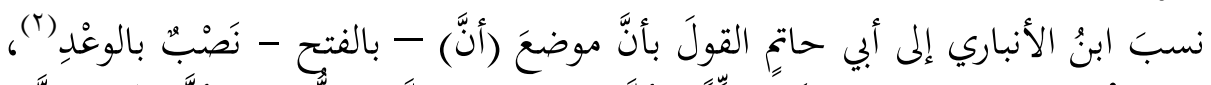

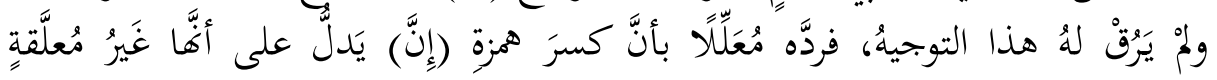
بالوعِد.

\section{وفي موضع (أنَّ) بالفتح اختلفتُ فيه تأويلاتُ المُعربينَ على النحو الآتي:}

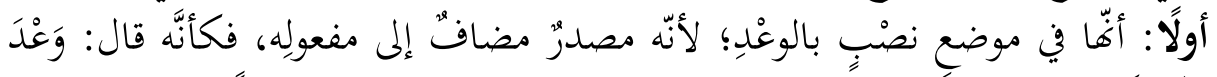

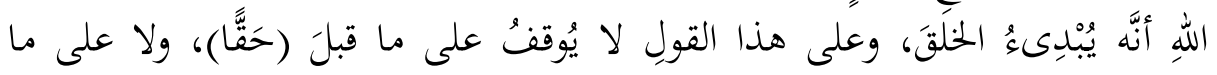

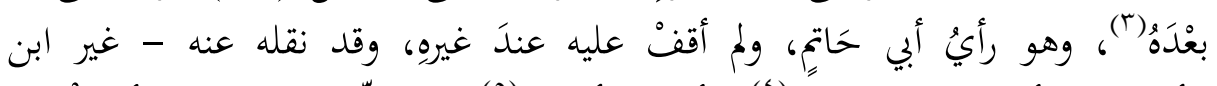

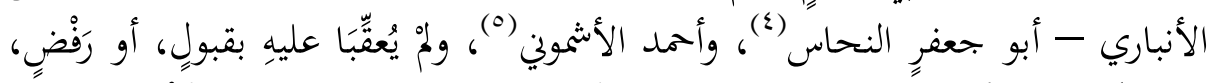

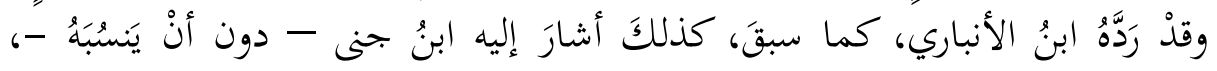

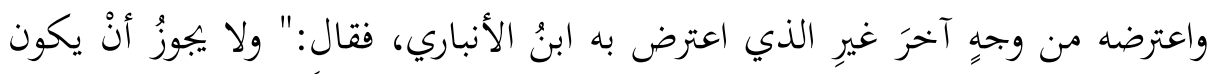

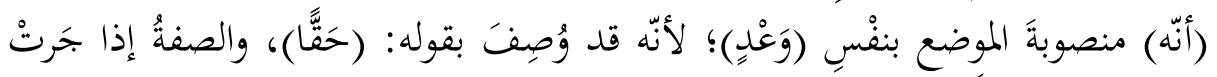

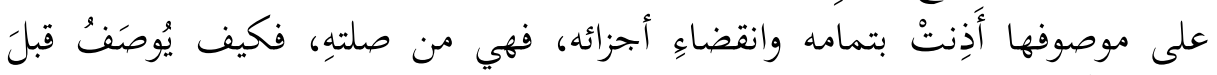

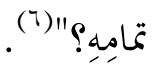

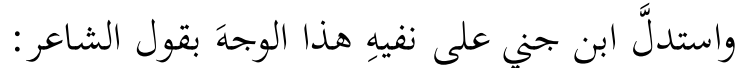

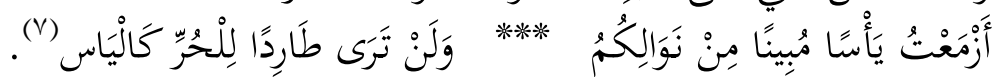

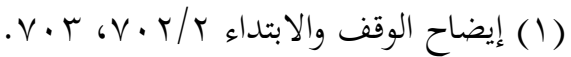

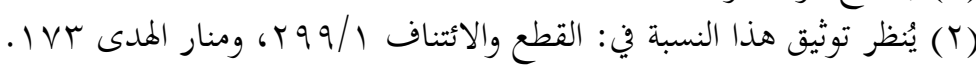

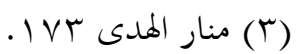

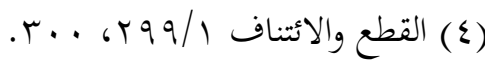

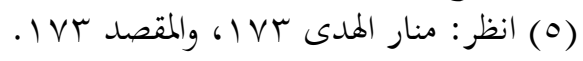

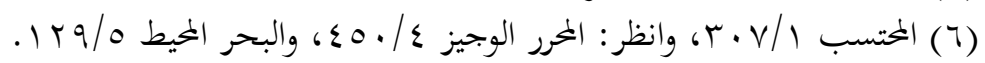

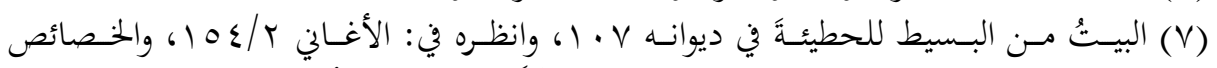

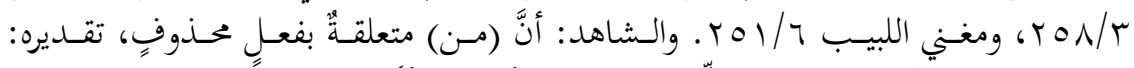

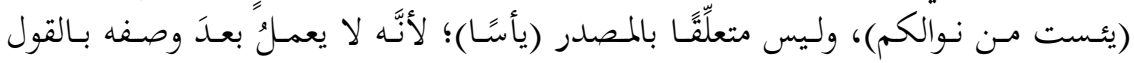

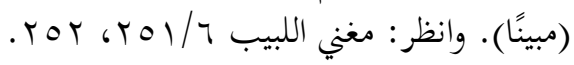




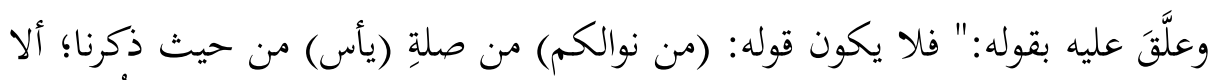

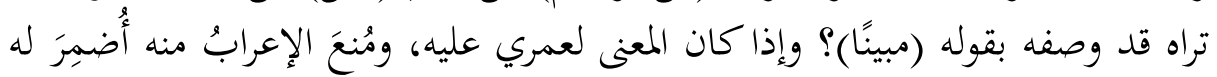

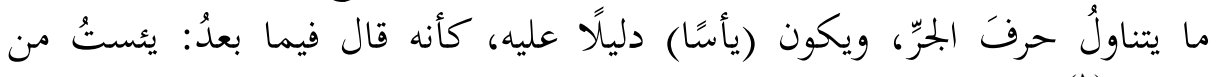

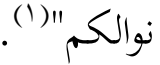

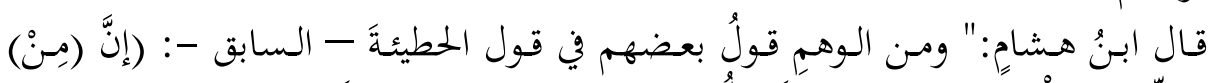

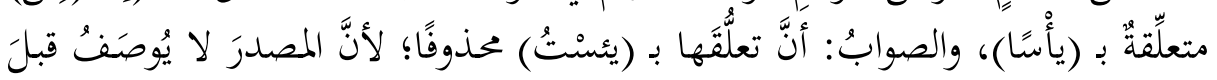

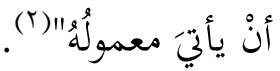

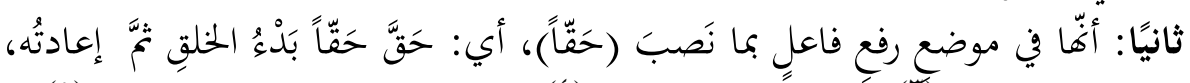

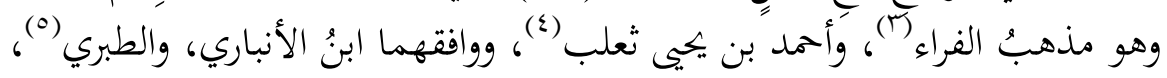

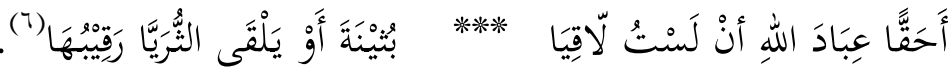

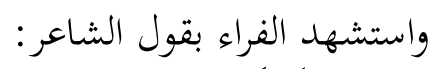

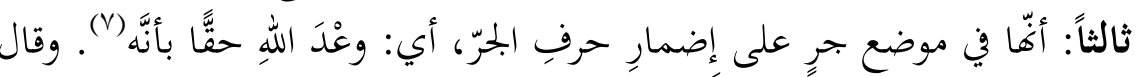

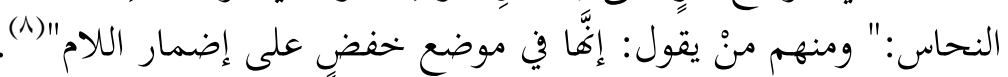

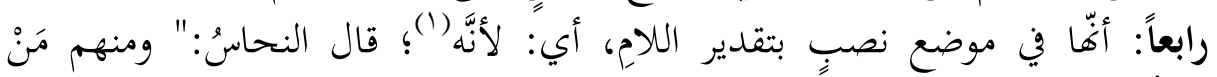

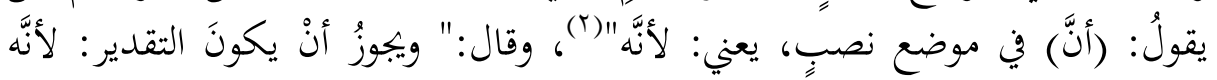

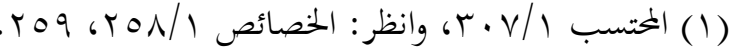

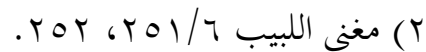

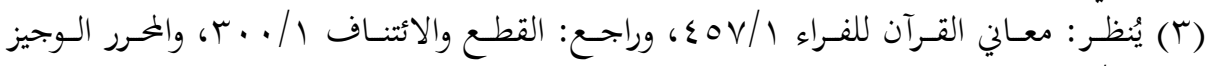
. $\{\leqslant 9 / \varepsilon$

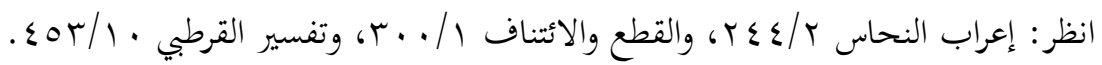

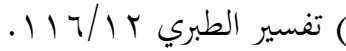

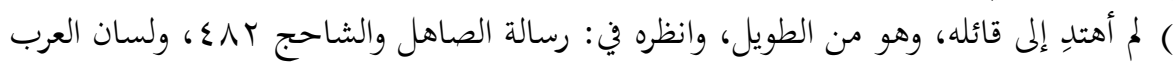

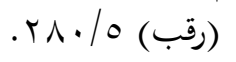

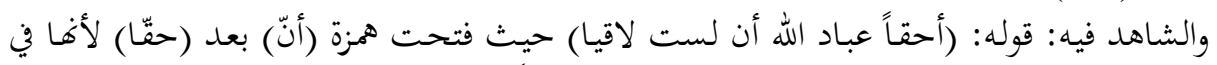

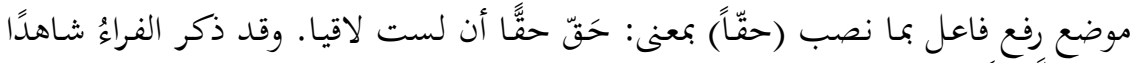

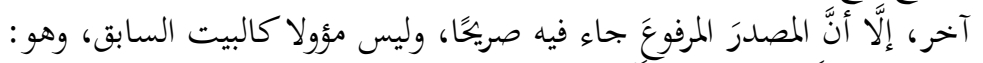

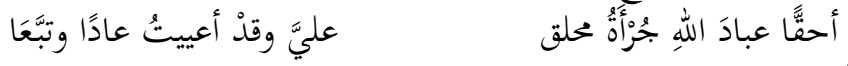

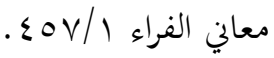

$$
\begin{aligned}
& \text { ( ) انظر: منار الهدى (V) }
\end{aligned}
$$

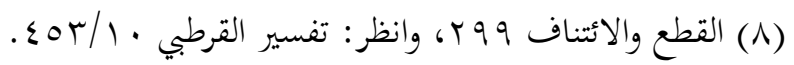




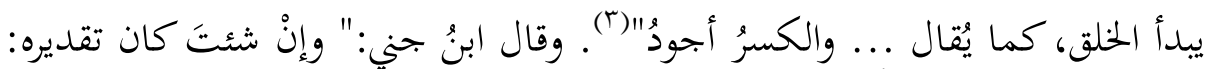

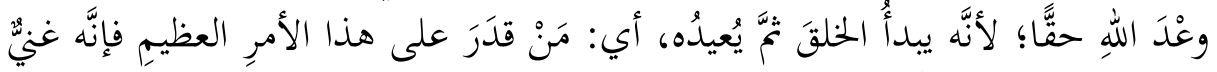

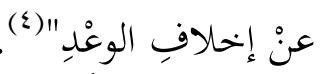

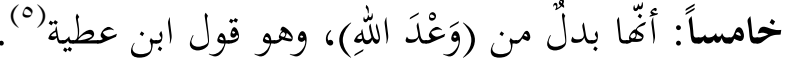

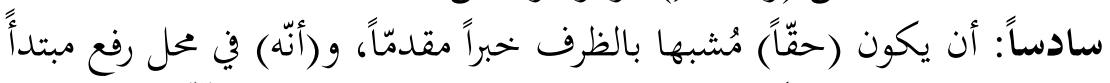

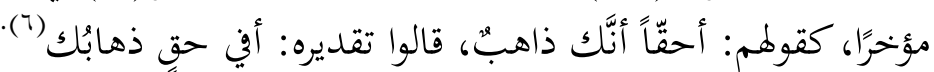

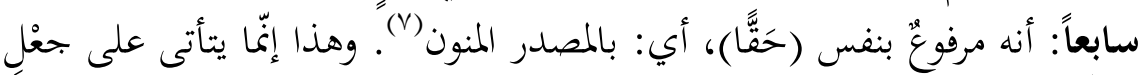

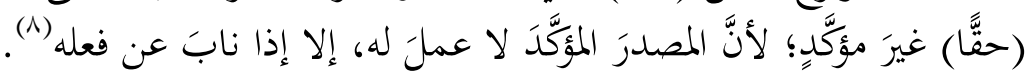

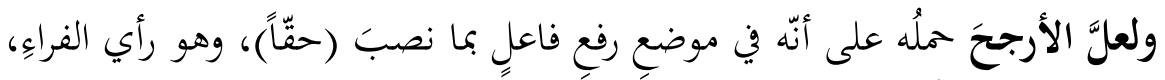

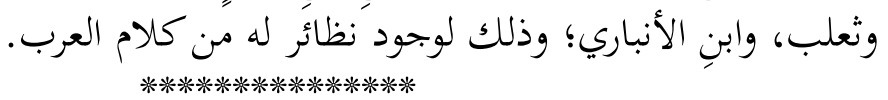

\section{المسألة الحادية والثلاثون: نوع الاستثناء في قوله تعالى: (إلاًّ مَن سَبَقَ..)}

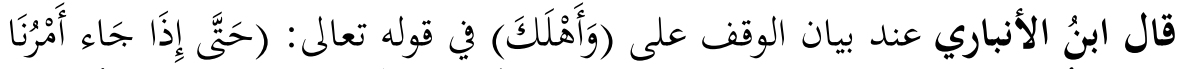

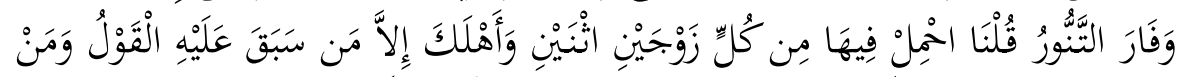

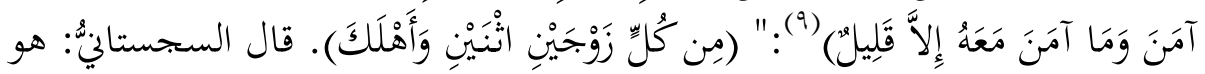

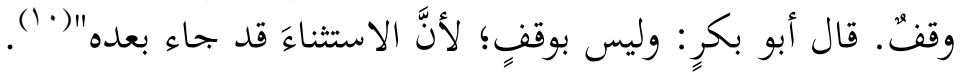

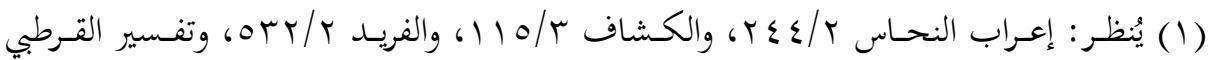

$$
\begin{aligned}
& \text {. }
\end{aligned}
$$

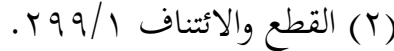

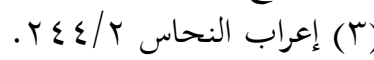

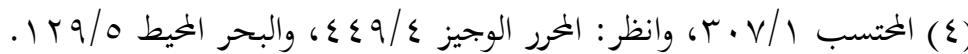

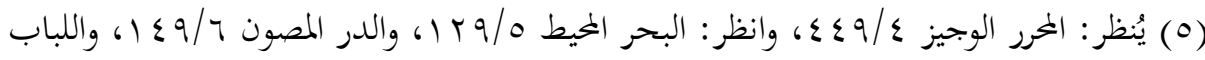

$$
\begin{aligned}
& \text {. }
\end{aligned}
$$

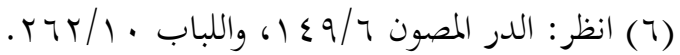

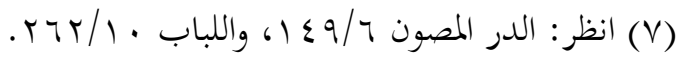

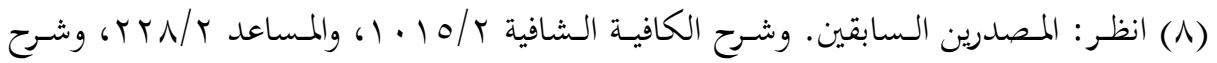

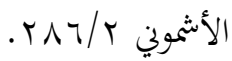

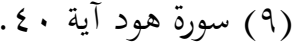

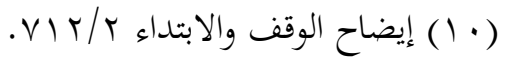




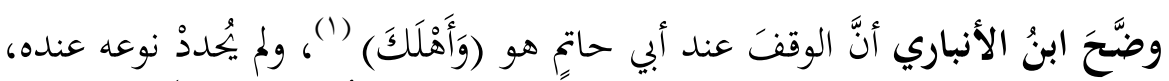

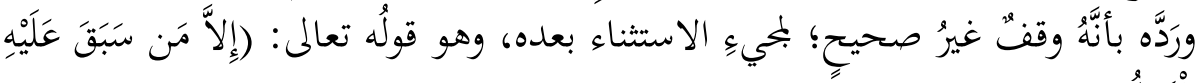

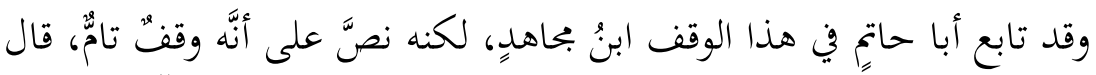

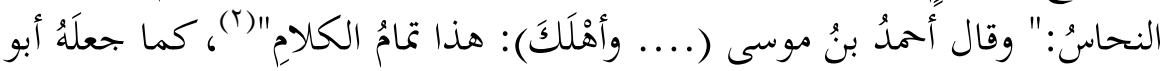

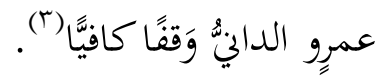

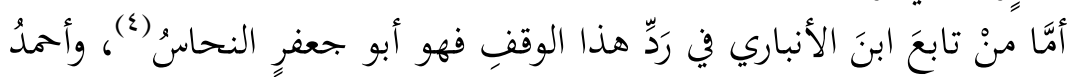

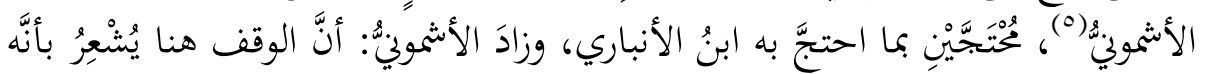

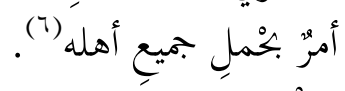

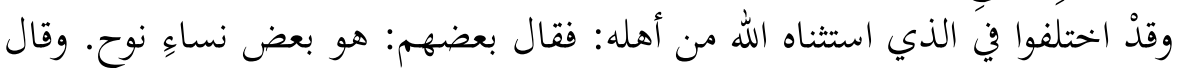

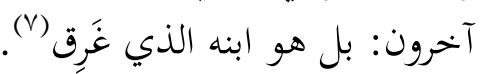

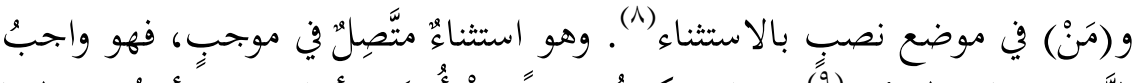

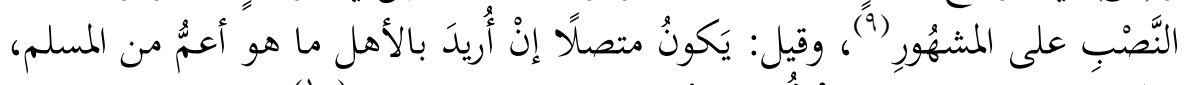

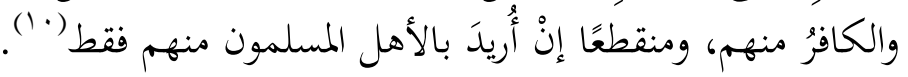

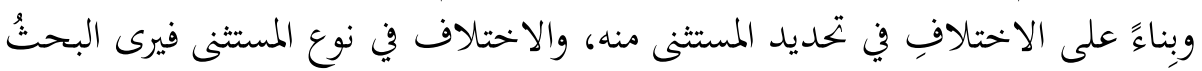

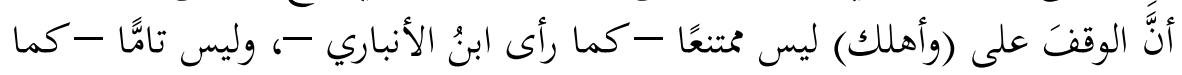

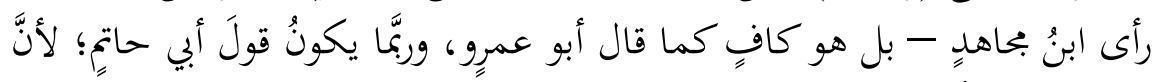

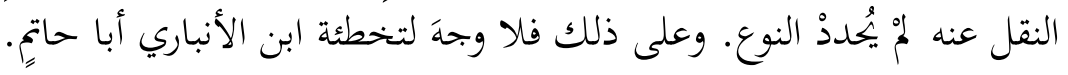
*********************

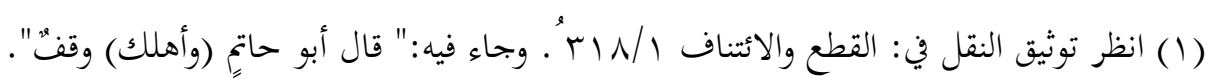

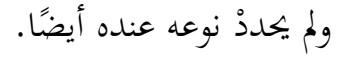
(Y) (Y) السابق نفسه.

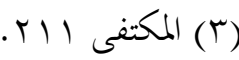

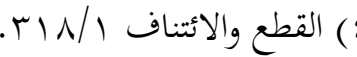

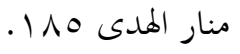

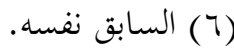

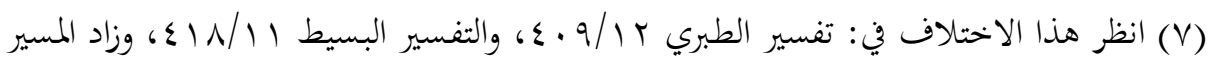

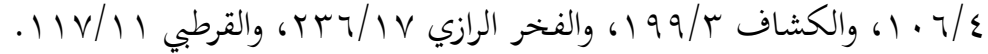

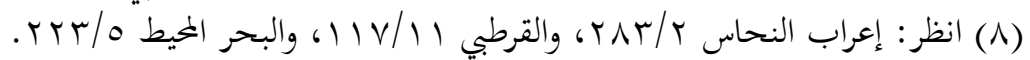

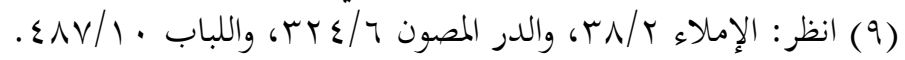

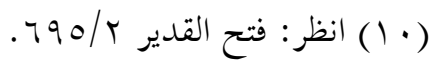




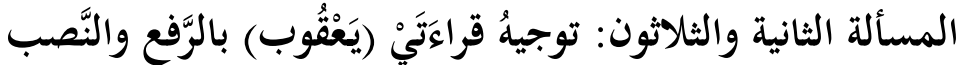

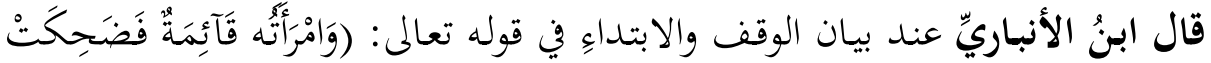

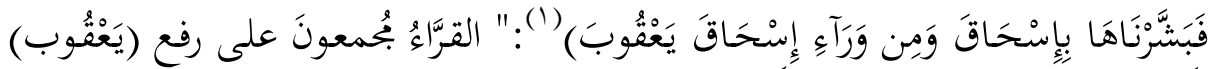

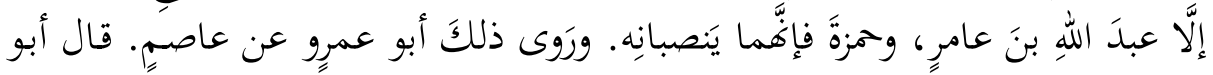

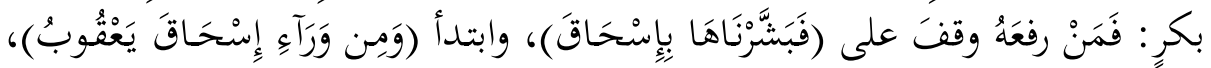

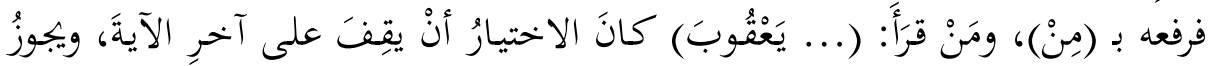

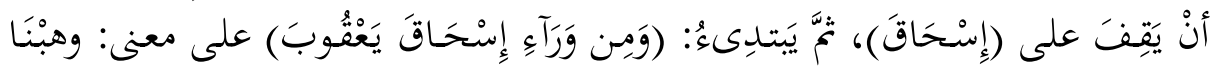

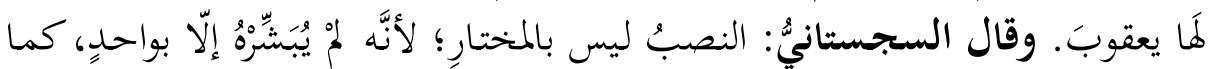

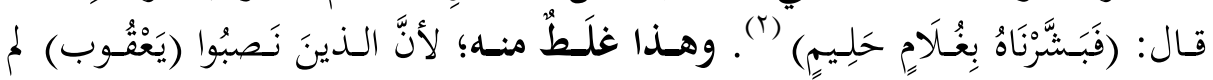

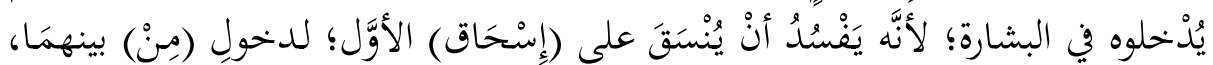

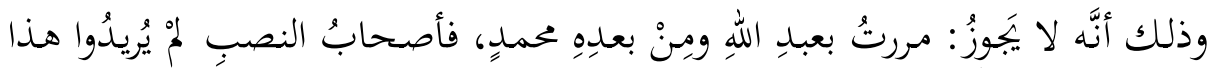

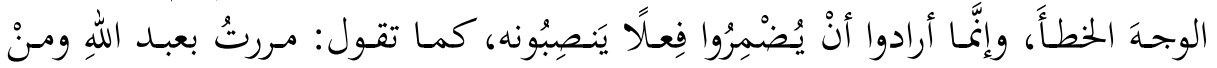

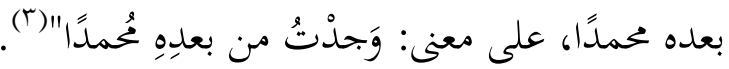

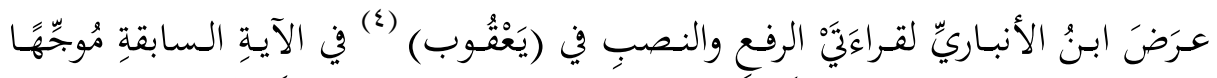

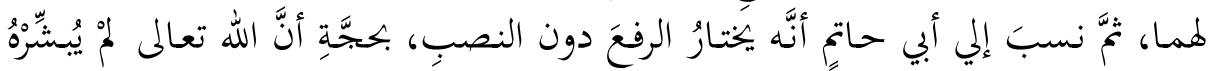

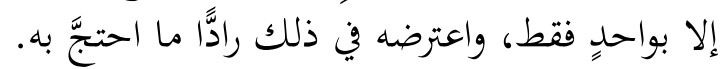

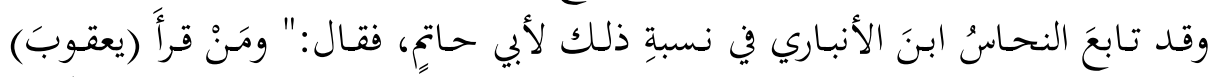

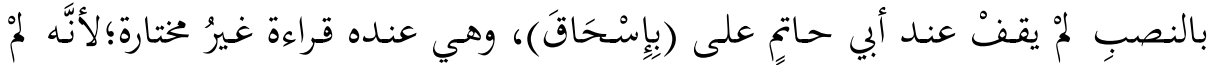

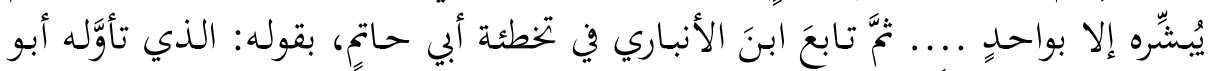

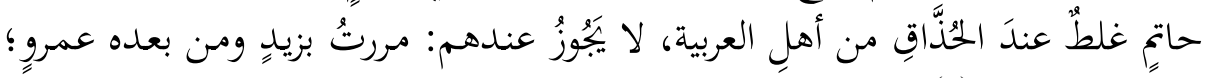

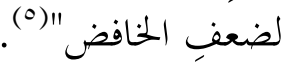
وفي توجيه هاتين القراءتين نحويَّا تفصيلٌ بيانُه على النحو الآتي:

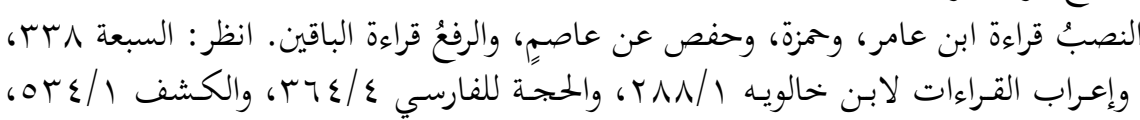

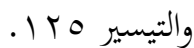

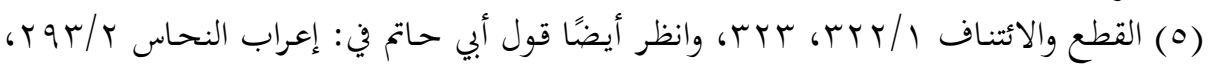

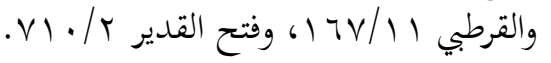


أولا: قراءة النصب:

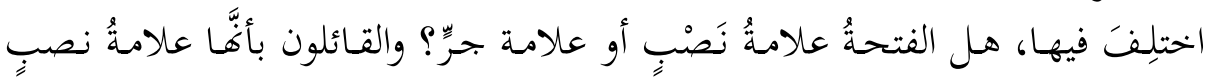

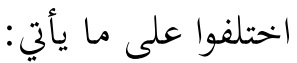

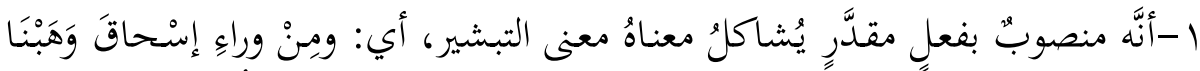

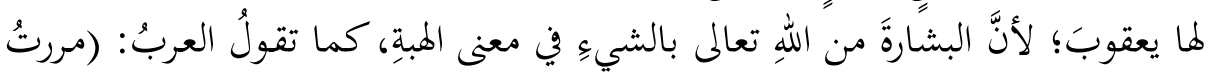

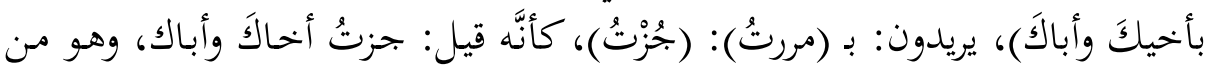

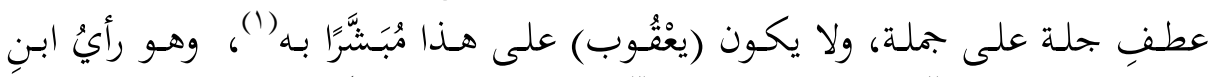

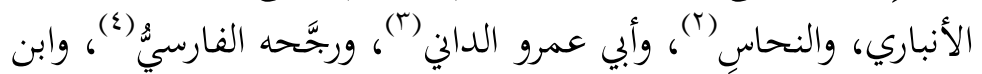

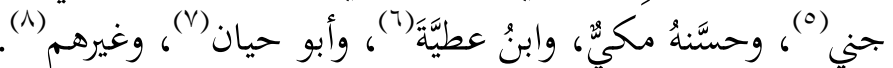

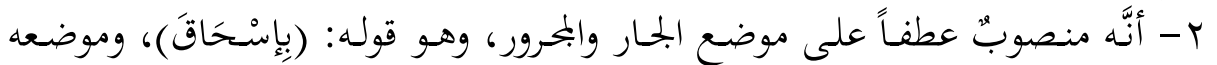

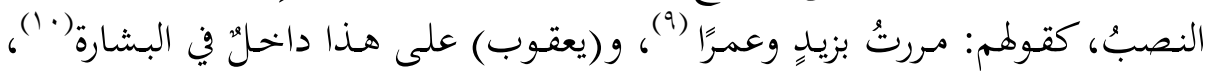

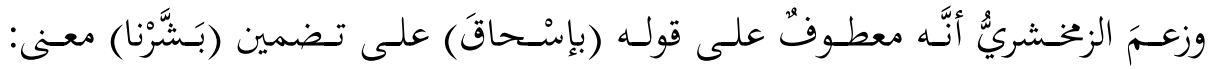

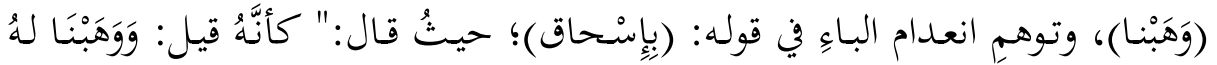

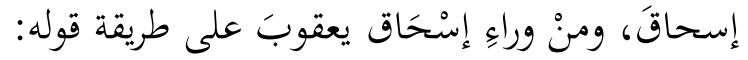

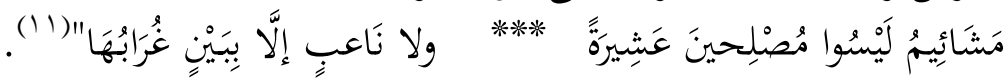

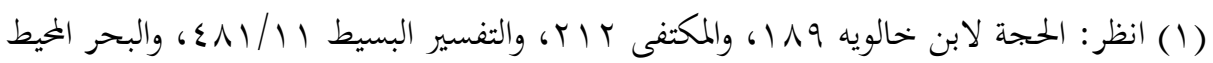

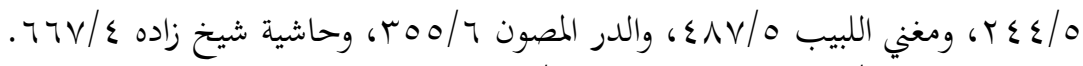

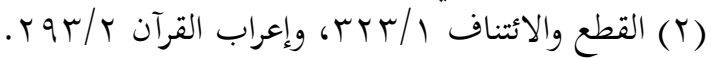

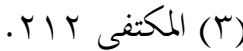

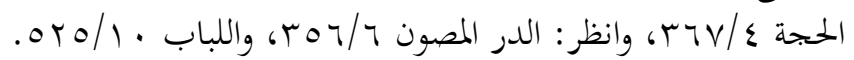

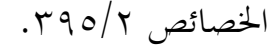

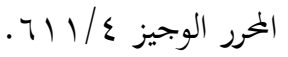

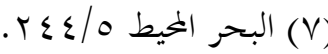

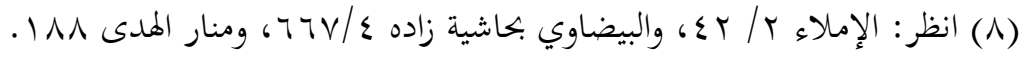

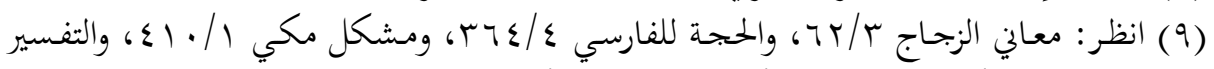

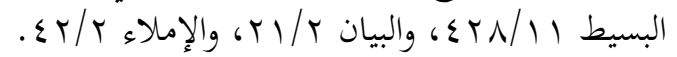

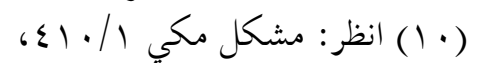

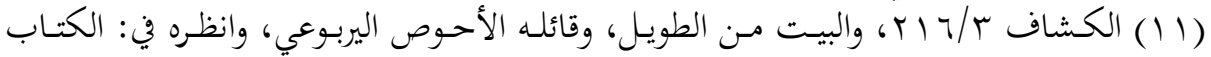
إبر/ وابن يعيش 
فإنَّ الشاعر عطفَ قولَه: (ولا ناعبٍ) على قوله (مصلحين) بِناءً على توهم وجود الباء

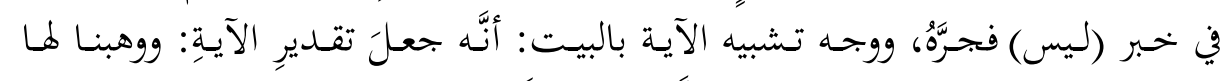

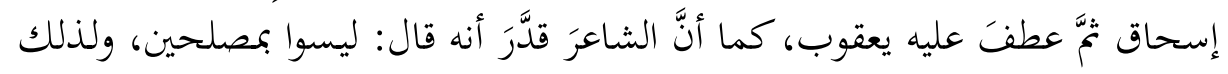

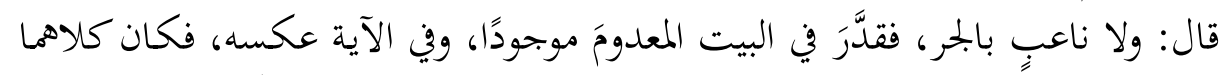

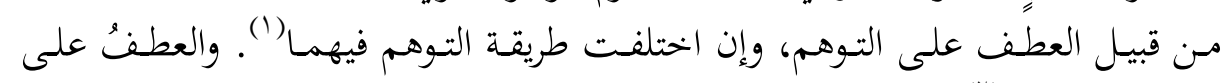

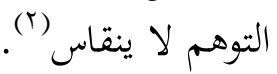

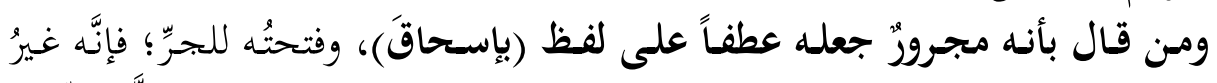

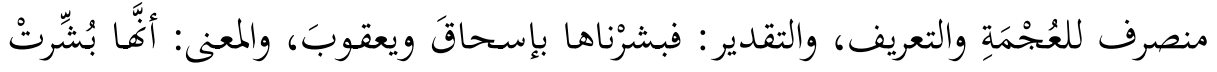

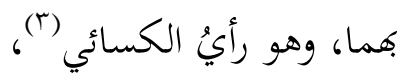

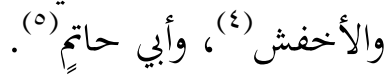

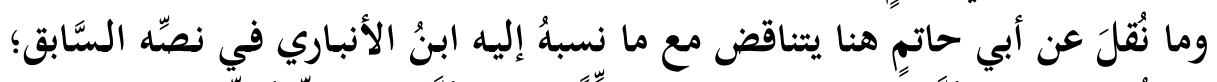

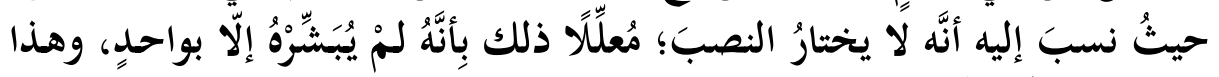

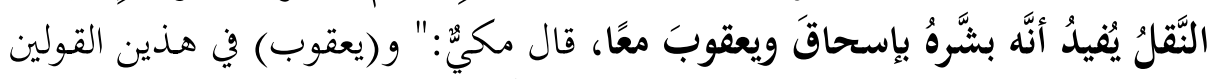

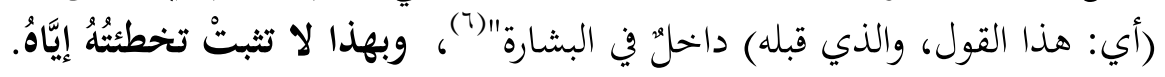

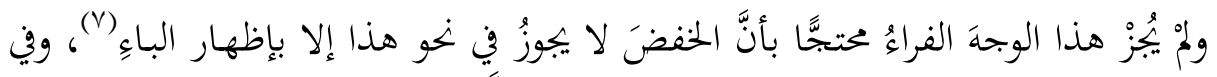

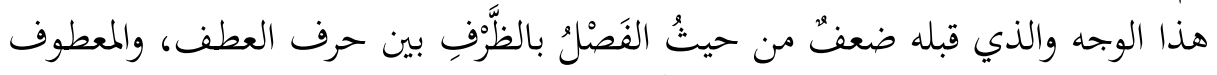
عليه، وهو ما ذكره ابنُ الأنباري سابقًا (^).

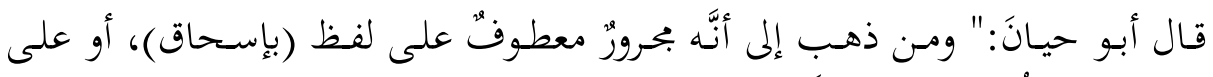

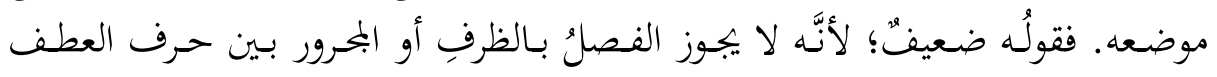

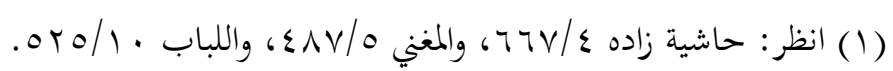

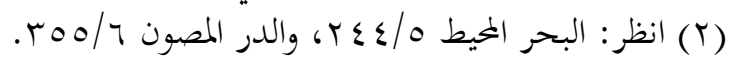

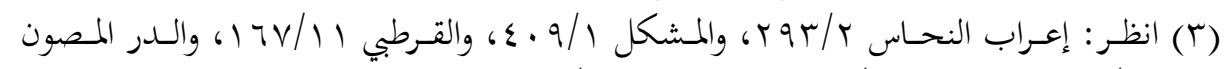

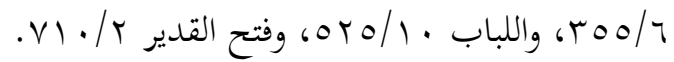

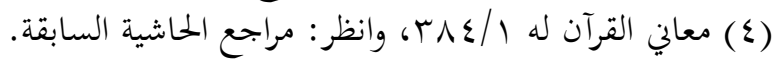

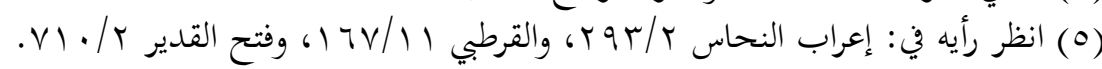

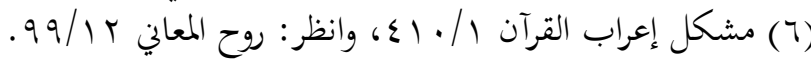

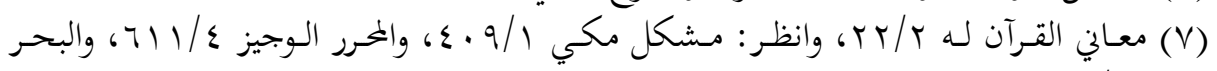

$$
\begin{aligned}
& \text {. } r \leqslant \leqslant / 0
\end{aligned}
$$

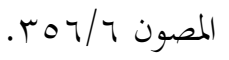




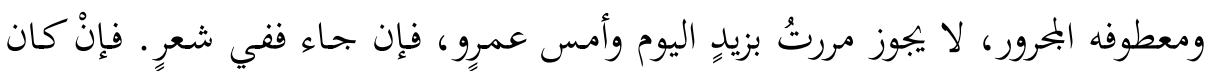

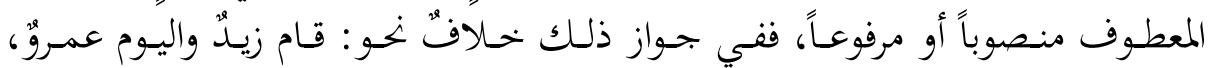

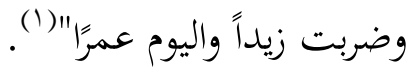

تنبيه:

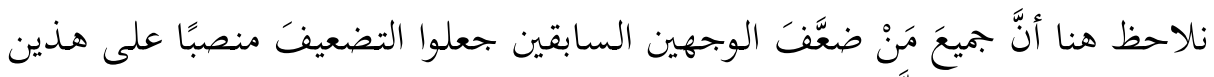

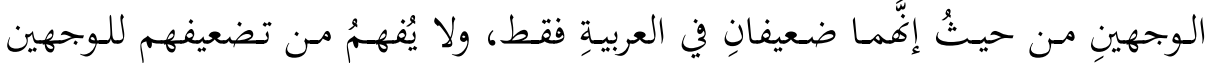

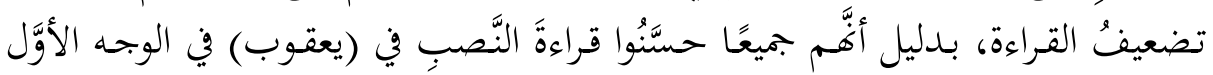

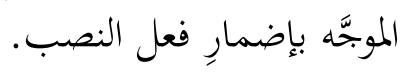

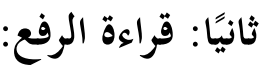

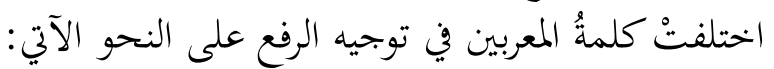

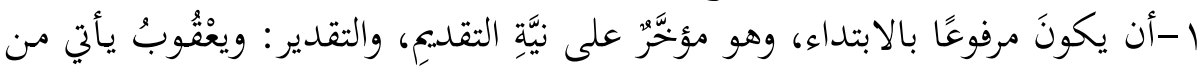

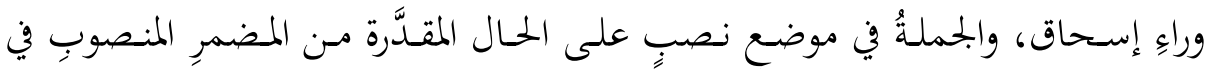

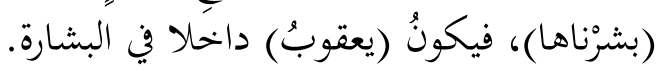

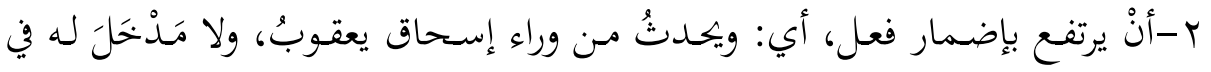

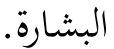

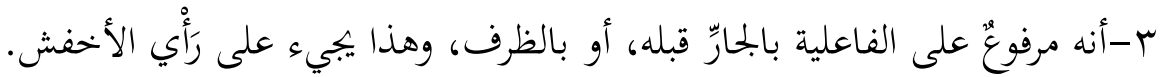

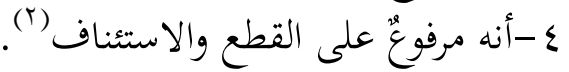

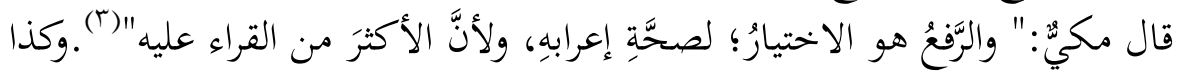

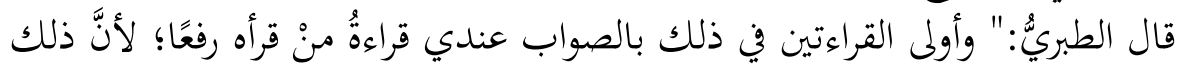

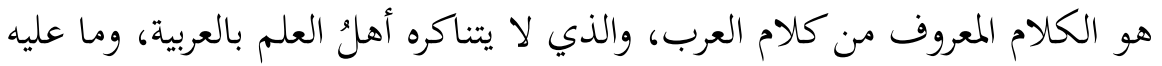

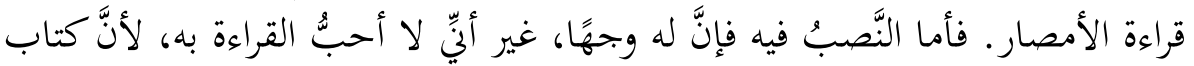

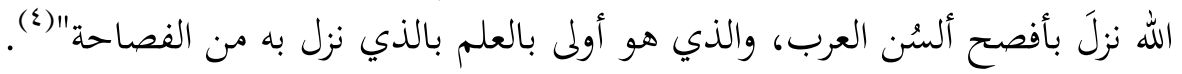

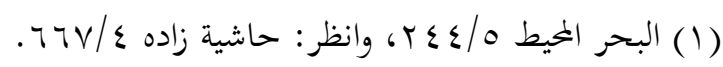

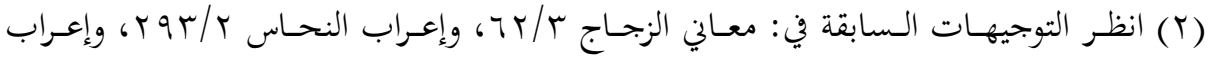

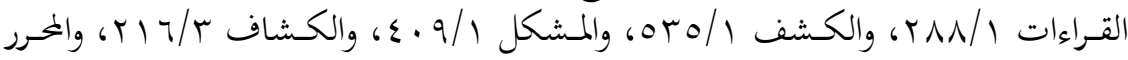

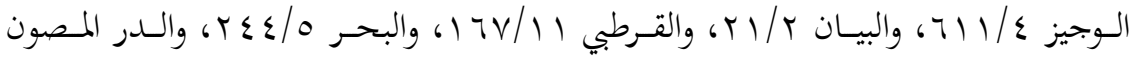

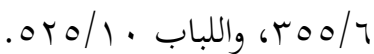

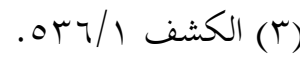

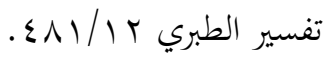




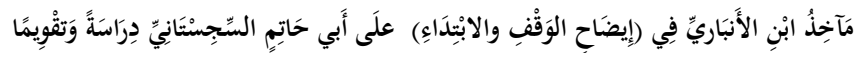

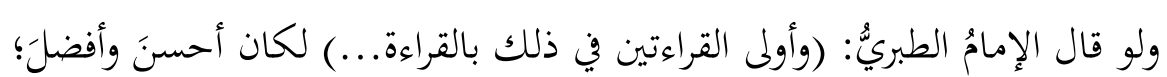

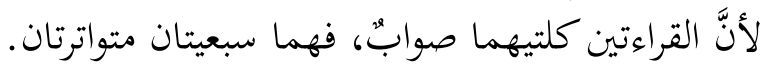
*******************

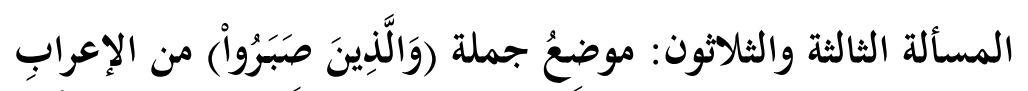

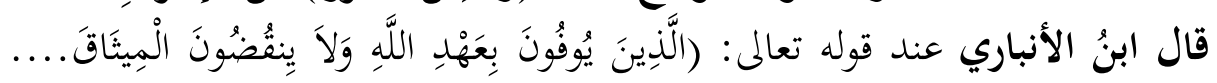

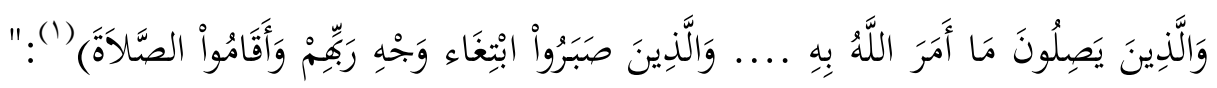

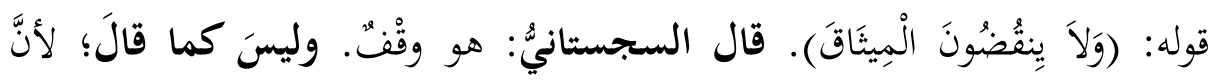

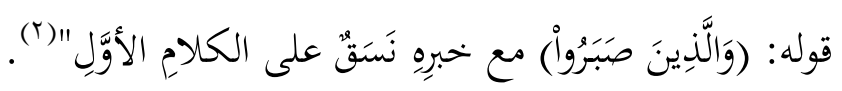

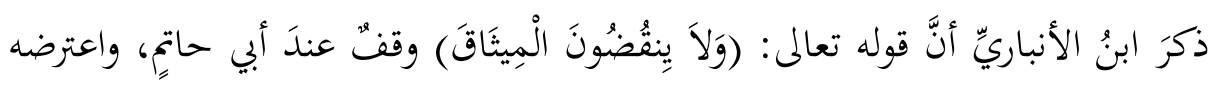

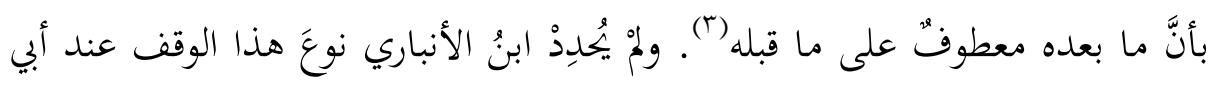

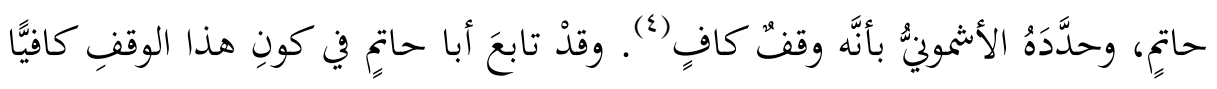

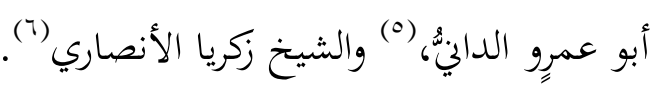

$$
\begin{aligned}
& \text { وفي موضع قوله تعالى: (وَالَّذِينَ صَبَرُواً) قولان: }
\end{aligned}
$$

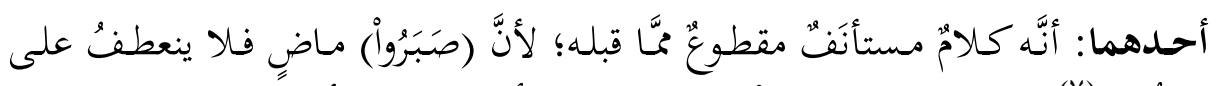

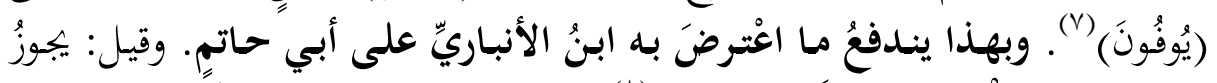

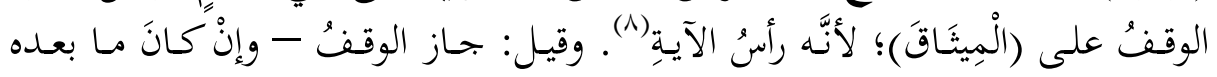

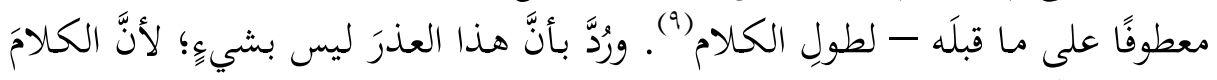

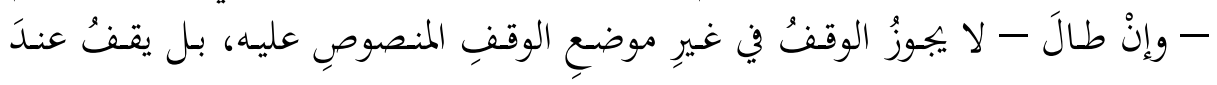

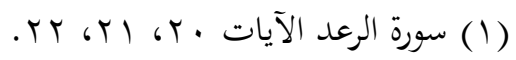

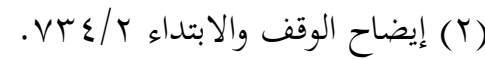

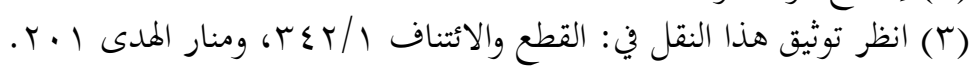

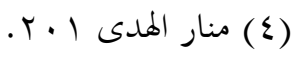

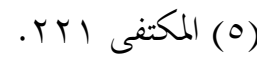

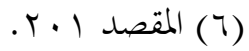

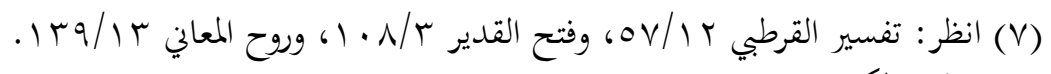

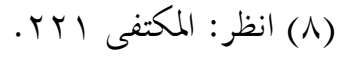

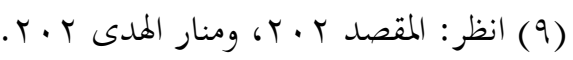




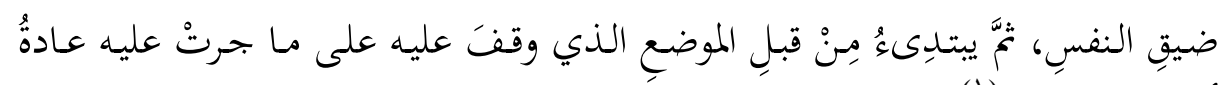

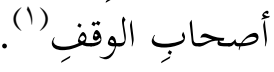

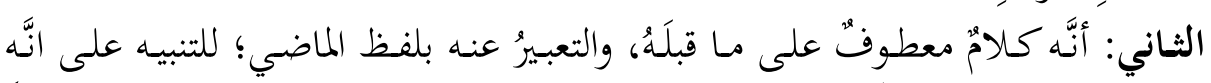

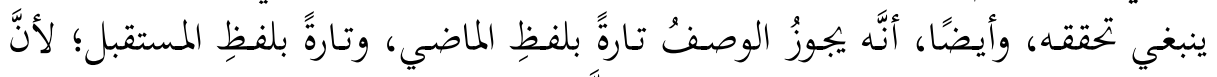

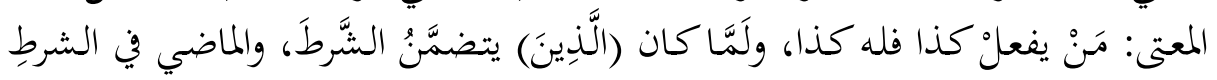

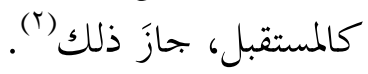

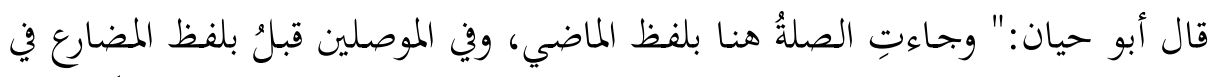

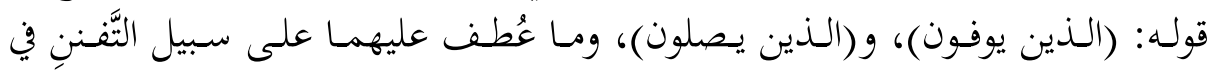

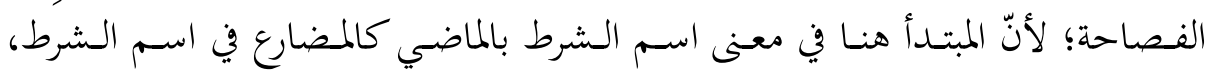

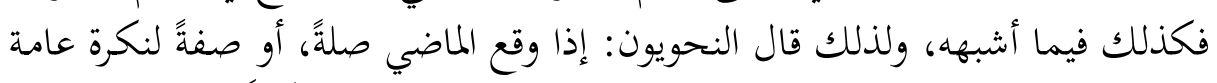

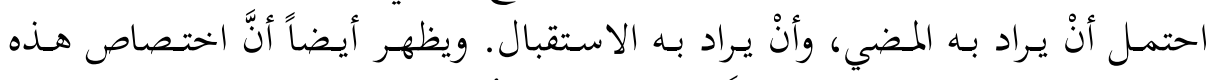

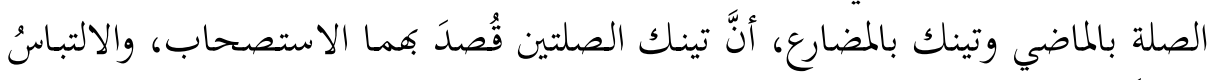

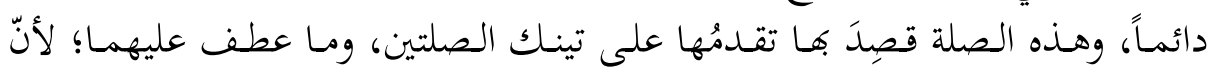

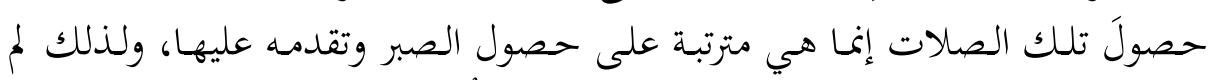

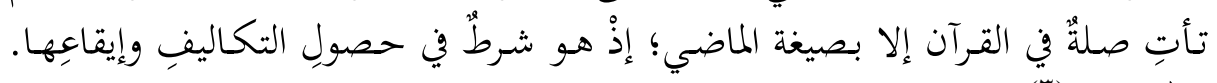

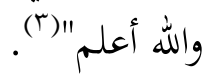
وقال ابنُ عادلٍ:" وهذه الآيةُ من أوَّها إلى آخرها جملةٌ واحدة شرطيَّة، وشرطها مشتملٌ

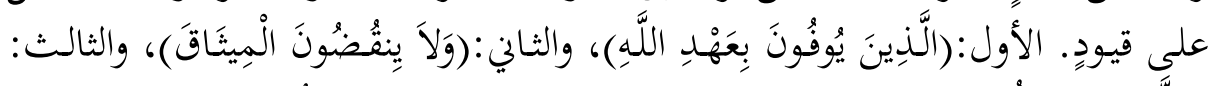

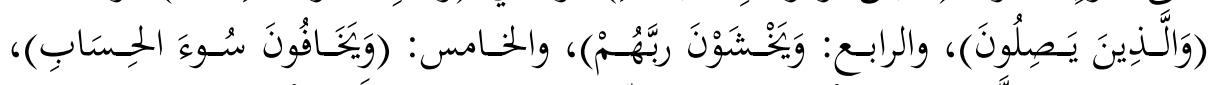

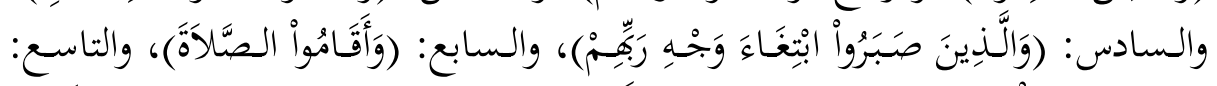

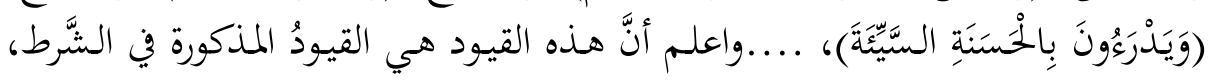

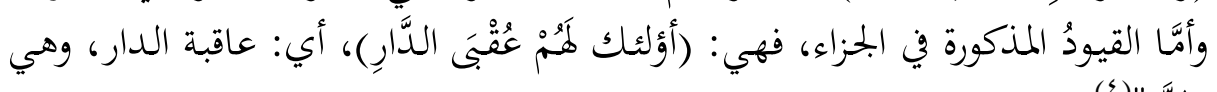




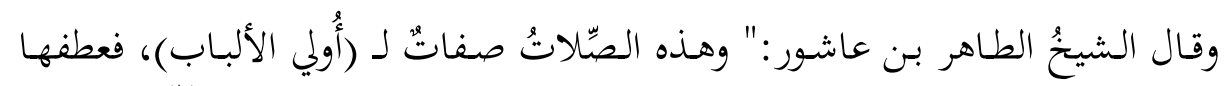

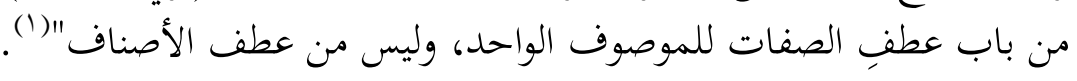

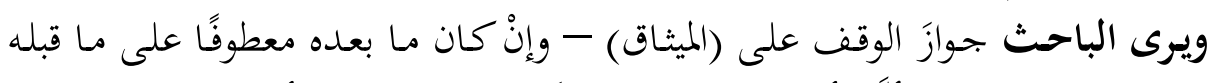

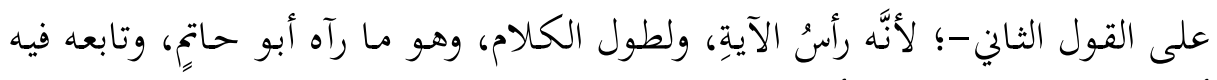
أبو عمروٍ، والشيخ زكريا الأنصاري.

\section{المسألة الرابعة والثلاثون: موقع جملة (فَسَوْْفَ يَعْلَمُونَ)}

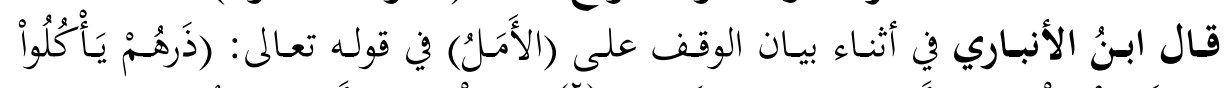

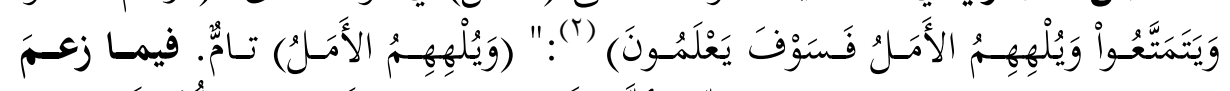

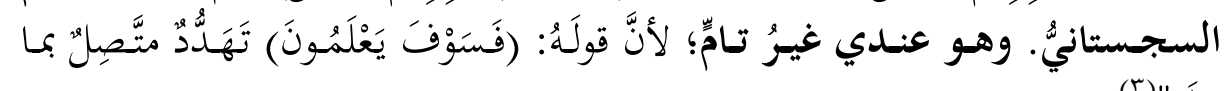

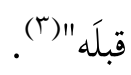

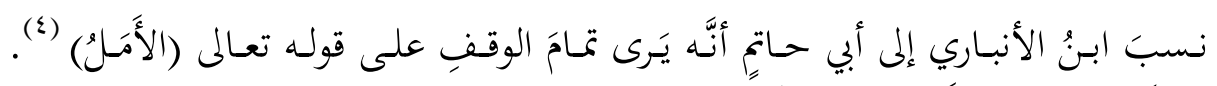
وخحالَفه في ذلك بأنَّهُ يَرى عَدَمَ تَمَامِهِ.

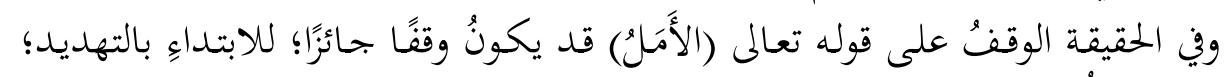

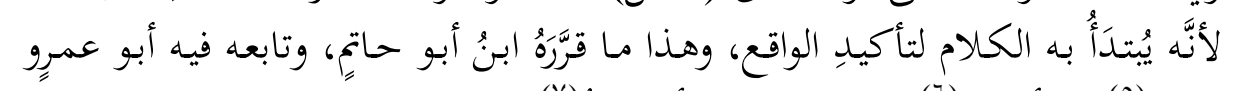

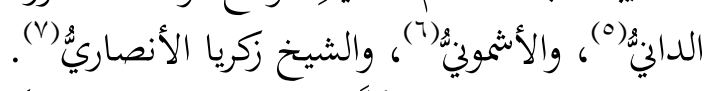

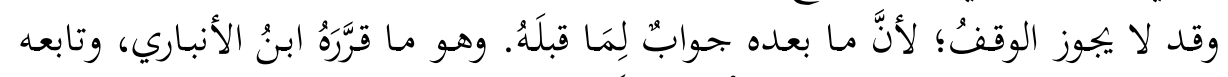

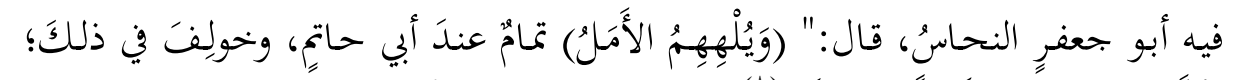

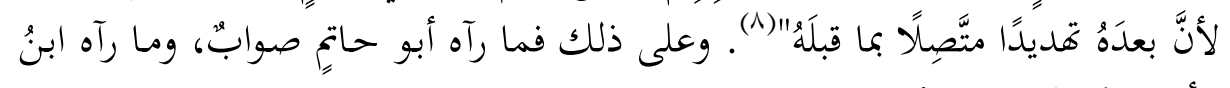

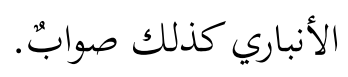

*********************

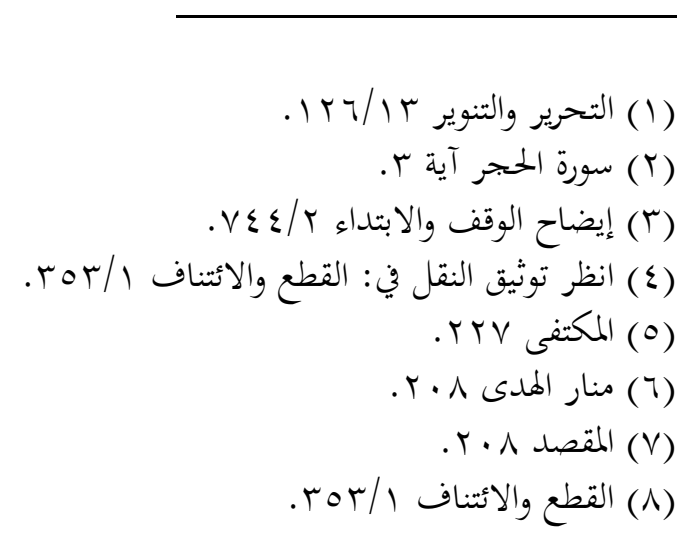




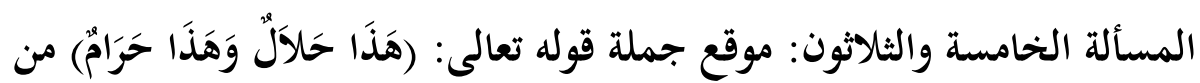
الإعراب

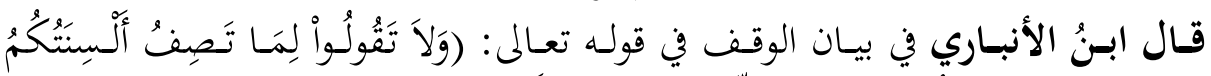

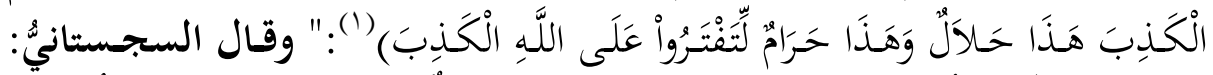

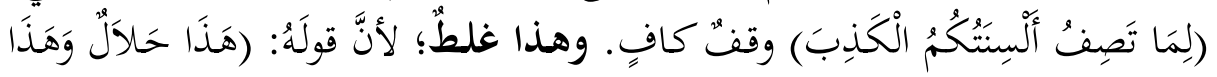

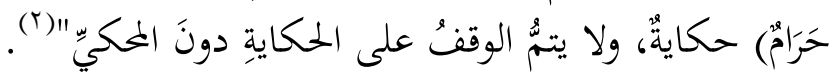

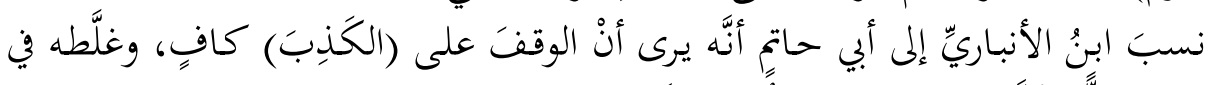

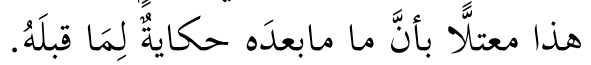

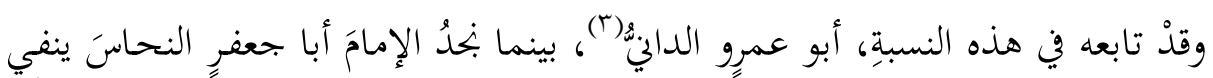

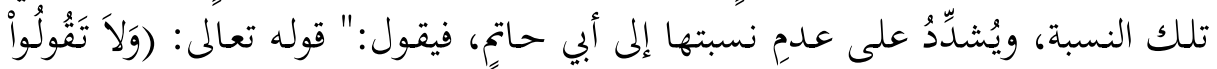

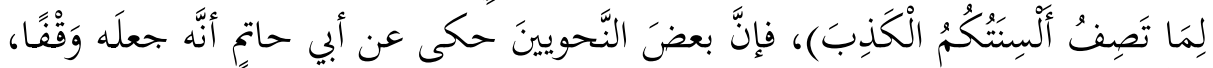

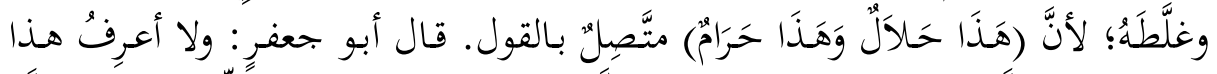

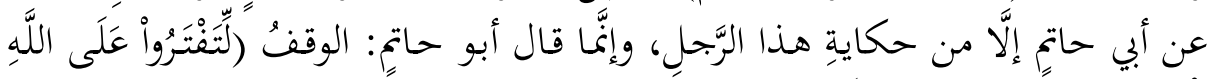

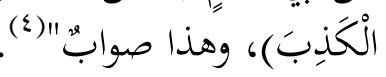

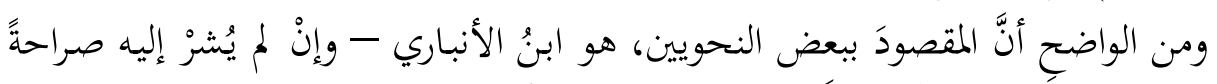

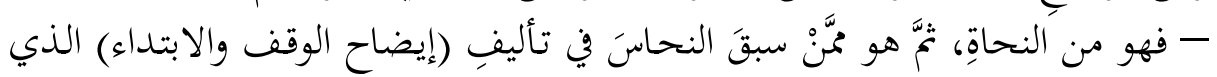

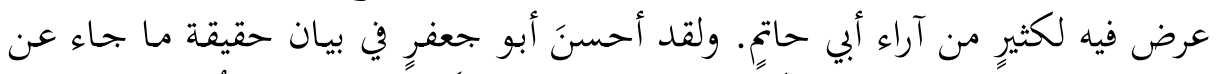

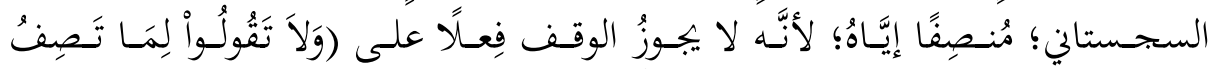

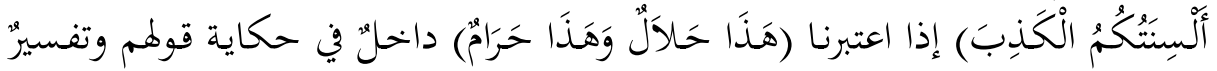

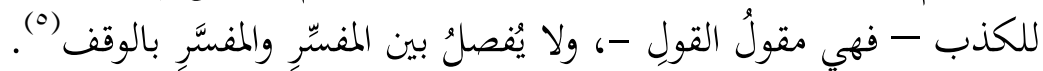

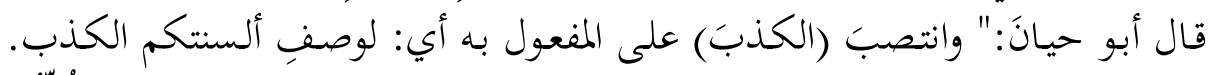

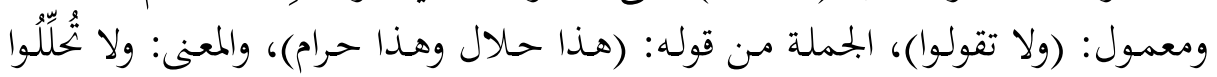

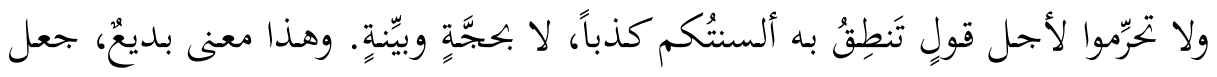

(1) (1) سورة النحل آية 71 (1)

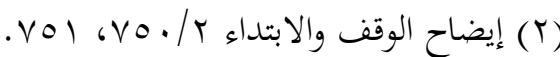

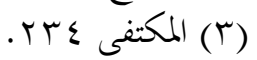

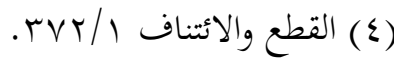

(0) انظر: منار الهدى . r. 


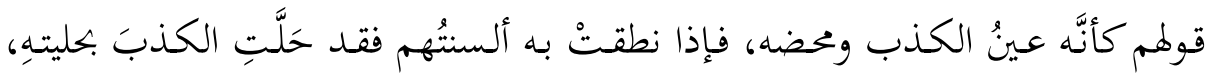

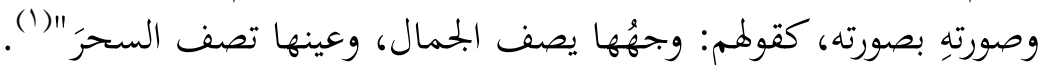

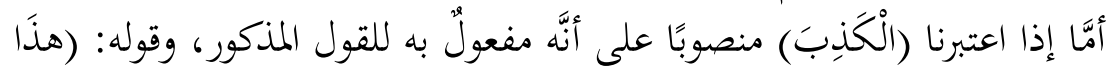

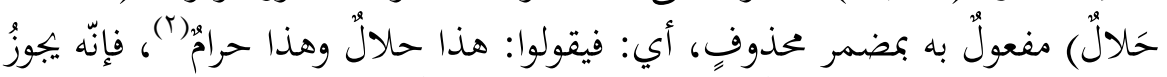

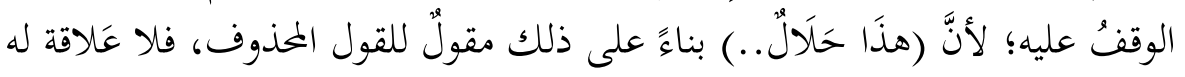

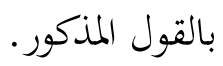

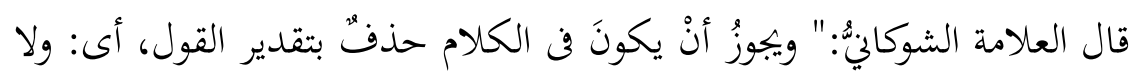

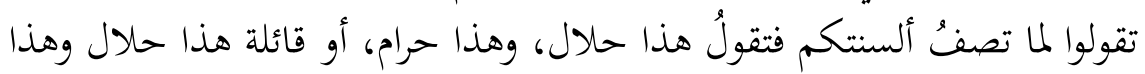

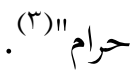

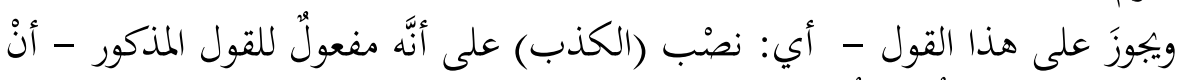

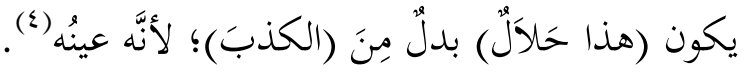
*********************

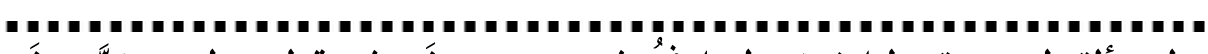
المسألة السادسة والثلاثون: الخلافُ في جوابِ (إذًا) في قوله تعالى: (حَتَّى إِذَا فُنَِْحَتْ).

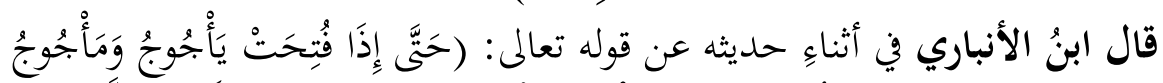

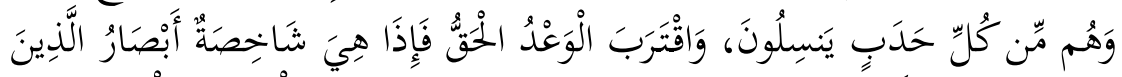

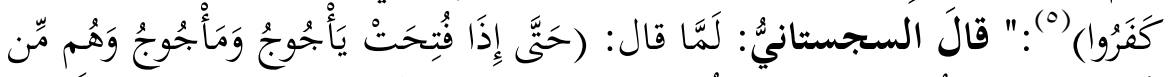

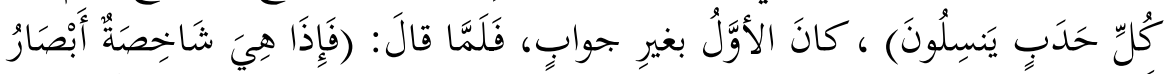

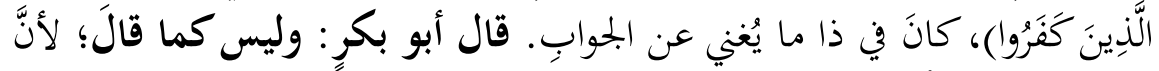

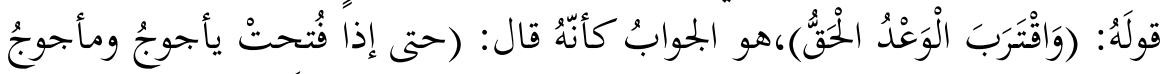

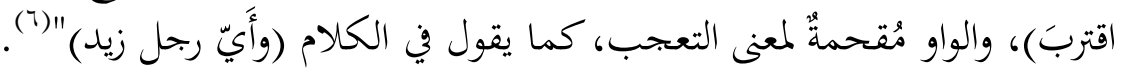

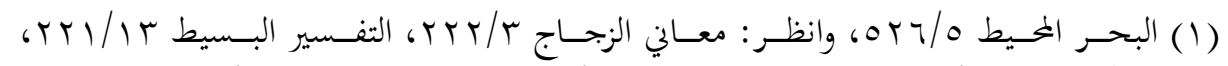

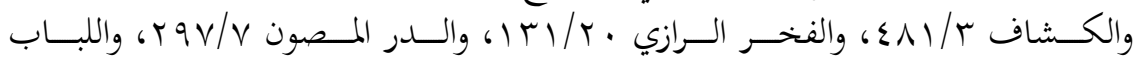

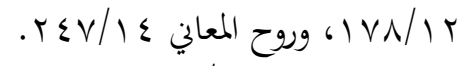

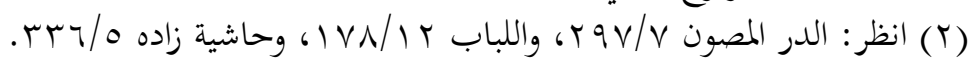

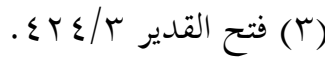

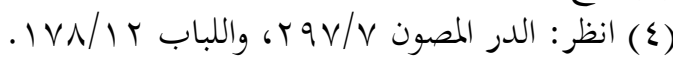

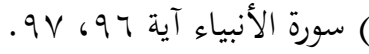

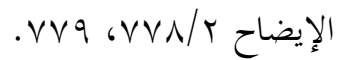




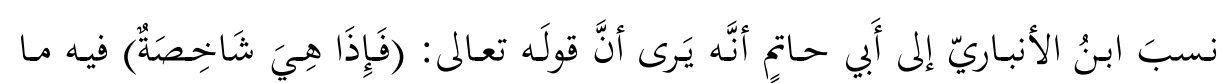

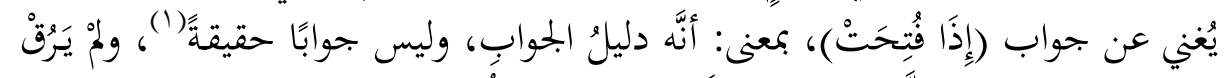

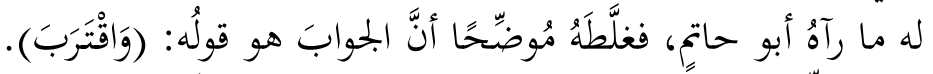

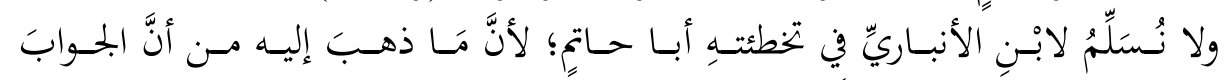

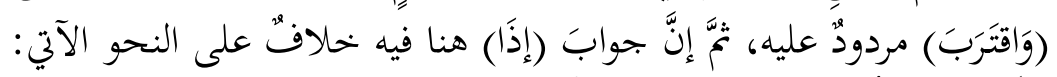

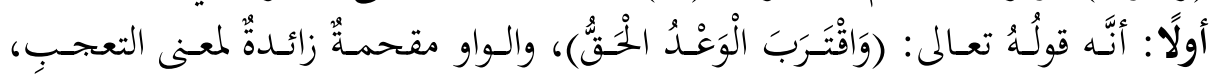

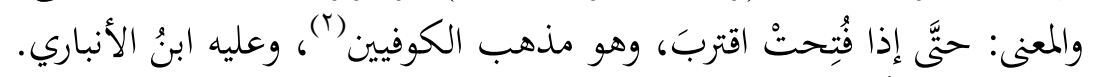

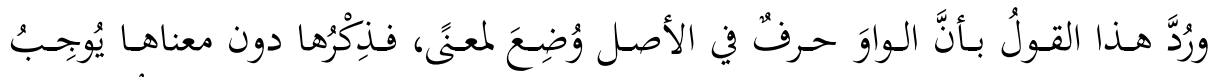

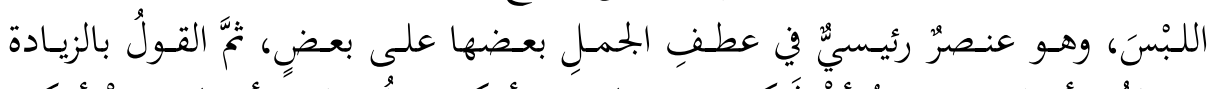

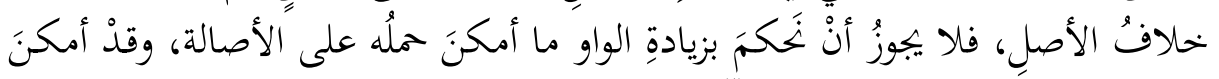

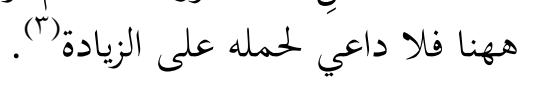

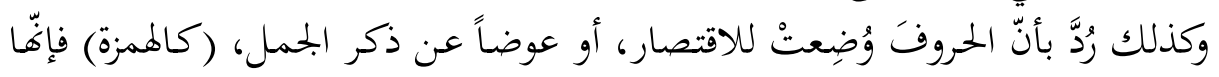

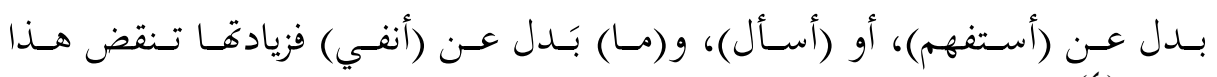

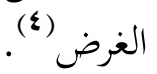

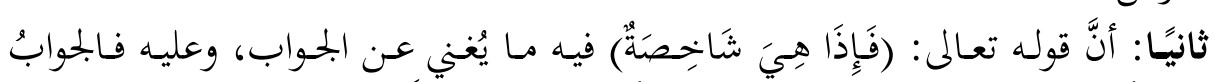

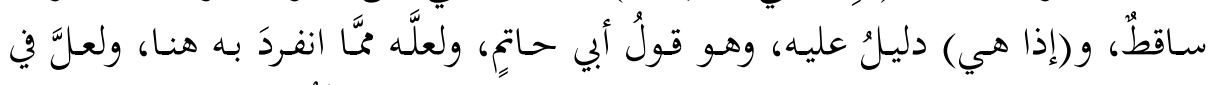

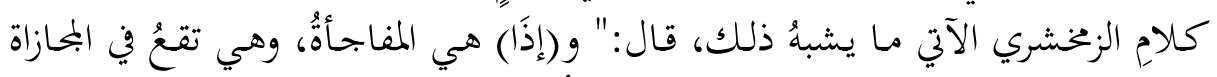

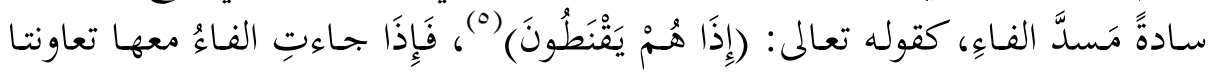

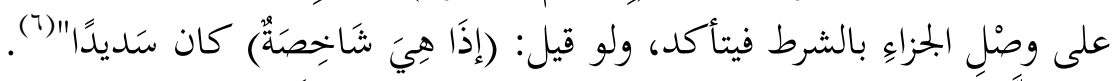

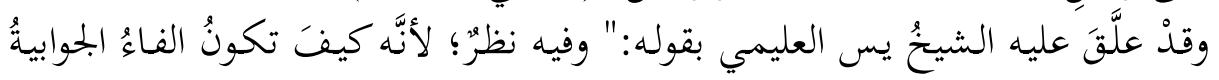

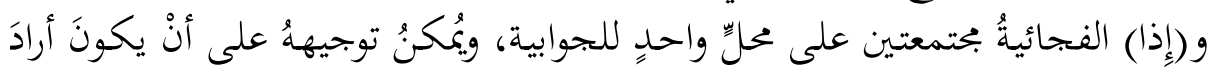

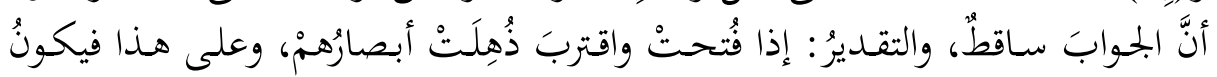

(1) (1) أم أقف على هذا النقل فيما اطلعتُ عليه من مصادر.

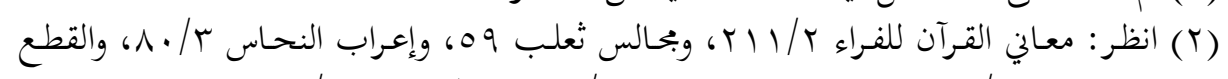

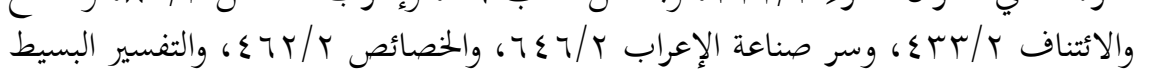

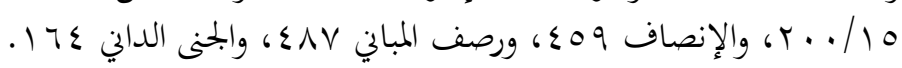

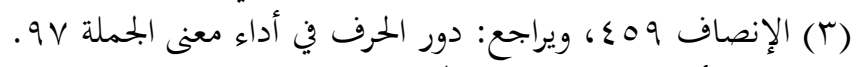

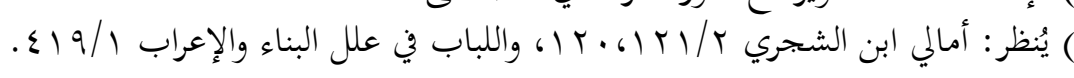

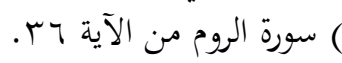

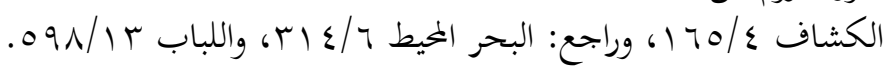




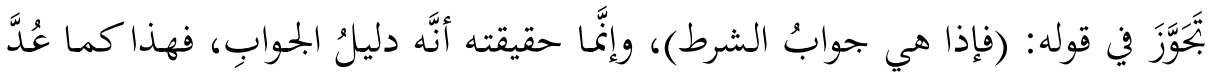

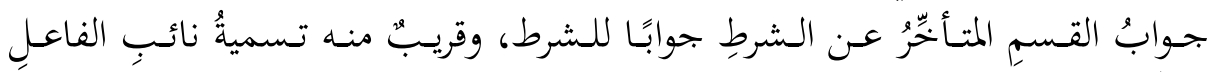

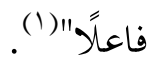

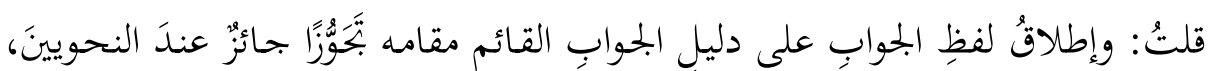

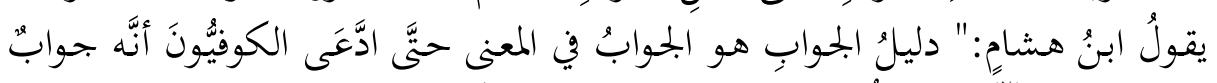

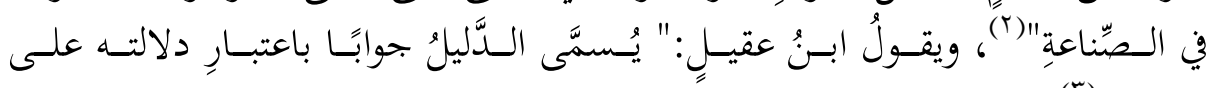

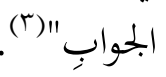

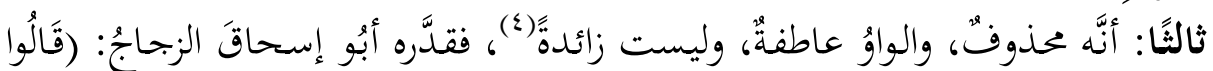

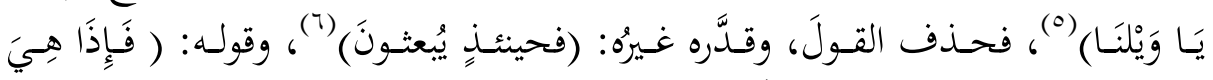

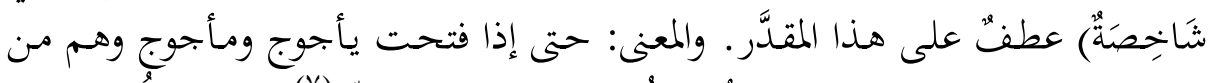

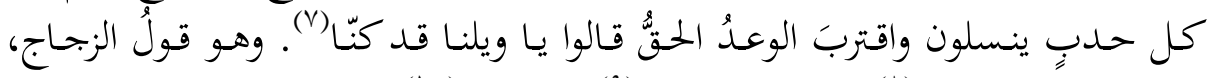

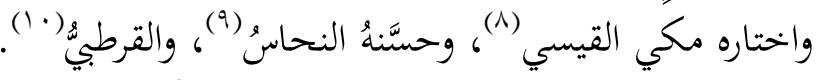

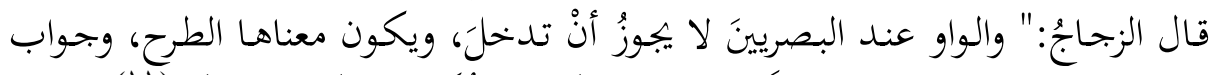

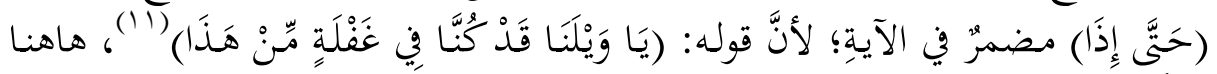

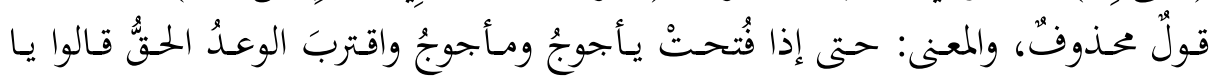
ويلنا" (ir)

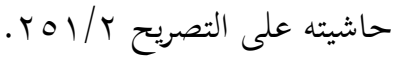

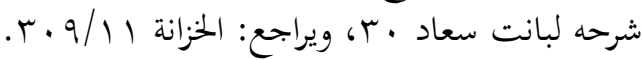

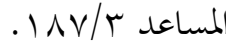

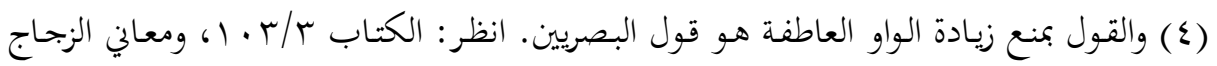

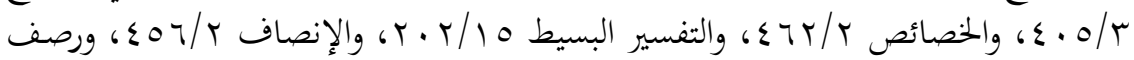

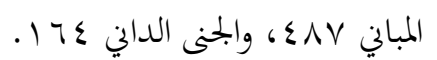

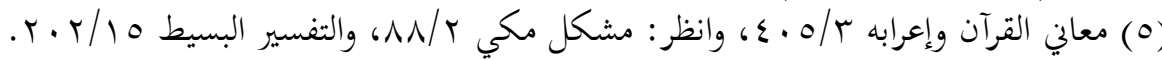

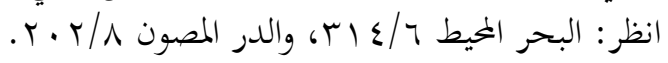

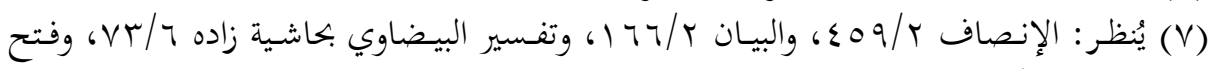

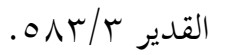

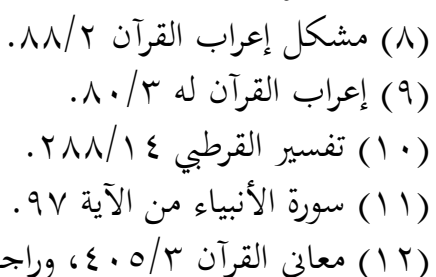

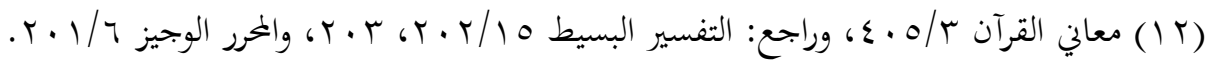




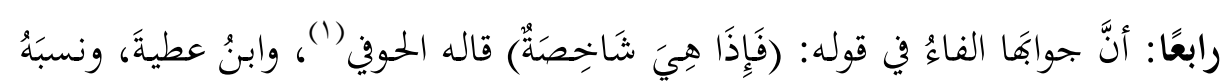

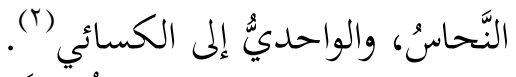

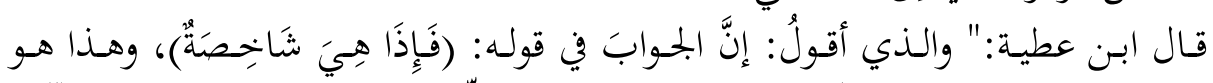

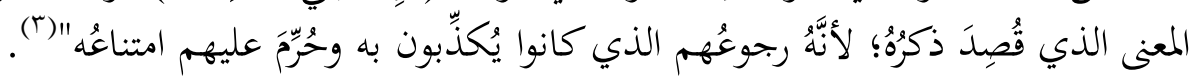

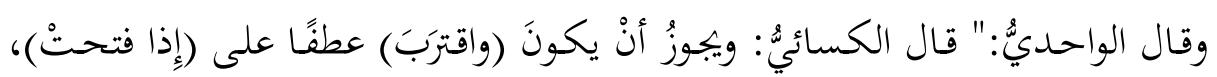

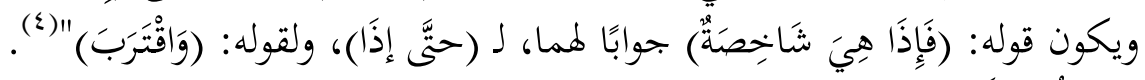

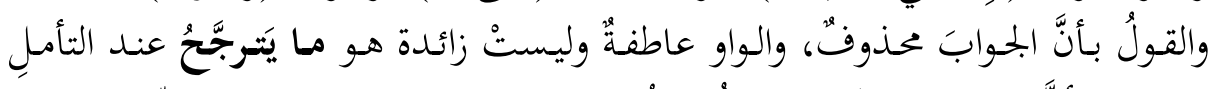

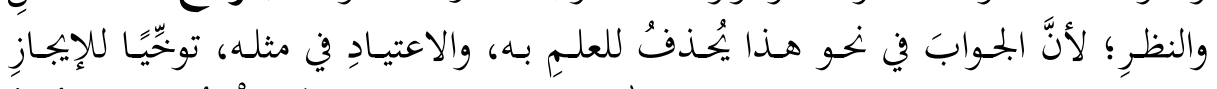

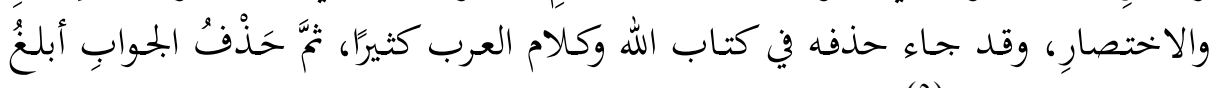
في المعنى من إظهاره (م)

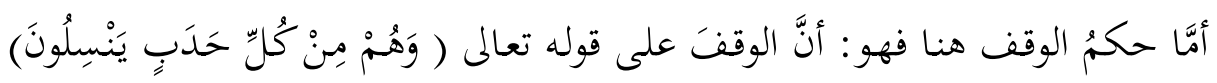

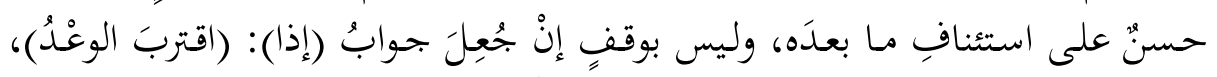

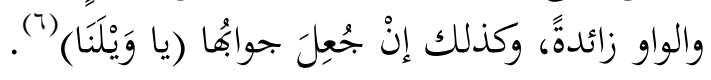

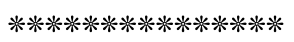

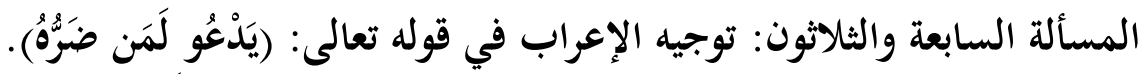

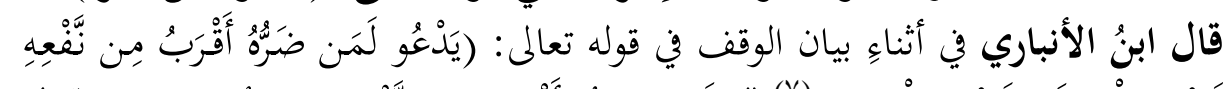

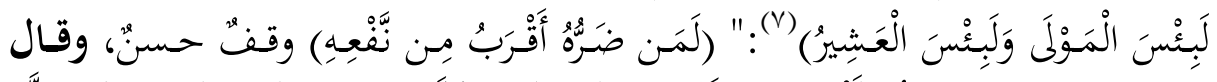

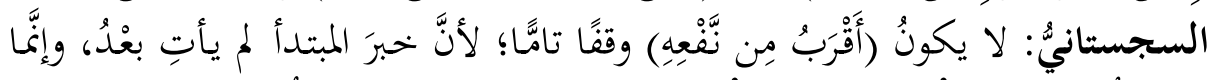

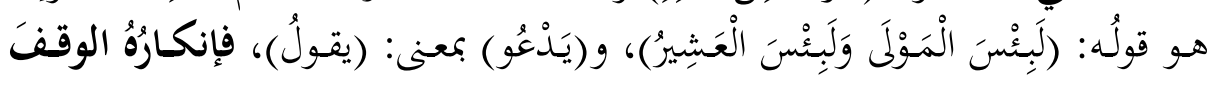

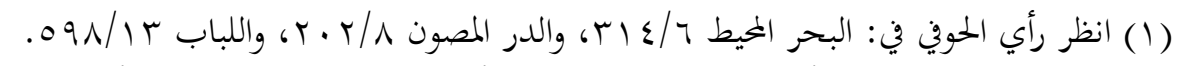

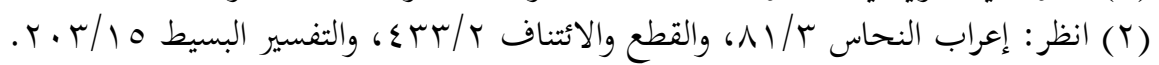

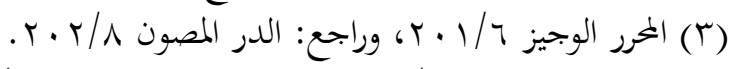

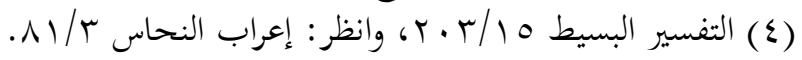

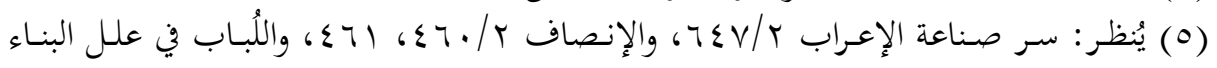

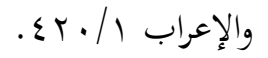

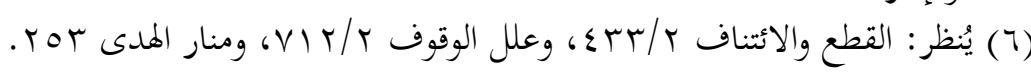

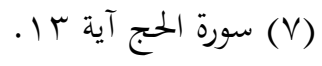




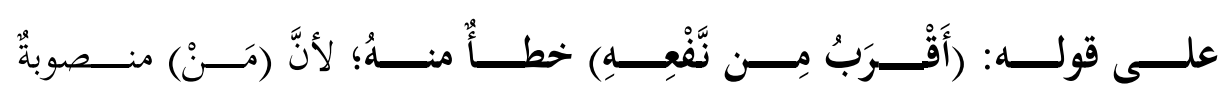

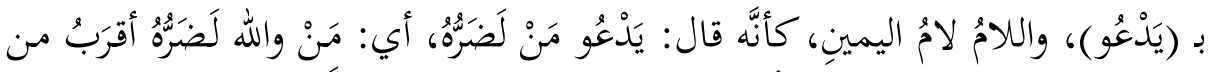

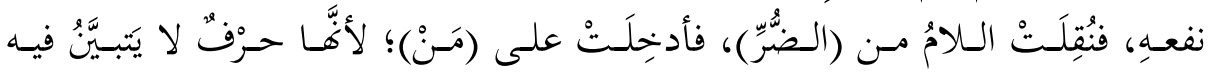

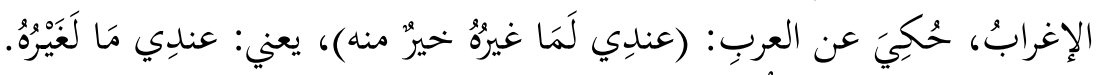

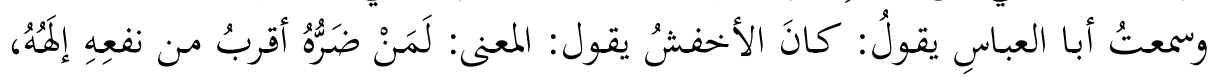

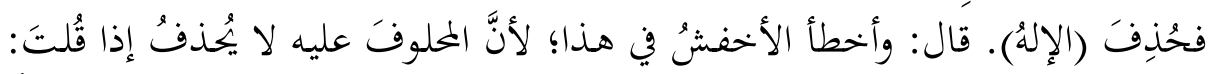

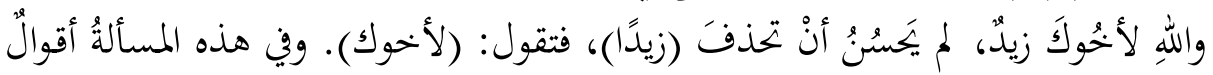

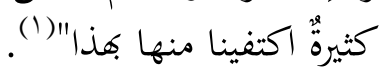

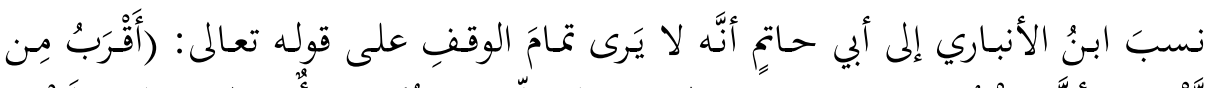

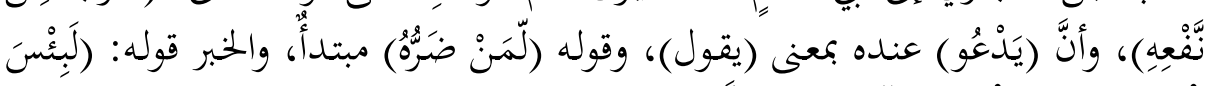

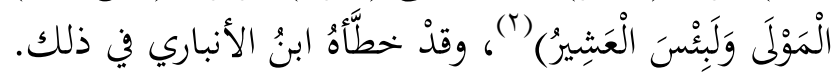

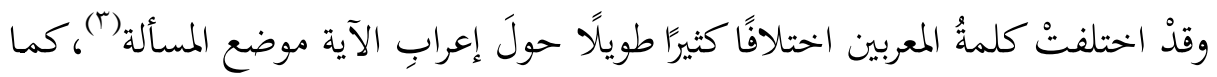

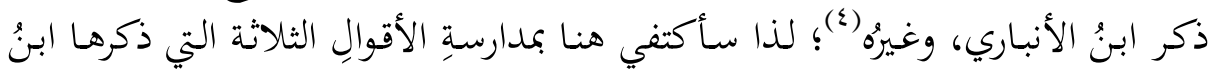

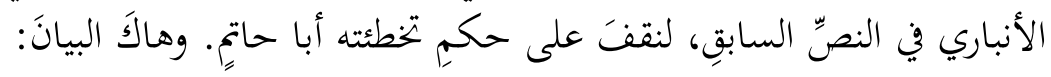

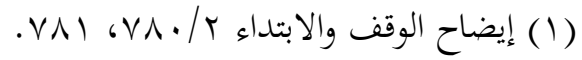

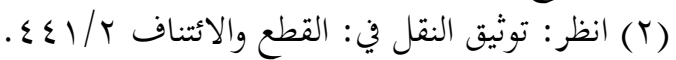

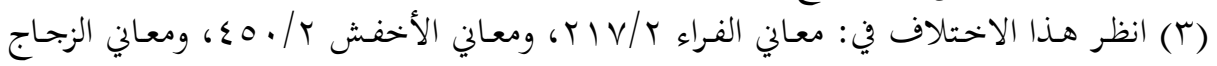

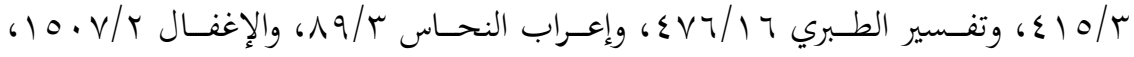

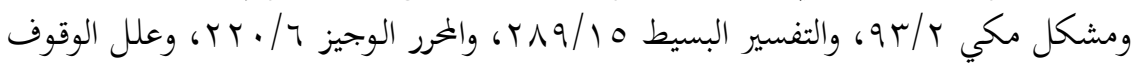

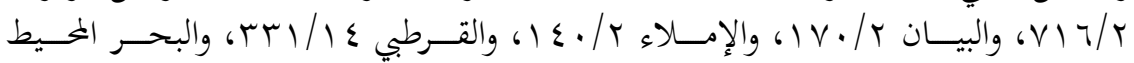

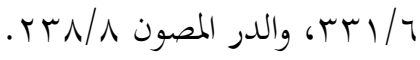

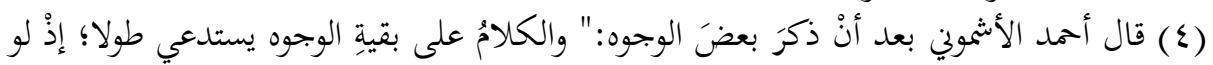

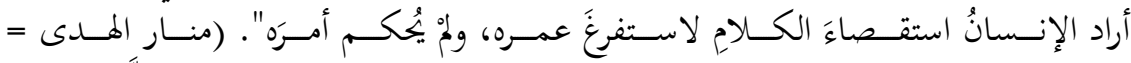

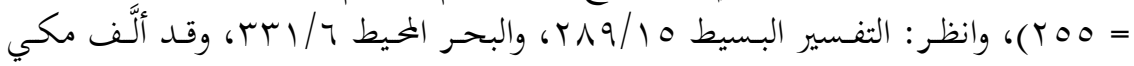

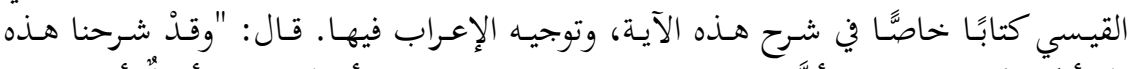

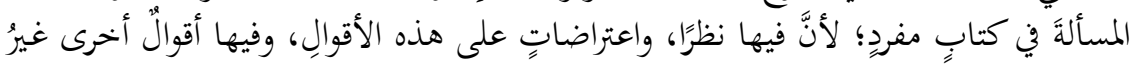

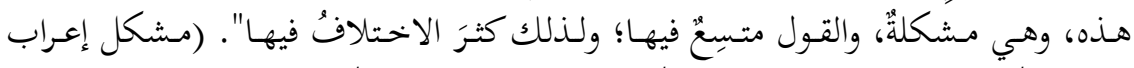

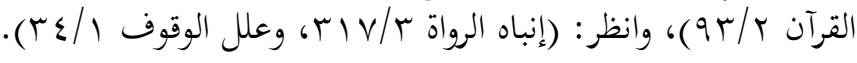




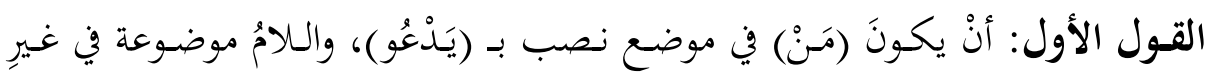

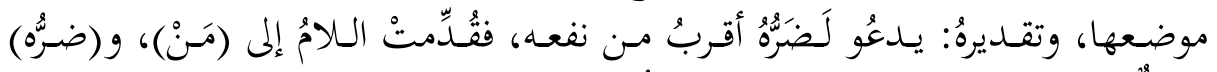

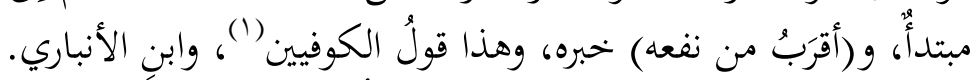

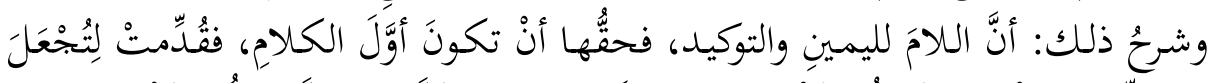

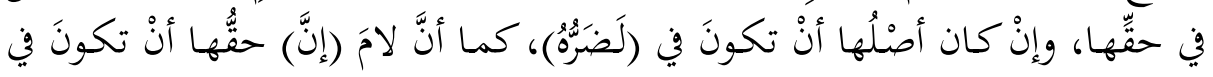

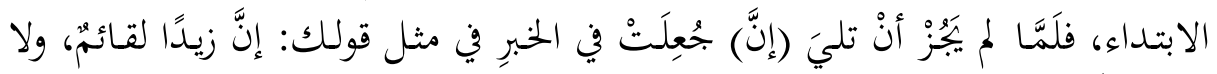

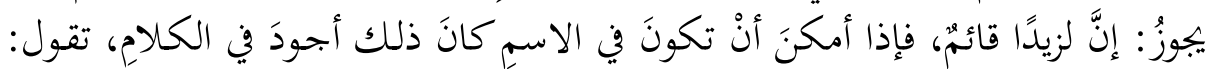

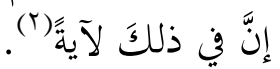

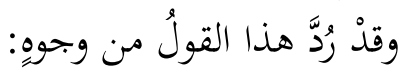

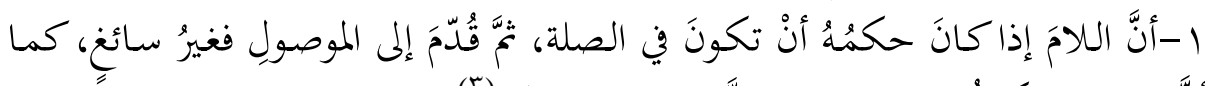

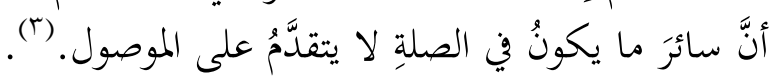

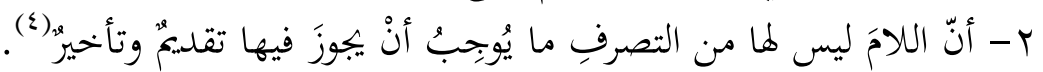

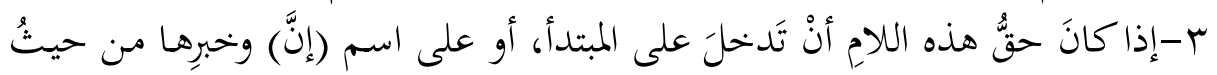

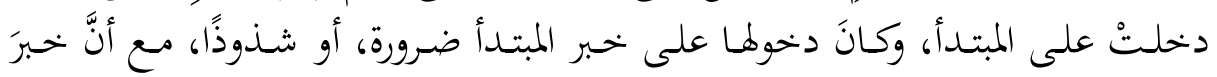

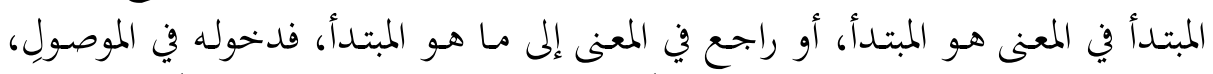

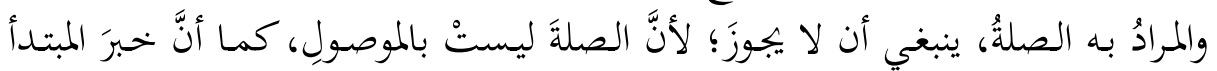
هو المبتدأ (0).

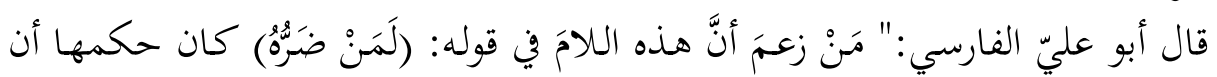

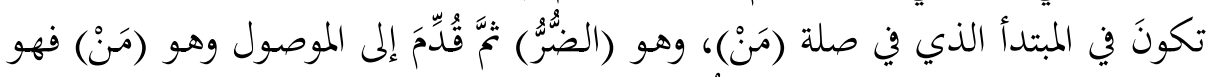

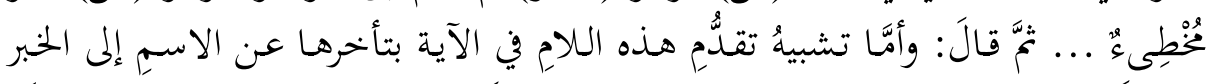

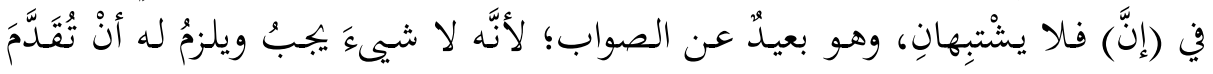

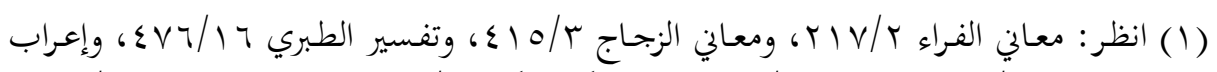

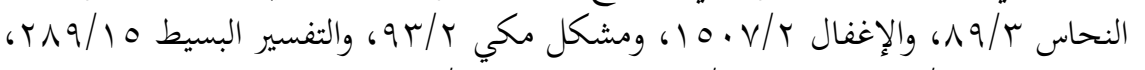

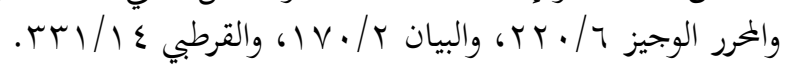

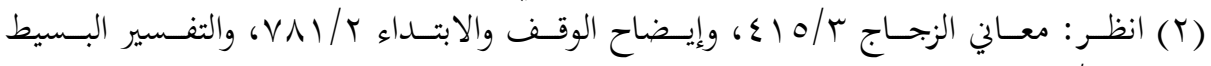
.r9./10

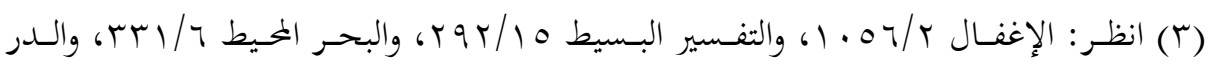

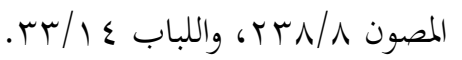

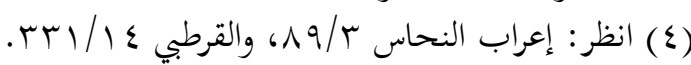

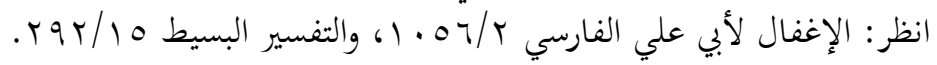




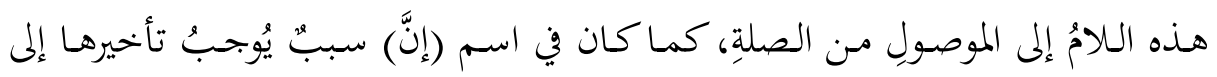

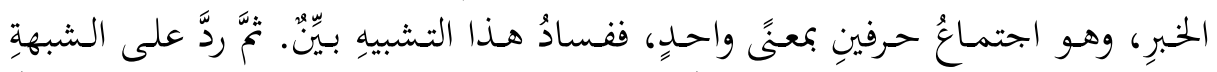

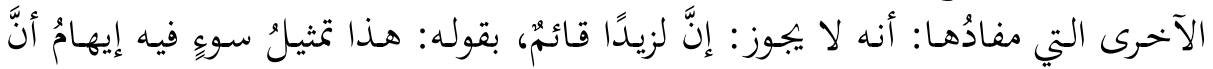

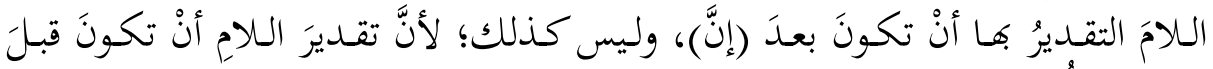

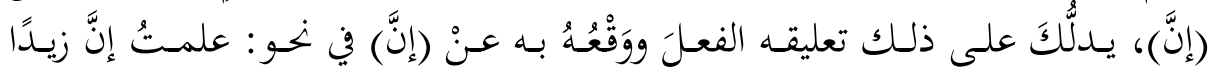

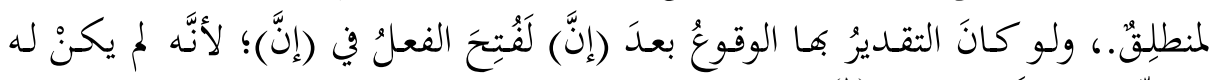

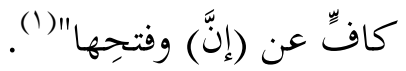

القول الثاني: أنّ (يَدْعُو) بمعنى: (يَقُوْل)، واللامُ للابتداء، و(مَنْ) موصولةٌ في محلِّ رفع

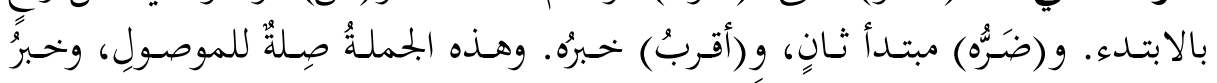

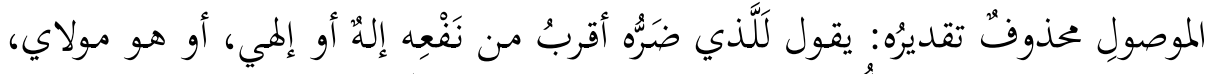

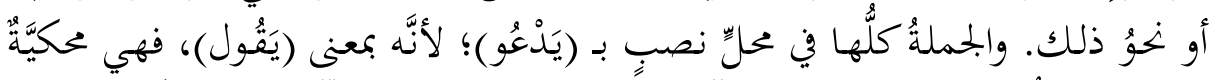

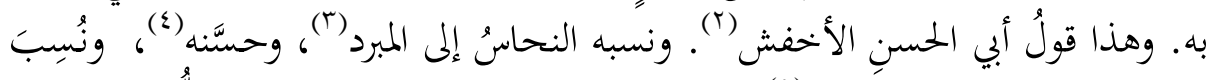

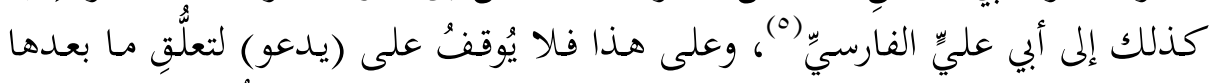

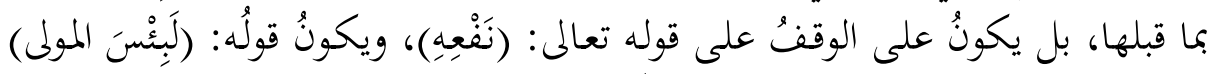

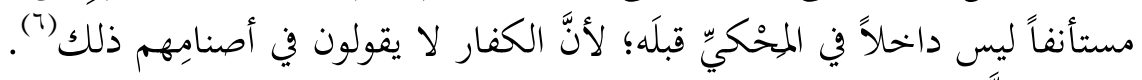

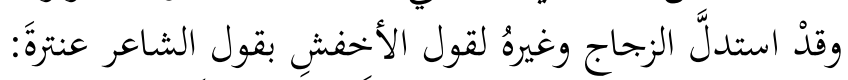

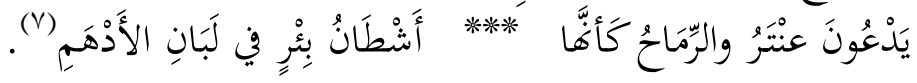

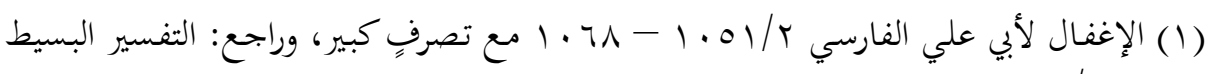
(

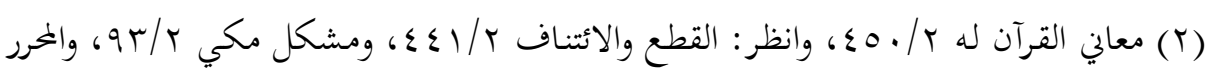

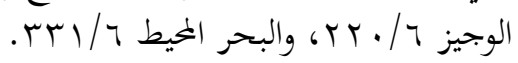

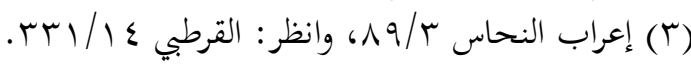

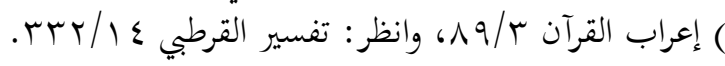

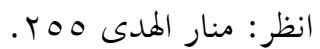

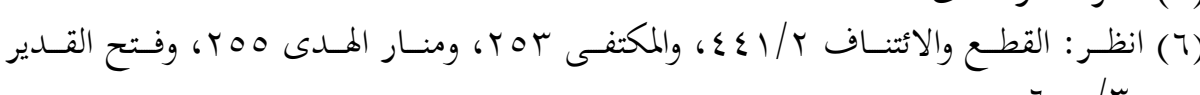

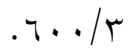

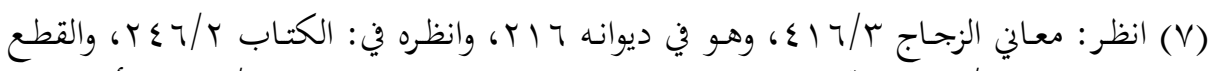

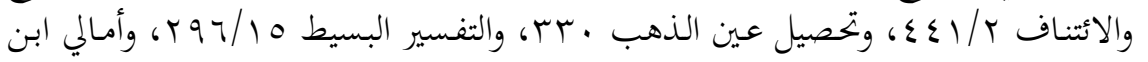

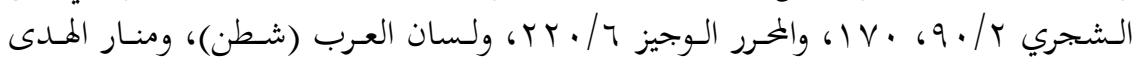

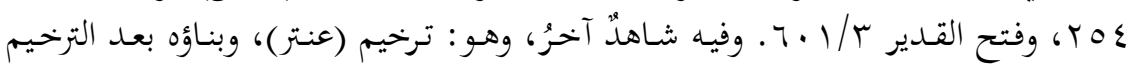




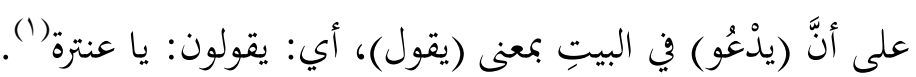

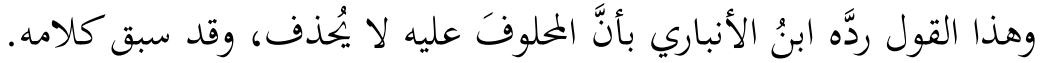

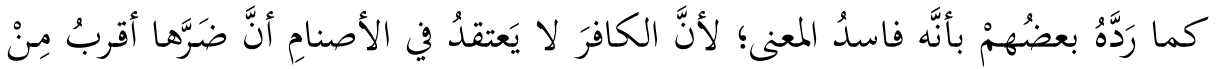
نفعِها البتة (؟).

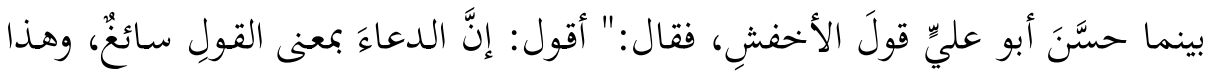

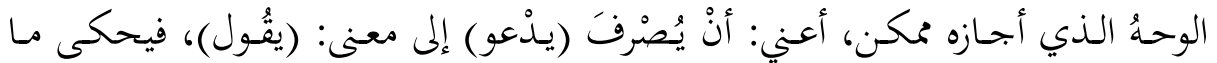

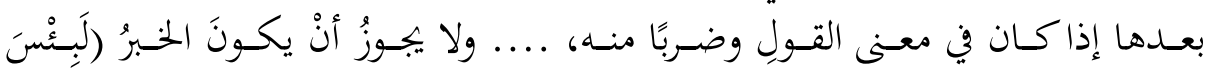

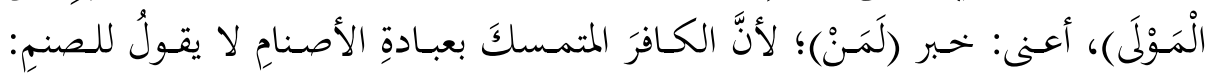

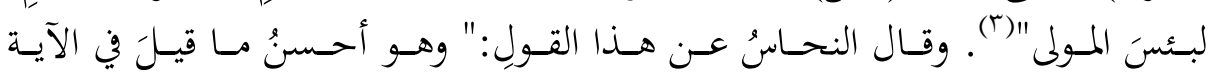

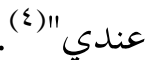

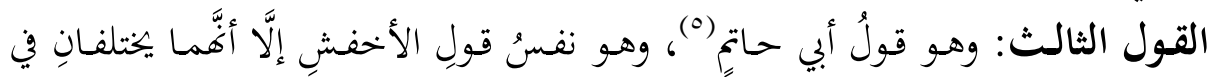

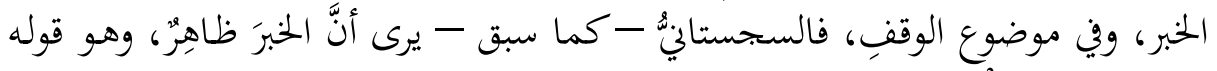

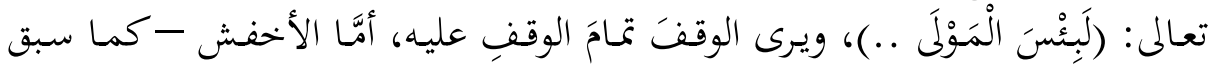

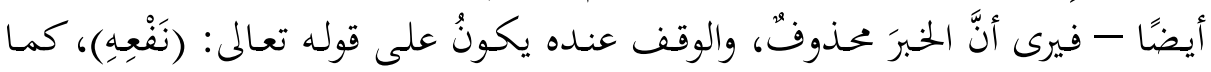
بيَّنا.

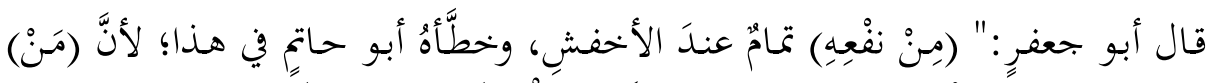

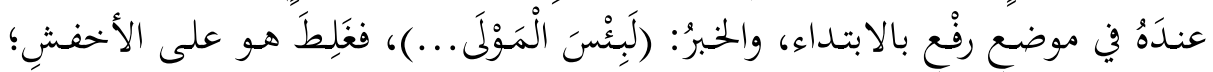

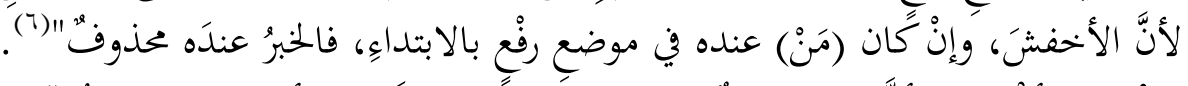

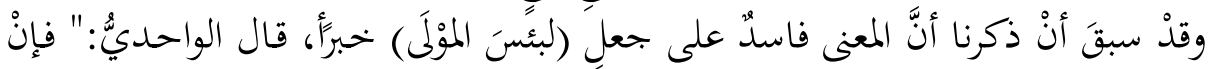

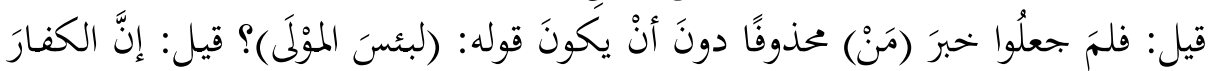

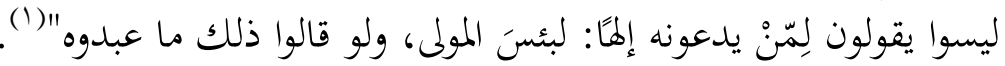

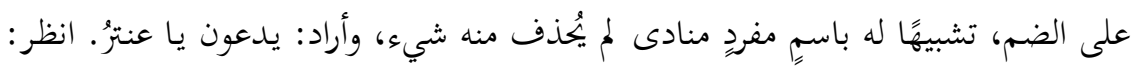

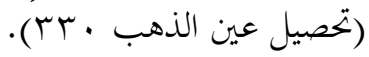

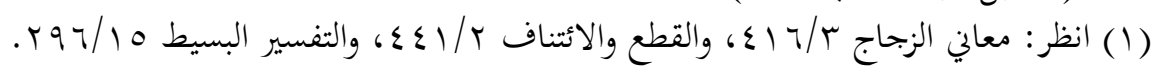

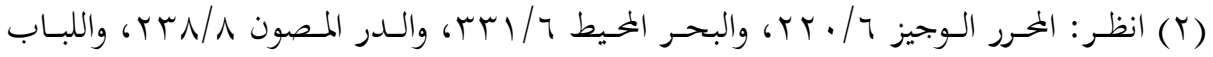
$. r \leqslant / 1 \leqslant$

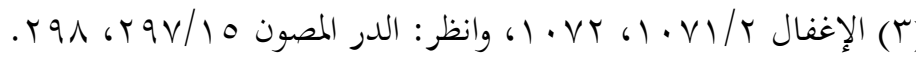

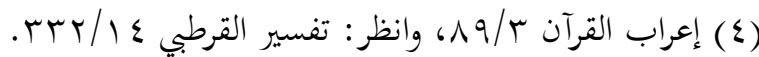

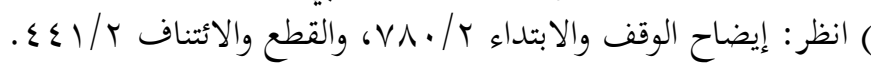

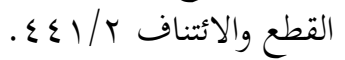




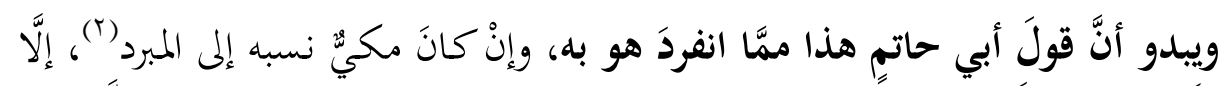

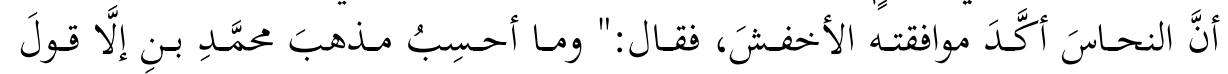

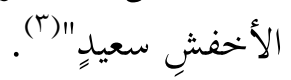

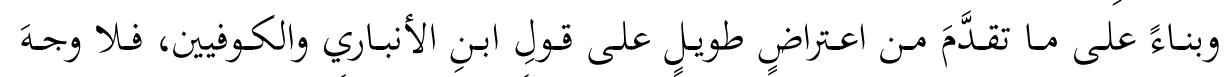

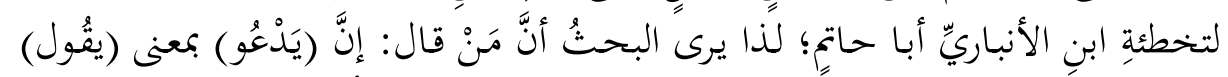

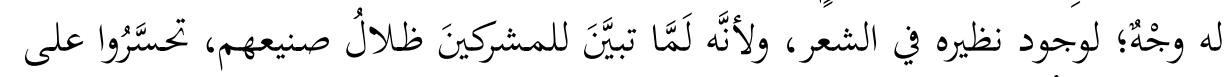

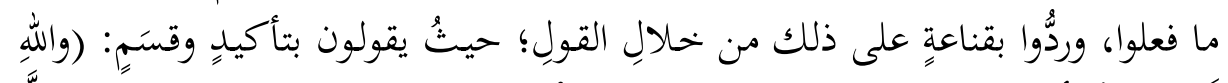

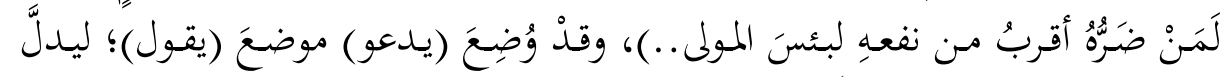

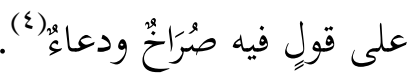
********************

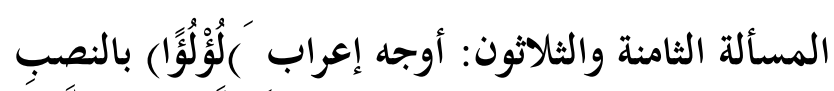

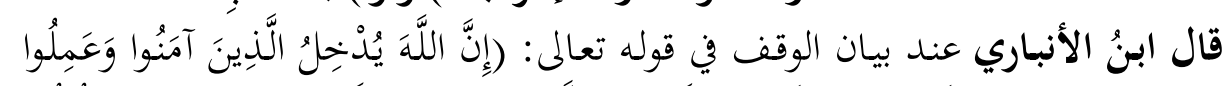

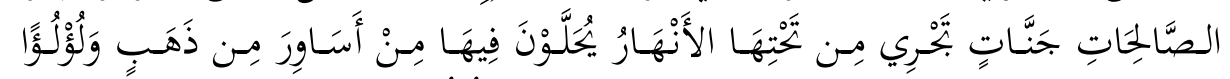

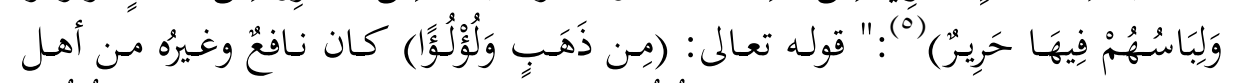

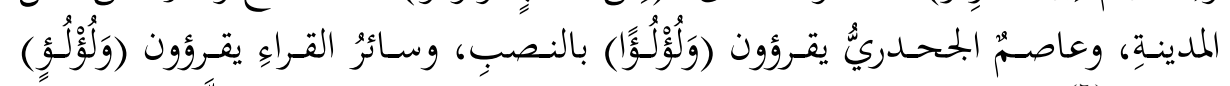

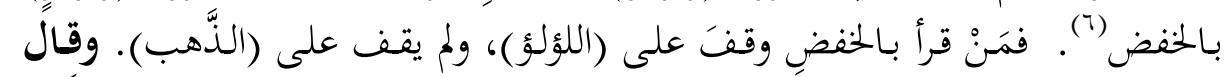

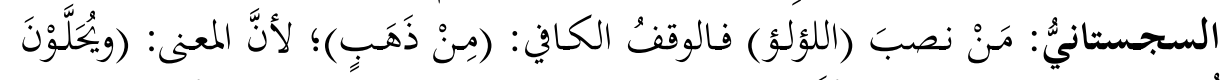

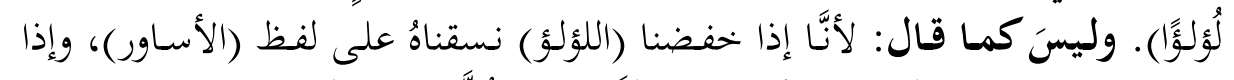

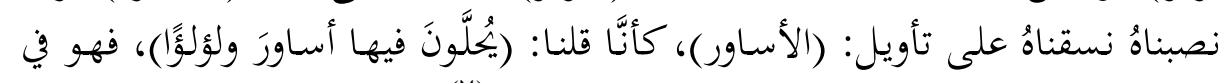

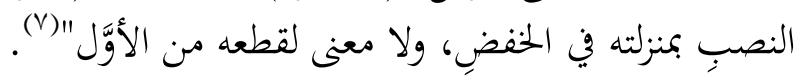

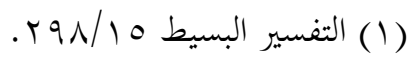

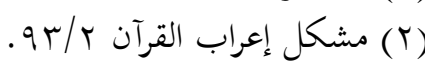

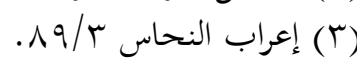

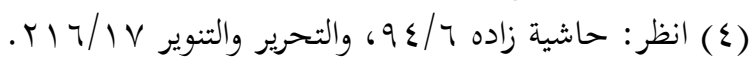

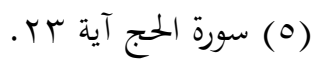

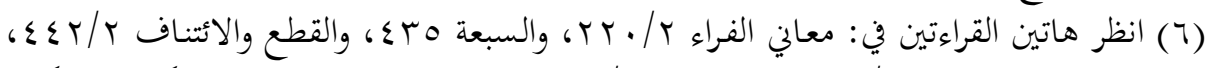

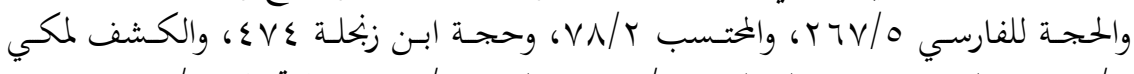

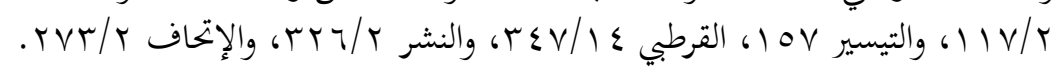
إيضاح الوقف والابتداء VIV/r) 


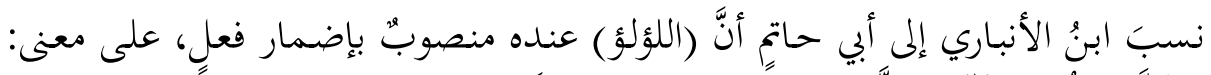

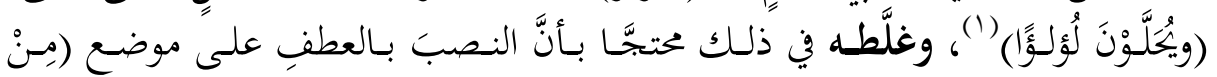

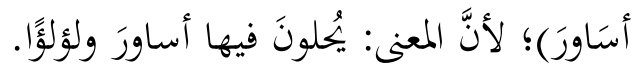

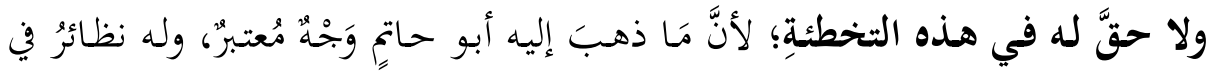

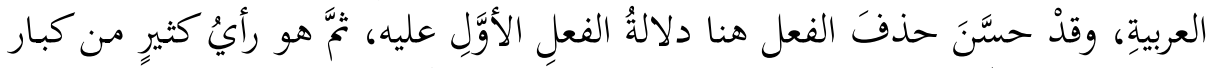

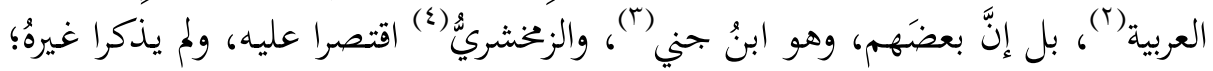

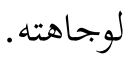

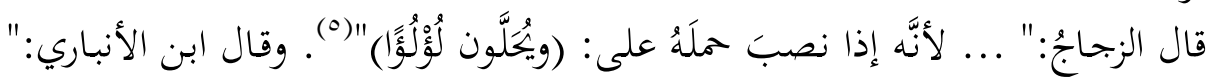

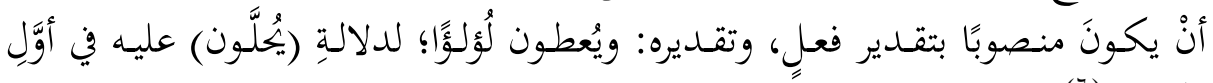

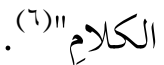

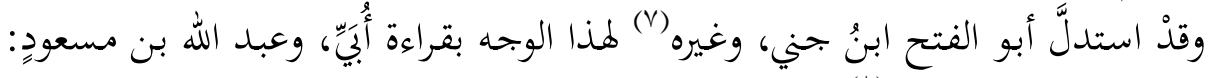

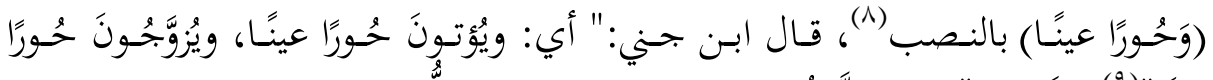

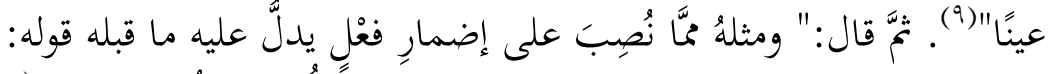

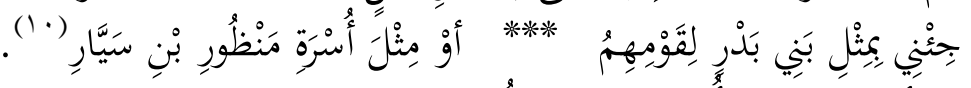

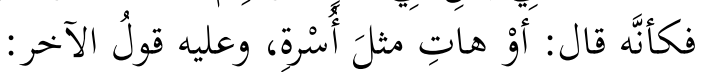

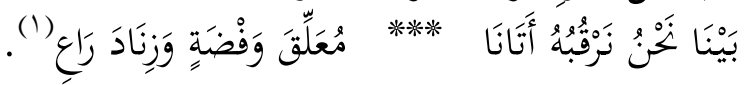

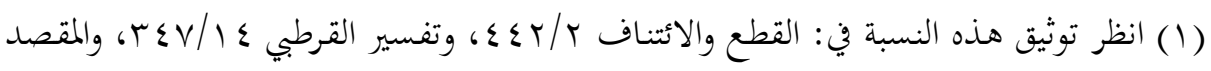

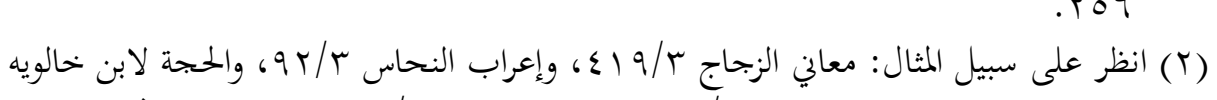

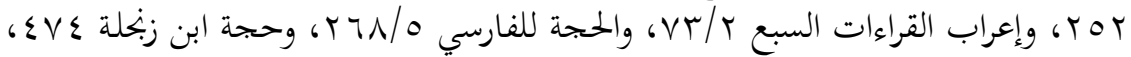

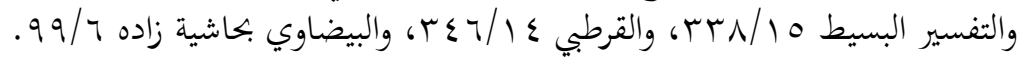

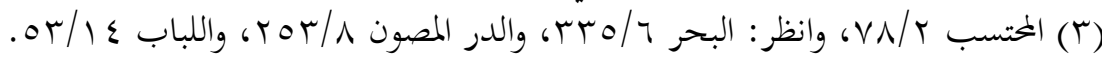

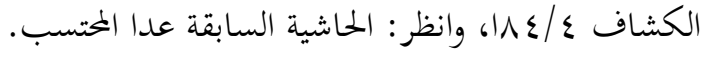

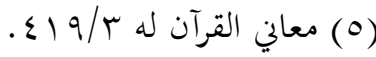

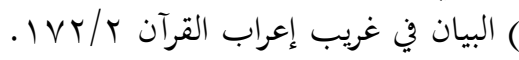

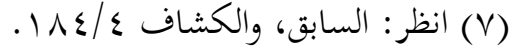

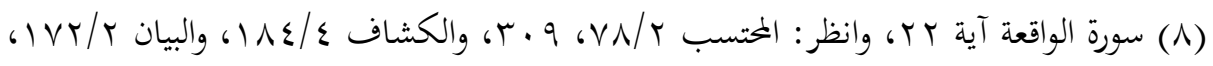

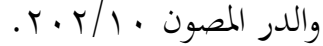

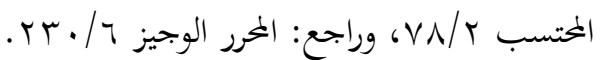

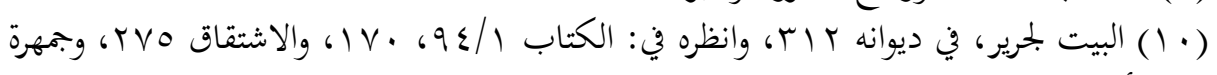

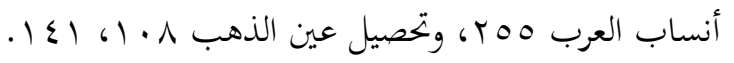




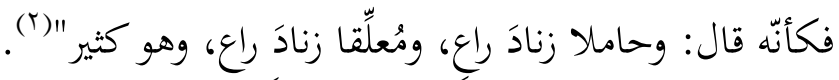

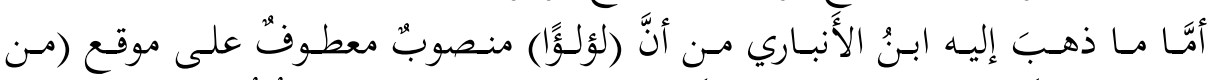

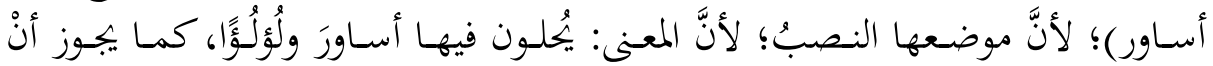

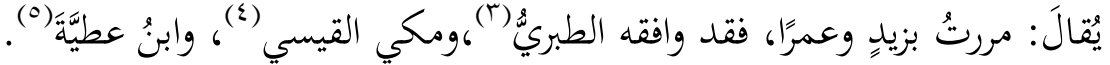

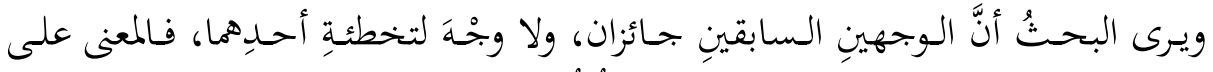

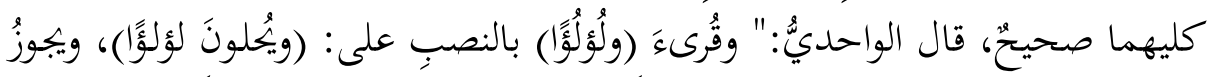

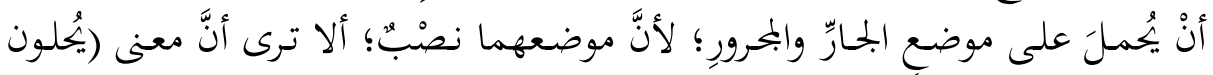

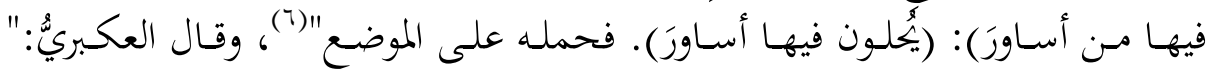

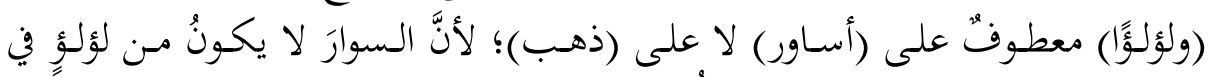

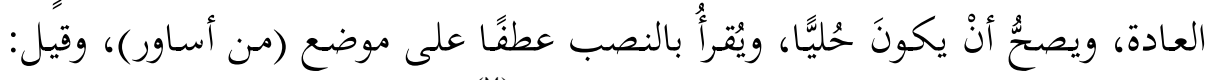

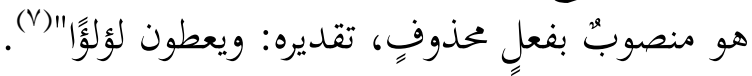

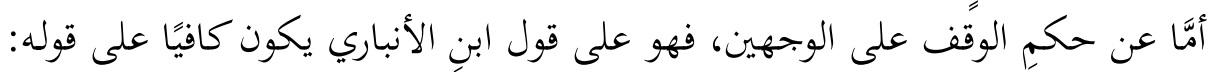

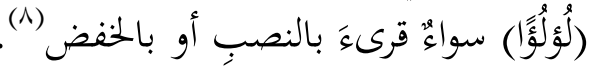

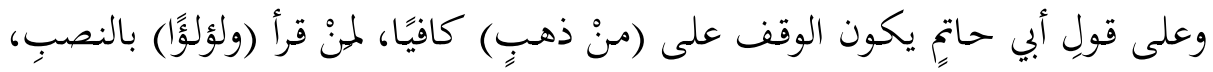

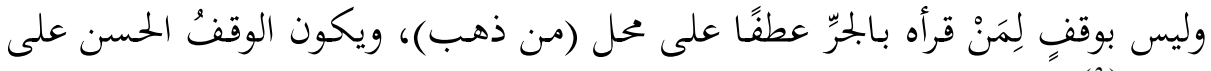

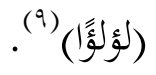

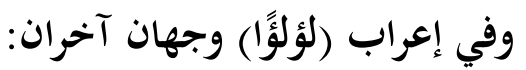

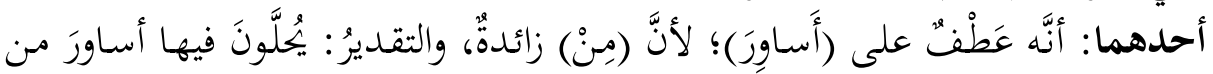
ذهبٍ ولؤلوَّا (1)

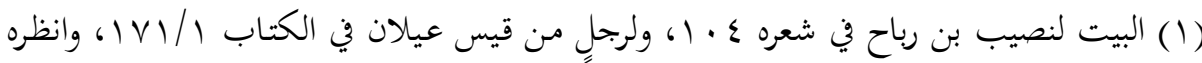

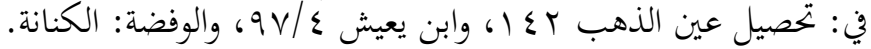

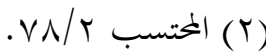

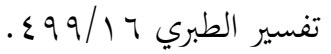

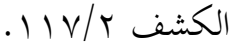

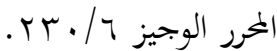

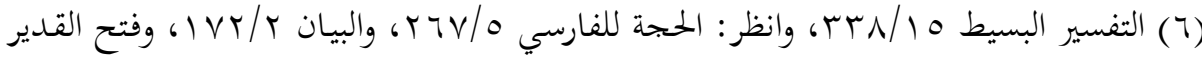

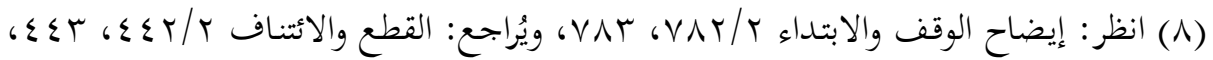




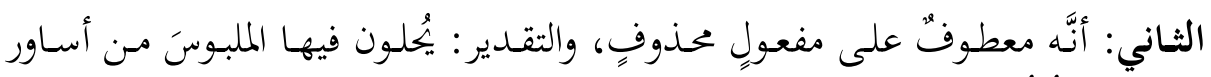

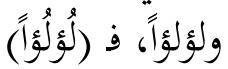

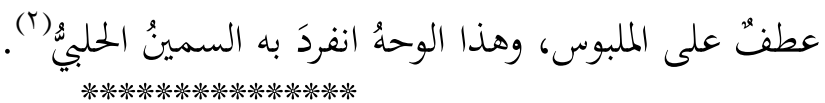

المسألة التاسعة والثلاثون: القول في مفعُولَي: (يَحْسَبُونَ)

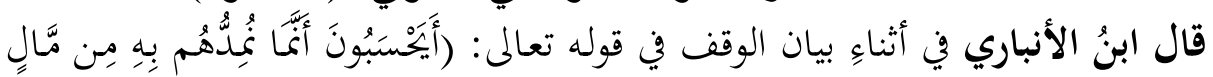

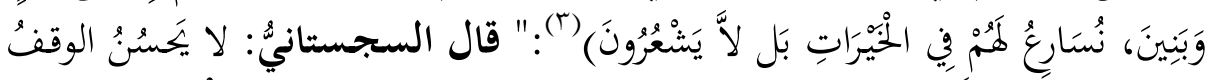

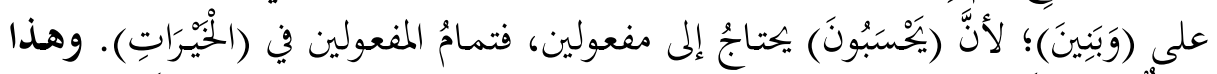

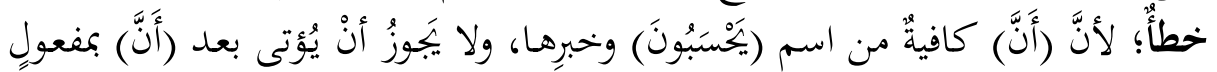

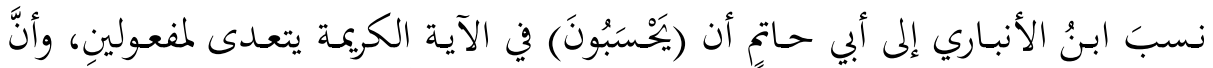

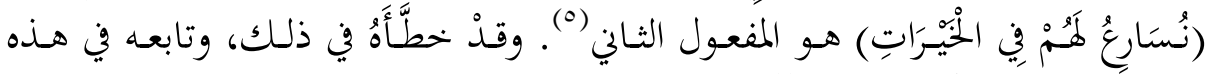

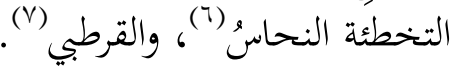

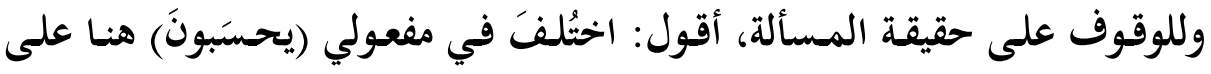
قولين: - (20)

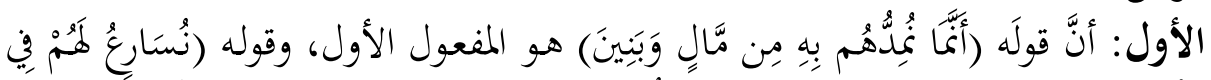

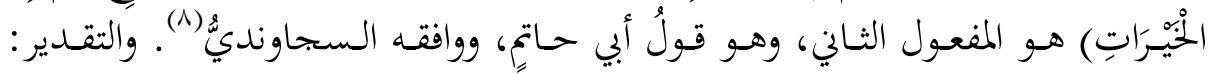

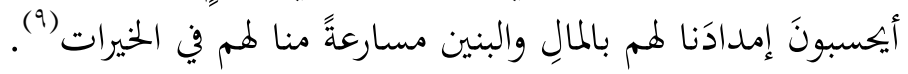

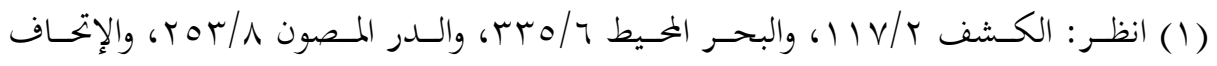
.rVT/r

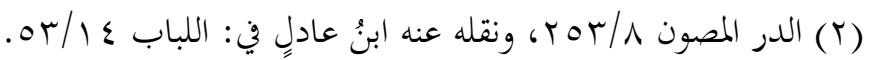

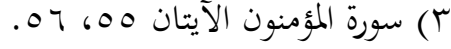

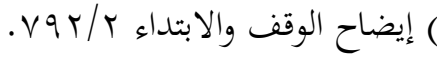

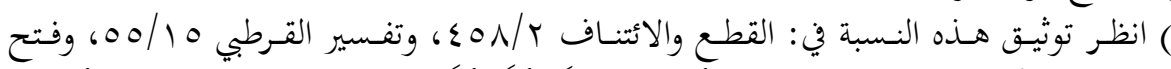

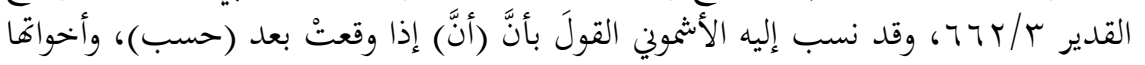

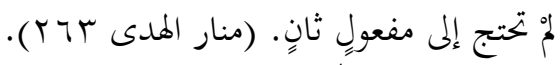

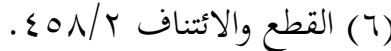

$$
\begin{aligned}
& \text { ( ) تفسير القرطبي (Y) }
\end{aligned}
$$

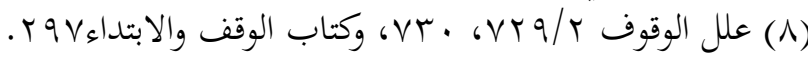

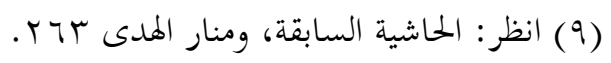




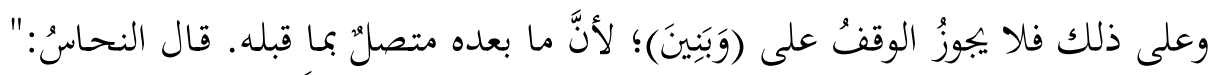

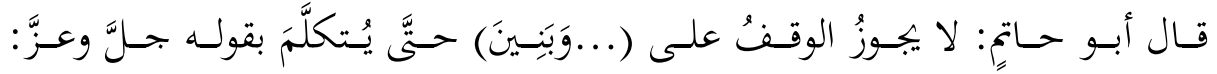

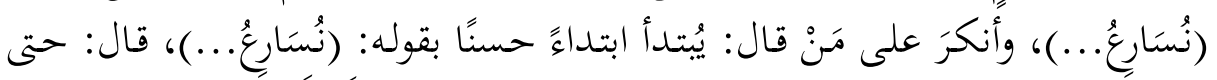

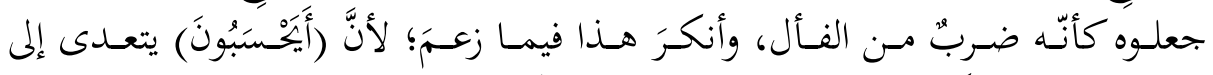

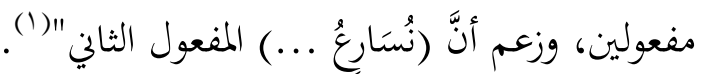
وهذا القول لم أقف عليه - فيما اطلعت - لغير أبي حاتعٍ، وقد خطأَهُ ابنُ الأنباري فيه

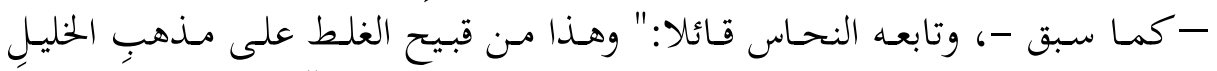

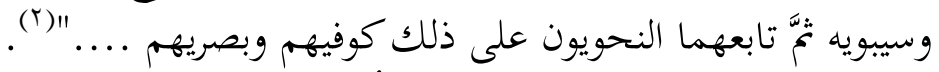

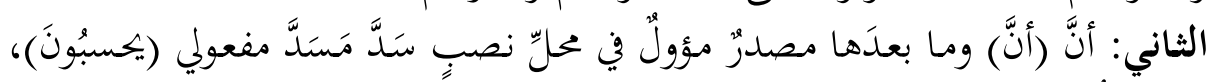

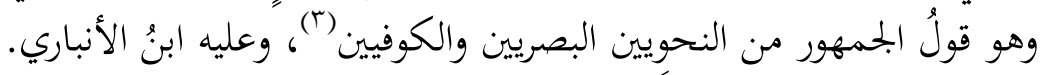

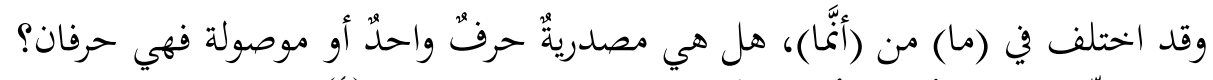

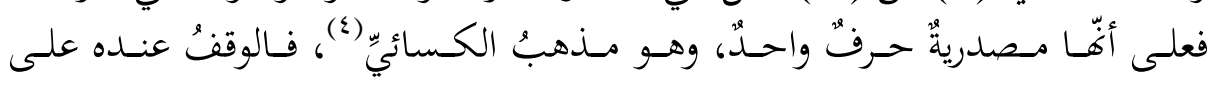

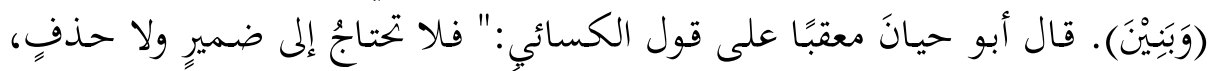

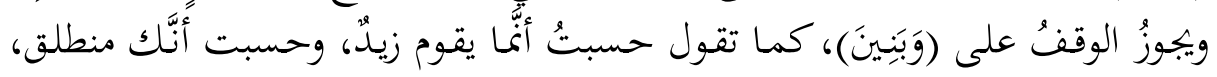

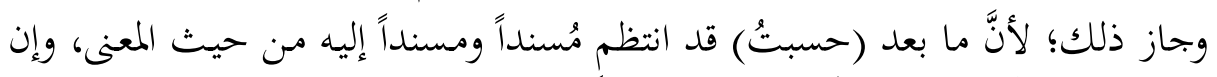

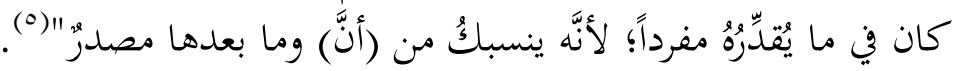

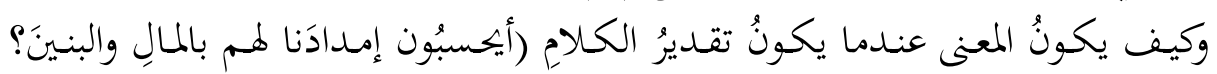

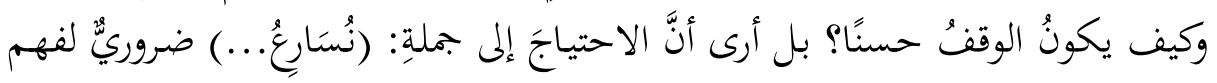
المعنى.

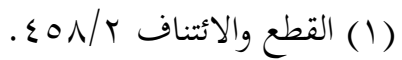

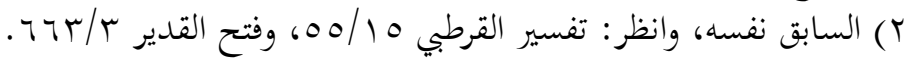

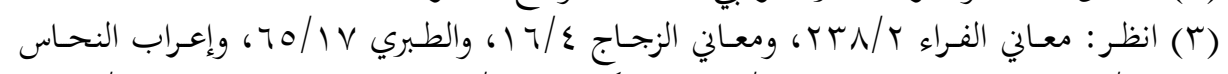

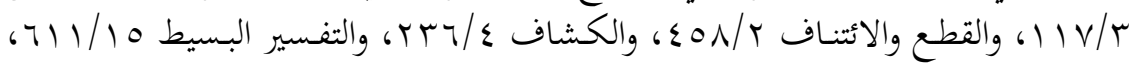
والبحر

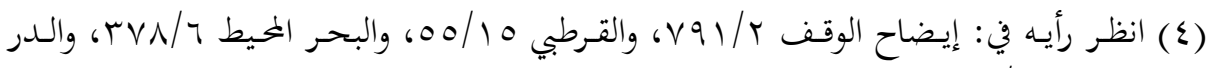

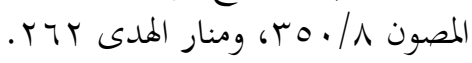

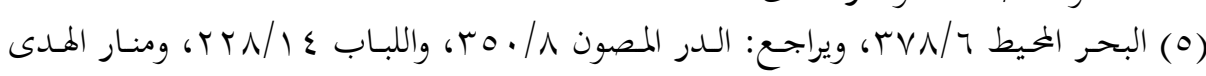




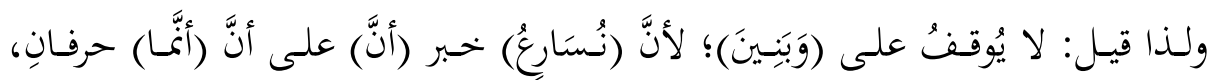

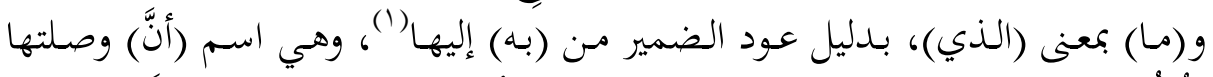

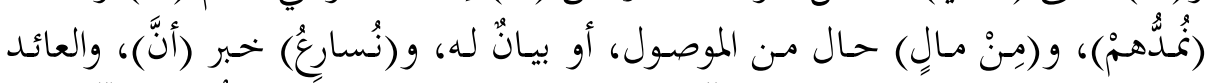

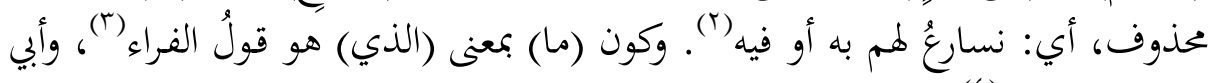

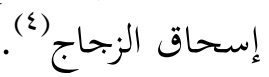

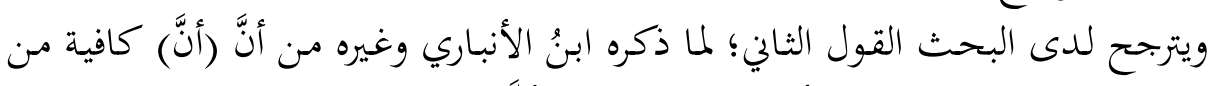

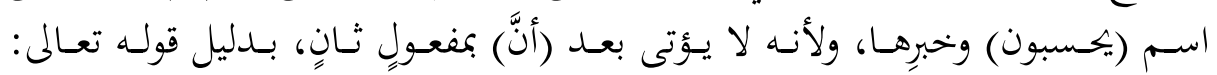

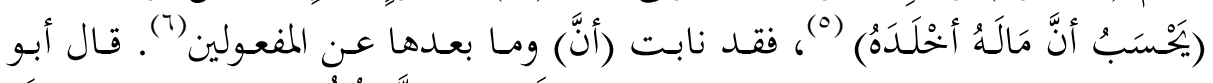

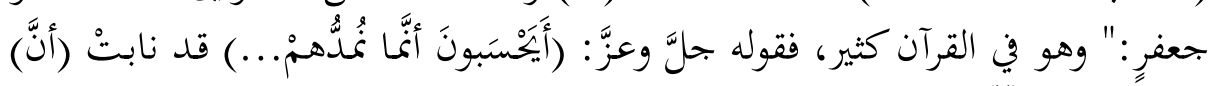

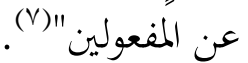

\section{********************}

\section{المسألة الأربعون: أوجه نصب (شُكْرًا)}

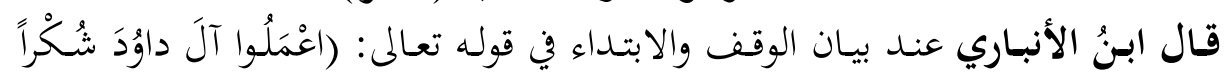

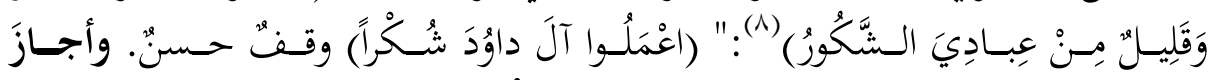

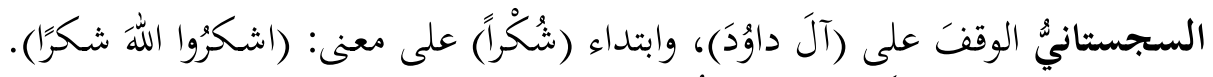

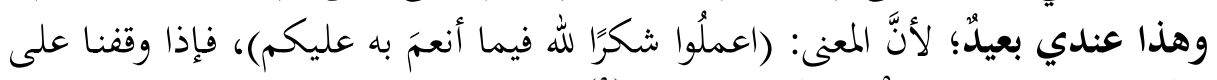

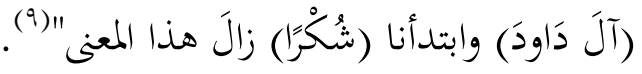

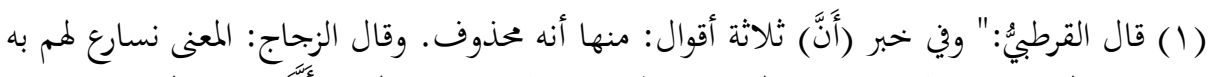

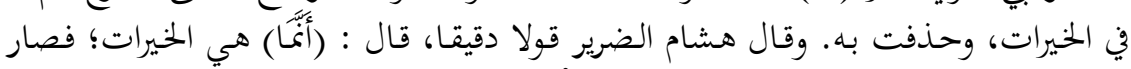

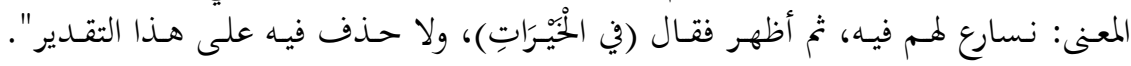

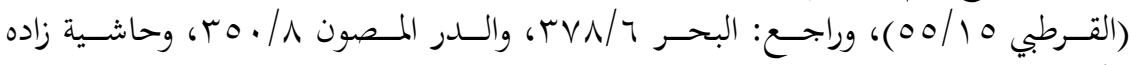
$.179 / 7$

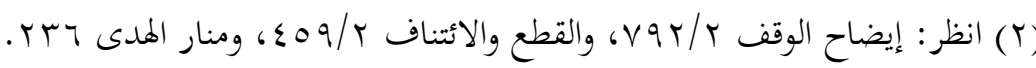

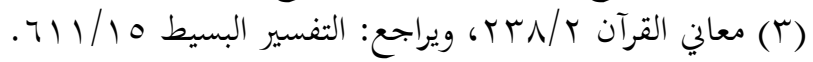

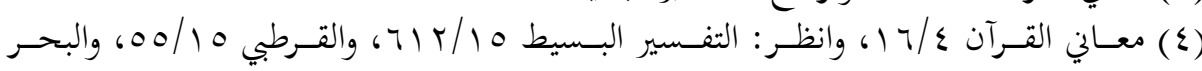
rV $r$ / 


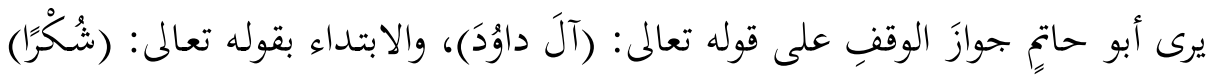

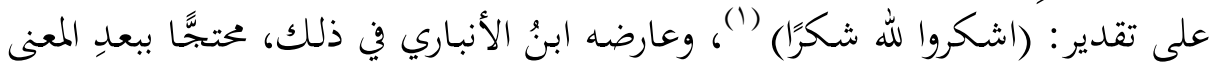
على قوله.

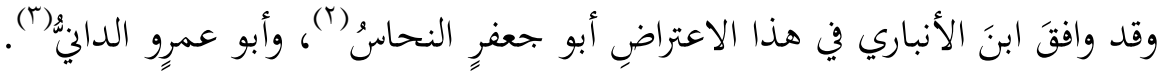

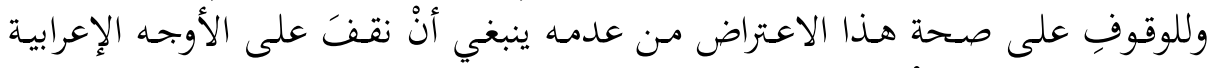

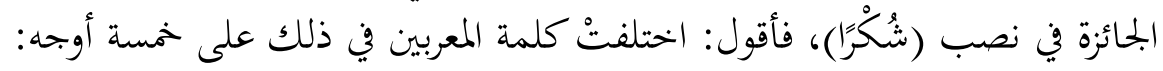

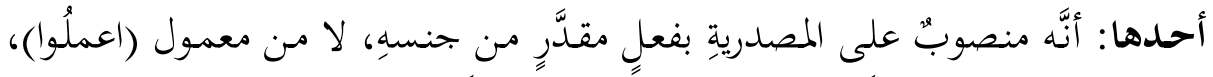

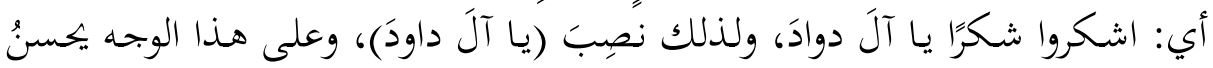

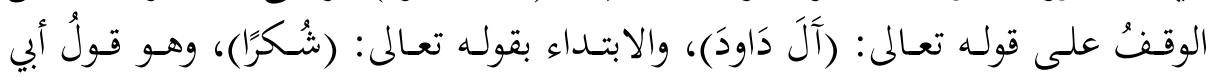

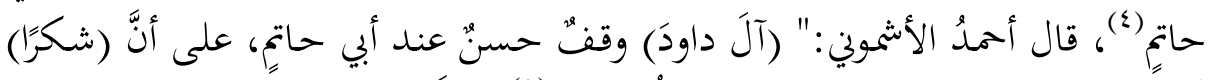

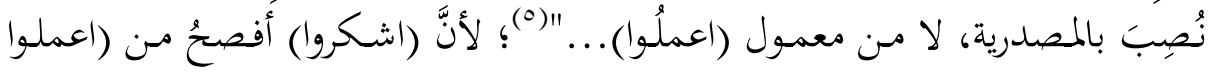

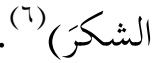

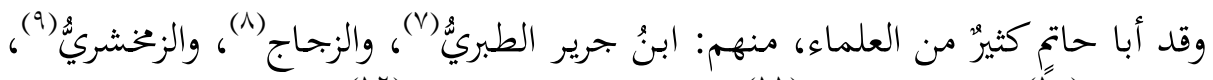

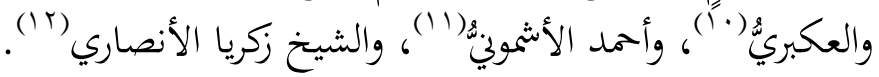

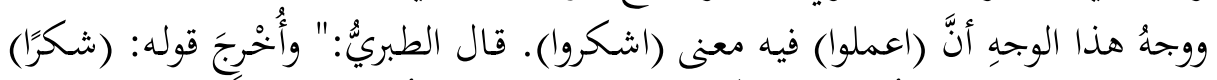

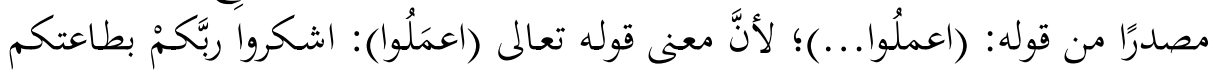

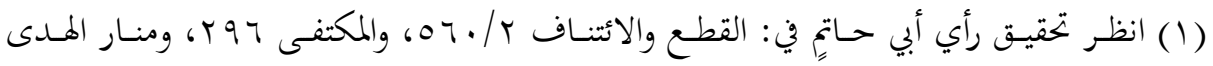
MIT

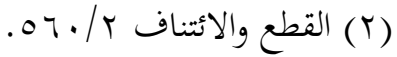

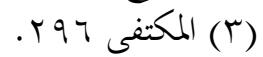

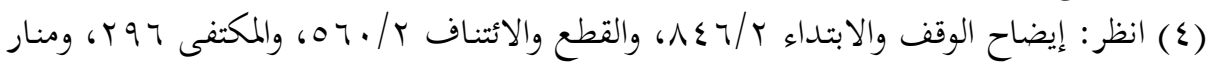

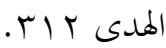

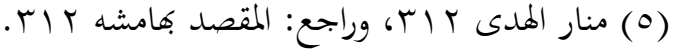

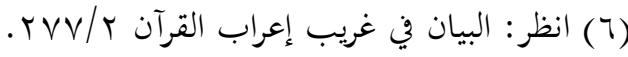

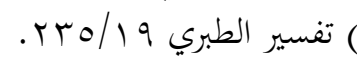

(^) 
إيَّاه، وأنَّ العملَ بالذي يُرْضي الله، لله شكرٌ، وبنحو الذي قلنّا قال أهل التأويلل" (1).

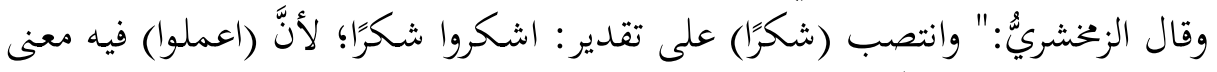

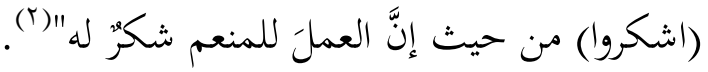

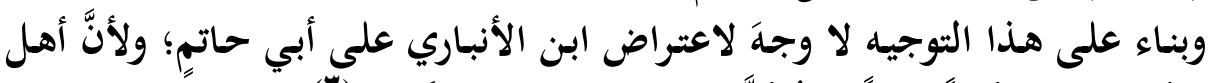

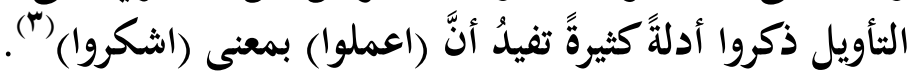

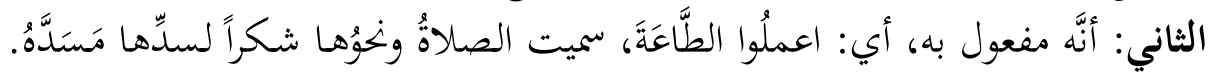

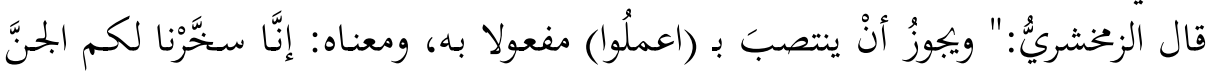

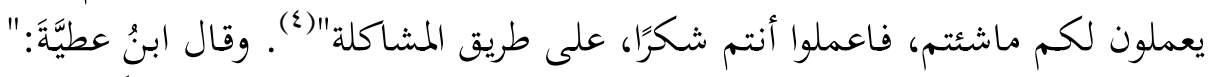

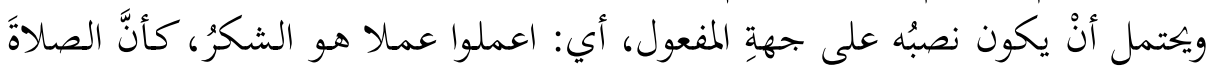

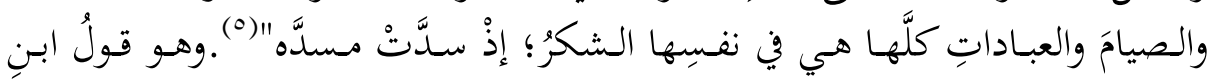

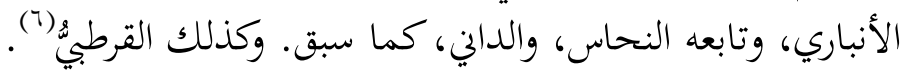

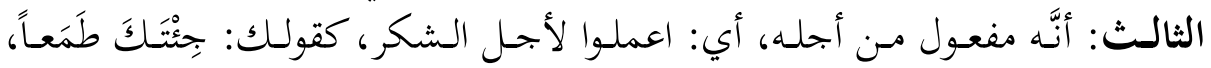

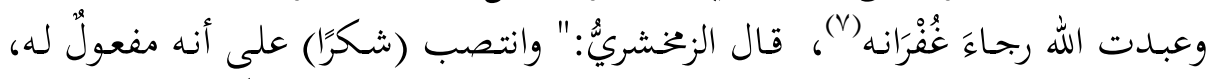

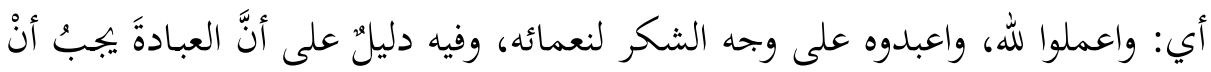

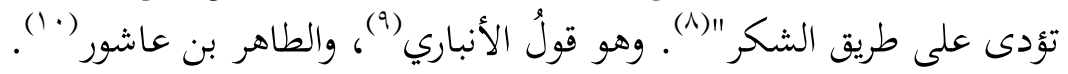

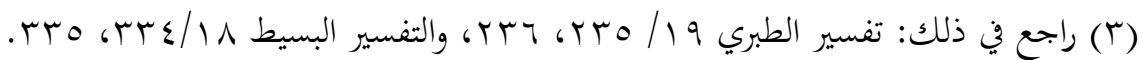
الكشاف

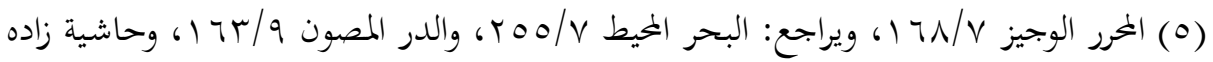

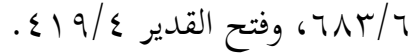

$$
\begin{aligned}
& \text { (T) تفسير القرطبي TVN/IV ) (7) }
\end{aligned}
$$

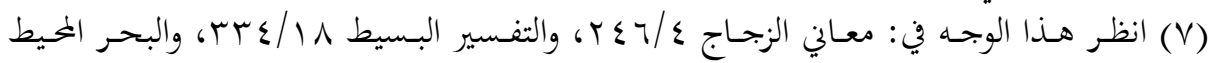

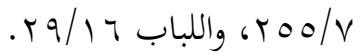

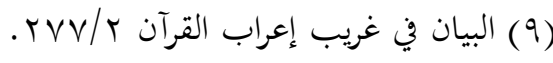

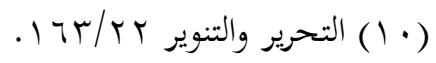




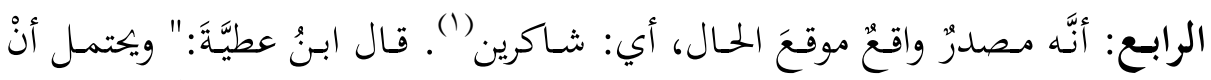

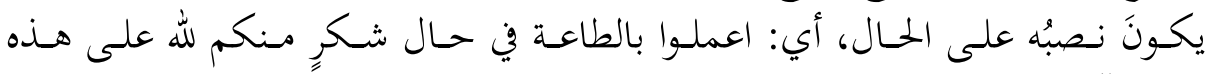

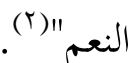

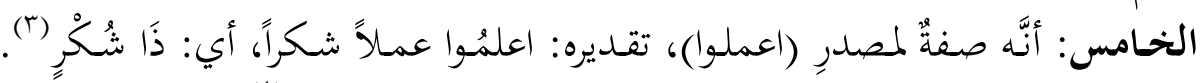

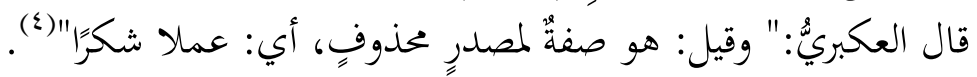

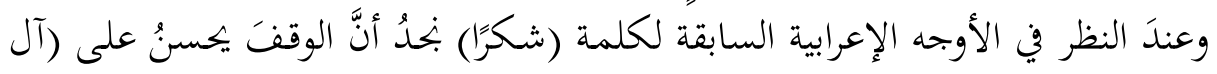

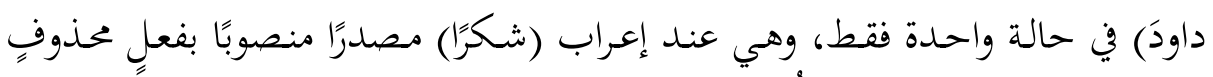

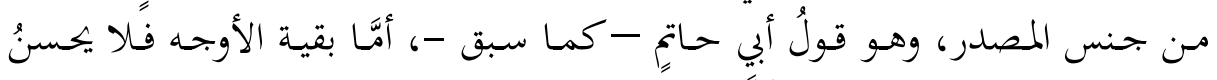

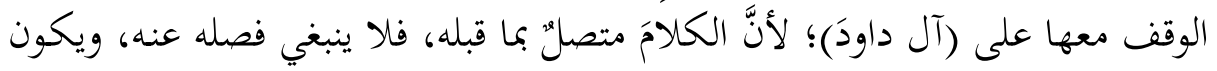

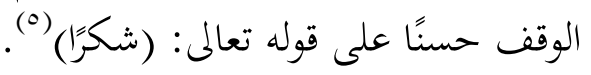
********************

\section{المسألة الحادية والأربعون: توجيهُ رفع (سَلَامُم)، ونصبِ (قَّوْلَا)}

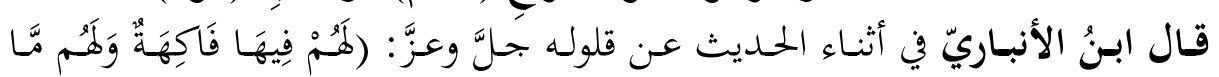

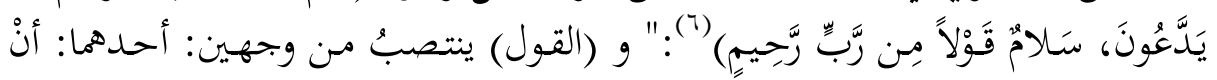

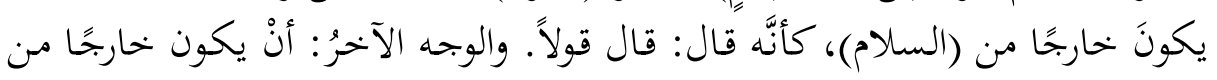

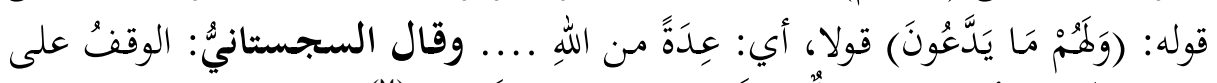

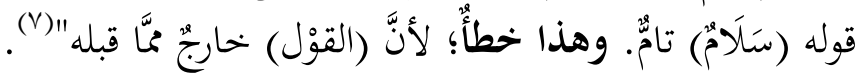

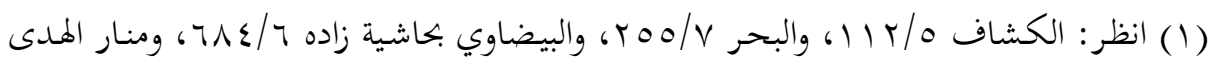
. Tा

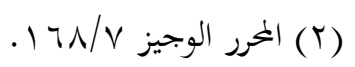

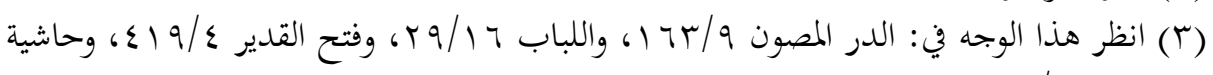

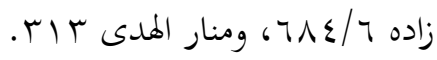

إماء

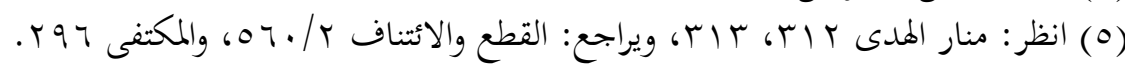




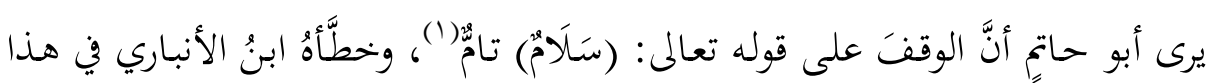

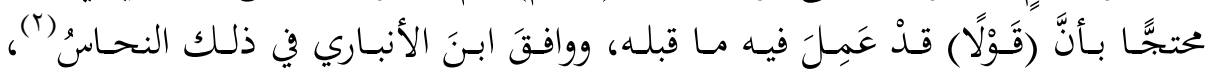

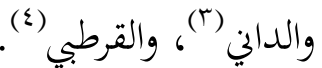

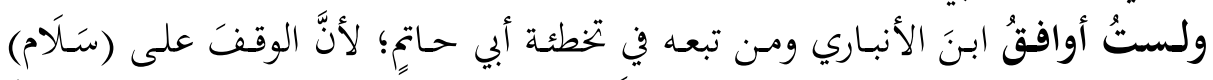

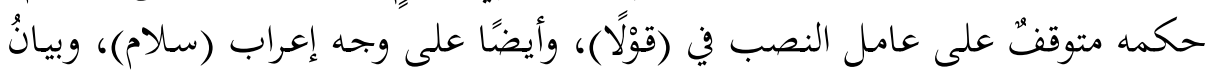
ذلك على النحو الآتي:

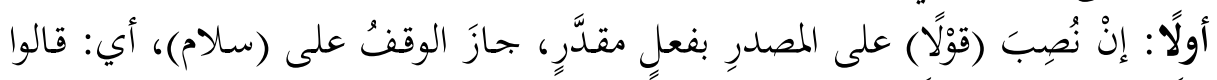

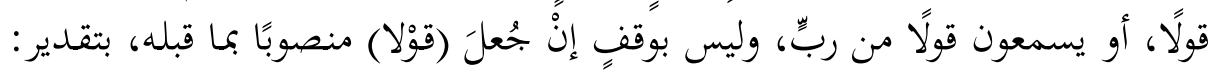

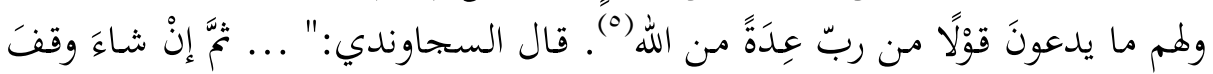

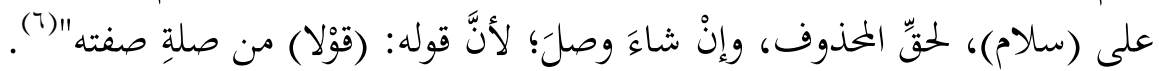

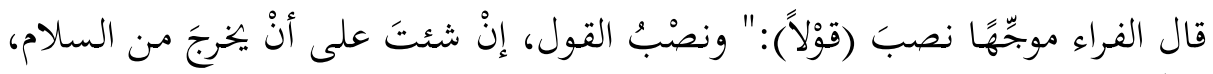

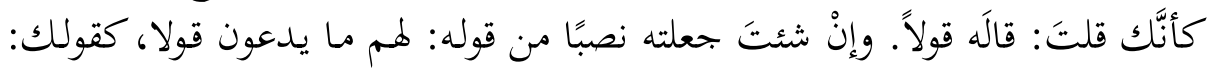

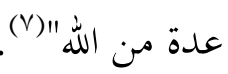

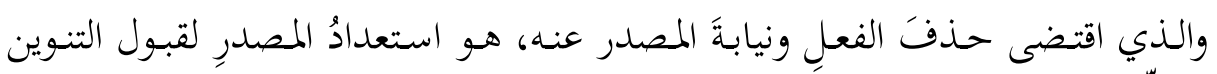

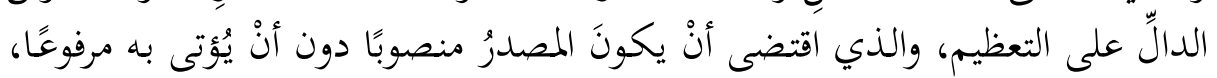

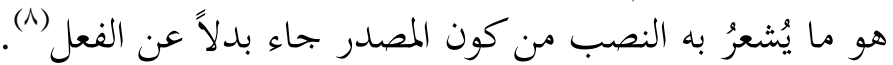

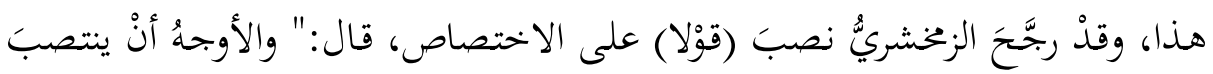

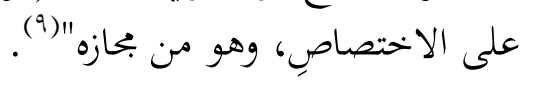

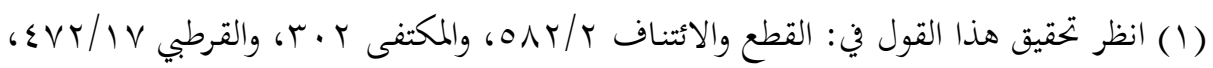

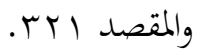

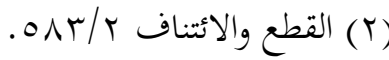

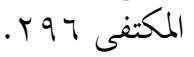

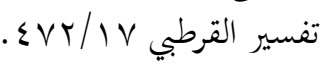

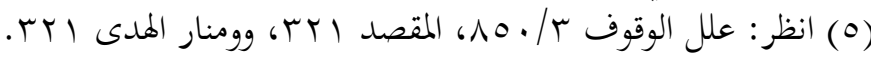

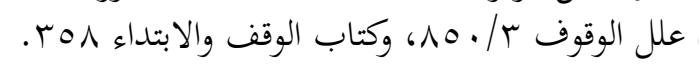

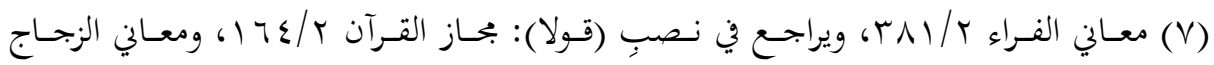

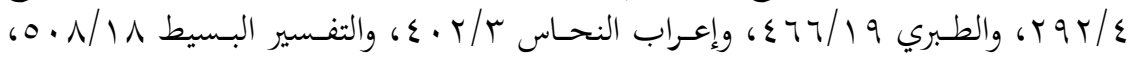

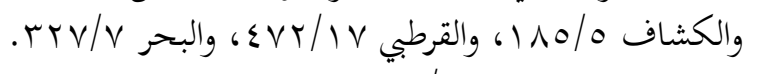

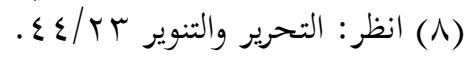

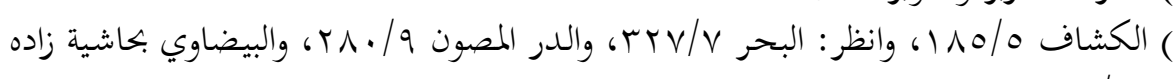

$$
.91 / \mathrm{V}
$$




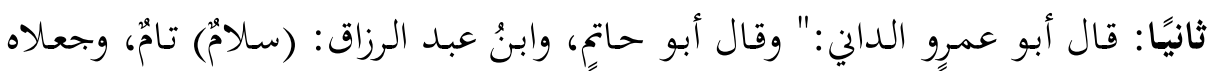

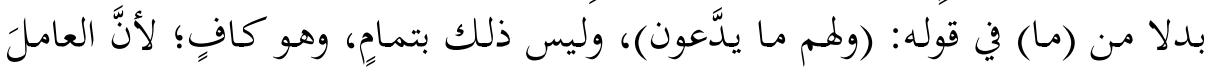

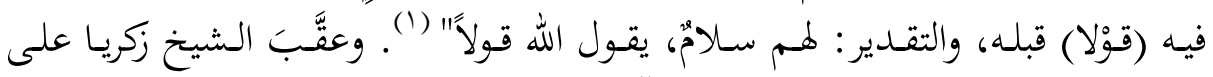

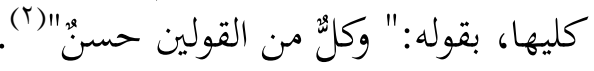

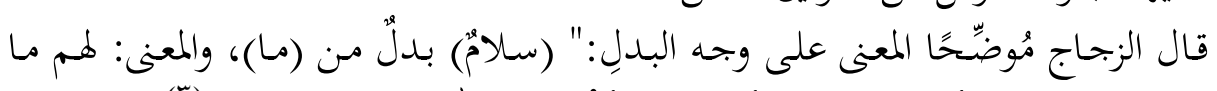

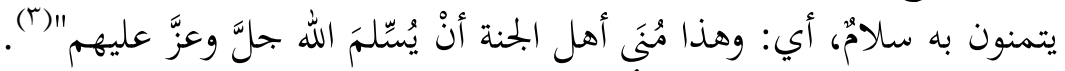

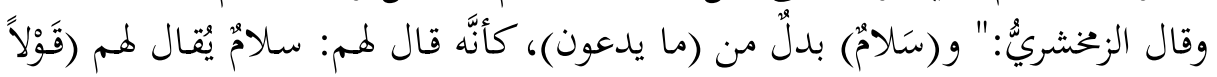

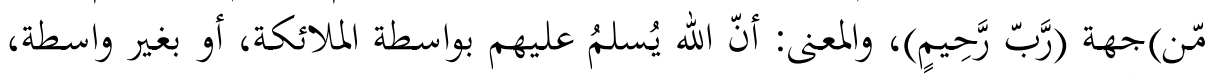

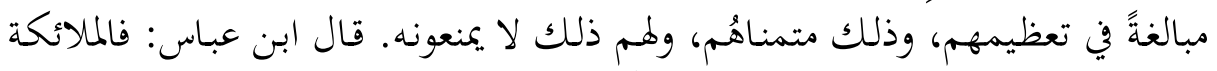

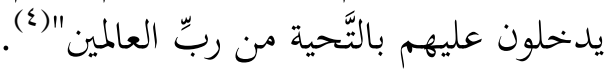

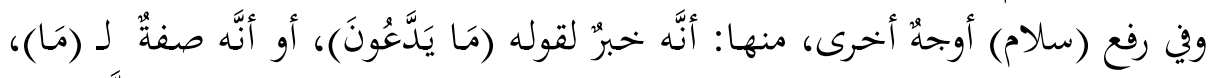

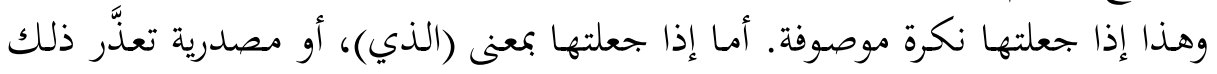

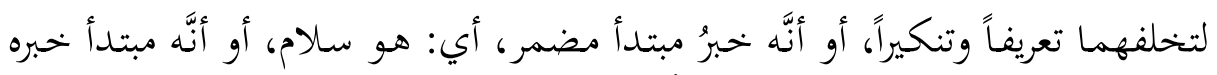

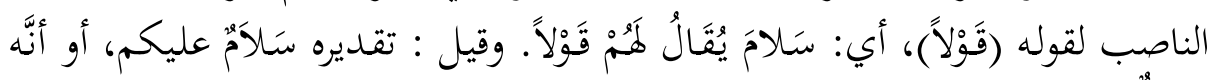

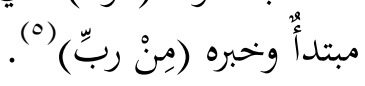

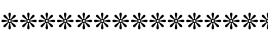

المسألة الثانية والأربعون: إعراب قوله تعالى: (أَتَخَذْنَأهُمْ)

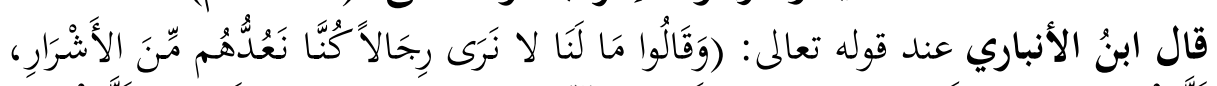

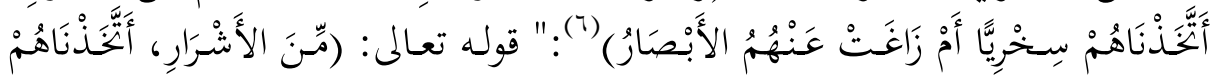

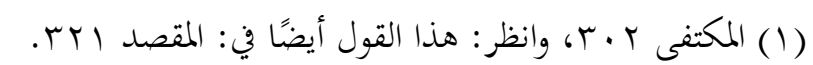

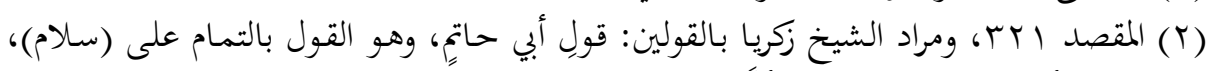

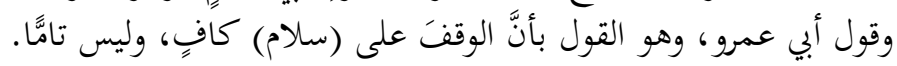

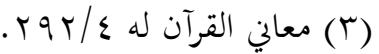

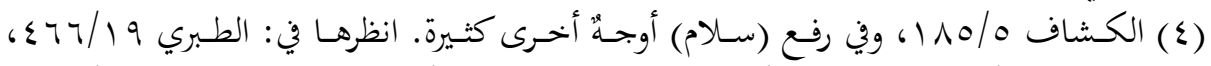

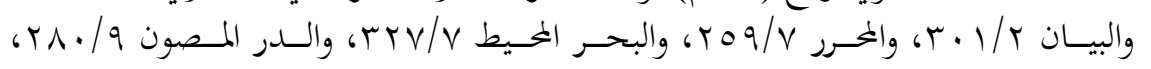

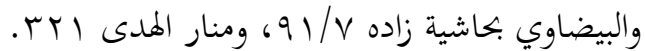

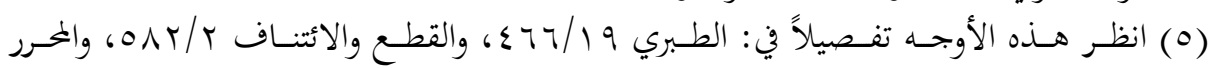


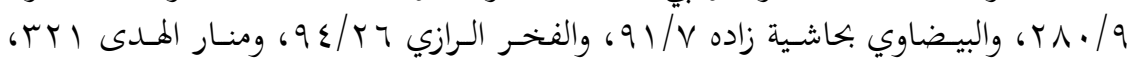

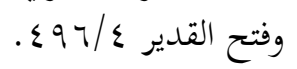

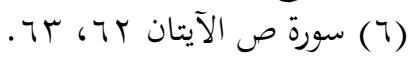




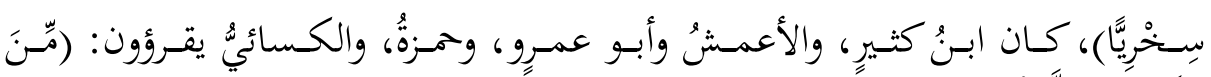

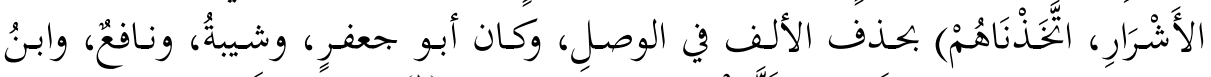

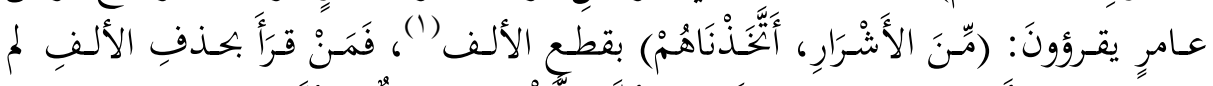

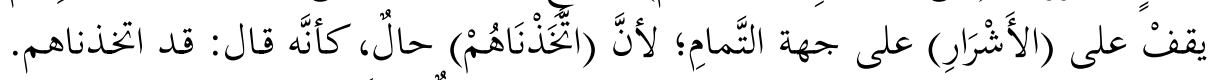

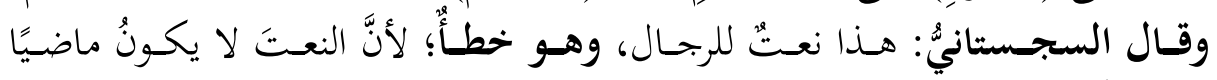

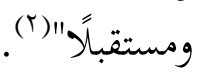

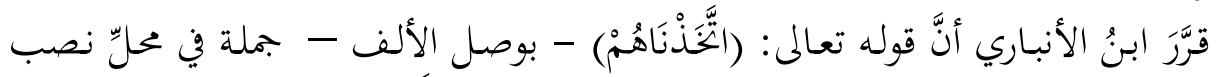

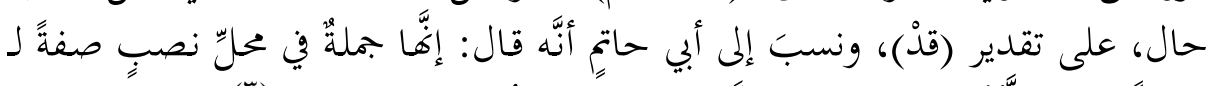

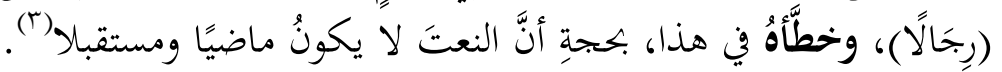

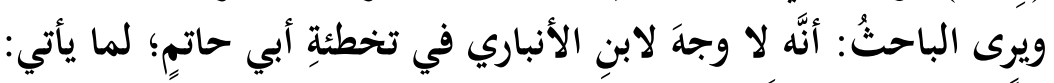

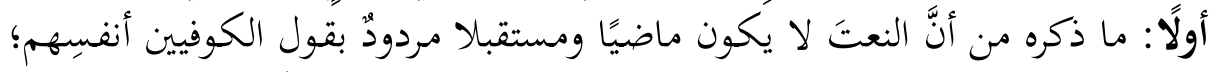

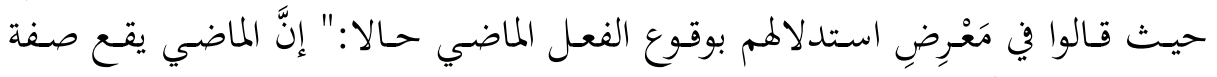

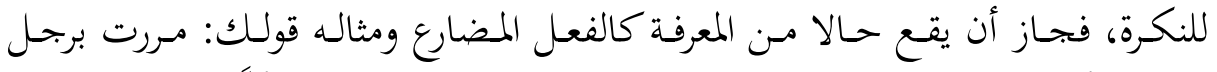

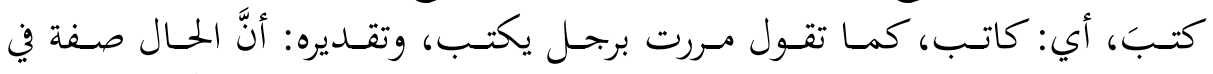

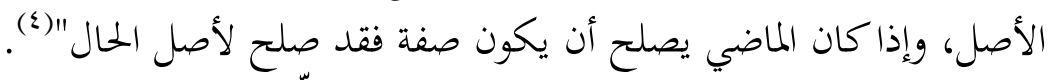

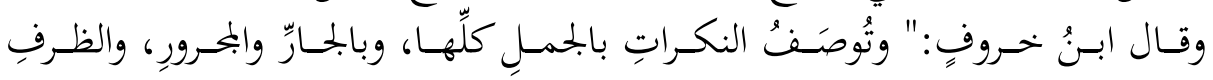

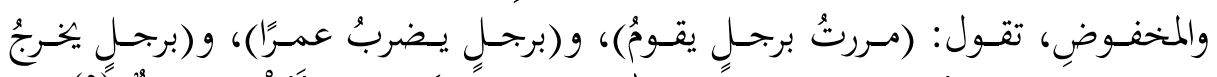

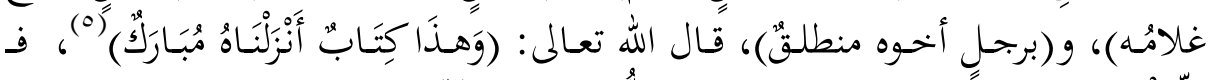

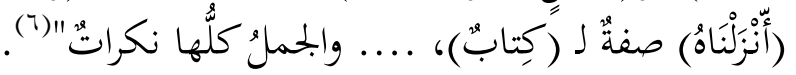

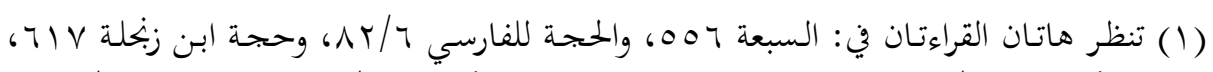

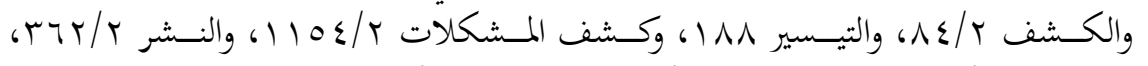

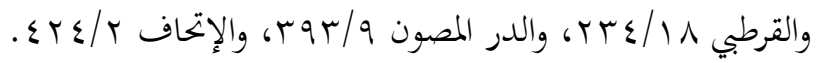

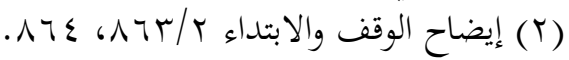

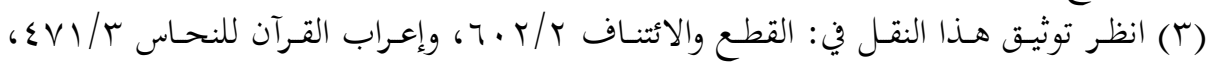

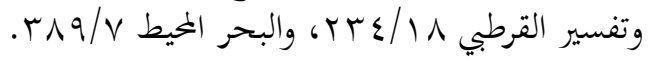

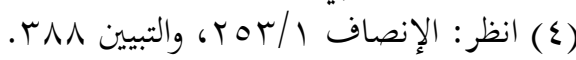

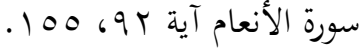

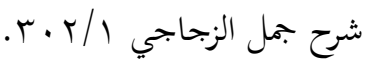




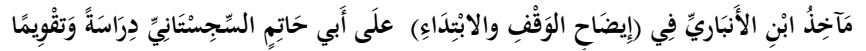

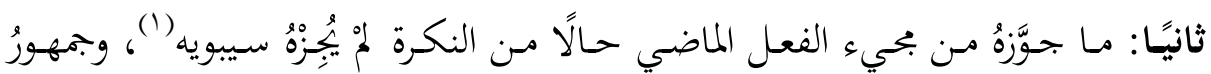

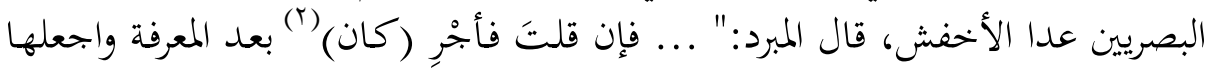

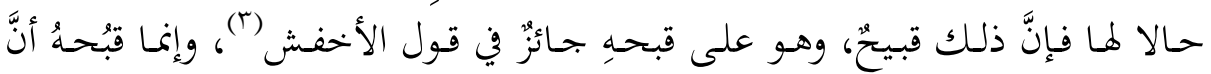

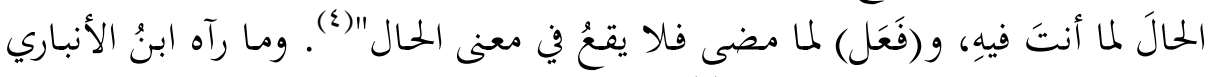

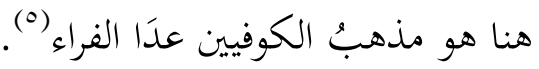

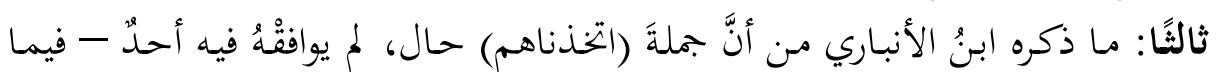

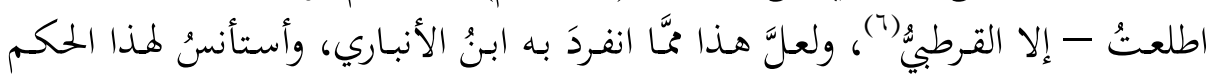

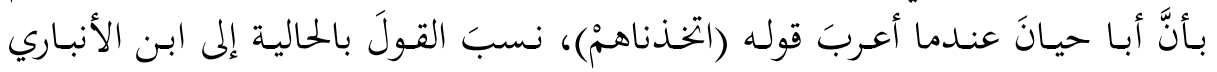
فقط (V)

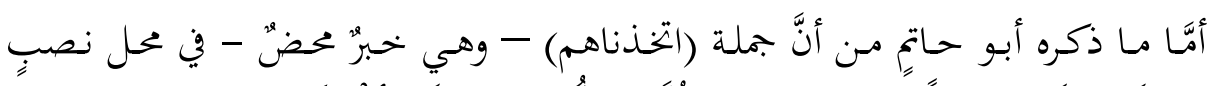

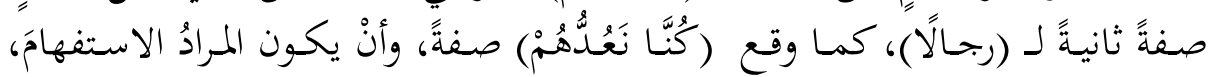

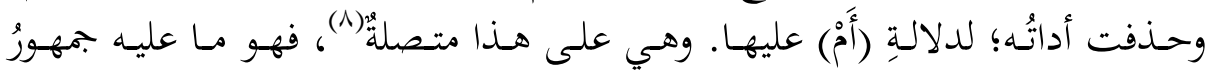
(9) المعربين (9)

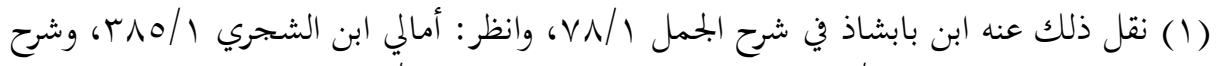

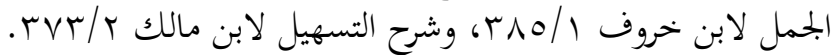

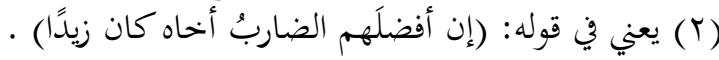

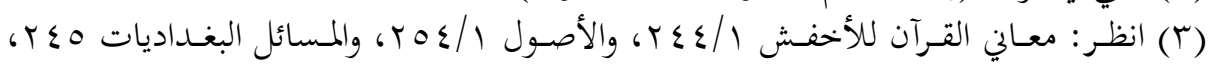

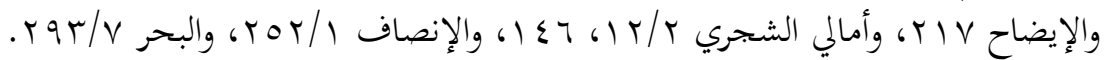

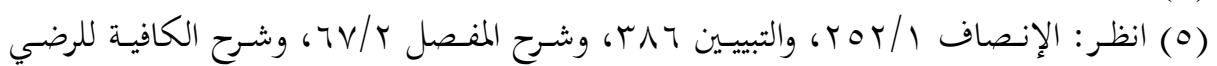

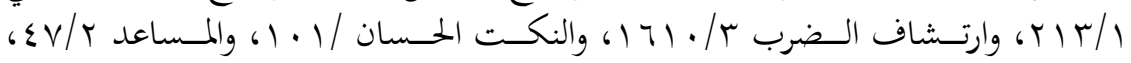

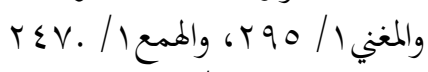

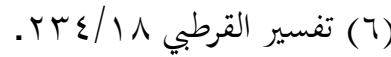

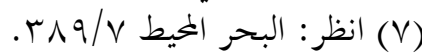

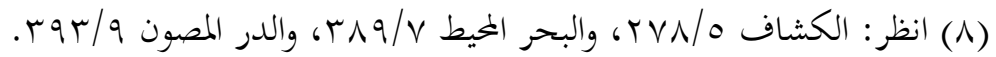

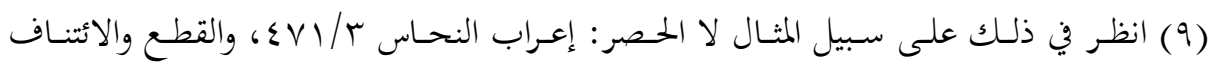

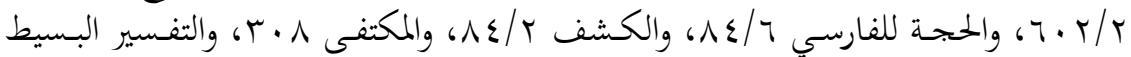

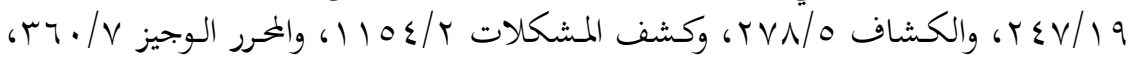

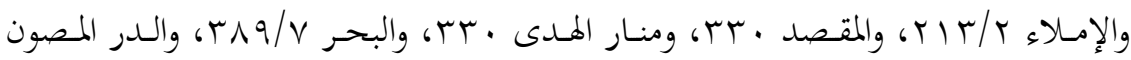
ـ ـ 


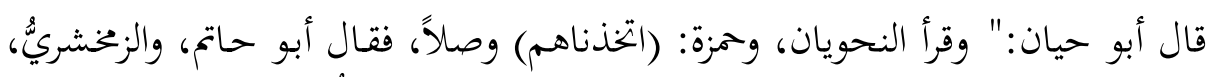

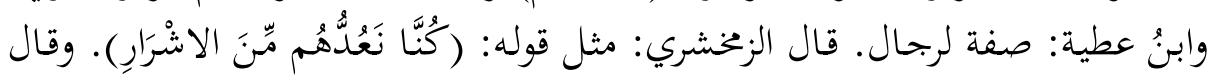

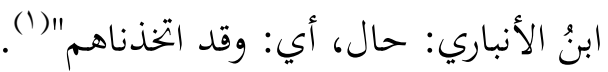

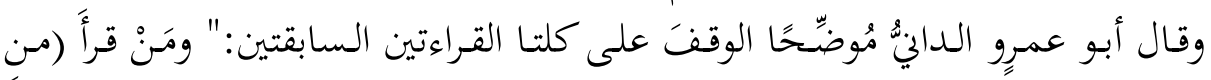

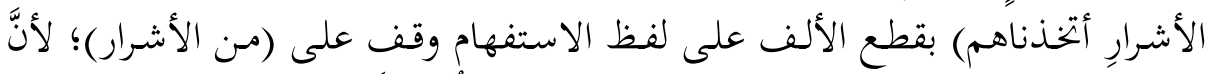

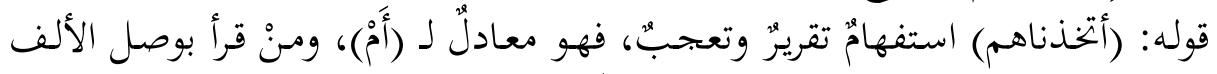

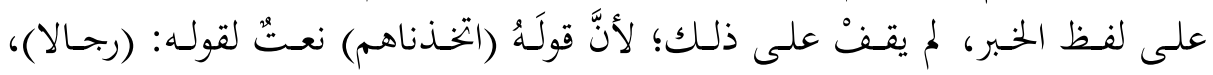

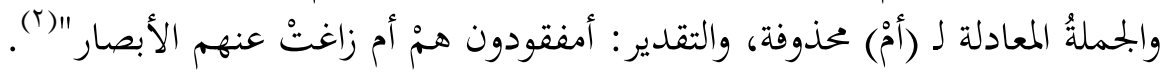
***********************1*

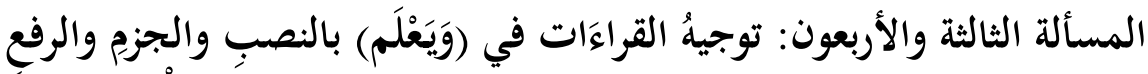

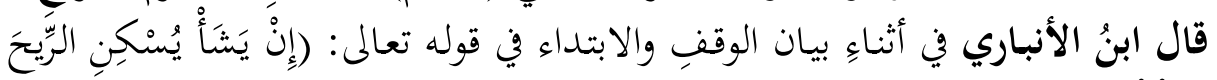

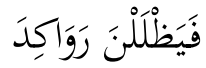

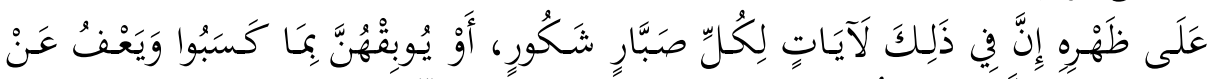

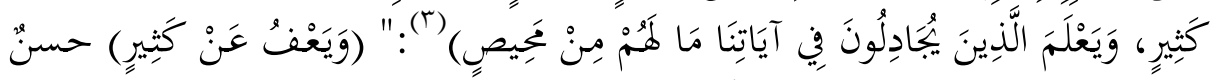

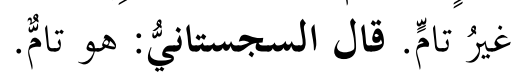

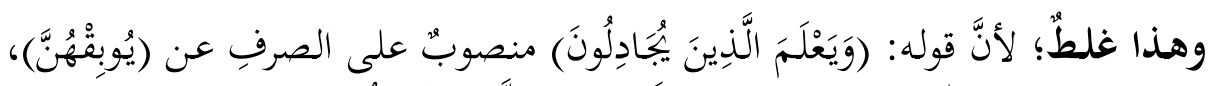

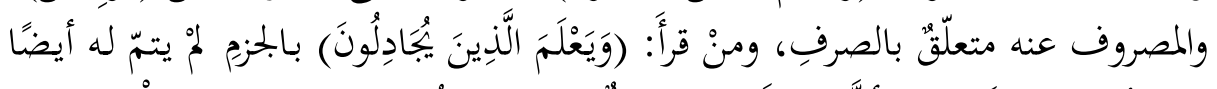

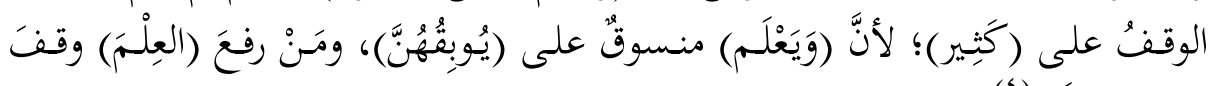

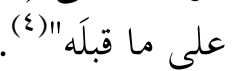

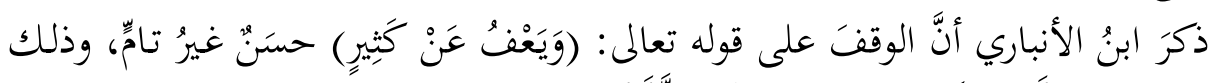

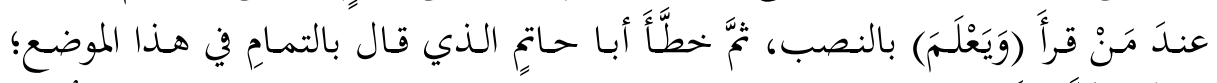

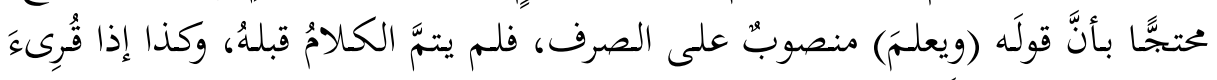

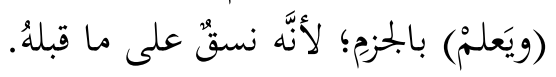




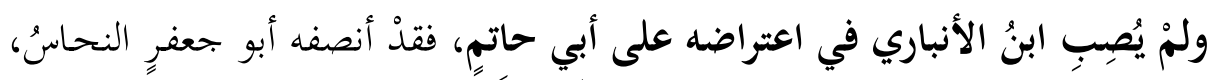

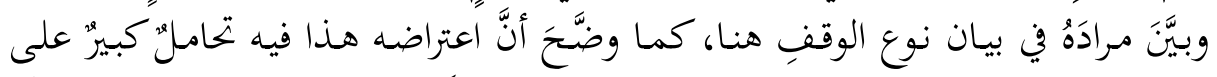

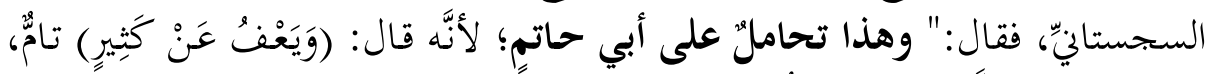

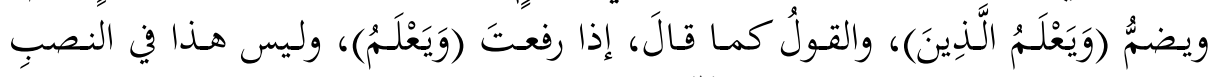

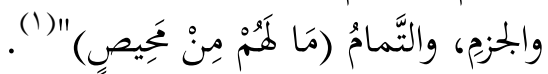

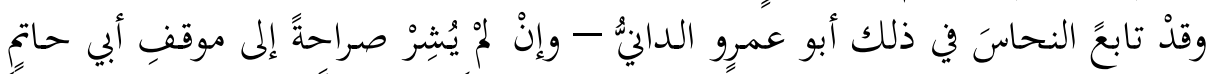

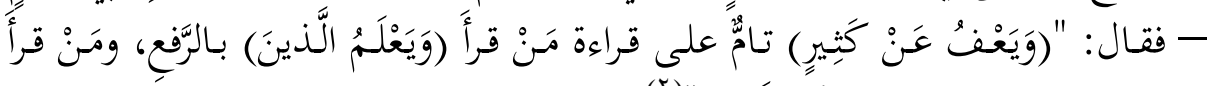

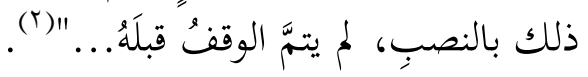

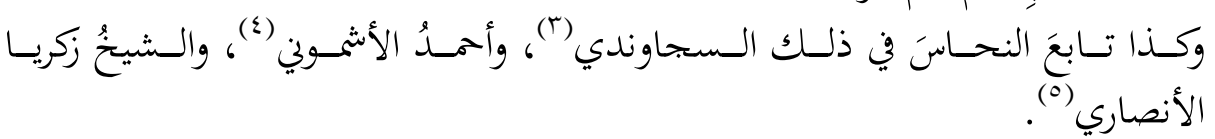

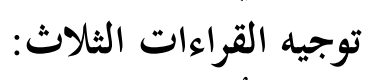

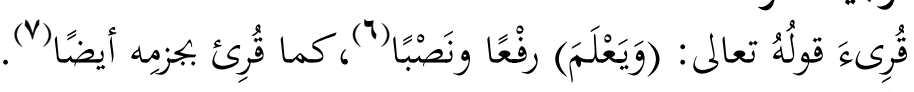

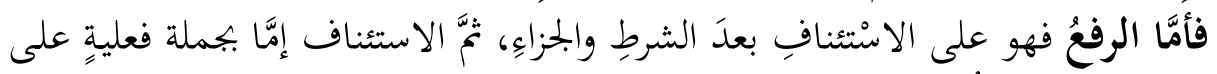

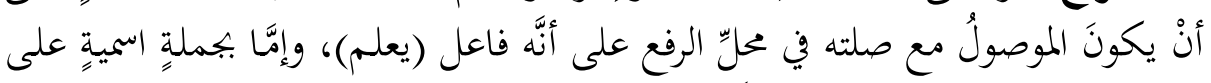

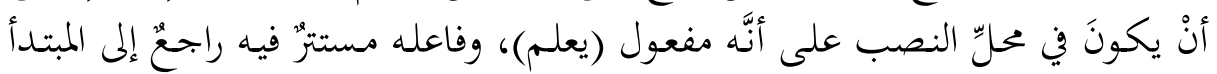

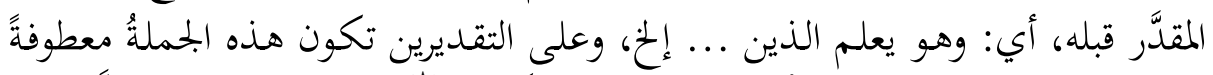

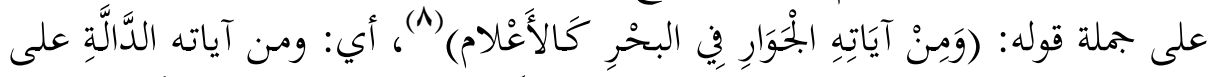

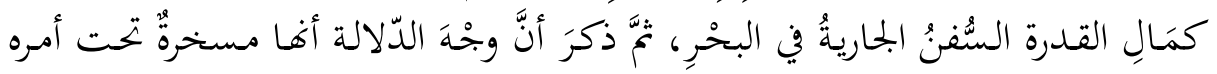

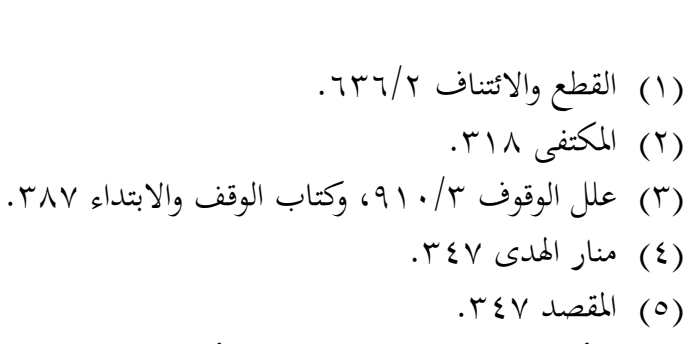

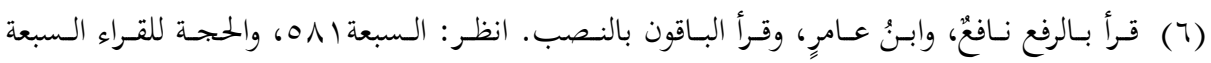

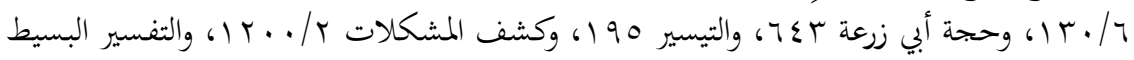
每

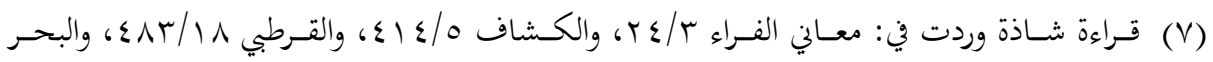

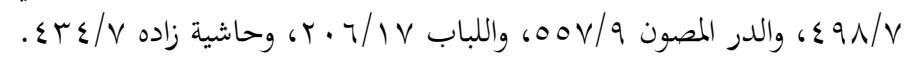




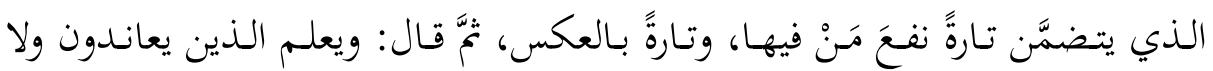

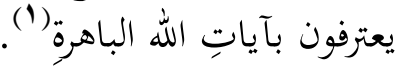

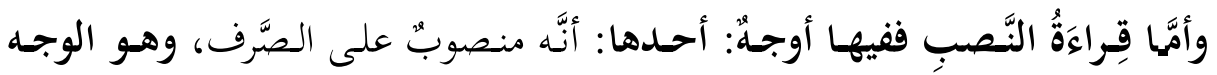

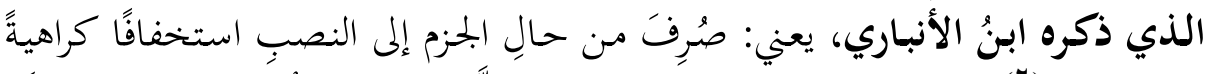

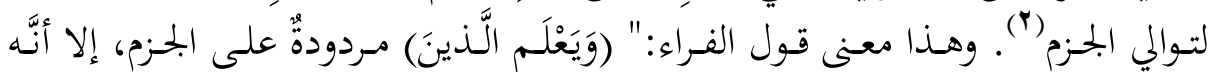

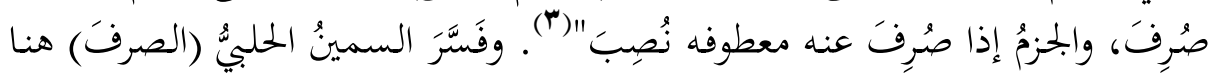

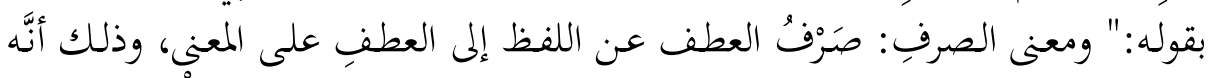

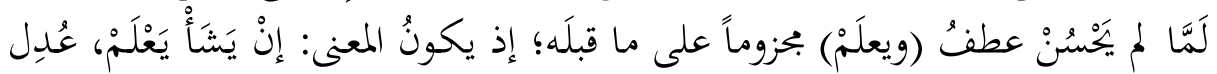

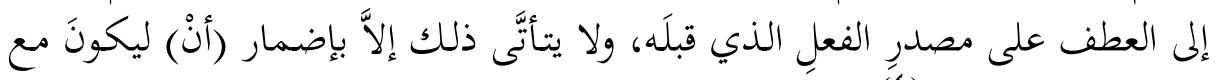

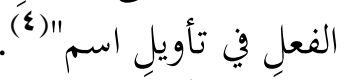

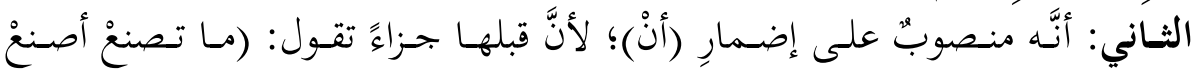

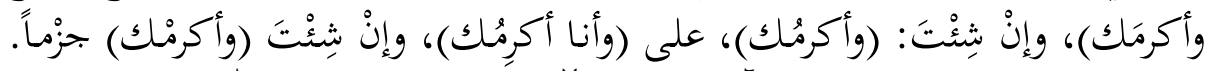

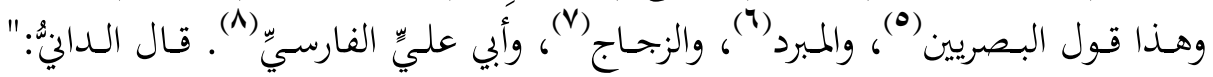

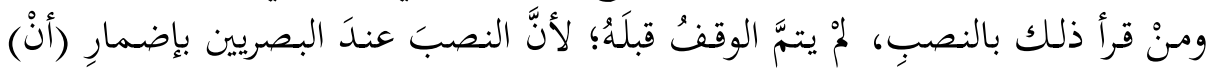

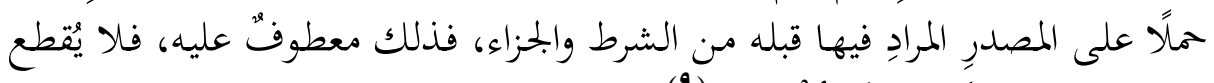

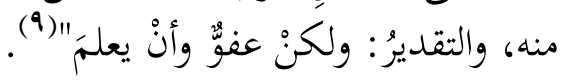

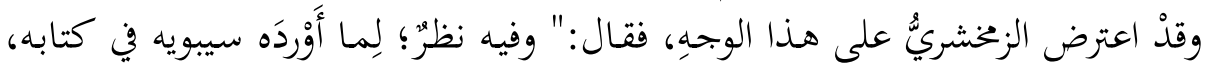
قال:

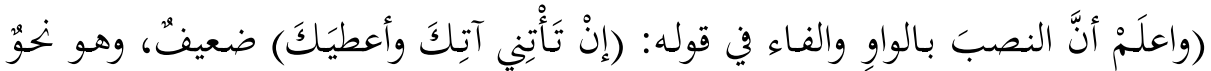

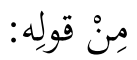

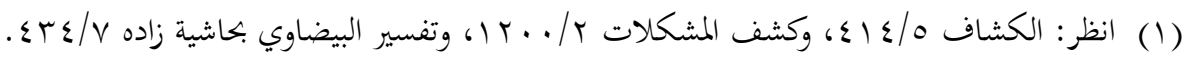

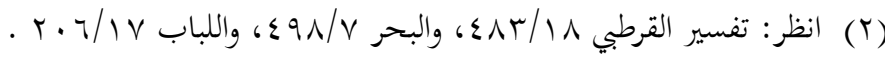

$$
\begin{aligned}
& \text { ) }
\end{aligned}
$$

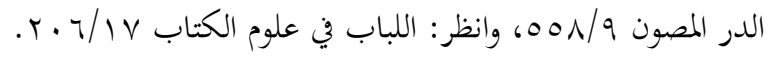

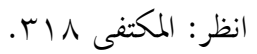

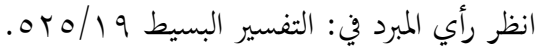

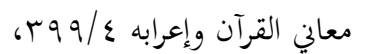

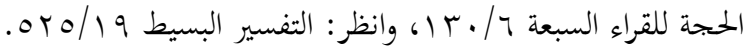

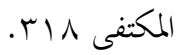




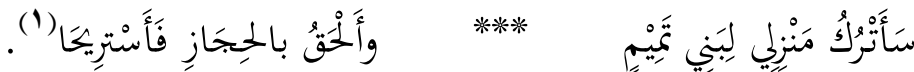

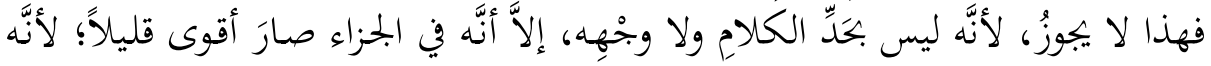

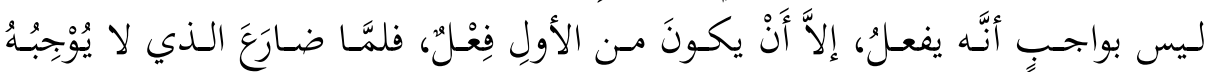

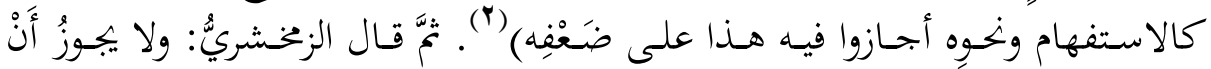

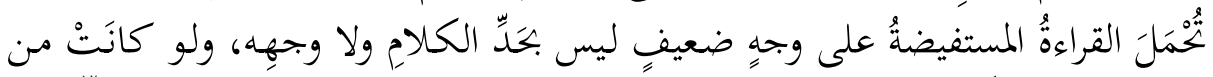

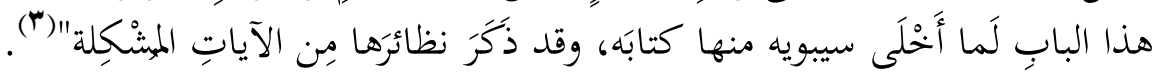

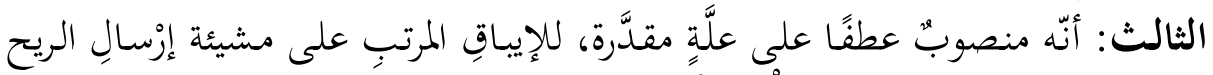

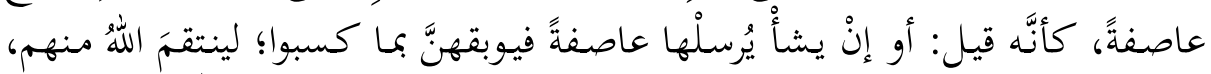

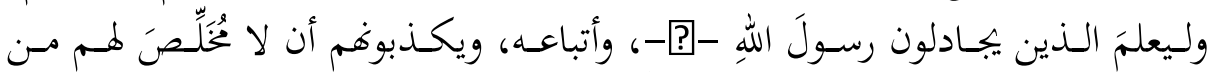

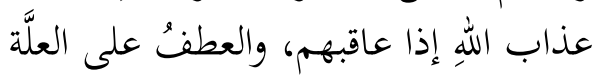

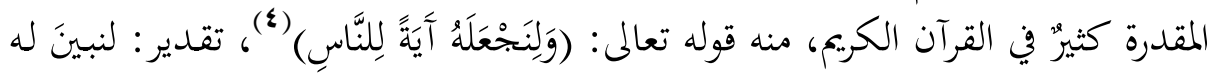
قدرتنا ولِنجعَلَه

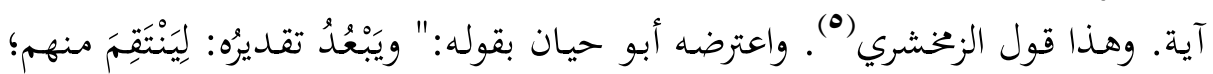

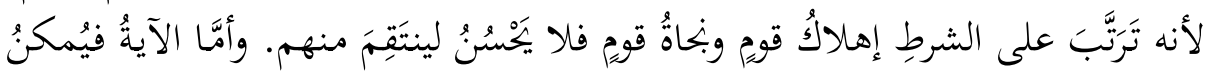

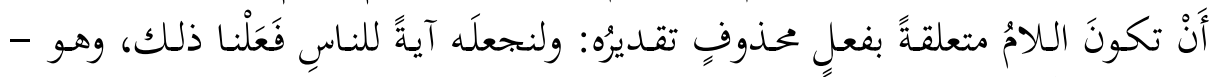

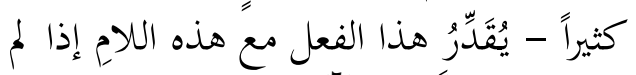

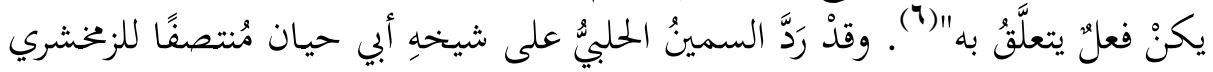
بقوله:" بل بل فعل بتعليق

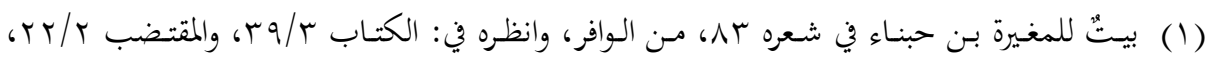

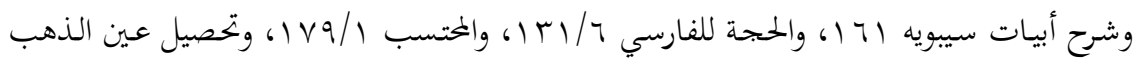

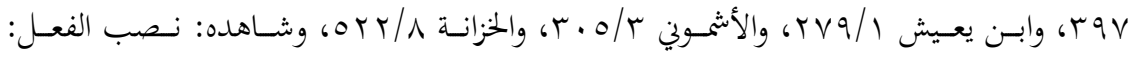

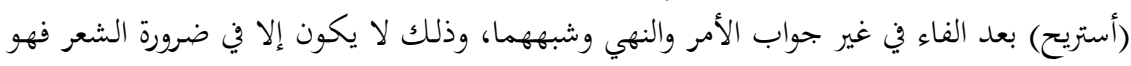
ضعيف كما قال سيبويه.

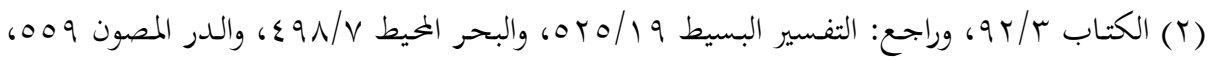

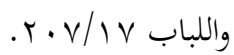

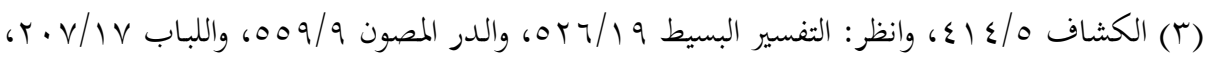

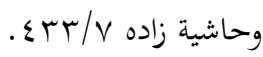

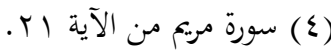

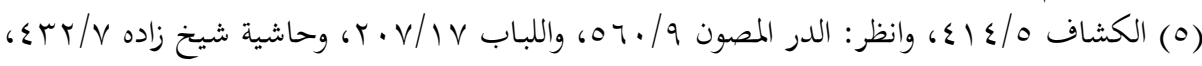




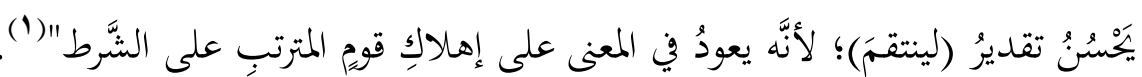

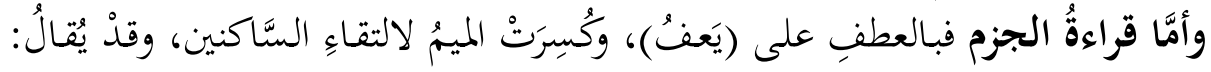

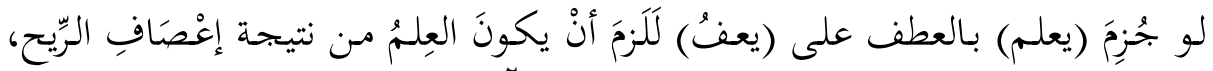

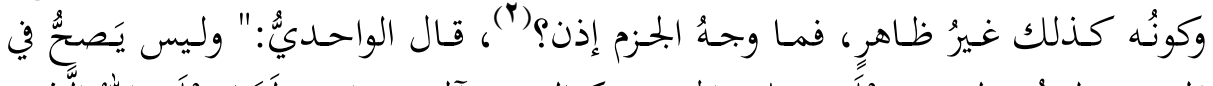

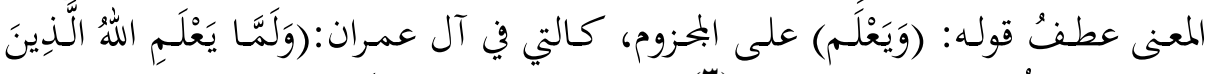

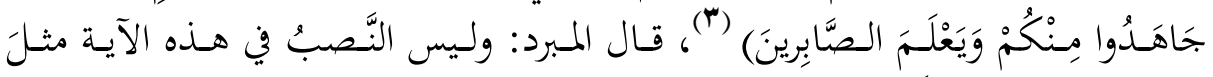

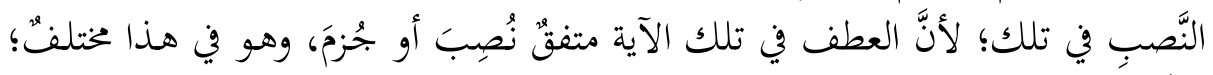

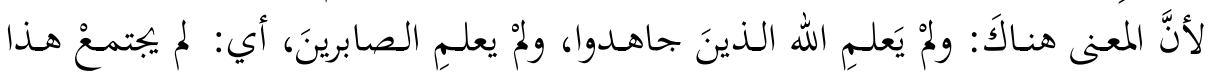

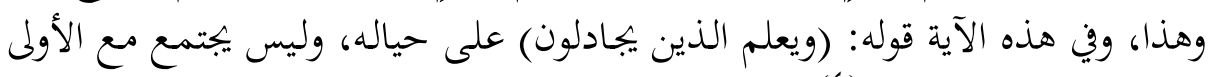

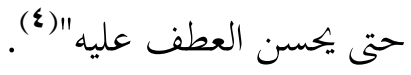

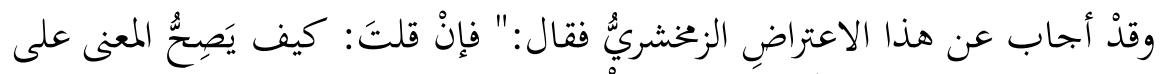

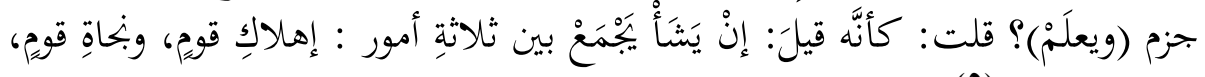

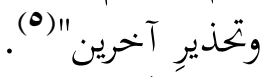

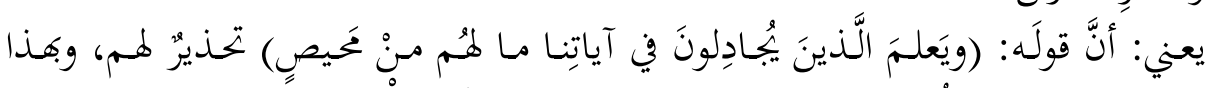

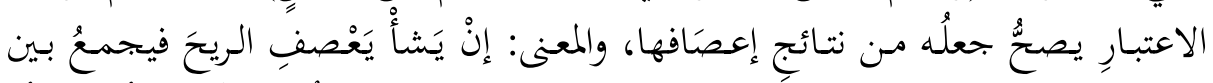

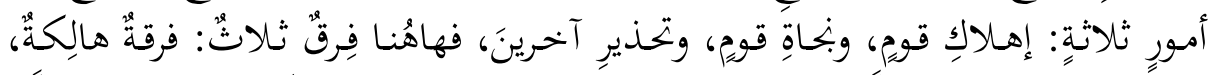

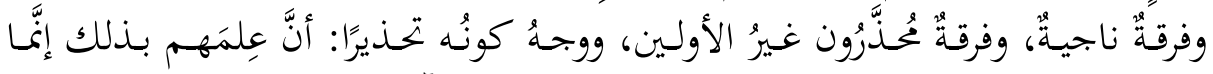

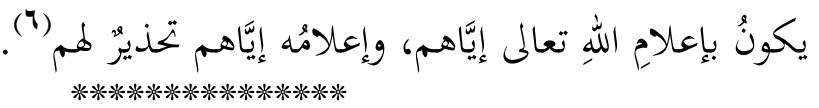
المسألة الرابعة والأربعون: موقع قوله تعالى: (إنْ هُوَ إلآَّ وَحْيُ يُوحَى) من الإعراب

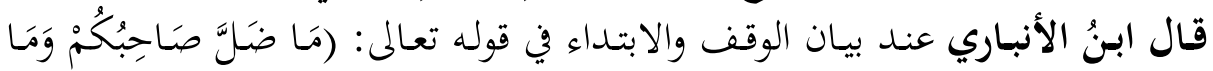

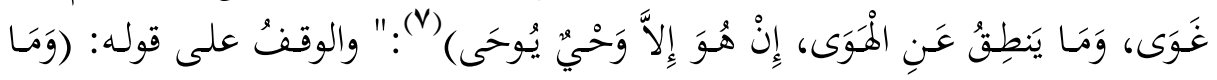

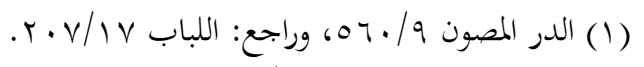

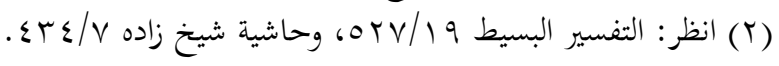

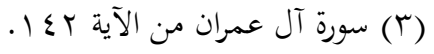

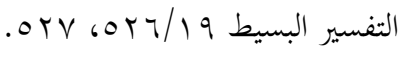

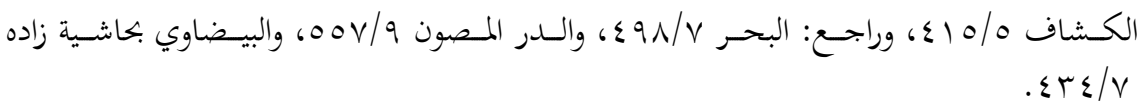

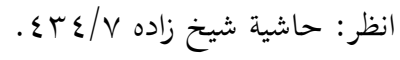

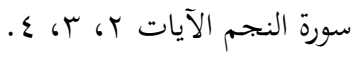




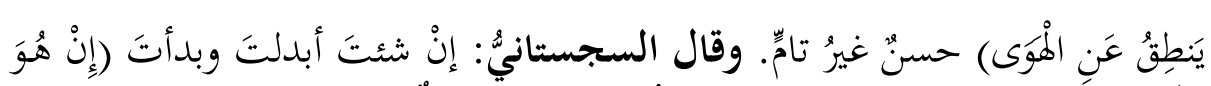

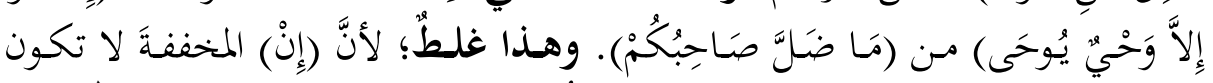

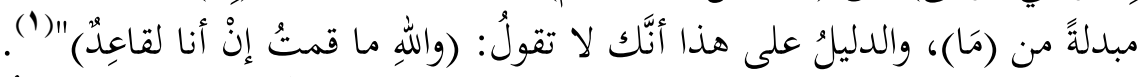

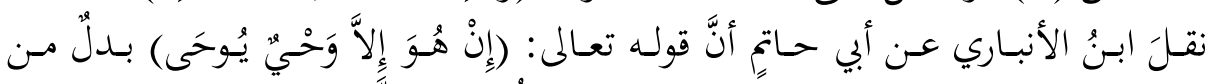

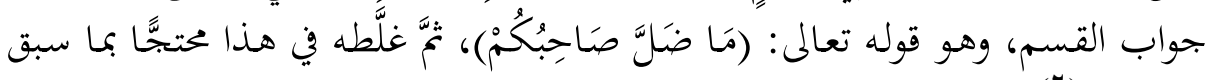

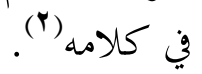

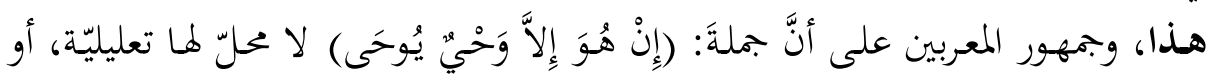

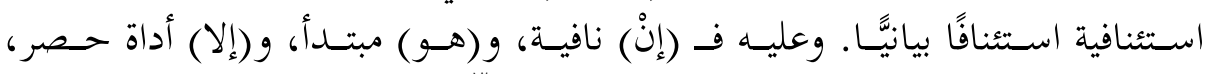

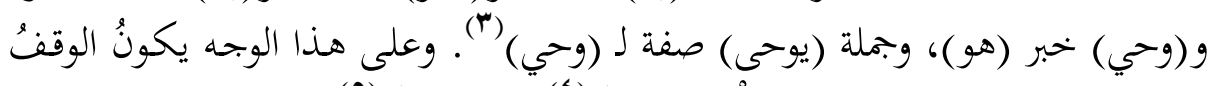

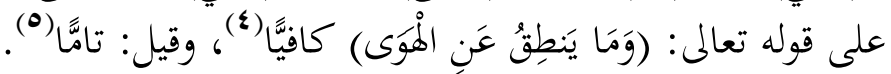

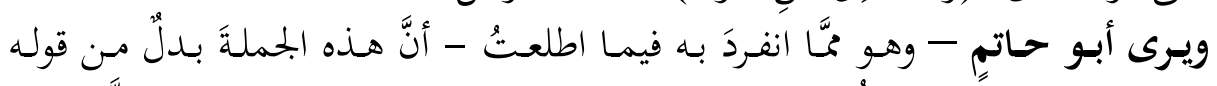

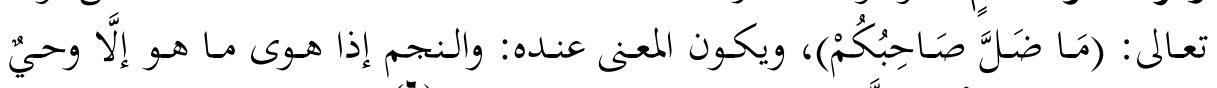

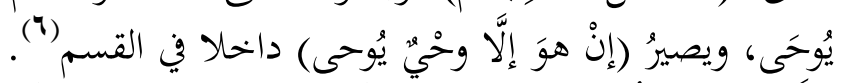

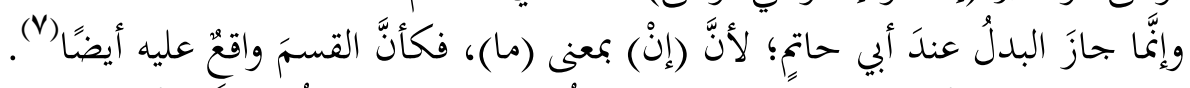

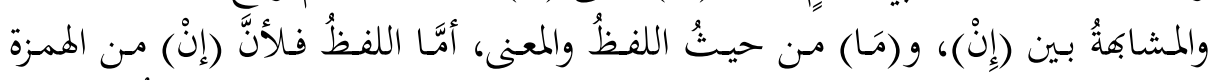

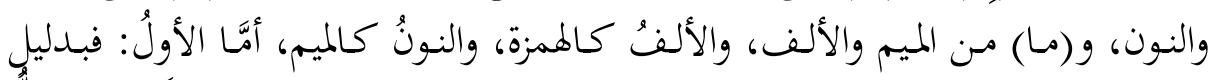

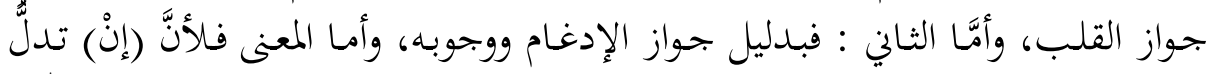

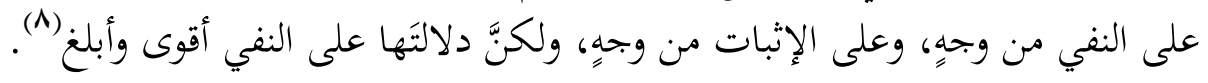

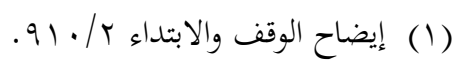

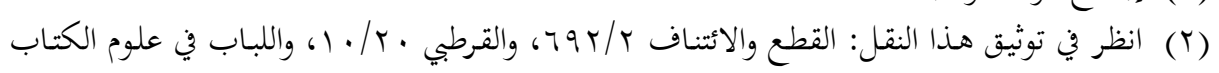

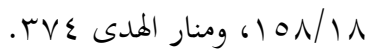

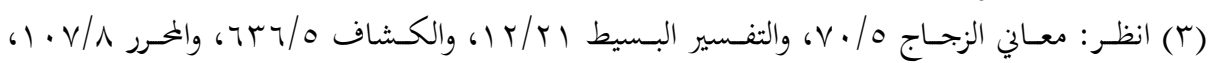

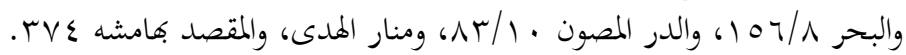

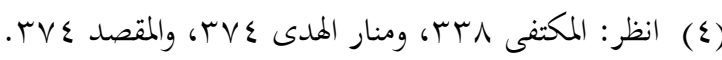

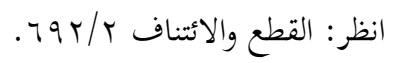

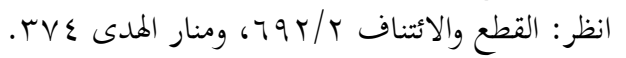

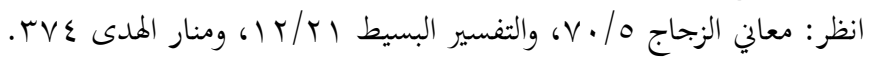

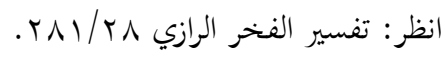




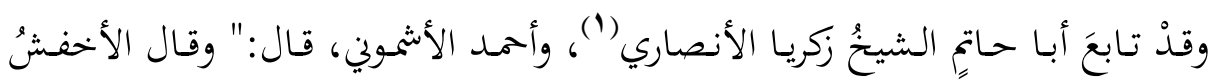

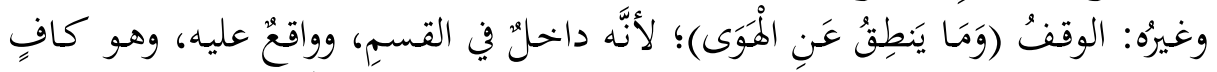

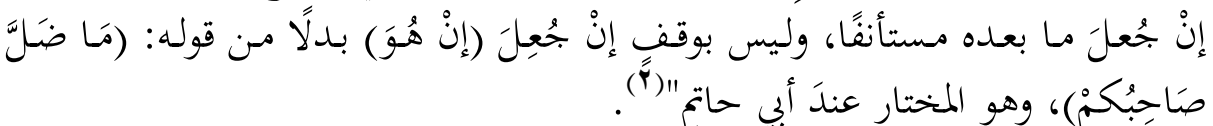

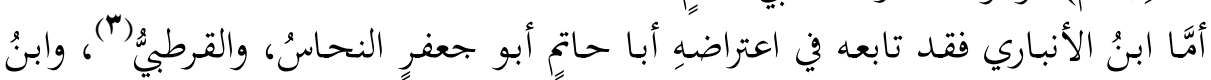

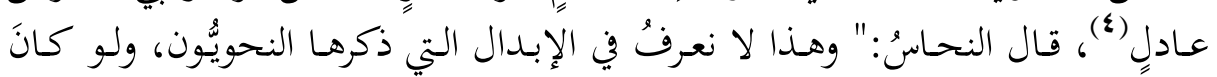

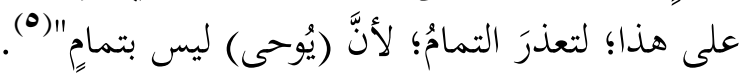

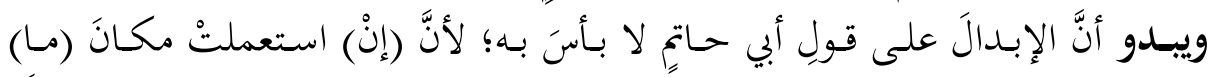

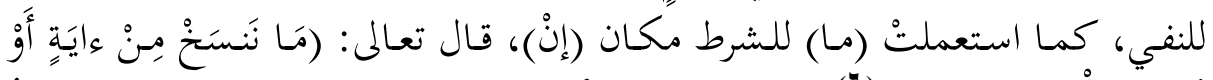

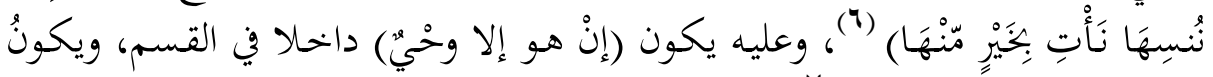

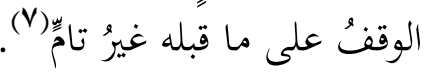

المسألة الخامسة والأربعون: نوع (ما) في قوله تعالى: (فَأَصْحَحَابُ الْمَيْمَنَّة مَا

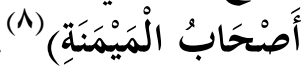

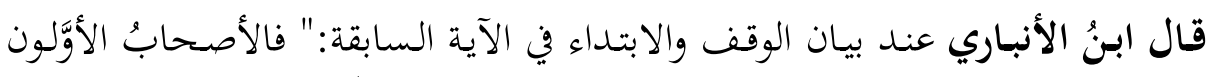

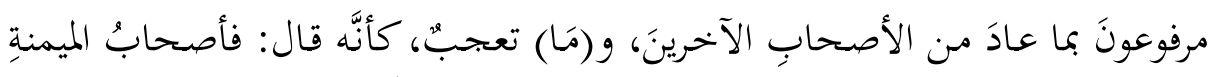

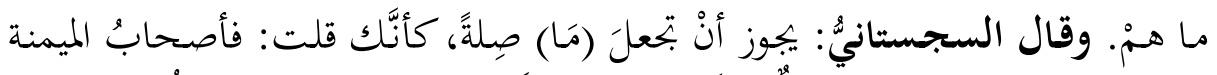

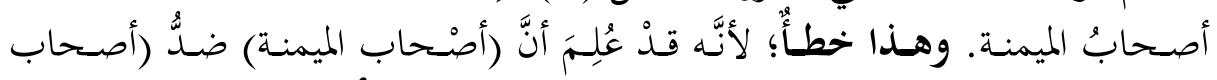

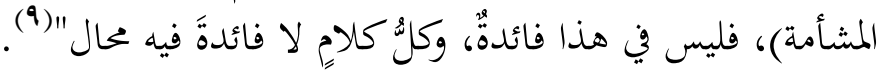

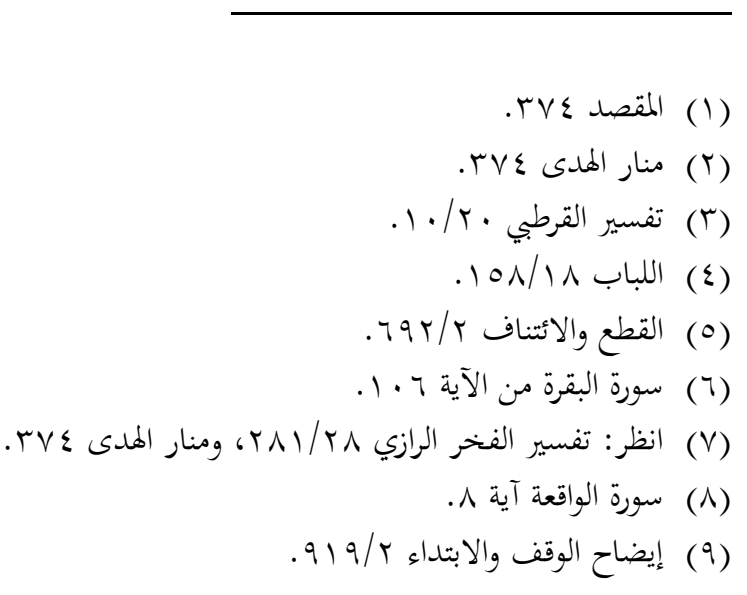




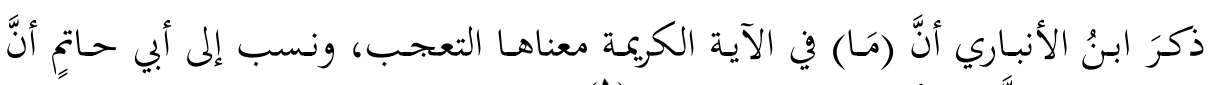

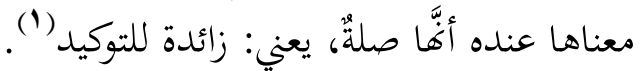

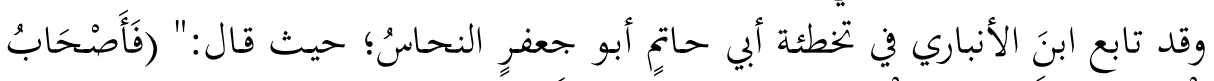

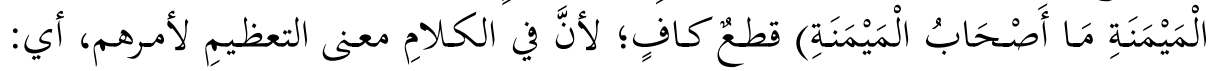

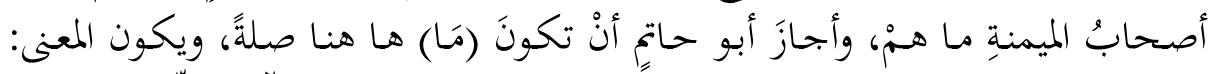

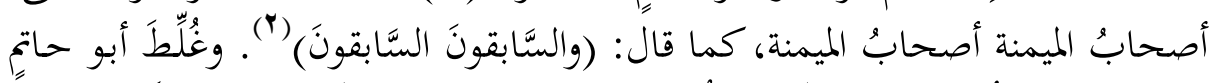

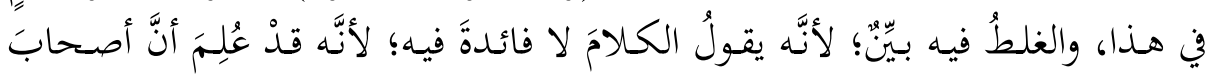

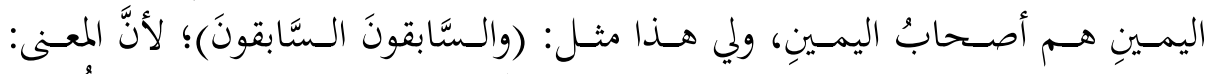

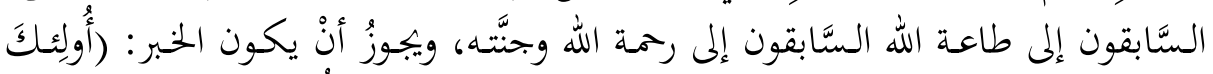

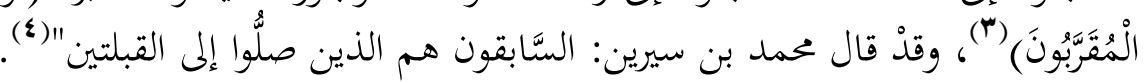

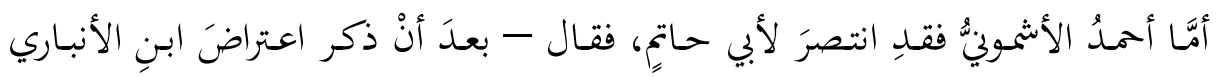

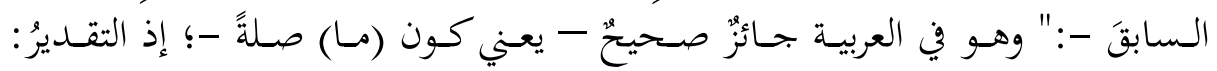

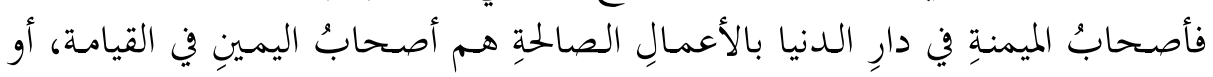

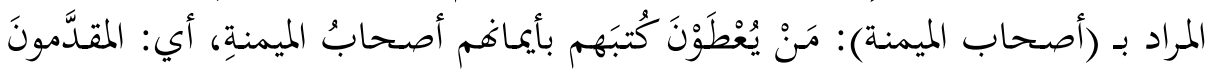

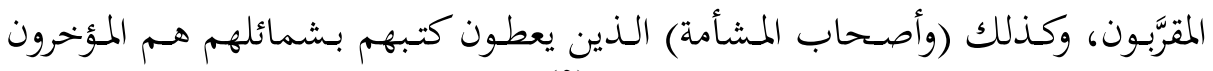

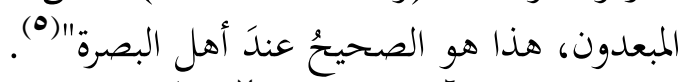

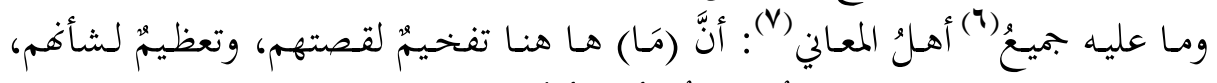

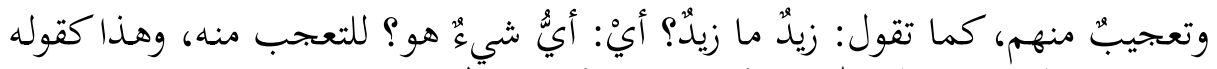

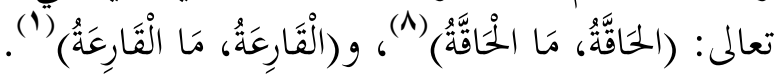

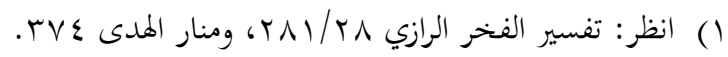

$$
\begin{aligned}
& \text { سورة الواقعة آية • 1. }
\end{aligned}
$$

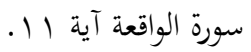

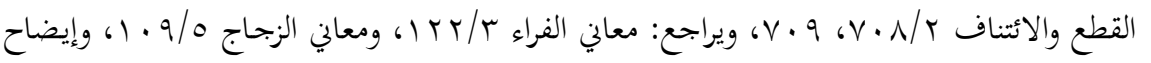

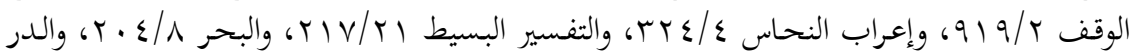

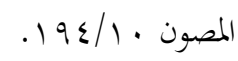

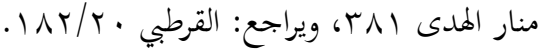

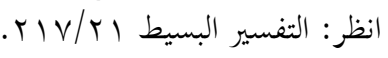

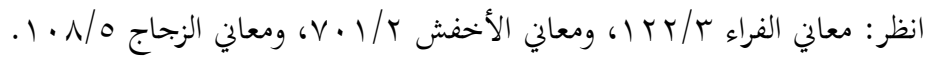




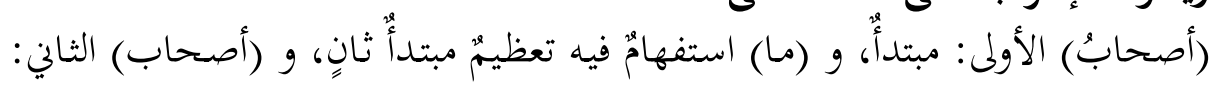

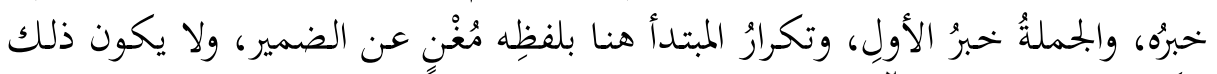

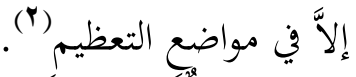

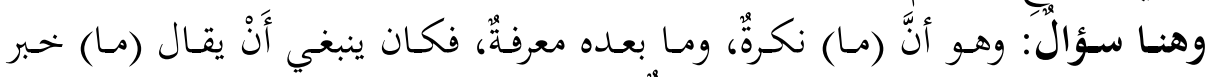

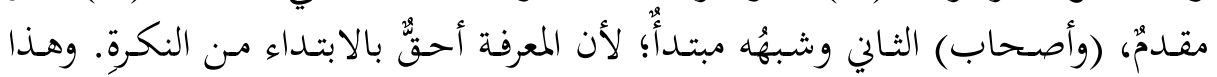

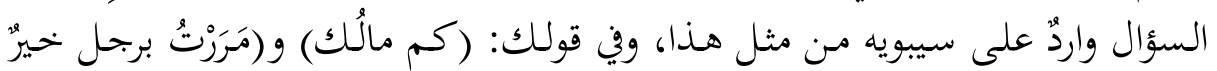

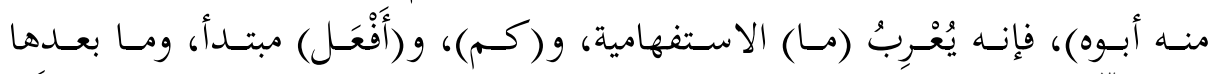

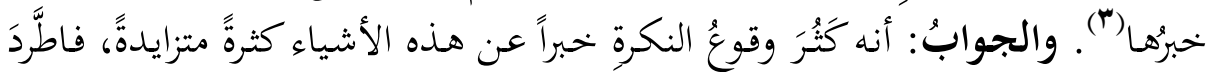

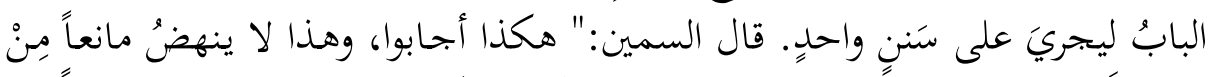

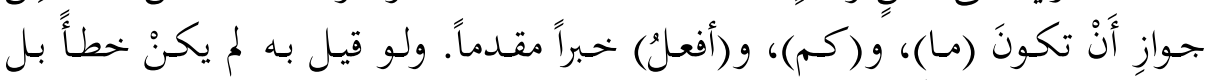

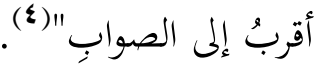

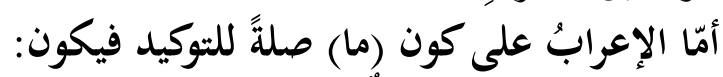

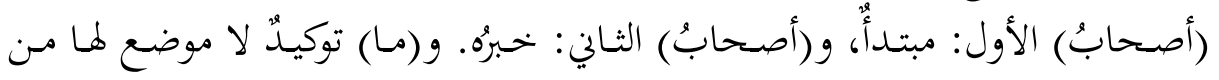

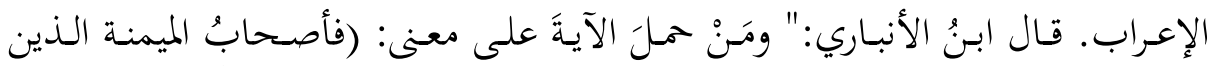

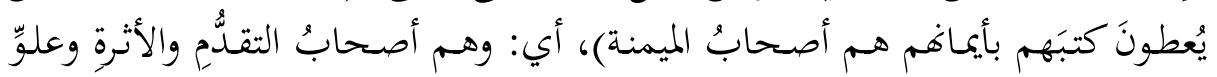

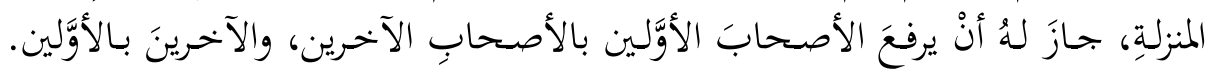

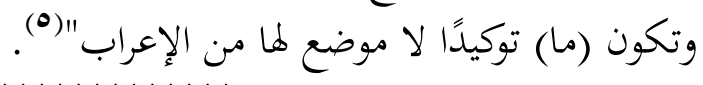

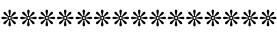

\section{المسألة السادسة والأربعون: توجيةُ قولِه تعالى: (وَحُورِ عِين) بالجرِّ}

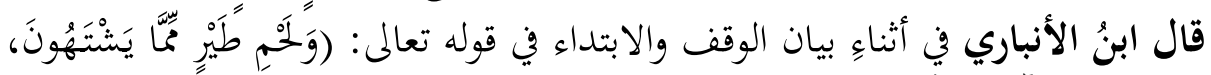

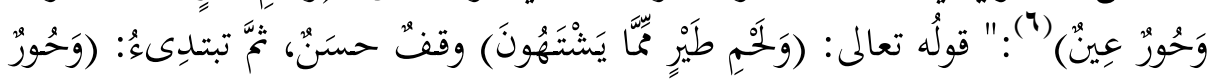

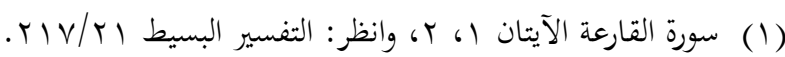

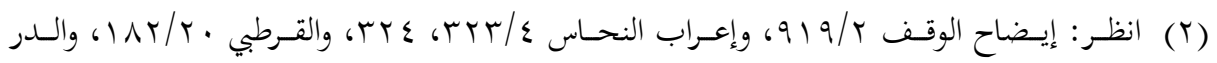

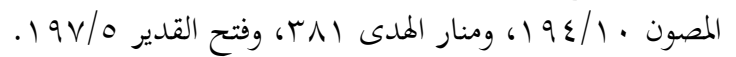

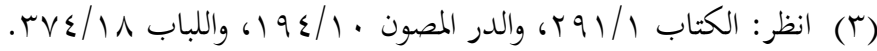

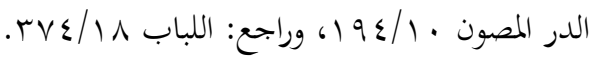

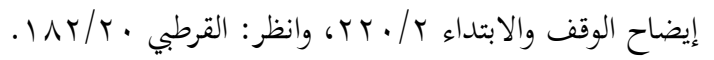

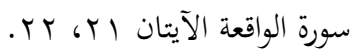




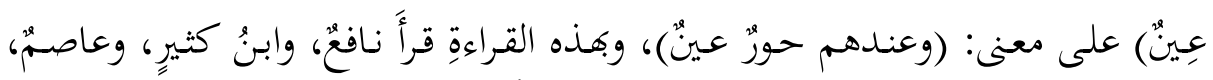

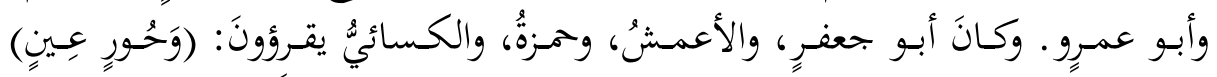

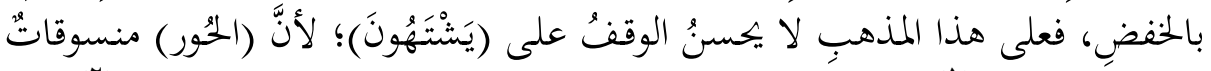

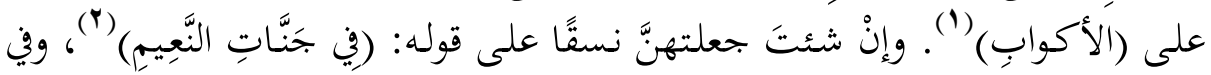

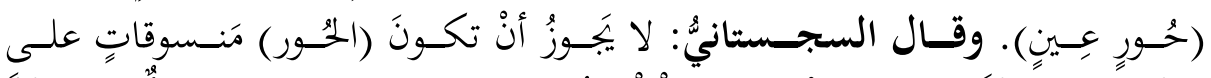

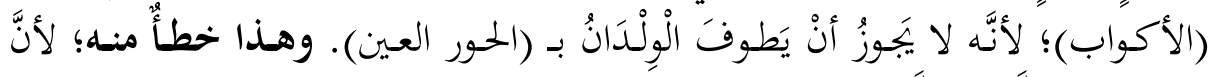

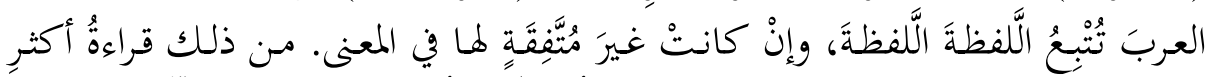

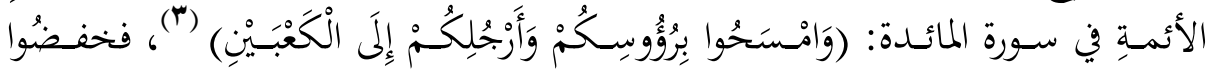

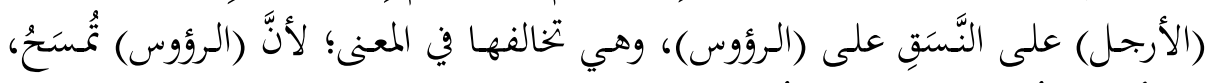

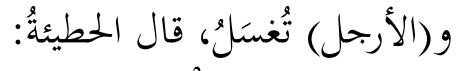

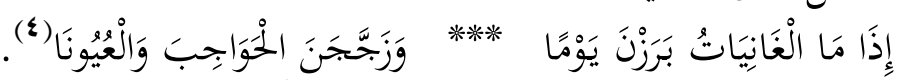

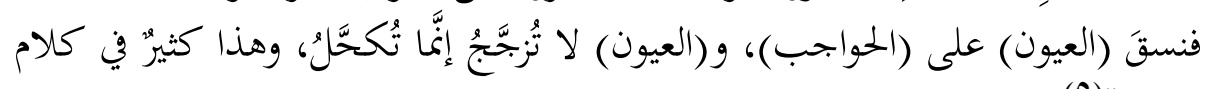

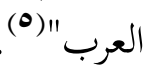

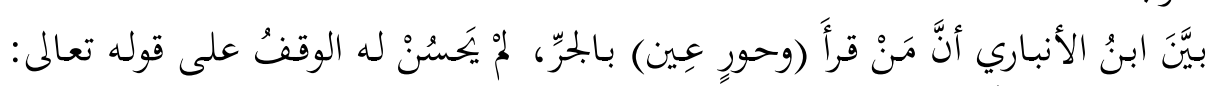

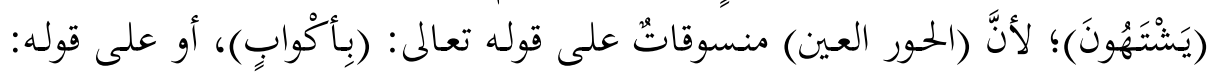

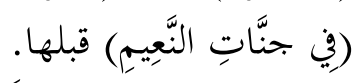

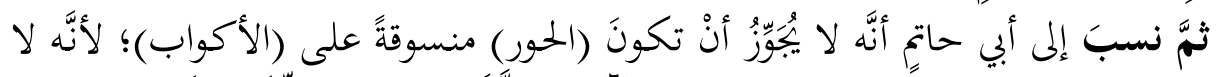

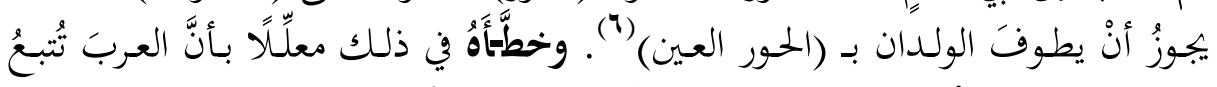

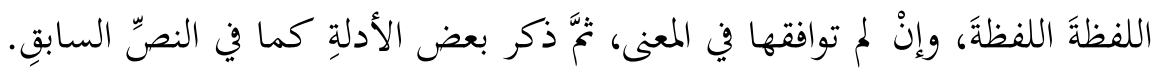

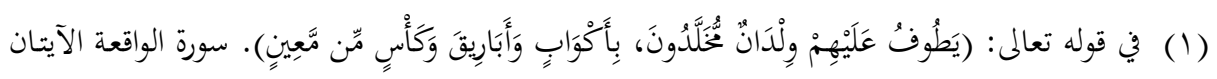
$.1161 \mathrm{~V}$

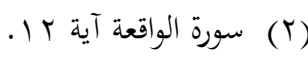

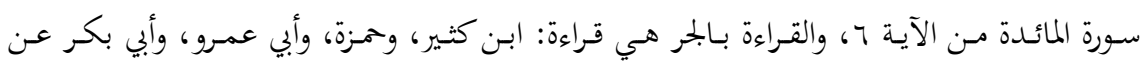

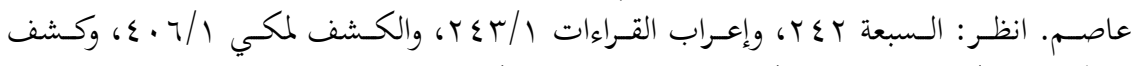

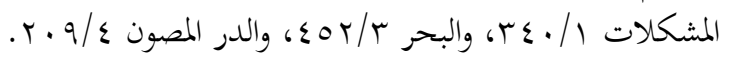

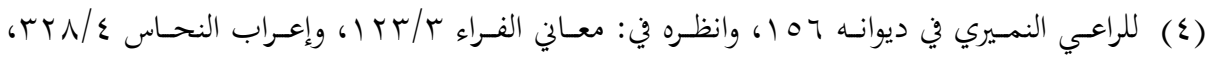

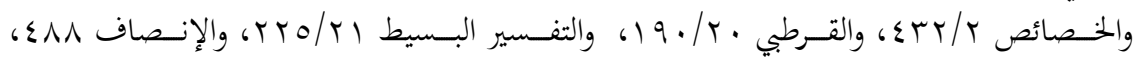

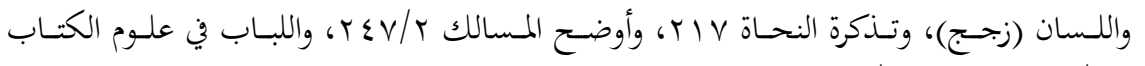

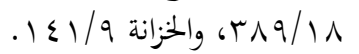

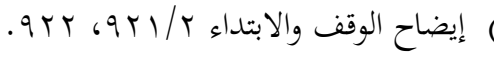

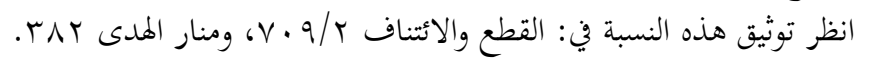




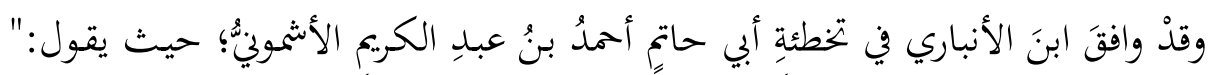

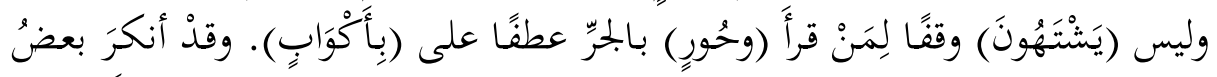

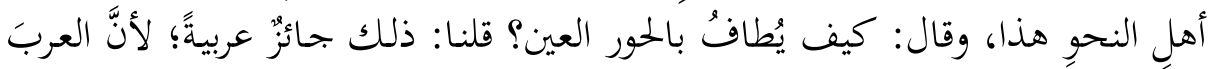

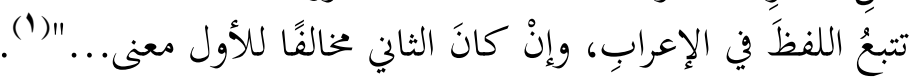

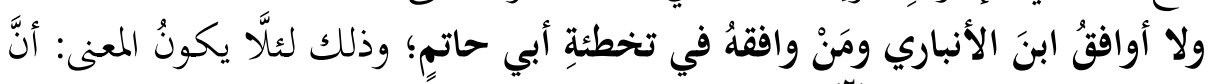

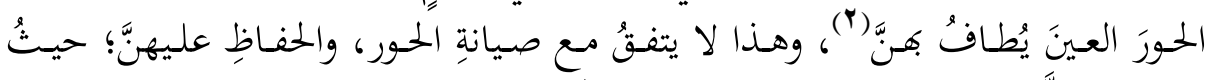

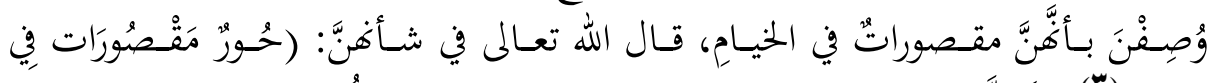

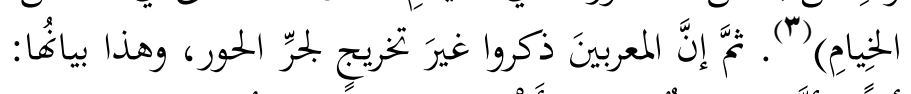

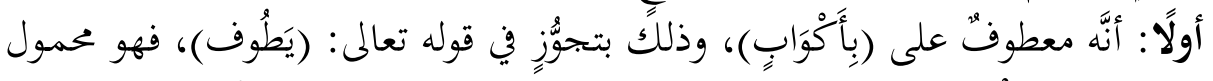

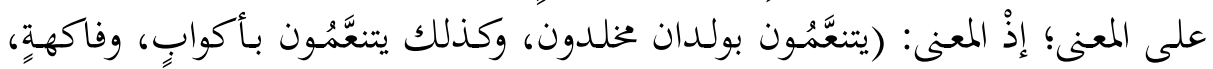

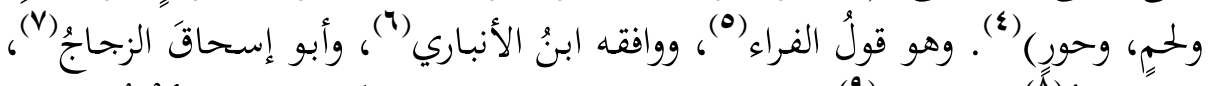

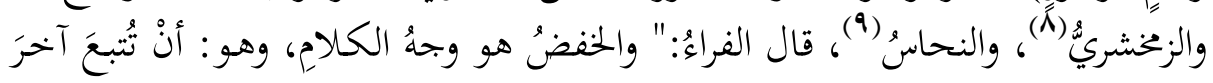

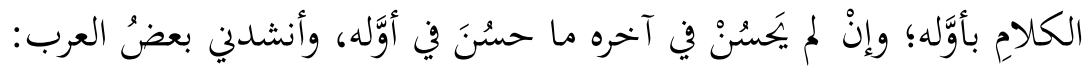

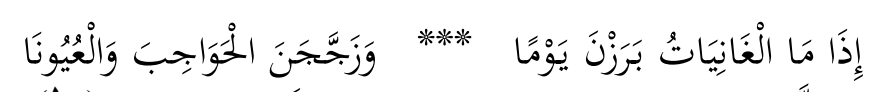

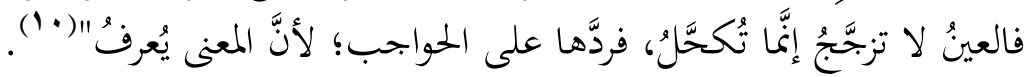

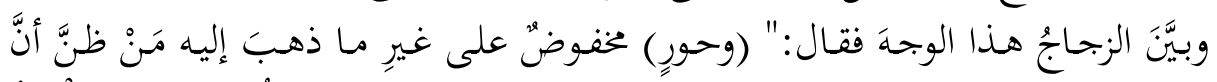

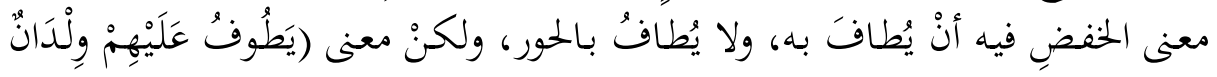

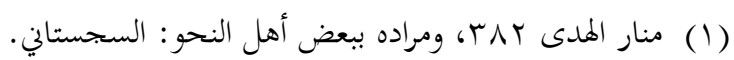

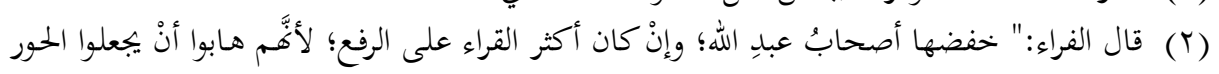

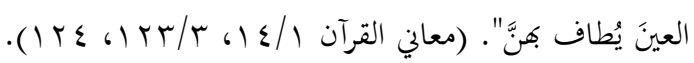

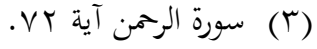

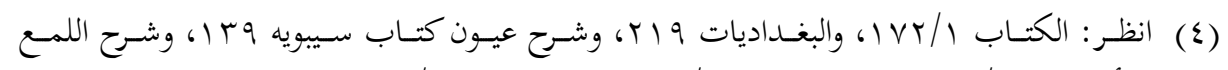

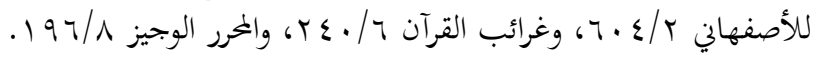

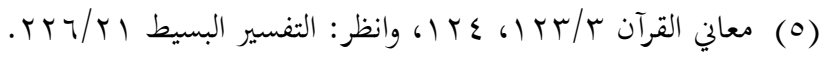

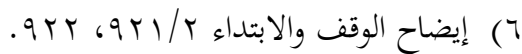

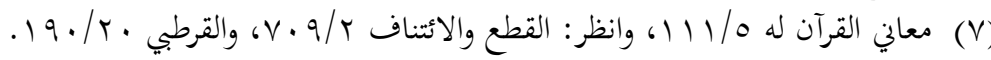

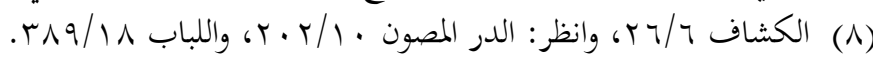

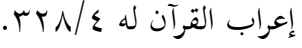

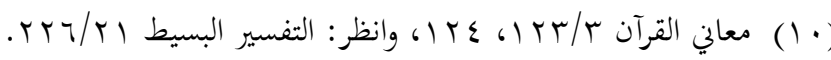




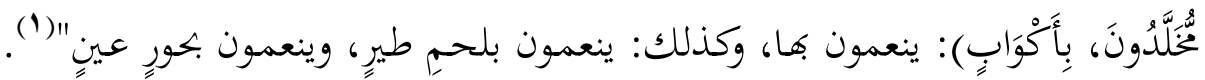

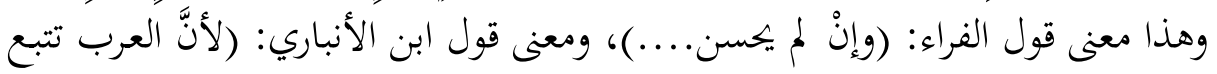

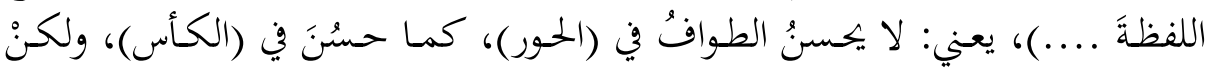

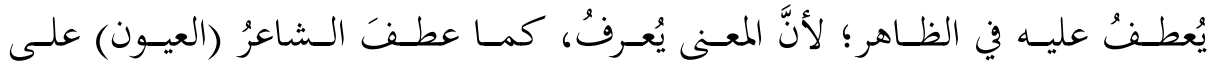

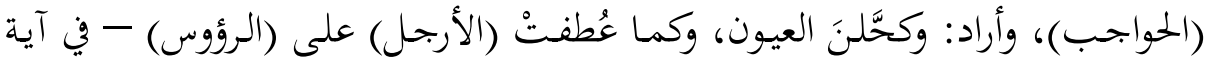

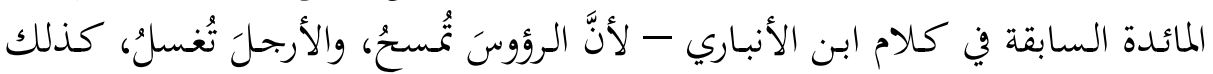

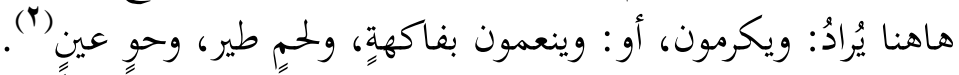

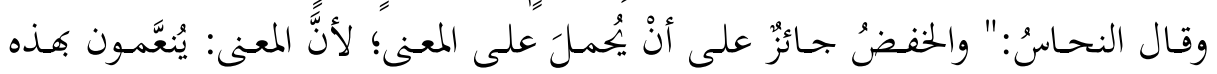

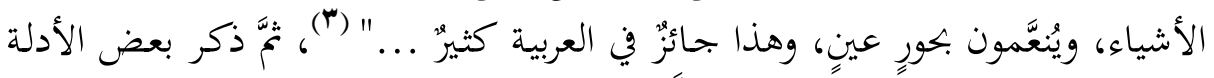

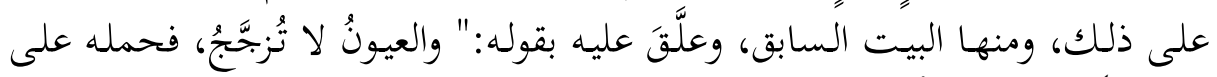

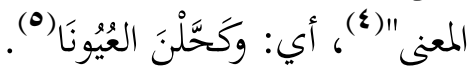

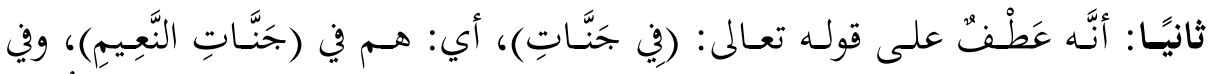

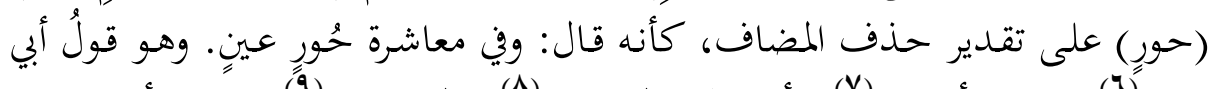

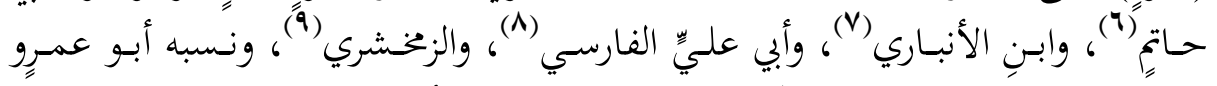

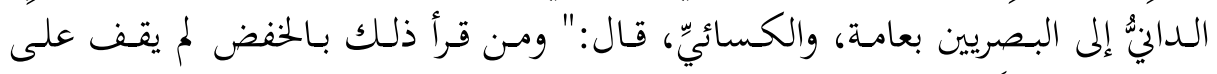

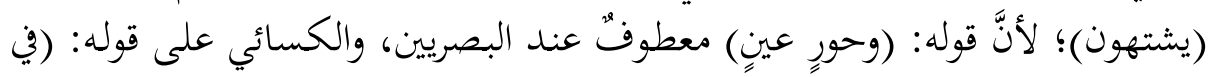

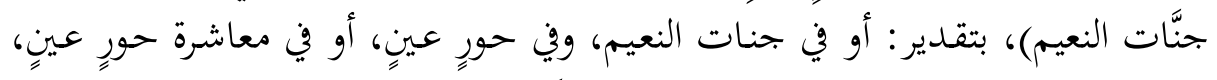

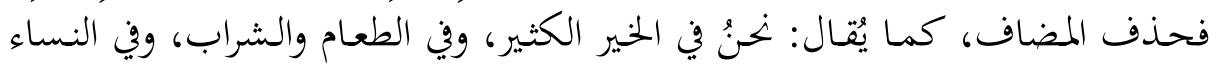
الحسانِ"(·) (1).

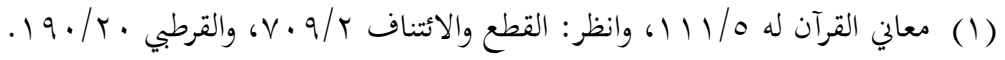

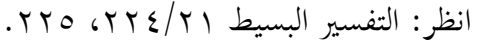

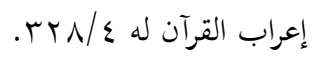

$$
\begin{aligned}
& \text { السابق نفسه. }
\end{aligned}
$$

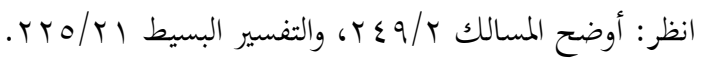

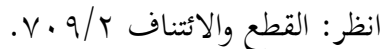

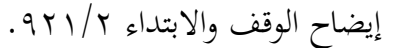

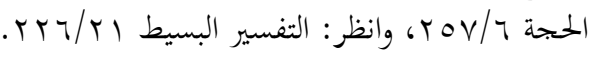

$$
\begin{aligned}
& \text { الكشاف r } \\
& \text { المكتفى ع }
\end{aligned}
$$




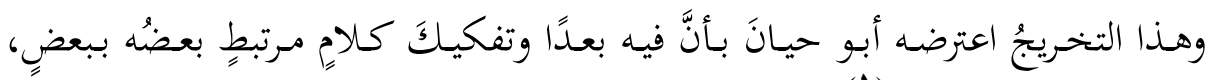

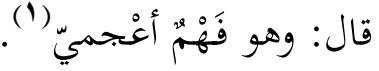

وأجحاب عن هذا الاعتراضِ تلميذُه السمينُ بقوله:" والذي ذهـب إليه الزخخشري معنى

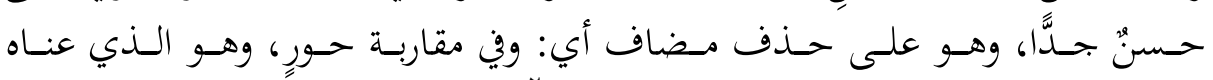

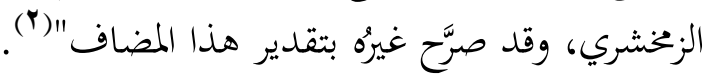

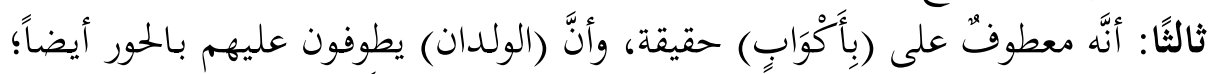

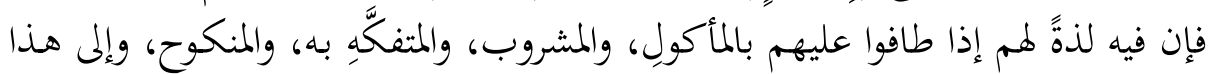

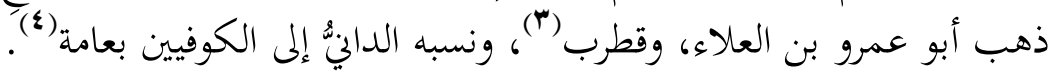

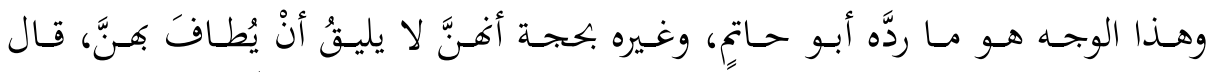

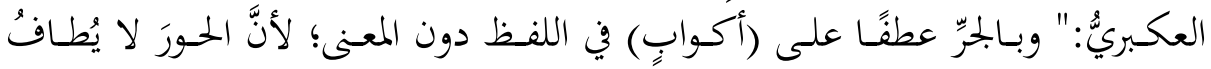

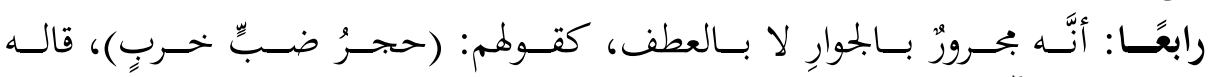
السجاوندي (7).

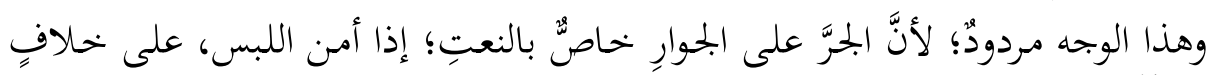

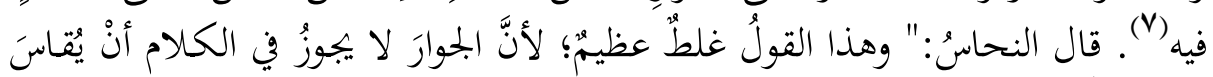

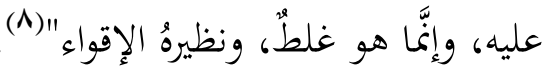

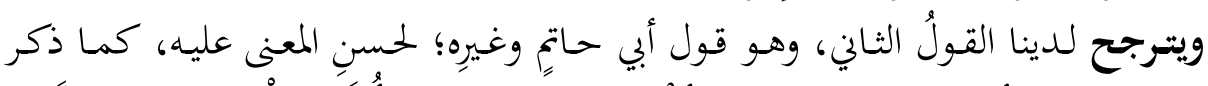

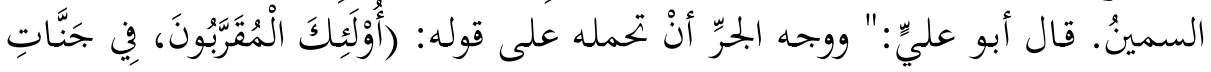

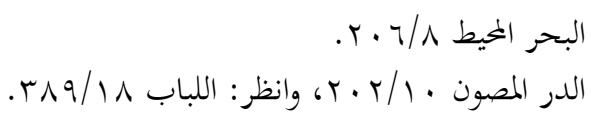

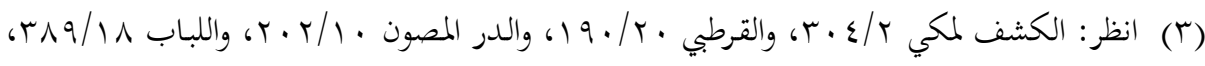

$$
\begin{aligned}
& \text { وفتح القدير م/99. 19. } \\
& \text { المكتفى 0ـ }
\end{aligned}
$$$$
\text { الإملاء }
$$

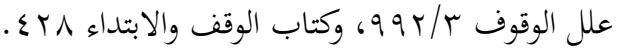

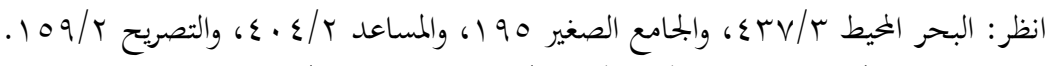

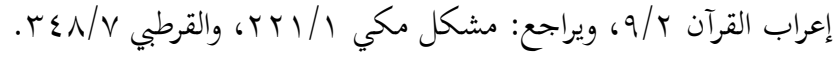




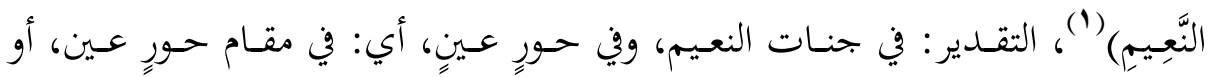

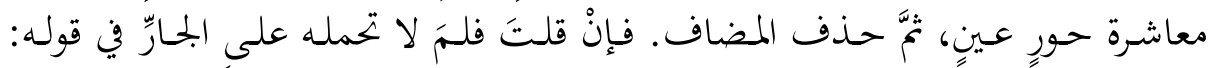

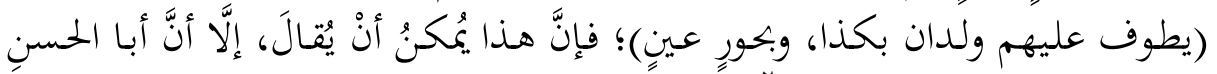

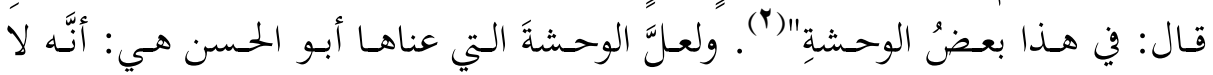

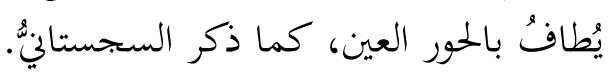

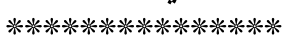

\section{المسألة السابعة والأربعون: أوجهُ نصبِ (رَسُولاًا)}

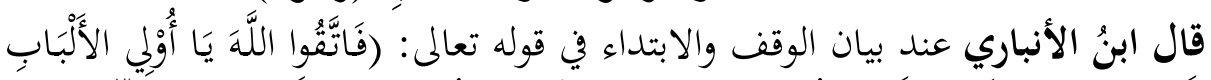

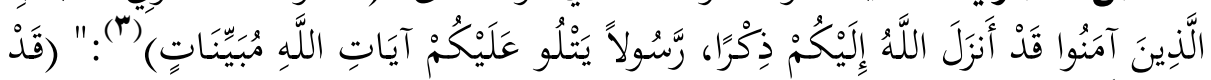

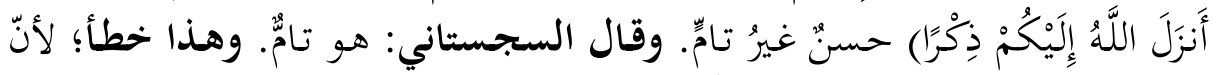

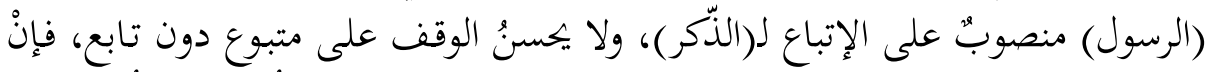

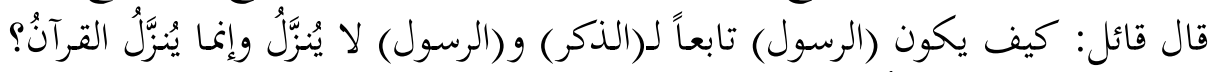

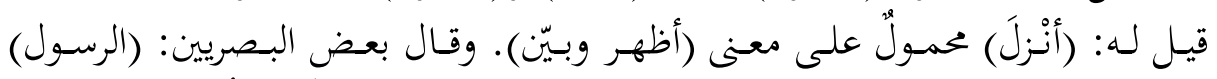

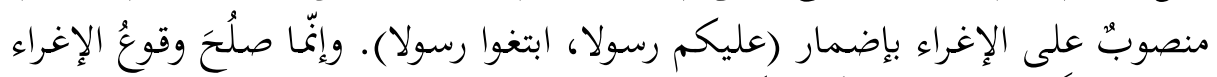

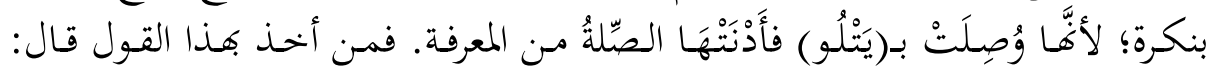

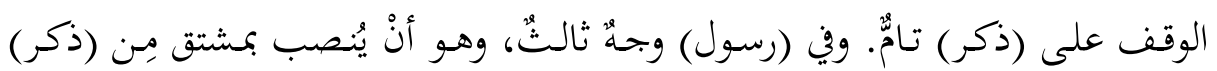

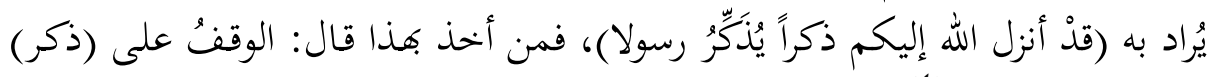

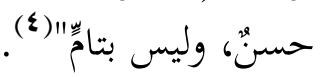

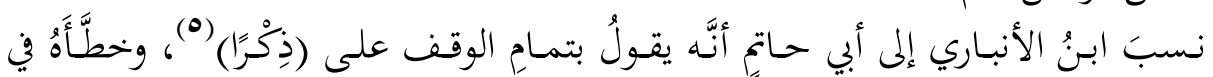

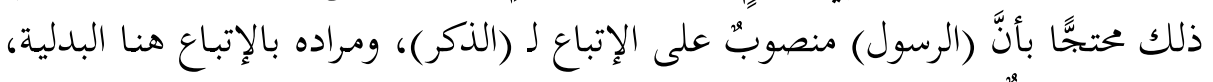

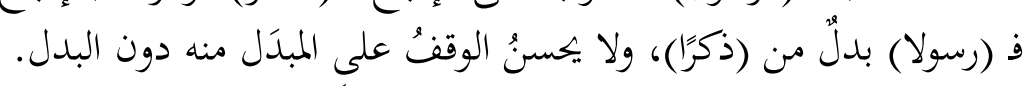

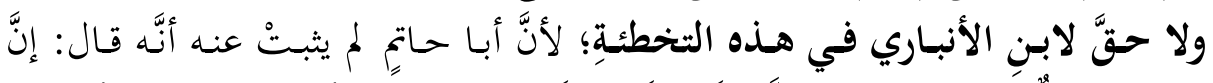

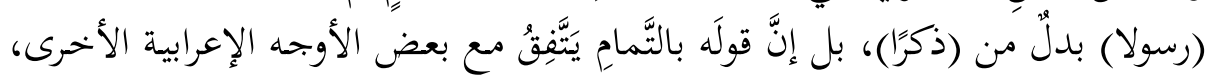

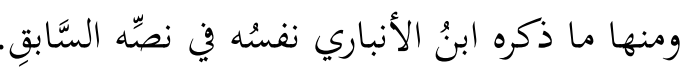

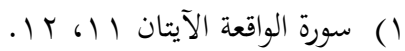

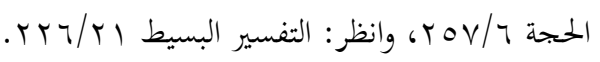

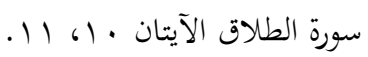

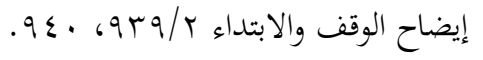

$$
\begin{aligned}
& \text { لم أقف على هذه النسبة عند أحد - فيما اطلعتُ - -. }
\end{aligned}
$$




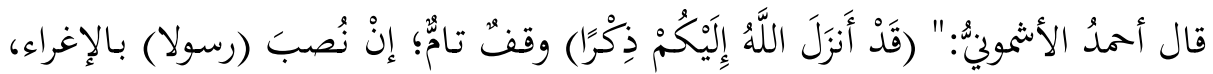

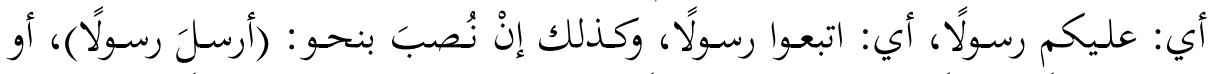

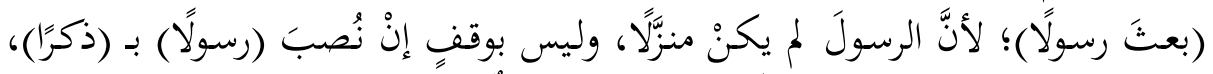

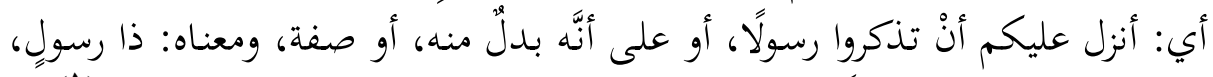

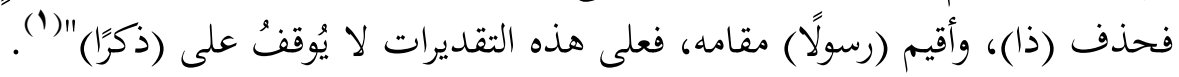

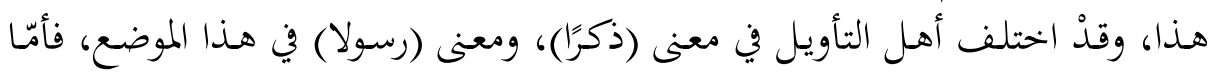

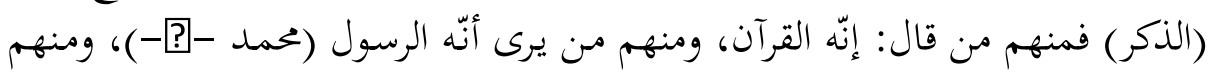

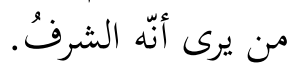

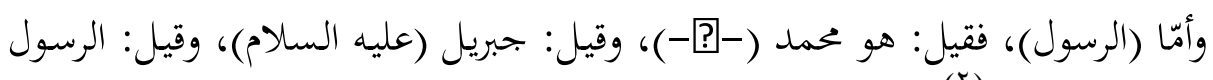

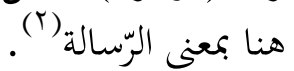
وقد ذكرَ المعربون أوْجهُا كثيرةً في نصبِ (رسولا) غيرَ التي ذكرها ابنُ الأنباري، ومنها

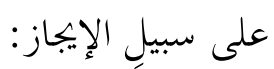

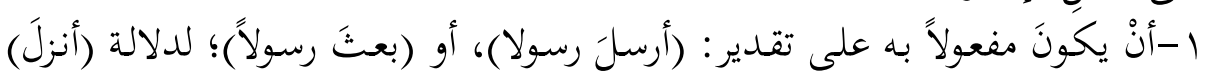

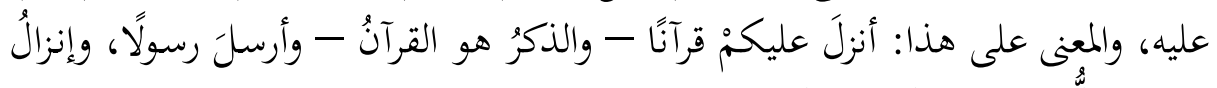

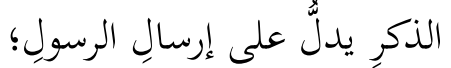

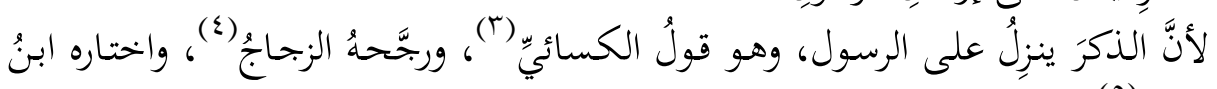
عطيَّة) (0)

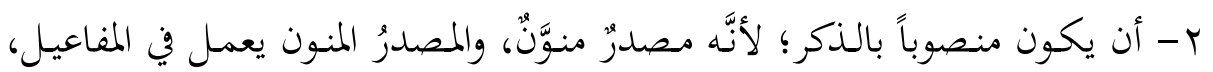

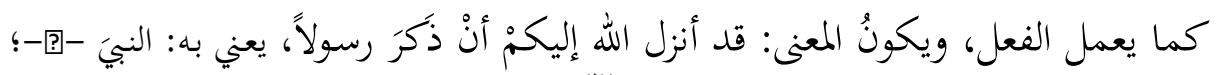
لأنْ يتبعوه فيهتدوا بالاقتداءِ به، واختاره الفارسيُّ (7).

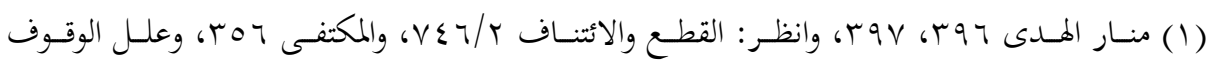

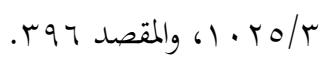

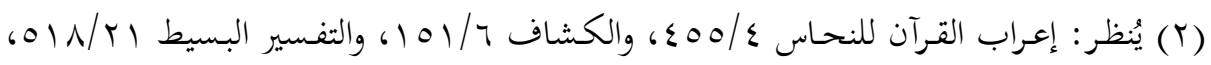

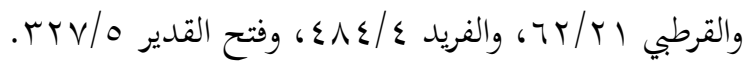

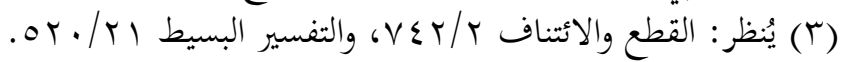

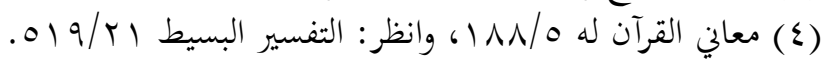

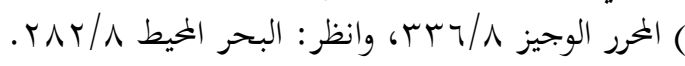

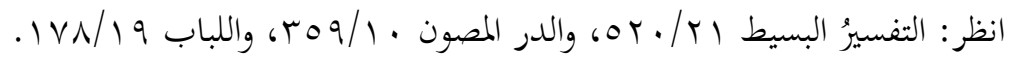




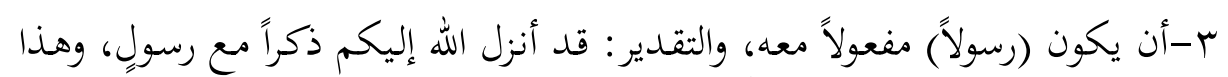

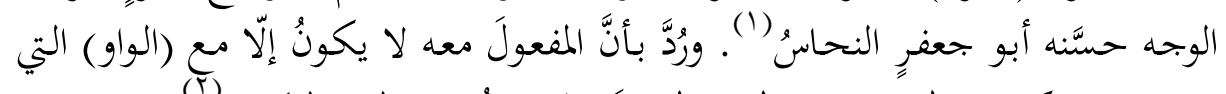

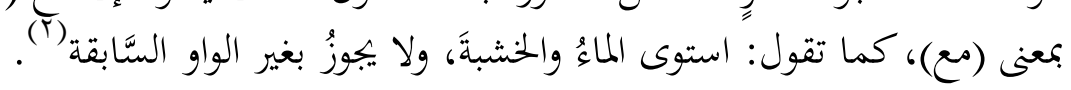

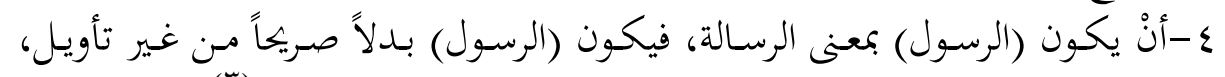

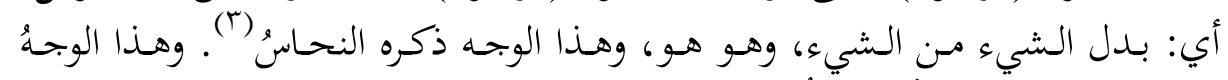

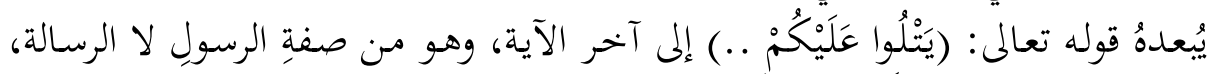

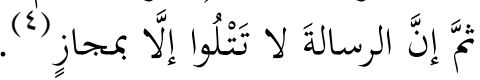

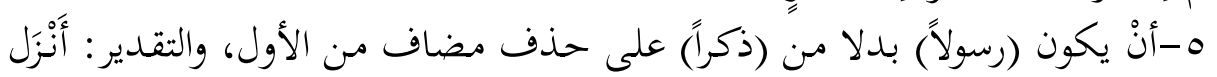

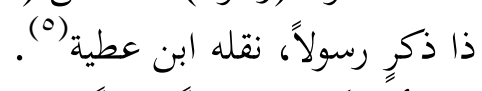

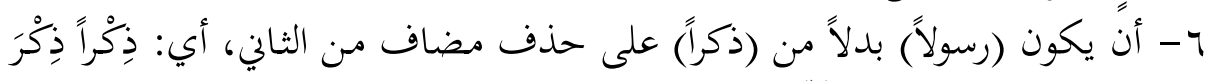

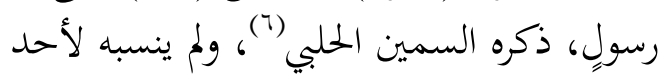

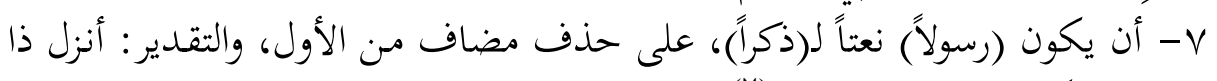

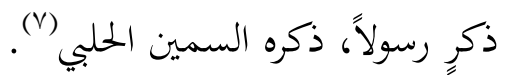

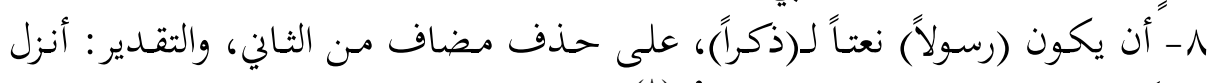

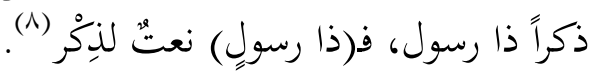

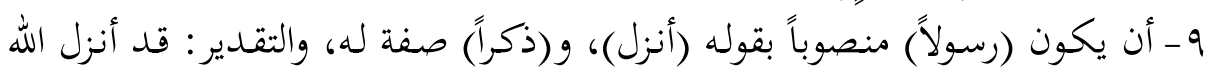

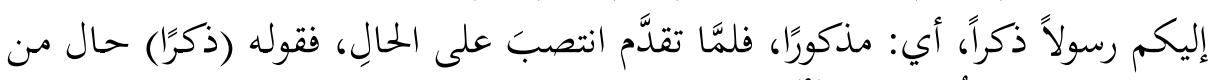

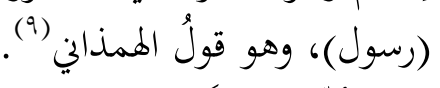

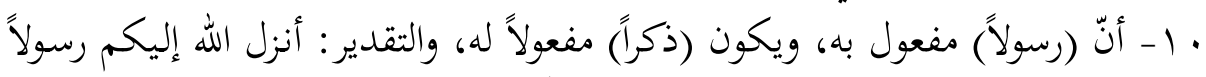

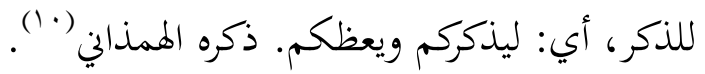

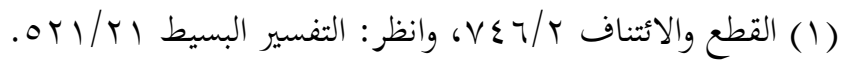

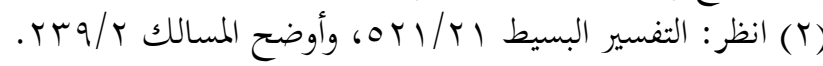

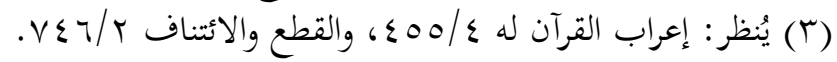

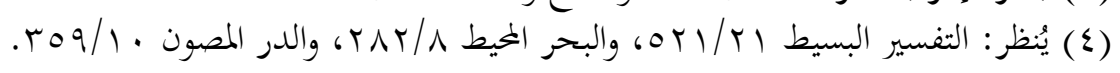

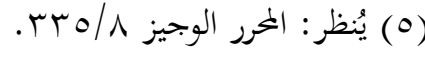

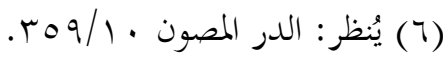

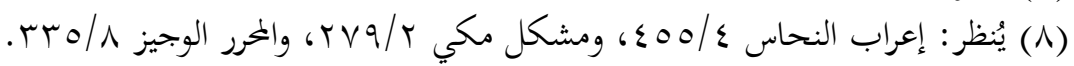

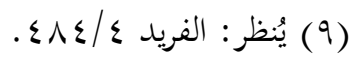
(1) (1) يُنظر: السابق نفسه. 


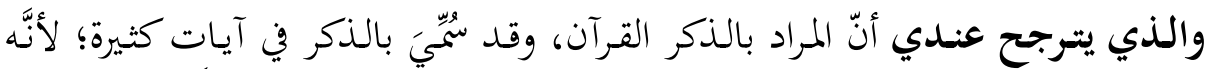

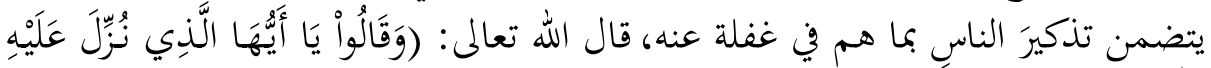

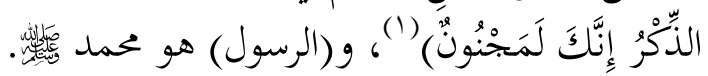

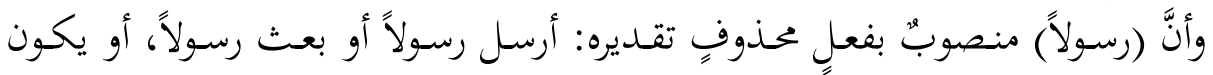

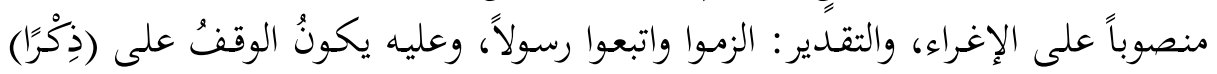

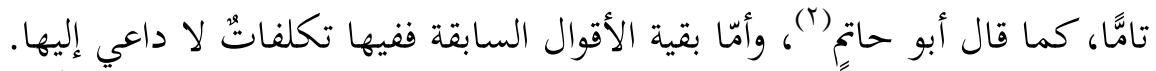

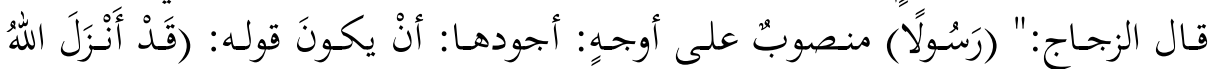

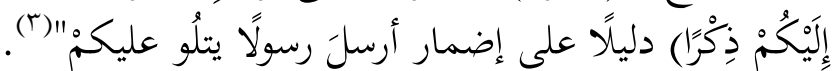

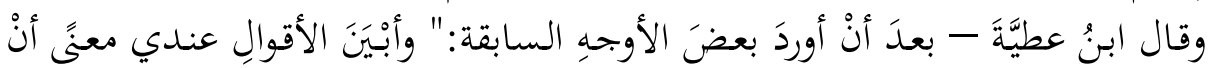

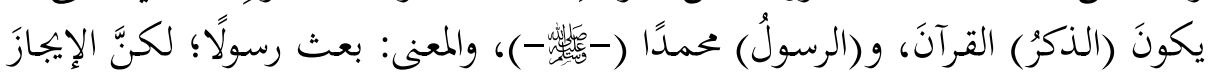

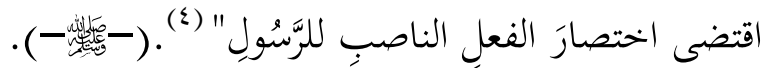

وَالحَحْدُ للهِهِ رَبِّ العَالَمِينَ.

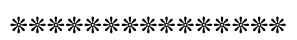

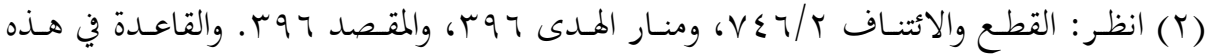

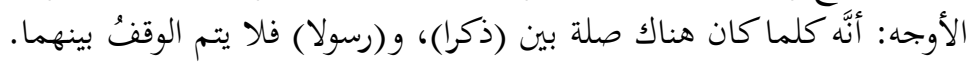




\section{الخاتمة}

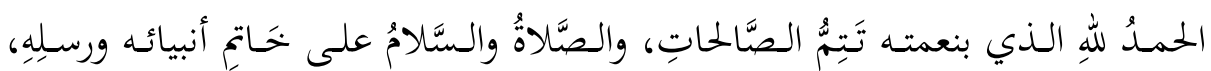

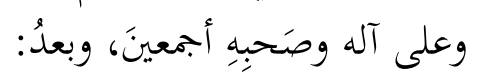

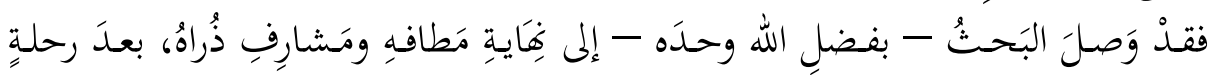

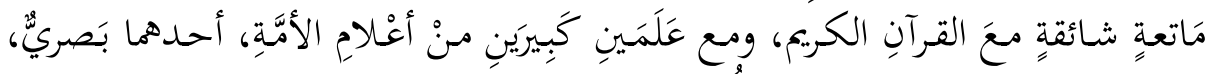

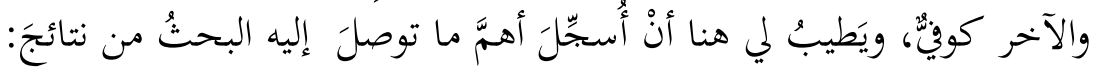

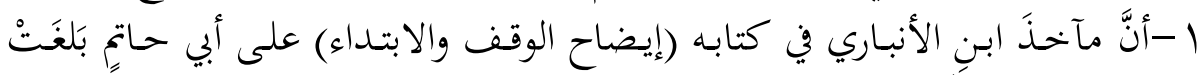

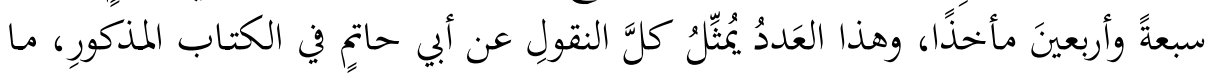

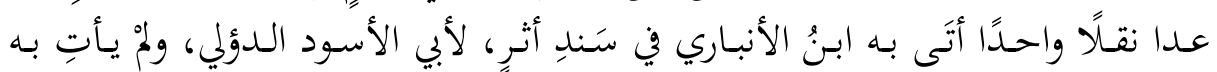

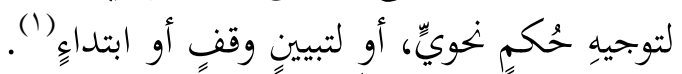

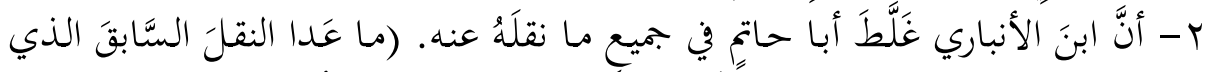

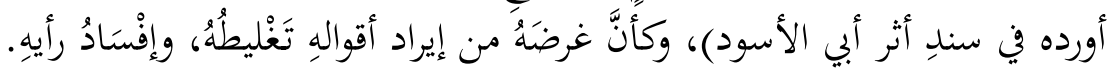

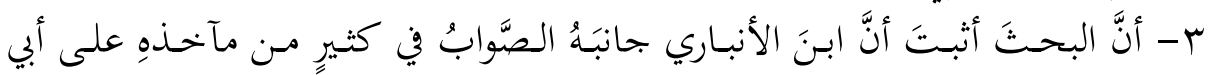

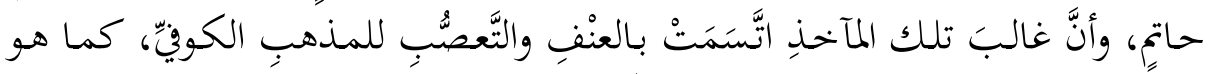

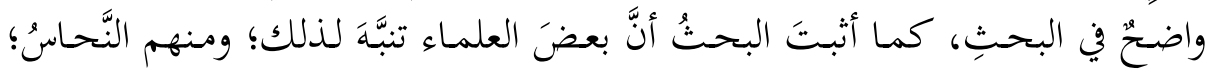

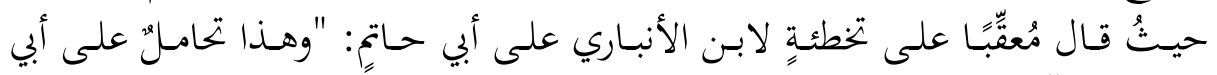

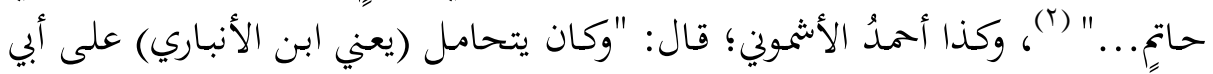

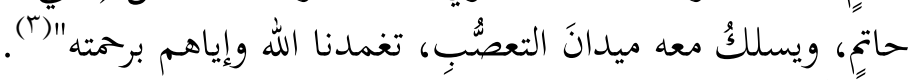

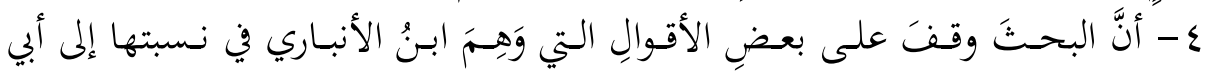

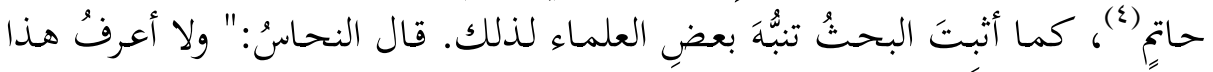

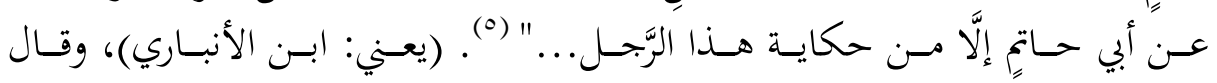

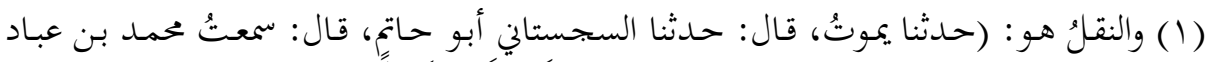

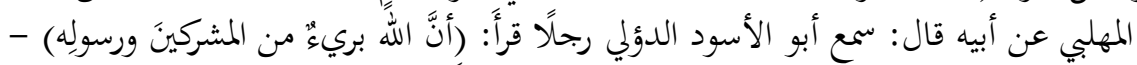

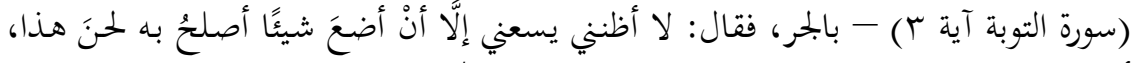

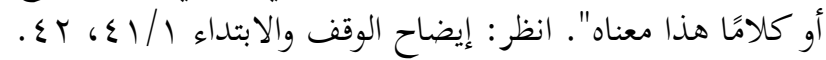

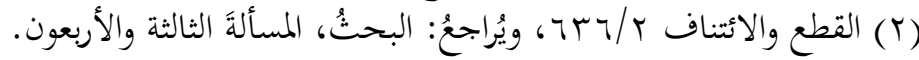

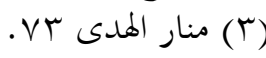

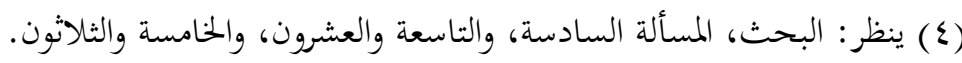

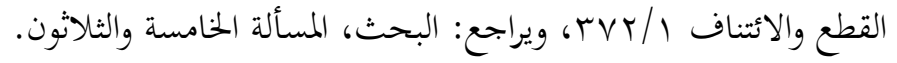




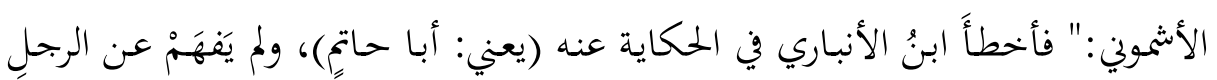

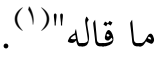

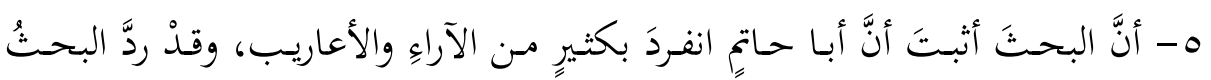

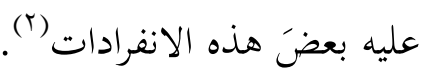

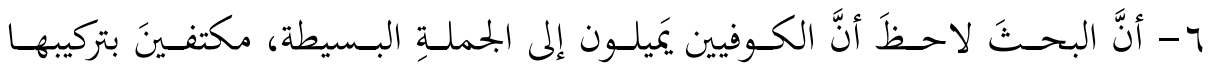

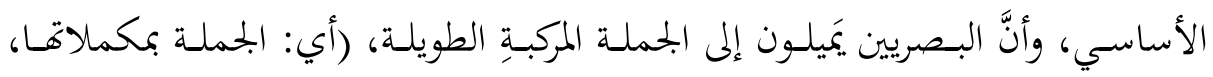

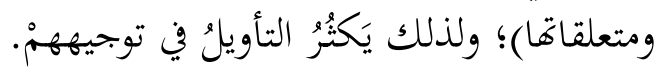

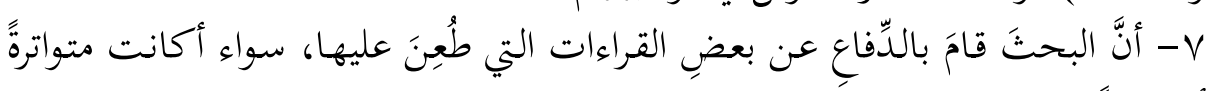
أحم شاذةً.

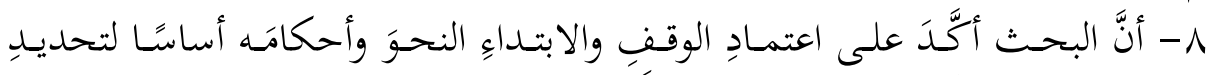

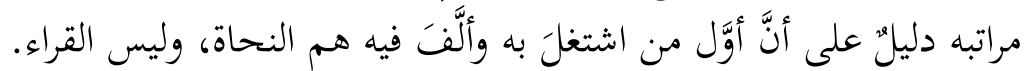

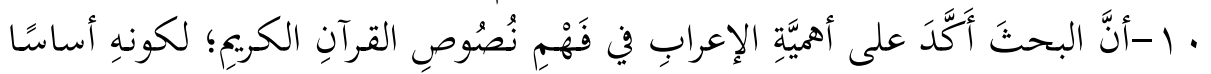

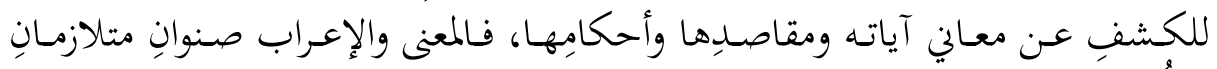

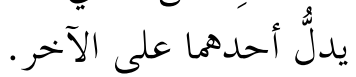

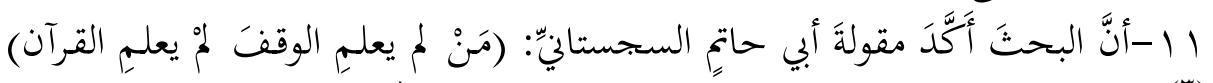

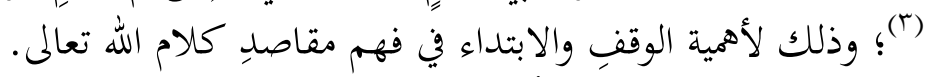

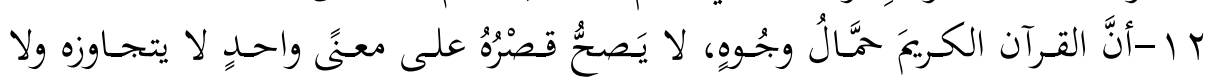

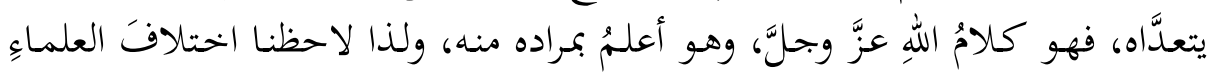

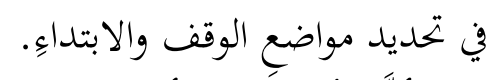

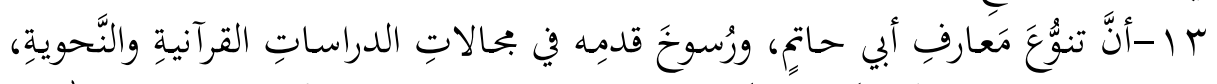

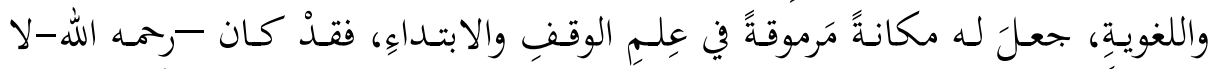

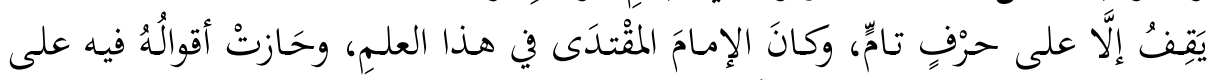

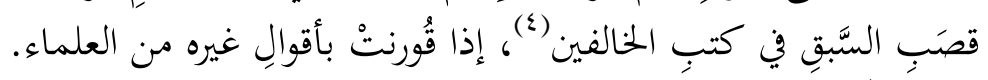

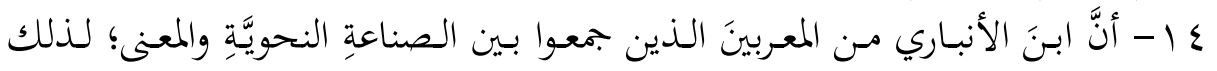

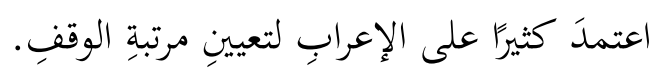

(1) منار الهدى VTr، وينظر : البحث، المسألة السادسة.

.

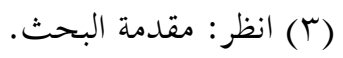

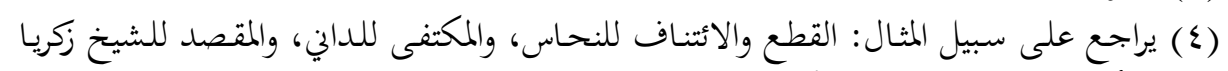

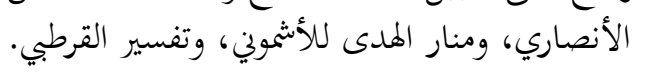




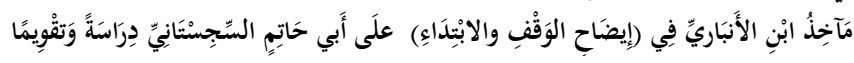

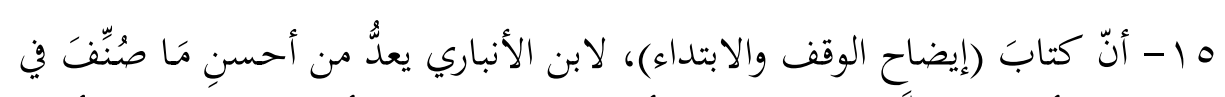

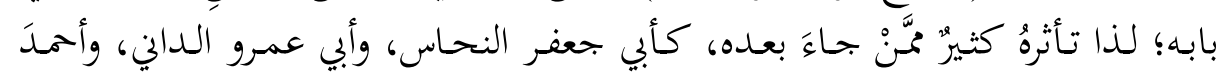

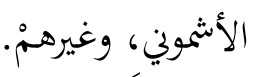

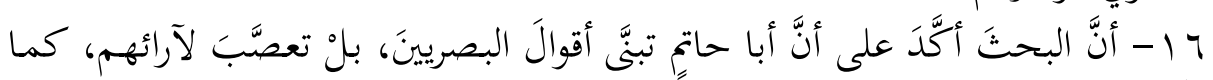

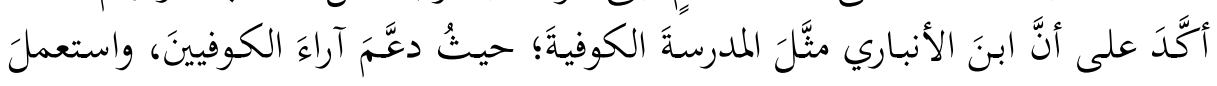
مصطلحاقمّ.

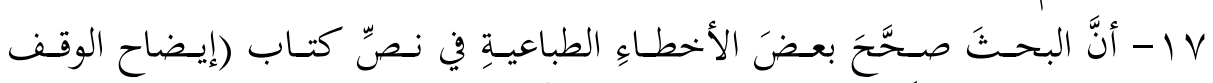

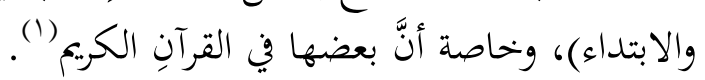

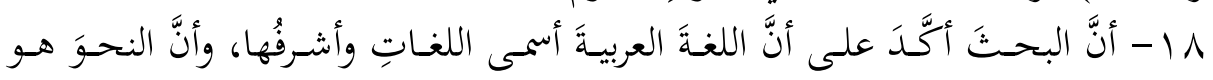
عمادُها، وعمادُ الدّيّنِ.

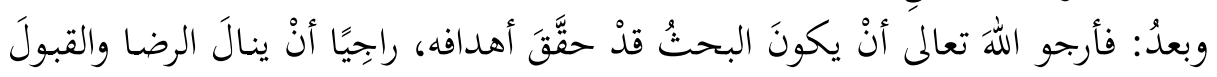

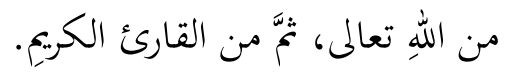
لهو 


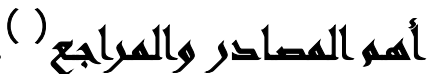

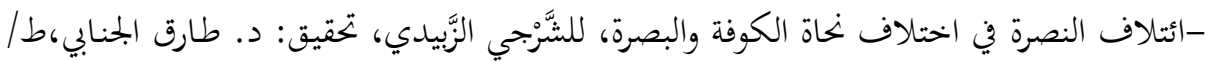
عالم الكتب-بيروت-(V) - ع أهـ).

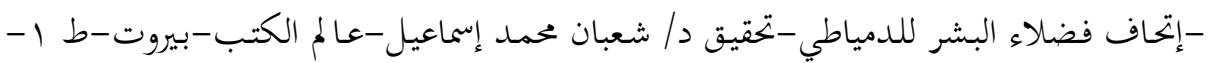
. $19 \wedge V=\infty 1 \varepsilon \cdot V$

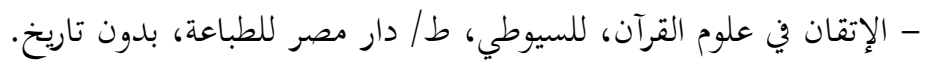

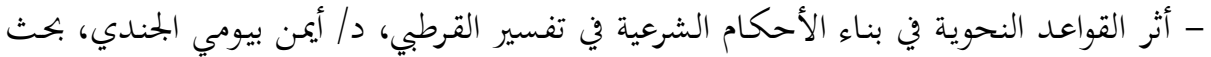

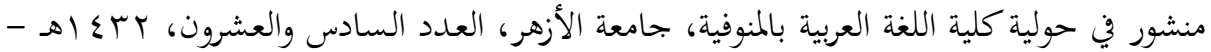
$.5 Y \cdot 11$

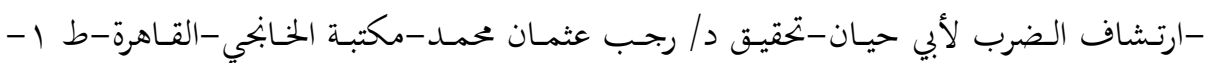
$.51991=-81 \leqslant 11$

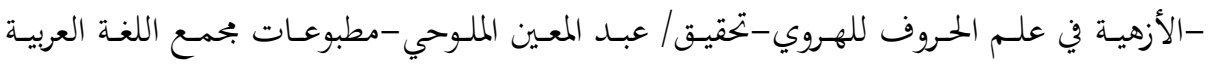
بلدمشق - | · ع | $191 \mid=0$ - الأضداد، لابن الأنباري، تحقيق/ محمد أبو الفضل إبراهيم-المكتبة العصرية-بيروت-V • ع اهـ اهـ . $) 9 \wedge \vee=$ - أضواء البيان في إيضاح القرآن بالقرآن، لمحمد الأمين الشنقيطي، عناية/ صلاح الدين العلايلي، ط/ دار إحياء التراث العربي، بيروت.

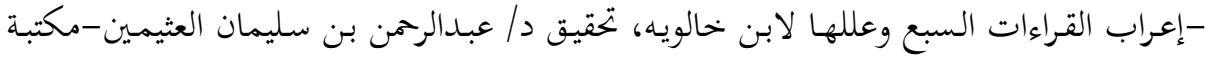

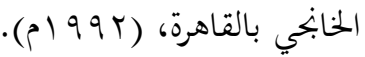

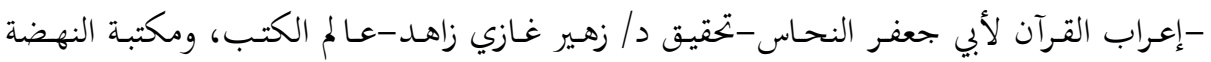

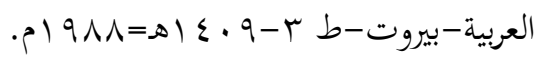

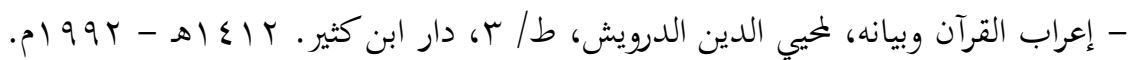

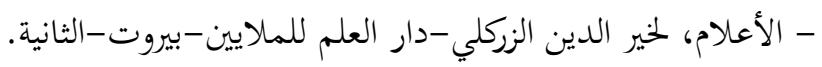

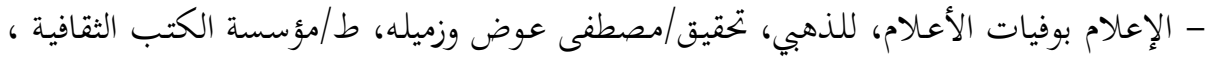
. $199 \mu-16$ - الإغفال- وهو المسائل المصلحة من كتاب معاني القرآن وإعرابه للزجاج- لأبي عليٍٍ الفارسي،

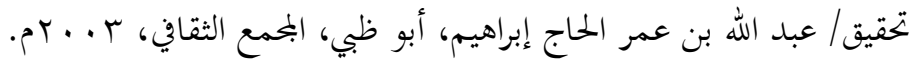

(1) مرتبة هحائيا حسب الحرف الأول من الكلمة الأولى بعد إسقاط (أل) أو (ابن) أو (أب) إنْ وُجدتُ. 


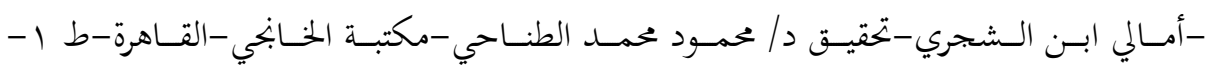
. $199 r=\Delta \mid \leqslant 1 r$

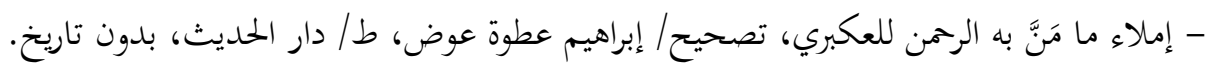

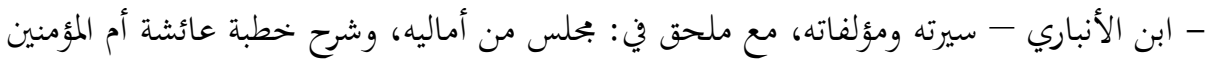

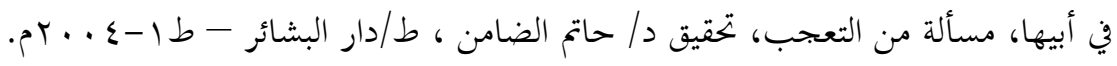

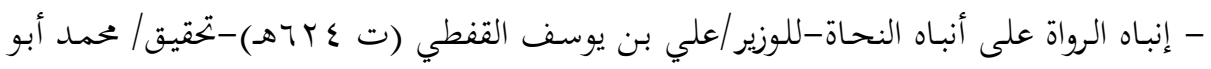

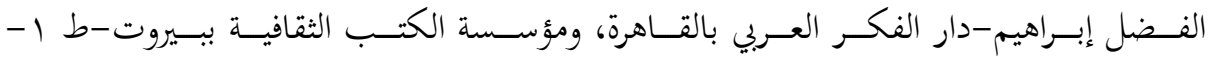

$$
\text { . } 9 \text { | } 9 \wedge 7=ه \mid \varepsilon \cdot 7
$$

- الانتصار للقرآن، للباقلاني، تحقيق/ / د. محمد عصام القضاة، ط/ دار الفتح-عمان- الأولى، .8 I $\leqslant T r$

- الأنساب تأليف: أبي سعيد عبد الكريم بن محمد ابن منصور التميمي السمعاني ، تحقيق: عبد الهب الله عمر البارودي، ط/ دار الفكر - بيروت - 991 1م، الطبعة: الأولى.

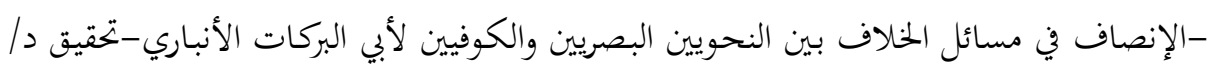

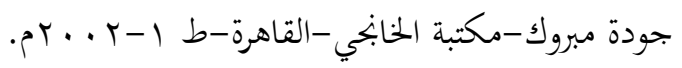

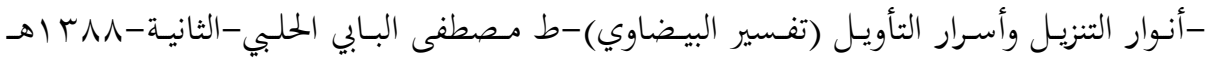
.01971 -أوضح المسالك إلى ألفية ابن مالك لابن هشام-تحقيق/ محمد محيي الدين عبد الحميد-المكتبة العصرية-صيدا-بيروت-بدون.

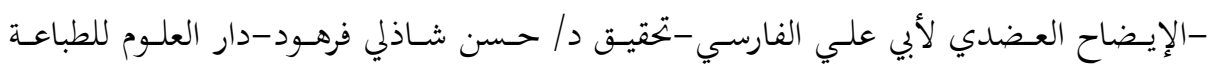

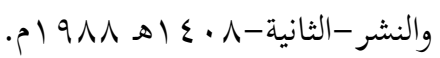
-الإيضاح في شرح المفصل لابن الحاجب-تحقيق د/ موسى بناي العليلي-وزارة الأوقاف العراقية.

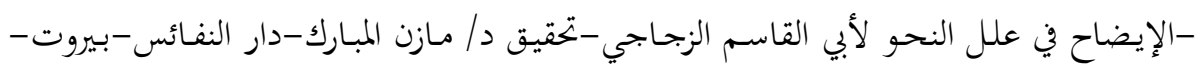

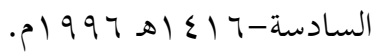
- إيضاح الوقف والابتداء في كتاب الله-هيَّلَ-لأبي بكر بن الأنباري-تحقيق/ محيي الدين عبدالرحمن

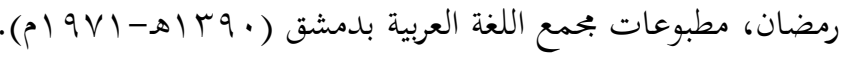

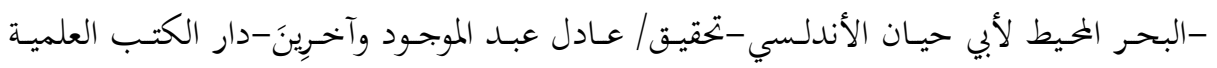

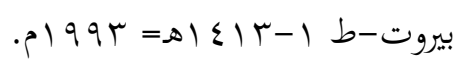

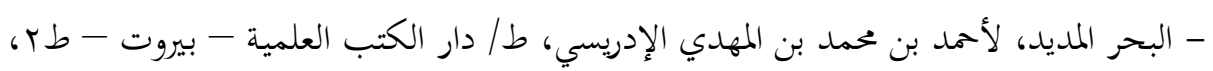
r - البداية والنهاية ، لابن كثير ، ط ط مك مكتبة المعارف - بيروت. 
-البرهان في علوم القرآن للزركشي-تحقيق/ محمد أبو الفضل إبراهيم-دار المعرفة-بيروت.

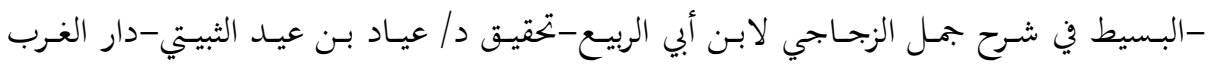

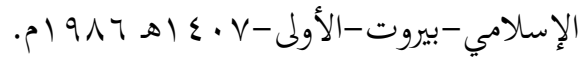

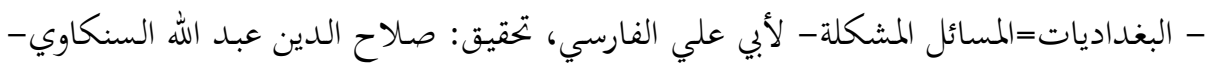

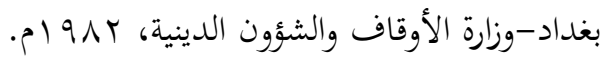

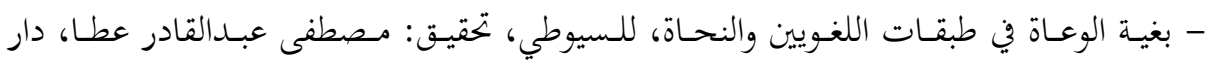

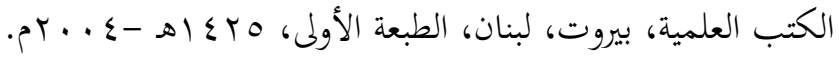

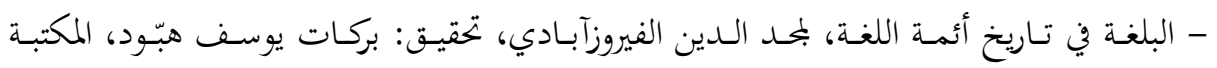

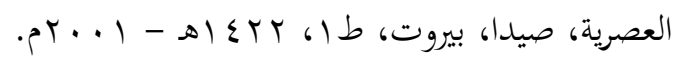

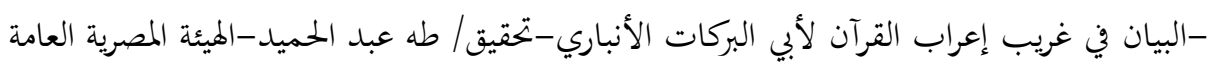

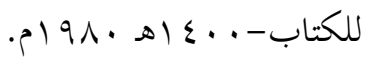

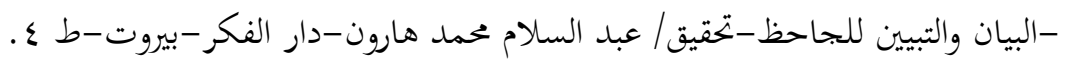

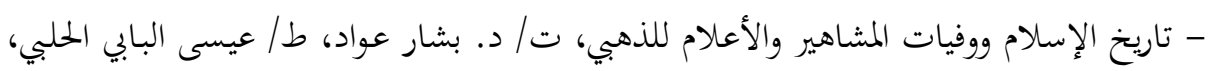
القاهرة، وشركة الفجر العربي، بيروت.

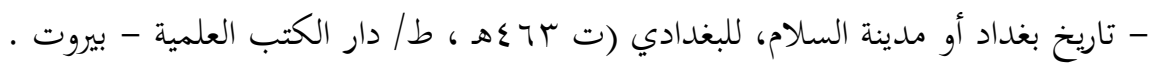
-تأويل مشكل القرآن لابن قتيبة-تحقيق/ السيد أحمد صقر -المكتبة العلمية.

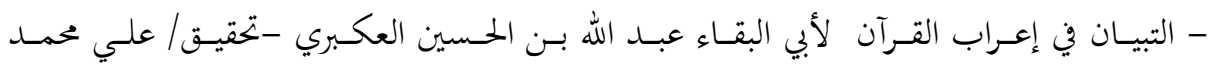
البجاوي-ط/ عيسى البابي الحلبي.

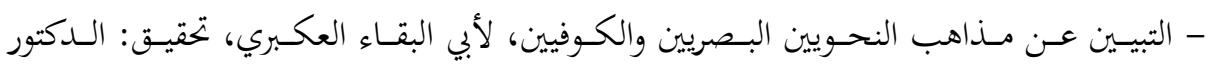

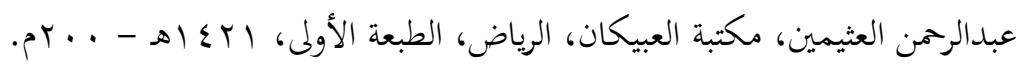

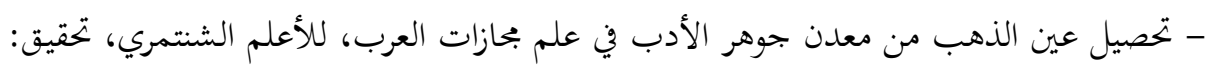

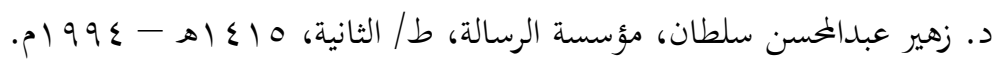

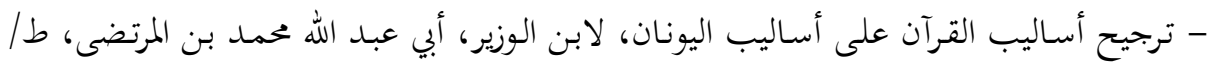

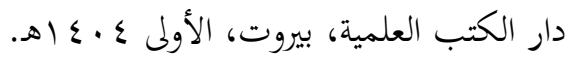

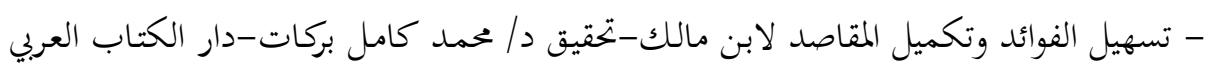

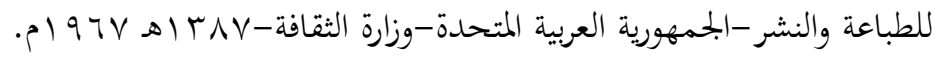

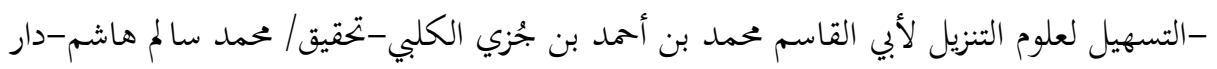

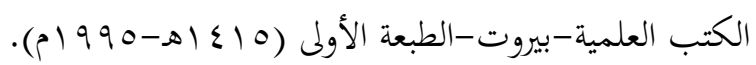


-التصريح بمضمون التوضيح للشيخ خالد الأزهري-تحقيق/ محمد باسل عيون السود-دار الكتب

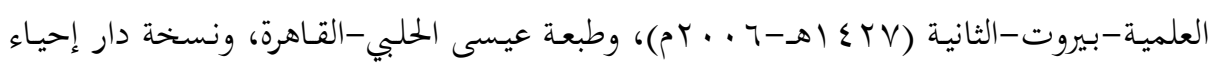

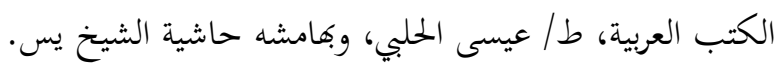

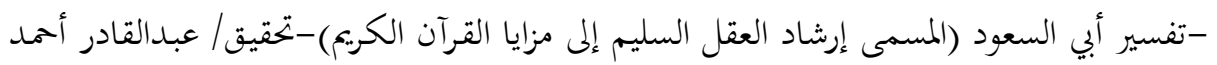
عطا-مكتبة الرياض الحديثة.

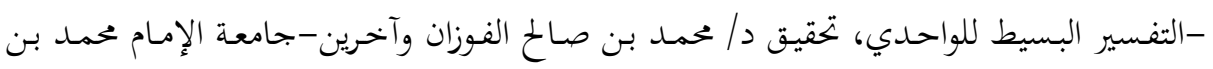

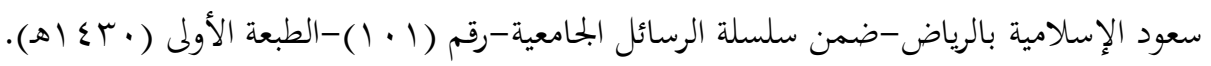

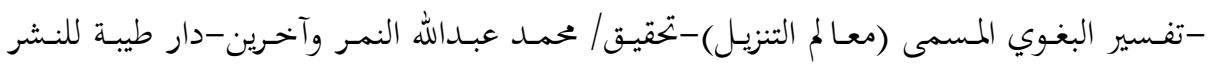

والتوزيع بالرياض (9 ( . ع الهـ). -تفسير التحرير والتنوير، للطاهر بن عاشور -الدار التونسية للنشر - تونس.

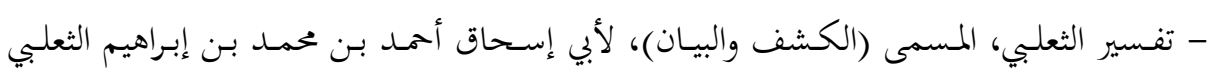

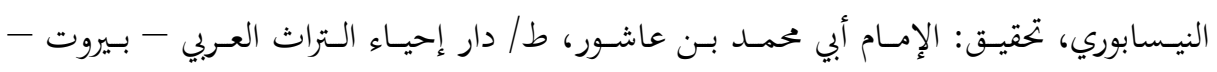

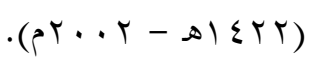

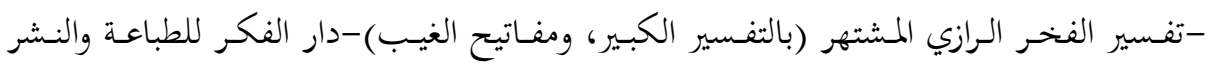

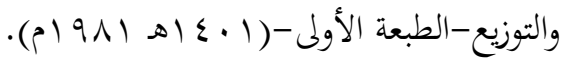
- تفسير القرآن الجليل المسمى (بمدارك التنزيل وحقائق التأويل) للنسفي -منشورات دار التهار الكتاب

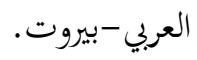
- تفسير القرآن العظيم لابن كثير، تحقيق/ سـامي بن محمد السلامة-دار طيبة للنشر والتوزيع-

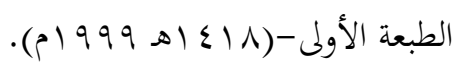

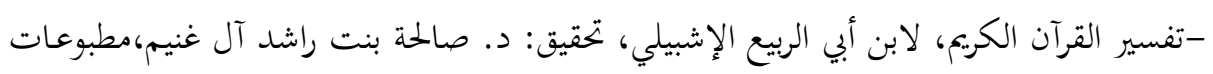

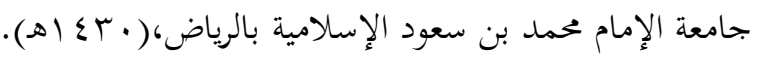

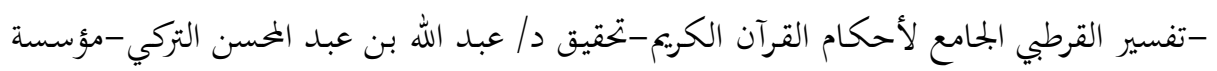

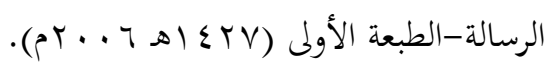

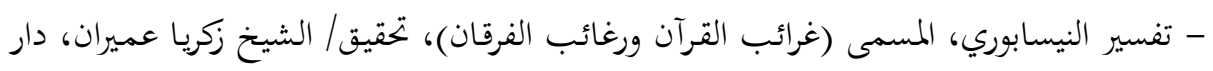

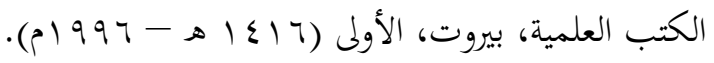
- تهذيب التهذيب، لابن حجر العسقلاني، دار صادر - بيروت، لبنان.

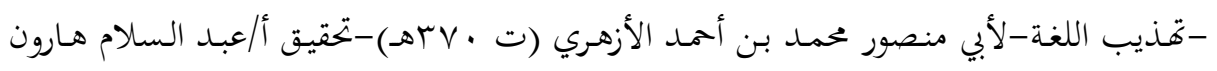

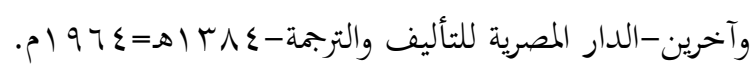

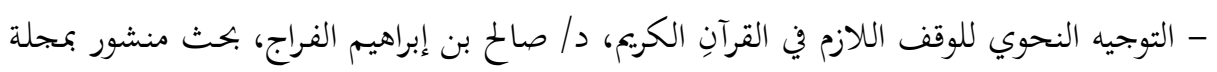

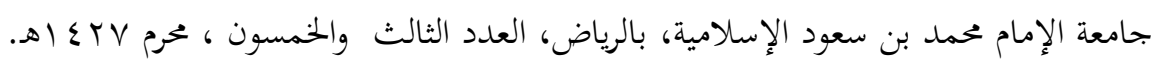


-التيسير في القراءات السبع لأبي عمرو عثمان بـن سعيد الـداني-عني بتصحيحه أوتو برتزل-

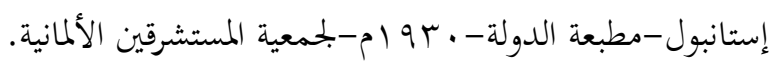

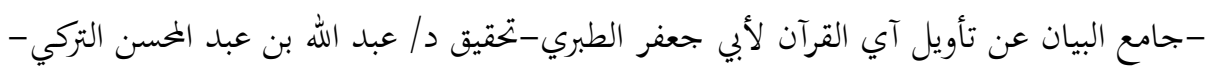

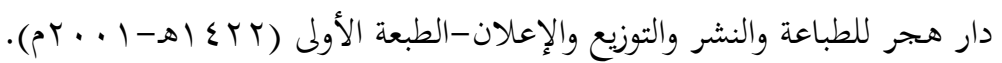

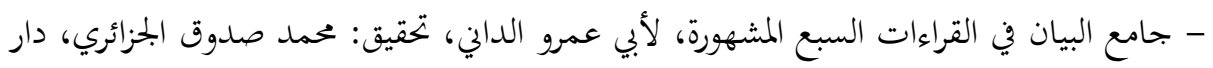

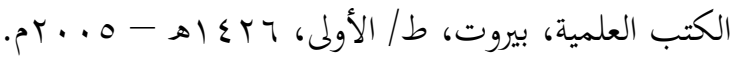

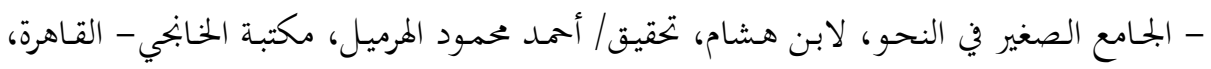
. 191 . - الجرح والتعديل، للرازي طا ماره دار الكتب العلمية، بيرون- لبنان.

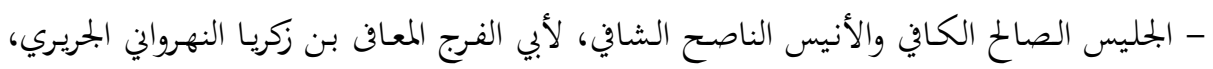

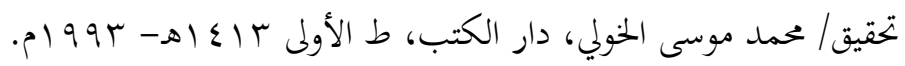

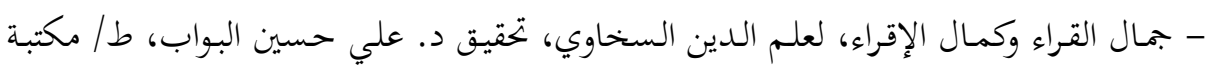

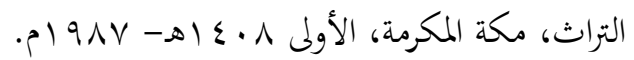

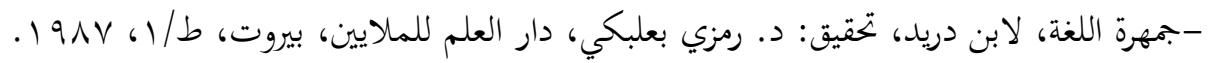

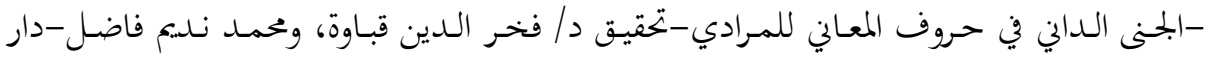

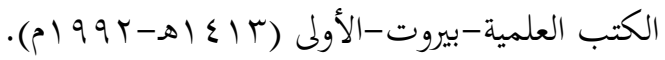
- حاشية الأمير على مغني اللبيب-دار إحياء الكتب العربية، فيصل عيسى البابي الحلبي-القاهرة. - حاشية الجمل على تفسير الجلالين- مطبعة الحلبي، القاهرة.

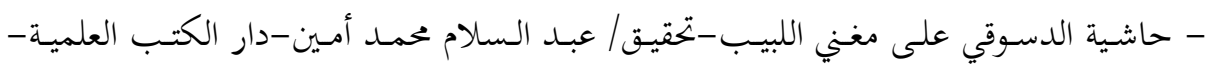

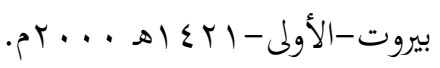

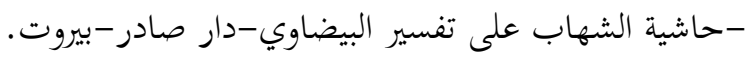
-حاشية شيخ زاده على البيضاوي-تحقيق/ محمد عبد القادر شاهين-دار الكتب العادئ العلمية-بيروت-

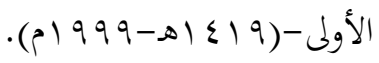
-حاشية الصبان على شرح الأشموين على ألفية ابن مالك-المكتبة الجلديدة-محمد علي صبيحالقاهرة.

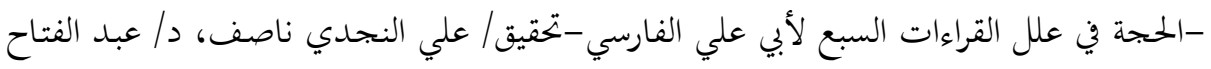

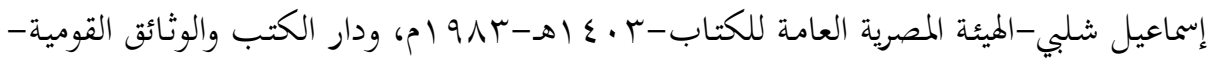

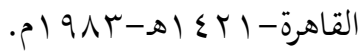


-الحجة في القراءات السبع لابن خالويه، ت-تحقيق/ أحمد فريد المزيدي-دار الكتب العلمية-

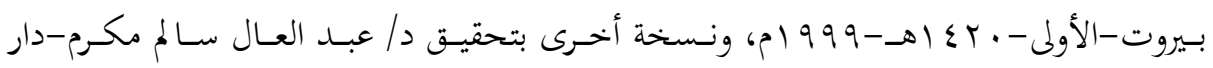

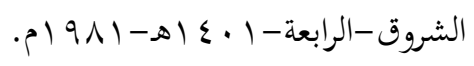

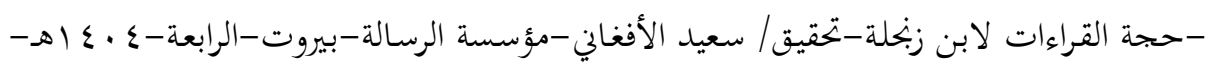
. $191 \varepsilon$

- حروف المعاني والصفات، للزجاجي، ت د. حسن فرهـود، طا دار العلوم للطباعـة والنشر، . $1914-ه 1 \varepsilon \cdot r$ -خزانة الأدب ولب لباب لسان العرب لعبد القادر البغدادي-تحقيق/ عبد السلام هارون-مكتبة

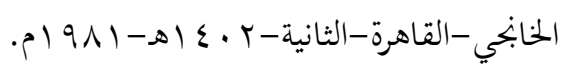

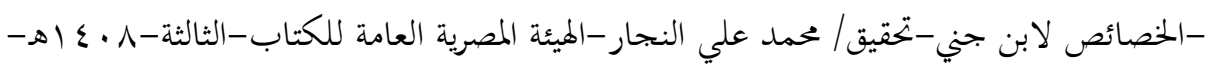
. 1911

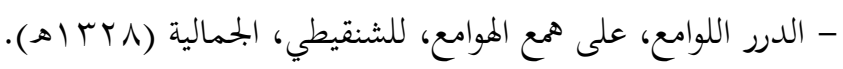

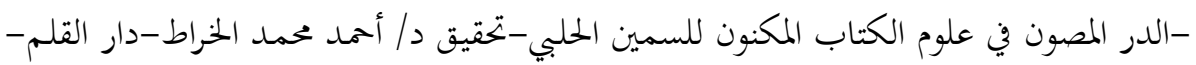

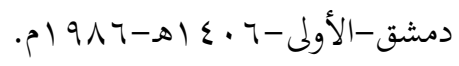

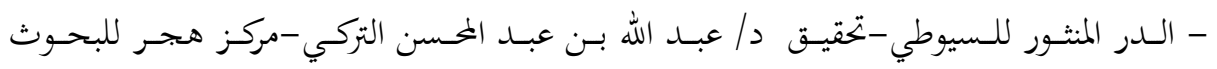

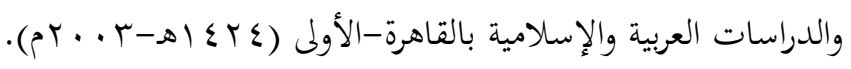

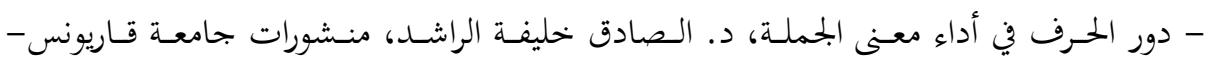
بنغازي، 997 ام. - رسم المصحف، دراسة لغويـة تاريخية، تأليف: غـانم قدوري الحمـد، الناشـر - اللجنـة الوطنية

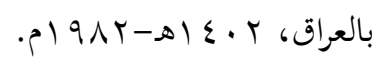
-رصف المباني في شرح حروف المعاني للمالقي-تمقيق/ أحمد محمد الحخراط-بحمع اللغة العربية بدمشق. -روح المعاني في تفسير القرآن العظيم والسبع المثاني للآلوسي-دار إحياء التراث العربي-بيروتلبنان.

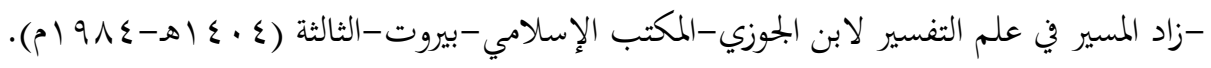

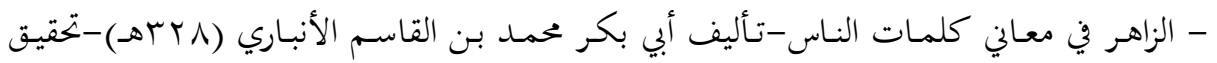

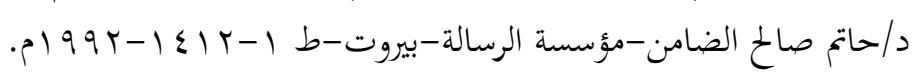

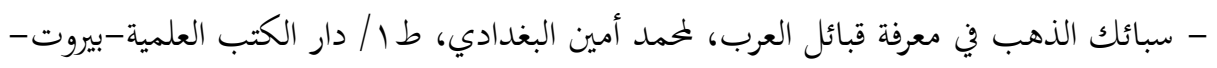
لبنان. -السبعة في القراءات لابن بحاهد-تحقيق د/ شوقي ضيف-دار المعارف-القاهرة-الثالثة. 
-سر صناعة الإعراب لابن جني-تحقيق د/ حسن هنداوي-دار القلم-دمشق وبيروت-الثانية.

- سنن أبي داود- تحقيق/ محمد محيي الدين عبد الحميد-دار إحياء التراث العربي-دار إحياء السنة النبوية.

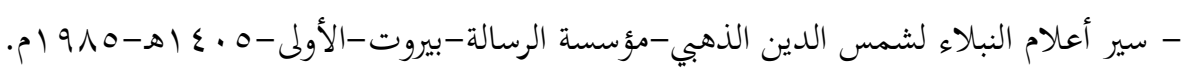

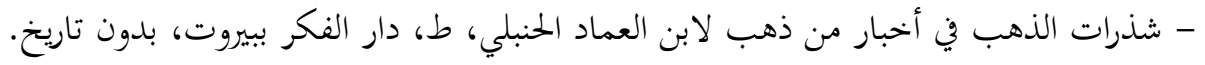

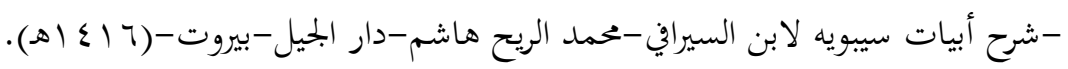

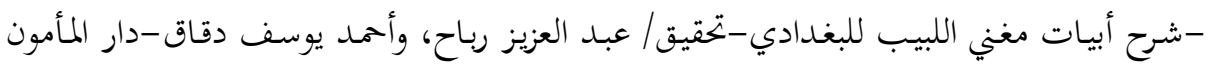

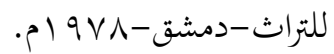
-شرح الأشموني على ألفية ابن مالك بحاشية الصبان-المكتبة الجحديدة-محمد علي صبيح-القاهرة.

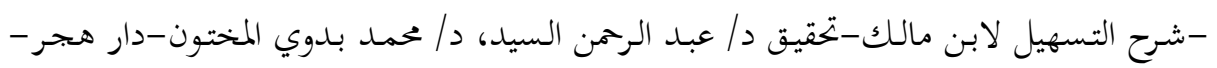

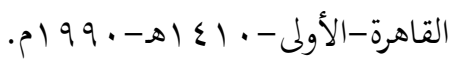
-شرح الجمل، لابن بابشاذ، تحقيق: د. مصطفى إمام، رسالة دكتوراه بكلية اللغة العربية بالقاهرة.

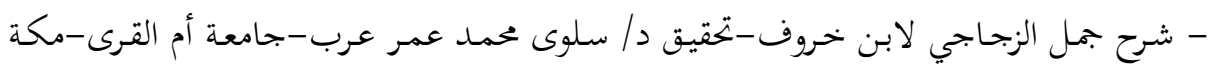

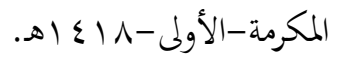
-شرح جمل الزجاجي لابن عصفور الإشبيلي-تحقيق د/ صاحب أبو جناح-دار الكتب-الموصل.

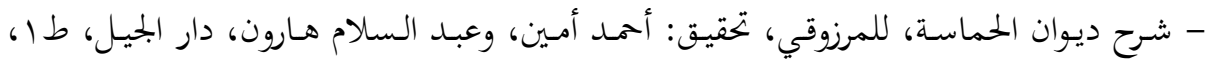
$.01991-81 \leqslant 11$

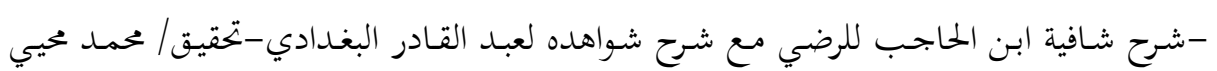
الدين وآخريْن -دار

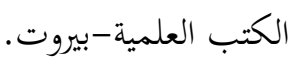
- شرح شواهد الإيضاح لابن بري - ت د / عيد مصطفى درويش - مطبوعات بجمع اللغة العربية

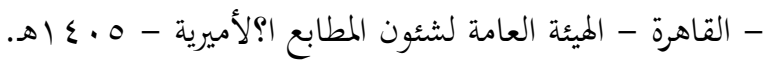

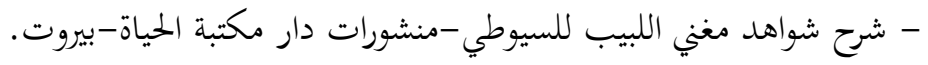

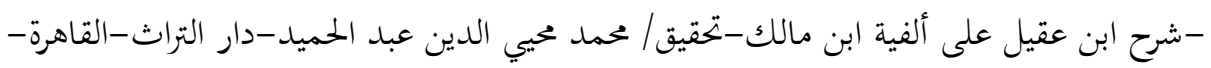
العشرون-... أه-. - 91 ام.

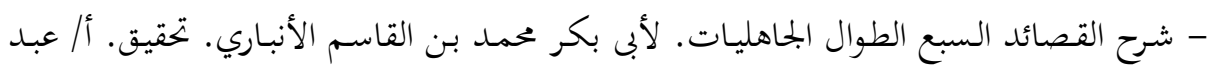

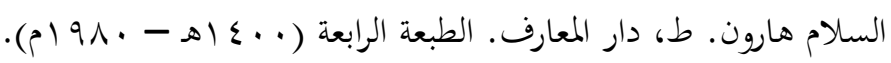

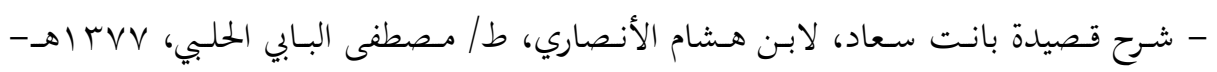
$.0190 \mathrm{~V}$ 


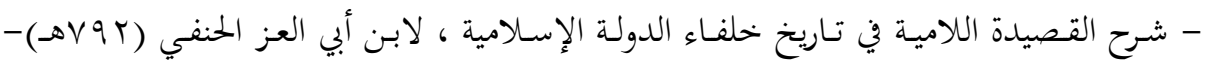

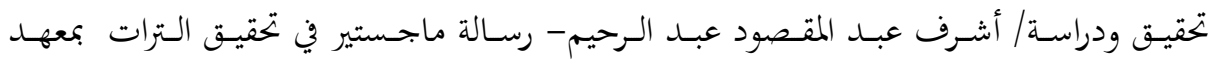

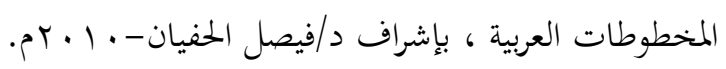

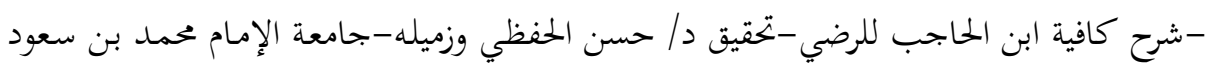

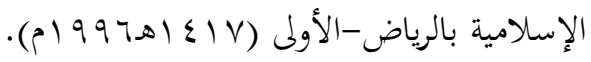

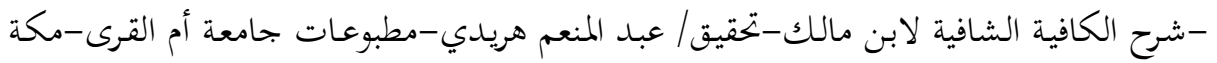

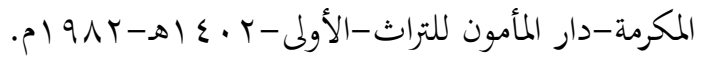

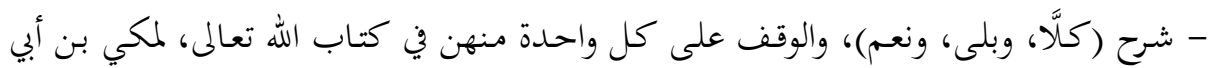

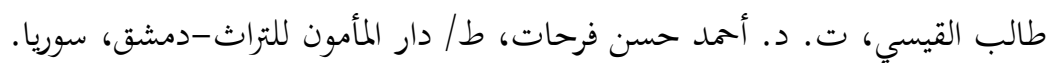

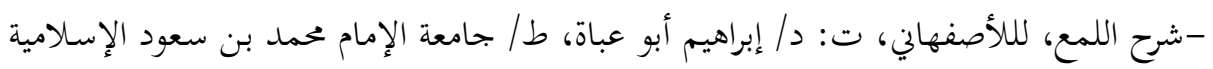

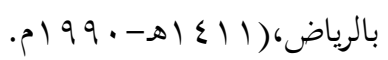
- شرح المفصل في صنعة الإعراب، الموسوم بالتخمير، للخوارزمي-تحقيق د.عبد الرحمن العثيمين-

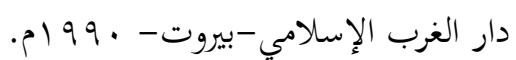

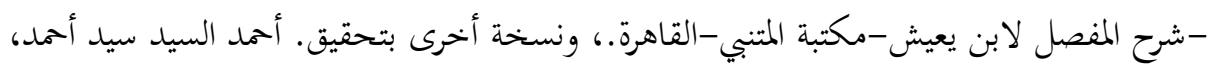

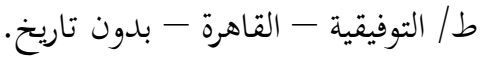
-الصاحبي في فقه اللغة لابن فارس-تحقيق د/عمر فاروق الطباع-مكتبة المعارف-بيروت-الأولى - عارفية .

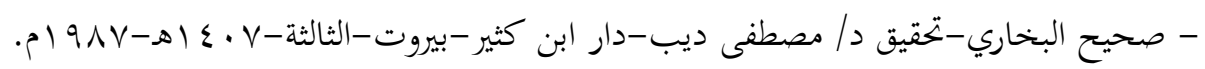

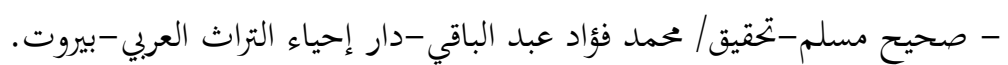

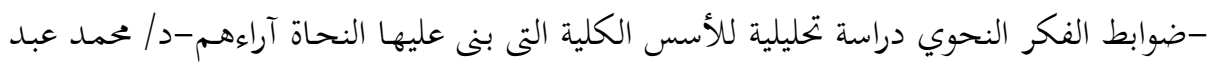
الفتاح الخطيب-دار البصائر للنشر والتوزيع-القاهرة.

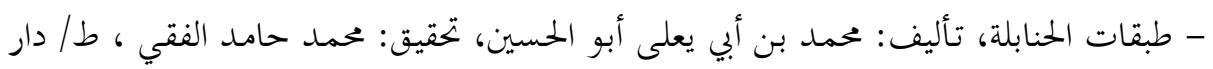

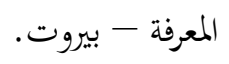

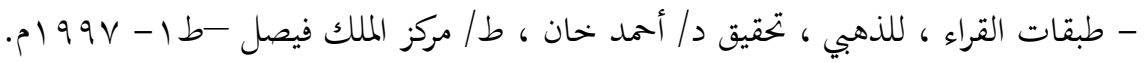

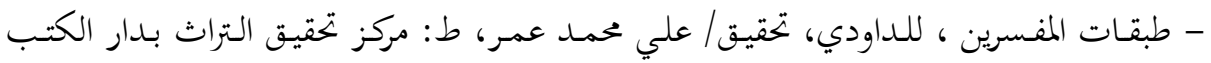

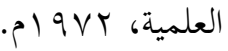

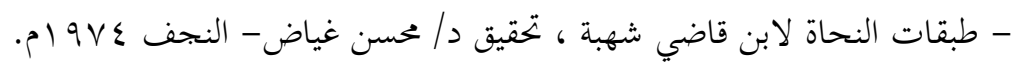

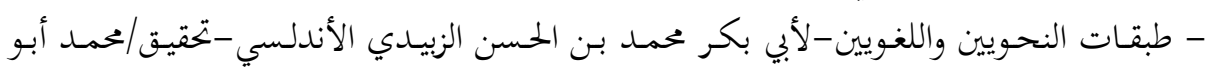
الفضل إبراهيم-دار المعارف-القاهرة-ط ب - [ع 91 ام] 


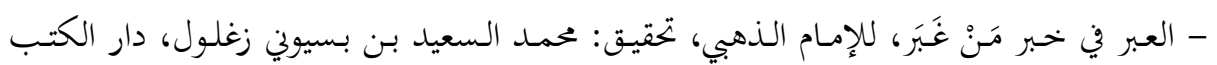
العلمية، بيروت، لبنان، بلا تاريخ.

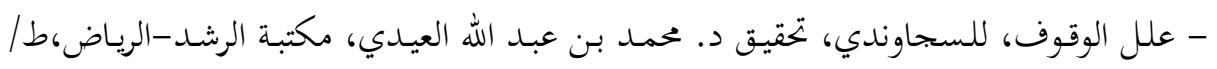

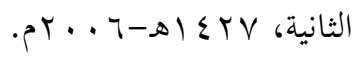
- غاية النهاية (طبقات القراء) لابن الجزري، عني بنشره برجيستراسر، مكتبة الخنانجي-القاهرة. $194 r$ -فتح القدير للشوكاني-تحقيق د/ عبد الرممن عميرة-دار الوفاء.

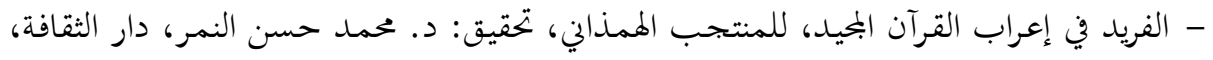

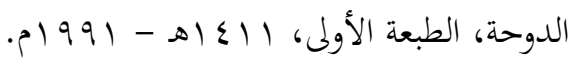

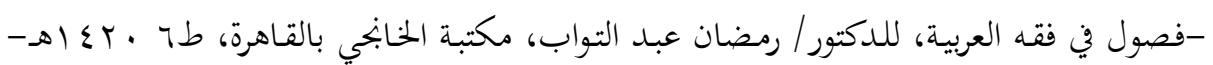

- الفهرست لابن النديم ، تحقيق د/ محمد عولي عبد الرءوف، و د/إيمان السعيد جلال، طا / الميئة

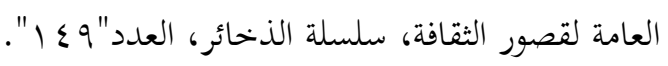
- في رحاب القرآن، للدكتور / محمد سا لم محيسن، مكتبة الكليات الأزهرية، بالقاهرة.

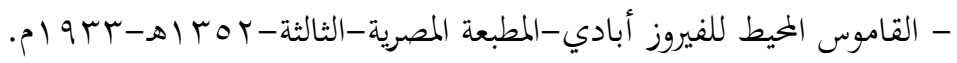

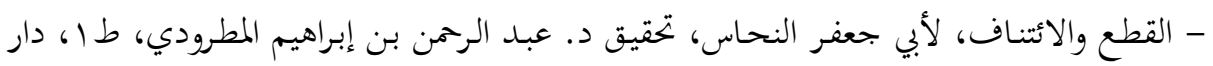

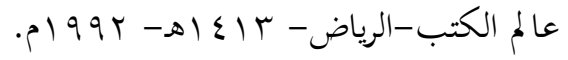

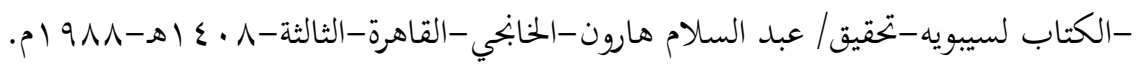

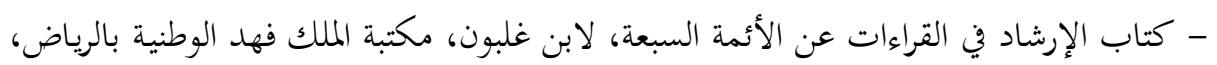

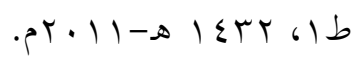
- كتاب الأوراق للصولي ، طاع/الهيئة العامة لقصور الثقافة - سلسلة الذخائر.

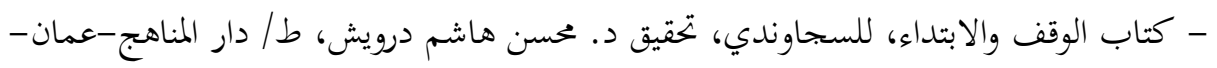

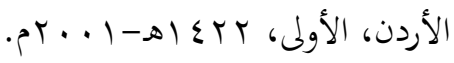

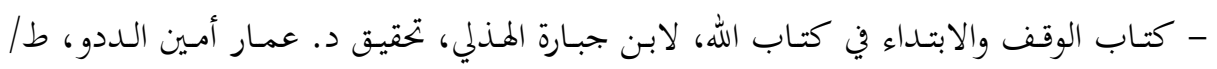

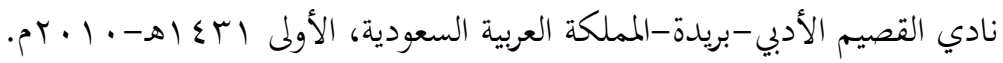

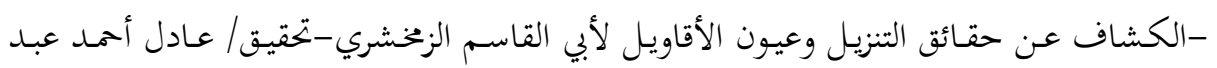

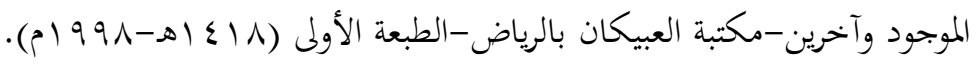

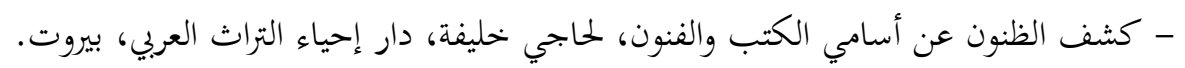

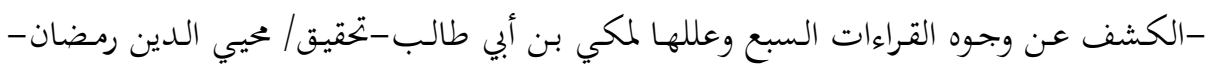

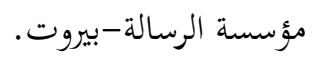




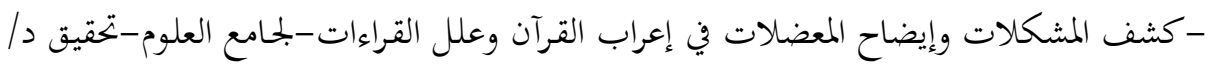

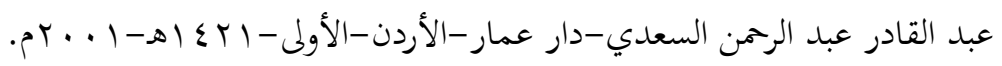

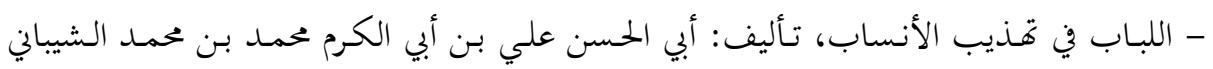

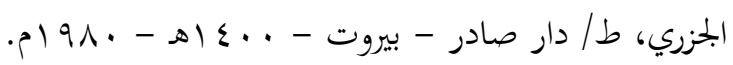

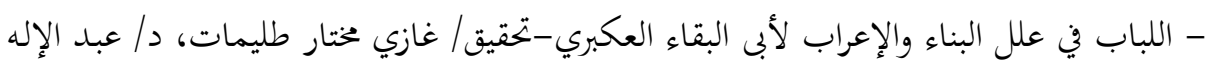

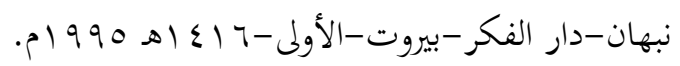

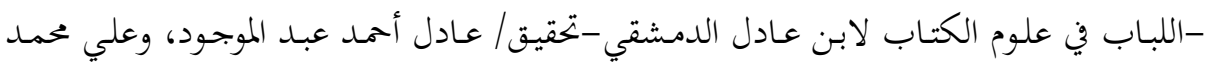

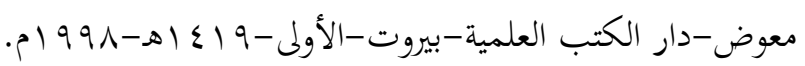

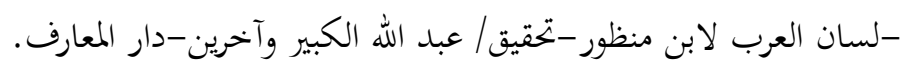

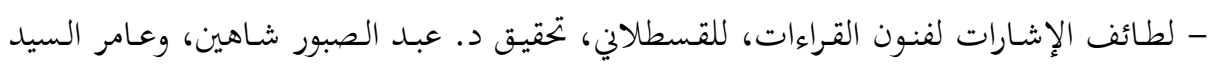

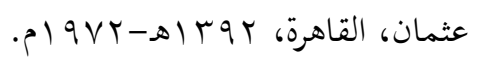

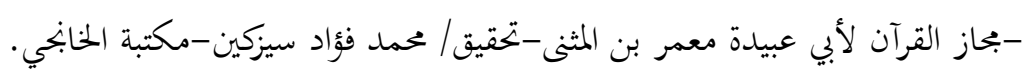

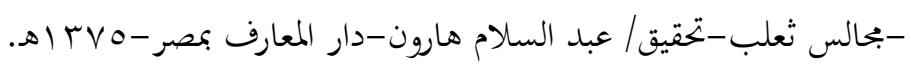

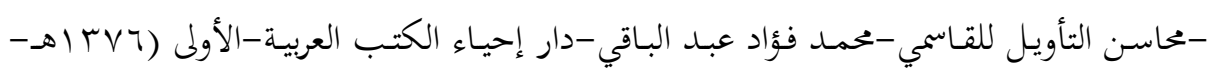
.$(\rho) 90 \mathrm{~V}$

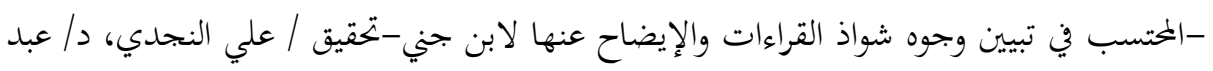

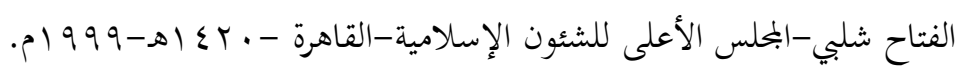

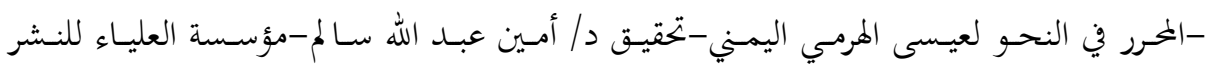

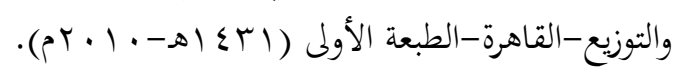

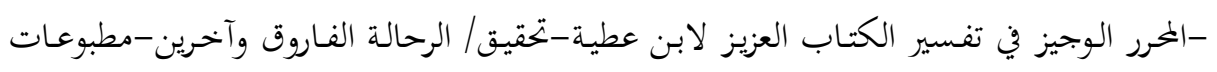

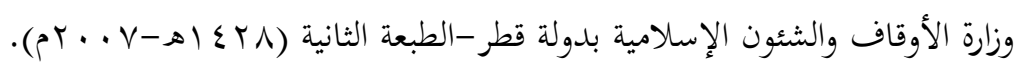

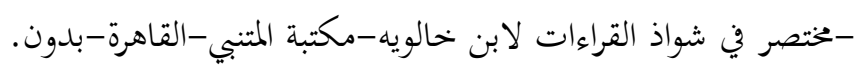

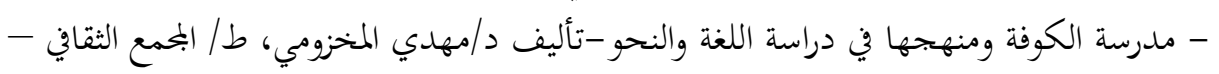

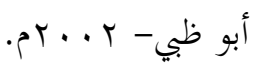

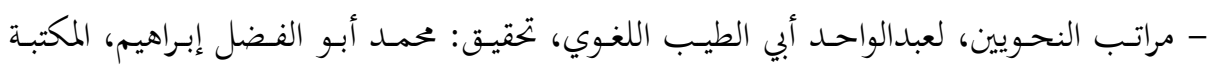

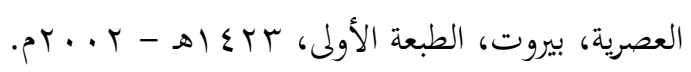

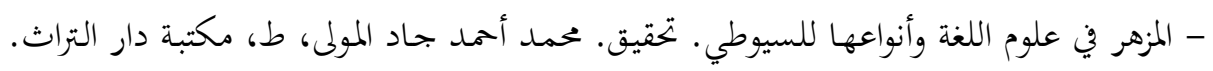
الطبعة الثالثة. بدون تاريخ.

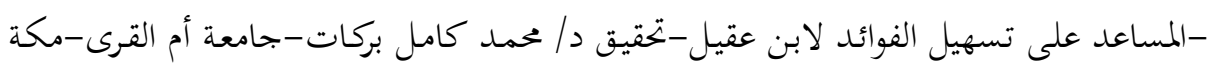

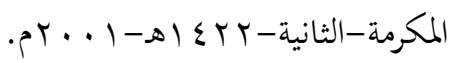


- مسالك الأبصار في ممالك الأمصار ، لابن فضل الله العمري، الجزء السابع -النحويون واللغويين

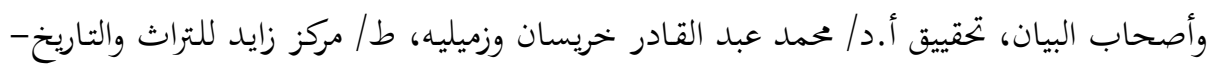
. 5 . .

-مشكل إعراب القرآن لمكي بن أبي طالب-تحقيق / ياسين محمد السواس-دار المأمون للتراثدمشق-الثانية. - مصطلح الخروج عند الكوفيين، دراسة لمدلوله وأضربه وعلاقته بالوظائف النحوية، للدكتور /

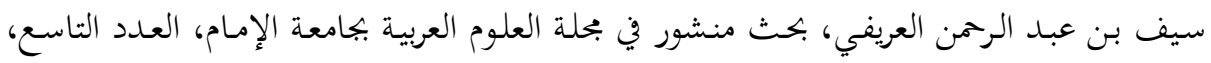

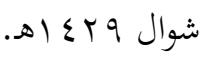

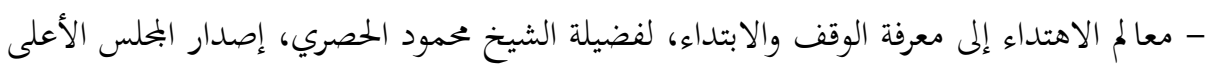
للشئون الإسلامية-القاهرة-

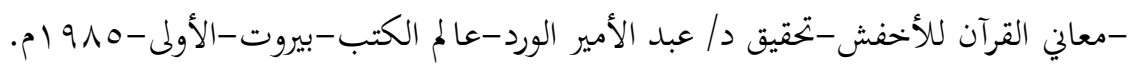

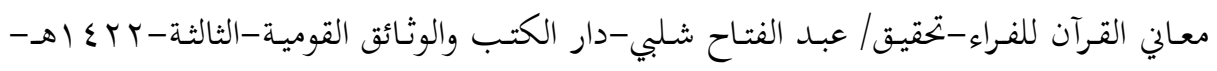
مT -معاني القرآن وإعرابه للزجاج-تحقيق د/ عبد الجليل عبده شلبي-عالم الكتب-بيروت-الأولى - مان 人 -معاني القرآن للنحاس-محمد ام. علي الصابوني-مركز إحياء التراث الإسلامي بمكة المكرمة-جامعة أم

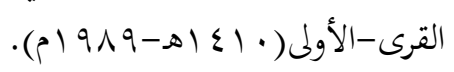

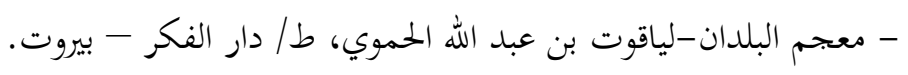

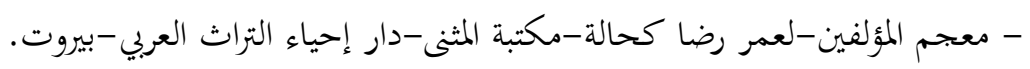

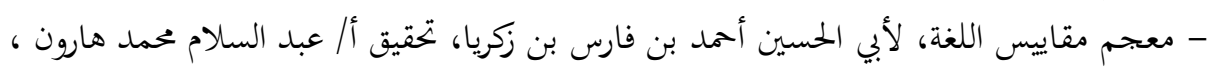

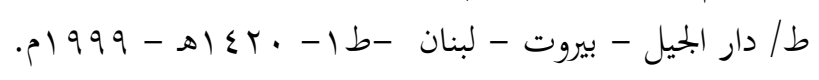

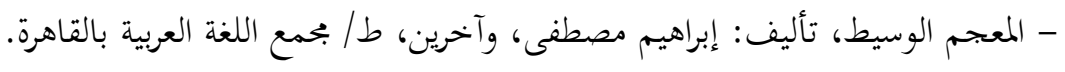

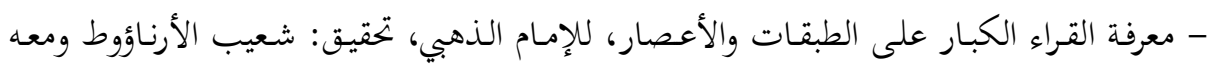

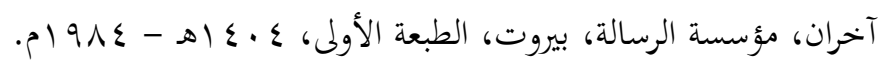

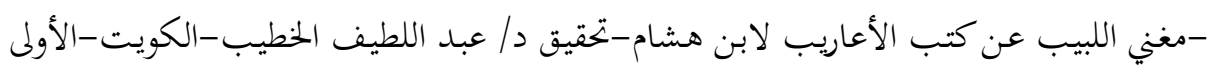

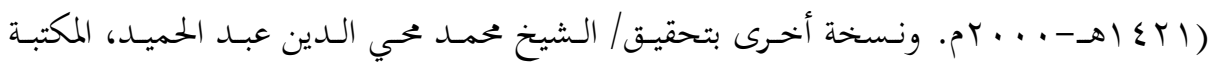

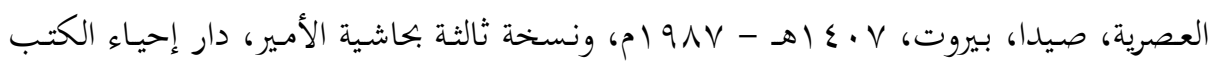
العربية، فيصل عيسى الحلبي. - المفصل في علم العربية للزخشري-دار الجيل-بيروت فيصيل الثانية. 
-المقاصد الشافية في شرح الخلاصة الكافية للشاطبي-تحقيق د/ محمد إبراهيم البنا وآخرين-مركز

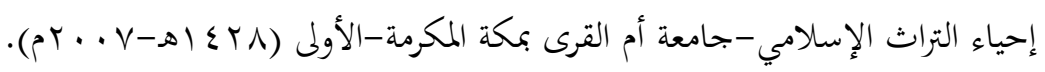

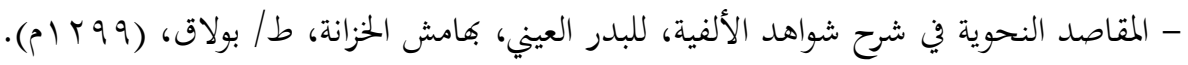

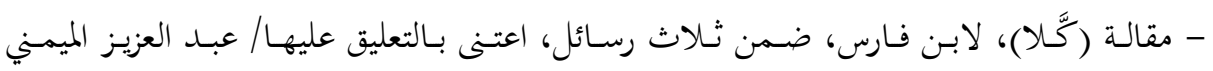

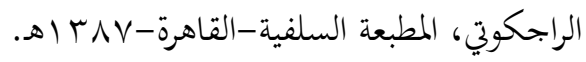
- المقتضب لأبي العباس المبرد-تحقيق/ محمد عبد الخالق عضيمة-البحلس المبلة الأعلى للشئون الإسلامية-

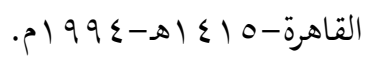
- مقدمة في الوقف والابتداء، للدكتور / أحمد خطاب العمر، بحث منشور في بحلة آداب الرافدين-

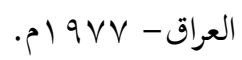
- المقصد الأرشد في ذكر أصحاب الإمام أحمد ، تأليف: الإمام برهان الدين إبراهيم بن محمد بن

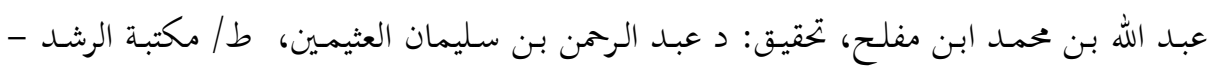

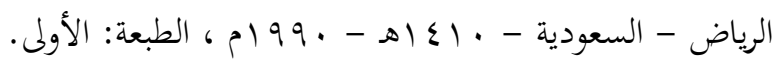

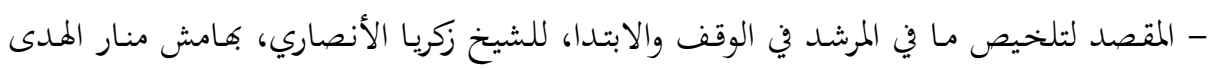

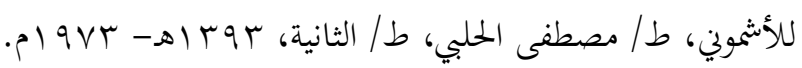

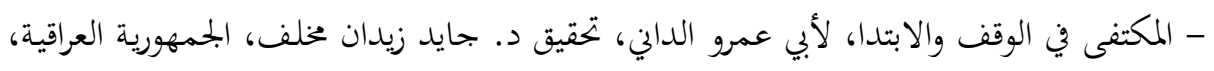

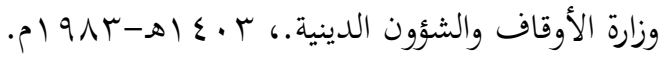

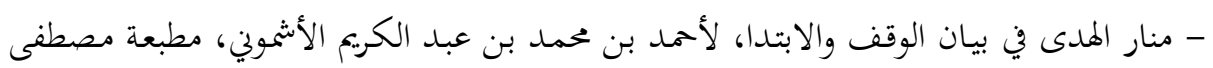

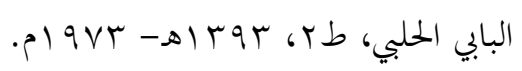

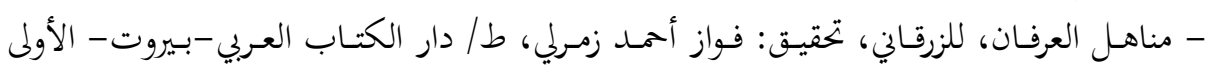
. $1990-81 \leqslant 10$

- المهذب في القراءات العشر وتوجيهها، للأستاذ الدكتور محمد سالم محسن، هذبه: أ. السادات

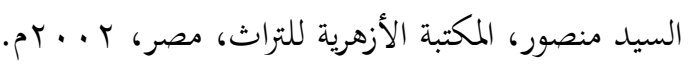

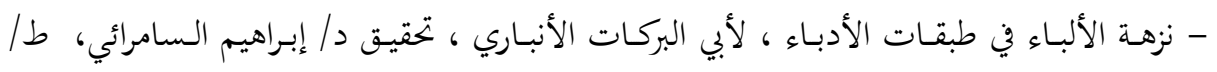

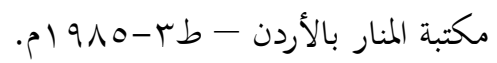
-النشر في القراءات العشر لابن الجزري-تحقيق/على محمد الضباع-دار الكتب العلمية-بيروت.

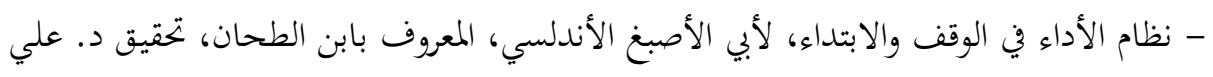

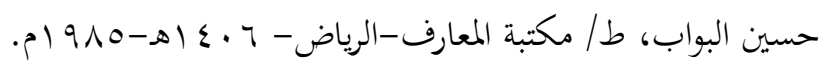

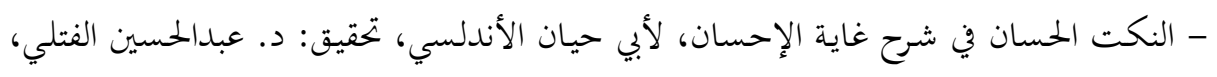

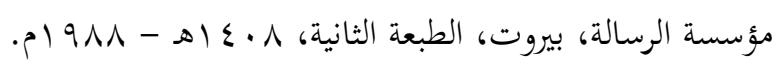




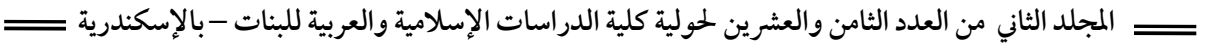

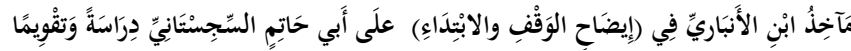

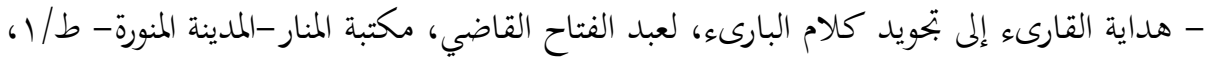
.

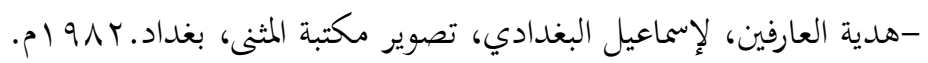

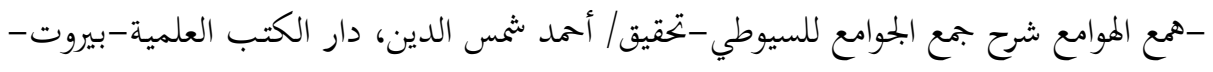

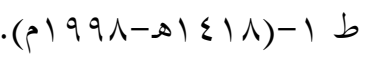

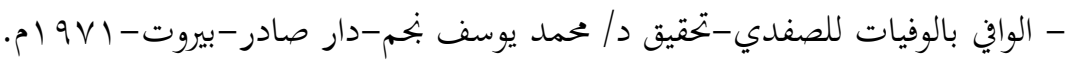

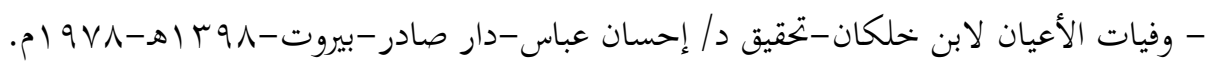

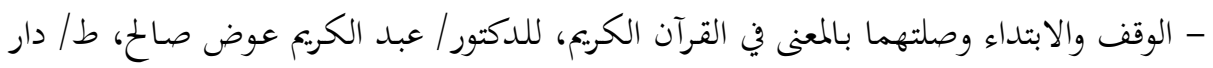

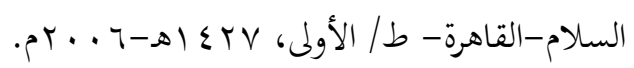




\section{فهر ??] ضو ضوعا ?}

\begin{tabular}{|c|c|}
\hline الصفحة & الموضــوع \\
\hline AM & مُقَقَدَّمَّة \\
\hline Arq & التمهيد \\
\hline Arv & المبحث الأول: التعريف بأبي حاتي، وابن الأنباري \\
\hline Arv & أَوَلَا: التعريف بأبي حاتح \\
\hline Arv & | اسمه ونسبه \\
\hline Arv & مولده ونشأته \\
\hline$\Lambda \mu \Lambda$ & صفاته \\
\hline$\Lambda \mu \Lambda$ & ثناءُ العلماءٍِ عليه \\
\hline Arq & مذهبه النَّحوي والعَقَدِي \\
\hline Arq & شيوخه \\
\hline$\Lambda \varepsilon$. & تلاميذه \\
\hline$\Lambda \leq 1$ & آثاره ومؤلفاته \\
\hline$\Lambda \varepsilon r$ & وفاته \\
\hline$\Lambda \varepsilon Y$ & ثانيًا: التعريف بابن الأنباريّ \\
\hline$\Lambda \varepsilon Y$ & السمه ونسبه \\
\hline$\Lambda \varepsilon Y$ & مولده ونشأته \\
\hline$\Lambda \varepsilon \mu$ & صفاته \\
\hline$\Lambda \varepsilon \mu$ & ثناءُ العلماء عليه \\
\hline$\Lambda \varepsilon \varepsilon$ & مذهبه النحوي والعَقَدِي \\
\hline$\Lambda \leq \varepsilon$ & شيوخه \\
\hline$\Lambda \varepsilon 0$ & تلاميذه \\
\hline$\Lambda \varepsilon \neg$ & آثاره ومؤلفاته \\
\hline$\Lambda \leq \vee$ & وفاته \\
\hline$\Lambda \varepsilon \wedge$ & المبحث الثاني: الوقف: تعريفه، أنواعه، صِلته بالنَّحْوِِ \\
\hline$\Lambda \varepsilon \wedge$ & أولاً: تعريف الوقف: \\
\hline$\Lambda \leq 9$ & ثنانيًا: أنواعُ الوقف \\
\hline$\Lambda \leq q$ & تعريف الابتداء \\
\hline
\end{tabular}




\begin{tabular}{|c|c|}
\hline الصفحة & الموضــوع \\
\hline 乏०. & ثنالثًا: صِلةُ الوقفِ بالنحْو \\
\hline Aor & المسألة الأولى: عِلَّةُ حَذفِ الواوِ من الفعل المُرفوع لغيرِ جَازٍٍ \\
\hline$\wedge \odot \wedge$ & المسألة الثانية: معنى (كَلَّا) \\
\hline 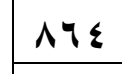 & المسألة الثالثة: أوجه إعراب (ذَلِكَ) في قوله تعالى: (ذَلِكَ الْكِتَابُ لَا رَيْبَ فِيْهِ) \\
\hline Аรฯ & 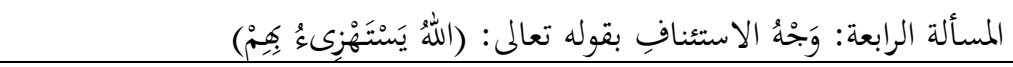 \\
\hline 199 & المسألة الخامسة: مَوَققعُ قوله تعالى: (أُعِدَّتْ بِلْكَافِرِينَ) من الإعراب \\
\hline$\Lambda V Y$ & 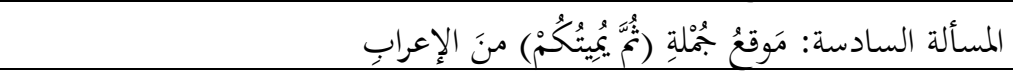 \\
\hline AV० & المسألة السَّابعة: موقعُ قوله تعالى: (تُثْيرُ الأَرْضَ) منَ الإعُرْابِ \\
\hline$\Lambda \vee q$ & 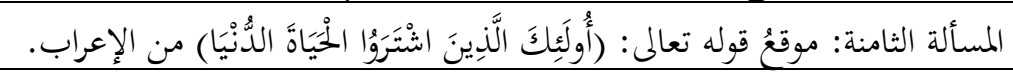 \\
\hline$\Lambda \wedge$. & 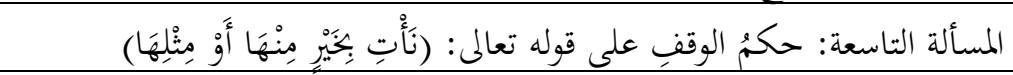 \\
\hline$\wedge \wedge 1$ & المسألة العاشرة: حكمُ الوقفِ على قوله تعالى: (وَحِينَ البَأْس) \\
\hline$\Lambda \Lambda \mathrm{r}$ & المسألةُ الحاديةَ عشرةً: حكمُ الوقفِ على قوله تعالى: (لِلنَّاس) \\
\hline$\Lambda \wedge \mathrm{r}$ & المسألة الثانية عشرة: تَوْجِيهُ رَفْعُع قوله تعالى: (الرَّاستخُونَ) \\
\hline$\Lambda \wedge \wedge$ & المسألة الثالثة عشرة: حُكمُم الوقف على قوله تعالى: (مَتَاعُ الحَلْيَاةِ الدُّنْيَا) \\
\hline$\wedge \wedge 9$ & المسألة الرابعة عشرة: توجيهُ إعرابِ قوله تعالى: (مِنَ الْهُعَرَبَينَ) \\
\hline$\wedge 91$ & المسألة الخامسة عشرة: موضعُ قولِه تعالى: (بَعضُكْم مِنْ بعْضِِ) من الإعْرابِ \\
\hline$\wedge 9 \varepsilon$ & المسألة السادسة عشرة: إعرابُ قولِهِ تعالى: (مَتَاعٌ قَلِليُو) \\
\hline$\wedge 90$ & المسألة السابعة عشرة: أوْْحهُ إعْرَابِ قوله تعالى: (وَصِيَّةً) \\
\hline$\wedge 9 \wedge$ & المسألة الثامنة عشرة: أوجهُ إعرابِ قوله تعالى: (وَأَخِي) \\
\hline $9 \cdot r$ & المسألة التاسعة عشرة: توجيه النَّصْبِ في قوله تعالى: (مَشَارِقَ الأَرْضِ وَمَغَارِبَهَا) \\
\hline $9 \cdot 0$ & 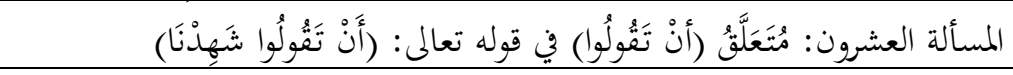 \\
\hline $91 \cdot$ & المُؤمنِينَ) الحمادية والعشرون: توجيهُ إعرابِ (مَنْ) في قوله تعالى: (ومَنِ اتَّبَعَكَ مِنَ \\
\hline $91 \mathrm{~V}$ & المسألة الثانية والعشرون: أوجهه إعراب قوله تعالى: (فَاللَّهُ أَحَقُّ أَن تَخْشَوْهُ) \\
\hline $91 \wedge$ & 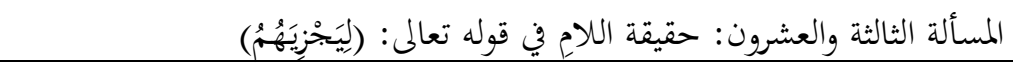 \\
\hline qr. & المسألة الرابعة والعشرون: حديثه عن قوله تعالى: (وَلِنَجْعَلَهُ آيَةًَ لِلنَّاسِ) \\
\hline $9 r_{1}$ & 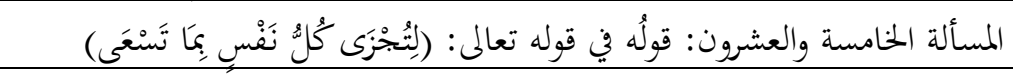 \\
\hline arr & 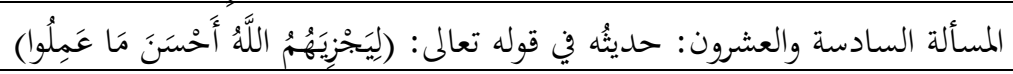 \\
\hline
\end{tabular}




\begin{tabular}{|c|c|}
\hline الصفحة & الموضــوع \\
\hline qru & 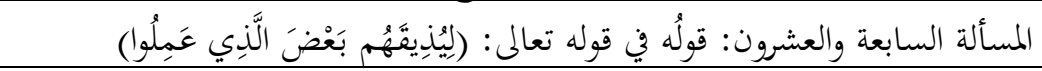 \\
\hline qrr & 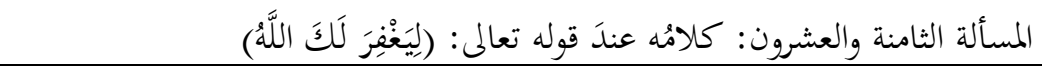 \\
\hline QY & 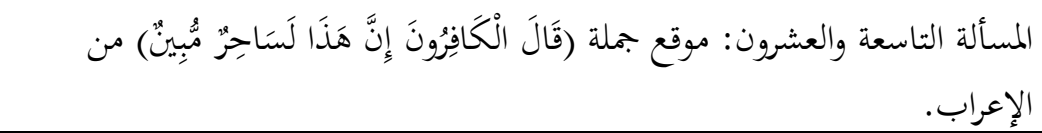 \\
\hline 9 YY & المسألة الثلاثون: توجيهُ فتح هزة (أَنَّ) في قوله تعالى: (إِنَّهُ يَبْدَاً \\
\hline 9 rq & المسألة الحادية والثلالثون: نوع الاستثناء في قوله تعالى: (إلآَّ مَن سَبَقَ..) \\
\hline $9+$ & 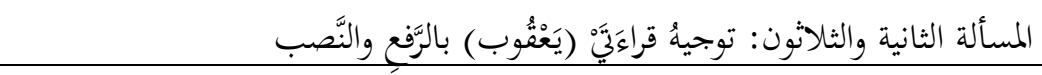 \\
\hline $9+0$ & المسألة الثالثة والثلاثون: موضعُ جملة (وَالَّذِينَ صَبَرُواُ من الإعرابِ \\
\hline $9 \mu \mathrm{V}$ & المسألة الرابعة والثلالثون: موقع جملة (فَسَوْفَ يَعْلَمُونَ) \\
\hline $9 \mu \wedge$ & المسألة الخامسة والثلاثون: موقع جملة قوله تعالى: (هَذَا حَلالَّ وَهَذَا حَرَامُم) من \\
\hline $9+9$ & المسألة السادسة والثلاثون: الخلافُ في جوابِ (إذًا) في قوله تعالى: (حَتَّى إِذَا فُتِحَتْ) \\
\hline $9 \varepsilon \mu$ & المسألة السابعة والثلالثون: توجيه الإعراب في قوله تعالى: (يَلْعُوُ لَمَن ضَرَهُه). \\
\hline $9 \leq V$ & 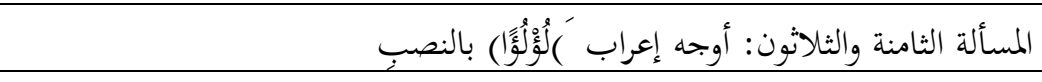 \\
\hline 90. & المسألة التاسعة والثلاثون: القول في مفعُولَي: (يَحَسْبُونَ) \\
\hline $90 \mathrm{r}$ & المسألة الأربعون: أوجهه نصب (شُكُرًاً) \\
\hline 907 & المسألة الحادية والأربعون: توجيهُ رفع (سَلَامُ)، ونصبَ (قَوْلَا) \\
\hline 901 & المسألة الثانية والأربعون: إعراب قولهِ تعالى: (أَخََّّْنَاهُمْمَ) \\
\hline 97. & المسألة الثالثة والأربعون: توجيهُ القراءَات في (وَيَعْلَم) بالنصبِ والحززج والرفِع \\
\hline 970 & المسألة الرابعة والأربعون: موقع قوله تعالى: (إنْ هُوَ إلإَّ وَحْيُ يُوحَى) من الَإعراب \\
\hline $97 \vee$ & 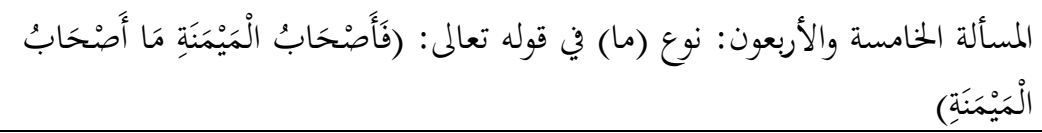 \\
\hline 979 & المسألة السادسة والأربعون: توجيهُ قولِه تعالى: (وَحُورِ عِينِ) بالجِرِّ \\
\hline $9 \vee \varepsilon$ & المسألة السابعة والأربعون: أوجهُ نصبَ (رَسُولًا) \\
\hline 9VA & 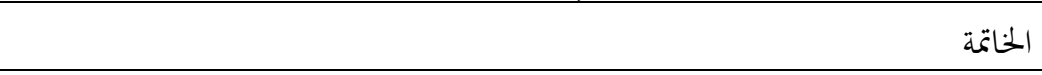 \\
\hline $9 \wedge 1$ & 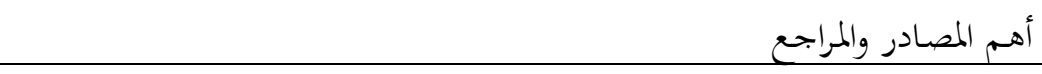 \\
\hline $99 \leq$ & فهرس الموضوعات \\
\hline
\end{tabular}




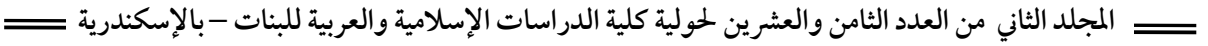

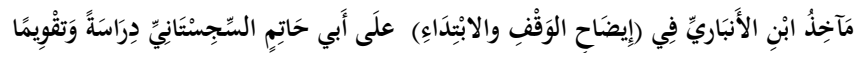

